
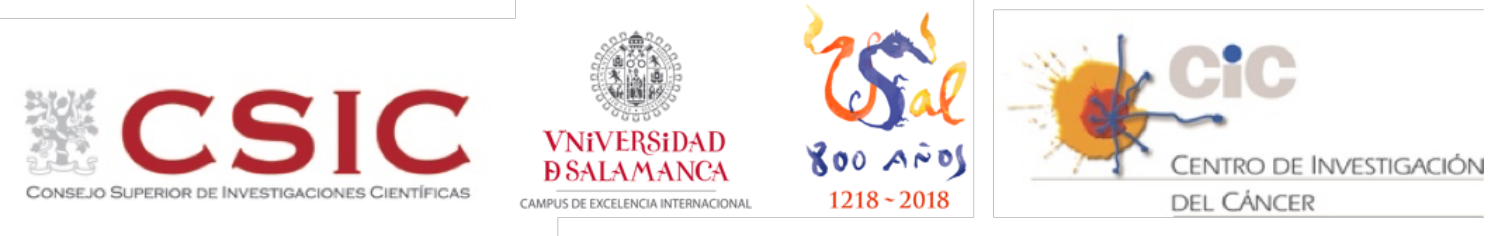

CENTRO DE INVESTIGACIÓN DEL CÁNCER / INSTITUTO DE BIOLOGÍA MOLECULAR Y CELULAR DEL CÁNCER (CSIC-USAL)

\title{
ESTUDIO FUNCIONAL DE SOS1 Y SOS2 IN VIVO E IN VITRO EN LA REGULACIÓN DE PROCESOS FISIOLÓGICOS Y TUMORALES. LAS PROTEÍNAS SOS COMO DIANAS TERAPÉUTICAS EN CÁNCER
}

TESIS DOCTORAL

Pilar Liceras Boillos

Salamanca, 2017 



\section{Resumen}

Los miembros canónicos de la familia Ras (H-Ras, N-Ras y K-Ras) codifican GTPasas que actúan en rutas de señalización que controlan procesos de proliferación, diferenciación y muerte celular, entre otros. La activación de las proteínas Ras se encuentra modulada por reguladores negativos (GAPs) y reguladores positivos (GEFs). La familia Sos es una de las varias familias de RasGEFs presentes en células eucariotas. Esta familia comprende dos miembros, Sos1 y Sos2, que presentan una elevada homología y se expresan de manera ubicua, aunque son funcionalmente diferentes. La eliminación constitutiva de Sos1 en ratones resulta letal en la etapa embrionaria, mientras que la eliminación de Sos2 es prescindible para la viabilidad en la etapa embrionaria y adulta. Esta clara diferencia muestra la especificidad funcional de Sos1, al menos en el desarrollo embrionario.

La reciente disponibilidad de un modelo animal knockout para Sos1 inducible en la etapa adulta, nos ha permitido estudiar la especificidad o redundancia funcional de Sos1 y Sos2 en la supervivencia durante la etapa adulta, así como en numerosos procesos biológicos. Empleando estos modelos animales hemos evaluado en este trabajo de Tesis Doctoral la especificidad o redundancia funcional de Sos1 y Sos2 en distintos contextos fisiológicos y patológicos, tanto in vitro como in vivo.

Mediante el empleo de fibroblastos embrionarios de ratón hemos analizado la especificidad funcional de Sos1 y Sos2, evaluando diversos parámetros celulares como la morfología, el crecimiento celular, la progresión del ciclo celular, la migración, la adhesión celular o el mantenimiento del estado redox de la célula, entre otros. Además, hemos estudiado la capacidad de Sos1 y Sos2 para activar a Ras y Rac, así como el estado de activación de varias proteínas clave en las rutas Ras/MAPK o PI3K/Akt. Los resultados muestran que Sos1 es clave en el mantenimiento de la morfología celular y la organización del citoesqueleto de actina, en el crecimiento celular, en la progresión del ciclo celular, el nivel de compactación de la cromatina y en el mantenimiento del estado redox de la célula. En consonancia con trabajos anteriores, la ausencia individual de Sos2 no afecta a la mayoría de estos procesos, excepto a la adhesión celular, donde juega un papel importante no descrito anteriormente. Tanto los niveles celulares de RasGTP como la activación de las rutas Ras/MAPK y PI3K/Akt se vieron disminuidas tras la eliminación simultánea de Sos1 y Sos2. Aunque la eliminación individual de Sos2 no parece alterar la homeostasis celular en prácticamente ningún proceso celular estudiado, la eliminación concomitante de ambas proteínas agrava más aun los defectos observados en 
fibroblastos que sólo carecían de Sos1, sugiriendo que la presencia de Sos2 es capaz de atenuar de algún modo algunos de los defectos ocasionados por la deficiencia de Sos1.

Los estudios in vivo nos han permitido conocer la función de Sos1 y Sos2 en la estructura y la homeostasis de la piel, en condiciones fisiológicas y/o patológicas. En condiciones fisiológicas y en el proceso de reparación de la piel en respuesta a un daño tisular, la ausencia individual de Sos1 altera la integridad epitelial a diferentes niveles. Estas alteraciones se ven agravadas cuando ambas proteínas están ausentes. Al igual que ocurre en muchos ensayos in vitro, la deficiencia individual de Sos2 no muestra modificaciones significativas en la arquitectura de la piel o en los mecanismos de respuesta durante un proceso de regeneración epitelial.

Basándonos en la participación de las proteínas Sos en el mantenimiento de la homeostasis de la piel y su papel en varios procesos tumorales, también estudiamos la función de las proteínas Sos en un modelo de carcinogénesis epitelial inducible químicamente. La eliminación de Sos1 no solo retrasa el inicio y la progresión tumorales, sino que previene el desarrollo de tumores malignos. Además, disminuye el crecimiento tumoral de tumores pre-existentes. Sin embargo, la eliminación de Sos2 no parece tener un efecto en la mayoría de estos procesos.

Este trabajo describe los mecanismos moleculares y celulares por los cuales las Sos1 y Sos 2 pueden contribuir a la regulación de distintos procesos biológicos. 


\section{Abstract}

Ras proteins are critical signal transduction regulators controlling cellular proliferation, differentiation and survival. These small GTPases are continuously cycling between inactive (Ras-GDP) and active (Ras-GTP) conformations in a process modulated by cellular negative (GTPase activating proteins, RasGAPs) and positive (Guanine nucleotide Exchange Factors, RasGEFs) regulators. Mammalian cells express a variety of RasGEFs including the Sos family. This family encompasses two highly homologous, ubiquitously expressed members, Sos1 and Sos2. Despite their similarities, Sos proteins are functionally different. In this regard, Sos1 is lethal during embryonic development while Sos2 depletion is dispensable for organism survival.

The embryonic lethality of Sos1 null mutants has hampered ascertaining the specific in vivo contributions of Sos proteins to processes controlling adult organism survival. The generation of the first tamoxifen-inducible mutant mouse model for Sos1 has allowed studying the specificity or functional redundancy of Sos proteins in different physiological and pathological contexts, both in vitro and in vivo. Using primary mouse embryonic fibroblasts, we have analyzed the functional specificity of Sos1 and Sos2 proteins in different cellular processes such as cell growth, cell cycle progression, cell migration, cell adhesion and redox homeostasis into the cell. In turn, we have also studied Sos 1 and Sos 2 ability to activate Ras and Rac as well as key proteins in Ras-mediated signaling pathways such as Ras/MAPK or PI3K/Akt. Our results in primary MEFs show that Sos1 plays a key role in Ras activation, cell morphology, cell growth, cell cycle progression, transcriptional status or maintenance of the redox state of the cell.

Tamoxifen-induced Sos1 KO and Sos1/2 DKO MEFs exhibit altered morphological and cytoskeletal organization that are not observed in the WT and Sos2 KO counterparts. Cellular proliferation and migration are impaired after single Sos1-deletion. These alterations are much more aggravated under concomitant Sos proteins depletion. On the other hand, cell adhesion is only impaired upon depletion of both Sos isoforms, although a significant role of Sos 2 in this process is unveiled. RasGTP formation was reduced upon Sos1 deletion and practically absent in Sos1/2DKO MEFs as compared with the other genotypes and extracellular signal-regulated kinase phosphorylation show only significant reduction after combined Sos1/2 depletion. In addition, increased levels of oxidative stress were detected in the Sos1-depleted MEFs. 
Using our viable Sos1- and Sos1/2-null mutants, we also evaluate the specific role of Sos proteins in maintenance of skin homeostasis and the healing processes of the skin upon injury. Additionally, potential effects of Sos1/2 disruption, individually or combined, on initiation and/or progression of mouse tumor models of epithelial origin.

Our data show that Sos1 depletion causes a general alteration of skin homeostasis under physiological conditions. These modifications in the skin homeostasis become worse when both Sos proteins are absent. Involvement of Sos isoforms upon skin wound healing is also evaluated. Simultaneous Sos $1 / 2$ disruption results in an impairment of wound repair. Moreover, Sos1 absence prevented malignant tumor formation and progression. In addition, deletion of Sos1 isoform in preexisting chemically-induced papillomas results in a decrease in tumor number and size.

The generation of these new cellular and animal models provides the opportunity to clarify the molecular and cellular mechanisms by which Sos proteins regulate different processes in vitro and in vivo. This study demonstrates the relevance of Sos proteins in cellular and tissue homeostasis. 
Índice 



\section{Resumen/Abstract Índice}

Índice de abreviaturas

Índice de Figuras

\section{Introducción}

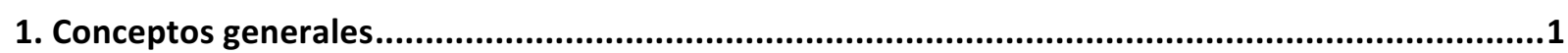

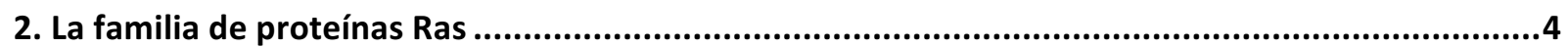

2.1. Localización de Ras en los diferentes compartimentos celulares ................................................4

2.2. Modelos animales modificados genéticamente para las proteínas Ras....................................6

2.3. Diferencias asociadas a cada proteína Ras en el perfil transcriptómico ........................................7

2.4. Especificad de las proteínas Ras en la recepción y emisión de estímulos ....................................7

2.5. Implicación de las proteínas Ras en procesos tumorales ..........................................................

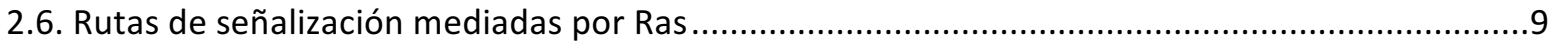

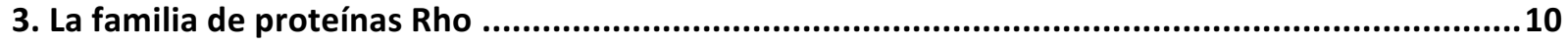

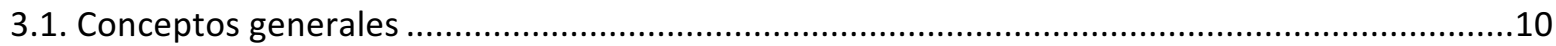

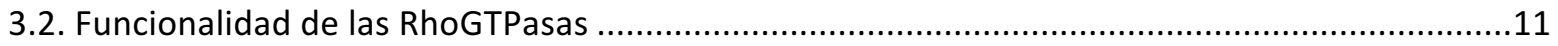

3.2.1. Función de las RhoGTPasas en la migración celular .........................................................12

3.3. Importancia de las proteínas Rho en procesos tumorales ......................................................14

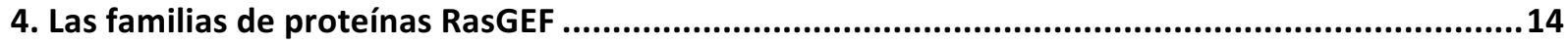

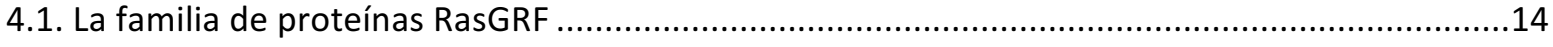

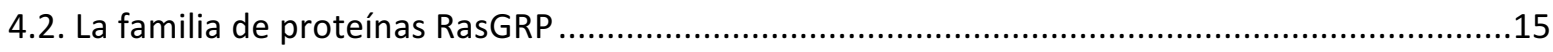

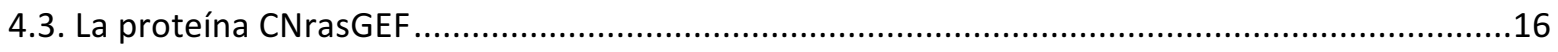

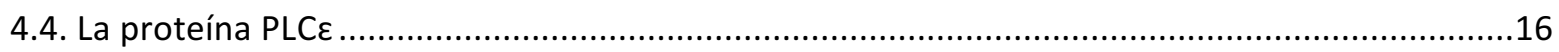

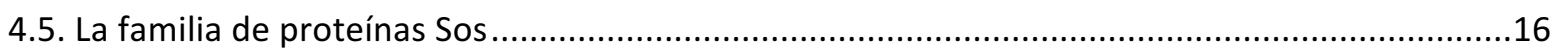

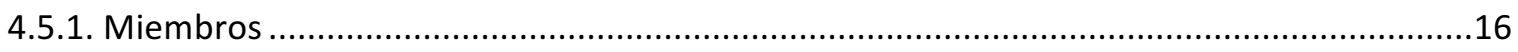

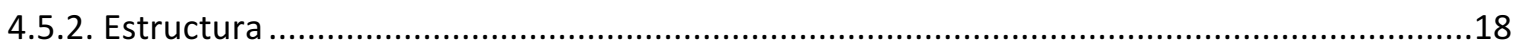

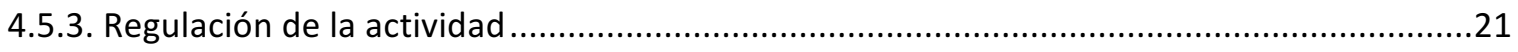

4.5.3.1 Modelo clásico de translocación a membrana ..............................................................21

4.5.3.2 Mecanismo de activación alostérica e inhibición intramolecular ..................................21

4.5.3.3. Regulación de la activación de Sos por el dominio alostérico ......................................23

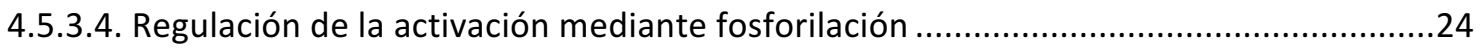

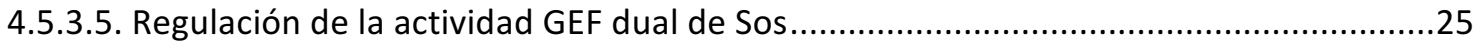

5. Participación de las proteínas Sos en rutas de señalización ........................................................26 


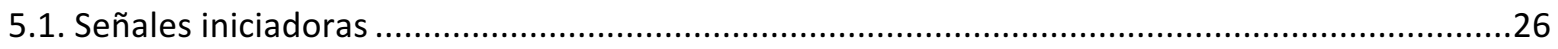

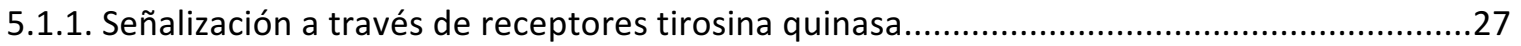

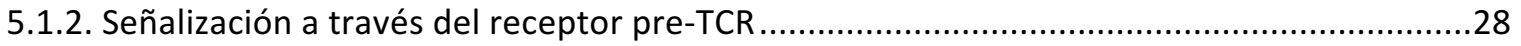

5.1.3. Señalización a través de receptores acoplados a proteínas $\mathrm{G}$...........................................28

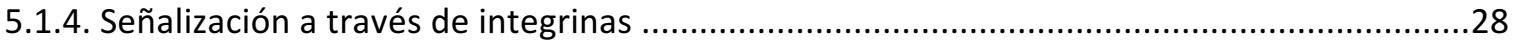

5.2. Principales rutas de señalización mediadas por Ras ..............................................................30

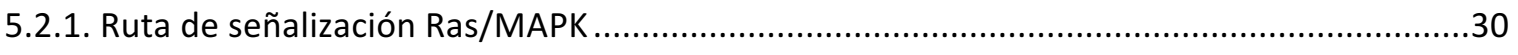

5.2.1.1. Señalización de las rutas Ras/p38 y Ras/JNK .........................................................31

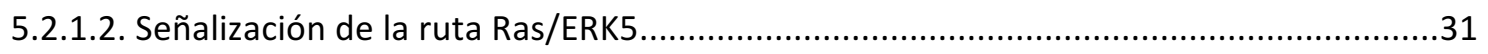

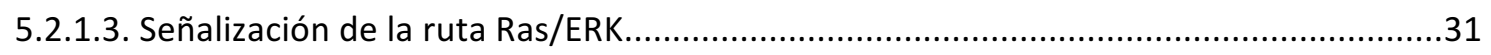

(i) Progresión del ciclo celular: fosforilación de sustratos nucleares ....................................32

(ii) Crecimiento celular y supervivencia: fosforilación de proteínas citoplasmáticas..............33

(iii) Remodelación del citoesqueleto de actina: fosforilación de proteínas del

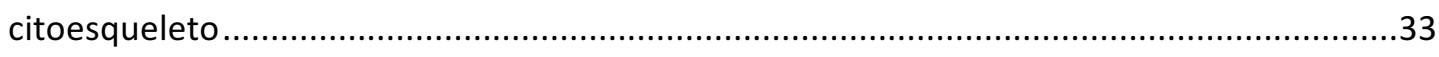

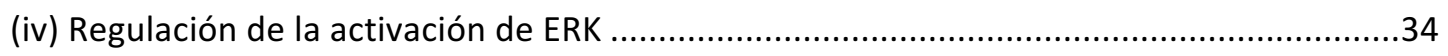

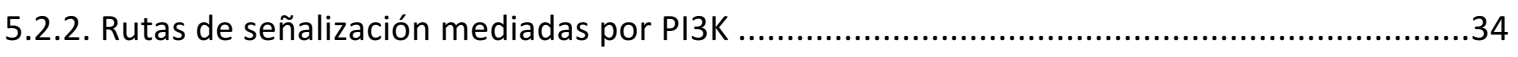

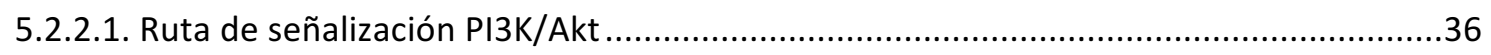

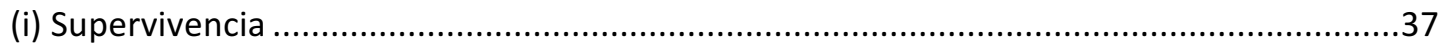

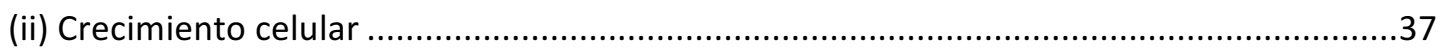

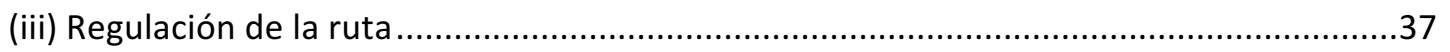

5.2.2.2. Señalización independiente de Akt mediada por PI3K ...............................................37

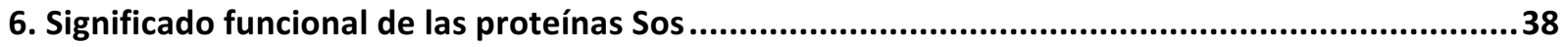

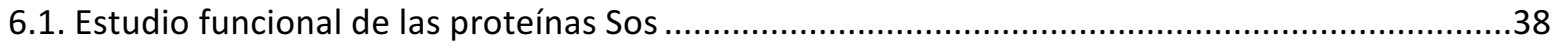

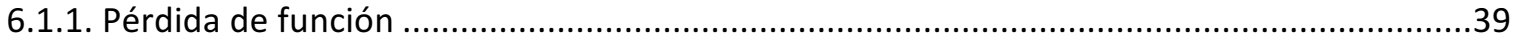

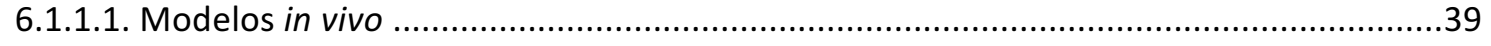

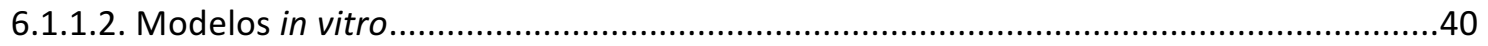

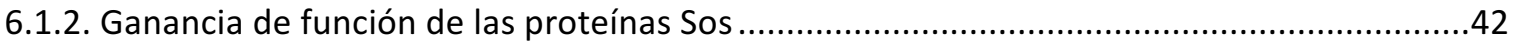

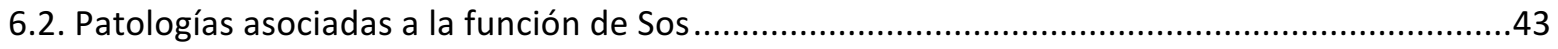

6.2.1. Implicación de las proteínas Sos en procesos tumorales .....................................................43

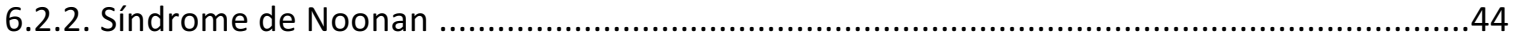

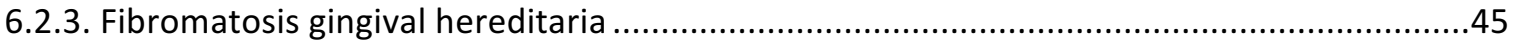

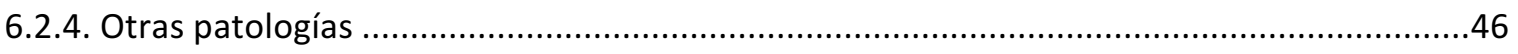

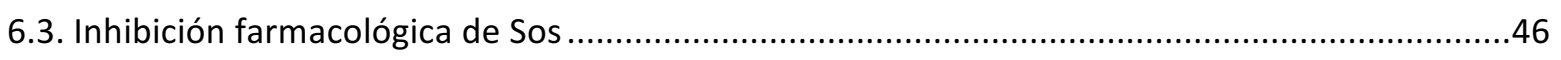

7. Implicación de Sos1 y Sos 2 en la homeostasis de la piel...........................................................48

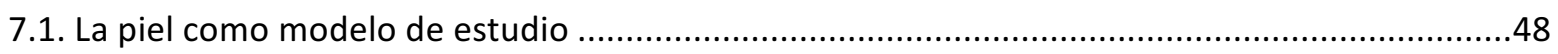


7.2. Estructura de la epidermis

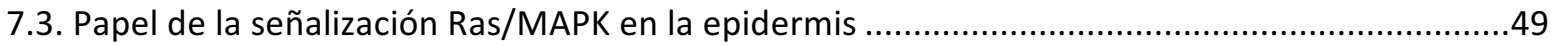

7.4. Importancia de las proteínas Ras y Rac en carcinogénesis epitelial ..........................................50

Justificación y objetivos/Aims............................. 53

Material y métodos ............................................. 59

1. Generación de la colonia de animales deficientes para las proteínas Sos ....................................61

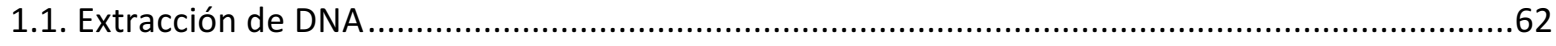

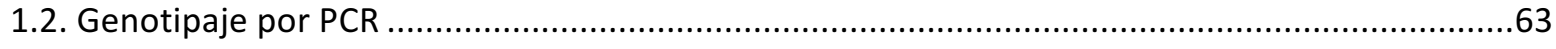

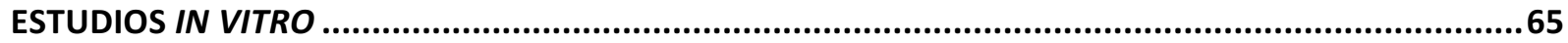

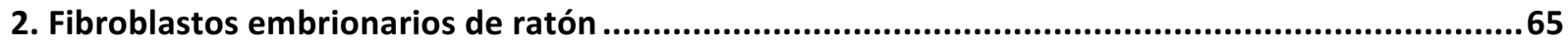

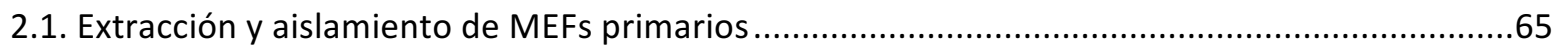

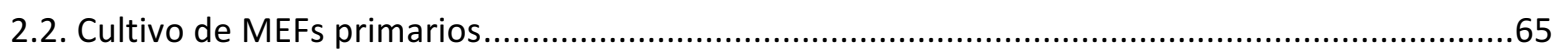

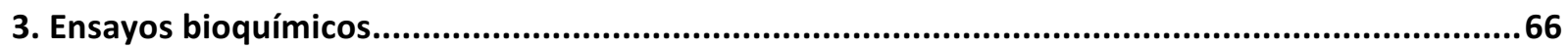

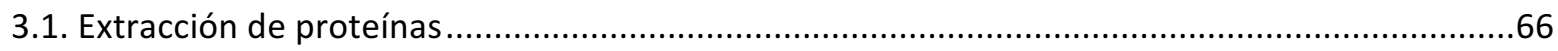

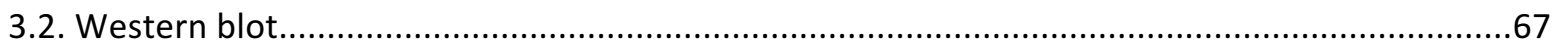

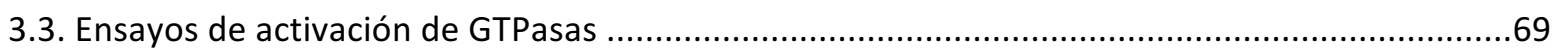

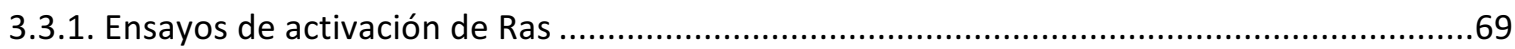

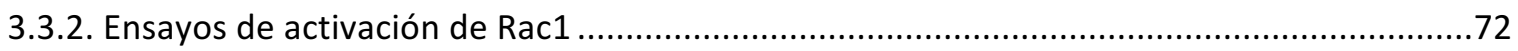

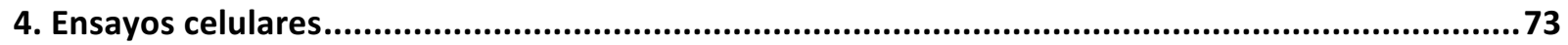

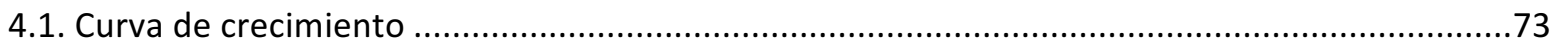

4.2. Ensayo de senescencia mediante tinción de $\beta$-Galactosidasa .................................................74

4.3. Ensayo de viabilidad celular y actividad metabólica con alamarBlue ${ }^{\circledR}$......................................75

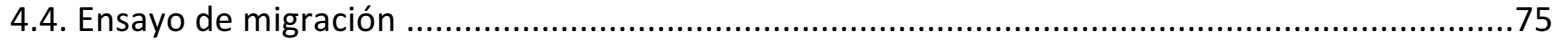

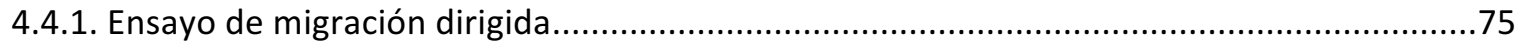

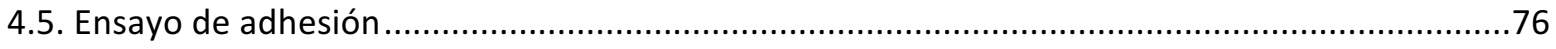

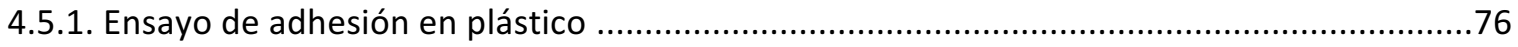

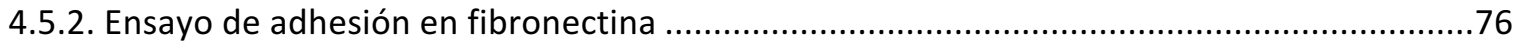

4.6. Estudio de la dinámica de adhesiones focales en célula viva mediante microscopía de

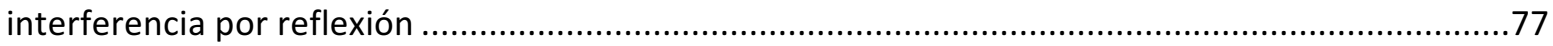

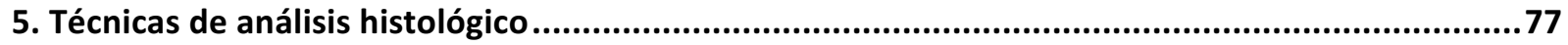

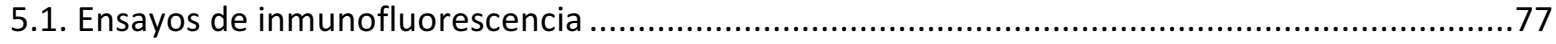

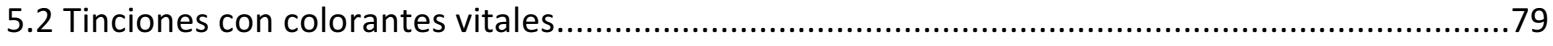

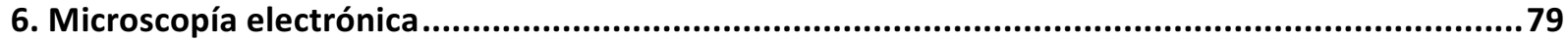




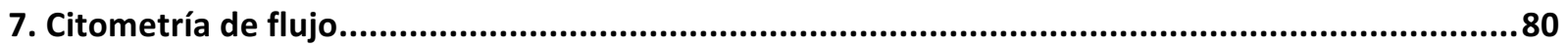

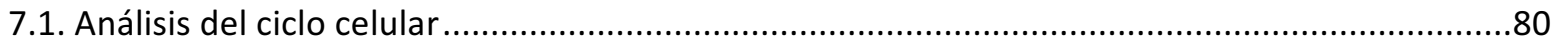

7.2. Análisis de la muerte celular por citometría de flujo .............................................................81

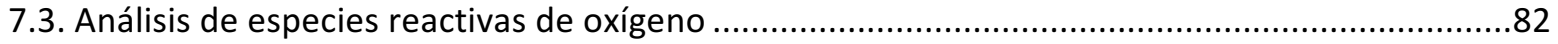

7.3.1. Análisis de las especies reactivas de oxígeno totales ..........................................................

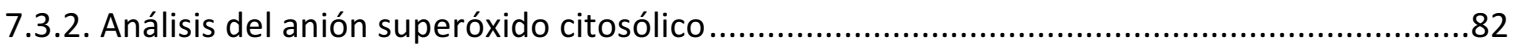

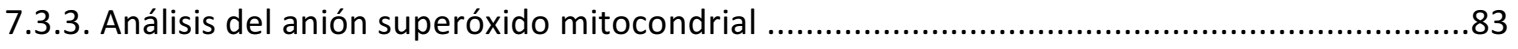

7.4. Análisis del potencial de membrana mitocondrial ...............................................................83

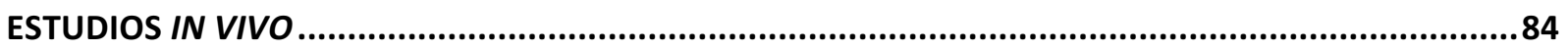

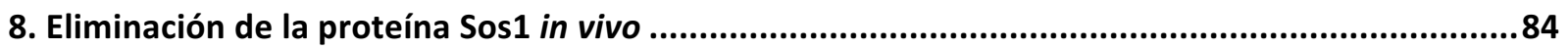

9. Ensayos de proliferación, muerte celular y respuesta inflamatoria tras la eliminación de Sos1 y

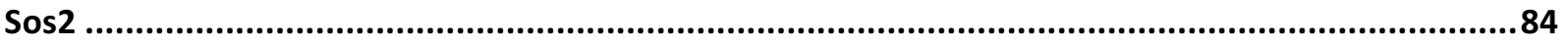

9.1. Ensayo de proliferación tras la administración tópica con TPA ...............................................85

9.2. Ensayo de muerte celular tras la administración tópica con DMBA ........................................85

9.3. Ensayo de respuesta proliferativa e inflamatoria tras administración tópica de TPA en dosis

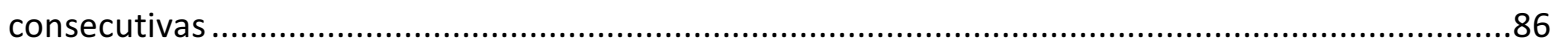

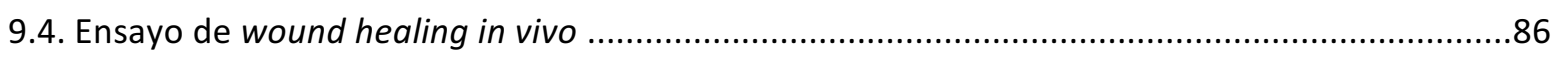

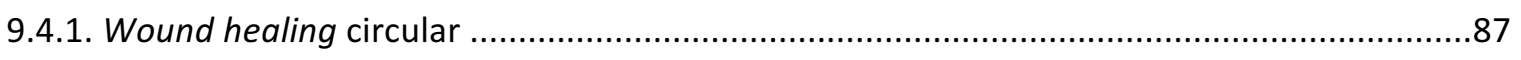

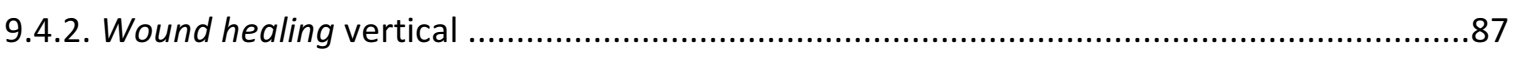

10. Modelo químico de carcinogénesis epitelial..............................................................................88

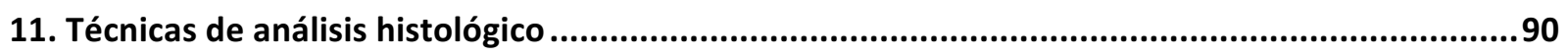

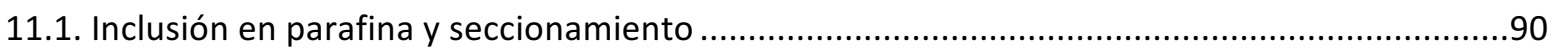

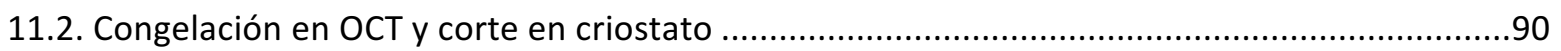

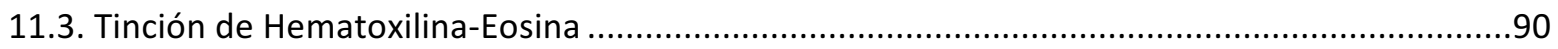

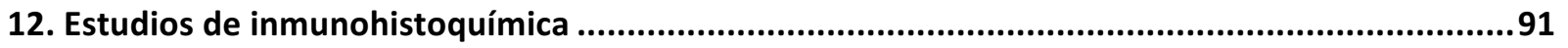

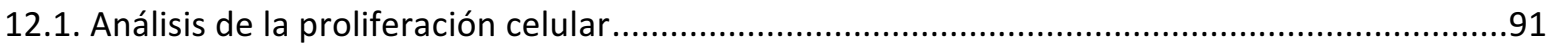

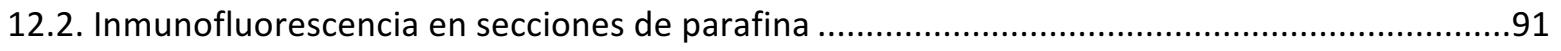

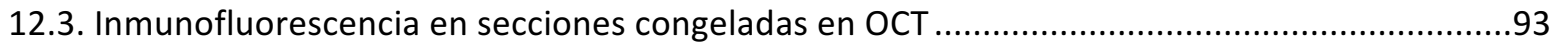

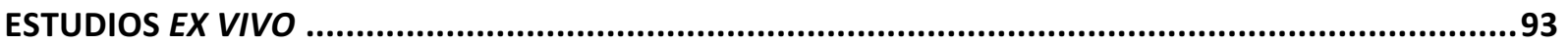

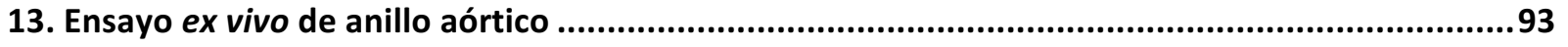

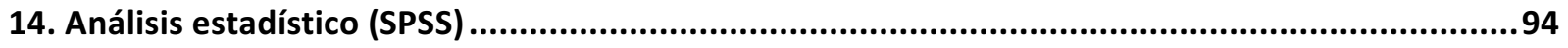

Resultados ...................................................... 95

1. Papel de las proteínas Sos en la regulación de la morfología celular, la proliferación, la migración y la adhesión celular........................................................................................................................97

1.1. Relevancia funcional de la proteína Sos1 en la morfología celular de los fibroblastos...............97 
1.2. Redundancia funcional parcial de Sos 1 y Sos 2 en el control de la proliferación celular 99

1.3. Represión transcripcional y daño en el DNA en células deficientes para la proteína Sos 1 ........103

1.4. Estudio de la función de las proteínas Sos en la organización y la dinámica del citoesqueleto106

1.4.1. Organización del citoesqueleto en células deficientes Sos1 y/o Sos2 ..............................106

1.4.2. Redundancia funcional parcial de Sos1 y Sos2 en la migración celular..............................107

1.4.3. Alteración de la adhesión celular tras la eliminación de Sos1 y Sos 2 ................................111

1.4.4. Importancia de Sos1 y Sos2 en la dinámica de adhesiones focales ................................115

1.5. Efecto de la eliminación de Sos1 y Sos2 en las rutas de señalización Ras/MAPK y PI3K/Akt....118

1.5.1. Activación de las rutas Ras/MAPK y PI3K/Akt en células deficientes de las proteínas Sos 118

1.5.2. Activación de Rac1 en células deficientes para Sos1 y Sos2 ..........................................122

2. Implicación de Sos1 y Sos2 en autofagia ..............................................................................123

2.1. La eliminación de Sos1 provoca acumulación de lisosomas ...................................................123

2.2. La ausencia de Sos1 activa mecanimos de autofagia .............................................................124

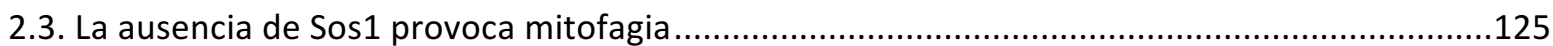

3. Importancia de Sos1 y Sos2 en el balance redox de la célula ..................................................126

3.1. Acumulación de especies reactivas de oxígeno en células carentes de la proteína Sos1 .........126

3.2. Disminución del potencial de membrana mitocondrial tras la eliminación de Sos1................129

3.3. Recuperación de la proliferación y organización del citoesqueleto en células deficientes para Sos1 tras el tratamiento con antioxidantes.... 130

3.4. Reversión del efecto en proliferación y del estado redox en células deficientes de Sos1 tras el

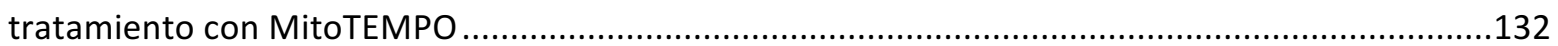

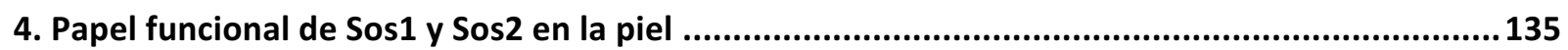

4.1. Relevancia de Sos1 y Sos2 en la fisiología de la piel..................................................................135

4.1.1. Redundancia funcional parcial de Sos 1 y Sos2 en la homeostasis de la piel.....................135

4.1.2. Importancia de Sos 1 y Sos 2 en los procesos de proliferación y muerte celular .................138

4.1.3. Implicación de Sos1 y Sos2 en la vascularización de la piel.............................................139

4.2. Papel de Sos1 y Sos2 en proliferación, muerte y respuesta inflamatoria en respuesta a estímulos.

4.2.1. Estudio de la proliferación dependiente de estímulo en la epidermis de animales deficientes para Sos.

4.2.2. Análisis de la muerte celular en ausencia de Sos1 y Sos2 tras un estímulo pro-apoptótico.

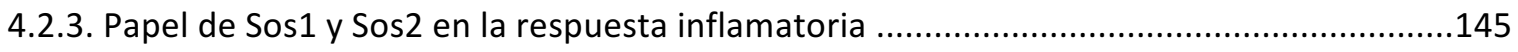

4.3. Implicación de Sos1 y Sos2 en el proceso de wound healing ..................................................148

4.3.1. Papel de Sos1 y Sos2 en el proceso de remodelación de la piel. WH circular....................148

4.3.2. Importancia de Sos1 y Sos2 en la regeneración cutánea. WH vertical 152 
5. Papel de Sos1 y Sos2 en un modelo de carcinogénesis epitelial inducida .................................156

5.1. Modelo 1: Importancia de las proteínas Sos en el inicio y progresión tumorales.....................156

5.1.1. La ausencia de Sos1 retrasa el inicio y la progresión tumoral ..........................................156

5.1.2. Sos1 y Sos2 son necesarias para el desarrollo de carcinomas de célula escamosa ...........159

5.1.3. La ausencia de Sos1 reduce la capacidad de proliferación de queratinocitos en tumores 162

5.1.4. Aumento de la apoptosis en tumores deficientes de Sos 1 y Sos 2 ...................................163

5.2. Modelo 2: Implicación de Sos1 en tumores pre-existentes .................................................165

5.2.1. Diminución de la progresión tumoral tras la eliminación de Sos1 en tumores pre-

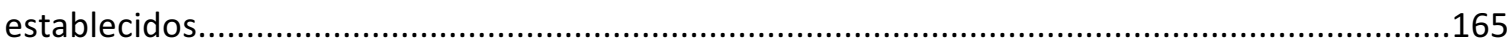

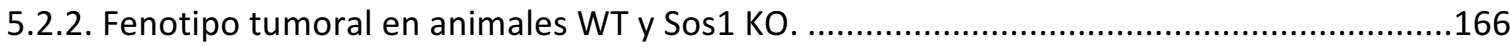

5.2.3. Disminución de la proliferación tumoral tras la eliminación de Sos 1 ...............................167

6. Implicación de Sos1 y Sos2 en angiogénesis. Ensayo de anillo aórtico. .....................................169

Discusión ......................................................173

1. Especificidad funcional de Sos1 en el mantenimiento de la morfología celular..........................176

2. Prevalencia funcional de Sos1 en el control de proliferación celular, la progresión del ciclo celular, el nivel de compactación de la cromatina y la integridad del DNA ............................................176

3. Implicación de las proteínas Sos en la organización del citoesqueleto........................................179

4. Papel de las proteínas Sos en la migración celular......................................................................180

5. Papel de las proteínas Sos en la adhesión celular.................................................................183

6. Activación de las rutas Ras/MAPK y PI3K/Akt en células carentes de las proteínas Sos ..............184

7. Activación de Rac1 en células deficientes de las proteínas Sos ..................................................186

8. Prevalencia de Sos1 sobre Sos 2 en la regulación del estado redox y el mantenimiento de la homeostasis mitocondrial ....................................................................................................... 187

9. Función prevalente de Sos1 en el mantenimiento de la homeostasis de la piel ..........................189

11. Importancia de las proteínas Sos en la reparación del daño tisular en la piel ...........................192

12. La eliminación de Sos1 afecta al inicio y a la progresión tumoral en tumores epiteliales inducidos

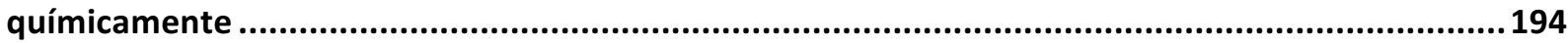

13. La eliminación de Sos1 en tumores epiteliales pre-existentes reduce el crecimiento tumoral .198

Conclusiones/Conclusions.......................................201

Bibliografía ................................................207

English summary ..................................................233 


\section{Índice de abreviaturas}

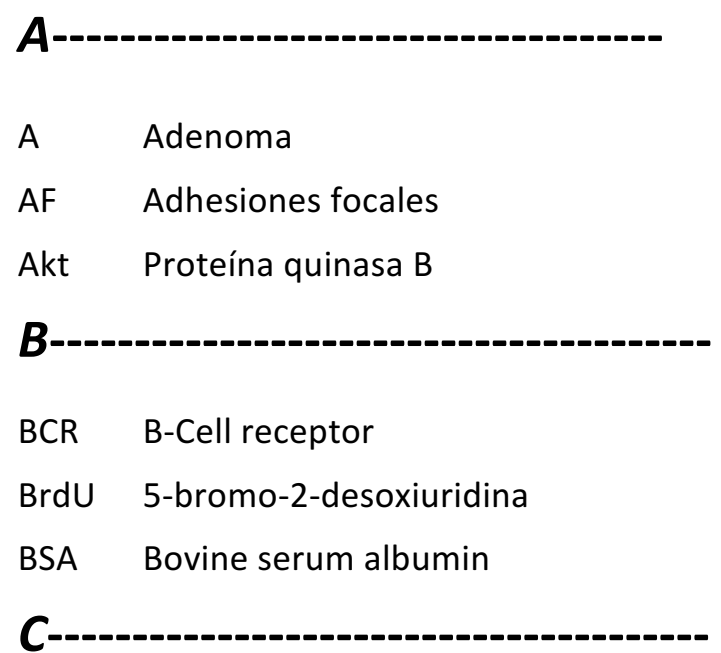

\section{CCE Carcinoma de célula escamosa \\ CDKs Quinasas dependientes de ciclinas \\ CKIs Inhibidores de CDKs}

CNrasGEF Cyclic Nucleotide dependent Ras GEF)

CRIB Cdc42- and Rac-interactive binding motif

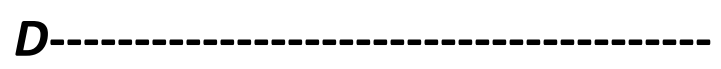

DAPI 4'6-diamino-2-fenilindol

DCFA Dicloro-fluoresceína

$\Delta \Psi \quad$ Potencial de membrana mitocondrial

DHE Dihidroetidio

DKO Doble knockout

DMBA 7,12-Dimetil-benz( $\alpha$ )antraceno

DMEM Dulbecco's Modified Eagle's Medium

\section{E}

EDTA Ácido etilen-diamino tetracético

EGCS Endothelial Cell Growth Supplement

EGF Epidermal growth factor

EGFR Epidermal growth factor receptor

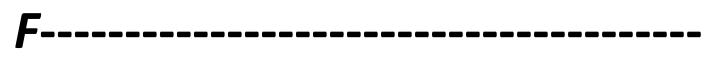

FBS Fetal bovine serum

FN Fibronectina

G

GAPs GTPase-activating proteins

GDP Guanosín 5'-difosfato

GEFs Guanine nucleotide exchange factors

GPCR G-protein coupled receptor

GSH Glutation

GTP Guanosín 5'-trifosfato

H----------------------------------------

h horas

HGF1 Fibromatosis ginvival hereditaria tipo 1

H3K9me3 Histona 3-trimetilada en la lisina 9

H4-acet Histona 4-acetilada

HP1 $\curlyvee$ Proteína de heterocromatina $1 \curlyvee$

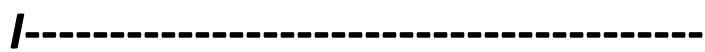

IF Inmunofluorescencia

IP loduro de propidio

i.p Inyección intraperitoneal

IPTG Isopropil- $\beta$-D-1-tiogalactopiranósido

IRM Interference reflection microscopy

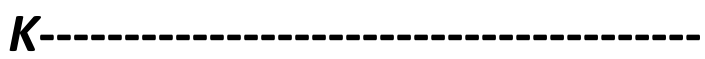

KO Knockout

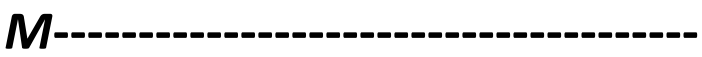

MEFs Mouse embryonic fibroblasts

min minutos

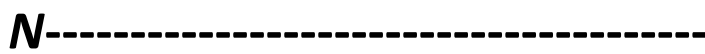

NAC N-acetil cisteina

NF1 Neurofibromina-1 


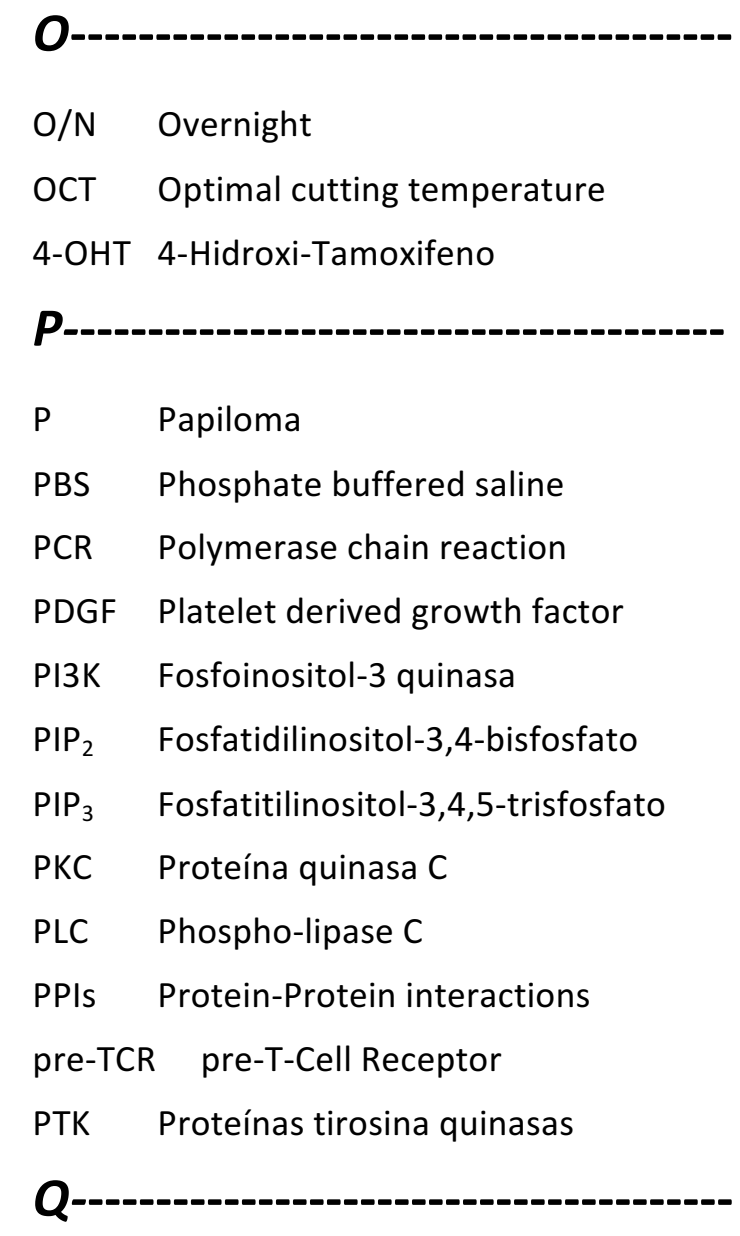

Q Queratoacantoma

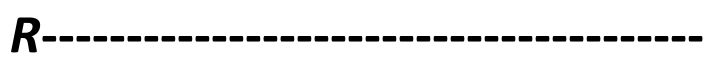

RalGDS Ras-like Guanine nucleotide Dissociation Stimulator

Ras Rat sarcoma

RasGRF Ras-specific guanine nucleotidereleasing factor

RasGRP Ras guanyl-releasing protein

Raf Rapidly accelerated fibrosarcoma

RE Retículo endoplásmico

Redox Reducción-oxidación
REM Ras exchanger motif

ROS Reactive oxygen species

RSK Ribosomal s6 kinase

RTK Receptor tirosina quinasa

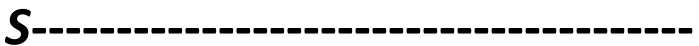

Sos Son of Sevenless

SDS Dodecil sulfato sódico

$\mathrm{SH} 2$ Dominio de homología a Src de tipo 2

SH3 Dominio de homología a Src de tipo 3

SN Síndrome de Noonan

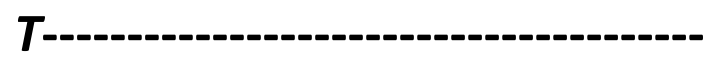

TA Temperatura ambiente

TAM Tamoxifeno

TAE Tris-acetate-EDTA

TBS-T Tampón tris salino con Twenn-20

TPA 12-O-TetradecanoylPhorbol-13Acetate

TCR T-Cell Receptor

W

WB Western blot

WH Wound healing

WT Wild-type 


\section{Índice de Figuras}

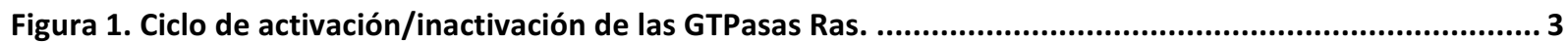

Figura 2. Localización subcelular de las proteínas Ras. ................................................................................ 6

Figura 3. Principales vías efectoras de las proteínas Ras. ......................................................................... 10

Figura 4. Estructuras citoplasmáticas reguladas por las RhoGTPasas...................................................... 12

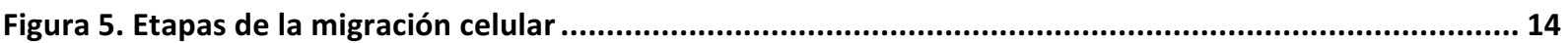

Figura 6. Dominios estructurales de las familias de RasGEF ....................................................................... 16

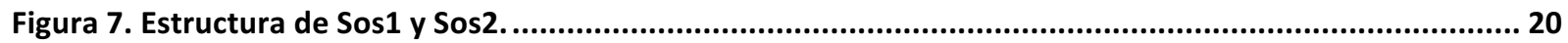

Figura 8. Modelo clásico de inhibición intramolecular de Sos. ...................................................................... 23

Figura 9. Nuevo modelo de la inhibición intramolecular de Sos1 .................................................................... 24

Figura 10. Señales activadoras de las proteínas Sos. ....................................................................................... 29

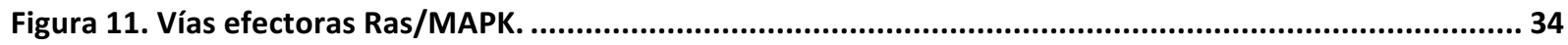

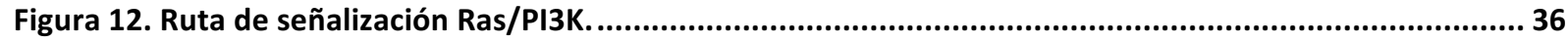

Figura 13. Estructura de la piel de un ratón adulto.......................................................................................... 48

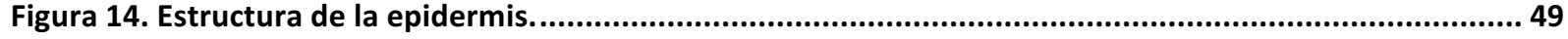

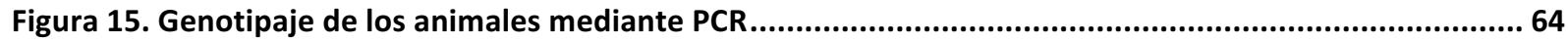

Figura 16. Cuantificación de la proteína Raf-GST tomando como referencia una recta patrón de BSA............ 71

Figura 17. Tinción con $\beta$-Galactosidasa en cultivos de MEFs tratados 9 días con $40 \mathrm{HT}$................................. 75

Figura 18. Fases del cierre de la herida en piel de ratón. ........................................................................... 87

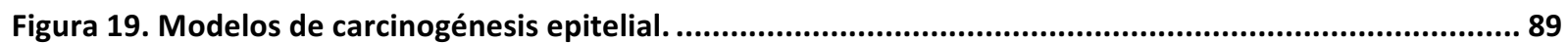

Figura 20. La ausencia de Sos1 provoca cambios morfología de los MEFs................................................. 99

Figura 21. Efecto de la eliminación de las proteína Sos en la proliferación celular...................................... 101

Figura 22. Alteraciones nucleares en MEFs carentes de Sos1.............................................................. 103

Figura 23. La eliminación de Sos1 induce represión transcripcional y daño en el DNA.................................. 105

Figura 24. Cambios en el citoesqueleto asociados a la eliminación de Sos1............................................... 107

Figura 25. Ensayo de migración celular en MEFs de los 4 genotipos experimentales. ................................... 111

Figura 26. Adhesión celular en MEFs de los 4 genotipos de interés tras 9 días de tratamiento con 40 HT. .... 114

Figura 27. Estudio de la dinámica de adhesiones focales en MEFs de los 4 genotipos de estudio. ................ 118

Figura 28. Efecto de la eliminación de Sos1 y/o Sos2 en la activación de Ras y sus principales rutas efectoras.

Figura 29. Efecto de la eliminación de Sos1 y/o Sos2 en la activación de Rac1. ...................................... 123

Figura 30. La eliminación de Sos1 induce acumulación de lisosomas.................................................. 124

Figura 31. Colocalización de autofagosomas y mitocondrias en ausencia de Sos1. .................................. 125

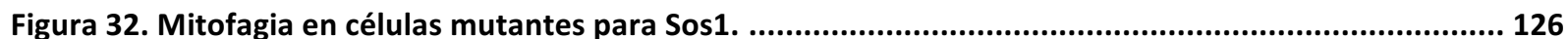


Figura 33. Estado redox en células de los 4 genotipos.................................................................... 128

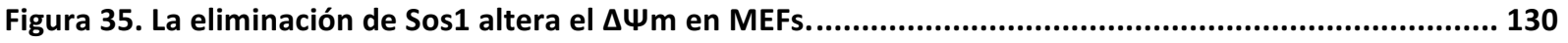

Figura 36. Efecto del tratamiento con los antioxidantes GSH y NAC en proliferación y morfología celular.... 132

Figura 37. Efecto del tratamiento con MitoTEMPO en MEFs de los 4 genotipos. ..................................... 134

Figura 38. Análisis histológico de la piel en animales de los 4 genotipos de estudio................................. 138

Figura 39. La ausencia de Sos1 afecta a la proliferación pero no a la viabilidad celular en la piel................ 139

Figura 40. Importancia de las proteínas Sos en la vascularización de la piel. ........................................... 141

Figura 41. Análisis de la proliferación tras tratamiento con una dosis de TPA. ....................................... 143

Figura 42. Estudio de la muerte celular tras la aplicación de DMBA. .................................................... 144

Figura 43. Efectos del TPA 1-4 en proliferación y respuesta inflamatoria aguda. ...................................... 147

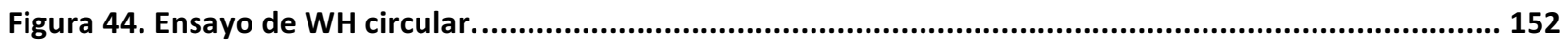

Figura 45. Estudio del proceso de WH vertical. ...................................................................... 156

Figura 46. La eliminación de Sos1 retrasa el inicio y la progresión tumoral. ............................................ 159

Figura 47. Caracterización y cuantificación de los tumores generados en el modelo 1 ................................ 162

Figura 48. La ausencia de Sos1 reduce la proliferación de las células tumorales...................................... 163

Figura 49. Análisis de muerte celular en tumores de los 4 grupos de estudio. .......................................... 164

Figura 50. La eliminación de Sos1 reduce el número y tamaño en tumores de piel pre-establecidos............ 166

Figura 51. Fenotipo tumoral en animales WT y Sos1 KO generados con el protocolo DMBA-TPA

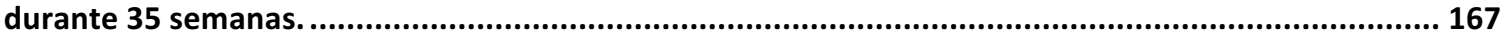

Figura 52. La eliminación de Sos1 reduce la proliferación en tumores pre-establecidos. ........................... 168 


\section{Introducción}



Introducción

\section{Conceptos generales}

La célula se comunica con el entorno a través de numerosas señales que recibe del medio exterior y que integra en distintas rutas de señalización. Los estímulos extracelulares son captados por receptores de superficie altamente específicos que transmiten la información a través de redes de transducción de señales. Muchos de estos receptores transmiten dicha información a través de las pequeñas GTPasas de la familia Ras (del inglés: Rat sarcoma) (Boguski and McCormick, 1993; Santos and Nebreda, 1989; Satoh et al., 1990; Schlessinger, 2000). Estas proteínas están altamente conservadas en todos los organismos eucariotas, desde levaduras hasta humanos. Este alto grado de conservación sugiere que las proteínas Ras ejercen un papel fundamental en numerosos procesos biológicos que controlan la homeostasis celular (Fernandez-Medarde and Santos, 2011a; Santos and Nebreda, 1989; Wennerberg et al., 2005).

La actividad de las proteínas Ras está altamente regulada por su unión a nucleótidos de guanina, de forma que en estado fisiológico estas GTPasas ciclan entre un estado activo (unidas a GTP), y un estado inactivo (unidas a GDP) (Santos and Nebreda 1989; Boguski and McCormick 1993) (Figura 1). Este ciclo de activación/desactivación les permite funcionar como interruptores moleculares conectando la estimulación de los receptores de membrana con múltiples rutas de señalización. De esta forma, regulan procesos celulares que incluyen la progresión del ciclo celular, la expresión génica, el transporte vesicular o la remodelación del citoesqueleto, entre otros. Mediante la regulación de estos procesos, la célula controla una amplia variedad de respuestas biológicas como la proliferación, diferenciación, motilidad, apoptosis y supervivencia celular (McKay and Morrison, 2007; Mitin et al., 2005; Takai et al., 2001; Tidyman and Rauen, 2016).

El balance y la coordinación entre estos procesos es esencial para el mantenimiento de la homeostasis de la célula. Por este motivo, defectos en la regulación de estas GTPasas, así como de sus rutas señalizadoras o efectoras, pueden desencadenar diversas patologías en humanos, desde enfermedades congénitas con graves trastornos en el desarrollo (Aoki et al., 2005; Kontaridis et al., 2006; Tidyman and Rauen, 2016) hasta diferentes tipos de cáncer o predisposición a desarrollarlos (Cawthon et al., 1990; Fernández-Medarde and Santos, 2011a; Karnoub and Weinberg, 2008). De hecho, a comienzos de la década de los 80 un gran número de trabajos probaron la existencia de mutaciones en Ras presentes en diversos tumores humanos (Bos et al., 1987; Parada et al., 1982; 
Perucho et al., 1981; Santos et al., 1982, 1984). Aproximadamente 1 de cada 3 tumores humanos expresan formas oncogénicas de Ras (http://www.sanger.ac.uk/genetics/CGP/cosmic). Estas formas mutantes de Ras son insensibles a la actividad de sus inhibidores, manteniéndose en un estado constitutivamente activo que les confiere una importante capacidad oncogénica (Feramisco et al., 1984; Karnoub and Weinberg, 2008; Malumbres and Barbacid, 2003; McGrath et al., 1984; Stacey and Kung, 1984).

Generalmente, la célula está sometida a gran cantidad de estímulos que debe integrar de forma adecuada. Además, debe garantizar que las proteínas que componen las rutas de transducción permanezcan inactivas en ausencia de los estímulos apropiados. Por esta razón, el ciclo de activación de Ras está controlado in vivo por dos grupos de proteínas reguladoras, los denominados GEFs (del inglés: Guanine nucleotide Exchange Factors) que activan a Ras catalizando el intercambio de GDP por GTP, y los GAPs (del inglés: GTPase-Activating Proteins) que lo inactivan estimulando su actividad intrínseca de hidrólisis de GTP a GDP (Boguski and McCormick, 1993). El equilibrio entre la actividad de ambos grupos de proteínas, GEFs y GAPs, determinará el nivel de activación de Ras (Figura 1).

Los factores intercambiadores de nucleótidos o GEFs son proteínas constituidas por varios dominios mediante los que interaccionan con distintos tipos de moléculas (proteínas, lípidos, segundos mensajeros, etc). Estas interacciones regulan su actividad en respuesta a un complejo balance de estímulos activadores e inhibitorios (Bos et al., 2007). Al igual que ocurre con las RasGTPasas, alteraciones en la regulación de la actividad de los GEFs por mutaciones activantes o por sobreexpresión, contribuyen a procesos de transformación celular, hiperplasia o alteraciones en el desarrollo (Hart et al., 2002; Tartaglia et al., 2007; Timofeeva et al., 2009; Tognon et al., 1998).

En mamíferos se han descrito 4 grupos principales de GEFs específicos de Ras: las proteínas Sos (del

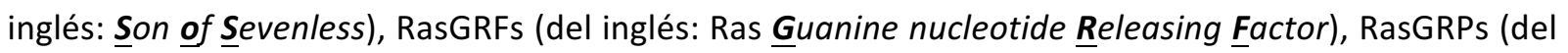

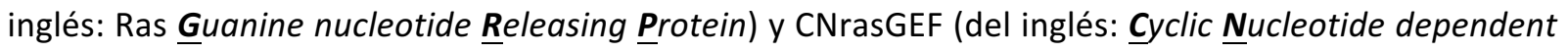
Ras GEF) (Bowtell et al., 1992; Ebinu et al., 1998; Pham et al., 2000; Rojas et al., 2011; Shou et al., 1992). Además, se ha descrito que la proteína PLCE puede presentar actividad RasGEF (Song et al., 2001). Todos los miembros de esta familia comparten el dominio Cdc25, que cataliza el intercambio de nucleótidos y siempre va acompañado por el dominio REM (del inglés: $\underline{R} a s$ Exchange $\underline{\text { Motif), }}$ ambos esenciales para activar a Ras. Sin embargo, existen diferencias en el patrón de expresión, 
localización, estructura y regulación de los distintos GEFs (Buday and Downward, 2008; FernándezMedarde and Santos, 2011b).

La gran diversidad en este grupo de proteínas respecto a sus sustratos (los GEFs superan considerablemente en número a las GTPasas) confiere a Ras la posibilidad de activarse en respuesta a una gran variedad de estímulos, en diferentes tejidos, y bajo una regulación espacio-temporal específica que depende además del tipo celular y del contexto (Mitin et al., 2005). Otro nivel de regulación viene dado por la alta especificidad de los GEFs sobre las distintas GTPasas. En el caso de las proteínas Sos, las cuales son el objeto de estudio de este trabajo, está descrito que pueden catalizar el intercambio de nucleótidos sobre las GTPasas clásicas de la familia Ras, H-Ras, K-Ras y NRas (Porfiri et al., 1994), aunque con distinta afinidad: H-Ras > N-Ras > K-Ras (Jaumot et al., 2002). Además, también activan otros miembros de la familia como TC21 (R-Ras2) y M-Ras (R-Ras3) (Graham et al., 1996; Ohba et al., 2000; Quilliam et al., 1999). Sin embargo, son incapaces de activar a las GTPasas R-Ras o RalA (Buday and Downward, 2008; Chardin et al., 1993; Gotoh et al., 1997). Sos puede también catalizar la activación de otras GTPasas como las de la familia Rho/Rac, cuya función principal es la regulación del citoesqueleto de actina (Nimnual et al., 1998; Sini et al., 2004).

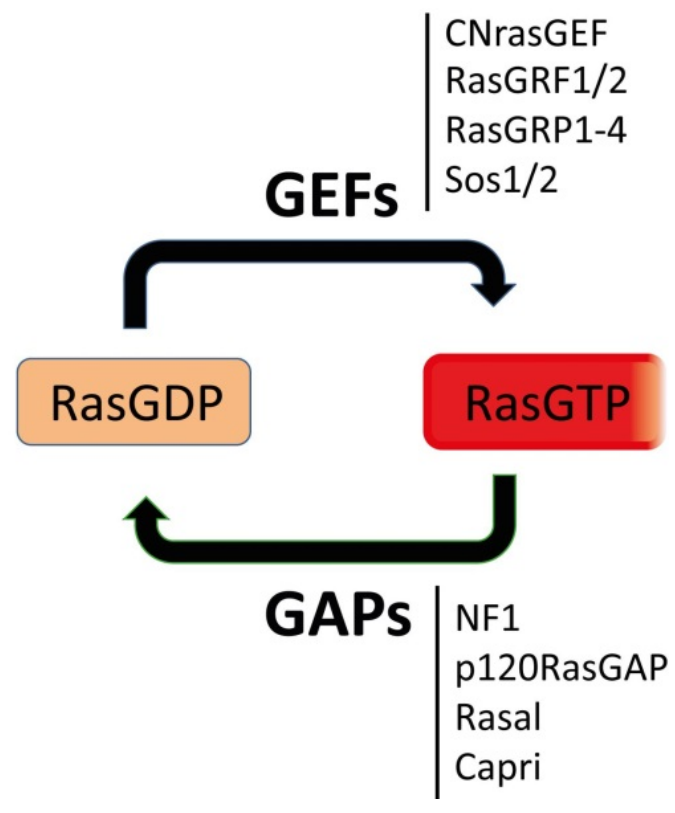

Figura 1. Ciclo de activación/inactivación de las GTPasas Ras. Los GEFs catalizan la activación de Ras mediante el paso entre GDP a GDP, por el contrario los GAPs controlan el paso entre el estado GTP a GDP mediante su capacidad de hidrólisis del GTP, inactivando así a Ras. El esquema indica las principales familias de RasGEFs y RasGAPs. 


\section{La familia de proteínas Ras}

Las proteínas Ras fueron las primeras GTPasas descritas y aisladas (Pulciani et al., 1982; Santos et al., 1982; Shimizu et al., 1983). Los 3 miembros canónicos de esta familia son: H-Ras, N-Ras, K-Ras4A y KRas 4B, dándose estos dos últimos por splicing alternativo a partir del mismo gen (Bar-Sagi, 2001; Barbacid, 1987; Jorge et al., 2002). Estas proteínas comparten una estructura molecular muy similar y la capacidad de unirse e hidrolizar nucleótidos de guanina. De este modo, las proteínas Ras transmiten señales extracelulares recibidas que desencadenan procesos específicos en la fisiología celular mediante su participación en rutas de señalización, siendo en este sentido la proliferación el proceso más relevante regulado por la familia de proteínas Ras. De hecho, la pérdida de su regulación supone su activación constitutiva que provoca el desarrollo de tumores y de enfermedades del desarrollo (Depeille et al., 2015; Haigis et al., 2008; Izeradjene et al., 2007; Jackson et al., 2001; Tartaglia et al., 2007, 2010). Su expresión es prácticamente ubicua aunque las diferencias de expresión dependen del tejido y de la fase de desarrollo (Denayer et al., 2010; Hancock, 2003; Leon et al., 1987; Roy et al., 2005). A pesar de su elevada homología ( $80 \%)$ las proteínas Ras muestran una especificidad funcional que basada en 1) las diferentes vías de procesamiento y localización en los diferentes compartimentos subcelulares, 2) los diferentes fenotipos mostrados en los modelos animales modificados genéticamente para $\mathrm{H}, \mathrm{K}$ y N-Ras, 3) el control transcripcional que ejerce cada isoforma en función de los diferentes contextos celulares, 4) las interacciones con sus moduladores RasGEFs y RasGAPs y con proteínas efectoras de la ruta de señalización Ras/MAPK y 5) el perfil de mutaciones de los diferentes tipos de tumores y enfermedades del desarrollo.

\subsection{Localización de Ras en los diferentes compartimentos celulares}

La distribución diferencial de las proteínas Ras en distintos compartimentos celulares depende principalmente de las diferentes modificaciones post-traduccionales que sufre cada una de ellas (Arozarena et al., 2011; Prior and Hancock, 2012). Aunque las proteínas Ras se localizan mayoritariamente en la membrana plasmática, se ha identificado la presencia de las diferentes formas canónicas de Ras en distintos compartimentos celulares (Figura 2). Aunque no se conoce en detalle cómo se regula esta distribución y la función específica en cada localización subcelular, se ha propuesto que gracias a esta localización diversa, las distintas proteínas Ras son capaces de integrar un elevado número de señales y les permite además activar un amplio número de proteínas 
efectoras, controlando de esta forma múltiples rutas de señalización. En este contexto, se ha encontrado que K-Ras localizado en el retículo endoplásmico (RE) puede activarse y generar una respuesta a determinados niveles de estrés oxidativo en la célula (Wu et al., 2010).

Se han identificado distintas proteínas Ras (H- y N-Ras) en el RE donde se farnesilan (Misaki et al., 2010) e incluso pueden sufrir metilación (K-Ras), y el aparato de Golgi donde H y N-Ras se pueden isoprenilar o palmitoilar, respectivamente (Hancock et al., 1990; Omerovic et al., 2007). Además, se ha descrito que cuando $\mathrm{H}$ - y N-Ras sufren despalmitoilación regresan al aparato de Golgi para ser nuevamente palmitoiladas y posteriormente transportadas a la membrana plasmática a través de endosomas (Goodwin et al., 2005) (Figura 2). Asimismo, Ras no sólo se transporta a través de endosomas, sino que se ha propuesto que puede regular la señalización en este compartimento celular en determinadas condiciones (Di Guglielmo et al., 1994) (Figura 2). También se ha encontrado Ras en la mitocondria. En concreto, se ha descrito que la proteína quinasa $C$ (PKC) es capaz de fosforilar a K-Ras en la serina 181 y así antagonizar el dominio de interacción de K-Ras con la membrana plasmática, promoviendo su translocación al citosol y su acumulación en la mitocondria (Bivona et al., 2006).

En este sentido, también se ha descrito la presencia de determinados RasGEFs en los diferentes orgánulos citados. Por ejemplo, algunos miembros de la familia RasGRP, pero no Sos, se localizan en el aparato de Golgi, aunque solo RasGRP1 es capaz de activar a Ras en este orgánulo (Bivona et al., 2003; Caloca et al., 2003; Chiu et al., 2002). Otro ejemplo es RasGRF, que también es capaz de localizarse en la membrana del aparato de Golgi (Komatsu et al., 2010). 


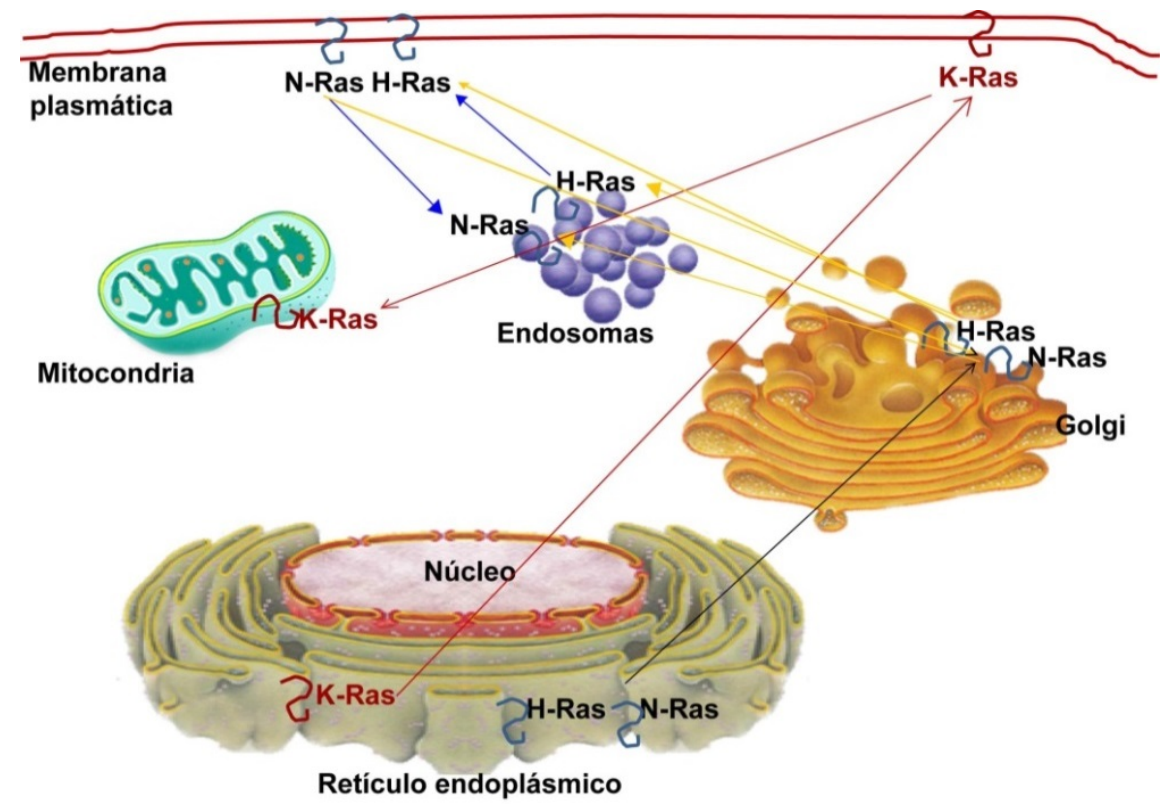

Figura 2. Localización subcelular de las proteínas Ras. Las proteínas Ras se localizan en distintos compartimentos celulares en función del procesamiento postraduccional de H, K y N-Ras. Modificada de (Alvarez-Moya, 2010).

\subsection{Modelos animales modificados genéticamente para las proteínas Ras}

La generación de modelos animales genéticamente modificados para las proteínas Ras permitió analizar la contribución específica de cada una de estas proteínas Ras en distintos contextos (Braun et al., 2006; Haigis et al., 2008; Jackson et al., 2001). Estos estudios permitieron también definir la importancia de cada una de las proteínas Ras durante el desarrollo embrionario. Por ejemplo, se ha demostrado la especificidad funcional K-Ras4B en el desarrollo embrionario (Albanese et al., 1995; Johnson et al., 1997; Koera et al., 1997) siendo la función de las formas H-Ras, N-Ras y/o K-Ras4A prescindibles durante este proceso (Esteban et al., 2001; Plowman et al., 2003, 2008; Umanoff et al., 1995). Los modelos animales generados recientemente permiten estudiar la ausencia individual o combinada de cada una de las proteínas canónicas permitiendo así estudiar en detalle la relación funcional entre cada una de ellas (Drosten et al., 2010).

El análisis conjunto de todos los trabajos realizados con modelos KO para una o varias proteínas Ras indica que sólo K-Ras4B es suficiente y necesario para el desarrollo de ratones hacia la etapa adulta. Esta noción se correspondería con la especificidad funcional de K-Ras4B que no presentan las proteínas H-Ras, N-Ras, o K-Ras4A (Johnson et al., 1997; Koera et al., 1997). Esta afirmación también se ha cuestionado ya que cuando se elimina K-Ras y se sustituye por secuencias de H-Ras bajo el 
control de regiones reguladoras del gen K-Ras, H-Ras puede reemplazar la función de K-Ras durante la embriogénesis, pero no durante la etapa adulta. De este modo se podría explicar la letalidad de los ratones K-Ras KO por su expresión en determinados tipos celulares en una o varias etapas del desarrollo y no por la incapacidad de las otras formas canónicas de Ras para compensar la función de K-Ras4B (Bar-Sagi, 2001).

\subsection{Diferencias asociadas a cada proteína Ras en el perfil transcriptómico}

El análisis de la expresión génica ha sido una herramienta ampliamente utilizada para estudiar la función de las proteínas Ras en condiciones tumorales (Vasseur S et al., 2003, Zuber J et al., 2000) así como para determinar las consecuencias de su ausencia en el contexto celular (Azrak et al., 2013; Castellano et al., 2007, 2009; Drosten et al., 2010).

El análisis de la especificidad funcional de las proteínas Ras en el perfil transcriptómico de fibroblastos carentes de los genes Ras canónicos H-Ras, N-Ras y K-Ras de forma individual o en combinación demostró que los genes Ras controlan específicamente diferentes funciones celulares (Azrak et al., 2013; Castellano et al., 2007, 2009). Por ejemplo, se identificó un conjunto de genes relacionados con la inmunidad y la apoptosis que estaban sobreexpresados en fibroblastos carentes de la proteína NRas (Castellano et al., 2007, 2009). Por otro lado, genes reguladores de la proliferación y progresión del ciclo celular estaban significativamente reprimidos tras la eliminación pérdida K-Ras (Azrak et al., 2013). Asignando de este modo una función reguladora específica de la inmunidad ligada a N-Ras y un papel fundamental en la proliferación asociado a K-Ras.

\subsection{Especificad de las proteínas Ras en la recepción y emisión de estímulos}

Existe una modulación diferente de los RasGEF y RasGAP sobre las diferentes formas canónicas de Ras (Bollag and McCormick, 1991; Clyde-Smith et al., 2000; Jaumot et al., 2002; Jones and Jackson, 1998; Shannon and Bollag, 2007). Por ejemplo, se ha descrito en estudios in vivo que RasGRF1 es capaz de activar a H-Ras y R-Ras pero no a N-Ras o K-Ras (Matallanas et al., 2003). También se ha mostrado que RasGRP2 puede activar a N-Ras y K-Ras pero no H-Ras (Clyde-Smith et al., 2000). Finalmente, se ha demostrado que las proteínas Sos activan a las tres proteínas canónicas $\mathrm{H}-, \mathrm{N}$ - y K-Ras, aunque con diferente grado de señal (H-Ras> N-Ras> K-Ras) (Jaumot et al., 2002). 
En cuanto a su participación en la señalización celular, H-, N-y K-Ras parecen ser capaces de activar cualitativamente las mismas vías efectoras, pero con distinta capacidad activadora de estas rutas (Liao et al., 2003; Plowman et al., 2005, 2008; Villalonga et al., 2001; Walsh and Bar-Sagi, 2001). Por ejemplo, los diferentes Ras tienen diferente capacidad para activar Raf-1 y PI3K (fosfoinositol 3quinasa) (Yan et al., 1998). De acuerdo con estos datos, la proteína K-Ras es supuestamente más potente que H-Ras para inducir la activación in vivo de Raf-1, en base a la mayor eficiencia mostrada por K-Ras para reclutar a Raf-1 a la membrana plasmática (Yan et al., 1998). Por el contrario, la proteína H-Ras activa con mayor eficacia que K-Ras a PI3K (Yan et al., 1998).

En resumen, la activación de las diferentes proteínas Ras induce respuestas celulares que dependen de su activación modulada por GEFs y GAPs, de los efectores activados de forma preferente y de la intensidad de esa activación.

\subsection{Implicación de las proteínas Ras en procesos tumorales}

Puesto que Ras es uno de los oncogenes mutados más frecuentemente en tumores humanos, tanto su activación como su señalización a distintas proteínas efectoras deben estar estrictamente controladas para asegurar la prevención de procesos oncogénicos (Barbacid, 1990).

Las mutaciones de ganancia de función de los genes Ras (H-Ras, N-Ras y K-Ras) constituyen una de las primeras alteraciones específicas identificadas en el cáncer humano (Cawthon et al., 1990; Fernández-Medarde and Santos, 2011a; Karnoub and Weinberg, 2008). Los diferentes tumores muestran una activación de una u otra isoforma Ras de manera preferente, describiendo una especificidad de las proteínas Ras en los diferentes tipos de neoplasias. Las mutaciones oncogénicas más comunes son las que afectan a los codones 12, 13 o 61 (Forbes et al., 2011). Concretamente, las formas $\mathrm{H}$ - y K-Ras están mutadas más frecuentemente en el codón 12 mientras que la mutación de NRas afecta preferentemente al codón 61. Mayoritariamente, las mutaciones que afectan a K-Ras se detectan en etapas tempranas de la progresión tumoral, lo que sitúa a K-Ras como una de las causas primarias en un elevado número de tumores en humanos (Forbes et al., 2011). Estas mutaciones se presentan con mayor frecuencia en cáncer de páncreas, cáncer de colon y cáncer de pulmón (Almoguera et al., 1988; Kipp et al., 2010; Vaughn et al., 2011) mientras que las mutaciones de $\mathrm{H}$ - y NRas son poco frecuentes en estas neoplasias. Las mutaciones en $\mathrm{N}$-Ras son frecuentes en varios tipos de leucemias (Forbes et al., 2011), tumores tiroideos y melanoma (Forbes et al., 2011) mientras que 
las mutaciones de $\mathrm{H}$ - y K-Ras en estos tumores son mucho menos frecuentes (Bentires-Alj $\mathrm{M}$ et al., 2006). Además, mutaciones en H-Ras tienen lugar en una proporción importante de cáncer de vejiga (Boulalas et al., 2009; Castillo-Martin et al., 2010). Estas observaciones apoyan la diferente especificidad biológica de las proteínas Ras en el contexto tumoral.

Se han empleado numerosas aproximaciones terapéuticas diseñadas para suprimir la activación de Ras oncogénico, aunque muchas de ellas han mostrado una eficacia muy limitada. Por ejemplo, los inhibidores de la farnesil transferasa que impiden la farnesilación de Ras, y así dificulta el reclutamiento y anclaje de Ras a la membrana y su posterior activación, no mostraron una eficiencia significativa (Appels et al., 2005; Mazieres et al., 2004). Una de las razones de su ineficacia se debía a modificaciones alternativas de Ras mediante otras enzimas como la geranilgeranilasa (Reid et al., 2004). Por otro lado, se han desarrollado compuestos dirigidos a bloquear la señalización efectora generada por Ras oncogénico. Estos fármacos inhiben la señalización efectora a través Raf o de PI3K (Edwards et al., 2002; Smith et al., 2006; Wong et al., 2010) y han resultado más eficaces que otras estrategias farmacológicas empleadas. Estos compuestos incluyen los inhibidores de Raf Sorafenib o Vemurafenib, que han resultado ser herramientas útiles en el tratamiento de determinadas neoplasias de pulmón con mutación en B-Raf, tumores del tiroides, melanomas con la mutación en BRaf V600E o en la leucemia mieloide aguda (Ascierto, 2012; Mori et al., 2008; Sánchez-Torres et al., 2013). Sin embargo, las células tumorales han sido capaces de desarrollar distintos mecanismos de resistencia a estos tratamientos (Baines et al., 2011; Pratilas et al., 2009). En los últimos años, el desarrollo de nuevos fármacos se ha focalizado en la generación de compuestos capaces de unirse a la interfaz de las moléculas activadoras y/o efectoras de Ras, dirigidos a impedir las interacciones proteína-proteína o PPIs (del inglés: Protein-Protein Interactions). Este grupo de fármacos emergentes se describe en más profundidad en el apartado 6.3.

\subsection{Rutas de señalización mediadas por Ras}

Aunque posteriormente detallaremos mucho más en profundidad las principales rutas de señalización mediadas por las proteínas Sos, muchas de ellas convergiendo en las proteínas Ras, describiremos muy brevemente las principales rutas de señalización mediadas por las proteínas Ras.

Las cascadas de señalización mediadas por las proteínas Ras inducen diferentes respuestas biológicas, siendo la proliferación celular una de las más relevantes (Meloche and Pouysségur, 2007). Las rutas 
mejor caracterizadas son la ruta Ras/ERK, que regula de manera principal las señales mitogénicas (Meloche and Pouysségur, 2007) y la ruta PI3K/Akt, que está implicada principalmente en supervivencia celular (Vivanco and Sawyers, 2002). Además, la ruta RaIGDS (del inglés: Ras-like Guanine nucleotide Dissociation Stimulator) que activa la familia de GTPasas Ral, está involucrada en el tráfico vesicular controlando procesos como la exocitosis (Malumbres and Barbacid, 2003) (Figura 3).

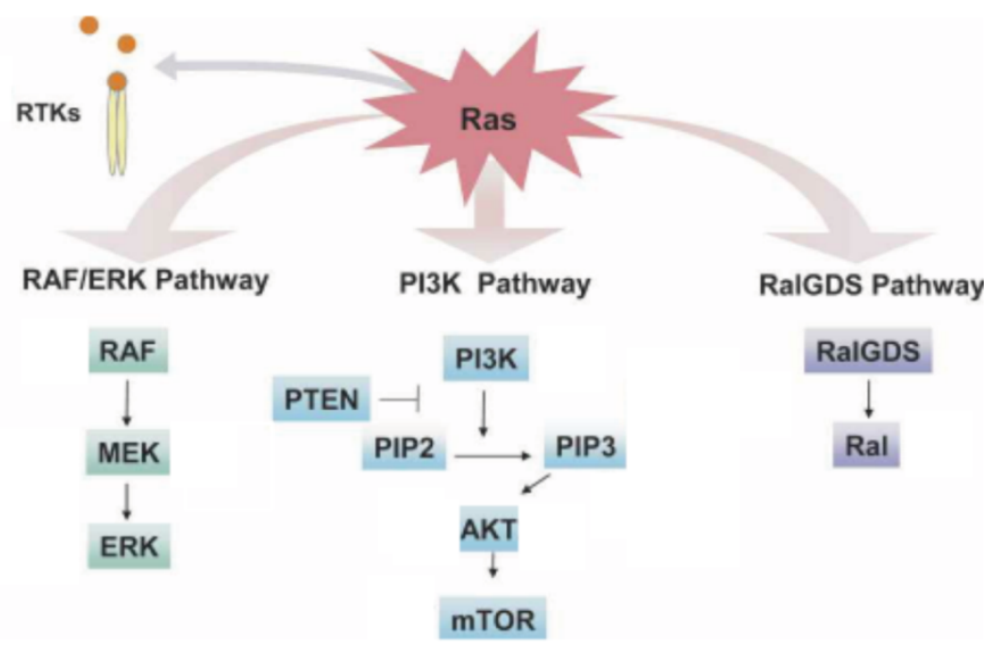

Figura 3. Principales vías efectoras de las proteínas Ras. Una vez activadas las GTPasas Ras, éstas interaccionan con proteínas efectoras regulando diferentes rutas de señalización. Las principales rutas controladas por Ras son la ruta Ras/MAPK, la ruta PI3K/Akt y la ruta iniciada por RaIGDS. A través de estas rutas, Ras controla procesos fundamentales como la proliferación diferenciación y supervivencia celulares. Tomado de (Hezel et al., 2006).

\section{La familia de proteínas Rho}

\subsection{Conceptos generales}

Esta familia de GTPasas se agrupa en ocho subfamilias: Cdc42, Rac, RhoBTB, RhoH, Rho, Rnd, RhoD y Miro. Su papel principal en la célula es la regulación del citoesqueleto de actina (Van Aelst and D’Souza-Schorey, 1997; Hall, 1998) aunque también regulan la expresión génica, la actividad enzimática y la progresión del ciclo celular, y además son importantes efectores de las rutas mediadas por Ras (Van Aelst and D'Souza-Schorey, 1997; Amano et al., 2010; Etienne-Manneville and Hall, 2002; Hall, 1998; Kumar et al., 2006). Las RhoGTPasas principales y más conservadas son Rac, Rho y Cdc42, que pertenecen al grupo RhoGTPasas denominadas "clásicas" mientras que al resto se las denominan RhoGTPasas "atípicas" (Aspenström et al., 2004). Estas últimas no son moduladas por 
GEFs y GAPs, sino que su regulación viene dada por el control de la expresión génica, por degradación vía proteasoma o por fosforilación (Ruusala and Aspenstrom, 2008). Como ya hemos citado, Sos1 es capaz de activar directamente a la RhoGTPasa Rac1 (Innocenti et al., 2002; Nimnual and Bar-Sagi, 2002; Nimnual et al., 1998). Asimismo, Ras es capaz de regular a Rac1 a través de sus efectores directos Tiam1 y RaIGDS, a través de PI3K (Lambert et al., 2002; Michiels et al., 1995; Nimnual et al., 1998; Rodríguez-Viciana et al., 1997).

\subsection{Funcionalidad de las RhoGTPasas}

Rac, Rho y Cdc42 conectan las señales recibidas en distintos tipos de receptores de membrana como receptores tirosina quinasa (RTK) receptores de citoquinas, GPCRs (del inglés: G-Protein-Coupled Receptors) e incluso integrinas, con el citoesqueleto de actina (Chiariello et al., 2010; Miao et al., 2002; Schiller, 2006). En concreto, Rac induce la formación de lamelipodios y ruffles de membrana, mientras que Rho controla la formación de fibras de estrés y adhesiones focales (AF), y Cdc42 contribuye a la generación de la polaridad celular y a la formación de filopodios (Jaffe and Hall, 2005; Nobes and Hall, 1999).

Las principales estructuras del citoesqueleto en las que la acción de las RhoGTPasas es necesaria para su formación son las siguientes (Figura 4):

-Adhesiones focales: son estructuras dinámicas que permiten el anclaje de las células a la matriz extracelular a través de integrinas. El desensamblaje de estas adhesiones se produce cuando la célula migra o se divide.

-Fibras de estrés: son haces contráctiles de filamentos de actina antiparalelos conectados mediante moléculas de miosina que permiten el desplazamiento de un filamento de actina respecto de otro generando tensión y contracción celular.

-Filopodios: son estructuras estrechas y alargadas formadas por actina en disposición paralela que permiten sensar el ambiente extracelular y además proporcionan rigidez a la célula.

-Lamelipodios: son extensiones amplias del citoplasma que se generan en el eje migratorio de las células cuando éstas se desplazan, y presentan filamentos de actina muy ramificados. La elongación de estos filamentos de actina hacia la membrana plasmática permite a la célula desplazarse.

-Ruffles de membrana: los lamelipodios pueden ondularse o doblarse hacia arriba o hacia atrás en un proceso llamado ruffling, generando ruffles periféricos o ruffles dorsales circulares. 
La regulación del citoesqueleto de actina, controlada por estas proteínas a través de estas estructuras (Figura 4), es esencial para los procesos de migración y adhesión celular.

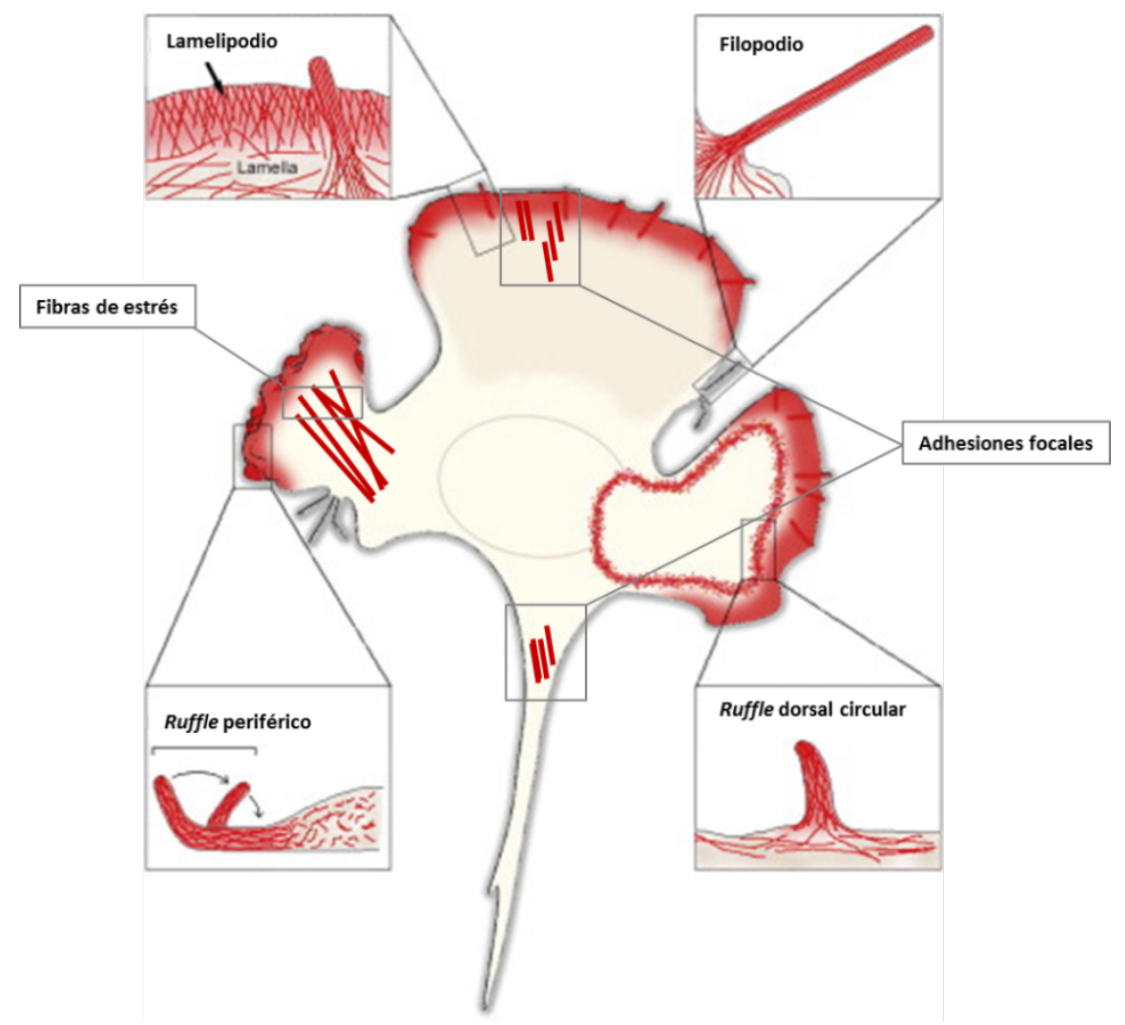

Figura 4. Estructuras citoplasmáticas reguladas por las RhoGTPasas. Estas formaciones de la membrana plasmática están implicadas en los procesos de migración y adhesión celulares. Modificada de (Ladwein and Rottner, 2008)

\subsubsection{Función de las RhoGTPasas en la migración celular}

La forma de migración celular más común es la migración dirigida por lamelipodios (Ladwein and Rottner, 2008; Takenawa and Suetsugu, 2007). Este proceso está controlado por un balance espaciotemporal en la activación/desactivación de las GTPasas Rac, Rho y Cdc42 (Ridley, 2001; Ridley et al., 2003). A continuación describimos las etapas de la migración celular a través de lamelipodios y el papel específico de las diferentes RhoGTPasas en cada una de ellas.

1. Polarización celular: La polaridad es básica para el inicio de la migración. Clásicamente, se ha descrito que la polarización estaba controlada por la proteína Cdc42, que junto con otras proteínas promueve el tráfico de vesículas hacia el frente de avance y el centro organizador de microtúbulos (Lee et al., 2005) (Figura 5). También se ha demostrado la importancia de la miosina II en el eje de 
retracción celular, que permite así una correcta polarización de la célula (Mseka and Cramer, 2011; Vicente-Manzanares et al., 2008) (Figura 5).

2. Formación del lamelipodio y establecimiento de: Rac1, a través del complejo WAVE, promueve la formación y mantenimiento de los lamelipodios (Figura 5). Éstos se estabilizan gracias a la formación de los complejos focales. A su vez, durante la formación de los complejos focales intervienen las integrinas y otros componentes estructurales (Kornberg et al., 1992). Además, debe producirse la contracción de los complejos de actomiosina para lograr que la célula se despegue del extremo posterior. Para este proceso es necesaria la implicación de la miosina II, que además estabiliza el lamelipodio, siendo todo ello regulado por la GTPasa RhoA (Barry and Critchley, 1994; EtienneManneville, 2013).

3. Retracción de la región posterior: Este paso lo controlan integrinas que reclutan RhoGTPasas como Rac1 y RhoA (Ridley, 2001; Ridley et al., 2003). Seguidamente RhoA media la contracción celular a través de la fosforilación de la cadena ligera de la miosina, que desencadena un aumento de la contractilidad y la tensión en las zonas de adhesión (Ridley, 2001; Ridley et al., 2003). Esta tensión genera que el extremo posterior de la célula se despegue (Figura 5). Para ello es necesario el desemsamblaje de las AF formadas. Se cree que la proteína Rho actúa sobre la proteína paxilina en este proceso (Etienne-Manneville, 2013).

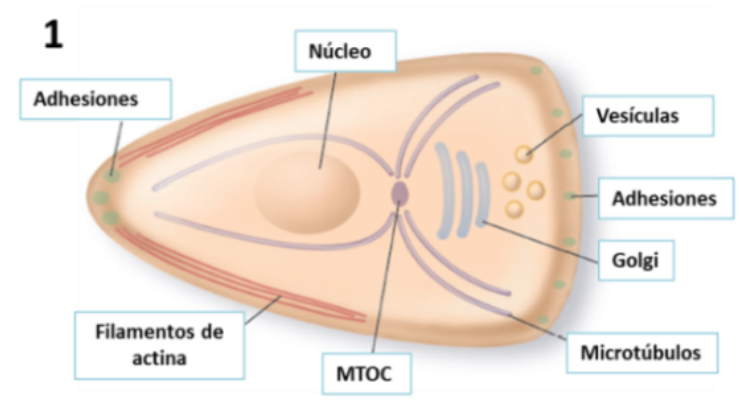

2

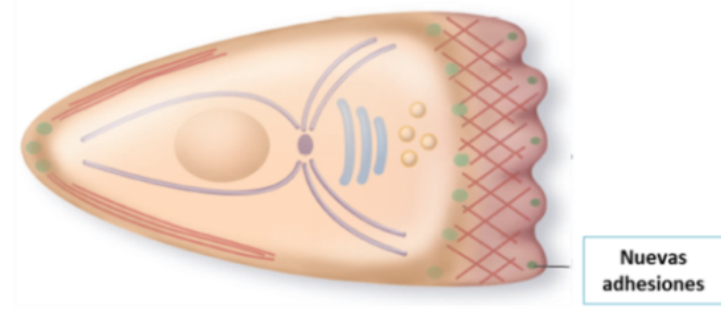

3

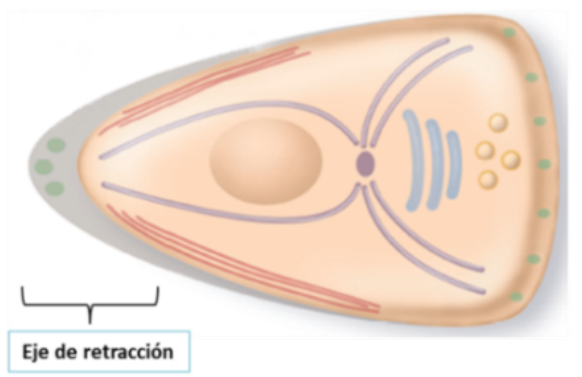


Figura 5. Etapas de la migración celular. En primer lugar se produce la generación de la polaridad celular, en segundo lugar se extiende el lamelipodio y se establecen las AF y finalmente el eje de posterior de la célula se retrae. Modificada de (Ridley et al., 2003).

\subsection{Importancia de las proteínas Rho en procesos tumorales}

Se han asociado alteraciones en la expresión y/o actividad de las proteínas Rho en diferentes procesos tumorales. Por ejemplo, el gen Rac1 aparece sobreexpresado o mutado en algunos tumores como el cáncer de mama o el melanoma (Davis et al., 2013; Krauthammer et al., 2012). Concretamente, en melanoma supone la tercera mutación activadora más frecuente, tras las de B-Raf y N-Ras (Halaban, 2015; Hodis et al., 2012; Krauthammer et al., 2012). En este sentido, se han encontrado mutaciones de RacGEFs como P-Rex, que está altamente involucrado en el desarrollo de melanoma (Lindsay et al., 2011). De hecho, la inhibición farmacológica de Rac1 en ratones con la mutación Q61K en N-Ras (que genera melanomas) impide el crecimiento del tumor y su metástasis (Li et al., 2011, 2012). Asimismo, se ha descrito que la activación incontrolada de Rac resulta crucial en el desarrollo de la leucemia mielógena crónica (Thomas et al., 2007). En cuanto a Cdc42, también se ha descrito una mutación activante (G12V) en esta proteína en ciertos casos de melanoma (Hodis et al., 2012). La sobreexpresión de Cdc42 ocurre también en ciertos cánceres de mama y testículos (Alan and Lundquist, 2013). Finalmente, varios trabajos han demostrado que la expresión de RhoA y RhoC está frecuentemente incrementada en procesos tumorales (Parri and Chiarugi, 2010). Parece que RhoA juega un papel importante en proliferación y supervivencia celular, mientras que RhoC parece estar involucrada durante los procesos invasivo y metastático (Parri and Chiarugi, 2010).

\section{Las familias de proteínas RasGEF}

\subsection{La familia de proteínas RasGRF}

Los GEFs de la familia RasGRF comprenden los miembros RasGRF1 y RasGRF2, que se expresan de forma mayoritaria en sistema nervioso (Fernández-Medarde et al., 2009; Jimeno et al., 2016; Tian and Feig, 2006). En el caso de RasGRF1, también puede localizarse, aunque en menor medida, en los islotes de Langerhans del páncreas (Font de Mora et al., 2003; Manyes et al., 2014) y en el pulmón (Fam et al., 1997). En concreto, estos RasGEFs están principalmente involucrados en la diferenciación neuronal (Yang and Mattingly, 2006). En particular, RasGRF1 está implicado en el proceso de aprendizaje y memoria (Brambilla et al., 1997; Fernández-Medarde and Santos, 2011b; Giese et al., 
2001). Además, RasGRF1 está involucrado en la respuesta a insulina en los islotes pancreáticos (Manyes et al., 2014). RasGRF2 participa en los circuitos reguladores de la adicción al alcohol (Stacey et al., 2012) así como en la fotorrecepción y en el correcto posicionamiento de fotorreceptores en la retina (Fernández-Medarde et al., 2009; Jimeno et al., 2016; Tian and Feig, 2006). Por otro lado, se ha descrito un papel importante de RasGRF2 en la proliferación de linfocitos y la señalización de células T (Ruiz et al., 2007, 2009)

La activación de las proteínas RasGRF (Figura 6) se produce en respuesta a un flujo de $\mathrm{Ca}^{2+}$ (Farnsworth et al., 1995) o tras estimulación de los GPCRs. También pueden ser activadas por la proteína quinasa A (Mattingly et al., 1999) y por otras proteínas tirosina quinasas como Ack1 y Src (Kiyono et al., 2000). De este modo, RasGRF1 es capaz de activar a las proteínas H, K, N-Ras, M-Ras y R-Ras (Gotoh et al., 2001; Ohba et al., 2000; Quilliam et al., 1999) aunque RasGRF2 sólo tiene la capacidad de activar las proteínas H, K y N-Ras, pero no a R-Ras (Gotoh et al., 2001).

\subsection{La familia de proteínas RasGRP}

La familia de proteínas RasGRP consta de 4 miembros: RasGRP1, RasGRP2, RasGRP3 y RasGRP4 (Ksionda et al., 2013). En general, estos GEFs son capaces de activar a H-, N- y K-Ras y a Rap. Se localiza de forma mayoritaria en el sistema inmune y en menor medida en el sistema nervioso (Ebinu et al., 1998; Guerrero et al., 1996; Wei et al., 1994). Los miembros RasGRP, además de presentar el dominio catalítico Cdc25-REM, contienen dos dominios de unión a $\mathrm{Ca}^{2+}$ y también un dominio de unión a diacil-glicerol, que son esenciales para su activación (Figura 6). En concreto, RasGRP1 se desempeña un papel importante durante la maduración y activación de linfocitos B y T (Dower et al., 2000; Kortum et al., 2013; Roose et al., 2007). RasGRP2 se expresa en neutrófilos y plaquetas, donde desempeña un papel importante en la señalización a través de integrinas (Crittenden et al., 2004; Ghandour et al., 2007; Lozano et al., 2016). RasGRP3 se expresa de forma mayoritaria en linfocitos B (Teixeira et al., 2003), mientras que RasGRP4 se expresa en células mieloides y linfocitos T, participando en la maduración de éstos últimos (Katsoulotos et al., 2008; Kortum et al., 2012; Yang et al., 2002; Zhu et al., 2012). 


\subsection{La proteína CNrasGEF}

Este RasGEF se expresa de forma predominante en el sistema nervioso (Ohtsuka et al., 1999). Su estructura, además de presentar el dominio catalítico Cdc25-REM para la activación de GTPasas, muestra también un dominio de unión a AMP cíclico y GMP cíclico, que coopera con el dominio Cdc25 para la activación de Ras (Pham et al., 2000) (Figura 6). Además, CNrasGEF activa tanto a las proteínas Ras como a Rap1, y podría estar implicado en procesos de apoptosis y melanogénesis (Amsen et al., 2006).

\subsection{La proteína $\mathrm{PLC \varepsilon}$}

Existe controversia en cuanto a la capacidad RasGEF de esta proteína. Hasta el momento se sabe que posee un dominio de asociación a Ras en la región C-terminal denominado RA (del inglés: RasAssociated domain) y un dominio similar a Cdc25 en la región $\mathrm{N}$-terminal (Figura 6). El dominio RA es capaz de unirse específicamente a H-Ras y a Rap1A (Dusaban et al., 2015; Song et al., 2001), aunque su capacidad como intercambiador de nucleótidos y potencial activador de Ras no ha sido aun totalmente demostrada.

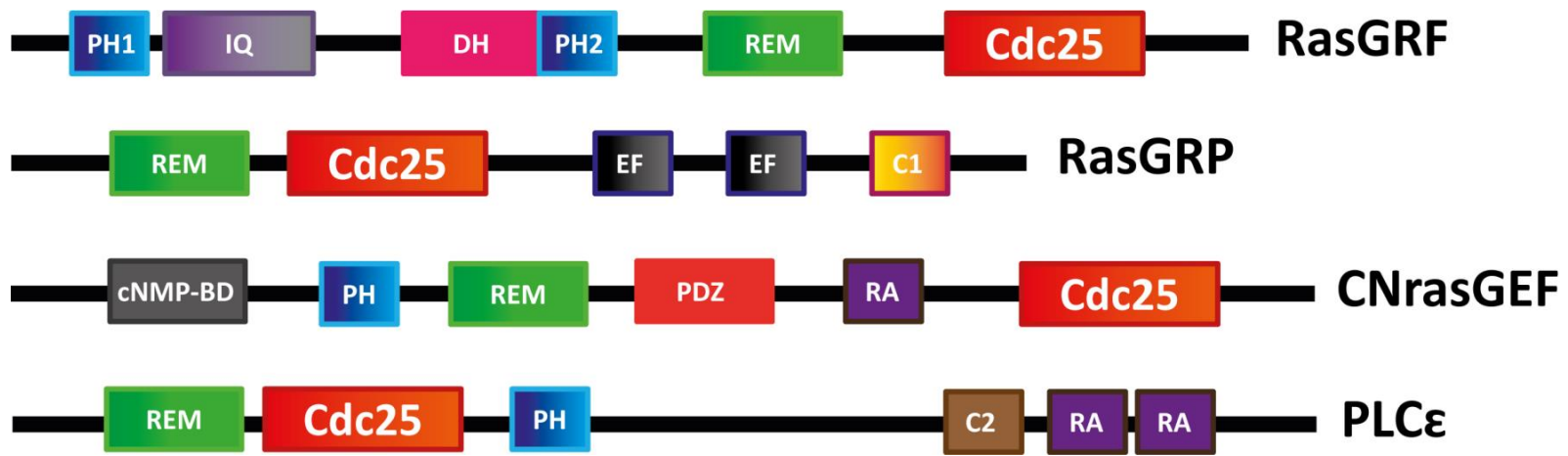

Figura 6. Dominios estructurales de las familias de RasGEF. Todos ellos comparten los dominios Cdc25 y REM. En el caso de los RasGRF, el dominio DH-PH les permite actuar también como RhoGEFs. Las proteínas RasGRP utilizan el dominio C1 para localizarse en la membrana para desempeñar su actividad GEF. Además, los dominios EF detectan el flujo de $\mathrm{Ca}^{2+}$ necesario para su activación y participan en la translocación de la proteína a la membrana plasmática. La proteína CNrasGEF presenta el dominio cNMP-BD de unión a AMP cíclico y GMP cíclico que colabora en la función intercambiadora de nucleótidos. La PLCE presenta los dominios RA que participan en la activación de Ras.

\subsection{La familia de proteínas Sos}

\subsubsection{Miembros}


Las proteínas Sos fueron descubiertas mediante estudios genéticos durante el desarrollo del ojo compuesto en Drosophila melanogaster (Rogge et al., 1991; Simon et al., 1991). La ruta de señalización activada por el RTK Sevenless es fundamental para la formación de las células fotorreceptoras R7 del ojo (Rogge et al., 1991; Simon et al., 1991). El análisis de esta ruta permitió identificar genes esenciales para la señalización a través de este receptor, entre los que se confirmó la presencia del homólogo de Ras en Drosophila y se descubrió el gen al que bautizaron como Sos (Son of Sevenless) (Rogge et al., 1991; Simon et al., 1991). El alineamiento de la secuencia proteica de dSos (Sos de Drosophila) con los activadores de Ras previamente descubiertos en levaduras Cdc25, Sdc25 y Ste6 mostró un alto grado de similitud y la existencia de un dominio común, correspondiente al dominio catalítico Cdc25 (Broek et al., 1987; Hughes et al., 1990; Robinson et al., 1987). Trabajos posteriores identificaron los homólogos del gen dSos en Caenorhabditis elegans en mamíferos (Chang et al., 2000), donde a diferencia de D. melanogaster y C. elegans existen dos genes homólogos, como en el ratón (mSos1 y mSos2; (Bowtell et al., 1992) y en humanos (hSos1 y hSos2) (Chardin et al., 1993).

Las proteínas dSos y sus equivalentes en mamíferos comparten un $45 \%$ de identidad aminoacídica, siendo la zona más conservada la que corresponde con el dominio catalítico Cdc25 (Chardin et al., 1993). La homología entre Sos1 y Sos2 en mamíferos es del $70 \%$ aproximadamente, reduciéndose al 40\% en la región C-terminal (Bowtell et al., 1992; Chardin et al., 1993). Sin embargo, entre mSos1 y hSos1, así como entre mSos2 y hSos2, la homología alcanza el $98 \%$, sugiriendo que cada uno de los loci que codifican estas proteínas está altamente conservado en mamíferos (Bowtell et al., 1992).

Los miembros de la familia Sos presentan un patrón de expresión muy amplio a lo largo del desarrollo y en la etapa adulta, así como en diversos linajes celulares. Los estudios realizados con dSos, al igual que con sus equivalentes en mamíferos (Sos1 y Sos2), mostraron expresión en prácticamente todos los tejidos y etapas del desarrollo analizadas (Bonfini et al., 1992; Bowtell et al., 1992; Chardin et al., 1993). A pesar de la homología entre Sos1 y Sos2, existen importantes diferencias bioquímicas y funcionales entre ambas proteínas. La región C-terminal es la que presenta mayor variabilidad entre ambas proteínas. Esto podría explicar por qué hSos2 tiene más afinidad por Grb2 que hSos1 (Yang et al., 1995). También existen diferencias en la región C-terminal, donde se han observado diferencias en las secuencias consenso de fosforilación entre hSos1 y hSos2, lo que implicaría una regulación diferente (Corbalán-García et al., 1996). Además, mSos1 es más estable que mSos2 pues éste es 
degradado en el proteasoma debido a la presencia de señales de ubiquitinación, que están ausentes en mSos1 (Nielsen et al., 1997). Además, se han descrito diferencias en la señalización inducida por EGF (del inglés: Epidermal Growth Factor), que apuntan a una participación de Sos1 en la transmisión de señales a corto y largo plazo, mientras Sos2 actuaría únicamente a corto plazo (Qian et al., 2000). Por último, probablemente reflejo de las diferencias bioquímicas y de regulación observadas entre ambas proteínas, la relevancia funcional de cada una de ellas en modelos animales difiere considerablemente. Los ratones deficientes para Sos1 mueren durante el periodo embrionario (Qian et al., 2000; Wang et al., 1997), mientras que los animales carentes de Sos2 son viables y sin fenotipo aparente (Esteban et al., 2000). Sin embargo, la eliminación de Sos1 durante la etapa adulta no afecta a la supervivencia del organismo (Baltanás et al., 2013), aunque la eliminación combinada de Sos1 y Sos2 en la etapa adulta provoca la muerte de los animales (Baltanás et al., 2013) reflejando una redundancia funcional de las proteínas Sos en la homeostasis del organismo y la supervivencia durante la etapa adulta.

\subsubsection{Estructura}

Las proteínas Sos en mamíferos tienen un alto peso molecular y están formadas por varios dominios conservados a lo largo de la evolución que pasamos a detallar a continuación (Figura 7):

- Dominio histona $(\mathrm{H})$ :

Ocupa el extremo $\mathrm{N}$-terminal y posee una estructura de pseudo-dímero semejante a los dímeros de histonas (Baxevanis et al., 1995; Sondermann et al., 2003). El dominio H ejerce una función de control negativo sobre la actividad de Sos (Jorge et al., 2002). Estudios posteriores han relacionado la función de este dominio con la regulación de la inhibición intramolecular de Sos, así como en la interacción de Sos con la membrana plasmática (Gureasko et al., 2008, 2010; Sondermann et al., 2005; Yadav and Bar-Sagi, 2010). Además, este dominio es clave en la unión de Sos con otras proteínas citosólicas como la Ezrina que participa en la regulación de la autoinhibición de Sos (Geissler et al., 2013).

\section{-Unidad DH-PH:}

Los dominios $\mathrm{DH}$ y PH constituyen un tándem funcional implicado en la activación de las GTPasas de la familia Rho/Rac (Hoffman and Cerione, 2002). Esta región también está implicada en la inhibición intramolecular de Sos (Corbalán-García et al., 1998; Kim et al., 1998; Qian et al., 1998) y en la 
interacción con la membrana a través de fosfoinositoles (Chen et al., 1997; Lemmon et al., 1996; Zhao et al., 2007) ( $\mathrm{PIP}_{2}$ y $\mathrm{PIP}_{3}$ : fosfatidilinositol-3,4-bisfosfato y fosfatidilinositol-3.4.5-trisfosfato, respectivamente). En concreto, el dominio DH posee actividad GEF sobre las GTPasas de la familia Rho/Rac (Li et al., 2017). En el caso de Sos, el dominio DH es capaz de activar a Rac pero no a otros miembros de la familia Rho, como Cdc42 (Nimnual et al., 1998). El dominio PH (homólogo a repeticiones internas de la proteína pleckstrina) está altamente conservado, especialmente en proteínas implicadas en la transducción de señales o proteínas con funciones en el mantenimiento del citoesqueleto (Lemmon and Ferguson, 2000; Lemmon et al., 1996). Esta región también es capaz de unirse a proteínas G heterotriméricas (Wang et al., 1994) y a la PKC (Yao et al., 1994) que median la transducción de las señales. La función del dominio PH en las proteínas Sos está principalmente asociada a la translocación a la membrana plasmática mediante su interacción con fosfoinositoles (Chen et al., 1997; Kubiseski et al., 1997; Nimnual et al., 1998; Rameh et al., 1997).

\section{-Región catalítica y dominio alostérico}

La región catalítica está unida a la N-terminal por un dominio conector helicoidal (L). Esta región contiene los dominios CDC25H o Cdc25 (homólogo a CDC25, el GEF de Ras en S. cerevisiae) y REM, conservados en todos los GEFs específicos de Ras (Bos et al., 2007; Zheng and Quilliam, 2003). Estos dominios son necesarios y suficientes para catalizar el intercambio de nucleótidos en Ras y así activarlo (Egan et al., 1993; Kim et al., 1998; Liu et al., 1993). La actividad catalítica reside en el dominio Cdc25 mientras que el dominio REM desempeña una función reguladora. En esta región existe un segundo sitio de unión a Ras denominado sitio alostérico, formado por parte del dominio REM y parte del Cdc25 (Margarit et al., 2003). La unión de RasGTP al sitio alostérico incrementa la actividad catalítica de Sos de manera muy sustancial (Boykevisch et al., 2006; Margarit et al., 2003). Esta unión del RasGTP al sitio alostérico produce un cambio conformacional en el dominio efector que favorece la interacción del GTP y la estabiliza. El dominio alostérico, junto con el dominio prolina del extremo C-terminal y con el dominio PH, está implicado además en el reclutamiento de Sos a la membrana (Gale et al., 1993; Gureasko et al., 2008; Zhao et al., 2007).

\section{-Dominio Pxx:}

Por último, las proteínas Sos poseen motivos ricos en prolina (PxxP) en su extremo C-terminal. Estos motivos interaccionan con los dominios SH3 (del inglés: $\underline{\operatorname{S} r c} \underline{H}$ Homology domain type 3) de proteínas 
implicadas en señalización celular, tales como Grb2, Crk o E3b1/Abl1 (Okada and Pessin, 1996; Scita et al., 1999). Por una parte, esta región está implicada en la translocación de Sos a la membrana mediante su unión a Grb2 (Egan et al., 1993; Olivier et al., 1993; Rozakis-Adcock et al., 1993; Simon et al., 1993) y por otra regula negativamente la actividad catalítica (Aronheim et al., 1994; Byrne et al., 1996; Corbalán-García et al., 1998; Karlovich et al., 1995; Zarich et al., 2000). Esta región, posee además secuencias de fosforilación específicas para diferentes quinasas, principalmente ERK1/2 (del inglés: Extracellular signal-Regulated Kinases) (Porfiri and McCormick, 1996). Como explicaremos más adelante, estos eventos de fosforilación se han asociado a un mecanismo de retroalimentación negativa de la ruta de señalización mediada por Ras. Sin embargo, en el caso de la fosforilación de Sos1 por la quinasa citosólica Abl en esta región, parece promover la configuración abierta de los dominios DH-PH para su actividad RacGEF (Sini et al., 2004).

Estudios recientes han descrito una función diferente para esta región, que es la obstaculización de la unión de RasGTP al dominio alostérico, independientemente de la autoinhibición del dominio Nterminal. De este modo, tendría lugar una limitación del reclutamiento de Sos (independiente de Grb2) a la membrana plasmática (Christensen et al., 2016; Lee et al., 2017).

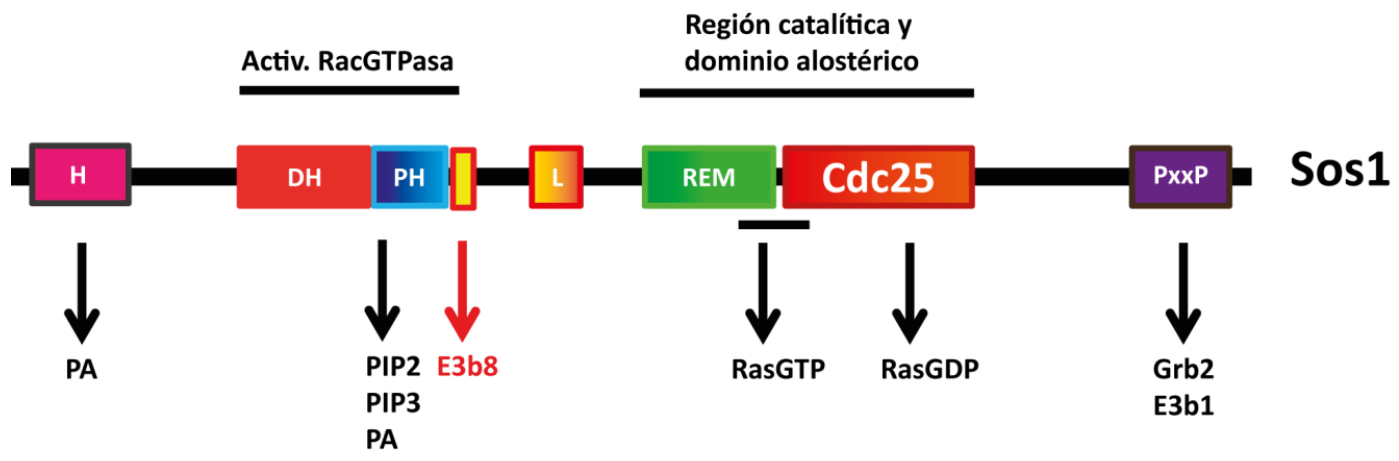

Figura 7. Estructura de Sos1 y Sos2. Las proteínas Sos presentan diferentes dominios que interaccionan con diferentes fosfolípidos, indicados como $\mathrm{PIP}_{2}$ y $\mathrm{PIP}_{3}$, y ácido fosfatídico, que le permiten la unión con la membrana plasmática. Además, se indican los dominios RasGEF (Cdc25) y RacGEF (DH). En el dominio RasGEF, diferenciamos la región catalítica como 
aquella que se une a RasGDP y la región alostérica como aquella que se une e RasGTP. El dominio PxxP es la región de unión a proteínas, tales como Grb2 y a E3b1. El conecto helicoidal L, une la región DH-PH con la región Cdc25-REM. "L" es un dominio conector entre la región DH-PH y Cdc25-REM. Sos1 y Sos2 presentan un elevado grado de homología pese a ello su región C-terminal presenta variabilidad entre ambas proteínas, y les confiere diferente estabilidad (mSos $2<\mathrm{mSos} 1)$ y diferente afinidad por Grb2 (hSos2>hSos1). Además junto a la región DH-PH se ha descrito una secuencia de unión a la proteína E3b8 en Sos1, que parece ausente en Sos2. Ub: Ubiquitinación

\subsubsection{Regulación de la actividad}

La regulación de la actividad de las proteínas Sos se establece fundamentalmente a nivel de la translocación a la membrana plasmática donde se encuentra Ras, en la eliminación del efecto inhibitorio que ejercen las regiones N-terminal y C-terminal sobre la región catalítica, en la estimulación alostérica del dominio catalítico, y por último en la fosforilación en su extremo Cterminal (Bos et al., 2007).

\subsubsection{Modelo clásico de translocación a membrana}

Según el modelo clásico de activación, en ausencia de estímulos celulares Sos se encuentra en el citosol formando un complejo con Grb2 (Egan et al., 1993; Gale et al., 1993; Rozakis-Adcock et al., 1993). Tras la activación de RTKs, este complejo es reclutado a la membrana plasmática mediante la unión de Grb2 a residuos de tirosina fosforilados en los receptores activados. Sin embargo, numerosas evidencias experimentales indican que la activación de Ras por Sos es un proceso más complejo de lo que proponía este modelo (Jiang et al., 1996; Karlovich et al., 1995; McCollam et al., 1995; Rojas et al., 1999; Wang et al., 1995).

\subsubsection{Mecanismo de activación alostérica e inhibición intramolecular}

El mecanismo de activación alostérica de Sos mediado por Ras está basado en la unión con alta afinidad de una molécula de RasGTP al lugar alostérico de Sos (Boykevisch et al., 2006; Christensen et al., 2016; Margarit et al., 2003) (Figura 8). Esta interacción induce cambios en la región catalítica que estabilizan a Sos en una conformación activa, estimulando intensamente su actividad intercambiadora de nucleótidos (Boykevisch et al., 2006; Freedman et al., 2006; Margarit et al., 2003). Además, la proteína RasGTP tiene más afinidad por el sitio alostérico que RasGDP, lo que convierte esta interacción en un mecanismo de retroalimentación positiva que es fundamental para la correcta activación de Sos (Boykevisch et al., 2006; Sondermann et al., 2004). 
Por otra parte, diversos trabajos describen un mecanismo de regulación de la actividad por interacciones intramoleculares denominado inhibición intramolecular. Este mecanismo consiste en la interacción entre varios dominios para estabilizar a la proteína Sos en su conformación inactiva (Figura 8). Muchos de estos trabajos atribuyen un control negativo de la actividad catalítica de Sos a las regiones N-terminal (Corbalán-García et al., 1998; Kim et al., 1998; Qian et al., 1998) y C-terminal (Aronheim et al., 1994; Byrne et al., 1996; Corbalán-García et al., 1998; Karlovich et al., 1995; McCollam et al., 1995; Wang et al., 1995).

Ambos mecanismos están íntimamente relacionados, pues la inhibición intramolecular consiste en evitar que Ras active alostéricamente a Sos en ausencia de los estímulos adecuados. En la conformación inactiva, la unidad DH-PH interacciona con el dominio REM bloqueando estéricamente el acceso de Ras al sitio alostérico (Boykevisch et al., 2006; Sondermann et al., 2004). El dominio H estabiliza la interacción inhibitoria de la unidad DH-PH y contribuye a la conformación inactiva interaccionando con el dominio L que existe entre los dominios PH y REM (Gureasko et al., 2010; Sondermann et al., 2005). Mutaciones activantes de Sos detectadas en pacientes con síndrome de Noonan (SN) ponen de manifiesto la importancia que puede tener esta inhibición intramolecular (Chen et al., 2010b).

Ante las señales adecuadas, Sos adquiere la conformación activa liberándose de las interacciones intramoleculares. La unión de los dominios $\mathrm{H}$ y $\mathrm{PH}$ a la membrana son fundamentales para esta liberación (Chen et al., 1997). El dominio PH se une al PIP 2 (Chen et al., 1997; Kubiseski et al., 1997) y también al ácido fosfatídico (Di Fulvio et al., 2006; Zhao et al., 2007). El dominio H también puede asociarse al ácido fosfatidíco, siendo esta interacción esencial para la activación de Ras en respuesta a EGF (Gureasko et al., 2010; Yadav and Bar-Sagi, 2010). Se cree que la asociación a la membrana reorienta a Sos provocando la liberación de la unidad $\mathrm{DH}-\mathrm{PH}$ del sitio alostérico. Esta nueva configuración hace posible la unión de Sos con dos moléculas de Ras (Ras alostérico y Ras sustrato) lo que refuerza la estabilización de Sos a la membrana.

Algunos autores sugieren que, al menos en los linfocitos $\mathrm{T}$, el feedback positivo que genera la activación alostérica de Sos dependería de la función de otro RasGEF, en concreto RasGRP1 (Roose et al., 2007). Además, en condiciones oncogénicas por mutación en K-Ras, la activación del sitio alostérico de Sos vendría dado por la forma constitutivamente activa de Ras, que aumentaría significativamente su capacidad catalítica sobre las proteínas Ras no oncogénicas (Jeng et al., 2012). 

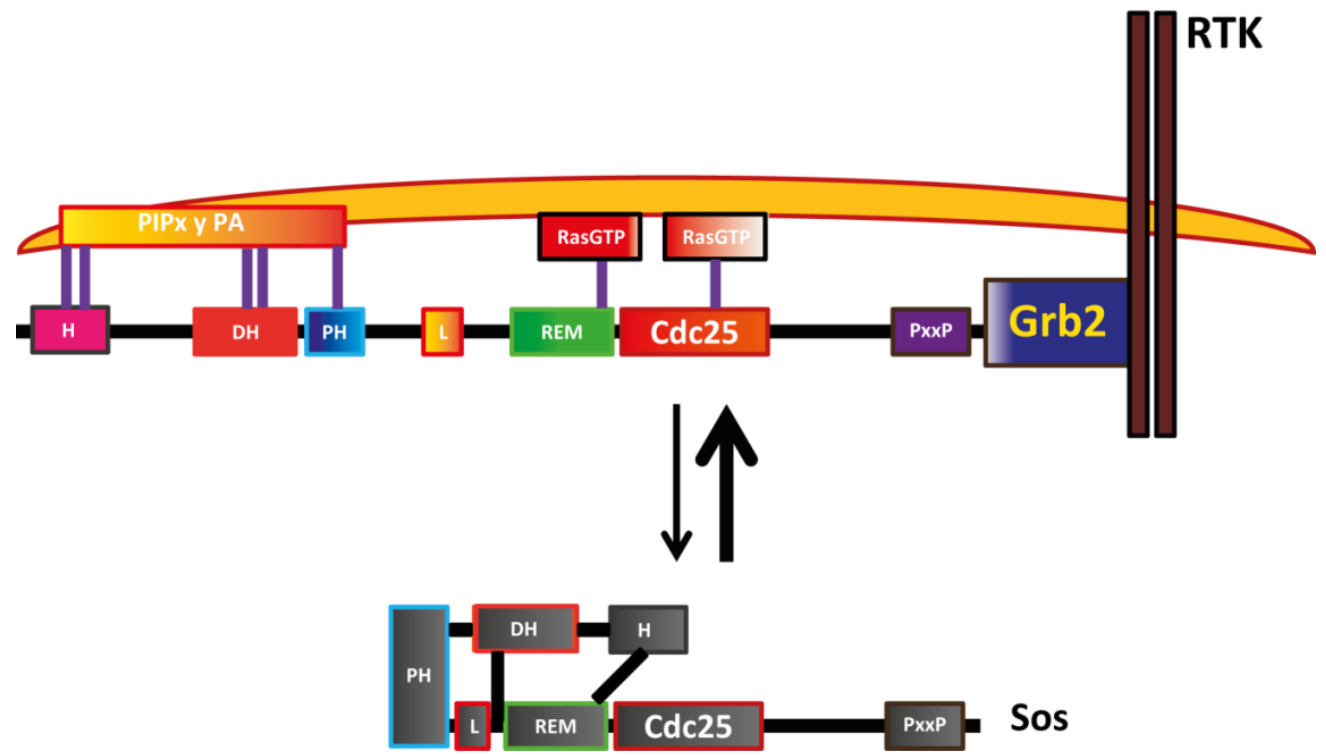

Figura 8. Modelo clásico de inhibición intramolecular de Sos. La conformación abierta permite a Sos anclarse a la membrana a través de varios dominios $(\mathrm{H}, \mathrm{PH}$ y $\mathrm{DH})$, y a las moléculas de Ras, tanto en el lugar catalítico como alostérico. Modificado de (Nickerson et al., 2013).

\subsubsection{Regulación de la activación de Sos por el dominio alostérico}

Recientemente se ha propuesto un nuevo modelo de regulación de Sos. Este modelo plantea que cuando Sos es reclutado en la membrana plasmática permanece anclado en ella, activando constantemente a Ras. Esta activación finaliza cuando Sos es eliminado de la membrana (Christensen et al., 2016) y es además independiente de una señal iniciadora a través de receptores de membrana (Christensen et al., 2016). Mediante el uso de membranas lipídicas artificiales, se ha demostrado que el dominio alostérico de Sos es el encargado de la interacción con el Ras que está anclado a la membrana. Además, Sos no requiere de dominios extra, como DH-PH o H para su unión, ya que el dominio alostérico de Sos le permite no solo anclarse a la membrana sino mantenerse unido a ella (Christensen et al., 2016). Sin embargo, el dominio DH-PH sí favorece el tiempo de activación de Sos (Christensen et al., 2016). Por otro lado, se describe que el dominio C-terminal PxxP ejerce un efecto inhibitorio del dominio alostérico, independiente del efecto inhibitorio ejercido por los dominios $\mathrm{DH}$ PH y H (Christensen et al., 2016; Lee et al., 2017) (Figura 9). 


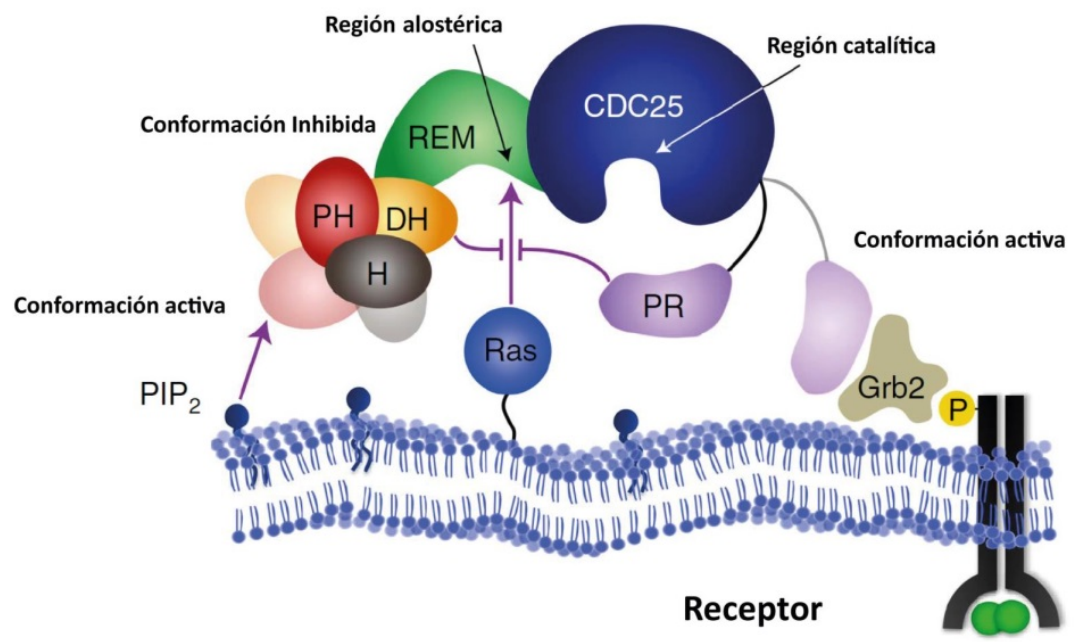

Figura 9. Nuevo modelo de la inhibición intramolecular de Sos1. Esta conformación de Sos inactiva requiere tanto la región $\mathrm{N}$-terminal como la región C-terminal. La inhibición por parte de la región C-terminal reside en el dominio PR o PxxP, y resulta independiente de la inhibición de la región N-terminal (DH-PH-H) y a su vez independiente de la unión con Grb2. Adaptado de (Lee et al., 2017).

\subsubsection{Regulación de la activación mediante fosforilación}

La fosforilación de Sos tras la estimulación con factores de crecimiento ha sido asociada a un mecanismo de retroalimentación negativa (Klarlund et al., 1995; Langlois et al., 1995; Waters et al., 1995). En la región C-terminal, Sos contiene secuencias consenso para MAPKs, cuyos residuos de serina/treonina son fosforilados por dichas quinasas (Cherniack et al., 1994; Corbalán-García et al., 1996; Porfiri and McCormick, 1996). No obstante, otras quinasas pueden participar en la fosforilación de Sos como por ejemplo MEK (Dong Chen et al., 1996; Holt et al., 1996; Zhao et al., 1997) o p90RSK2 (Douville and Downward, 1997).

La retroalimentación negativa consiste en la inhibición de la señalización tras una estimulación. Por ejemplo, la fosforilación de Sos mediada por ERK o JNK tras la estimulación con insulina promueve la disociación de los complejos Grb2-Sos (Klarlund et al., 1995). La activación de Mek puede tambien regular negativamente a Sos (Dong Chen et al., 1996; Holt et al., 1996; Klarlund et al., 1995; Langlois et al., 1995; Waters et al., 1995), mientras que tras una estimulación con EGF, la señal de activación finaliza mediante la disociación entre el complejo Grb2-Sos y la proteína adaptadora Shc unida al receptor (Klarlund et al., 1995; Porfiri and McCormick, 1996; Rozakis-Adcock et al., 1995). La internalización y degradación de los receptores activados como ocurre con los receptores de EGF y 
PDGF (pero no de Insulina), contribuye a la desactivación de la ruta (Klarlund et al., 1995; Osterop et al., 1993). Recientemente, se ha publicado que la activación de la quinasa JNK hiperfosforila a Sos1 en determinados residuos de serina/treonina y esta hiperfosforilación hace que Sos1 no sea capaz de responder a señales upstream lo que supondría un control de la activación de la ruta Sos-Ras-MAPK en condiciones de estrés (Ritt et al., 2016).

Finalmente, se ha planteado que la fosforilación de Sos1 en un determinado residuo de tirosina por la proteína tirosina quinasa Abl promueve la actividad intercambiadora de Sos sobre la GTPasa Rac (Sini et al., 2004). En concreto, esta fosforilación de Sos1, en la tirosina 1196, parece necesaria para la adquisición de una conformación accesible de los dominios DH-PH con capacidad RacGEF (Dr. Giorgio Scita, comunicación personal).

Todos estos modelos propuestos en las última décadas se complementan, ya que la conformación inhibida de Sos es esencial para la regulación de su actividad y posterior señalización. Los dominios H, DH-PH, L, Cdc25-REM y PxxP regulan su actividad mediante la modulación de la conformación autoinhibida. Una vez que Sos presenta su conformación activa, parece que es el dominio alostérico el responsable de la función activadora de Sos sobre Ras. De este modo los dominios de anclaje a la membrana plasmática, como los dominios $\mathrm{PH}$ y $\mathrm{DH}$, favorecen la activación de Sos y el dominio PxxP estabiliza la unión de Sos con la membrana. Sin embargo, el dominio alostérico sería suficiente para la activación de Sos.

\subsubsection{Regulación de la actividad GEF dual de Sos}

Las proteínas Sos tienen actividad GEF dual sobre las GTPasas Ras y Rac (Innocenti et al., 2002; Nimnual and Bar-Sagi, 2002; Nimnual et al., 1998). La actividad catalítica de Sos sobre la GTPasa Rac reside en el dominio DH-PH (Nimnual et al., 1998) y está regulada por diferentes mecanismos. Además, la interacción de Sos con $\mathrm{PIP}_{3}$ en la membrana plasmática y la asociación con las proteínas Eps8 y E3b1/Abl-1 son otros mecanismos que favorecen la actividad RacGEF de Sos.

Esta actividad dual está determinada por la asociación de Sos a diferentes complejos moleculares de señalización. Sos funciona como GEF de Ras cuando está unido a Grb2 y sobre Rac cuando forma un complejo con E3b1 y Eps8 (Innocenti et al., 2002; Scita et al., 1999). E3b1 estabiliza la unión entre Sos1 y Eps8, el cual interacciona con el receptor activado y con la F-actina, permitiendo la localización 
del complejo en estructuras como los ruffles (Scita et al., 1999, 2001). Estas ondulaciones se asocian con la activación de Rac1 mediada por Sos1 tras un estímulo con factores de crecimiento, independientemente de la activación de Rac1 por otros RacGEFs como Vav (Scita et al., 1999; Sini et al., 2004).

La interacción de Sos con Grb2 o E3b1 es excluyente, y la afinidad de Sos in vitro por ambas proteínas es similar (Innocenti et al., 2002). Sin embargo, en fibroblastos la abundancia de los complejos SosGrb2 es aproximadamente 10 veces mayor que los complejos Sos1/E3b1/Eps8 (Innocenti et al., 2002). Además, la dinámica y la regulación de ambos complejos tras la activación del receptor es diferente. Mientras que los complejos Grb2-Sos se disocian rápidamente tras la estimulación, los complejos Sos1/E3b1/Eps8 permanecen más estables en las mismas condiciones. Estas diferencias explican, en parte, la cinética de activación transitoria de Ras comparada con la activación prolongada de Rac en respuesta a factores de crecimiento (Innocenti et al., 2002).

Además, PI3K desempeña un papel esencial en la regulación de la actividad GEF de Sos sobre Rac. Por un lado, la interacción de la subunidad reguladora de PI3K, p85, con el complejo Sos1/E3b1/Eps8 es necesaria para esta actividad (Innocenti et al., 2003). Por otro lado, la asociación del dominio PH de Sos con $\mathrm{PIP}_{3}$ provoca un cambio conformacional que libera al dominio $\mathrm{DH}$ de la inhibición intramolecular, promoviendo así la activación de Rac (Das et al., 2000; Soisson et al., 1998). De hecho, diversos experimentos han demostrado que la activación de Rac, mediada por Ras, a través de PI3K, controla ciertos mecanismos en la regulación del citoesqueleto (Nimnual et al., 1998; RodríguezViciana et al., 1997). La regulación de la actividad GEF dual de Sos constituye un mecanismo de coordinación espacial y temporal de las rutas de señalización mediadas por ambas GTPasas (Mitin et al., 2005; Nimnual and Bar-Sagi, 2002).

\section{Participación de las proteínas Sos en rutas de señalización}

\subsection{Señales iniciadoras}

La estimulación de la célula con ciertos factores de crecimiento desencadena la activación de RTKs específicos de la superficie celular. Estos receptores ejercen un importante papel en numerosos procesos biológicos incluyendo el desarrollo embrionario y la oncogénesis, para lo cual controlan procesos celulares fundamentales como la progresión del ciclo celular, migración, metabolismo, 
supervivencia y diferenciación celular (Schlessinger, 2000). La mayoría de RTKs estimulan la actividad de las GTPasas Ras (Satoh et al., 1990; Schlessinger, 2000) cuya activación en este contexto está mediada principalmente por las proteínas Sos. Sin embargo, Sos puede activar también a Ras a través de la estimulación de otros receptores, incluyendo receptores GPCR, el receptor de células T en estadios tempranos de maduración (pre-TCR) y también a través de integrinas, entre otros (Figura 10).

\subsubsection{Señalización a través de receptores tirosina quinasa}

Los RTKs son proteínas transmembrana que contienen un dominio N-terminal extracelular de unión al ligando y un dominio C-terminal intracelular con actividad tirosina quinasa. La mayoría están en la membrana en forma de monómeros inactivos, cuya dimerización es consecuencia de la unión de la parte extracelular a un ligando específico. La dimerización induce la activación del receptor y su autofosforilación en residuos de tirosina del dominio C-terminal, que sirven como sitios de unión específicos para proteínas intracelulares con dominios SH2 o PTB (Schlessinger, 2000). Estas proteínas pueden ser enzimas cuya actividad es estimulada al unirse al receptor (incluyendo las quinasas Src y PI3K, la PLC o la fosfatasa Shp2), y proteínas adaptadoras como Grb2 y Shc (Lowenstein et al., 1992; Skolnik et al., 1993) que contienen dominios de interacción con otras proteínas. Asimismo, algunos RTK pueden reclutar las denominadas proteínas "acopladoras" como IRS, FRS, y Gab (HolgadoMadruga et al., 1996; Kouhara et al., 1997; Skolnik et al., 1993). Estas proteínas acopladoras son fosforiladas por el RTK y son capaces de reclutar a otras proteínas. El receptor activado funciona como una plataforma de reclutamiento de diversas proteínas señalizadoras que amplifican la señal y activan las rutas efectoras necesarias para una respuesta biológica apropiada (McKay and Morrison, 2007; Schlessinger, 2000) (Figura 10).

La participación de Sos en estas rutas consiste en su capacidad para integrar las señales procedentes de los RTKs y asegurar una correcta activación de Ras (Figura 10). Grb2 se une a las fosfotirosinas del receptor activado y así el tándem Grb2/Sos permite el inicio de la señal activadora a través de RTK. Sin embargo, no todos los RTKs poseen secuencias consenso para la unión de Grb2, en cuyo caso otras proteínas como Shc, Gab1 o Shp2 median el reclutamiento del complejo Grb2 al receptor activado (Holgado-Madruga et al., 1996; Li et al., 1994; Rozakis-Adcock et al., 1993). Una vez en la membrana, Sos presenta la conformación activa gracias a la función coordinada de varios de sus 
dominios, donde cataliza el intercambio de nucleótidos sobre las GTPasas Ras presentes en las proximidades.

\subsubsection{Señalización a través del receptor pre-TCR}

Sos también puede participar en la señalización iniciada por la activación de otros receptores, como el receptor pre-TCR (Kortum et al., 2011) (Figura 10). El pre-TCR consiste en un heterodímero formado por la de la subunidad TCR- $\beta$ en asociación con la cadena pre-TCR- $\alpha$, que carece, de igual manera que el receptor TCR, de actividad tirosina quinasa. Sin embargo, su unión al ligando induce la fosforilación de proteínas quinasas como Syk y ZAP -70 (Vanoers and Weiss, 1995), que a su vez fosforilan residuos de tirosina de este receptor que desencadena la activación de Ras y otras rutas de señalización (Iritani et al., 1999). El receptor pre-TCR participa en la expansión y diferenciación de células T inmaduras. En concreto, se ha descrito que Sos es clave en esta etapa temprana de maduración de células T en el timo (Baltanás et al., 2013; Kortum et al., 2011, 2012).

\subsubsection{Señalización a través de receptores acoplados a proteínas $\mathrm{G}$}

La estimulación de los GPCRs puede activar la ruta Ras/MAPK a través de la activación de distintas PTKs como Pyk2 (Avraham et al., 2000; Dikic et al., 1996), miembros de la familia de quinasas Src, como Shc (Ward et al., 1996) o PI3K (López-llasaca et al., 1997). En todos los casos estas quinasas fosforilan residuos de tirosina en el dominio intracelular del receptor, lo que de nuevo conduce al reclutamiento del complejo Grb2-Sos y la consiguiente activación de la ruta de señalización. Un ejemplo es el caso de la activación de GPCRs tras un estímulo con ésteres de forbol como el TPA (del inglés: 12-O-Tetradecanoy/Phorbol-13-Acetate) (Rubio et al., 2006). Primeramente, el TPA induce la activación de la PKC que resulta suficiente para activar a Ras. Además, la PKC fosforila al EGFR (del inglés: Epidermal growth factor receptor), lo que permite que la quinasa Shc se una a los residuos de tirosina de este receptor, y que a continuación se una el complejo Grb2/Sos. Este mecanismo supondría la transactivación del EGFR. De este modo, el TPA es capaz de activar la activación de Ras a través de PKC y de EGFR/Shc/Grb2/Sos (Rubio et al., 2006).

\subsubsection{Señalización a través de integrinas}


Por último, la fosforilación de Shc por la quinasa Fyn tras la activación de determinadas integrinas provoca la translocación del complejo Grb2-Sos y la activación de la ruta Ras/ERK (Widmann et al., 1999; Winston and Hunter, 1996). Asimismo, la activación de integrinas induce la fosforilación de FAK, la cual puede formar un complejo con Grb2-Sos y activar también la ruta Ras/ERK (Barberis et al., 2000; Vuori et al., 1996). En células endoteliales, la estimulación de integrinas específicas induce la activación de Rac mediada por Sos. Esta mayor actividad de Rac a su vez contribuye a la progresión del ciclo celular mediante la expresión de la ciclina D1 (Mettouchi et al., 2001).

En este sentido, recientemente se ha atribuido un nuevo papel a Sos1, en colaboración con los RhoGEFs ARHGEF1 y DOCK2, en la activación de linfocitos T tras la señalización por quimiocinas a través de integrinas. La cooperación de estos tres GEFs permite una correcta adhesión de los linfocitos T y una activación adecuada de Rac y de Rho, que resultan deficientes cuando falta Sos1. De este modo, se propone una nueva función a Sos1 en la adhesión celular mediada por integrinas (Toffali et al., 2017).

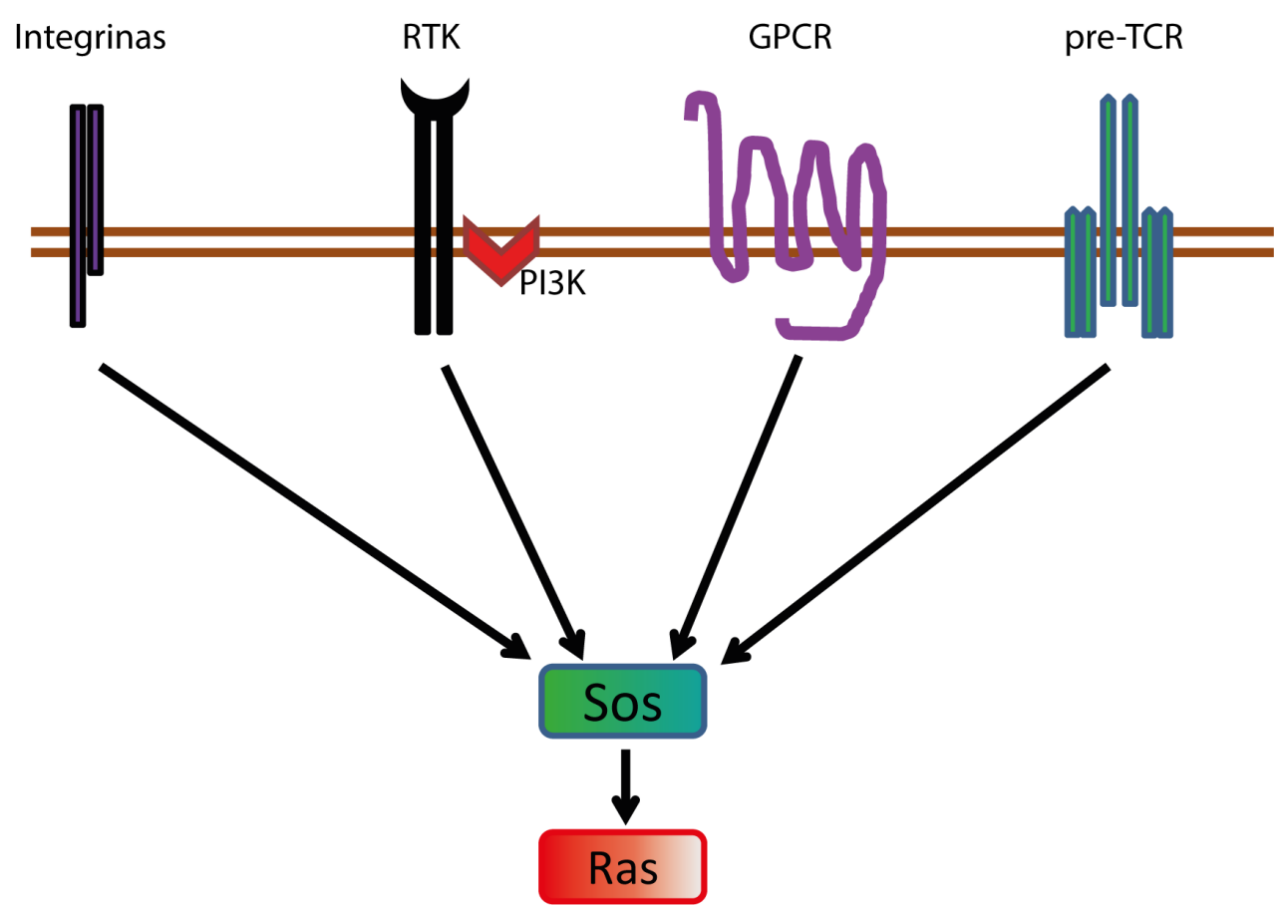

Figura 10. Señales activadoras de las proteínas Sos. Diversos tipos de receptores pueden desencadenar la activación de las proteínas Sos. La estimulación de RTKs promueve la activación de las GTPasas Ras mediante la translocación del complejo Grb2/Sos a la membrana. Asimismo, receptores de citoquinas, GPCRs e integrinas, pueden estimular la actividad GEF de Sos, generalmente a través de la activación de PTKs que fosforilan a los receptores y a proteínas adaptadoras como Shc, promoviendo el reclutamiento del complejo Grb2/Sos al receptor activado. Una vez activo, Ras transmite la señal a diversas rutas efectoras. Además, el receptor pre-TCR es capaz de desencadenar la activación de las proteínas Sos. 


\subsection{Principales rutas de señalización mediadas por Ras}

La actividad GEF de las proteínas Sos sobre las GTPasas Ras y Rac induce la activación de un gran número de proteínas efectoras en las rutas de señalización en las que éstas participan. Las proteínas Ras en su forma activa pueden interaccionar con un gran número de efectores, entre los que encontramos quinasas (Raf, PI3K, MEKK1), GEFs de otras GTPasas (RaIGDS, Tiam, RIN), GAPs (NF1, p120GAP), etc, de forma que la señal puede amplificarse y diversificarse activando numerosas rutas de señalización (Karnoub and Weinberg, 2008; Reinke and Sorg, 2012; Repasky et al., 2004; Shields et al., 2000; Vojtek and Der, 1998) (Figura 7). La activación de una u otra vía dependerá principalmente del estímulo recibido y del tipo celular. Las rutas efectoras de Ras más estudiadas son Ras/MAPKs, PI3K/Akt, y Ras/RalGDS. La señalización a través de Ras/MAPKs y PI3K/Akt participa en la regulación de funciones celulares diversas y a veces opuestas, tales como: proliferación, supervivencia, muerte celular, diferenciación, motilidad, metabolismo y senescencia (Meloche and Pouysségur, 2007; Vivanco and Sawyers, 2002; Vojtek and Der, 1998). Puesto que ambas rutas son efectoras de Ras y responden a la estimulación de RTKs, explicaremos a continuación más detalladamente la señalización a través de las mismas (Figuras 11 y 12).

\subsubsection{Ruta de señalización Ras/MAPK}

En mamíferos, la familia de proteínas quinasas activadas por mitógenos o MAPKs está constituida principalmente por 4 grupos: ERK1/2, JNK1/2/3, p38 (p38 $\alpha / \beta / \gamma / \delta)$ y ERK5 (Figura 11), además de las MAPKs denominadas atípicas, que agrupan a ERK3/4, ERK7 y NLK (Cargnello and Roux, 2011).

Estas quinasas ejercen una función clave en la transducción de señales, modulando la expresión génica y la actividad de diversas proteínas en respuesta a estímulos extracelulares. De esta manera, controlan procesos biológicos tales como la embriogénesis, proliferación, diferenciación, migración y apoptosis, entre otros (Pearson et al., 2001; Turjanski et al., 2007). En todos los casos, las rutas de señalización de MAPKs conservadas en todos los organismos eucariotas desde levaduras a humanos, están formadas por módulos de 3 componentes que se activan en cascada mediante fosforilación: las quinasas MAPKKK, MAPKK y por último las MAPKs (Chang and Karin, 2001; Roberts and Der, 2007) (Figura 11). 


\subsubsection{Señalización de las rutas Ras/p38 y Ras/JNK}

La familia de proteínas p38 es una familia de MAPK convencional que comprende las isoformas p38 $\alpha$, $p 38 \beta, p 38 \gamma$ y $p 38 \delta$. Las isoformas $p 38 \alpha / \beta$ se expresan de manera ubicua mientras que las isoformas p38ץ/ס lo hacen en localizaciones más restringidas (Jiang et al., 1996). La activación de estas proteínas tiene lugar a través de señales de estrés en el microambiente celular y también por citoquinas inflamatorias. Además, la familia p38 es capaz de activarse a través de GPCRs (Fisher and Blenis, 1996) así como por Rac y Cdc42 (Bagrodia et al., 1995). La activación de p38 desempeña una función crítica en la respuesta inmune (Cuadrado and Nebreda, 2010) y en menor medida, también están implicadas en proliferación y supervivencia (Thornton and Rincon, 2009). La mayoría de estímulos activadores de p38 también lo son de las proteínas de la familia JNK, y además muchas quinasas mediadoras del eje de señalización p38 son compartidas en la señalización Ras/JNK. La familia de proteínas JNK se localizan tanto en el citosol como en el núcleo. En esta última localización, las proteínas JNK regulan la expresión del factor de transcripción c-Jun (Weston and Davis, 2002), controlando así la proliferación (Sabapathy et al., 2004). Además, tanto la familia de quinasas p38 como JNK son capaces de inducir la activación de ERK1/2 (Johnson and Lapadat, 2002; Pearson et al., 2001; Raman et al., 2007).

\subsubsection{Señalización de la ruta Ras/ERK5}

La proteína ERK5 se expresa de forma ubicua y es esencial para el desarrollo embrionario, así como para el desarrollo del sistema vascular y la supervivencia celular (Regan et al., 2002; Sohn et al., 2002). Las señales activadoras de ERK5 incluyen factores de crecimiento, estrés oxidativo e hiperosmolaridad (Wang et al., 2006). Igualmente a otras proteínas quinasas se localiza en citoplasma y tras su estimulación se transloca al núcleo (Wang et al., 2006). En términos generales, ERK5 regula supervivencia celular y proliferación y también es capaz de aumentar la señalización a través de MAPK (Ranganathan et al., 2006).

\subsubsection{Señalización de la ruta Ras/ERK}

La ruta Ras/ERK es esencial para la transmisión de señales mitogénicas procedentes de RTKs. El primer componente (MAPKKK) es la serina/treonina quinasa Raf (A-Raf, B-Raf, C-Raf; Figura 11). La unión de Raf al dominio efector de RasGTP implica su translocación a la membrana, requisito esencial 
para su posterior activación (Marais et al., 1995; Stokoe et al., 1994). El mecanismo de activación de Raf está sujeto a una regulación compleja, donde la liberación de la conformación inactiva es crucial, dependiendo del contexto celular, intervienen interacciones con diversas proteínas y eventos de fosforilación y defosforilación de residuos específicos en los que pueden participar las quinasas Src, PKC o PAK, y fosfatasas como PP2A (Dhillon and Kolch, 2002; Kolch et al., 1993; Marais et al., 1995). Raf activado fosforila y activa al segundo componente de la cascada, las quinasas Mek1/2, que son capaces de fosforilar en treonina y tirosina al último efector, las serina/treonina quinasas ERK1/2 (Kyriakis et al., 1992; Seger et al., 1992) (Figura 11).

La señalización mediada por ERK regula numerosos procesos celulares, tales como la expresión génica, proliferación, supervivencia, muerte celular, motilidad, metabolismo y diferenciación (Raman et al., 2007). Para ello fosforila más de 175 proteínas efectoras conocidas (Roskoski, 2012; Yoon and Seger, 2006) que incluyen desde factores de transcripción, quinasas o fosfatasas, hasta proteínas del citoesqueleto y reguladores de la apoptosis (Brondello et al., 1999; Yoon and Seger, 2006).

En condiciones basales ERK se encuentra inactivo en el citoplasma y tras su activación se transloca al núcleo donde regula la expresión y la actividad de múltiples sustratos, gran parte de ellos relacionados con la progresión del ciclo celular (Chambard et al., 2007; Yoon and Seger, 2006). A continuación describiremos las funciones más importantes de ERK en distintos procesos celulares.

\section{(i) Progresión del ciclo celular: fosforilación de sustratos nucleares}

Tras su activación, ERK1/2 fosforila numerosos factores de transcripción como Ets, Elk y c-Fos. Además, fosforila también algunos de sus reguladores (Mendoza et al., 2011; Yoon and Seger, 2006) entre ellos la familia TCF, que juegan un papel principal en la inducción de la expresión de genes de respuesta inmediata como c-Fos, c-Jun y c-Myc. Posteriormente, la activación sostenida de ERK produce la estabilización de c-Fos por fosforilación directa (Murphy et al., 2002, 2004), que se asocia con c-Jun constituyendo el complejo AP-1. Este complejo induce la transcripción de importantes reguladores del ciclo celular como la ciclina D1 (Albanese et al., 1995; Balmanno and Cook, 1999) o cMyc (lavarone et al., 2003). Además, ERK también regula la expresión de ciclina D1 a través de otros factores de transcripción como c-Myc (Daksis et al., 1994). Se ha demostrado que la activación sostenida de ERK es esencial para la acumulación de la ciclina D1 a lo largo de la fase G1 (Lavoie et al., 1996; Weber et al., 1997). De este modo, la ciclina D1 forma complejos con las proteínas CDK4 y 
CDK6, que fosforilan la familia de proteínas del retinoblastoma, lo que permite la transcripción de genes necesarios para la entrada en la fase $S$ del ciclo celular (Malumbres and Barbacid, 2003). Además, ERK1/2 también regula la represión transcripcional y la remodelación de la cromatina (Plotnikov et al., 2011).

\section{(ii) Crecimiento celular y supervivencia: fosforilación de proteínas citoplasmáticas}

Se conocen más de 50 efectores citoplasmáticos de ERK que incluyen fosfatasas, proteínas quinasas

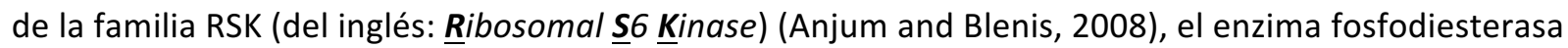
de AMPc, la fosfolipasa A2, proteínas del citoesqueleto y proteínas pro-apoptóticas como Bad y Bim, entre otras (Yoon and Seger, 2006). La familia de proteínas RSK regula la transcripción mediante la activación de factores de transcripción como CREB, SRF, NK-kß, etc. Las proteínas RSK fosforilan también proteínas asociadas a ribosomas como la proteína ribosomal S6 y elF4B (Shahbazian et al., 2006) que promueven la síntesis proteica. Además, las proteínas RSK1/2, promueven la progresión de la fase G1 del ciclo celular mediante fosforilación e inhibición de p27 $7^{\mathrm{KIP}}$ (Fujita et al., 2003).

La supervivencia celular promovida por la acción de factores de crecimiento es otra de las funciones mediadas por la ruta Ras/ERK. Las quinasas RSKs promueven la supervivencia celular mediante la inactivación de proteínas pro-apoptóticas como Bim o DAPK, y a través de la inducción transcripcional de genes implicados en supervivencia como Bcl-2 y Bcl-XL (Anjum et al., 2005; Bonni et al., 1999; Ley et al., 2003).

(iii) Remodelación del citoesqueleto de actina: fosforilación de proteínas del citoesqueleto

La fosforilación de proteínas de unión a actina desempeña un papel clave en la remodelación del citoesqueleto de actina, que influye en la capacidad mitogénica, en la morfología y en la migración celular. Entre estas proteínas se encuentra la paladina, que es fosforilada por ERK1/2 en los residuos Ser77 y Ser197 tras la estimulación con factores de crecimiento, y que regula negativamente la migracion (Asano et al., 2011). Por otro lado, ERK1/2 fosforila la paxilina, proteína encargada de la regulación de la proteína FAK, que promueve la morfogénesis celular (Yoon and Seger, 2006). Además, ERK1/2 fosforila también a la proteína Mlck, que facilita la actividad de la paxilina favoreciendo la motilidad celular (Klemke et al., 1997). 


\section{(iv) Regulación de la activación de ERK}

Las proteínas de andamiaje desempeñan un papel esencial en la regulación espacio-temporal de la señalización mediada por ERK. Estas proteínas se unen a más de un componente de la ruta de señalización regulando e integrando la transducción de señales (Dhanasekaran et al., 2007; Kolch, 2005). Algunas proteínas acopladoras en esta ruta son KSR1/2, IQGAP1, MP1, MORG1, arrestina1/2, Sef, MEKK1, y paxillina. Además, ERK puede unirse a proteínas de anclaje como la tubulina (Reszka AA et al., 1995), la actina (Leinweber et al., 1999) y la vimentina de los filamentos intermedios (Perlson et al., 2005) que pueden modular su activación.

En conjunto, la regulación de una respuesta celular específica a los estímulos recibidos depende de varios factores: la intensidad y duración de la señal, que puede ser modulada por la cantidad y la tasa de internalización de receptores, la interacción de ERK con proteínas de andamiaje o scaffold como KSR1/2, IQGAP1, MP1, $\beta$-Arrestina1/2, la localización subcelular de ERK1/2 así como la disponibilidad de sustratos (Murphy and Blenis, 2006; Raman et al., 2007).

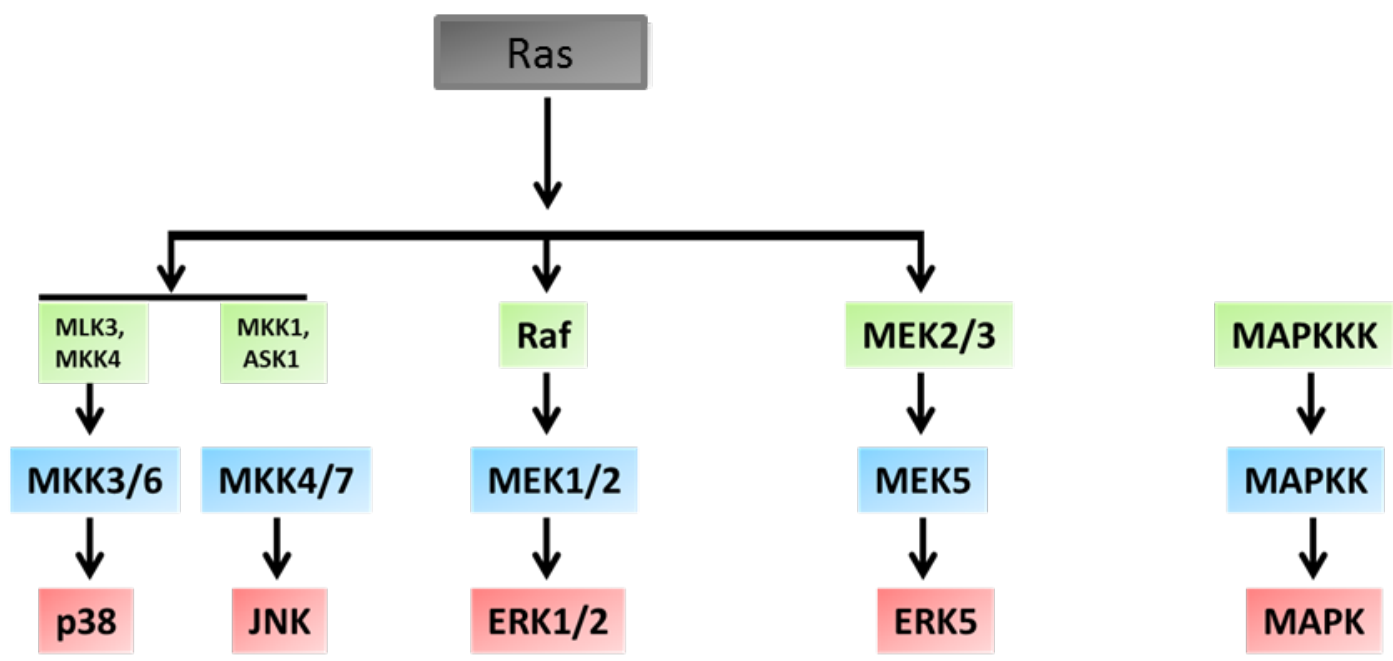

Figura 11. Vías efectoras Ras/MAPK. Existen 4 grupos principales de MAPKs en mamíferos (ERK1/2, p38 $\alpha / \beta / \delta / \gamma, J N K 1 / 2 / 3$ y ERK5). Las rutas de señalización de las MAPKs están formadas por 3 elementos que se activan en cascada mediante fosforilación. JNK y p38 son estimuladas por señales de estrés, ERK1/2 es activada principalmente por factores de crecimiento y ERK5 tanto por factores de crecimiento como señales de estrés. Muchos de los sustratos de las MAPKs son factores de transcripción a través de los cuales regulan la expresión génica.

\subsubsection{Rutas de señalización mediadas por PI3K}

La activación de RTKs o GPCRs induce el reclutamiento de multitud de proteínas a los residuos fosforilados del receptor, entre ellas, las proteínas de la familia PI3K (Kazlauskas and Cooper, 1990; 
Ruderman et al., 1990). Estas proteínas están formadas por una subunidad catalítica (p110) y una subunidad reguladora ( $\mathrm{p85}$ ), y se unen al receptor directamente, o a través de proteínas adaptadoras mediante el dominio SH2 de la subunidad p85 (Escobedo et al., 1991; Otsu et al., 1991). Esta interacción produce un cambio conformacional en p85 que se transmite a p110, aumentando así su actividad enzimática, que cataliza la formación de $\mathrm{PIP}_{2}$ y $\mathrm{PIP}_{3}$ en la membrana. Estos fosfolípidos actúan como segundos mensajeros, constituyendo un punto de anclaje para multitud de moléculas efectoras como PDK1 y Akt (proteína quinasa B) (Franke et al., 1995). Además, PI3K a través de la unión de su dominio PH con $\mathrm{PIP}_{3}$, se une a otras proteínas como Rac, S6K y GSK3, ciertos GEFs y GAPs y a otras proteínas quinasas y adaptadoras (Dowler et al., 2000; Isakoff et al., 1998; Krugmann et al., 2002; Welch et al., 2002).

RasGTP puede activar a PI3K a través de la interacción con la subunidad catalítica p110 (Kodaki et al., 1994; Rodríguez-Viciana et al., 1997). Concretamente, se ha visto que la Lys227 de PI3K es clave en la interacción entre Ras y PI3K (Rodríguez-Viciana et al., 1997). Esta interacción estimula la actividad de PI3K, complementando así la activación, no dependiente de Ras, que pueda tener PI3K a través de la estimulación de receptores específicos (Rodríguez-Viciana et al., 1996) (Figura 12).

Por otra parte, existen al menos dos fosfatasas, PTEN y SHIP, cuya actividad regula negativamente la señalización a través de PI3K mediante la reducción de los niveles de $\mathrm{PIP}_{3}$ en la membrana (Vivanco and Sawyers, 2002). 


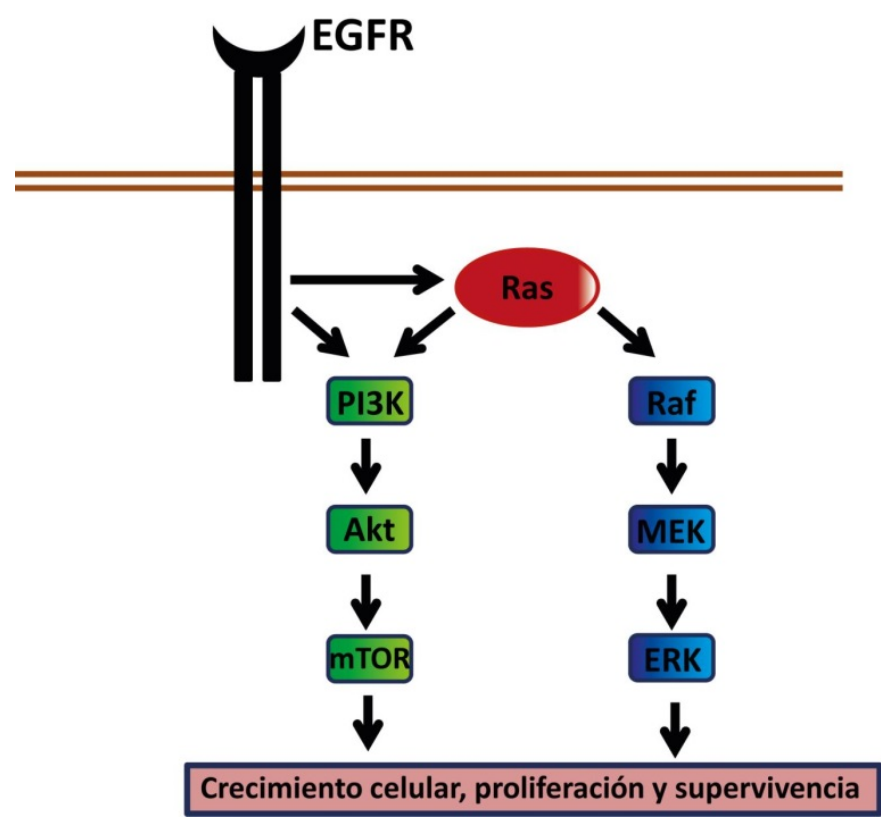

Figura 12. Ruta de señalización Ras/PI3K. La activación de la ruta PI3K mediada por Ras y la activación de PI3K directamente por el EGFR convergen en la activación de la ruta PI3K/Akt.

\subsubsection{Ruta de señalización PI3K/Akt}

Akt es uno de los principales efectores de PI3K (Alessi et al., 1996; Mayer et al., 1993). La quinasa Akt se ancla a la membrana plasmática a través de su dominio $\mathrm{PH}$ e interacciona con $\mathrm{PIP}_{2}$ y $\mathrm{PIP}_{3}$ para favorecer su activación por PI3K (Andjelković et al., 1997). Una vez activado, Akt puede fosforilar un gran número de sustratos y regular así diversos procesos fundamentales como la supervivencia, la proliferación, el crecimiento celular, la angiogénesis, el metabolismo y la migración (Franke, 2008; Manning and Cantley, 2007). Aunque la fosforilación de Akt en la Thr308 es suficiente para activar a Akt, la activación completa requiere la fosforilación también en la Ser473 (Alessi et al., 1996; Stokoe et al., 1997). PDK1 fosforila Akt en Thr308 (Alessi et al., 1997; Andjelković et al., 1997) lo que promueve un cambio de conformación que permite la fosforilación de la Ser473 por mTORC2 (Sarbassov et al., 2005). Se han descrito otras quinasas que pueden fosforilar Akt en la Ser473 dependiendo del contexto, por ejemplo DNA-PK (Bozulic et al., 2008), proteínas asociadas a lipid-rafts (Hill et al., 2002), e incluso la auto-fosforilación del propio Akt (Toker and Newton, 2000). No obstante, se considera que tras la estimulación con factores de crecimiento la fosforilación de Akt en Ser473 es mediada principalmente por mTORC2. 


\section{(i) Supervivencia}

La supervivencia celular está principalmente controlada por las señales de la ruta PI3K/Akt, aunque también participa en su regulación la ruta Ras/ERK. Diversas proteínas pro-apoptóticas son dianas de Akt (Franke et al., 1997), como es el caso de ASK1, JNK, Bad, Bax, la caspasa 9 y los factores de transcripción FoxO, que regulan la expresión de genes pro-apoptóticos como Bim (Brunet et al., 1999; Cardone et al., 1998; Datta et al., 1997; Gardai et al., 2004; Kops and Burgering, 1999). Akt fosforila estas proteínas pro-apoptóticas promoviendo su secuestro por la familia de proteínas 14-3-3 bloqueando así su actividad.

\section{(ii) Crecimiento celular}

El crecimiento celular está regulado por la ruta PI3K/Akt a través de las quinasas mTOR y p70S6K, reguladores fundamentales de la síntesis de proteínas y del crecimiento celular (Franke, 2008; Wullschleger et al., 2006). La quinasa mTOR puede formar dos complejos excluyentes y funcionalmente distintos: mTORC1 cuando está unido a raptor y mTORC2 cuando está asociado a rictor. mTORC1 funciona como un sensor que regula la síntesis proteica, el crecimiento celular y la autofagia en función de la disponibilidad de nutrientes y el nivel energético de la célula (Shaw and Cantley, 2006). mTORC2 sin embargo, parece estar implicado en el control de la polaridad celular y el control espacial del crecimiento (Shaw and Cantley, 2006).

\section{(iii) Regulación de la ruta}

Entre los mecanismos de regulación negativa conocidos para esta ruta, podemos señalar la participación de las fosfatasas PTEN y SHIP en la inhibición de la actividad de PI3K (Vivanco and Sawyers, 2002), y la fosforilación de IRS y Rictor por p70S6K (Mendoza et al., 2011). Asimismo, se han descrito fosfatasas que pueden catalizar la de-fosforilación directa de Akt, como PHLPP1 y PHLPP2 y las fosfatasas de la familia PP2A (Brognard et al., 2007; Gao et al., 2005; Kuo et al., 2008).

\subsubsection{Señalización independiente de Akt mediada por PI3K}

Además de la multitud de procesos que PI3K controla a través de Akt, existen otras vías efectoras independientes de esta quinasa (Vivanco and Sawyers, 2002). PI3K puede activar a la quinasa GSK3 (Cross et al., 1995; Welsh et al., 1994) y a las GTPasas Cdc42 y Rac (Hawkins et al., 1995), así como 
otras proteínas pertenecientes a familias de GAPs y GEFs (Krugmann et al., 2002; Welch et al., 2002) sin la necesidad de actuación de Akt.

En este sentido, la señalización coordinada entre las GTPasas Ras y Rac está mediada por PI3K (Rodríguez-Viciana et al., 1997) y de este modo se podría explicar la capacidad de Ras para generar ruffles a través del eje de señalización PI3K/Rac (Ridley and Hall, 1992; Wennström et al., 1994a, 1994b). De hecho, la proteína PI3K, junto con PTEN, participa en la migración celular (Servant et al., 2000). En procesos de quimiotaxis, la célula se dirige hacía el estímulo atrayente y PI3K se relocaliza y se activa en el frente migratorio generando una acumulación de $\mathrm{PIP}_{3}$ en esta región y así desencadenando la señalización efectora. Este gradiente de activación de PI3K en el eje migratorio colabora en la formación de la polaridad celular (Devreotes and Janetopoulos, 2003; Huang et al., 2003) y la migración (Servant et al., 2000).

En estos procesos Sos tiene un papel fundamental acoplando la señalización entre ambas GTPasas, Rac y Ras (Innocenti et al., 2003; Nimnual et al., 1998). No obstante, Ras también puede activar a Rac mediante la activación de Tiam1, independientemente de la mediación de PI3K (Lambert et al., 2002).

\section{Significado funcional de las proteínas Sos}

\subsection{Estudio funcional de las proteínas Sos}

La mayoría de trabajos publicados sobre las proteínas Sos se han centrado en Sos1. De hecho, la bibliografía relativa a las posibles funciones de Sos2 es muy reducida. Sólo en algunos casos se realiza un estudio comparativo entre Sos1 y Sos2 aportando información sobre la redundancia o especificidad funcional que existe entre ellas (Baltanás et al., 2013; Guittard et al., 2015, 2017; Liceras-Boillos et al., 2016; Nielsen et al., 1997; Oh-hora et al., 2003; Qian et al., 2000; Yang et al., 1995). Los ratones KO (knockout) individuales para Sos1 y Sos2 han aportado información crucial acerca de la función específica de cada proteína en distintos contextos celulares y/o tisulares (Baltanás et al., 2013; Esteban et al., 2000; Qian et al., 2000; Wang et al., 1997). Nuestro grupo de investigación generó recientemente el primer modelo animal que posibilita analizar la especificidad o redundancia funcional de Sos1 y Sos2 de forma conjunta (Baltanás et al., 2013). En general, los trabajos anteriores han inferido las funciones de las proteínas Sos basándose en los efectos de su eliminación, aunque se han publicado ciertos estudios que emplean la estrategia contraria, es decir, 
inducir una ganancia de función de Sos. A continuación, detallaremos los resultados obtenidos en este tipo de estudios tanto en modelos in vivo como in vitro.

\subsubsection{Pérdida de función}

\subsubsection{Modelos in vivo}

El análisis funcional de las proteínas Sos in vivo ha proporcionado información valiosa sobre la redundancia o especificad funcional de estas proteínas. La generación de ratones deficientes para Sos1 o Sos2 demostró que Sos1 es esencial para el desarrollo embrionario, pues su ausencia es letal durante el periodo de gestación (Qian et al., 2000; Wang et al., 1997). Inicialmente, se asoció la muerte de los embriones deficientes de Sos1 con la existencia de defectos cardiovasculares (Wang et al., 1997) pero más tarde se demostró que la muerte prematura de estos animales se debía a defectos en el desarrollo de la placenta (Qian et al., 2000). Un fenotipo similar se ha descrito en otras especies como D. melanogaster y C.elegans donde la expresión de Sos también es necesaria en el desarrollo (Chang et al., 2000; Rogge et al., 1991; Simon et al., 1991). En cambio, los ratones deficientes en Sos2 son viables, fértiles y sin fenotipo aparente (Esteban et al., 2000). Este hecho es importante pues demuestra que Sos2 no es capaz de compensar la deficiencia de Sos1 durante el desarrollo embrionario, a pesar del alto grado de homología entre ambas proteínas e incluso del amplio patrón de expresión de proteínas, y además apunta a que ninguno de los GEFs específicos de Ras que se expresen en ese momento del desarrollo puede sustituir la función de Sos1.

Las diferencias observadas respecto a la causa de la muerte de los embriones en ambos estudios se pueden deber a la variabilidad genética entre las estirpes murinas y las células madre embrionarias utilizadas, así como a las distintas estrategias empleadas para la inactivación genética de Sos1 (eliminación de exones distintos).

La letalidad embrionaria de los animales mutantes Sos1 ha imposibilitado analizar la función de esta isoforma en modelos murinos in vivo durante la etapa adulta. Por ello nuestro grupo de investigación generó un modelo murino inducible por tamoxifeno que permitía eliminar la proteína Sos1 en el momento deseado durante la etapa adulta (Baltanás et al., 2013). Los resultados obtenidos a partir de este estudio demostraron que la ausencia de Sos1 no afecta a la supervivencia del organismo 
durante la etapa adulta (Baltanás et al., 2013). Sin embargo, la ausencia combinada de Sos1 y Sos2 producía la muerte rápida del animal (Baltanás et al., 2013).

En cuanto a la función específica de las proteínas Sos en distintos órganos, muchos de los estudios han demostrado la importancia de Sos1 y Sos2 en el desarrollo y mantenimiento de ciertos órganos linfoides como el timo y el bazo, y linajes celulares como los linfocitos B y $\mathrm{T}$ y sus precursores de la medula ósea, entre otros (Baltanás et al., 2013; Kortum et al., 2011). Además, la ausencia de combinada de Sos1 y Sos2 provocaba aplasia medular (Baltanás et al., 2013).

En términos generales, no se han descrito apenas funciones específicas para la proteína Sos2, aunque recientemente se han generado embriones de zebrafish knockdown para Sos2. En este modelo se ha observado que la ausencia de Sos2 altera la fisiología del glomérulo renal y la morfología de los túbulos renales (Li et al., 2017). Estos resultados sugieren que Sos2 podría estar implicado en el desarrollo renal durante la etapa embrionaria pudiendo afectar la función renal en la etapa adulta.

\subsubsection{Modelos in vitro}

Pese a que comparten la misma actividad biológica y gran parte de la estructura molecular, las proteínas Sos1 y Sos2 presentan diferencias en sus propiedades bioquímicas y de señalización como explicamos anteriormente. La estabilidad proteica de mSos1 es mayor que la de mSos1 (Nielsen et al., 1997), mientras que hSos2 tiene más afinidad que hSos1 por Grb2 (Yang et al., 1995). Es probable que las diferencias entre Sos1 y Sos2 en la región C-terminal puedan ser responsables, al menos en parte, de algunas de estas diferencias bioquímicas y funcionales, por ejemplo en lo que a la afinidad por Grb2 se refiere.

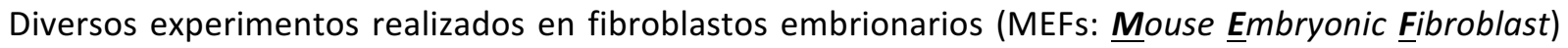
inmortalizados derivados de ratones KO para Sos1, han proporcionado información sobre las propiedades señalizadoras de ambas proteínas. Primeramente se describió que la eliminación de Sos1 en MEFs primarios provocaba una reducción de la fosforilación de ERK1/2 respecto a MEFs wt solamente a tiempos cortos (Wang et al., 1997). En cambio, otro trabajo posterior describe que Sos1 participa en la señalización a corto y largo plazo, mientras que Sos2 sólo es capaz de mediar señales a corto plazo (Qian et al., 2000). Esto se debe a que la unión de Sos1 a los complejos formados tras una estimulación (complejo EGFR-Shc-Grb2-Sos) es más estable que la unión de Sos2 a estos mismos complejos (Qian et al., 2000). 
Finalmente, los MEFs ko-Sos1 muestran resistencia a la transformación por los oncogenes v-Src o EGFR, indicando que Sos2 no es capaz de trasmitir la señal oncogénica (Qian et al., 2000). La transformación celular requiere la continua actividad del oncogén, lo que correlaciona con la capacidad de la proteína Sos1 para señalizar a largo plazo. Apoyando esta idea, experimentos de inmunoprecipitación con Shc y v-Src (constitutivamente activo y por tanto señalizando a largo plazo) confirmaron que Sos1 se une a estas proteínas más eficientemente que Sos2. Además, se ha demostrado que la restauración de la expresión de Sos1 en los MEFs deficientes de Sos1 restablece la susceptibilidad de estas células a la transformación por v-Src (Qian et al., 2000) Igualmente, otros estudios han descrito que la expresión de formas miristoiladas de Sos1 en fibroblastos NIH3T3 exhiben mayor capacidad transformante que las de Sos2. Según los autores, esto puede ser debido a diferencias en la estabilidad de ambas proteínas mSos1 (Nielsen et al., 1997).

Dos de los linajes celulares más estudiados en cuanto a la función de las proteínas Sos son las linfocitos T y B. Se ha demostrado que la participación de Sos1 es esencial durante las primeras fases de maduración de los linfocitos T en el timo (Baltanás et al., 2013; Kortum et al., 2011). Aunque la ausencia individual de Sos2 no parecía afectar este proceso, su presencia atenúa en parte las deficiencias observadas cuando Sos1 está también ausente (Baltanás et al., 2013). Además, la ausencia de Sos1 de forma individual o combinada con Sos2, afecta incluso a la viabilidad de los precursores de linfocitos T procedentes de la medula ósea (Baltanás et al., 2013). Debemos señalar que durante este proceso de maduración de los timocitos, tiene lugar una reducción progresiva de la implicación de Sos que se corresponde con un aumento de función del GEF RasGRP1 (Kortum et al., 2011; Oki et al., 2012; Roose et al., 2005, 2007). Es decir, las proteínas Sos son importantes durante las primeras etapas de maduración de linfocitos mientras que RasGRP1 lo es en las etapas finales. En este sentido, Sos1 no es necesario para la fosforilación de ERK tras estimulación del receptor TCR en linfocitos T circulantes (Guittard et al., 2015; Warnecke et al., 2012). Sin embargo, debemos señalar que las proteínas Sos sí parecen mediar la fosforilación de ERK tras estimulación con IL-2 en linfocitos T maduros (Guittard et al., 2015). Curiosamente, estas células también mostraron una reducción de la migración tras la eliminación de Sos1 (Guittard et al., 2015). Recientemente, se ha asociado la eliminación de Sos1 en linfocitos T primarios humanos a una pérdida de la adhesión, acompañada de una menor activación de Rac1 y RhoA y de una disminución de la señalización a través de integrinas (Toffali et al., 2017). 
En lo referente al desarrollo y maduración de células $B$, se ha descrito que la eliminación individual de las proteínas Sos1 o Sos2 no afecta a los progenitores de linfocitos B de la medula ósea, aunque la ausencia de ambas proteínas supone una eliminación casi completa de estos precursores, en particular de las poblaciones pro-B y pre-B (Baltanás et al., 2013). De este modo, se demuestra una redundancia funcional de las proteínas Sos durante la diferenciación de progenitores de células B en la médula ósea que no es suplida por otro RasGEF (Baltanás et al., 2013). Poco se sabe aún de la posible función de las proteínas Sos en las poblaciones maduras de linfocitos B. Trabajos previos han demostrado que la activación de ERK durante la maduración de células B es regulada de manera prevalente por RasGRP1/3 y no por las proteínas Sos (Oh-hora et al., 2003; Roose et al., 2007), aunque un estudio reciente sugiere que la disminución de expresión de Sos1 y Sos2 conduce a una reducción de las señalización Ras/ERK en dos líneas celulares distintas de linfocitos B (Alles et al., 2017).

\subsubsection{Ganancia de función de las proteínas Sos}

Además de los modelos basados en la inactivación de la función de Sos, se han empleado modelos genéticos mutantes para Sos1 que inducen una ganancia de función de esta proteína (Chen et al., 2010b; Modzelewska et al., 2007; Sibilia et al., 2000).

En C. elegans, la ganancia de función de Sos1 causada por una mutación en el dominio DH produce defectos en el desarrollo del gusano (Modzelewska et al., 2007). En este trabajo además, la mutación Sos1C282R, homóloga a la encontrado en C. Elegans, en células humanas. Esta mutación altera la inhibición que ejerce el dominio $\mathrm{DH}$ sobre el sitio alostérico provocando un aumento en la actividad de Sos1 y una mayor estimulación de la ruta Ras/ERK en células humanas en cultivo (Modzelewska et al., 2007).

Se ha generado también un modelo murino que expresa de forma inducible la mutación Sos1E846K, que es la misma mutación activante presente en algunos pacientes con SN y que afecta al dominio catalítico Cdc25 aumentando la actividad GEF de Sos1 (Chen et al., 2010b). Los ratones homocigotos para esta mutación sufren en su mayoría letalidad embrionaria por defectos severos en la función cardiovascular, mientras que los heterocigotos desarrollan un fenotipo muy parecido al que sufren los pacientes de SN, incluyendo anomalías hematológicas, facio-cutáneas y graves defectos cardíacos (Chen et al., 2010b). 
Asimismo, mutaciones que provocan la ausencia de la región C-terminal de Sos1 por la aparición de un codón stop prematuro inducen una ganancia de función de esta proteína. Cuando estos mutantes se encuentran en la línea germinal provocan un crecimiento exacerbado en la encía, dando lugar a una patología denominada fibromatosis gingival hereditaria tipo 1 (HGF1) (Hart et al., 2002) que se describirá más en detalle en el apartado 6.2.3.

Por otro lado, las mutaciones en Sos1 que implican ganancia de función pueden contribuir también al desarrollo tumoral. La expresión específica en queratinocitos de una forma constitutivamente activa de Sos (construida mediante la eliminación de gran parte de la región C-terminal y la adición de un grupo farnesilo para su localización estable en la membrana) induce la formación de tumores en la piel (Sibilia et al., 2000). Curiosamente, los tumores que desarrollan estos animales dependen de la función de EGFR y están asociados a un aumento de la proliferación. Además, EGFR transmite señales anti-apoptóticas independientes de Sos1 (probablemente a través de Akt) necesarias para la supervivencia de las células tumorales (Sibilia et al., 2000). En consonancia con estos resultados, estudios anteriores realizados con fibroblastos NIH3T3 y Rat-1 demostraron que formas constitutivamente activas de Sos, mediante farnesilación, miristoilación o a través de la eliminación de su región C-terminal, pueden inducir transformación celular (Aronheim et al., 1994; Nielsen et al., 1997; Wang et al., 1995).

A continuación, detallaremos en profundidad algunas de las patologías más importantes asociadas a alteraciones funcionales de las proteínas Sos, principalmente debidas a alteraciones en Sos1.

\subsection{Patologías asociadas a la función de Sos}

\subsubsection{Implicación de las proteínas Sos en procesos tumorales}

Actualmente, las patologías humanas conocidas asociadas a alteraciones en la función de las proteínas Sos están causadas principalmente por una ganancia de función, bien por mutaciones puntuales en la secuencia génica o bien por sobreexpresión. Se ha descrito sobreexpresión de Sos1 en ciertos tipos de tumores humanos, como en cáncer de vejiga (Watanabe, Nobuo Shinohara, Kimihiko et al., 2000), de riñón (Shinohara et al., 1997) y en cáncer de mama y próstata, entre otros (Field et al., 2012; Timofeeva et al., 2009). Indirectamente a una ganancia o pérdida de función de Sos, se ha descrito que la proteína p $27^{\mathrm{KIP} 1}$, que inhibe la unión de Grb2-Sos1, está reducida en tumores con alta agresividad (Moeller et al., 2003). Además, en el caso de la leucemia mieloide se ha demostrado que 
la activación de Rac1 mediada por Sos1, es necesaria para la función oncogénica de la proteína BcrAbl en el desarrollo de esta enfermedad (Sini et al., 2004).

También se ha observado que la estabilidad del complejo Sos1/Eps8/E3b1 en carcinoma de ovario es crítica para la adquisición de la capacidad metastásica (Fang et al., 2017). En este sentido, la deficiencia en la expresión de al menos uno de los elementos de este complejo correlaciona con la incapacidad para metastatizar observada en células tumorales de ovario (Chen et al., 2010a).

En este contexto, es interesante señalar que existen contaminantes ambientales con propiedades cancerígenas que pueden estimular directamente la sobreexpresión de Sos1 (Pierre et al., 2011). Por ejemplo, la dioxina TCDD (2,3,7,8-tetrachlorodibenzodioxin) es un potente carcinógeno conocido por su afinidad por el receptor AhR. Una vez estimulado, AhR se transloca al núcleo y promueve la transcripción de genes relacionados con funciones de detoxificación y metabolismo (Barouki et al., 2007). Estudios realizados en la línea celular de hepatocarcinoma humano HepG2, demuestran que tras el tratamiento con esta dioxina, AhR promueve la transcripción de Sos1. Así, la sobreexpresión de Sos1 en estas células desencadena un aumento de la activación de su ruta efectora Ras/ERK y consecuentemente una mayor tasa proliferativa (Pierre et al., 2011). La exposición continuada a este tipo de tóxicos ambientales puede producir una estimulación constitutiva y patológica de la ruta Sos/Ras/ERK, un proceso que puede ser particularmente relevante en aquellas células cancerosas que no poseen mutaciones en Ras.

Curiosamente, se ha demostrado, que la proteína Sos1 promueve la activación de la forma no oncogénica de Ras a través de la forma oncogénica (Jeng et al., 2012). El mecanismo de esta activación se produce por la unión del RasGTP generado por la forma oncogénica de Ras, con el dominio alostérico de Sos1. Este proceso se describió como independiente de la señalización a través de RTK. Estos resultados atribuyen a Sos un papel clave en el control del crecimiento tumoral en tumores dependientes de Ras oncogénico (Jeng et al., 2012). Este conjunto de hallazgos que involucran a Sos en diversos procesos oncogénicos mediante mecanismos muy diferentes, sitúan a Sos1 como un buen candidato de estudio como posible diana terapéutica para la prevención o tratamiento de determinados tumores.

\subsubsection{Síndrome de Noonan}


EI SN es una enfermedad autosómica dominante, genéticamente heterogénea, que produce un desorden del desarrollo y que se caracteriza por baja estatura, rasgos faciales únicos, anomalías hematológicas, defectos cardíacos congénitos y un grado variable de retrasos neurocognitivos en los paciente (Noonan, 2007; Tartaglia et al., 2010; Tidyman and Rauen, 2016). Los individuos con esta enfermedad tienen una predisposición a desarrollar tumores para-espinales (Santoro et al., 2017) y otros tipos de tumores como rabdomiosarcoma embrionario, tumores de células de Sertoli o tumores granulares en la piel (Denayer et al., 2010).

Se han descrito varias mutaciones en la línea germinal en el gen Sos1, que son responsables de un 15\% de los casos de SN familiar y esporádico (Roberts and Der, 2007; Tartaglia et al., 2007). Todas están basadas en una sustitución aminoacídica que da lugar a una ganancia de función de Sos1. La mayoría se encuentran en los dominios $\mathrm{DH}, \mathrm{PH}, \mathrm{REM}$, en la zona de unión entre el dominio PH y REM, y en menor proporción, en los dominios H y Cdc25 (Roberts and Der, 2007; Shannon and Bollag, 2007; Tartaglia et al., 2007, 2010). Estas mutaciones alteran la conformación de Sos en estado inactivo, pues afectan a las interacciones intramoleculares entre la unidad DH-PH y el sitio alostérico, y entre el dominio $\mathrm{H}$ y la zona de unión $\mathrm{L}$, que en ausencia de estímulo mantienen a Sos en un estado inactivo. Aunque estudios previos no habían detectado mutaciones en el gen Sos 2 relacionadas con esta enfermedad (Roberts and Der, 2007; Tartaglia et al., 2007), un estudio reciente ha documentado casos de SN que presentaban mutaciones en el dominio DH de Sos2 (Cordeddu et al., 2015). Aparte de las proteínas Sos, mutaciones en otros elementos de la ruta Ras/MAPK pueden causar también este síndrome, como ocurre con PTPN11 (que codifica la fosfatasa Shp2) cuyas mutaciones producen el 50\% de los casos de SN (Tartaglia et al., 2001) o en menor proporción con otros genes como K-Ras, Raf1, B-Raf o MEK1 (Nava et al., 2007; Pandit et al., 2007; Sarkozy et al., 2009; Schubbert et al., 2006; Tartaglia et al., 2007).

\subsubsection{Fibromatosis gingival hereditaria}

La HGF1 es una condición genética rara, autosómica dominante, caracterizada por un crecimiento benigno de la encía (Hart et al., 2002). Mediante estudios genéticos se ha identificado una mutación en el gen Sos1 en pacientes con esta enfermedad. Esta mutación consiste en la inserción de una citosina que origina un cambio en el marco de lectura, dando lugar a un codón de stop prematuro, que genera una proteína truncada que carece de gran parte de la región C-terminal y que además posee 22 aminoácidos nuevos en el extremo C-terminal (Hakkinen and Csiszar, 2007; Hart et al., 
2002), generando así una ganancia de función de Sos1. Los estudios realizados con fibroblastos procedentes de la encía de pacientes con HGF1 han demostrado que existe un incremento significativo en la proliferación de estas células (Lee et al., 2006). Los niveles de activación de Ras y ERK en fibroblastos HGF1 son más elevados que en fibroblastos procedentes de la encía de individuos sanos (Jang et al., 2007).

\subsubsection{Otras patologías}

Estudios diseñados para identificar componentes genéticos que contribuyen a la predisposición a padecer diabetes tipo 2 han relacionado la presencia de polimorfismos del gen Sos1 con un mayor riesgo de sufrir esta enfermedad (Barroso et al., 2003). Posteriormente, escogieron los mismos genes candidatos utilizados en diabetes para buscar genes de susceptibilidad para desarrollar la enfermedad Alzheimer, pues existen evidencias sólidas de que el metabolismo de la glucosa y la señalización mediada por insulina están íntimamente relacionados con la aparición de la enfermedad de Alzheimer. En este estudio encontraron una asociación significativa de algunas variantes de Sos2 con la predisposición a desarrollar esta enfermedad (Hamilton et al., 2007).

Como curiosidad, se ha publicado un estudio que relaciona Sos1 con el hirsutismo, un trastorno caracterizado por el crecimiento excesivo de vello en mujeres, que se asocia a niveles excesivos de andrógenos (Minella et al., 2011). En este trabajo analizaron el perfil transcripcional de fibroblastos de pacientes con hirsutismo severo, y encontraron sobreexpresión del gen Sos1 en todas las muestras analizadas. Se ha sugerido que Sos1 podría ejercer una efecto paracrino y proliferativo en la célula tras estimulación con andrógenos, que desempeña un papel importante en la proliferación del folículo piloso y en la regulación del mismo (Minella et al., 2011).

\subsection{Inhibición farmacológica de Sos}

A pesar de los numerosos estudios que se han realizado, no se han descubierto inhibidores efectivos en clínica que actúen sobre las proteínas Ras (Cox et al., 2014). Esto se debe principalmente a la elevada afinidad de Ras por el GTP y a que la proteína Ras dispone de escasos compartimentos estructurales donde podría unirse una molécula de forma estable. Ambas características dificultan el desarrollo de inhibidores efectivos (Ledford, 2015). Una aproximación alternativa sería el desarrollo de una molécula que pueda unirse a la interfaz de las moléculas activadoras y/o efectoras de Ras, o 
que consigan impedir las PPIs. El diseño de inhibidores dirigidos a las PPIs está generando un interés creciente como estrategia farmacológica para la inhibición de Ras.

Cuando una molécula de GDP se une al dominio catalítico Cdc25 de Sos, se produce un cambio conformacional en Ras que resulta en la apertura del sitio de unión del nucleótido de guanina, lo que debilita la afinidad de Ras por Sos, facilitando así la disociación/unión de nucleótidos de guanina (Quilliam et al., 1996). En base a ello, se han desarrollado diferentes moléculas inhibidoras de pequeño tamaño como son los derivados de glúcidos (Ganguly et al., 1997; Iversen et al., 2014; Peri et al., 2005), derivados de indol y sulfonamidas (Sun et al., 2012), compuestos como el Bisfenol A (Schöpel et al., 2013), derivados del compuesto andrografolida (Hocker et al., 2013) y compuestos que se unen de forma covalente a Ras (Winter et al., 2015). Por otro lado se han desarrollado compuestos péptido-miméticos (Patgiri et al., 2011) que impiden la formación del tándem Sos/Ras.

En particular, los derivados de glúcidos se unen al sitio de unión de RasGDP con Sos, de este modo impiden la asociación de H-Ras con el GTP e inhiben la disociación de H-Ras con el GDP (Ganguly et al., 1997; Iversen et al., 2014; Peri et al., 2005). Los derivados del indol y sulfonamidas inhiben la activadad catalítica de Sos sobre K-Ras mediante el bloqueo de las interacciones entre el dominio catalítico de Sos y la proteína K-Ras (Maurer et al., 2012; Sun et al., 2012), mientras que el compuesto Bisfenol A disminuye el intercambio de nucleótidos de guanina, uniéndose a K-Ras impidiendo su interacción con Sos, pero el mecanismo de acción no se conoce con exactitud (Schöpel et al., 2013). Por otro lado, los derivados de andrografolida se unen directamente con K-Ras y bloquean el intercambio GDP/GTP mediado por Sos (Hocker et al., 2013). Además, en el caso de los compuestos que se unen de manera covalente con H- y K-Ras impiden la interacción éstas con Sos (Winter et al., 2015). Finalmente, los compuestos péptido-miméticos de Sos impiden la unión del complejo Sos/Ras mediante interacción con Ras, impidiendo el intercambio de nucleótidos de guanina (Patgiri et al., 2011) o por asociación al sitio de unión de Sos en la proteína K-Ras (Leshchiner et al., 2015).

Dada la poca eficacia de los fármacos empleados en la clínica dirigidos a inhibir mediante diferentes mecanismos la señalización mediada por Ras en el proceso tumoral, resulta necesario el desarrollo de nuevos fármacos que actúen sobre nuevas dianas terapéuticas o que actúen mediante mecanismos diferentes. Por ello, el estudio de Sos como diana terapéutica y el posterior desarrollo farmacológico de compuestos que impidan su capacidad RasGEF supone un importante avance para el desarrollo de nuevos tratamientos en cáncer. 


\section{Implicación de Sos1 y Sos2 en la homeostasis de la piel.}

\subsection{La piel como modelo de estudio}

La piel constituye el mayor órgano del cuerpo y actúa como barrera protectora que aísla al organismo del medio. Su estratificación en epidermis, dermis e hipodermis nos permite diferenciar de manera clara los diferentes tipos celulares que participan en los distintos procesos que tienen lugar en este órgano, incluyendo el estudio de la regeneración epidérmica, la formación de los folículos pilosos y glándulas sebáceas, el componente inmunitario de la dermis, el grado de vascularización y el mantenimiento de la termorregulación que le confiere la hipodermis.

En particular, la epidermis de la protuberancia de los folículos pilosos o "bulge region" alberga las células madre epidérmicas. La población celular más abundante de esta capa son los queratinocitos (Figura 13). Por otro lado, la dermis es una capa formada principalmente por tejido conjuntivo con función de sostén donde además de encontrar de forma mayoritaria células inmunes (neutrófilos, macrófagos y linfocitos), también se encuentran en esta capa los folículos pilosos, las glándulas sebáceas, las terminaciones nerviosas, y los vasos linfáticos y sanguíneos (Figura 13). Finalmente, la hipodermis está formada mayoritariamente por tejido adiposo que permite el mantenimiento de la termorregulación, además contiene también ligamentos y nervios cutáneos y vasos sanguíneos y linfáticos (Figura 13).

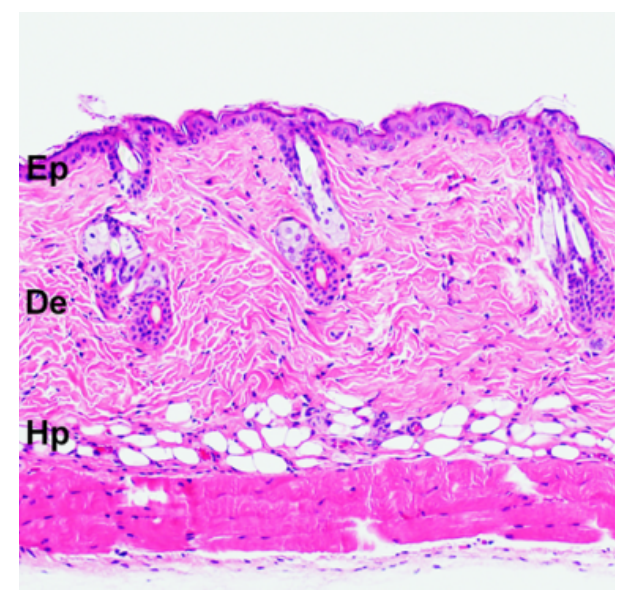

Figura 13. Estructura de la piel de un ratón adulto. Ep: epidermis, De: dermis y $\mathrm{Hp:} \mathrm{hipodermis.}$ 


\subsection{Estructura de la epidermis}

La epidermis es un epitelio escamoso estratificado que está en permanente renovación. Se compone principalmente de queratinocitos, aunque también se pueden encontrar melanocitos, células inmunes (células de Langerhans y linfocitos T) y células de Merkel. La epidermis a su vez está organizada en 4 estratos en función de su grado de diferenciación (de menor a mayor): estrato basal, estrato espinoso, estrato granuloso y finalmente, estrato corneo (Figura 14). El principal papel que desempeña la epidermis es su función barrera esta depende de una correcta adhesión entre queratinocitos que se encuentran en diferentes capas de la epidermis cuya capacidad proliferativa es diferencial dependiendo de su localización (Blanpain and Fuchs, 2009; Koster et al., 2007). El balance entre diferenciación y proliferación es crucial para la homeostasis de la epidermis.

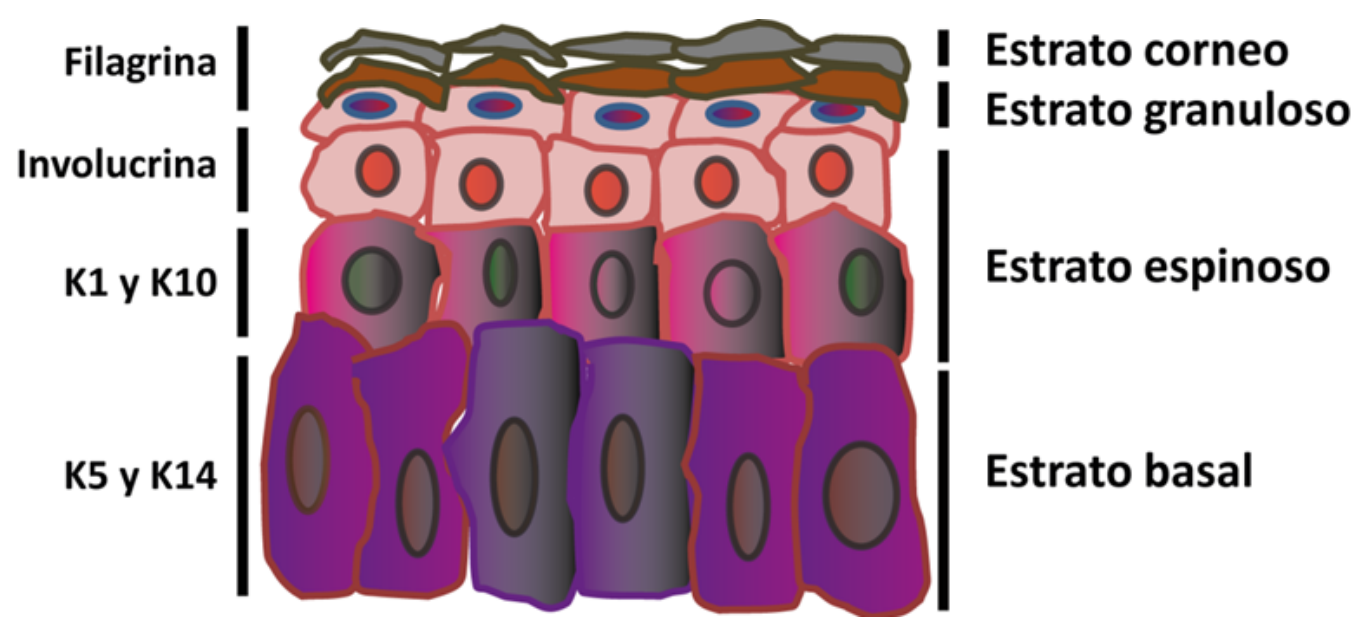

Figura 14. Estructura de la epidermis. Esquema de los estratos de la epidermis desde la capa basal hasta el estrato corneo. En cada uno de los estratos se especifica que proteínas se expresan en cada uno, de manera que pueden ser utilizados como marcadores para definir cada estrato.

\subsection{Papel de la señalización Ras/MAPK en la epidermis}

Se ha demostrado que el eje de señalización Ras/MAPK desempeña un papel clave en la homeostasis de la epidermis (Dajee et al., 2002; Dumesic et al., 2009; Scholl et al., 2007; Sibilia and Wagner, 1995). En este sentido, el EGFR es un regulador crítico de la homeostasis de esta capa, que junto con la activación de Ras a través de integrinas (Janes and Watt, 2006) mantienen activo el eje Ras/MAPK.

La ausencia de las formas $\mathrm{H}$ - y N-Ras no supone cambios en el desarrollo y homeostasis de la epidermis. Sin embargo, la eliminación adicional de K-Ras afecta notoriamente a la integridad de la 
epidermis (Drosten et al., 2010). Hay que destacar que un solo alelo de la isoforma K-Ras es suficiente para mantener el desarrollo y estratificación de la epidermis, pero la ausencia combinada de las tres proteínas canónicas de Ras ( $\mathrm{H}-, \mathrm{N}$ - y K-Ras) supone un cese de la proliferación de los queratinocitos. Este bloqueo de la proliferación induce un proceso senescente, sin signos evidentes de apoptosis, en este tipo celular (Drosten et al., 2014). La ausencia concomitante de $\mathrm{H}-, \mathrm{N}$ - y K-Ras también afecta al desarrollo de los folículos pilosos, generando un retraso en la evolución de los mismos (Drosten et al., 2014). Además del papel esencial de las proteínas Ras en la epidermis, la eliminación combinada de las proteínas efectoras de Ras como Mek1/2 (Scholl et al., 2007) o ERK1/2 (Dumesic et al., 2009) genera también defectos en el desarrollo y/o la homeostasis de la epidermis.

Como ya hemos descrito, las rutas de señalización de Ras y de Rac están íntimamente relacionadas. En consecuencia, es importante describir el papel de Rac1 en la piel. Brevemente, la expresión de Rac1 en la piel se localiza en el estrato basal de la epidermis y en la epidermis interfolicular (Tumbar et al., 2004). La eliminación de Rac1 provoca una pérdida de las células madre de la piel en el folículo piloso, que va acompañada de una pérdida progresiva de las células sebáceas (Benitah et al., 2005). Sin embargo, no produce cambios en la homeostasis y estratificación epidérmica, por ello Rac1 parece prescindible para el mantenimiento de la epidermis en condiciones fisiológicas (Chrostek et al., 2006).

\subsection{Importancia de las proteínas Ras y Rac en carcinogénesis epitelial}

El papel que desempeña Ras en carcinomas de célula escamosa en humanos (CCE) y en modelos de ratones está ampliamente documentado. El número de CCE que presentan Ras constitutivamente activo es mucho mayor que otras mutaciones (Khavari and Rinn, 2007). Además, la mayoría de los CCE presentan una activación descontrolada del eje Ras/MAPK (Khavari and Rinn, 2007).

El protocolo de carcinogénesis química DMBA-TPA reproduce fielmente el desarrollo de tumores epiteliales de célula escamosa en humanos. Concretamente, se ha descrito que este protocolo induce tumores generando un sumatorio de mutaciones, donde la mutación en $\mathrm{H}$-Ras parece fundamental (Balmain et al., 1984; Quintanilla et al., 1986). En este sentido, se ha demostrado que la eliminación de $\mathrm{H}$-Ras reduce muy significativamente el desarrollo de tumores generados por protocolo (Ise et al., 2000). Del mismo modo que en condiciones fisiológicas, en condiciones tumorales la célula madre

tumoral mantiene el nuevo tejido estableciendo una organización jerárquica (Pérez-Losada and Balmain, 2003). En este protocolo se sabe que una parte de los papilomas generados tiene su origen 
en las células madre de la bulge region, lo que conduce al desarrollo de carcinomas malignos, mientras que mutaciones en células de la epidermis interfolicular generan papilomas con bajo riesgo de conversión tumoral (Pérez-Losada and Balmain, 2003).

Por otra parte, se ha descrito que la expresión de Rac1 está incrementada en CCE en humanos (Benitah et al., 2005; Karlsson et al., 2009) y en ratones (Benitah et al., 2005). En este sentido, se ha demostrado que Rac1 es esencial para la formación de tumores generados con el protocolo DMBATPA mediante el control del eje Pak1/Mek/ERK (Wang et al., 2010). Se ha demostrado que la activación de Mek y ERK1/2 dependiente de Rac1, a través de Pak1 es fundamental para este proceso tumoral. De este modo encontramos nuevas conexiones de señalización entre ambas rutas, donde Rac1 juega un papel importante en la carcinogénesis dependiente de Ras. 



\section{Justificación y objetivos}

\section{Aims}



El cáncer engloba un amplio conjunto de patologías cuya etiología reside en la aparición de mutaciones en diversos genes que conducen, entre otros procesos, a una proliferación celular descontrolada.

Los oncogenes Ras constituyen una de las familias génicas más frecuentemente activadas en cáncer. Las proteínas Ras son clave en la regulación de una gran variedad de rutas de señalización celular que controlan entre otros procesos, la proliferación celular, la migración o la supervivencia. La activación/inactivación de las proteínas Ras está controlada por las proteínas reguladoras negativas de Ras (RasGAPs) y las proteínas activadoras de Ras (RasGEFs). El abordaje terapéutico en tumores que presentan mutaciones en Ras se centra en el desarrollo de fármacos que intervienen en diferentes puntos de la señalización efectora. Sin embargo, no se ha prestado especial atención a las proteínas responsables de la activación de Ras como potenciales dianas terapéuticas. Un mayor conocimiento de las funciones específicas de las proteínas activadoras de Ras, en especial de las proteínas Sos, podría suponer un avance en el desarrollo de nuevas estrategias terapéuticas en cáncer.

Trabajos anteriores han sugerido una clara dominancia funcional de Sos1 sobre Sos2 en la mayoría de procesos celulares estudiados. Sin embargo, la letalidad embrionaria de los animales mutantes para Sos1 ha limitado mucho la información obtenida por estos diseños experimentales. Nuestro grupo de investigación generó recientemente el primer modelo animal knockout para Sos1 viable durante la etapa adulta. De este modo, hemos sido capaces de estudiar animales carentes de expresión de las proteínas Sos1 y Sos2 de forma concomitante. 
Mediante el uso de estos animales, este trabajo tiene como objetivo principal tratar de definir la especificidad o redundancia funcional de las proteínas Sos1 y Sos2 en distintos contextos experimentales tanto in vitro como in vivo, en condiciones fisiológicas y/o patológicas. Para ello, nos planteamos los siguientes objetivos específicos:

1. Definir la especificidad o redundancia funcional de Sos1 y Sos2 en el proceso de proliferación, supervivencia y progresión del ciclo celular, así como en el nivel de compactación de la cromatina y en la integridad del DNA en fibroblastos embrionarios primarios de ratón.

2. Determinar mediante ensayos in vitro la función de Sos1 y/o Sos2 en los procesos de migración y adhesión celular.

3. Evaluar el papel de Sos1 y/o Sos 2 en el mantenimiento del balance redox de la célula.

4. Estudiar el efecto de la eliminación individual o concomitante de las proteínas Sos en los niveles de activación de las proteínas Ras y Rac y de las principales proteínas efectoras de las rutas de señalización mediadas por Ras en fibroblastos embrionarios primarios de ratón.

5. Analizar in vivo el papel de Sos1 y/o Sos2 en el mantenimiento de la homeostasis de la piel en condiciones fisiológicas.

6. Definir la función de las proteínas Sos en los distintos procesos biológicos que regulan la reparación tisular en el proceso de cierre de una herida en la piel.

7. Evaluar la contribución funcional de las proteínas Sos1 y/o Sos2 en un modelo de carcinogénesis epitelial inducido químicamente. 
Gain-of-function mutations in Ras genes are the first specific genetic alterations identified in human cancer. Ras proteins are essential components of signaling networks controlling cellular proliferation, differentiation, or survival. Ras proteins are binary switches that cycle between active state (RasGTP) and inactive state (RasGDP). This process is regulated by positive (RasGEFs) and negative regulators (RasGAPs). Dependence of Ras on GEFs and GAPs to switch them on and off allows both processes to be highly regulated and responsive to multiple signal inputs. Among the main families of RasGEFs, the Sos family of proteins (Sos1 and Sos2) are the most widely expressed and functionally relevant.

Recently, we successfully bypassed the lethality of homozygous Sos1-null mutations by placing a floxed Sos1-null allele under the control of a tamoxifen-inducible Cre allowing full-body deletion of the targeted Sos1 gene and subsequent analysis of resulting phenotypes in adult mice. The availability of viable Sos1- and Sos1/2-null mutants made possible by our conditional Sos1-KO experimental system allows us now to address previously unanswered questions regarding functional specificity and/or redundancy of Sos1 and Sos2 in different biological contexts. 
Here, we use this genetically modified mice colony with the aim at evaluating the functional specificity or redundancy of the Sos1 and Sos2 by using both in vitro and in vivo studies. The specific objectives to be addressed in this work are:

1. To evaluate the functional specificity or redundancy of the Sos 1 and Sos 2 alleles at the cellular level in cell proliferation, cell survival, cell cycle progression chromatin remodeling and DNA integrity in primary MEFs.

2. To define the role of Sos1 and/or Sos2 in cell migration and cell adhesion in primary MEFs.

3. To determine Sos1 and/or Sos 2 functionality in the regulation of intracellular oxidative stress.

4. To evaluate the level of activation of Ras and Rac and the main Ras downstream effectors in primary MEFs after Sos1 and/or Sos2 depletion.

5. To analyze in vivo the role of Sos 1 and/or Sos 2 in the maintenance of skin homeostasis in physiological conditions.

6. To investigate the involvement of Sos1 and/or Sos2 during skin wound repair.

7. To study the functional contribution of Sos1 and/or Sos 2 in the DMBA/TPA-induced carcinogenesis 
Material y métodos 



\section{Generación de la colonia de animales deficientes para las proteínas Sos}

La colonia de animales mutantes para las proteínas Sos se generó como se describió anteriormente (Baltanás et al., 2013). El fondo genético de los ratones era C57BL/6 y la cría y el mantenimiento de los animales de experimentación se realizó en las instalaciones del animalario libre de patógenos del Centro de Investigación del Cáncer (Salamanca). Para evitar la letalidad durante la etapa embrionaria de los animales mutantes para Sos1 (Qian et al., 2000), se generó mediante técnicas de ingeniería genética un sistema en el que el exón 10 del gen Sos1 de ratones se encontraba flanqueado por sitios

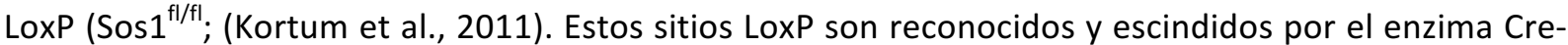
recombinasa. Estos animales fueron cruzados posteriormente con ratones que tenían la capacidad de expresar la Cre-recombinasa tras la administración de tamoxifeno (TAM). La enzima Cre-recombinasa se encontraba controlada bajo el promotor RNA polimerasa II permitiendo así que, tras la administración de TAM, la Cre-recombinasa se expresara en todas las células del organismo (Sos $1^{\mathrm{fl}-}$ Cre/f-Cre). Puesto que nuestro laboratorio disponía de ratones knockout (KO) constitutivos para la proteína Sos2 $\left(\operatorname{Sos}_{2}^{-1-}\right)$, los cruzamos con los ratones Sos $1^{\mathrm{fl}-\mathrm{Cre}} / \mathrm{Sos} 1^{\mathrm{fl}-\mathrm{Cre}}$ generados con anterioridad. Mediante selección mendeliana, generamos finalmente los 4 grupos de animales de experimentación que se emplearán durante el presente proyecto de Tesis Doctoral:

1) Aquellos que porten el gen Sos1 flanqueado por los sitios LoxP, que sean mutantes constitutivos para Sos2 y susceptibles de activación de la Cre-recombinasa tras la administración de TAM. Los denominaremos Dobles mutantes (Sos1/2 DKO).

2) Aquellos que porten el gen Sos1 flanqueado por los sitios LoxP, que sean controles para Sos2 y susceptibles de activación de la Cre-recombinasa tras la administración de TAM. Los denominaremos Simples mutantes Sos1 (Sos1 KO).

3) Aquellos que no porten el gen Sos1 flanqueado por los sitios LoxP, que sean mutantes para Sos2 y susceptibles de activación de la Cre-recombinasa tras la administración de TAM. Los denominaremos Simples mutantes Sos2 (Sos2 KO).

4) Aquellos que no porten el gen Sos1 flanqueado por los sitios LoxP, que sean controles para Sos2 y susceptibles de activación de la Cre-recombinasa tras la administración de TAM. Los denominaremos Wild-type (WT). 
Este sistema permite silenciar la expresión de Sos1 en el momento deseado, ya sea en modelos in vivo o in vitro a partir de linajes celulares aislados de estos animales, mediante la administración de TAM.

Los animales se criaron y mantuvieron en el Servicio de Experimentación Animal de la Universidad de Salamanca a temperatura y humedad relativa constantes, fotoperiodo artificial de $12 \mathrm{~h}$ y alimentados ad libitum con $\mathrm{H}_{2} \mathrm{O}$ y pienso compuesto para roedores (T2014 Teklad Global 14\% Protein Rodent Diet, Oxon, Reino Unido). Para los experimentos in vivo empleamos piensos adicionales con una composición distinta, primeramente con pienso libre de fitoestrógenos (Harlan, Teklad 16\% global protein rodent diet, 2916) y posteriormente con un pienso que contenía TAM (Harlan; Teklad CRD TAM400/CreER).

El protocolo de mantenimiento, manejo y sacrificio de los animales cumplió con la actual normativa europea (Directiva 86/609/EEC y Recomendación 2007/526/EC) y legislación española (RD 1201/2005 completado con la Ley 32/2007). Además, los procedimientos que se han empleado en la presente Tesis Doctoral fueron previamente aprobados por el Comité de Bioética del Centro de Investigación del Cáncer.

\section{Genotipado de los animales}

\subsection{Extracción de DNA}

Para la identificación del genotipo de los animales de experimentación se empleó la técnica de la reacción en cadena de la polimerasa (PCR, del inglés: Polymerase $\underline{\text { Chain }}$ Reaction). Para ello obtuvimos DNA (del inglés: $\underline{D} e o x y r i b o \underline{N} u c l e i c \underline{A}$ Acid) genómico de los ratones de edades inferiores a P10 (10 días posnatales) a partir de tejido de la cola. Para la extracción del DNA, las colas se homogeneizaron con aproximadamente $300 \mu \mathrm{l}$ tampón de lisis. Para cada $8 \mathrm{ml}$ de tampón de lisis (Tris $100 \mathrm{mM} \mathrm{pH} \mathrm{8,} \mathrm{EDTA} 5 \mathrm{mM} \mathrm{pH} \mathrm{8.0,} \mathrm{NaCl} 200$ mM, SDS 0.2\% y $\mathrm{H}_{2} \mathrm{O}$ MilliQ) añadimos $100 \mu \mathrm{l}$ de

proteinasa $\mathrm{K}$ (Roche). Incubamos las muestras con tampón de lisis o/n (del inglés: over $\underline{\text { night), en }}$ agitación y a $56{ }^{\circ} \mathrm{C}$. Posteriormente, las muestras se centrifugaron a $13000 \mathrm{rpm} 2$ minutos (min), se recogió el sobrenadante y el DNA se precipitó con un volumen de etanol al $70 \%$ (v/v). Se volvió a centrifugar durante 10 min a 13000, se dejó secar y se resuspendió en $50 \mu \mathrm{l}$ de $\mathrm{H}_{2} \mathrm{O}$ Mili-Q. 


\subsection{Genotipaje por PCR}

La técnica de la PCR permite obtener un elevado número de copias de un fragmento de DNA determinado a partir de muy poca cantidad de DNA original, en un corto periodo de tiempo (Mullis et al., 1986).

Para un volumen final de $10 \mu \mathrm{l}$ por muestra, el medio de la PCR contenía: $5.5 \mu \mathrm{l}$ de DreamTaq ${ }^{\text {TM }}$ Green PCR Master Mix 2X (4 mM MgCl $2,0.4$ mM de cada dNTP), $0.4 \mu$ de cada oligonucleótido $(0.4 \mu \mathrm{M}), 1 \mu \mathrm{l}$ de DNA ( 200 ng) y $2.3 \mu \mathrm{l} \mathrm{H}$ O Mili-Q. Los oligonucleótidos utilizados para cada caso se recogen en la tabla 1. La PCR se realizó en el termociclador (PT-100, MJ Research) cuyas condiciones de amplificación para cada caso se recogen en las tablas 2 y 3. Los productos de la PCR para la detección de los alelos Sos1, Sos2, Cre-Recombinasa y RERT, se separaron mediante electroforesis (80V) en un gel de agarosa al 3\% (p/v) en tampón TAE (del inglés: Tris-Acetate-EDTA; 89 mM Tris-acetato, 2 mM EDTA, pH 8). Al gel se añadieron $0.4 \mu \mathrm{g} / \mathrm{ml}$ de bromuro de etidio (Invitrogen) o el producto no citotóxico Green Safe Premium ( $3 \mu \mathrm{l} / 100 \mathrm{ml}$ de mezcla; Nzytech) para la visualización de las distintas bandas del DNA amplificado, observándolo bajo una lámpara de luz ultravioleta (BioRad). En los carriles podían aparecer tres bandas de diferente tamaño para cada caso: para Sos1 wt 331pb (+/+), Sos1 en heterocigosis (+/-) y Sos1 mutante (inducible) en homocigosis 390pb (-/-). Además, para los alelos wt de Sos $2(+/+)$ una banda de $375 \mathrm{pb}$, dos bandas en heterocigosis (+/-) y una tercera del mutante en homocigosis a 410pb (-/-). Asimismo, reconocemos RERT wt mediante un banda de $480 \mathrm{pb}(+/+)$, dos bandas en el caso del mutante en heterocigosis de $480 \mathrm{pb}$ y $390 \mathrm{pb}(+/-)$ y una en los mutantes homocigotos 390pb (-/-) (Figura 15).

Tabla 1. Oligonucleótidos utilizados para el genotipaje de ratones.

\begin{tabular}{|c|c|}
\hline Oligonucleótidos & Secuencia \\
\hline Sos1 Wt9 & 5'-CTA CCG GTG GAT GTG GAA TGT GTG CGA- 3' \\
\hline Sos1 Rv4 & 5'-ATC TGG TGA AGG GGC AAA GTC- 3' \\
\hline Sos1Cre* & 5'-GCA ATT TTC CCT GCT TAC TCC C- 3' \\
\hline Sos2 LM82 & 5'-CTA CCG GTG GAT GTG GAA TGT GTG CGA- 3' \\
\hline Sos2 LM127 & 5'-CTT TCT GCC CCT GTA ATT TAC ACC AGA TGA- 3 \\
\hline Sos2 LM129 & 5'-GTG GTC CTG ACT TAG TTC CAC AGC GTC A- 3' \\
\hline RERT-CRE Pol2A-F & 5'-CCA GAT GAC AGC GAT GAG GA- 3' \\
\hline RERT-CRE Pol2A-R & 5'-CCT CTC TGA GCC TCA ATT AAG CAG- 3' \\
\hline RERT-CRE ESR1 & 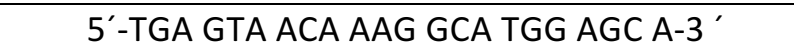 \\
\hline
\end{tabular}


Tabla 2. Condiciones de la PCR para genotipar las mutaciones Sos1 y RERT-Cre. $\mathrm{N}^{\circ}$ de ciclos: 35.

\begin{tabular}{|c|c|c|}
\hline Paso & Tiempo & Temperatura $\left({ }^{\circ} \mathbf{C}\right)$ \\
\hline 1 Desnaturalización & 4 min & 95 \\
\hline 2 Desnaturalización & 20 segundos & 95 \\
\hline 3 Anillamiento & 20 segundos & 55 \\
\hline 4 Extensión & $5 \mathrm{~min}$ & 72 \\
\hline 5 Extensión & $10 \mathrm{~min}$ & 72 \\
\hline 6 Almacenamiento & - & 4 \\
\hline
\end{tabular}

Tabla 3. Condiciones de la PCR para genotipar la mutación Sos2. $\mathrm{N}^{\circ}$ de ciclos: 30.

\begin{tabular}{|c|c|c|}
\hline Paso & Tiempo & Temperatura $\left({ }^{\circ} \mathbf{C}\right)$ \\
\hline 1 Desnaturalización & $4 \mathrm{~min}$ & 94 \\
\hline 2 Desnaturalización & $1 \mathrm{~min}$ & 94 \\
\hline 3 Anillamiento & $1 \mathrm{~min}$ & 62 \\
\hline 4 Extensión & $1 \mathrm{~min}$ & 72 \\
\hline 5 Extensión & $10 \mathrm{~min}$ & 72 \\
\hline 6 Almacenamiento & - & 4 \\
\hline
\end{tabular}

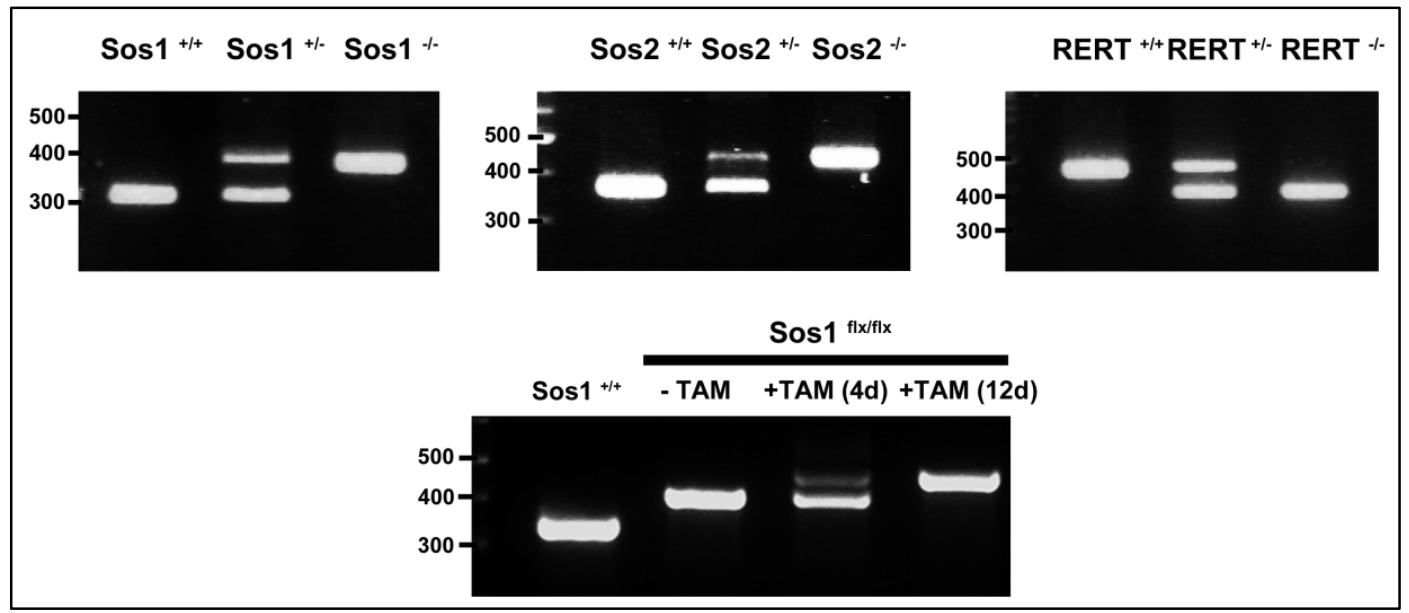

Figura 15. Genotipaje de los animales mediante PCR. Los tamaños de las regiones amplificadas son las siguientes: Sos $1 w t$ $331 \mathrm{pb}(+/+)$ y Sos $1^{\mathrm{fl} / \mathrm{fl}} 390 \mathrm{pb}(-/-)$, Sos2 wt 375pb (+/+) y Sos2 KO 410pb (-/-), RERT-Cre wt 480pb (+/+) y mutante en homocigosis 390pb (-/-). En la última imagen de PCR mostramos en la primera muestra un animal Sos1 wt (331pb), en segundo lugar una muestra de animal Sos $1^{\mathrm{fl} / \mathrm{fl}}$ en ausencia de TAM (390pb). Tras la adición de TAM los sitios LoxP comienzan a ser escindidos generando regiones amplificadas de distinto tamaño molecular, parcialmente (4 días con TAM) y totalmente (12 días con TAM, banda de 450pb). 


\section{ESTUDIOS IN VITRO}

\section{Fibroblastos embrionarios de ratón}

\subsection{Extracción y aislamiento de MEFs primarios}

Aislamos MEFs a partir de hembras gestantes homocigotas (que fueron cruzadas con machos homocigotos para el genotipo correspondiente) de los 4 genotipos de interés anteriormente detallados: WT, Sos1 KO, Sos2 KO y Sos1/2 DKO. Aun siendo los parentales homocigotos para cada caso, el genotipo de los embriones se confirmó adicionalmente por PCR (Figura 15). Se extrajeron los embriones en condiciones de esterilidad de hembras gestantes entre los días 11.5 y 13.5 de gestación (E11.5-E13.5). Separamos y descartamos el sistema cardiovascular y el sistema nervioso, y disgregamos mecánicamente el resto del embrión, que incubamos con tripsina $(0.25 \%$ tripsina-EDTA $1 \mathrm{X}$, Gibco) $\mathrm{o} / \mathrm{n}$ a $4{ }^{\circ} \mathrm{C}$. El lisado resultante se sembró en las condiciones que especificamos en el apartado siguiente.

\subsection{Cultivo de MEFs primarios}

Los MEFs resultantes del lisado se sembraron en medio DMEM completo (del inglés: Dulbecco's Modified Eagle Medium, Gibco) suplementado con $10 \%(\mathrm{v} / \mathrm{v})$ de suero bovino fetal (FBS del inglés: Fetal Bovine Serum; Gibco), antibióticos $(50 \mathrm{U} / \mathrm{ml}$ de penicilina y $50 \mu \mathrm{l} / \mathrm{ml}$ de estreptomicina; Gibco) y glutamina ( $2 \mathrm{mM}, \mathrm{Gibco})$ en placas de poliestireno (10 cm; BD Bioscience) y se emplazaron en incubadores (Heracell, Heraeus, BioStar) a $37{ }^{\circ} \mathrm{C}$, en atmósfera de $5 \%$ de $\mathrm{CO}_{2}$ y un $98 \%$ de humedad relativa.

La totalidad de los experimentos in vitro realizados en la presente Tesis Doctoral se llevaron a cabo empleando MEFs que hemos definido como "primarios". Es decir, estos fibroblastos no han sido sometidos a proceso de inmortalización alguno y como máximo han llegado a un pase 6 de división.

Los pases o divisiones de las células se realizaron normalmente cada 48-72 horas (h) bajo campana de flujo laminar (Telstar, Biostar). Se lavaba el cultivo previamente con PBS estéril a temperatura ambiente (TA) y se incubaban las células con $0.25 \%$ tripsina-EDTA durante $2-4$ min a TA. Por último, se neutralizaba la tripsina con medio de cultivo completo fresco (filtrado previamente en filtros de 0.22 
$\mu m)$ y se sembraban las células en nuevas placas de cultivo a la dilución deseada para cada experimento.

Como hemos detallado anteriormente, el sistema que hemos diseñado para eliminar la expresión de la proteína Sos1 (en Sos1 KO y Sos1/2 DKO) requiere del uso de TAM. Por lo tanto, nuestra primera aproximación experimental consistió en determinar las condiciones necesarias para conseguir la escisión del exón 10 y eliminar la expresión de la proteína. La inmensa mayoría de experimentos detallados a continuación se realizaron en MEFs tratados durante 9 días con 4-Hidroxi-Tamoxifeno (4OHT, $0.3 \mu \mathrm{M}$, Sigma, H7904) cuando la eliminación de la proteína Sos1 era prácticamente completa. Todos los cultivos celulares, independientemente de su genotipo fueron tratados en las mismas condiciones con $4 \mathrm{OHT}$ para evitar posibles efectos off-target de este compuesto.

Desarrollamos además otro sistema de eliminación de la proteína Sos1 independiente a la adición de 4OHT. En este caso empleamos infección con adenovirus que expresaban la Cre-recombinasa (Ad5CMVCre, VVC-U lowa-1174). Se sembraron $10^{4}$ MEFs de cada genotipo en placas de 6 pocillos con medio DMEM. El volumen total de DMEM en el que se cultivaron los MEFs era de $2 \mathrm{ml}$, pero un $10 \%$ de este volumen era "medio condicionado", este medio pertenecía al medio de crecimiento de estas mismas células del pase anterior y aporta factores secretados por éstas. Esto permite que el bajo número de células sembrado sea suficiente para que el cultivo crezca en condiciones adecuadas. 6-8 h post-siembra, se infectaron los MEFs de los 4 genotipos con $1 \mathrm{ml}$ de medio de infección (Ad5CMV- Cre-eGFP, $300 \mathrm{MOI}$ (unidades de infección) partiendo de un stock: $4 \times 10^{10} \mathrm{pfu} / \mathrm{ml}$ ) y se incubó o/n. El día siguiente se añadió otro ml de medio DMEM completo para conseguir el volumen adecuado de cultivo. En el tercer día de cultivo se realizó una segunda infección, en las mismas condiciones, para aumentar la eficacia de la eliminación de Sos1. Este protocolo alternativo de eliminación de Sos1 se extendió hasta los 9 días (igual que el protocolo de eliminación de Sos1 mediante adición de 4OHT).

\section{Ensayos bioquímicos}

\subsection{Extracción de proteínas}

Para la extracción de proteínas se mantuvieron las placas de cultivo (de los 4 genotipos) en hielo, se descartó el medio y se lavaron dos veces con PBS a $4{ }^{\circ} \mathrm{C}$. A continuación, se añadieron a cada placa 
200-250 $\mu$ l de tampón de lisis (Cell Lysis Buffer; Roche) que estaba suplementado con los inhibidores de fosfatasas $\mathrm{NaF}(1 \mathrm{mM})$, y $\mathrm{Na}_{3} \mathrm{VO}_{4}(1 \mathrm{mM})$, y los inhibidores de proteasas PMSF (1 mM) y Complete ${ }^{\circledR}$ ( 1 pastilla/50 $\mu$ l de tampón; Roche). Las células se despegaron de la placa con ayuda de un rascador y los lisados se recogieron en un tubo eppendorf de $1.5 \mathrm{ml}$ (en hielo) y se les dio un pulso de agitación o vórtex. Seguidamente, se centrifugaron las muestras a $13000 \mathrm{rpm} 10 \mathrm{~min}$ a $4{ }^{\circ} \mathrm{C}$ y el sobrenadante se transfirió a tubos nuevos. Finalmente, se determinó la concentración proteica para cada caso mediante el método Bradford (BioRad). Las muestras se almacenaron a $-80^{\circ} \mathrm{C}$ hasta su uso.

\subsection{Western blot}

Los lisados celulares se desnaturalizaron añadiéndoles tampón de carga Laemmli $4 \mathrm{X}$ (Tris $\mathrm{HCl} 200$ $\mathrm{mM}$, pH 6.8; $40 \%$ Glicerol; $4 \%$ SDS; $4 \% \beta$-mercaptoetanol y $0.04 \%$ azul de bromofenol) e hirviendo durante $5 \mathrm{~min}$. Las proteínas se separaron acorde a su peso molecular en geles de poliacrilamida de distintos porcentajes (Tablas 4 y 5). El porcentaje del gel de poliacrilamida depende del tamaño de las proteínas de estudio, utilizándose mayores porcentajes cuanto menor es el peso molecular de las proteínas de interés. El gel se introdujo en una cubeta (BioRad) la cual se rellenó con tampón de

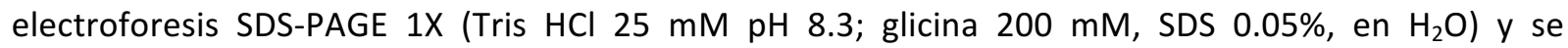
aplicaron 80-100V hasta que el frente escapó por la parte inferior de los cristales que contienen el gel. Una vez finalizada la electroforesis, las proteínas se transfirieron, mediante transferencia húmeda, a membranas de PVDF (IPFL00010, Immobilion-FL, Millipore). El tampón de transferencia contenía: Tris- $\mathrm{HCl} 25$ mM, glicina 192 mM, metanol 20\% y $\mathrm{H}_{2} \mathrm{O}$ MiliQ. Para su activación, la membrana fue sumergida previamente en metanol durante 1 min y aclarada con tampón de transferencia. La transferencia se realizó a $4{ }^{\circ} \mathrm{C}$, a un voltaje constante de $100 \mathrm{~V}$ durante $90 \mathrm{~min}$ o bien a $40 \mathrm{~V}$ o/n. Posteriormente, las membranas se incubaron durante $1 \mathrm{~h}$ a TA en solución de bloqueo que contenía TBS-T (Tris Buffered Saline-Tween; $20 \mathrm{mM}$ Tris pH 7.5, $137 \mathrm{mM} \mathrm{NaCl}$ y 0.05\% Tween-20) con un 5\% de BSA o con $5 \%$ de leche desnatada (Tabla 6). A continuación, las membranas fueron incubadas con el anticuerpo primario deseado en las condiciones descritas en la Tabla 6. Posteriormente, las membranas se lavaron con TBS-T $(3 \times 10 \mathrm{~min})$ y se incubaron los anticuerpos secundarios correspondientes en las condiciones detalladas en la Tabla 7. El sistema de revelado se detalla igualmente en la Tabla 7. La cuantificación de las proteínas detectadas se realizó con el programa ImageJ (v 1.6.0). 
Tabla 4: Reactivos para la parte inferior del gel (running). Volúmenes correspondientes a un gel.

\begin{tabular}{|c|c|c|c|c|}
\hline Porcentaje & $\mathbf{7 . 5} \%$ & $\mathbf{1 0 \%}$ & $\mathbf{1 2 . 5} \%$ & $\mathbf{1 5 \%}$ \\
\hline LOWER Tris & $2.5 \mathrm{ml}$ & $2.5 \mathrm{ml}$ & $2.5 \mathrm{ml}$ & $2.5 \mathrm{ml}$ \\
\hline $\mathbf{H}_{\mathbf{2}} \mathbf{O}$ miliQ & $5 \mathrm{ml}$ & $4.12 \mathrm{ml}$ & $3.32 \mathrm{ml}$ & $2.5 \mathrm{ml}$ \\
\hline Acrilamida (30\%) & $2.5 \mathrm{ml}$ & $3.32 \mathrm{ml}$ & $4.16 \mathrm{ml}$ & $5 \mathrm{ml}$ \\
\hline TEMED & $5 \mu \mathrm{l}$ & $5 \mu \mathrm{l}$ & $5 \mu \mathrm{l}$ & $5 \mu \mathrm{l}$ \\
\hline APS 10\% & $70 \mu \mathrm{l}$ & $70 \mu \mathrm{l}$ & $70 \mu \mathrm{l}$ & $70 \mu \mathrm{l}$ \\
\hline
\end{tabular}

*Lower Tris: Tris $\mathrm{HCl} 1.5 \mathrm{M} \mathrm{pH} 8$, SDS 10\%.

Tabla 5: Reactivos para la parte superior de un gel de acrilamida (stacking). Volúmenes correspondientes a un gel.

\begin{tabular}{|c|c|c|c|c|}
\hline UPPER Tris & $\mathbf{H}_{\mathbf{2}} \mathbf{O}$ miliQ & Acrilamida (30\%) & TEMED & APS (10\%) \\
\hline $1.25 \mathrm{ml}$ & $3.11 \mathrm{ml}$ & $0.58 \mathrm{ml}$ & $3.75 \mu \mathrm{l}$ & $50 \mu \mathrm{l}$ \\
\hline
\end{tabular}

*Upper Tris: Tris 1 M pH 6.5, SDS 10\%.

Tabla 6: Lista de anticuerpos primarios utilizados para WB y condiciones de uso.

\begin{tabular}{|c|c|c|c|c|c|c|}
\hline Anticuerpo & Casa comercial & Origen & Bloqueo & Soluc. Ac & Dilución & Incubación \\
\hline$\alpha$-Sos1 & Santa Cruz (sc-256) & Rabbit & BSA 5\%/1h & BSA 5\% & $1: 1000$ & $1 \mathrm{~h} / \mathrm{TA}$ \\
\hline$\alpha$-Sos1 & BD (60095) & Mouse & BSA 5\%/1h & BSA 5\% & $1: 1000$ & $\mathrm{o} / \mathrm{n} / 4^{\circ} \mathrm{C}$ \\
\hline$\alpha$-Sos2 & Santa Cruz (sc-258) & Rabbit & BSA 5\%/1h & BSA 5\% & $1: 1000$ & $\mathrm{o} / \mathrm{n} / 4^{\circ} \mathrm{C}$ \\
\hline$\alpha-p$ ERK1/2 & Santa Cruz (sc-7383) & Mouse & BSA 5\%/1h & BSA $5 \%$ & $1: 1000$ & $1 \mathrm{~h} / \mathrm{TA}$ \\
\hline$\alpha$-ERK2 & Santa Cruz (sc-154) & Rabbit & BSA 5\%/1h & BSA 5\% & $1: 2000$ & $\mathrm{o} / \mathrm{n} / 4^{\circ} \mathrm{C}$ \\
\hline$\alpha-p A k t$ & Cedido Dr. Pandiella & Rabbit & BSA 5\%/1h & BSA 5\% & $1: 1000$ & $\mathrm{o} / \mathrm{n} / 4^{\circ} \mathrm{C}$ \\
\hline$\alpha-A k t$ & Cell Signaling (9272) & Rabbit & BSA 5\%/1h & BSA 5\% & $1: 1000$ & $\mathrm{o} / \mathrm{n} / 4^{\circ} \mathrm{C}$ \\
\hline$\alpha-\beta$ Tub & Sigma (T-5293) & Mouse & BSA 5\%/1h & BSA 5\% & $1: 5000$ & $1 \mathrm{~h} / \mathrm{TA}$ \\
\hline$\alpha$-Casp3act & Cell Signaling (9661) & Rabbit & BSA 5\%/1h & BSA 5\% & $1: 1000$ & $\mathrm{o} / \mathrm{n} / 4^{\circ} \mathrm{C}$ \\
\hline$\alpha$-Ras & Upstate (005-516) & Mouse & Leche $5 \% / 1 \mathrm{~h}$ & Leche $5 \%$ & $1: 1000$ & $\mathrm{o} / \mathrm{n} / 4^{\circ} \mathrm{C}$ \\
\hline$\alpha$-Rac1 & Santa Cruz (sc-9566) & Rabbit & Leche $5 \% / 1 \mathrm{~h}$ & Leche $5 \%$ & $1: 500$ & $\mathrm{o} / \mathrm{n} / 4^{\circ} \mathrm{C}$ \\
\hline
\end{tabular}


Tabla 7: Lista de anticuerpos secundarios utilizados para WB y método de revelado.

\begin{tabular}{|c|c|c|c|c|c|}
\hline Anticuerpo & Casa comercial & Soluc. Ac & Dilución & Incubación & Revelado \\
\hline Sheep $\alpha$-mouse HRP & Amersham (NA931V) & BSA 5\% & $1: 5000$ & $1 \mathrm{~h} / \mathrm{TA}$ & ECL-Película \\
\hline Sheep $\alpha$-rabbit HRP & Amersham (NA934V) & BSA 5\% & $1: 10000$ & $1 \mathrm{~h} / \mathrm{TA}$ & ECL-Película \\
\hline $\begin{array}{c}\text { Goat } \alpha \text {-mouse Alexa } \\
\text { fluor 680 }\end{array}$ & Invitrogen (\#A21057) & BSA 5\% & $1: 5000$ & $1 \mathrm{~h} / \mathrm{TA}$ & Oddysey $^{\circledR}$ \\
\hline $\begin{array}{c}\text { Goat } \alpha \text {-rabbit Alexa } \\
\text { fluor 680 }\end{array}$ & Invitrogen (\#A21076) & BSA 5\% & $1: 10000$ & $1 \mathrm{~h} / \mathrm{TA}$ & Oddysey $^{\circledR}$ \\
\hline $\begin{array}{c}\text { Goat } \alpha \text {-mouse } \\
\text { DyLight 800 }\end{array}$ & Invitrogen (\#35521) & BSA 5\% & $1: 5000$ & $1 \mathrm{~h} /$ TA & Oddysey $^{\circledast}$ \\
\hline $\begin{array}{c}\text { Goat } \alpha-\text {-rabbit } \\
\text { DyLight } 800\end{array}$ & Invitrogen (\#35571) & BSA 5\% & $1: 10000$ & $1 \mathrm{~h} /$ TA & Oddysey $^{\circledR}$ \\
\hline
\end{tabular}

\subsection{Ensayos de activación de GTPasas}

\subsubsection{Ensayos de activación de Ras}

\section{a) Purificación de la proteína de fusión Raf-RBD}

Las proteínas Ras se activan de manera transiente, el Ras activo (RasGTP) se une a la serina/treonina quinasa, Raf. Esta habilidad de unirse a la proteína Raf nos permite "secuestrar" el RasGTP de las muestras en estudio y analizar el estado de activación de Ras. EI DNA que codifica para la proteína de fusión recombinante Raf-GST se encuentra incorporado en la bacteria Escherichia coli (E.coli, cepa DH10B) transformada con pGEX-2T (GE Healthcare, 28-9546-53) que contiene el gen de resistencia a ampicilina. Empleamos para su crecimiento medio LB (Luria Bertani) con ampicilina (100 $\mathrm{gg} / \mathrm{ml}$, Calbiochem) y realizamos un preinóculo de esta bacteria en $50 \mathrm{ml}$ del medio LB, y lo mantuvimos en agitación o/n a $37^{\circ} \mathrm{C}$. Al día siguiente incubamos el preinóculo en 1 litro de medio LB fresco en agitación durante $1.5-2 \mathrm{~h}$ a $37{ }^{\circ} \mathrm{C}$. El crecimiento bacteriano deseado fue determinado mediante espectrofotometría hasta llegar a una densidad óptica (DO) entre 0.5 a 0.7, medido a una longitud de onda de $600 \mathrm{~nm}$ ( $\left.\mathrm{DO}_{600 \mathrm{~nm}} \sim 0.5-0.7\right)$. Una vez alcanzada la DO ideal añadimos isopropil- $\beta$-Dtiogalactopiranósido (IPTG; utilizado para inducir la expresión del gen clonado) a una concentración final de $0.5 \mathrm{mM}$ e incubamos durante $4 \mathrm{~h}$ a $37^{\circ} \mathrm{C}$, en agitación. Después distribuimos el cultivo en tubos de centrífuga de $250 \mathrm{ml}$ y centrifugamos durante $20 \mathrm{~min}$ a $8000 \mathrm{rpm}$ a $4{ }^{\circ} \mathrm{C}$. A continuación, 
lisamos mecánicamente las células con $10 \mathrm{ml}$ de tampón de lisis: 2 mM EDTA, 0.1\% $\beta$-mercaptoetanol y $0.2 \mathrm{mM}$ PMSF, en PBS-Tween (PBST). Para conseguir una extracción más completa de la proteína sonicamos (Vibra-Cell, SONICS) 4-5 veces durante 20 segundos cada pulso (4 ${ }^{\circ} \mathrm{C}$ ). Centrifugamos de nuevo a $15000 \mathrm{rpm}$ durante $30 \mathrm{~min}$ a $4{ }^{\circ} \mathrm{C}$, recogimos el sobrenadante y lo distribuimos en alícuotas que congelamos a $-80^{\circ} \mathrm{C}$.

\section{b) Unión de la proteína Raf-RBD a esferas de glutatión-sefarosa}

Para precipitar la proteína Raf utilizamos esferas capaces de unirse al dominio GST. Estas esferas de glutatión-sefarosa (GE Healthcare, 17-5132-01) se encontraban a una concentración del $80 \%$, y el 20\% restante del volumen es etanol, por lo que lavamos previamente las esferas con tampón PBST (3×1 min) a $13000 \mathrm{rpm} 4{ }^{\circ} \mathrm{C}$. Para adherir la proteína Raf a las esferas de glutation-sefarosa empleamos alrededor de $1 \mathrm{ml}$ de lisado Raf-GST y lo incubamos con aproximadamente 100-120 $\mu \mathrm{l}$ de esferas glutatión-sefarosa durante $1.5-2 \mathrm{~h}$ en rueda giratoria a $4{ }^{\circ} \mathrm{C}$. Tras la incubación, se lavan las esferas Raf-GST con tampón de lisis MLB 1X (MLB 5X: 25 mM Hepes pH 7.5, 150 mM NaCl, 1\% Igepal CA-630, $10 \mathrm{mM} \mathrm{MgCl}$, $1 \mathrm{mM}$ EDTA, 10\% glicerol, $25 \mathrm{mM} \mathrm{NaF}, 1 \mathrm{mM} \mathrm{Na} \mathrm{VO}_{4}, 100 \mathrm{mM} \mathrm{PMSF}, 10 \mu \mathrm{g} / \mathrm{ml}$ leupeptina y $10 \mu \mathrm{g} / \mathrm{ml}$ apropotinina en $\mathrm{H}_{2} \mathrm{O}$; MLB $1 \mathrm{X}$ : MLB 5X,10\% glicerol, Complete ${ }^{\circledR} 1$ pastilla/ 50 ml, 100 mM PMSF, 25 mM NaF, en $\left.\mathrm{H}_{2} \mathrm{O}\right)$, (3x1 min) a 13000 rpm. A continuación, se resuspendieron las esferas de sefarosa Raf-GST en $1 \mathrm{ml}$ de tampón MLB 1X por lo que el volumen total de esferas RafGST con MLB 1X es aproximadamente $1.2 \mathrm{ml}$. Para la cuantificación de la proteína de fusión obtenida, tomamos como referencia una recta patrón de BSA, ya que de manera estándar se conoce la relación entre un volumen de BSA y la concentración proteica. La concentración ideal de proteína Raf-GST es de $0.5-1 \mu \mathrm{g} / \mu \mathrm{l}$ (Figura 16). 


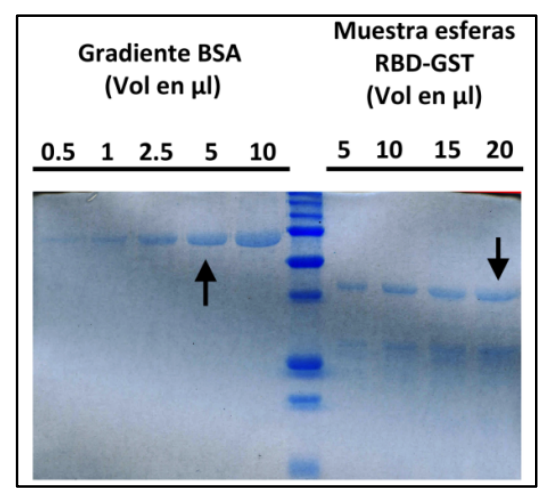

Figura 16. Cuantificación de la proteína Raf-GST tomando como referencia una recta patrón de BSA. Conociendo la equivalencia de una solución de BSA al $0.1 \%$ en agua con su concentración proteica, estimamos visualmente la banda equiparable de un volumen conocido de la solución de esferas Raf-GST con alguna banda en el gradiente de BSA.

\section{c) Pull down de Ras}

Los niveles de RasGTP de las células se determinaron mediante ensayos de pull down. Se utilizaron cultivos subconfluentes (65-85\%) de MEFs de los 4 genotipos de estudio ( $n=4 /$ genotipo) tratados con $4 \mathrm{OHT}$ durante 9 días. Aspiramos el medio en el que se encontraban las células y lavamos las células 2 veces con PBS frio. Posteriormente añadimos medio sin suero e incubamos los cultivos o/n a $37^{\circ} \mathrm{C}$ y $5 \%$ de $\mathrm{CO}_{2}$.

Al día siguiente se estimularon las células con PDGF (del inglés: $\underline{P}$ latelet-ㅁerived $\underline{G}$ rowth Factor) o EGF (ambos a una concentración de $50 \mathrm{ng} / \mathrm{ml}$ ) durante distintos tiempos (2, 5 y 15 min para el PDGF y 2, 5 y 10 min para el EGF). La estimulación se detuvo colocando las placas de cultivo en hielo, aspirando el medio y lavando con PBS frio dos veces. Posteriormente, se añadió medio MLB 1X fresco (500-700 $\mu \mathrm{l} /$ placa) y con ayuda de un rascador se despegaron las células y el lisado se recogió en eppendorf de $1.5 \mathrm{ml}$ en hielo. Dimos un vórtex a los lisados y centrifugamos durante $10 \mathrm{~min}$ a $13000 \mathrm{rpm}$ a $4^{\circ} \mathrm{C}$. A continuación, separamos $50 \mu \mathrm{l}$ del sobrenadante para la detección de la proteína Ras total. EL volumen restante de sobrenadante $(\sim 600 \mu \mathrm{l})$ se incubó con aproximadamente $100 \mu \mathrm{l}$ de esferas con Raf-GST (cuyo proceso de producción fue descrito en el apartado anterior) durante 30 min en un agitador rotatorio a $4{ }^{\circ} \mathrm{C}$. Después centrifugamos las muestras $1 \mathrm{~min}$ a $13000 \mathrm{rpm}$ a $4{ }^{\circ} \mathrm{C}$, descartamos el sobrenadante y lavamos con tampón MLB $1 X(3 \times 1 \mathrm{~min})$ a $13000 \mathrm{rpm}$ y $4{ }^{\circ} \mathrm{C}$. Tras el último lavado, aspiramos con mucho cuidado el sobrenadante y añadimos un volumen de aproximadamente $20 \mu l$ de LB $4 \mathrm{X}$ y hervimos las muestras 5 min a $100{ }^{\circ} \mathrm{C}$. Por último, los niveles de expresión de RasGTP y Ras total para cada caso se detectaron mediante la técnica de WB. 


\subsubsection{Ensayos de activación de Rac1}

\section{a) Purificación de la proteína de fusión CRIB-RBD}

El protocolo utilizado es muy similar al descrito para los ensayos de activación de Ras. En este caso las bacterias E.coli se transformaron con el plásmido pGEX-2T que codifica para la proteína de fusión recombinante CRIB-GST (CRIB: $\underline{\mathbf{C}} d c 42$ and $\underline{R} a c$ Interactive $\underline{B}$ inding Domain) y contiene además el gen de resistencia a ampicilina. Empleamos medio LB con ampicilina $(100 \mu \mathrm{g} / \mathrm{ml})$ para el crecimiento y selección bacteriana. Realizamos un preinóculo de la bacteria en $100 \mathrm{ml}$ de medio LB y lo mantuvimos en agitación o/n a $37^{\circ} \mathrm{C}$. El día siguiente incubamos el total del preinóculo en $500 \mathrm{ml}$ de medio fresco LB en agitación a $37^{\circ} \mathrm{C}$ hasta llegar a la DO entre 0.5 a 0.9 (medida a $600 \mathrm{~nm}$ ). Una vez alcanzada la DO añadimos IPTG $(0.5 \mathrm{mM})$ e incubamos aproximadamente $1 \mathrm{~h}$ a $37^{\circ} \mathrm{C}$ y en agitación. Después distribuimos el cultivo en tubos de centrífuga $(250 \mathrm{ml}$ ) y centrifugamos durante $10 \mathrm{~min}$ a $6000 \mathrm{rpm}$ (4 $\left.{ }^{\circ} \mathrm{C}\right)$. A continuación, se descartó el sobrenadante y el total de pellet se lisó con $12 \mathrm{ml}$ de tampón de lisis de bacterias (1 pastilla de Complete ${ }^{\circledR}$ EDTA free y $1 \mathrm{mM}$ de DTT en $50 \mathrm{ml}$ de PBS). Para conseguir una extracción mayor de la proteína CRIB-GST, sonicamos 6 veces durante 30 segundos cada pulso (4 ${ }^{\circ} \mathrm{C}$ ) y posteriormente añadimos $1 \%$ de Triton $\mathrm{X}-100$ y mantuvimos las muestras en hielo durante 30 min. Centrifugamos de nuevo a $10000 \mathrm{rpm} 10 \mathrm{~min}$ a $4{ }^{\circ} \mathrm{C}$, recogimos el sobrenadante y lo distribuimos en alícuotas que congelamos a $-80^{\circ} \mathrm{C}$.

\section{b) Unión de la proteína CRIB-RBD a esferas de glutatión-sefarosa}

Las esferas de glutatión-sefarosa se lavaron con el tampón tampón de lisis de bacterias (1 pastilla de Complete $^{\circledR}$ EDTA free, $1 \mathrm{mM}$ de DTT en $50 \mathrm{ml}$ de PBS; 3x1 min) a 13000 rpm. Para adherir la proteína CRIB a las esferas de glutation-sefarosa utilizamos aproximadamente $1 \mathrm{ml}$ de lisado CRIB-GST y lo incubamos con aproximadamente 100-120 $\mu \mathrm{L}$ de esferas de glutatión-sefarosa durante 1.5-2 h en agitador rotatorio a $4{ }^{\circ} \mathrm{C}$. Tras la incubación, las esferas CRIB-GST se lavaron ( $3 \times 1 \mathrm{~min}$ ) con tampón de lisis GLP que contenía: $10 \%$ glicerol, 1\% NP-40, $50 \mathrm{mM}$ Tris $\mathrm{HCl} \mathrm{pH} \mathrm{7.5,} 200 \mathrm{mM} \mathrm{NaCl}$ y $2 \mathrm{mM} \mathrm{MgCl}$, $25 \mathrm{mM} \mathrm{NaF}, 1 \mathrm{mM} \mathrm{Na}_{3} \mathrm{VO}_{4}, 1$ pastilla de Complete ${ }^{\circledR}$ por cada $50 \mathrm{ml}, 1 \mathrm{mM} \mathrm{PMSF}$, en $\mathrm{H}_{2} \mathrm{O}$, a $13000 \mathrm{rpm}$ y $4{ }^{\circ} \mathrm{C}$. A continuación, se descartaba el sobrenadante y se resuspendían las esferas de sefarosa CRIBGST en $1 \mathrm{ml}$ de tampón GLP. Con el fin de cuantificar la cantidad de proteína de fusión obtenida, 
sometemos las muestras a electroforesis y tomamos como referencia una recta patrón de BSA. La concentración ideal de proteína CRIB-RBD es de 0.5-0.8 $\mu \mathrm{g} / \mu \mathrm{l}$.

\section{c) Pull down de Rac1}

Los niveles de RacGTP de las células se determinaron también mediante ensayos de pull down. Se utilizaron cultivos subconfluentes (65-75\%) de MEFs de los 4 genotipos de estudio ( $n=4 /$ genotipo) tratados con $4 \mathrm{OHT}$ durante 9 días. Aspiramos el medio en el que se encontraban las células y lavamos 2 veces con PBS frio. Posteriormente, añadimos medio sin suero y dejamos los cultivos o/n a $37^{\circ} \mathrm{C}$ y $5 \%$ de $\mathrm{CO}_{2}$. Los MEFs fueron entonces estimulados con EGF (100 ng/ml) durante 2, 5 y $10 \mathrm{~min}$. La placas se colocaron en hielo para detener la estimulación y se lavaron dos veces con PBS frio. A continuación, se añadieron entre 500-700 $\mu \mathrm{l}$ de tampón GLP y las células se despegaron las células con ayuda de un rascador y se recogieron en un eppendorf de $1.5 \mathrm{ml}$ (en hielo). Los lisados fueron entonces centrifugados durante 6-8 $\mathrm{min}$ a $13000 \mathrm{rpm}$ a $4{ }^{\circ} \mathrm{C}$. Recogimos el sobrenadante, separamos un volumen suficiente para la posterior cuantificación de la proteína Rac1 total (50 $\mu$ l) y utilizamos un mismo volumen $(\sim 500 \mu \mathrm{l})$ de cada muestra e incubamos las muestras durante 30 min en agitación giratoria con las esferas CRIB-GST a $4{ }^{\circ} \mathrm{C}$. Después centrifugamos las muestras y las esferas se lavaron con tampón GLP y se centrifugaron (3x1 $\mathrm{min}$ ) a $13000 \mathrm{rpm}$. Tras el último lavado, aspiramos el sobrenadante, añadimos $20 \mu \mathrm{l}$ de LB $4 \mathrm{X}$ y hervimos las muestras $5 \mathrm{~min}$ a $100{ }^{\circ} \mathrm{C}$. Los niveles de expresión de RacGTP y Rac total fueron medidos mediante la técnica de WB (Apartado) y se cuantificaron como se indica en el apartado 4.2.

\section{Ensayos celulares}

\subsection{Curva de crecimiento}

Estudiamos la curva de crecimiento en MEFs de los 4 genotipos ( $n=6 /$ genotipo). Las células se trataron durante 8 días con $4 \mathrm{OHT}$, se despegaron, y un total $8 \times 10^{4} \mathrm{MEFs}$ de cada genotipo fueron resembrados en placas de 6 pocillos $(3.5 \mathrm{~cm})$. Se cuantificó del número de células en cámara de Neubauer (Zuzi) cada 24 h, durante los 7 días siguientes. Los datos se expresaron como un ratio entre número de células cada día del recuento con respecto al número inicial de células sembradas. Al número de células inicial se le asignó el valor 1 . Se realizaron medias de todos los individuos del mismo genotipo y se representó una sola curva para cada uno de ellos. 
Evaluamos asimismo el efecto del tratamiento con ciertos antioxidantes en la curva de crecimiento de MEFs de los 4 genotipos ( $n=6 /$ genotipo). Para ello, las células se trataron durante 8 días con $40 \mathrm{HT}$, se despegaron y un total de $2 \times 10^{4}$ células se sembraron en placas de 24 pocillos. En ese momento se añadieron los antioxidantes, GSH o NAC (10 $\mu \mathrm{M}$, Sigma) al medio de cultivo manteniendo como grupo control para cada genotipo cultivos en ausencia de antioxidantes. La cuantificación del número de células se realizó cada 24 h y durante 4 días consecutivos.

Finalmente, realizamos una última curva de crecimiento similar a las anteriores. En este caso evaluamos el efecto del antioxidante MitoTEMPO en la capacidad de crecimiento celular. $2 \times 10^{4} \mathrm{MEFs}$ de los 4 genotipos de estudio tratadas con $4 \mathrm{OHT}$ durante 8 fueron sembradas en placas de 24 pocillos. Se añadió entonces MitoTEMPO (100 $\mu \mathrm{M}$, Santa Cruz, 1334850-99-5) al medio de cultivo (excepto a los grupos controles para cada genotipo), y se cuantifico el número de MEFs durante 7 días consecutivos y cada $24 \mathrm{~h}$ de la misma manera que en los casos anteriores.

\subsection{Ensayo de senescencia mediante tinción de $\beta$-Galactosidasa}

Nos propusimos determinar si la ausencia de una o ambas proteína Sos pudiera desencadenar la entrada en senescencia de los MEFs. Para ello, empleamos el kit "Senescence $\beta$-Galactosidase" (Cell Signaling, \#9860). Utilizamos células subconfluentes de los 4 genotipos tratadas 9 días con 4OHT. Se siguió el protocolo recomendado en la hoja de especificaciones del producto. Brevemente, retiramos el medio de cultivo de las placas y lavamos con PBS. Posteriormente, añadimos $1 \mathrm{ml} /$ pocillo de solución de fijación (2\% PFA, 0.2\% glutaraldehído en PBS) y lo mantuvimos durante 10-15 min a TA. A continuación, lavamos de nuevo con PBS dos veces y añadimos $1 \mathrm{ml} /$ pocillo de solución de marcaje, e incubamos o/n a $37^{\circ} \mathrm{C}$ en estufa. El resultado fue analizado al día siguiente bajo al microscopio (Nikon Eclipse Ti; Figura 17). 
Tinción $\beta$ - Galactosidasa -

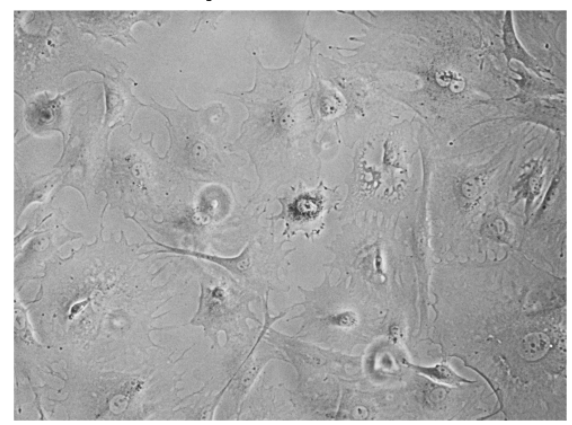

Tinción $\beta$-Galactosidasa +

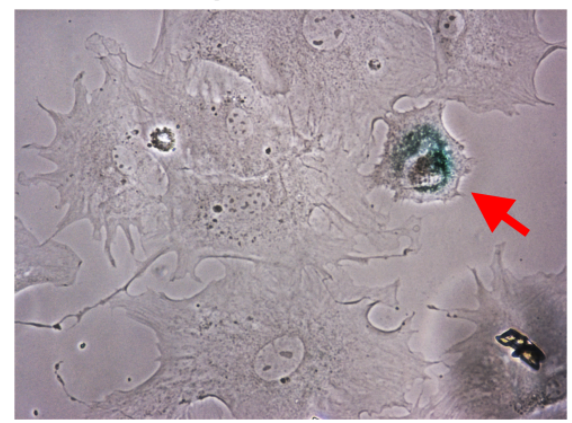

Figura 17. Tinción con $\beta$-Galactosidasa en cultivos de MEFs tratados 9 días con $40 H T$. A la izquierda un cultivo de células Sos2 KO, donde no observamos ninguna célula senescente, y a la derecha una imagen de un cultivo de células Sos1/2 DKO donde observamos una célula positiva (flecha) para el marcaje con $\beta$-Galactosidasa.

\subsection{Ensayo de viabilidad celular y actividad metabólica con alamarBlue ${ }^{\circledast}$}

El ensayo con el alamarBlue (Invitrogen, DAL1100) se utilizó para medir la viabilidad y la actividad metabólica de las células. En concreto, evaluamos estos parámetros en células que fueron, o no, tratadas con diferentes antioxidantes, concretamente con GSH, NAC o MitoTEMPO. Para ello, partimos de MEFs de los 4 genotipos que habían sido tratados 8 días con $4 \mathrm{OHT}$. Sembramos un total de 1500 de estas células en placas de 96 pocillos, y añadimos individualmente, para cada caso, los antioxidantes GSH $(10 \mathrm{mM})$, NAC $(10 \mathrm{mM})$ o MitoTEMPO $(100 \mu \mathrm{M})$ y analizamos el efecto de estos compuestos en la viabilidad y la actividad metabólica de las células durante los 4 días posteriores. Para el análisis en cada uno de estos días, añadimos el alamarBlue (1:10) en cada uno de los pocillos y se incubó durante $1 \mathrm{~h}$ a $37^{\circ} \mathrm{C}$ y $5 \mathrm{CO}_{2}$. A continuación, se midió la fluorescencia emitida por las células a $590 \mathrm{~nm}$ en el lector de fluorescencia Synergy 4 (BioTec).

\subsection{Ensayo de migración}

\subsubsection{Ensayo de migración dirigida}

Realizamos el ensayo de wound healing (WH) o "herida" en placa para medir la capacidad de migración de las células. En este ensayo empleamos MEFs confluentes (>85\%) de los 4 genotipos tratados durante 9 días con $4 \mathrm{OHT}$ y cultivadas en este caso en placas de 12 pocillos. La "herida" se realizó con punta de pipeta de aproximadamente de $600 \mu \mathrm{m}$ de diámetro. Posteriormente, lavamos con PBS dos veces para retirar los restos celulares y añadimos medio de cultivo con $2 \%$ de FBS. La 
reducción en el porcentaje de suero añadido al medio respecto a las condiciones en crecimiento activo (10\%) pretendía detener o al menos reducir al máximo la proliferación normal de las células. Monitorizamos con el microscopio de célula viva (Nikon Eclipse TE2000), el cierre de la herida mediante la captura de imágenes consecutivas en intervalos regulares de tiempo de 5 min, durante 24 h. El análisis detallado de las imágenes permitió comparar la tasa de migración (área libre/área total) de las células de cada genotipo cada hora durante 24 h. Este método también nos permitió estudiar la migración de células individuales en el eje migratorio de la herida, pudiendo conocer el recorrido, distancia y velocidad migratorios. El programa informático utilizado para este análisis fue ImageJ (v 1.6.0).

\subsection{Ensayo de adhesión}

\subsubsection{Ensayo de adhesión en plástico}

Analizamos la capacidad de adhesión de MEFs de los 4 grupos de estudio en placas de cultivo sin ningún tipo de recubrimiento. Tras 9 días de tratamiento con 4OHT, MEFs de todos los grupos experimentales fueron despegados de la placa de cultivo con TrypLE ${ }^{T M}$ Express Enzyme (Gibco, 12604013). Posteriormente, sembramos $2 \times 10^{4}$ células de cada genotipo en placas de $3.5 \mathrm{~cm}$ y se mantuvieron en las condiciones de cultivo estándares durante $2 \mathrm{~h}$. Después, aspiramos el medio y lavamos dos veces con PBS y añadimos de nuevo el TrypLE ${ }^{T M}$ Express para realizar de nuevo un recuento celular con cámara Neubauer. Estos recuentos permitieron determinar el número de células que se adhirieron a la placa. Los valores se representaron como el porcentaje de células adheridas respecto al total de células sembradas inicialmente.

\subsubsection{Ensayo de adhesión en fibronectina}

Asimismo, estudiamos la capacidad de los MEFs de los 4 grupos de estudio de adherirse en este caso a un sustrato, concretamente a fibronectina (FN). Primeramente, se recubrieron placas de fondo de cristal de $2 \mathrm{~cm}$ (P35G-0-10-C, MatTek) con $500 \mu \mathrm{l}$ de FN (10 $\mu \mathrm{g} / \mathrm{ml}$, Sigma) y se dejaron o/n a $37{ }^{\circ} \mathrm{C}$. Antes de su utilización se eliminó el exceso de FN con dos lavados de PBS. Correspondiente con el día 9 de tratamiento con $4 \mathrm{OHT}$, MEFs de los 4 genotipos en condiciones de subconfluencia se despegaron de sus placas de cultivo $(10 \mathrm{~cm})$ con TrypLE ${ }^{T M}$ Express y un total de $1.5 \times 10^{5}$ células de cada genotipo fueron sembradas en las placas recubiertas con FN. En este caso, se tomaron imágenes en el 
microscopio de célula viva NIKON TE2000 y se cuantificó el porcentaje de adhesión celular a las 4 h tras la siembra.

\subsection{Estudio de la dinámica de adhesiones focales en célula viva mediante microscopía} de interferencia por reflexión

La IRM (del inglés: Interference $\underline{R}$ eflection Microscopy) es una técnica de microscopia muy útil para estudiar de forma pormenorizada los procesos de migración y adhesión celular. La interferencia de las ondas de la luz reflejadas en diferentes estructuras genera imágenes contrastadas de alta definición, gracias a los diferentes índices de refracción de las estructuras que atraviesa. Es especialmente útil para estudiar las regiones de contacto directo entre una célula y el sustrato. En concreto, empleamos esta técnica para analizar la dinámica de las AF.

Para ello se utilizó el microscopio confocal Zeiss LSM510. Sembramos, en placas de fondo de cristal de $2 \mathrm{~cm}$ recubiertas con $\mathrm{FN}(10 \mu \mathrm{g} / \mathrm{ml}), 1.5 \times 10^{5}$ células de los 4 genotipos que habían sido tratadas 8 días con $4 \mathrm{OHT}$. El día 9 de tratamiento con $4 \mathrm{OHT}$ realizamos este ensayo en células WT, Sos1 KO, Sos2 KO y Sos1/2 DKO. La intensidad en las imágenes de IRM indica la fuerza o capacidad de adhesión celular a la superficie. El programa informático que se empleó fue ZEN (ZEISS Microscopy), que programamos para adquirir imágenes cada 20 segundos durante $1 \mathrm{~h}$. Las imágenes de alta resolución obtenidas nos permitieron cuantificar el número de lamelipodios, de AF, el área de extensión celular, y por último, la intensidad de las $\mathrm{AF}$, que nos permitía conocer la estabilidad de las mismas. Las imágenes fueron procesadas y cuantificadas en el software ImageJ ( $v$ 1.6.0).

\section{Técnicas de análisis histológico}

\subsection{Ensayos de inmunofluorescencia}

Las células se crecieron hasta una confluencia aproximada del 70-75\%, sobre cubreobjetos de vidrio estériles de $10 \mathrm{~mm}$ de diámetro. Se lavaron con PBS y se fijaron con una solución al 4\% de PFA en PBS, durante 15 min a TA. Tras la fijación se realizaron dos lavados con PBS, a partir de este momento se mantuvieron en PBS frio. Las células se permeabilizaron durante 20 min con $0.2 \%$. Triton X-100. Posteriormente, los cubreobjetos se lavaron con PBS ( $3 \times 5 \mathrm{~min}$ ) y un último lavado con $0.05 \%$ PBST y se bloquearon con una solución de PBS con BSA (5\%) y suero de cabra (2\%) durante 45 min. 
Posteriormente, se incubaron los anticuerpos primarios correspondientes en las condiciones indicadas en la tabla 8 . Al día siguiente, las muestras se lavaron con PBS ( $3 \times 5 \mathrm{~min}$ ) y $0.05 \%$ PBST y se incubaron en oscuridad con los anticuerpos secundarios correspondientes en las condiciones indicadas (tabla 9). A la solución de anticuerpo secundario se le añadió DAPI (2 gotas/ml, Molecular Probes, R37606). Finalmente, las muestras se lavaron con PBS y se montaron con medio de montaje (ProLong ${ }^{\circledR}$, Life Technologies, P36970). En ocasiones, se utilizó el marcador faloidina en combinación con ciertos inmunomarcajes. En este caso, la faloidina (1:40, Invitrogen, A12379) se incubo simultáneamente, tras la incubación de los anticuerpos primarios, junto con los anticuerpos secundarios correspondientes.

En el caso específico del doble marcaje con MitoTracker ${ }^{\circledR}$ y LC3B, el ensayo se realizó en condiciones algo diferentes. Se retiró a las células el medio completo de cultivo y se sustituyó por medio DMEM sin rojo fenol, en el que se diluyó el MitoTracker ${ }^{\circledR}$ (50 nM, Invitrogen, L7526) durante 15 min. Posteriormente, los MEFs se fijaron (PFA 4\%, $15 \mathrm{~min}$ ), lavaron, permeabilizaron y bloquearon como hemos descrito en el párrafo anterior. Finalmente, incubamos el anticuerpo contra la proteína LC3B en las condiciones descritas en la tabla 8. A partir de aquí se trató como cualquier otra inmunotinción. En el caso particular de realizar una doble inmunofluorescencia, se incubó uno de los anticuerpos primarios $\mathrm{o} / \mathrm{n}$ a $4{ }^{\circ} \mathrm{C}$ y al día siguiente, tras los lavados descritos antes, se incubó el segundo de los anticuerpos primarios durante $1 \mathrm{~h}$ a TA. A continuación se incubaron los anticuerpos secundarios acoplados a fluorocromo correspondientes junto con DAPI durante $1 \mathrm{~h}$ a TA y en oscuridad. Finalmente se lavaron las muestras con PBS $(3 \times 5 \mathrm{~min})$ y se montaron los cubreobjetos sobre los portas con medio de montaje. Las muestras se analizaron con el microscopio láser confocal (Leica SP5). 
Tabla 8: Lista de anticuerpos primarios.

\begin{tabular}{|c|c|c|c|c|}
\hline Anticuerpo & Casa comercial & Origen & Dilución & Incubación \\
\hline$\alpha$-H3K9me3 & BD (07-442) & Rabbit & $1: 400$ & $\mathrm{o} / \mathrm{n} / 4^{\circ} \mathrm{C}$ \\
\hline$\alpha-H 4-a c e t$ & Chemicon (06-866) & Rabbit & $1: 400$ & $\mathrm{o} / \mathrm{n} / 4^{\circ} \mathrm{C}$ \\
\hline$\alpha-H P 1 \gamma$ & Millipore (MAB3450) & Mouse & $1: 400$ & $\mathrm{o} / \mathrm{n} / 4^{\circ} \mathrm{C}$ \\
\hline$\alpha-\gamma H 2 A X$ & BD (05-636) & Mouse & $1: 200$ & $\mathrm{o} / \mathrm{n} / 4^{\circ} \mathrm{C}$ \\
\hline$\alpha$-LC3B & Cell Signaling (2775S) & Rabbit & $1: 800$ & $\mathrm{o} / \mathrm{n} / 4^{\circ} \mathrm{C}$ \\
\hline$\alpha$-Paxilina & Millipore (05-417) & Mouse & $1: 400$ & $2 \mathrm{~h} / \mathrm{TA}$ \\
\hline$\alpha$-Casp3 activa & Cell Signaling (9661) & Rabbit & $1: 400$ & $\mathrm{o} / \mathrm{n} / 4^{\circ} \mathrm{C}$ \\
\hline
\end{tabular}

Tabla 9: Lista de anticuerpos secundarios.

\begin{tabular}{|c|c|c|}
\hline Anticuerpo secundario & Referencia & Dilución \\
\hline Goat $\alpha$-mouse Alexa 488 & Jackson Inmunoresearch (115-545-146) & $1: 500$ \\
\hline Goat $\alpha$-rabbit Alexa 488 & Jackson Inmunoresearch (111-545-144) & $1: 500$ \\
\hline Goat $\alpha$-mouse Cy3 & Jackson Inmunoresearch (115-165-146) & $1: 500$ \\
\hline Goat $\alpha$-rabbit Cy3 & Jackson Inmunoresearch (111-165-003) & $1: 500$ \\
\hline
\end{tabular}

\section{$\underline{5.2}$ Tinciones con colorantes vitales}

En el caso de la tinción con Lysotracker ${ }^{\circledR}$ (Invitrogen, L7526), partimos de células vivas de los 4 genotipos a las que retiramos el medio completo DMEM y lo sustituimos por DMEM sin rojo fenol, al que añadimos Lysotracker ${ }^{\circledast}(1 \mu \mathrm{M})$ y lo mantuvimos durante 30 min. Seguidamente estas células se lavaron con PBS (2x1 min) y se añadió de nuevo medio DMEM sin rojo fenol. Finalmente, las células se fotografiaron en la cámara acoplada del microscopio de fluorescencia Delta Vision.

\section{Microscopía electrónica}

Cultivos subconfluentes de MEFs primarios de los 4 genotipos tratados 9 días con 4OHT fueron mantenidos en hielo y fijados con glutaraldehído (2\%) y PFA (2\%) en tampón cacodilato $0.1 \mathrm{M}$ a pH 7.3, y $\mathrm{CaCl}_{2} 2 \mathrm{mM}$ durante un tiempo máximo de $30 \mathrm{~min}$. Las muestras fueron posteriormente lavadas con tampón cacodilato $0.1 \mathrm{M} \mathrm{pH} 7.3$ y a continuación las células fueron post-fijadas con $1 \%$ tetraóxido de osmio y $1 \%$ ferrocianuro potásico diluidos en agua destilada durante $1 \mathrm{~h}$ a $4{ }^{\circ} \mathrm{C}$ y en 
oscuridad. Las muestras se lavaron con abundante agua y se deshidrataron en concentraciones crecientes de etanol $\left(4^{\circ} \mathrm{C}\right): 50 \%, 70 \%, 80 \%, 90 \%, 95 \%, 100 \%(2 x)$ durante 10 min en cada una y en agitación. Seguidamente, las muestras se sumergieron en óxido de propileno ( $3 \times 10 \mathrm{~min})$ y se mantuvieron en agitación. Posteriormente, las secciones fueron incluidas en resina EmBed 812 (Electron Microscopy Sciences, \#14120) y se colocaron en los moldes definitivos (Electron Microscopy Science, 70901) con la orientación deseada, y los mantuvimos en estufa a $60{ }^{\circ} \mathrm{C}$ durante $12 \mathrm{~h}$. Finalmente, se tallaron los bloques con las muestras incluidas para obtener secciones ultrafinas de 50-70 $\mathrm{nm}$ de grosor, que se realizaron con cuchilla de diamante y se recogieron en rejillas de cobre. Para obtener un buen contraste de los orgánulos y las membranas, se utilizó una solución de acetato de uranilo al $2 \%$ (en etanol del 50\%) y citrato de plomo (50 ml de solución: $30 \mathrm{ml} \mathrm{H} \mathrm{H}_{2} \mathrm{O}$ MiliQ, $1.33 \mathrm{~g}$ de nitrato de plomo, $1.76 \mathrm{~g}$ de citrato sódico, $8 \mathrm{ml}$ de $1 \mathrm{M} \mathrm{NaOH}$ y de nuevo $12 \mathrm{ml}$ de $\mathrm{H}_{2} \mathrm{O}$ MiliQ). Se colocaron las rejillas en gotas de acetato de uranilo y se mantuvieron en oscuridad 20 min a TA. Se lavaron con $\mathrm{H}_{2} \mathrm{O}$ MiliQ y se retiró el exceso de agua con papel de filtro. Finalmente, se colocaron las rejillas en gotas de citrato de plomo y se mantuvieron en oscuridad $10 \mathrm{~min}$ TA. Seguidamente se lavaron de nuevo con $\mathrm{H}_{2} \mathrm{O}$ MiliQ y se dejaron secar. Finalmente, las muestras se analizaron en el microscopio ZEISS EM900 TEM y se tomaron las imágenes con una cámara digital (Slow Scan CCD) utilizando el programa informático ImageSP.

\section{Citometría de flujo}

\subsection{Análisis del ciclo celular}

La BrdU es un análogo de la timidina, que se incorpora al DNA en la fase $\mathrm{S}$ del ciclo celular y que se emplea normalmente para analizar el proceso de proliferación. Añadimos BrdU (10 $\mu \mathrm{M}$, Sigma, B5002) a cultivos celulares subconfluentes (60-80\%) en crecimiento activo de los 4 genotipos, y se mantuvo durante $1 \mathrm{~h}$ en condiciones de cultivo estándares. A continuación, se lavaron las placas con PBS, se tripsinizaron las células y se centrifugaron a $1200 \mathrm{rpm}$ durante $6 \mathrm{~min}$. Se descartó el sobrenadante y las células se recogieron en $1 \mathrm{ml}$ de PBS en tubos de citometría y se volvieron a centrifugar en las mismas condiciones (1200 rpm, $6 \mathrm{~min}$ ). Posteriormente, decantamos el sobrenadante y fijamos los MEFs con etanol al $70 \%\left(-20^{\circ} \mathrm{C}\right)$ o/n a $4{ }^{\circ} \mathrm{C}$. Al día siguiente, se centrifugaron los tubos (1200 rpm, $6 \mathrm{~min}$ ) se descartó el sobrenadante y se lavaron con agua, repitiéndose este proceso dos veces. El pellet de células se resuspendió en $200 \mu l$ de solución desnaturalizante de DNA ( $2 \mathrm{M} \mathrm{HCl}, 0.5 \%$ Triton X-100 en agua) e incubamos las muestras durante 30 
min a TA. Añadimos $2 \mathrm{ml}$ de agua, centrifugamos de nuevo (1200 rpm, $6 \mathrm{~min}$ ) y decantamos para retirar la solución desnaturalizante. A continuación, añadimos $500 \mu \mathrm{l}$ de solución de tetraborato sódico (0.1 M, pH 8.5) y lo mantuvimos 2-5 min. Centrifugamos de nuevo (1200 rpm, $6 \mathrm{~min}$ ) y decantamos. Posteriormente, incubamos el anticuerpo anti-BrdU conjugado al fluorocromo FITC (1:10, BD, 556028) en 1\% BSA y $0.5 \%$ Triton $\mathrm{X}-100$, en PBS, durante $1 \mathrm{~h}$ a TA y en oscuridad. Centrifugamos (1200 rpm, $6 \mathrm{~min}$ ), decantamos, lavamos con PBS, y repetimos el mismo proceso una vez más. A continuación, añadimos la solución de marcaje del DNA, entre 300 y $400 \mu \mathrm{l} /$ muestra (para $1 \mathrm{ml}$ de PBS: $5 \mu \mathrm{l}$ de solución RNAsa ( $25 \mathrm{mg} / \mathrm{ml}$, Sigma) y $5 \mu \mathrm{l}$ de solución de loduro de propidio (1 $\mathrm{mg} / \mathrm{ml}$, Sigma) durante $45 \mathrm{~min}$ TA, en agitación. Finalmente, se adquirieron $10^{4}$ células/muestra en el citómetro FACSCanto II (BD) y los resultados se analizaron con el programa Infinicyt ${ }^{\circledR}$ (Cytognos).

\subsection{Análisis de la muerte celular por citometría de flujo}

En células viables, la fosfatitilserina se localiza en la cara interna de la membrana celular. Sin embargo, en etapas intermedias del proceso de apoptosis se produce una translocación desde la cara interna a la cara externa de la membrana plasmática, dejando expuesta a la fosfatitilserina hacia el ambiente extracelular donde podemos detectarla. La Anexina $\mathrm{V}$ presenta una unión a fosfolípidos dependiente de $\mathrm{Ca}^{2+}$, mostrando alta afinidad y especificidad por la PS. Por lo tanto, la Anexina $\mathrm{V}$ se une a la PS en células cuyo proceso apoptótico se haya iniciado. Cuando las células se encuentran en una fase más avanzada de la apoptosis (o en una muerte por necrosis), pierden de la integridad de la membrana plasmática que permite el marcaje de DNA por colorantes vitales, como la 7-Actinomicina $D$ (7-AAD). De esta manera, el doble marcaje con Anexina $V$ y 7-AAD puede ser cuantificado por citometría de flujo. Este ensayo no permite distinguir la apoptosis tardía de la muerte por necrosis, pues en ambas situaciones se ha perdido la integridad de la membrana y los marcadores vitales tiñen el DNA.

Se utilizaron cultivos celulares subconfluentes de células WT, Sos1 KO, Sos2 KO y Sos1/2 DKO tratadas 9 días con $4 \mathrm{OHT}$, se recogió el medio de cada condición, se lavaron las placas con PBS dos veces y se tripsinizaron durante 2-3 min. La tripsina se neutralizó con el medio anteriormente recogido de cada condición. Las muestras se centrifugaron a $1200 \mathrm{rpm}$ durante $5 \mathrm{~min}$, se lavaron con $1 \mathrm{ml}$ de PBS y se centrifugaron de nuevo en las mismas condiciones. Decantamos el sobrenadante y resuspendimos cada muestra en $100 \mu \mathrm{l}$ de Binding Buffer $1 X$ (10 mM HEPES/NaOH pH 7.4, $140 \mathrm{mM} \mathrm{NaCl}, 25 \mathrm{mM}$ $\mathrm{CaCl}_{2} ; \mathrm{BD}$ ) a los que se añadieron $5 \mu \mathrm{l}$ de 7-AAD (BD, 51-68981) y $5 \mu \mathrm{l}$ de Anexina V-FITC (BD, 556420) 
por muestra. Se incubaron en agitación y en oscuridad durante 15 min, y se añadieron 100-200 $\mu$ l de PBS para facilitar la adquisición de las células en el citómetro. Se adquirieron $2 \times 10^{4}$ células en el citómetro FACScalibur (BD). El análisis de los datos se realizó con el programa WinMDI (v 2.9).

\subsection{Análisis de especies reactivas de oxígeno}

\subsubsection{Análisis de las especies reactivas de oxígeno totales}

El compuesto 2-7, dihidrocloro-fluoresceína ( $\mathrm{H}_{2}$ DCFDA; Molecular Probes, D-399) es un indicador general de especies reactivas de oxígeno (ROS) en la célula. La $\mathrm{H}_{2}$ DCFDA es oxidada por el $\mathrm{H}_{2} \mathrm{O}_{2}$ convirtiéndose en dicloro-fluoresceína, emitiendo una fluorescencia directamente proporcional a la concentración citoplasmática de $\mathrm{H}_{2} \mathrm{O}_{2}$. El análisis por citometría se realizó en MEFs de los 4 genotipos sin tratamiento con $4 \mathrm{OHT}$ y a diferentes tiempos de tratamiento con $4 \mathrm{OHT}$ ( 3,6 y 9 días). Utilizamos cultivos celulares subconfluentes $(70-80 \%$ ) crecidos en placas de $10 \mathrm{~cm}$, a las que les retiramos el medio de cultivo y tras un lavado con PBS, les añadimos $1 \mathrm{ml}$ de Tripsina y seguidamente recogimos las células con medio fresco, se centrifugaron durante 5 min a $1500 \mathrm{rpm}$, se descartó el sobrenadante

y se lavaron con PBS a $37^{\circ} \mathrm{C}$, y de nuevo se volvieron a centrifugar en las mismas condiciones y se descartó el sobrenadante. Se resuspendieron las células en $1 \mathrm{ml}$ DMEM (sin rojo fenol y sin FBS) con $\mathrm{H}_{2}$ DCFDA $(5 \mu \mathrm{M})$ y se incubaron durante $20 \mathrm{~min}$ a $37^{\circ} \mathrm{C}$. Después se centrifugaron de nuevo en las condiciones descritas, se decantó el sobrenadante, y se resuspendieron en $300 \mu \mathrm{l}$ de DMEM sin rojo fenol y sin suero. Se mantuvieron en hielo hasta que fueron analizadas ( $2 \times 10^{4}$ células/muestra) en el citómetro FACScalibur (BD) utilizando el programa CellQuest ${ }^{\mathrm{TM}}$.

\subsubsection{Análisis del anión superóxido citosólico}

Utilizamos el dihidroetidio (DHE, Molecular Probes, D-1168) para cuantificar los niveles citosólicos del anión superóxido $\left(\mathrm{O}_{2}{ }^{-}\right)$. En presencia de $\mathrm{O}_{2}{ }^{-}$el DHE se oxida generando productos intermedios como el etidio que emite una fluorescencia que podemos medir. Utilizamos MEFs de los 4 genotipos de estudio, sin tratamiento con $4 \mathrm{OHT}$ y tras 3,6 y 9 días de tratamiento con $4 \mathrm{OHT}$. En primer lugar tripsinizamos las células y las centrifugamos durante $5 \mathrm{~min}$ a $1500 \mathrm{rpm}$ a TA, se descartó el sobrenadante y se lavaron con PBS atemperado, y de nuevo se volvieron a centrifugar en las mismas condiciones. Tras descartar el sobrenadante, resuspendimos las células en $1 \mathrm{ml}$ de DMEM (sin rojo fenol y sin FBS) y añadimos el DHE $(5 \mu \mathrm{M})$, que se incubó durante $45 \mathrm{~min}$ a $37^{\circ} \mathrm{C}$. Finalmente, se 
resuspendieron en $300 \mu \mathrm{l}$ de DMEM sin rojo fenol y sin suero y se mantuvieron en hielo hasta que se analizaron por citometría $\left(2 \times 10^{4}\right.$ células/muestra), FACScalibur (BD) utilizando el programa CellQuest $^{\mathrm{TM}}$.

\subsubsection{Análisis del anión superóxido mitocondrial}

Finalmente, analizamos los niveles $\mathrm{mO}_{2}{ }^{-}$con MitoSOX ${ }^{\mathrm{TM}}$ (Molecular Probes, M36008). Este reactivo penetra en las mitocondrias de células vivas y se oxida rápidamente por el $\mathrm{mO}_{2}^{-}$generando un producto oxidado altamente fluorescente. Empleamos MEFs (70-80\% de confluencia) de los 4 genotipos sin tratamiento ( 0 días) y a diferentes tiempos de tratamiento con $40 H T$ (3, 6 y 9 días). Se retiró el medio de cultivo y tras un lavado con PBS añadimos tripsina para despegar las células, que fueron recogidas en medio fresco y centrifugadas ( $1500 \mathrm{rpm}, 5 \mathrm{~min}$ ). Se descartó el sobrenadante y le realizó un lavado con PBS TA y se volvió a centrifugar en las condiciones descritas previamente. Se descartó el sobrenadante y las células se resuspendieron en $1 \mathrm{mI}$ DMEM (sin rojo fenol y sin FBS) con MitoSOX ${ }^{\mathrm{TM}}(5 \mu \mathrm{M})$, e incubamos durante $45 \mathrm{~min}$ a $37{ }^{\circ} \mathrm{C}$. Centrifugamos $1500 \mathrm{rpm} 5 \mathrm{~min}$, descartamos el sobrenadante y resuspendimos en $300 \mu \mathrm{l}$ de medio DMEM sin rojo fenol y sin suero, y las mantuvimos en hielo hasta su análisis por citometría ( $2 \times 10^{4}$ células/muestra), en el FACScalibur (BD) utilizando el programa CellQuest ${ }^{\mathrm{TM}}$.

Analizamos también este mismo parámetro en MEFs en los cuales la eliminación de Sos1 se realizó mediante el Adeno-Cre y no con $4 \mathrm{OHT}$. El protocolo seguido fue muy similar al anterior, a excepción de que en vez de añadir $4 \mathrm{OHT}$ al medio de cultivo se añadieron los adenovirus a MEFs de los 4 genotipos durante 3, 6 y 9 días. El procesado y medición de $\mathrm{mO}_{2}^{-}$fue idéntico al párrafo anterior con la única diferencia de que se cuantificaron $1 \times 10^{4}$ células.

\subsection{Análisis del potencial de membrana mitocondrial}

La Carbocianida (JC-1; Molecular Probes, T-3168) es un compuesto cuya conformación varía dependiendo del potencial de membrana mitocondrial $(\Delta \Psi \mathrm{m})$. Estas variaciones provocan un cambio de emisión de fluorescencia detectable en el citómetro. El análisis se realizó en células de los 4 genotipos sin tratamiento y con diferentes tiempos de tratamiento con $40 H T$ (3, 6 y 9 días) sembradas en placas de $10 \mathrm{~cm}$ (70-80\% confluencia), a las que les retiramos el medio de cultivo y tras un lavado con PBS, les añadimos $1 \mathrm{ml}$ de tripsina. Recogimos las células con medio fresco, se 
centrifugaron durante 5 min a $1500 \mathrm{rpm}$ a TA, se descartó el sobrenadante y se lavaron con PBS a $37{ }^{\circ} \mathrm{C}$, y de nuevo se volvieron a centrifugar en las mismas condiciones y se descartó el sobrenadante. Se resuspendieron las células en $1 \mathrm{ml} \mathrm{DMEM} \mathrm{(sin} \mathrm{rojo} \mathrm{fenol} \mathrm{y} \mathrm{sin} \mathrm{FBS)} \mathrm{con} \mathrm{JC-1} \mathrm{(3}$ $\mu \mathrm{M}$ ) y se incubaron durante $30 \mathrm{~min}$ a $37^{\circ} \mathrm{C}$. Por último, las células se centrifugaron (1500 rpm, 5 min) y se descartó el sobrenadante. Las células se resuspendieron en $300 \mu \mathrm{l}$ de medio DMEM (sin rojo fenol y sin FBS) y se mantuvieron en hielo hasta su análisis ( $2 \times 10^{4}$ células/muestra) en el citómetro FACScalibur (BD) utilizando el programa CellQuest ${ }^{\mathrm{TM}}$.

\section{ESTUDIOS IN VIVO}

En la presente Tesis Doctoral nos hemos propuesto estudiar in vivo la implicación de las proteínas Sos en la homeostasis de la piel en condiciones fisiológicas, tras un daño tisular y también en condiciones patológicas como el cáncer. Para ello, hemos empleado animales de los 4 genotipos de estudio (WT, Sos1 KO, Sos2 KO y Sos1/2 DKO) que han sido sometidos a distintos tratamientos experimentales que describiremos a continuación.

\section{Eliminación de la proteína Sos1 in vivo}

En la caso de los experimentos in vivo, el TAM fue administrado de forma oral, incluido en la dieta de los animales. Ratones de los 4 genotipos fueron tratados con el mismo tipo de dieta para evitar posibles efectos off-target del TAM. De forma general, alimentamos a animales de los 4 genotipos de entre 6 y 8 semanas de edad, con dieta de habituación libre de fitoestrógenos durante 10 días (para mejorar la eficiencia del TAM). A continuación, administramos dieta con TAM a animales de todos los grupos. Estudios de PCR y WB permitieron determinar que la completa eliminación de Sos1 ocurría tras 11-12 días de tratamiento con TAM.

\section{Ensayos de proliferación, muerte celular y respuesta inflamatoria tras la eliminación de Sos1 y Sos2}

Estudiamos la implicación de las proteínas Sos en distintos procesos que pueden ocurrir la piel como la proliferación, muerte o respuesta inflamatoria, entre otros. Para ello desarrollamos distintos protocolos que describiremos a continuación. De forma general, para evaluar el efecto de la eliminación de las proteínas Sos en la piel tras la administración tópica de diferentes estímulos, se 
depiló la piel de la espalda de estos animales, y se aplicó al pelo restante una crema depilatoria que permitía la completa eliminación del pelo del animal. En términos generales, los ratones fueron depilados el día 9 de tratamiento oral con dieta con TAM, y los experimentos se realizaron entre el día 11 y 12 de TAM oral.

\subsection{Ensayo de proliferación tras la administración tópica con TPA}

Empleamos el reactivo TPA (12-O-tetradecanolforbol-13-acetato, Sigma, P-8139) para generar una respuesta hiperproliferativa en células de la piel y determinar un posible rol de las proteínas Sos en este proceso. Ratones de los 4 genotipos fueron alimentados con dieta con TAM y depilados como se describió en el apartado anterior. El día 12 de administración de TAM oral, se aplicó de forma tópica una sola dosis de TPA en la piel de la espalda (6.8 nmol en $200 \mu$ lacetona). Debido a la toxicidad de este producto, la aplicación se realizó en campana de extracción de seguridad química (Captair ${ }^{\circledR}$ Chem, Filtair 936-1, erlab). Al día siguiente, los animales fueron inyectados intraperitonealmente (i.p) con BrdU (100 $\mu \mathrm{g} / \mathrm{g}$ peso, Sigma, B5002) y fueron sacrificados transcurridas 1.5-2 h. Se aisló piel de la zona de la espalda y se fijó en PFA al $4 \%$ o/n a $4{ }^{\circ} \mathrm{C}$. Posteriormente, el tejido se incluyó en parafina para su posterior seccionamiento.

\subsection{Ensayo de muerte celular tras la administración tópica con DMBA}

Utilizamos el reactivo DMBA (7,12-Dimetil-benz( $\alpha$ )antraceno, Sigma, D3254) para estudiar la muerte celular por apoptosis en la piel de animales de los 4 grupos experimentales. Tras el la administración de TAM oral (12 días), se administró tópicamente una dosis de DMBA ( $25 \mathrm{nmol}$ en $200 \mu \mathrm{l}$ de acetona) en la piel de la espalda de los animales. Este compuesto además de promover la apoptosis, también tiene un papel inmunosupresor en la piel (Thurmond et al., 1987). Debido a su carácter carcinogénico, los animales fueron manipulados en campana de extracción química. El análisis del efecto proapoptótico del DMBA se realizó a las $24 \mathrm{~h}$ después de su aplicación. Los animales fueron sacrificados y se aisló la piel de la zona de la espalda tratada, que fue fijada en PFA al $4 \%$ o/n a $4{ }^{\circ} \mathrm{C}$ y e incluida en parafina. 


\subsection{Ensayo de respuesta proliferativa e inflamatoria tras administración tópica de TPA}

\section{en dosis consecutivas}

EI TPA administrado tópicamente en 4 dosis consecutivas provoca una reacción inflamatoria aguda, que promueve la infiltración de neutrófilos y de linfocitos a la zona afectada (Florin et al., 2006). Se emplearon animales WT, Sos1 KO y Sos $2 \mathrm{KO}$, de entre 6 y 8 semanas, alimentados 12 días con dieta con TAM y depilados en la zona de la espalda. Posteriormente, aplicamos TPA (6.8 nmol en $200 \mu$ l acetona) durante 4 días consecutivos (1 dosis/día). Por otro lado, los ratones inducibles Sos1/2 DKO recibieron TAM durante 8 días y el TPA fue aplicado los días 9, 10, 11 y 12 de dieta de TAM. Un día después de la última dosis de TPA, los animales de los 4 genotipos fueron inyectados i.p con BrdU (100 $\mu \mathrm{g} / \mathrm{g}$ peso) y sacrificados tras $1.5-2 \mathrm{~h}$. Se aisló la piel de la y se procesaron las muestras como se describe en los apartados anteriores.

\subsection{Ensayo de wound healing in vivo}

En ensayo de WH epitelial permite analizar en un mismo experimento un conjunto de procesos biológicos ocurren tras el daño y que incluyen proliferación, migración y respuesta inmune, entre otros (Figura). El cierre de la herida se fundamenta en dos funciones en lo referente a queratinocitos epidérmicos. Primero, la capacidad de generar una respuesta proliferativa necesaria para recuperar el tejido dañado, y en segundo lugar una respuesta de migración para cubrir la herida generada.

La respuesta a este daño tisular se divide en las siguientes fases: hemostasia, inflamación, proliferación y re-epitelización (Figura 18). El ensayo duró 10 días, siendo suficientes para observar el proceso gradual de cierre de la herida. 


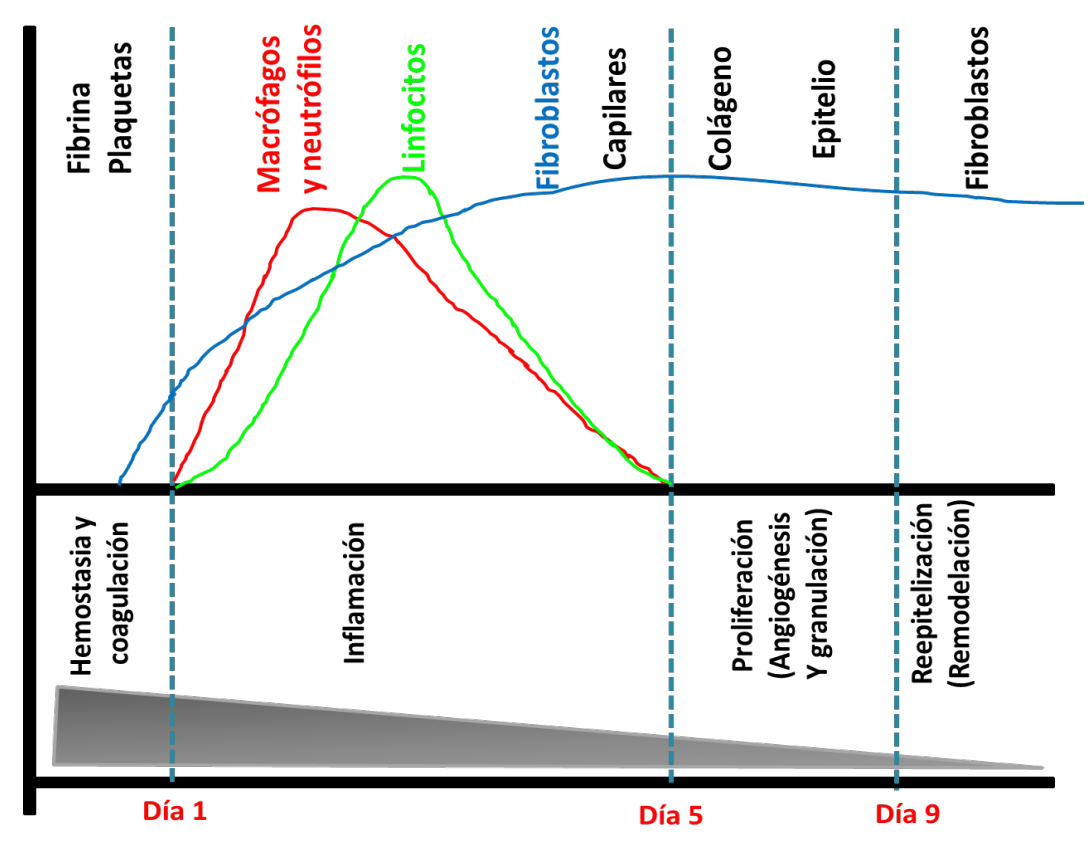

Figura 18. Fases del cierre de la herida en piel de ratón. Modificado de (Park and Barbul, 2004).

\subsubsection{Wound healing circular}

En el caso del WH circular se realizaron dos heridas circulares en la piel de la espalda con Biopsy punch $\left(\right.$ Stiefe $^{\circledR}{ }^{\circledR}$ ) de $4 \mathrm{~mm}$ de diámetro en condiciones de esterilidad y anestesia en animales WT, Sos1 KO y Sos2 KO tratados 12 días con TAM. En el caso de los animales inducibles Sos1/2 DKO, debido a la letalidad que provoca la eliminación combinada de ambas proteínas Sos tras 15 días de tratamiento con TAM oral (Baltanás et al., 2013), el experimento se realizó de forma diferente. Los animales Sos1/2 DKO fueron alimentados durante 4 días con TAM, tiempo mínimo para observar el inicio de escisión del gen Sos1. En ese momento se realizó el WH circular, combinando el proceso de gradual de la eliminación de Sos1, junto con el proceso de cierre de la herida. El seguimiento del cierre de la herida en todos los grupos de estudio se realizó midiendo el diámetro de las heridas diariamente, durante 10 días, con un calibre electrónico $\left(\right.$ Caliper $\left.^{\circledR}\right)$. Tras la última medición, los animales fueron inyectados i.p con BrdU (100 $\mu \mathrm{g} / \mathrm{g}$ peso) y fueron sacrificados transcurridas 1.5-2 h. La piel de la espalda con las heridas fue extraída, fijada en PFA al $4 \%$ o/n a $4{ }^{\circ} \mathrm{C}$ e incluida en parafina.

\subsubsection{Wound healing vertical}


Animales de los genotipos WT, Sos1 KO y Sos2 KO de 6-8 semanas de edad fueron alimentados con TAM durante 12 días y depilados en la piel de la espalda. El protocolo seguido para los animales Sos1/2 DKO fue el mismo que el descrito en el apartado anterior. En condiciones de anestesia, se realizó un corte vertical de aproximadamente $1.5 \mathrm{~cm}$ de longitud en la piel de la espalda con un bisturí estéril. Se realizó la medición de la longitud y anchura de la herida diariamente con el calibre electrónico durante los 10 días siguientes. Tras la última medición, los animales fueron inyectados i.p con $\mathrm{BrdU}(100 \mu \mathrm{g} / \mathrm{g}$ peso) $1.5 \mathrm{~h}$ previas a su sacrificio y la piel de la espalda de la región de la herida fue aislada, fijada e incluida en parafina, en las mismas condiciones descritas anteriormente.

\section{Modelo químico de carcinogénesis epitelial}

El modelo de carcinogénesis epitelial DMBA-TPA constituye un modelo estandarizado que consta de dos fases (Perez-Losada y Balmain., 2003). La primera es el inicio tumoral, promovido por la aplicación de una sola dosis del agente carcinogéno DMBA a dosis sub-carcinogénica ( $25 \mu \mathrm{g} / 200 \mu \mathrm{l}$ de acetona). $Y$ una segunda fase, de promoción tumoral, que consta de un tratamiento dos veces a la semana con TPA ( $1 \times 10^{-4} \mathrm{M}$ en acetona, $200 \mu \mathrm{l} /$ ratón) un mínimo de 30 semanas (dependiendo del protocolo seguido). Durante todo el experimento de carcinogénesis, realizamos el manejo y aplicación tópica de los reactivos DMBA y TPA en campana de seguridad química. Este protocolo reproduce la generación de papilomas en la piel humana y su posterior progresión hacia tumores de célula escamosa.

En la presente Tesis Doctoral hemos analizado el papel de las proteínas Sos en el inicio y desarrollo tumoral, como una posible diana terapéutica para el tratamiento de estas patologías. Asimismo, hemos estudiado el efecto de la eliminación de Sos1 en tumores ya pre-existentes (Figura 19). Para ello hemos utilizado dos protocolos de generación tumoral diferentes:

1) Inicio y promoción tumoral en animales deficientes para las proteínas Sos1 o Sos2: Animales WT, Sos1 KO inducibles y Sos $2 \mathrm{KO}$ de entre 6 y 8 semanas de edad fueron alimentados con dieta libre de estrógenos (10 días) y posteriormente con dieta con TAM durante 12 días. Los animales fueron depilados en la zona de la espalda, y sometidos al protocolo DMBA-TPA durante 30 semanas (Figura). Se realizó un seguimiento semanal sobre la aparición y progresión de los tumores generados (medición del tamaño con Caliper ${ }^{\circledR}$ ) y una revisión del estado general de los animales (control del peso). En este punto es importante concretar que el criterio utilizado para cuantificar el número de tumores, era que estas lesiones midieran al menos $1.5 \mathrm{~mm}^{2}$ de área. En cuanto a los animales 
inducibles Sos1/2 DKO, estos fueron tratados durante 28 semanas con DMBA-TPA, y entonces aplicamos la dieta con TAM oral para evaluar la progresión o regresión tumoral en animales deficientes para Sos1 y Sos2. En la semana número 30, los animales de los 4 genotipos fueron inyectados i.p con BrdU (100 $\mu \mathrm{g} / \mathrm{g}$ peso) y posteriormente sacrificados. Se extrajeron los tumores generados y fueron fijados en PFA al 4\% e incluidos en parafina. De esta manera analizamos el papel de ambas proteínas Sos1 o Sos2 en el inicio y progresión tumorales.

2) Inicio y promoción tumoral en animales WT e inducibles Sos1 KO, y posterior eliminación de Sos1. Animales WT y Sos1 KO de entre 6 y 8 semanas de edad fueron alimentados con dieta normal y tratados con el protocolo DMBA-TPA durante 28.5 semanas. A partir de este tiempo, se les administró primero dieta libre de estrógenos (10 días) y en la semana 30 se añadió dieta con TAM durante 2.5 semanas (Figura). Al finalizar el tratamiento, los animales fueron inyectados i.p con BrdU (100 $\mu \mathrm{g} / \mathrm{g}$ peso) y sacrificados a las 1.5-2 h. Además, hubo un segundo grupo de animales al que se le administró durante 5 semanas la dieta con TAM (desde la semana 30), tras este periodo fueron inyectados con i.p BrdU y sacrificados para el estudio posterior de los lesiones generadas. Siguiendo este protocolo podemos evaluar el efecto de la desaparición de la proteína Sos1 en tumores previamente establecidos.

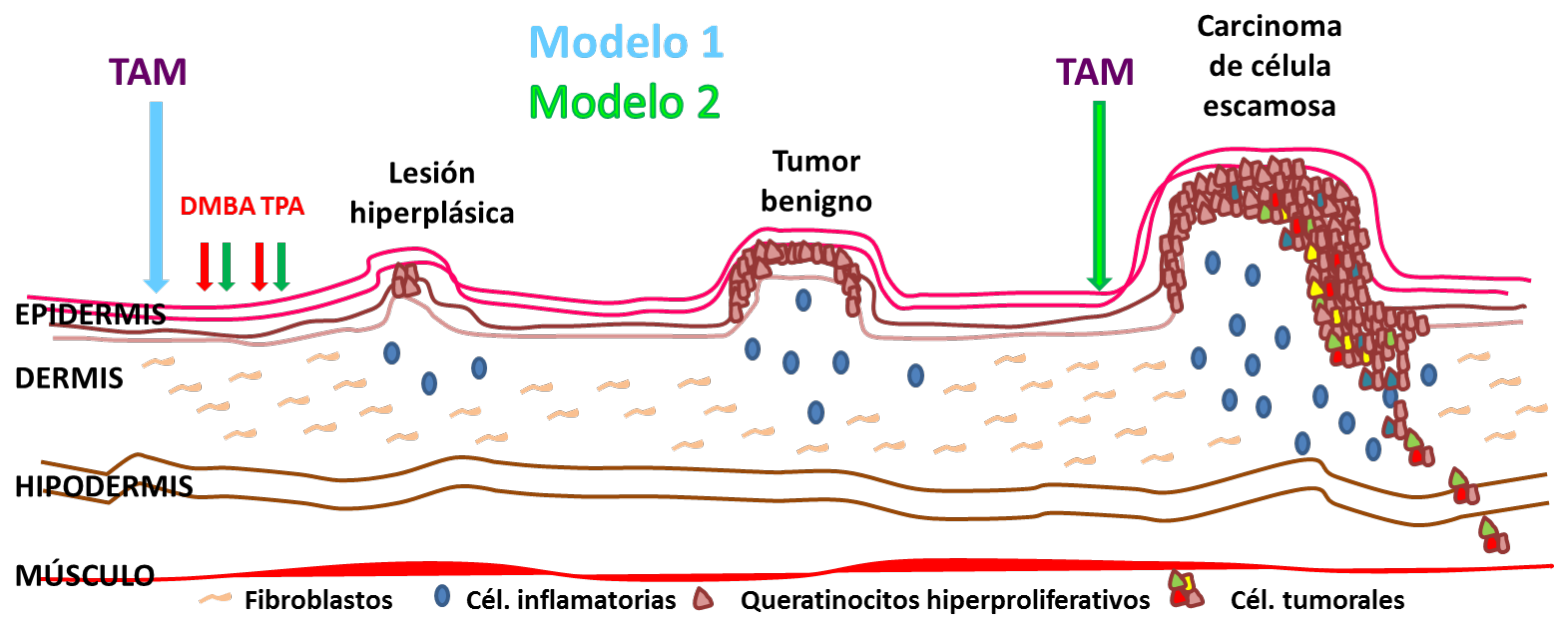

Figura 19. Modelos de carcinogénesis epitelial. En el Modelo 1 la eliminación de la proteína Sos1 es anterior a la generación de los tumores aplicando el protocolo DMBA-TPA. En el Modelo 2 la eliminación de Sos1 es posterior a la generación de los tumores. 


\section{Técnicas de análisis histológico}

\subsection{Inclusión en parafina y seccionamiento}

La piel de la espalda (aislada en estudios en condiciones fisiológicas, ensayos a corto plazo y WH) y los tumores generados mediante el uso de ambos modelos, originales de animales de los 4 genotipos, fueron fijados con PFA $4 \%$ o/ $\mathrm{n}$ en frio. Las muestras fueron deshidratadas en concentraciones crecientes de etanol: 75\%, 90\%, 96\% y etanol absoluto (3x), 1 h de duración en cada condición y a TA. A continuación, se mantuvieron las muestras en xileno (3x) durante $1 \mathrm{~h}$ cada vez a TA. Las muestras se colocaron entonces en soportes metálicos y se incluyeron en un baño de parafina líquida a $60{ }^{\circ} \mathrm{C}$ (3x80 min, Thermo Scientific, 6774060). Finalmente, los bloques se dejaron enfriar hasta su solidificación. Por último, con un microtomo (Leica 2065) se realizaron cortes de $3 \mu \mathrm{m}$ de grosor que se recogieron en portaobjetos.

\subsection{Congelación en OCT y corte en criostato}

Algunas muestras de piel y/o tumores fueron directamente congelados en OCT (del inglés: $\underline{\text { Optimal }}$

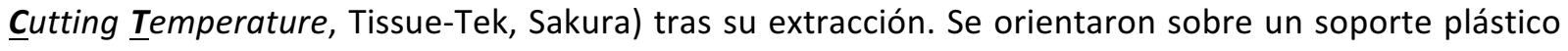
(Tissue Teck, Dako) que se rellenó con OCT situado encima de una superficie plana sobre hielo seco para su rápida congelación y se cubrió por completo con OCT. Se realizaron secciones seriadas de 14 $\mu \mathrm{m}$ de grosor con el criostato (Microm, HM520) que se recogieron en portaobjetos. Las muestras se mantuvieron a $-80^{\circ} \mathrm{C}$ hasta su uso.

\subsection{Tinción de Hematoxilina-Eosina}

Las secciones de tejido en parafina (piel o tumores epiteliales) se sometieron a baños ( $3 \times 5 \mathrm{~min}$ ) con el reactivo Histoclear II (National Diagnostics, HS-202). A continuación, las muestras se hidrataron en concentraciones decrecientes de etanol: $100 \%, 90 \%, 80 \%$ y $50 \%$ (5 min a TA cada lavado). Después se lavó con $\mathrm{H}_{2} \mathrm{O}$ destilada durante 5 min a TA y seguidamente las secciones se tiñeron con hematoxilina Harris durante $10 \mathrm{~min}$ a TA. El exceso de tinción se eliminó con un lavado adicional con agua corriente durante 20 min conseguir el viraje de la hematoxilina. Posteriormente, añadimos la eosina al $0.5 \%$ en solución alcohólica durante 30 segundos, y lavamos con agua destilada. Finalmente, las muestras se 
deshidrataron en alcoholes del $70 \%, 80 \%, 90 \%$ y $100 \%$ de $1-2$ min cada uno. Seguidamente, las muestras se aclararon tres veces con Histoclear II previo al montaje de los cubreobjetos.

En las secciones incluidas en OCT y cortadas mediante criostato realizamos el mismo protocolo saltando el paso de hidratación, y comenzando en el paso de incubación en hematoxilina.

Las imágenes de las muestras anteriores fueron tomadas utilizando el microscopio de contraste de fases (Olympus BX51) que tenía acoplada una cámara (Olympus DP70).

\section{Estudios de inmunohistoquímica}

\subsection{Análisis de la proliferación celular}

Para la realización de la inmunotinción para la BrdU en secciones incluidas en parafina seguimos el siguiente protocolo. Primero, las muestras sumergieron en Xilol ( $2 \times 3 \mathrm{~min})$ y posteriormente en concentraciones decrecientes de alcohol, 100\%, 100\%, 90\%, 80\%, 70\%, y 50\% durante 3 min cada una, a TA. Finalmente las muestras se lavaron con $\mathrm{H}_{2} \mathrm{O}$ destilada. Posteriormente, las muestras fueron tratadas con una solución de $\mathrm{HCl} 2 \mathrm{~N}$ durante $45 \mathrm{~min}$ a $37{ }^{\circ} \mathrm{C}$. Después se sumergieron los

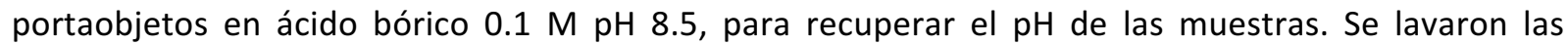
muestras con PBS (3x5 min), y finalmente una cuarta vez con $0.1 \%$ PBST durante 10 min. Posteriormente, se añadió una solución de bloqueo que contenía BSA al $5 \%$ y suero de cabra al $2 \%$ en PBS, durante 45 min a TA. Se incubaron entonces las muestras con anticuerpo primario anti-BrdU (tabla 10) o/n a $4{ }^{\circ} \mathrm{C}$ en cámara húmeda. Al día siguiente se lavaron las muestras PBS ( $3 \times 5$ min) y una cuarta vez con $0.1 \%$ PBST durante $10 \mathrm{~min}$. Incubamos los cortes con el anticuerpo secundario correspondiente (tabla 11) durante $1 \mathrm{~h}$ a TA en oscuridad. Las muestras se lavaron con PBS (3x5 min) y se utilizó medio de montaje que contenía DAPI (ProLong ${ }^{\circledR}$, Life Technologies, P36971) para montar los cubreobjetos.

\subsection{Inmunofluorescencia en secciones de parafina}

La detección mediante inmunofluorescencia de distintos marcadores en secciones en parafina se realizó como describimos a continuación. Las secciones se desparafinaron lavando en Xilol (2x5 min), seguidos de lavados consecutivos en concentraciones decrecientes de etanol: 100\% ( $2 \times 3 \mathrm{~min}$ ), 90\%, $80 \%, 70 \%$ y $50 \%$, de 3 min cada una, seguido de un último lavado en $\mathrm{H}_{2} \mathrm{O}$. Después se realizó una 
recuperación antigénica con tampón citrato $\left(0.1 \mathrm{M}, \mathrm{pH}\right.$ 6) precalentado a $100{ }^{\circ} \mathrm{C}$ y en el que se incluyeron las muestras después y se volvió a aplicar un pulso de $15 \mathrm{~min}$ en microondas a una potencia de $200 \mathrm{~W}$. Se dejaron atemperar las muestras a TA durante $20 \mathrm{~min}$, y posteriormente se lavaron con PBS ( $3 \times 5 \mathrm{~min}$ ) y una cuarta vez con $0.1 \%$ PBST durante $10 \mathrm{~min}$. Las secciones fueron bloqueadas con una solución de BSA (5\%) y suero de cabra (2\%) durante $1 \mathrm{~h}$ a TA. De nuevo se realizaron los lavados con PBS ( $3 \times 5 \mathrm{~min}$ ) y $0.1 \%$ PBST durante $10 \mathrm{~min}$. Las muestras se incubaron con los anticuerpos primarios correspondientes (Tabla 10) con solución de bloqueo o/n a $4{ }^{\circ} \mathrm{C}$ en cámara húmeda y en oscuridad. Al día siguiente se lavaron las secciones con PBS ( $3 \times 5 \mathrm{~min}$ ) y PBST $0.1 \%$ una vez durante $10 \mathrm{~min}$ y se incubaron con los anticuerpos secundario correspondientes (Tabla 11) durante $1 \mathrm{~h}$ a TA y en oscuridad. Se realizaron los lavados con PBS ( $3 \times 5 \mathrm{~min}$ ) y se montaron los cubreobjetos con medio de montaje con DAPI.

En ciertos casos utilizamos el marcaje para la faloidina (1:40, Invitrogen, A22283) en combinación con ciertos inmunomarcajes en la piel y en los tumores incluidos tanto en parafina como en OCT. Éste marcaje se realizó posterior a la incubación del anticuerpo primario, junto con el anticuerpo secundario correspondiente, durante $1 \mathrm{~h}$ TA y en oscuridad.

Tabla 10: Lista de anticuerpos primarios utilizados en piel y tumores.

\begin{tabular}{|c|c|c|c|}
\hline Anticuerpo primario & Referencia & Origen & Dilución \\
\hline$\alpha$-BrdU & Accurate Chemical (OBT0030CX) & Rat & $1: 5000$ \\
\hline$\alpha$-Keratina 14 & Covance (PRB-155P) & Rabbit & $1: 5000$ \\
\hline$\alpha$-Caspasa3 activa & Cell Signaling (9661) & Rabbit & $1: 500$ \\
\hline$\alpha$-Elastasa de neutrófilos & Abcam (ab68672) & Rabbit & $1: 400$ \\
\hline$\alpha$-CD31 & BD (557355) & Mouse & $1: 2500$ \\
\hline
\end{tabular}


Tabla 11: Lista de anticuerpos secundarios utilizados.

\begin{tabular}{|c|c|c|}
\hline Anticuerpo secundario & Referencia & Dilución \\
\hline Goat $\alpha$-rat Cy2 & Jackson Inmunoresearch (112-225-167) & $1: 2000$ \\
\hline Goat $\alpha$-mouse Alexa 488 & Jackson Inmunoresearch (115-545-146) & $1: 500$ \\
\hline Goat $\alpha$-rabbit Cy2 & Jackson Inmunoresearch (111-095-003) & $1: 500$ \\
\hline Goat $\alpha$-rabbit Alexa 488 & Jackson Inmunoresearch (111-545-144) & $1: 500$ \\
\hline Goat $\alpha$-rabbit Cy3 & Jackson Inmunoresearch (111-165-003) & $1: 500$ \\
\hline Goat $\alpha$-mouse Cy3 & Jackson Inmunoresearch (115-165-146) & $1: 500$ \\
\hline
\end{tabular}

\subsection{Inmunofluorescencia en secciones congeladas en OCT}

La detección de algunas proteínas mediante inmunoflurorescencia no fue posible en tejidos incluidos en parafina, por lo que empleamos muestras a partir de tejido congelado incluido en OCT. Los cortes congelados en OCT se mantuvieron a TA durante $30 \mathrm{~min}$ y posteriormente se sumergieron en PBS durante 5 min. A continuación, se bloquearon con la misma solución de bloqueo anteriormente descrita durante al menos $30 \mathrm{~min}$. Lavamos las muestras con PBS ( $3 \times 5 \mathrm{~min}$ ) y $0.1 \%$ PBST durante 10 min e incubamos con el anticuerpo primario correspondiente (tabla 10) en solución de bloqueo o/n a $4{ }^{\circ} \mathrm{C}$ en cámara húmeda y oscuridad. Al día siguiente se lavaron las secciones con PBS ( $3 \times 5$ min) y $0.1 \%$ PBST durante $10 \mathrm{~min}$, y se incubaron con el anticuerpo secundario correspondiente (tabla 11) durante $1 \mathrm{~h}$ a TA. Se realizaron los lavados con PBS ( $3 \times 5 \mathrm{~min}$ ) como anteriormente describimos y se montaron los cubreobjetos con medio de montaje con DAPI.

\section{ESTUDIOS EX VIVO}

\section{Ensayo ex vivo de anillo aórtico}

Los ensayos ex vivo nos permiten estudiar procesos biológicos en tejidos extraídos de un organismo, en un ambiente artificial, pero que mantiene en gran medida las condiciones fisiológicas in vivo. En este caso, estudiamos el proceso de angiogénesis mediante el ensayo del anillo aórtico. Nos propusimos analizar el efecto de la eliminación de las proteínas Sos (de forma individuos o combinada) en el proceso de formación de nuevos pseudocapilares sanguíneos a partir de un vaso de mayor calibre (aorta torácica). Para ello, empleamos una red tridimensional generada por Matrigel 
(BD, 356237) que permite la formación de estructuras vasculares a partir de las células endoteliales de la aorta.

Utilizamos ratones de los 4 genotipos de 8 semanas de edad que fueron alimentados 10 días con dieta libre de estrógenos (Harlan, \#2916) y a continuación con dieta que contenía TAM (Harlan, CRD TAM400/CreER) durante 12 días. Tras el tratamiento, los ratones fueron sacrificados y la aorta torácica fue extraída. La aorta se introdujo en solución Hanks-PB (Gibco, 14170-088) suplementada con antibióticos (50 U/ml de penicilina, $50 \mu \mathrm{g} / \mathrm{ml}$ de estreptomicina y $25 \mu \mathrm{g} / \mathrm{ml}$ de anfotericina B), se limpió y se cortó en secciones coronales de aproximadamente $1 \mathrm{~mm}$ de grosor. Posteriormente, se colocaron $20 \mu \mathrm{l}$ de Matrigel en cubreobjetos cuadrados estériles de $2 \times 2 \mathrm{~mm}$ (en placas de $3.5 \mathrm{~cm}$ ), y con ayuda de unas pinzas se introdujo cada anillo en cada gota de Matrigel. Los explantes se incubaron en condiciones de cultivo, a $37^{\circ} \mathrm{C}$ y $5 \% \mathrm{CO}_{2}$ durante $30 \mathrm{~min}$, para la correcta gelificación del Matrigel. Posteriormente, se añadió a cada placa $1 \mathrm{ml}$ de medio de cultivo que contenía: DMEM F-12 (Gibco) suplementado con $20 \%$ de FBS, $50 \mathrm{mg}$ de heparina (Hospira), $15 \mathrm{mg}$ de ECGS (del inglés: Endothelial Cell Growth Supplement, Sigma, E2759), $0.3 \mu \mathrm{M}$ 4OHT, $1 \mathrm{mM}$ de glutamina, $50 \mathrm{U} / \mathrm{ml}$ de penicilina, $50 \mu \mathrm{g} / \mathrm{ml}$ de estreptomicina y $25 \mu \mathrm{g} / \mathrm{ml}$ de anfotericina B. Los explantes se mantuvieron en condiciones de cultivo a $37{ }^{\circ} \mathrm{C}$ y $5 \% \mathrm{CO}_{2}$ durante 8 días. El análisis de la aparición y el seguimiento del crecimiento de los pseudocapilares se realizaron utilizando un microscopio de fases invertido (Zeiss Axiovert 135), acoplado a una cámara digital (Hamamatsu C4792-80). Se cuantificó el área ocupada por los pseudocapilares relativizada al área de cada anillo de aorta, el número total de pseudocapilares y la longitud de los mismos. El programa informático que utilizamos fue el ImageJ (v 1.6.0).

\section{Análisis estadístico (SPSS)}

Como nuestros estudios se llevaron a cabo en los grupos experimentales WT, Sos1 KO, Sos2 KO y Sos1/2 KO y siguieron una distribución homogénea normal, se aplicó el análisis estadístico ANOVA de una vía seguido de los tests de Tukey y Bonferroni, que informa de las diferencias significativas encontradas en el análisis de ANOVA. Además, también se realizó en análisis t de Student, en el que los datos se analizaron por pares. Para el análisis estadístico utilizamos el programa IBM SPSS Statistics 23. Los resultados se consideraron como significativos cuando el $p$ valor es igual o menor que 0.05 . 


\section{Resultados}





\title{
1. Papel de las proteínas Sos en la regulación de la morfología celular, la proliferación, la migración y la adhesión celular.
}

\author{
1.1. Relevancia funcional de la proteína Sos1 en la morfología celular de los \\ fibroblastos
}

Como hemos descrito en el apartado "Material y métodos", el sistema de eliminación de la proteína Sos1, in vitro, ocurre mediante la adición de $4 \mathrm{OHT}$ al medio de cultivo. En primer lugar analizamos mediante WB la eficacia del $40 \mathrm{HT}$ en la correcta eliminación de la proteína Sos1. Debemos señalar que en todos los estudios in vitro que mostraremos en esta sección, los MEFs de los 4 genotipos objeto de estudio (WT, Sos1 KO, Sos2 KO y Sos1/2 DKO) fueron tratados con $4 \mathrm{OHT}$ en las mismas condiciones, para evitar posibles efectos off-target de este compuesto. La mayoría de los resultados concernientes a los estudios in vitro y que detallaremos a continuación han sido ya publicados (Liceras-Boillos et al., 2016).

Nuestros resultados demostraron que la eliminación prácticamente completa de Sos1 (tanto en MEFs Sos1 KO como Sos1/2 DKO) ocurría tras 9 días de tratamiento con 4OHT (Figura 20a). Además, la supresión de la proteína Sos1 no causaba una alteración en los niveles de expresión de Sos2 (Figura 20a). De igual manera, en MEFs Sos2 KO comprobamos que la ausencia de Sos2 no inducía cambios en los niveles de proteína Sos1 (Figura 20a). Basándonos en estos resultados, a no ser que se indique lo contrario, los resultados que mostraremos en los siguientes apartados corresponderán principalmente a MEFs de los 4 genotipos que fueron tratados durante 9 días con 4OHT.

En primer lugar, las observaciones a microscopía de contraste de fases mostraron una fuerte alteración de la citoarquitectura de los MEFs carentes de la proteína Sos1. Tras 9 días de tratamiento con $4 \mathrm{OHT}$, las células WT mostraban una morfología fibroblástica clásica, en forma de huso y de carácter bipolar (Figura 20b). Los MEFs Sos2 KO presentaban una morfología muy similar a la previamente descrita para los WT (Figura 20b). Sin embargo, las células mutantes para Sos1 (Sos1 KO y Sos1/2 DKO) mostraban una marcada alteración de la morfología celular en comparación con los MEFs WT y Sos2 KO. En concreto, estas células presentaban una forma aplanada con pérdida de la polaridad (Figura 20b). La medición del perímetro celular mostraba un aumento significativo del tamaño de los MEFs Sos1 KO y Sos1/2 DKO respecto a las células WT y Sos2 KO (Figura 20c). 
Además, en las células deficientes para Sos1, individualmente o en combinación con Sos2, observamos un conjunto de vesículas citoplasmáticas de naturaleza desconocida (flechas y aumentos en Figura 20b), que no detectamos en MEFs WT y Sos2 KO (Figura 20b). Estudios que describiremos en apartados posteriores se han centrado en la identificación y caracterización de estas estructuras intracelulares.

En conjunto, los resultados obtenidos sugieren una especificidad funcional de la proteína Sos1 en el mantenimiento de la morfología celular en MEFs. Asimismo, estos datos apuntan también que la ausencia de Sos2 (ya sea de forma individual o en combinación con Sos1) no influye en este proceso.

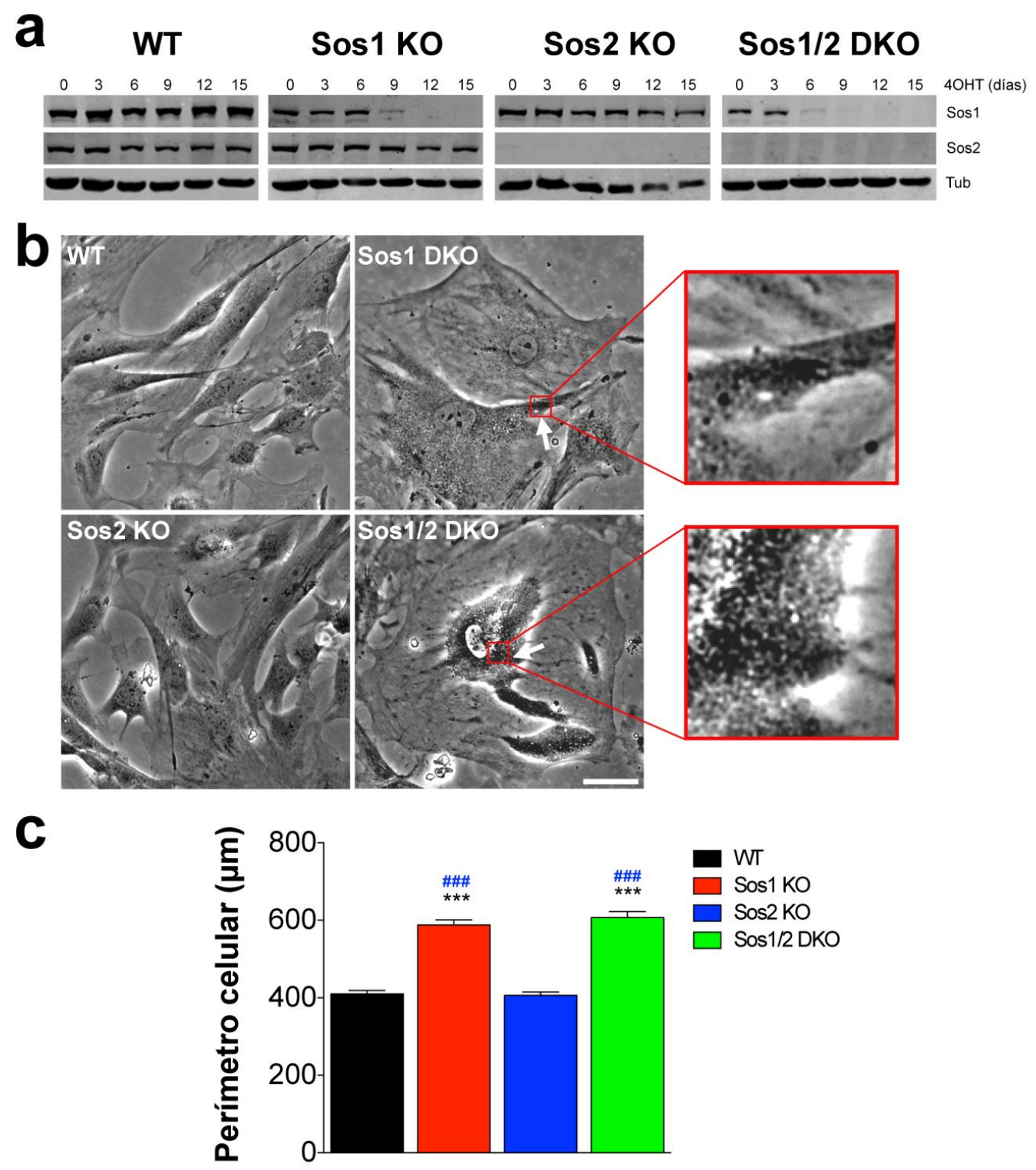


Figura 20. La ausencia de Sos1 provoca cambios morfología de los MEFs. (a) Análisis mediante WB de los niveles de expresión de las proteínas Sos1 y Sos2 tras 3, 6, 9, 12 y 15 días de tratamiento con 4OHT en MEFs de los 4 genotipos de estudio. El tiempo 0 se consideró a las células $\sin 4 \mathrm{OHT}$. Los niveles de expresión de la tubulina se emplearon como control de carga. n=3/genotipo. (b) Imágenes de microscopía de contraste de fases en MEFs de los 4 genotipos. Las flechas y los aumentos señalan cuerpos vesiculares acumulados en las células Sos1 KO y Sos1/2 DKO. Barra de escala: $100 \mu$ m. (c) Cuantificación del perímetro celular de MEFs de los 4 grupos experimentales. $n=300$ células/genotipo. Las barras de error representan el error típico de la media (SEM). Las diferencias significativas se establecieron en: ***/\#\#\# p<0.001 vs WT y Sos2 KO, respectivamente.

\subsection{Redundancia funcional parcial de Sos1 y Sos2 en el control de la proliferación} $\underline{\text { celular }}$

Una de las funciones conocidas de las proteínas Ras es el control de la proliferación celular (Drosten et al., 2010; Shapiro, 2002). Puesto que las proteínas Sos son las principales activadoras de las proteínas Ras, nos planteamos que la familia Sos pudiera tener un papel clave en este proceso celular.

En primer lugar realizamos una curva de crecimiento en MEFs de los 4 genotipos objeto de estudio. Comenzamos dicho estudio tras 9 días de tratamiento con 4OHT (tiempo necesario para eliminar de forma completa Sos1) y se extendió durante los 7 días siguientes. Nuestros resultados demostraron que los MEFs Sos2 KO presentaban una cinética de crecimiento muy similar a la mostrada por las células WT (Figura 21a). Sin embargo, las células Sos1 KO exhibían una disminución significativa del crecimiento celular con respecto a los MEFs WT y Sos2 KO (Figura 21a). Además, la eliminación combinada de ambas formas de Sos conducía a un bloqueo total del crecimiento celular a lo largo del tiempo, en comparación con el resto de genotipos (Figura 21a).

Las alteraciones en la curva de crecimiento mostradas por los MEFs mutantes para Sos1 podrían tener causas diversas. Por ejemplo, el proceso de senescencia celular causaría una cinética en la curva de crecimiento similar a la observada en los MEFs Sos1/2 DKO, y en menor medida en las células Sos1 KO. Sin embargo, no detectamos, o de forma muy excepcional, células senescentes en ninguno de los genotipos analizados (datos no mostrados). Otra posibilidad era que el balance de proliferación celular/muerte celular estuviese descompensado, habiendo una mayor tasa de muerte celular en los MEFs mutantes para Sos1 respecto al ratio de proliferación. En nuestros estudios de WB e inmunohistoquímica para la caspasa-3 activa (marcador de apoptosis), de citometría de flujo en MEFs marcados para anexina-V/7AAD (marcadores de apoptosis) y en los análisis mediante microscopía electrónica, no detectamos procesos de muerte celular mediados por apoptosis y/o necrosis (datos no mostrados). Por último, nos planteamos que la afectación detectada en el recuento celular de 
MEFs mutantes para Sos1 (Sos1 KO y Sos1/2 DKO) fuera el resultado de un bloqueo en alguna de las fases del ciclo celular. Por lo tanto, nos propusimos estudiar en detalle, mediante citometría de flujo, el porcentaje de células contenidas en cada una de las fases del ciclo para cada uno de los genotipos.

Dicho análisis se realizó a diferentes tiempos de tratamiento con $4 \mathrm{OHT}$, en concreto tras 6,9 y 15 días. En condiciones de crecimiento activo, comprobamos que la eliminación única de Sos2 no provocaba cambios significativos en el porcentaje de células que se encontraban en las distintas fases del ciclo celular con respecto a las células WT, en ninguno de los tiempos analizados (Figura 21b). Tras 6 días de tratamiento con $4 \mathrm{OHT}$ observamos una ligera reducción del porcentaje de MEFs Sos1 KO que se encontraban en la fase S, en comparación con las células WT y Sos2 KO (Figura 21b). Además, tras 9 días de tratamiento con 4OHT, la eliminación de Sos1 (en MEFs Sos1 KO y Sos1/2 DKO) causaba una reducción significativa en el porcentaje de células en fase $S$, acompañado de un incremento del porcentaje de MEFs localizados en la fase G2/M, respecto a las células WT y Sos2 KO (Figura 21b). Finalmente, tras 15 días de tratamiento con $4 \mathrm{OHT}$, la disminución en el porcentaje de células en fase S en los MEFs carentes de Sos1 era incluso más acusada que en los tiempos anteriores (Figura 21b). Es más, en este caso también se observó una reducción en el porcentaje de células en la fase G0/G1 (Figura 21b). La reducción de células contenidas en las fases G0/G1 y fase $\mathrm{S}$ se correlacionaba con un incremento significativo del porcentaje de células en fase G2/M (Figura 21b). Estos resultados sugieren que la eliminación de Sos1 provoca un bloqueo en el ciclo celular de MEFs, en concreto en la fase $\mathrm{G} 2 / \mathrm{M}$.

Para determinar si la acumulación de células en la fase G2/M detectada en los MEFs Sos1 KO y Sos1/2 DKO era debida específicamente a un fallo en mitosis, cuantificamos el número de eventos mitóticos y la duración de este proceso en células de los 4 genotipos (Figura 21c y d). En consonancia con los resultados obtenidos en el análisis del ciclo celular, la ausencia de Sos2 no causaba cambios en el número ni en la duración de los eventos mitóticos, respecto a las células WT (Figura 21c y d). En cambio, la eliminación de Sos1 (individual o en combinación con Sos2) afectaba al proceso de mitosis, reduciéndose el número de eventos mitóticos y aumentado de forma significativa la duración de los mismos (Figura 21c y d).

Otra explicación al aumento de células en la fase G2/M detectado en las células KO para Sos1 sería un fallo en el proceso de citocinesis (que tiene lugar al final de mitosis). Por ello, estudiamos este proceso en MEFs de los 4 genotipos. Aunque en un bajo porcentaje, encontramos células Sos1 KO y 
Sos1/2 DKO (con mayor frecuencia) que presentaban citocinesis incompletas, no observando esta alteración en MEFs de los otros 2 genotipos (Figura 21e). Sin embargo, el reducido porcentaje de células que mostraban fallo en la citocinesis sugiere que esta alteración no es la causa primaria del bloqueo en la proliferación celular detectado para las células carentes de expresión de Sos1.



Figura 21. Efecto de la eliminación de las proteína Sos en la proliferación celular. (a) Curva de crecimiento celular en MEFs de los 4 genotipos de estudio que fueron sembrados tras 8 días de tratamiento con 4OHT. El recuento celular se realizó cada 24 h durante los 7 días posteriores. Se consideró valor 1 al número inicial de células sembradas, y el resto de valores se calcularon en número de veces con respecto a este valor 1. (b) Análisis del ciclo celular tras 6, 9 y 15 días de tratamiento con $4 \mathrm{OHT}$ en MEFs de los 4 genotipos. El tiempo 0 se consideró a las células sin tratamiento. Las gráficas representan el porcentaje de células en cada fase del ciclo celular. (c) Cuantificación del porcentaje de eventos mitóticos en células de los 4 grupos experimentales tratadas 9 días con $4 \mathrm{OHT}$. (d) Cuantificación de la duración del proceso de mitosis en MEFs de los 4 genotipos tratados 9 días con $4 \mathrm{OHT}$. (e) Representación del porcentaje de MEFs con fallo en citocinesis en los 4 grupos de interés tratados 9 días con $4 \mathrm{OHT}$. $\mathrm{n}=6 /$ genotipo en cada uno de los experimentos. Las barras de error representan el SEM. Las diferencias significativas se establecieron en: ${ }^{*} / \& / \# p<0.05, * * / \& \& / \# \# p<0.01$ y ***/\&\&\&/\#\#\# $p<0.001$ vs WT, Sos1 KO y Sos $2 \mathrm{KO}$, respectivamente.

Un fallo en el proceso de mitosis y/o citocinesis podría conducir al aumento anormal del número de núcleos en la célula (Serres et al., 2012). Por ello, cuantificamos el porcentaje de MEFs que presentaban más de un núcleo en las células de los 4 genotipos (Figura 22a y b). El número de células trinucleadas o tetranucleadas era extremadamente bajo, por ello, los porcentajes indicados se 
refieren a células binucleadas. En condiciones normales, un bajo porcentaje ( $\sim \%)$ de los MEFs primarios WT eran binucleados (Figura 22b). El porcentaje de MEFs Sos2 KO que presentaban dos núcleos era similar al de las células WT (Figura 22b). Sin embargo, el porcentaje de MEFs Sos1 KO y Sos1/2 DKO con dos núcleos era significativamente mayor que el de los MEFs WT y Sos2 KO (Figura 22b).

Alteraciones en la mitosis, concretamente en la anafase, también pueden desencadenar la formación de "micronúcleos" (Zhang et al., 2015). Estos micronúcleos se generan cuando un cromosoma o parte de una cromátida no se incorporan al núcleo de la célula "hija". Decidimos estudiar si los defectos encontrados durante la mitosis en las células mutantes para Sos1 conducían a la formación de estas estructuras. Para ello, cuantificamos el porcentaje de MEFs que presentaban micronúcleos en los 4 genotipos de estudio (Figura 22a y c). En cultivos WT y Sos2 KO detectamos un bajo porcentaje de células que mostraban micronúcleos (Figura 22c). En cambio, la eliminación de la proteína Sos1 (individualmente o en combinación con Sos2) provocaba un incremento significativo del porcentaje de MEFs con micronúcleos, con respecto a células WT y Sos2 KO (Figura 22c).

Aunque no se conoce el significado biológico preciso de un aumento anormal del tamaño nuclear, se ha descrito que un aumento del contenido en DNA provocado por defectos en mitosis conduciría a este fenotipo (Webster et al., 2009). Cuantificamos por lo tanto el tamaño del núcleo en células mononucleadas de los 4 grupos experimentales, y observamos que la ausencia de Sos2 no suponía cambios en el tamaño nuclear con respecto a MEFs WT (Figura 22d). Sin embargo, las células deficientes para la proteína Sos1 (Sos1 KO y Sos1/2 DKO) contenían núcleos de mayor tamaño que el de los MEFs WT y Sos2 KO (Figura 22d).

Estos resultados apuntan a un papel relevante de la proteína Sos1 en la proliferación y progresión del ciclo celular. Su ausencia afecta al proceso mitótico y conduce a alteraciones nucleares estrechamente ligadas a un fallo en este proceso celular. Aunque nuestros datos sugieren que Sos1 es la isoforma principalmente involucrada en la proliferación también podemos concluir que Sos2 participa, aunque forma mucho menos activa, en el control de este proceso. 


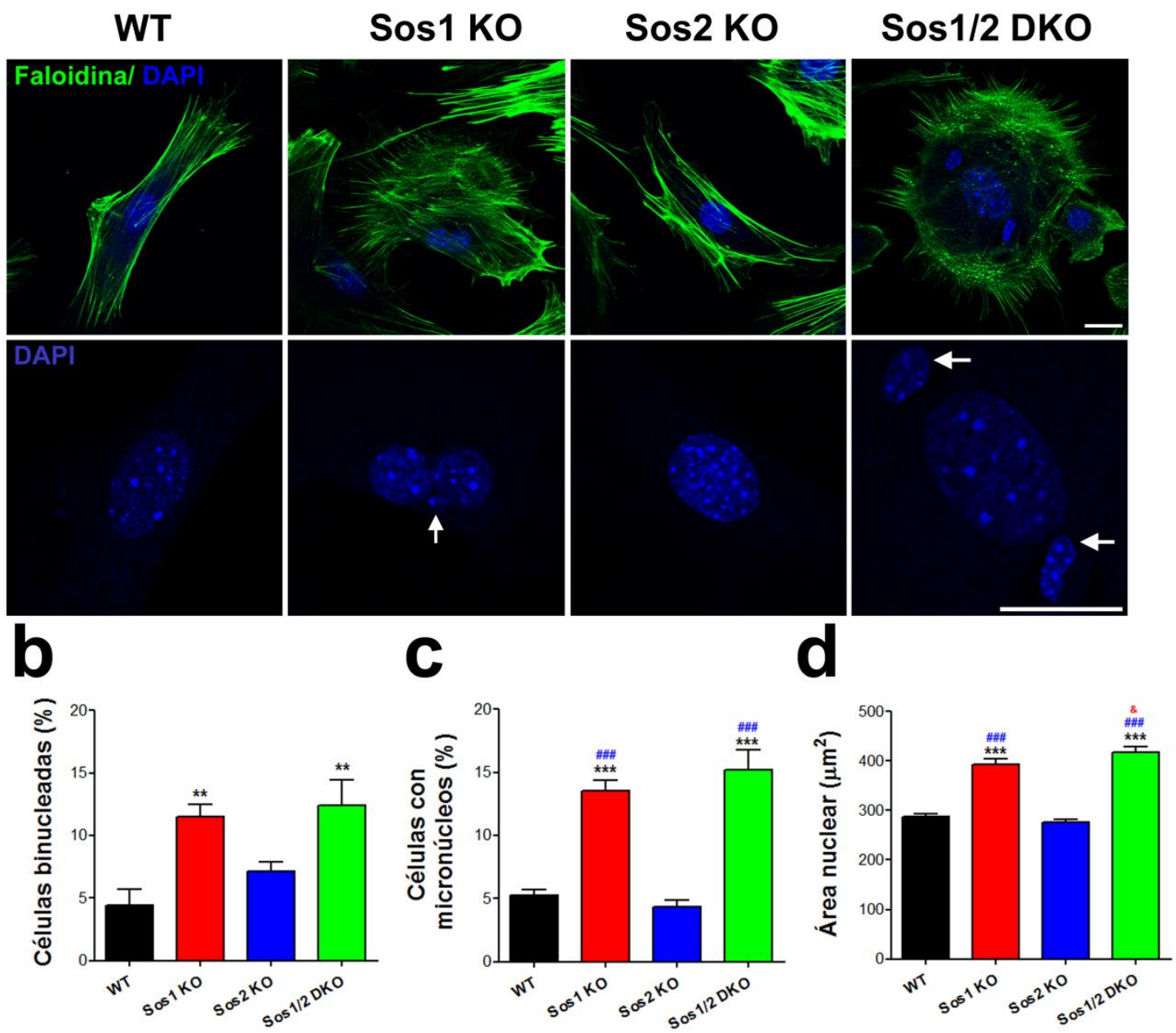

Figura 22. Alteraciones nucleares en MEFs carentes de Sos1. (a) El panel superior muestra imágenes representativas de microscopía confocal de MEFs de los 4 genotipos de estudio teñidos con faloidina (F-actina; verde) y DAPI (núcleo; en azul). En los paneles inferiores, las flechas y el aumento de las imágenes con el marcaje DAPI muestran la aparición de micronúcleos y células multinucleadas en las células Sos1 KO y Sos1/2 DKO. Barras de escala: $25 \mu \mathrm{m}$. (b) Cuantificación del porcentaje de células binucleadas en los 4 grupos experimentales. (c) Cuantificación del porcentaje de células que presentan micronúcleos. (d) Cuantificación del área nuclear en células mononucleadas de los 4 genotipos. (a-d) Los MEFs fueron tratados durante 9 días con $40 H T$. (b-d) $n=300$ células/genotipo en cada una de las cuantificaciones. Las barras de error representan el SEM. Las diferencias significativas se establecieron en: $\& p<0.05$ vs Sos1 KO, ${ }^{* *} p<0.01$ vs WT y ***/\#\#\# $p<$ 0.001 vs WT y Sos $2 \mathrm{KO}$, respectivamente.

\subsection{Represión transcripcional y daño en el DNA en células deficientes para la proteína}

\section{Sos1}

La organización del DNA presenta una compartimentalización funcional del espacio nuclear, donde las regiones transcripcionalmente activas e inactivas del DNA se encuentran físicamente separadas. El DNA transcripcionalmente inactivo suele estructurarse en una conformación plegada en las regiones 
de heterocromatina, mientras que los genes inducibles y aquellos transcripcionalmente activos se localizan en las regiones de eucromatina (Carvalho et al., 2001).

La proporción entre heterocromatina y eucromatina en la célula se asocia con diferentes modificaciones de las histonas. La eucromatina se encuentra frecuentemente enriquecida en histonas H3 y H4 hiperacetiladas (Gorisch, 2005), mientras que la heterocromatina presenta hipoacetilación o trimetilación de la histona H3 (Barski et al., 2007). Además, la trimetilación de la histona H3 en la lisina 9 (H3K9me3) favorece su interacción con proteínas estructurales de heterocromatina, como la proteína de heterocromatina $1 \curlyvee$ (HP1Y), que desempeña importantes funciones incluyendo la represión génica o el mantenimiento de la heterocromatina (Lomberk et al., 2006).

En este estudio, nos propusimos determinar si la ausencia de las proteínas Sos, de forma individual o combinada, afectaba a la conformación de la cromatina y al estado transcripcional de la célula. Para ello, estudiamos el patrón de expresión de las proteínas H3K9me3 y la HP1Y mediante inmunofluorescencia. El inmunomarcaje para la H3K9me3 en las células WT mostraba que esta proteína se localizaba en focos redondeados, bien definidos y de tamaño homogéneo, distribuidos por el nucleoplasma (Figura 23a). Además, existía una colocalización prácticamente completa con la proteína HP1Ү (Figura 23a). Este patrón de marcaje era equivalente al detectado en los MEFs Sos2 KO (Figura 23a). Sin embargo, aunque la expresión de la H3K9me3 en células deficientes para la proteína Sos1 (Sos1 KO y Sos1/2 DKO) también colocalizaba con el de la histona HP1Y, pero en este caso los focos de heterocromatina presentaban un tamaño heterogéneo y sustancialmente mayor con respecto a células WT y Sos2 KO (Figura 23a).

De la misma manera, estudiamos el estado de la cromatina transcripcionalmente activa o eucromatina. Para ello, estudiamos el nivel de expresión de la histona $\mathrm{H} 4$ acetilada (H4-act). Esta modificación debilita las interacciones entre histonas y el DNA, lo que supondría una conformación más relajada de la cromatina para facilitar el proceso de transcripción (Chahal et al., 1980). El marcaje de H4-act en células WT mostraba una intensa señal ampliamente distribuida por todo el nucleoplasma, a excepción de los nucléolos (Figura 23b). De forma análoga, el intenso marcaje detectado en las células WT era muy similar al observado en células Sos2 KO (Figura 23b). Sin embargo, el patrón de expresión de esta proteína en los MEFs carentes de expresión de Sos1 era sustancialmente distinto. En estos casos la intensidad de la señal detectada era radicalmente menor, siendo casi imperceptible, que la observada en MEFs WT y Sos2 KO (Figura 23b). 
A continuación, investigamos si la represión transcripcional observada en las células mutantes para Sos1 estaba asociada a un daño en el DNA. Para ello, estudiamos el marcaje de la histona $y \mathrm{H} 2 \mathrm{AX}$, que es una variante de la histona H2A que ante un daño en el DNA de doble cadena, es fosforilada en la Ser139, y se localiza flanqueando los focos de lesión (Fernandez-Capetillo et al 2004). Mientras que las células WT y las células Sos2 KO mostraban una ausencia de expresión de $\mathrm{yH} 2 \mathrm{AX}$ (Figura 23c), los MEFs deficientes para la proteína Sos1 (Sos1 KO y Sos1/2 DKO) presentaban microfocos de lesión del DNA distribuidos por el nucleoplasma, aunque de forma preferente estaban asociados a regiones de heterocromatina (Figura 23c).

En conjunto, estos resultados demuestran que la ausencia de Sos1 conduce a la célula a un estado de heterocromatinización y represión transcripcional que está asociado con un daño en el DNA. La ausencia individual de Sos 2 no parece afectar a los MEFs a este nivel, y tampoco hemos observado un efecto aditivo cuando su eliminación es concomitante a la de Sos1.

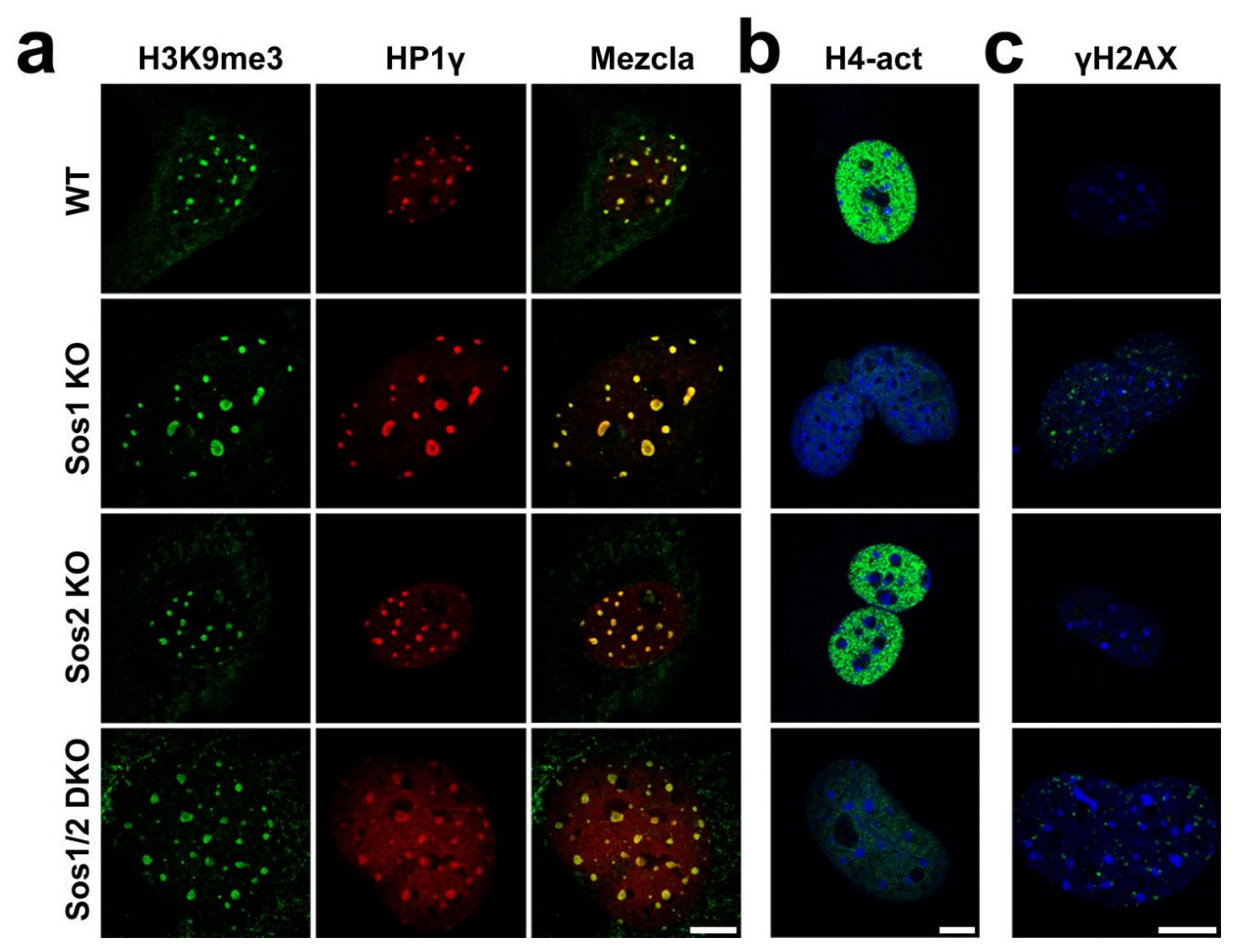

Figura 23. La eliminación de Sos1 induce represión transcripcional y daño en el DNA. (a) Imágenes de microscopía confocal de MEFs de los 4 genotipos marcados para la H3K9me3 (verde) y HP1Y (rojo) en MEFs de los cuatro genotipos. (b) Inmunomarcaje para la H4-act (verde) y DAPI (azul) en células de los 4 grupos de interés. (c) Inmunomarcaje para la $\mathrm{\gamma H} 2 \mathrm{AX}$ 
(verde). Las células fueron contrateñidas con DAPI (azul). Todas las inmunotinciones se realizaron en MEFs de los 4 grupos experimentales, tras 9 días con $4 \mathrm{OHT}$. $\mathrm{n}=3$ /genotipo. Barras de escala: $10 \mu \mathrm{m}$.

\subsection{Estudio de la función de las proteínas Sos en la organización y la dinámica del citoesqueleto}

\subsubsection{Organización del citoesqueleto en células deficientes Sos1 y/o Sos2}

Las proteínas Sos son capaces de modular la organización del citoesqueleto a través de las proteínas Ras (Drosten et al., 2010) y también mediante la activación de la proteína Rac1 (Innocenti et al., 2002). Por ello, y basándonos en las alteraciones morfológicas que habíamos detectado en los MEFs carentes de expresión de Sos1, decidimos estudiar en detalle la organización de dinámica del citoesqueleto en células de todos los grupos experimentales de nuestro estudio.

Estudiamos la organización del citoesqueleto en MEFs de los 4 genotipos tratados 9 días con 4OHT. Para ello, empleamos la tinción de la faloidina y el inmunomarcaje para la paxilina. La faloidina es un colorante vital que se une selectivamente a filamentos de actina (F-actina) permitiendo ver la organización general del citoesqueleto (Dominguez and Holmes, 2011), y la paxilina es una proteína que se expresa en las AF, que son complejos generados tras la interacción de las integrinas con la matriz extracelular (Turner, 2000).

En MEFs WT, el marcaje con faloidina reveló que las fibras de actina se disponían a lo largo del eje de polaridad siguiendo una disposición longitudinal (Figura 24a y c). Las AF marcadas con la proteína paxilina, se localizaban mayoritariamente en los extremos de las fibras de actina, coincidiendo con los polos. Esta región dirige la migración celular donde se forman AF nuevas, y en el polo opuesto o parte posterior de la célula se observaba la retracción de AF (Figura 24b y c). La ausencia de expresión de Sos2 no parecía generar cambios en la distribución de F-actina y/o AF con respecto a las células WT (Figura 24b y c). Sin embargo, los MEFs Sos1 KO mostraban una distribución de estos marcadores alterada respecto a los genotipos anteriores. Aunque las fibras de actina mantenían cierta polaridad, podíamos encontrar estas fibras dispuestas radialmente al eje de polaridad (Figura 24b y c). En cuanto a las AF, las células Sos1 KO presentaban un patrón de distribución sustancialmente distinto a los anteriores, ya que se disponían en múltiples direcciones por gran parte de la membrana plasmática. La desorganización en las fibras de actina y las AF era incluso mayor en los MEFs Sos1/2 DKO (Figura $24 \mathrm{~b}$ y c). Las fibras de actina se disponían en todas las direcciones, perdiendo totalmente 
el eje de polaridad (Figura 24a y c). Además, las AF se localizaban distribuidas de manera homogénea a lo largo de toda la membrana plasmática, además también se disponían por zonas centrales del citoplasma (Figura 24a y b).

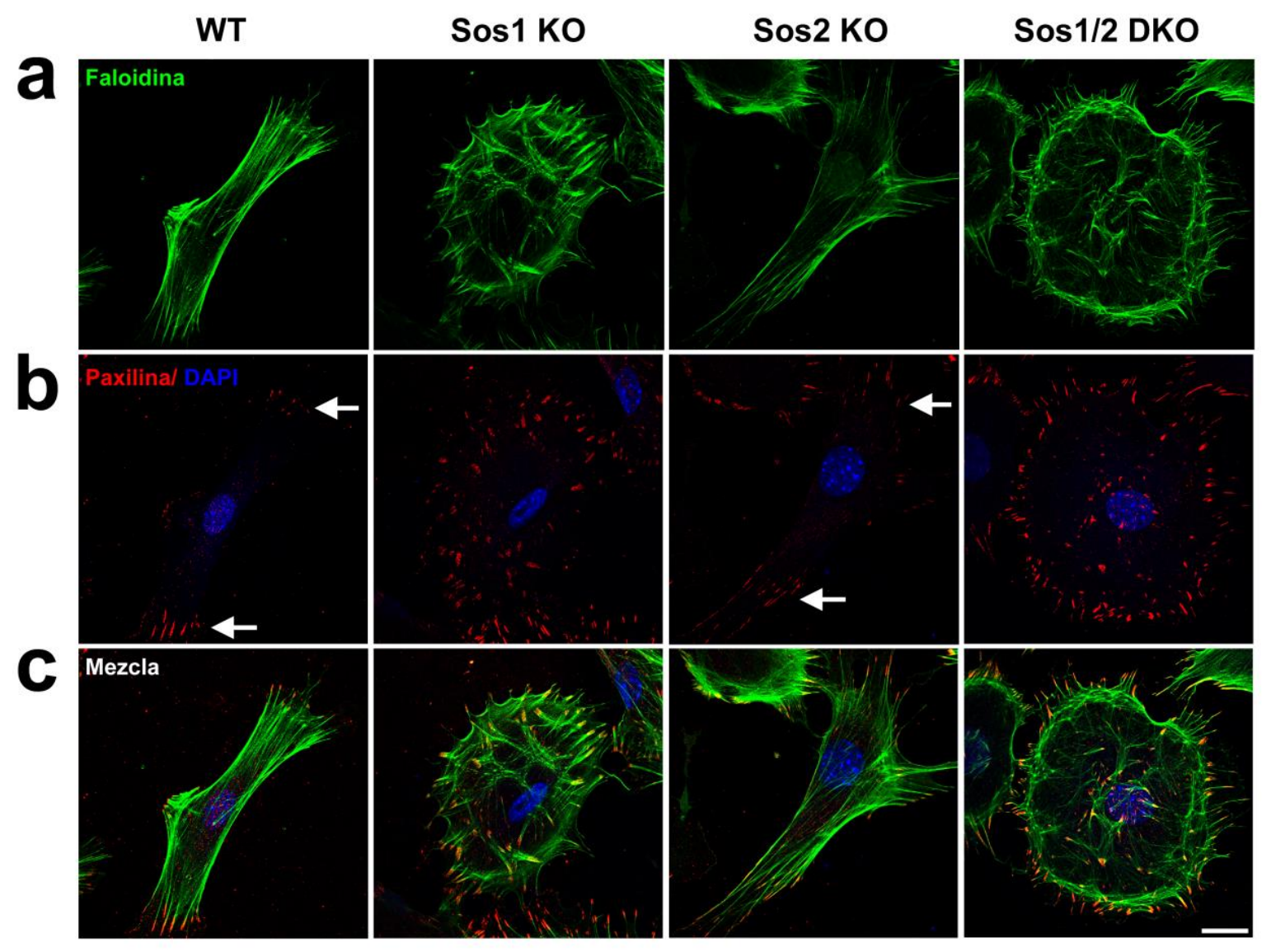

Figura 24. Cambios en el citoesqueleto asociados a la eliminación de Sos1. (a-c) Organización del citoesqueleto de F-actina y la distribución de las AF en células de los 4 genotipos de estudio tras 9 días de tratamiento con 4OHT. (a) Distribución de las fibras de actina marcadas con faloidina. (b) Localización de las AF, señalizado con flechas, con respecto a la posición núcleo tras el marcaje con paxilina (rojo) y contratinción con DAPI (azul). (c) Imágenes generadas con los marcajes faloidina, paxilina y DAPI anteriores. $\mathrm{n}=3$ /genotipo. Barra de escala: $25 \mu \mathrm{m}$.

\subsubsection{Redundancia funcional parcial de Sos1 y Sos2 en la migración celular}

La señalización a través de Ras en MEFs es crucial para la migración celular (Drosten et al., 2010). Además, Rac es también esencial para una migración eficiente (Steffen et al., 2013). Por lo tanto, el papel dual Ras/RacGEF de Sos1 y Sos2 las convierte en un buen candidato de estudio en cuanto a su participación en el proceso de migración celular. Por ello, realizamos el ensayo de WH o "cierre de la herida". 
Analizamos el efecto de la ausencia de las proteínas Sos en la capacidad de migración de los MEFs. Para ello, realizamos el ensayo de WH en cultivos confluentes de MEFs de los 4 genotipos, y estudiamos su habilidad para migrar durante las siguientes $24 \mathrm{~h}$ (Figura 25a y b). Nuestros resultados indicaron que los MEFs WT tardaban alrededor de $6 \mathrm{~h}$ en cubrir la mitad del área libre de células con respecto al tiempo 0, cubriendo el $80 \%$ del área tras $10 \mathrm{~h}$ (Figura 25a). Transcurridas $18 \mathrm{~h}$, el cierre de la "herida" era prácticamente total (Figura 25a y b). La ausencia individual de la proteína Sos2 no afectaba a este proceso ya que las células Sos2 KO presentaban una capacidad de migración prácticamente idéntica a la observada en MEFs WT (Figura 25a y b). Sin embargo, las células Sos1 KO mostraban un retraso de la migración con respecto a MEFs WT y Sos2 KO (Figura 25a y b). Este genotipo empleaba alrededor de 8 h (2 más que células WT y Sos2 KO) para cubrir la mitad del área libre de células con respecto a tiempo 0 (Figura 25b), y necesitaban entre 14 y $16 \mathrm{~h}$ para cubrir el $80 \%$ del área (Figura 25b). Estas células completaban el cierre de la "herida" tras 22-24 h (Figura 25a). Por último, la ausencia combinada de Sos1/2 resultaba en un retraso sustancial en la cinética de migración de los MEFs comparado con el resto de genotipos (Figura 25a y b). Estos MEFs necesitaban unas 14 h para ocupar el 50\% del área libre de células (Figura 25b) y durante todo el ensayo no eran capaces de cubrir más del $70-80 \%$ del área libre de células con respecto al tiempo inicial, quedando un porcentaje importante del área sin cerrar al final del experimento (Figura 25a y b).

En este mismo ensayo, cuantificamos la distancia y la velocidad de migración de los MEFs de los 4 genotipos durante las $12 \mathrm{~h}$ posteriores al WH (Figura 25c yd). La eliminación simple de Sos2 no afectaba a la distancia recorrida ni a la velocidad de migración con respecto a MEFs WT (Figura 25c y d). Sin embargo, las células deficientes para la proteína Sos1 (Sos1 KO y Sos1/2 DKO), mostraban una reducción en la distancia recorrida (significativa en caso de las células Sos1/2 DKO) con respecto a las células WT y Sos2 KO, así como una menor velocidad de migración con respecto a los MEFs que sí expresaban Sos1 (Figura 25c y d).

Para completar este estudio, analizamos la direccionalidad de la migración de cada célula individual en cada genotipo. La representación del recorrido de cada célula reveló que los MEFs WT y Sos2 migraban activamente y de manera dirigida (persistencia y direccionalidad) hacia el frente opuesto de células (Figura 25e). Por otro lado, la eliminación individual de Sos1 resultaba en una pérdida parcial de la direccionalidad y la persistencia migratorias (Figura 25e). Este patrón se vio agravado en los 
MEFs Sos1/2 DKO, que exhibían una pérdida sustancial de la direccionalidad y la persistencia de la migración (Figura 25e).

Estos datos sugieren una redundancia funcional de las proteínas Sos en el control de la migración celular, donde la ausencia individual de cada isoforma puede ser suplida parcialmente por la otra. Sin embargo, debemos señalar que parece existir una función más prioritaria de Sos1 en este proceso. Además, la presencia de al menos una de las proteínas Sos se antoja esencial para la capacidad de migración de los MEFs, ya que la ausencia de ambas proteínas conduce a una fuerte afectación de este proceso celular. 

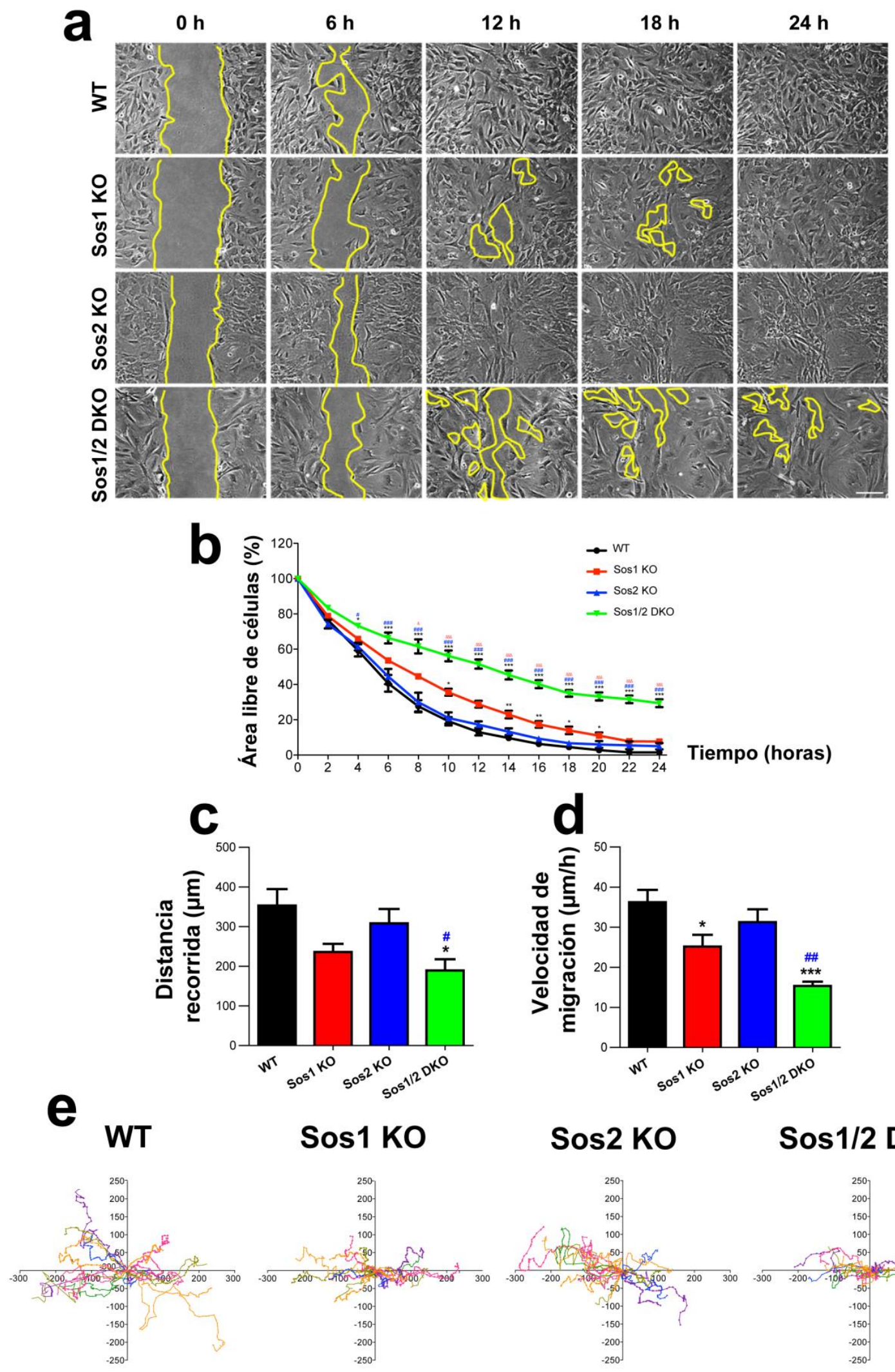

Sos2 KO

Sos1/2 DKO

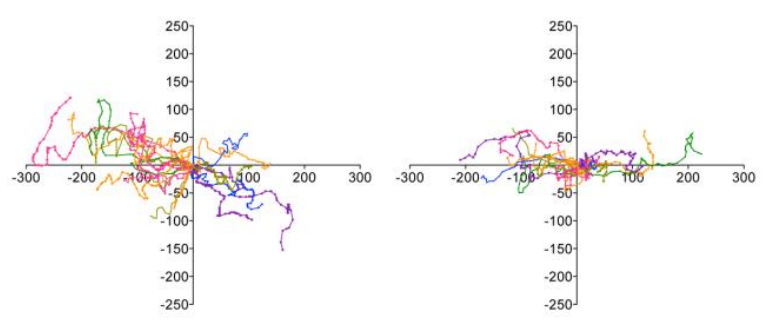


Figura 25. Ensayo de migración celular en MEFs de los 4 genotipos experimentales. (a) Imágenes de contraste de fases representativas del proceso de "cierre de herida" en cultivos de los 4 genotipos de estudio cada $6 \mathrm{~h}$, durante $24 \mathrm{~h}$ tras la "herida". Barra de escala: $400 \mu \mathrm{m}$. (b) Cuantificación del porcentaje del área libre de MEFs durante 24 h, en cultivos de los 4 genotipos de estudio. $n=5 /$ genotipo. (c y d) Distancia recorrida (c) y velocidad de migración media (d) de 20 células (no mitóticas) individuales de cada genotipo durante las primeras $12 \mathrm{~h}$ de ensayo. $\mathrm{n}=4$ /genotipo. (e) Representación de la direccionalidad migratoria de 20 células individuales de cada genotipo en las primeras $12 \mathrm{~h}$ de ensayo. $\mathrm{n}=4$ /genotipo. Las barras de error representan el SEM. Las comparaciones se representaron de la siguiente manera: */\&/\# p<0.05 vs WT, Sos1 KO y Sos2 KO, respectivamente. Además **/\&\& $p<0.01$ vs WT y Sos 2 KO y ***/\&\&\&/\#\#\# $p<0.001$ vs WT, Sos 1 KO y Sos 2 $\mathrm{KO}$, respectivamente.

\subsubsection{Alteración de la adhesión celular tras la eliminación de Sos1 y Sos2}

Tras analizar el papel funcional de las proteínas Sos en distintos procesos biológicos descritos anteriormente, decidimos estudiar si los componentes de esta familia de RasGEFs participaban de alguna manera en la regulación de la adhesión celular. Para ello, realizamos ensayos de adhesión célula-sustrato en placas sin recubrimiento o con recubrimiento de FN en MEFs de los 4 genotipos de estudio.

En primer lugar describiremos el proceso de adhesión célula-sustrato en placas sin recubrimiento. Se sembró el mismo número de MEFs de los 4 genotipos y se cuantificó el porcentaje de células adheridas tras $2 \mathrm{~h}$. Los resultados obtenidos en este caso difieren notablemente de los que hemos descrito en anteriores apartados para las células de cada genotipo, donde normalmente los MEFs WT y Sos2 KO por un lado, y los Sos1 KO y Sos1/2 DKO por el otro, mostraban patrones fenotípicos y de actuación en distintos procesos celulares muy similares. Sorprendentemente, la ausencia individual de Sos1 no afectaba a la capacidad de adhesión de estos MEFs, mostrando valores similares a los WT en cuanto porcentaje de células adheridas (Figura 26a). Por el contrario, los MEFs Sos2 KO presentaban un incremento muy significativo en el porcentaje de células adheridas con respecto al resto de genotipos analizados (Figura 26a). Por último, las células que carecían de la expresión de ambas formas de Sos exhibían una disminución sustancial en su capacidad de adhesión en comparación con el resto de genotipos (WT, Sos1 KO y Sos2 KO; Figura 26a).

Para el ensayo de adhesión celular en FN se sembró un mismo número de células de cada genotipo en placas recubiertas y el porcentaje de células adheridas se cuantificó en este caso a las $4 \mathrm{~h}$ tras el cultivo. Los resultados obtenidos para cada genotipo seguían una tendencia similar a los descritos en los procesos de proliferación y migración. Aunque las células Sos2 KO seguían mostrando una capacidad para adherirse mayor que el resto de genotipos, los valores obtenidos en su caso eran similares a los de los MEFs WT (Figura 26b). El porcentaje de células Sos1 KO adheridas a la FN, sin ser 
estadísticamente significativo, sí mostraba una clara tendencia a ser menor que el de las células WT y Sos2 KO (Figura 26b). Al igual que en el ensayo anterior, la ausencia concomitante de Sos1 y Sos2 reducía significativamente la capacidad de adhesión de los MEFs en comparación con el resto de genotipos (Figura 26b). Debemos señalar que el porcentaje de células WT adheridas en el ensayo con FN era mayor que el cuantificado en el ensayo sin sustrato (Figura 26a). Sin embargo, este patrón no se observaba para el resto de genotipos.

Puesto que para el estudio de adhesión en FN empleamos la video-microscopía, usamos esta misma técnica para analizar en detalle la dinámica de las protrusiones plasmáticas para este caso determinado (Figura 26c). La tasa de adhesión celular se correlaciona directamente con la dinámica de protrusiones, a mayor dinámica mayor adhesión (Parsons JT et al., 2010).

Los resultados anteriores indicaban que las células Sos2 KO tenían una capacidad de adhesión mayor que la del resto de genotipos (Figura $26 a$ y b). El análisis de las imágenes mostraba que las protrusiones lamelipodiales generadas en los MEFs Sos2 KO son, por lo general, mucho más dinámicas y móviles que las de los otros genotipos (WT, Sos1 KO, Sos1/2 KO; Figura 26c). Frecuentemente, las células Sos2 KO no presentan una polaridad definida durante el proceso de adhesión, probablemente debido al elevado número de protrusiones que presentan en múltiples direcciones, a diferencia de las células WT que presentan un número menor de protrusiones que se disponen principalmente en los polos, lo que le confiere a la célula WT una morfología bipolar (Figura 26c). Probablemente, la configuración bipolar que muestran de forma normal los MEFs Sos2 KO (Figura 24) se adquiera una vez que la que el proceso de adhesión ha finalizado. Por otro lado, las protrusiones de membrana en MEFs Sos1 KO aparecen más tarde que en MEFs WT, y se disponen a lo largo de todo el citoplasma y son menos dinámicas, lo que podría ser la causa de una adhesión más lenta y una posterior pérdida de la polaridad (Figura 26c). Los MEFs Sos1/2 DKO no eran, en muchas ocasiones, capaces de adherirse siquiera al sustrato y observábamos la aparición de unas estructuras en forma de burbujas alrededor de la membrana plasmática, que podrían ser indicativas de un proceso de muerte (Figura 26c), aunque también encontramos MEFs Sos1/2 DKO capaces de adherirse al sustrato, pero con dificultad y de forma retrasada en el tiempo, con respecto al resto de genotipos (Figura 26c). Las protrusiones eran apenas distinguibles del resto de la membrana plasmática, muy similares a las que se producían en células Sos1 KO (Figura 26c). Esta baja actividad de las protrusiones podría explicar un proceso de adhesión más lento y en ocasiones inefectivo. 
Estos resultados sugieren un papel importante de las proteínas Sos en el proceso celular de adhesión. La ausencia individual de Sos2 incrementa la capacidad de adhesión en MEFs, probablemente debido a una intensa actividad de las protrusiones de la membrana plasmática durante el proceso de adhesión. Sin embargo, los resultados obtenidos en las células Sos1 KO son más controvertidos. Mientras que la ausencia individual de Sos1 no afecta a la habilidad de las células para adherirse a una superficie sin recubrimiento, sí parece que su eliminación dificulta la capacidad de adhesión de estos MEFs en una superficie recubierta con FN. La ausencia concomitante de Sos1 y Sos2 altera de forma sustancial este proceso celular 

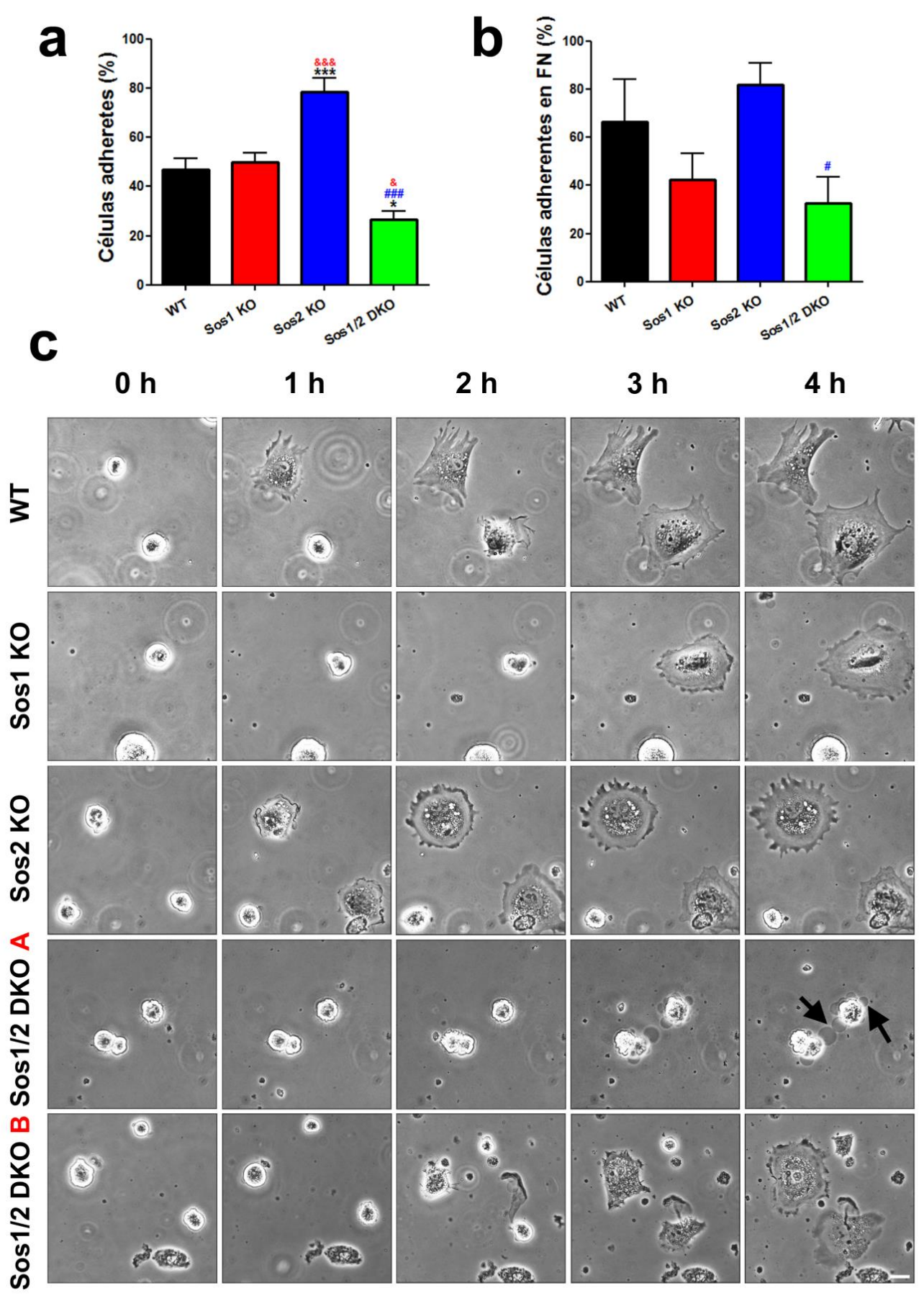

Figura 26. Adhesión celular en MEFs de los 4 genotipos de interés tras 9 días de tratamiento con 4OHT. (a) Porcentaje de células adheridas, en placa sin recubrimiento después de $2 \mathrm{~h}$ desde su siembra. $n=6 /$ genotipo. (b) Porcentaje de MEFs de los 4 genotipos adheridos en FN tras $4 \mathrm{~h}$ desde su cultivo. $\mathrm{n}=3$ para los genotipos WT y Sos1 KO, y $\mathrm{n}=6$ para los genotipos Sos 2 KO y Sos1/2 DKO. (c) Imágenes del proceso de adhesión en los 4 grupos experimentales en placas recubiertas con FN tomadas en intervalos de $1 \mathrm{~h}$ durante $4 \mathrm{~h}$. En el caso de las células Sos1/2 DKO mostramos células con dos comportamientos diferentes en el proceso de adhesión ( $\mathrm{a}$ y b). Barra de escala: $25 \mu \mathrm{m}$. Las barras de error representan el SEM. Las comparaciones se representaron de la siguiente manera: */\&/\# p< 0.05 vs WT, Sos1 KO y Sos2 KO. Además ***/\&\&\&/\#\#\# $\mathrm{p}<0.001$ vs WT, Sos1 KO y Sos2 KO, respectivamente. 


\section{Resultados}

\subsubsection{Importancia de Sos1 y Sos2 en la dinámica de adhesiones focales}

Los cambios detectados en el citoesqueleto, la distribución de las AF y las alteraciones en migración y adhesión tras la eliminación de las proteínas Sos, nos llevaron a estudiar en detalle la dinámica de las AF en estos tipos celulares. Para estudiar en detalle la dinámica de AF empleamos la técnica de IRM.

Los MEFs WT presentaban AF en los extremos de la célula, muy próximas al frente de avance y también en la parte posterior (Figura 27a y b). La dirección de estas AF era por lo general, paralela al eje longitudinal y eran paralelas también unas con otras (Figura 27a y b). Esta distribución en células WT era, comparable a la observada en MEFs Sos2 KO (Figura 27a y b). Por el contrario, las AF observadas por IRM en MEFs Sos1 KO y Sos1/2 DKO mostraban una disposición muy diferente, ya que se encontraban distribuidas por la periferia celular y también por regiones centrales (Figura 27a y b). Además, la disposición entre ellas no era homogénea, puesto que se disponían en paralelo, perpendicular y/u oblicuas unas con otras (Figura 27a y b). El examen visual sugería que los MEFs deficientes de Sos1 presentaban un número mayor de AF con respecto a los MEFs WT y Sos2 KO, por lo que analizamos en detalle la abundancia de estas estructuras en los 4 genotipos. Cuantificamos el número de AF por célula y vimos que los MEFs carentes de Sos1 (Sos1 KO y Sos1/2 DKO) presentaban un número mayor de AF con respecto a WT y Sos2 KO (Figura 27b y f). Curiosamente, los MEFs Sos2 KO mostraban un número menor de AF en comparación con el resto de genotipos (Figura 27b y f).

Ya que las AF determinan la movilidad celular, analizamos la dinámica de éstas en células individuales en los 4 genotipos. Debe de haber una formación y estabilización de las mismas en el eje de migración, y una retracción y desaparición en la parte posterior de la célula (Parsons et al., 2010). Las AF menos estables reflejan una movilidad celular más activa, mientras que las AF estables limitan la capacidad de movimiento de la célula. Con el fin de cuantificar la estabilidad de las AF, creamos una imagen con un código de colores (rojo, verde y azul). Las imágenes de células individuales estaban compuestas por la superposición de todas las imágenes individuales fotografiadas, generando así una imagen donde se distinguen AF de color rojo que se corresponderían con las AF más estables (Figura 27c). Por el contrario, las zonas representadas con los colores verde y azul, reflejaban AF más transitorias (verde: AF de estabilidad intermedia y azul: AF inestables; Figura 27c). La cuantificación de la intensidad para cada color reveló que las AF de las células Sos2 KO son menos estables y por lo 
tanto más transitorias o dinámicas que las AF de las células WT, Sos1 KO y Sos1/2 DKO (Figura 27c y g).

Analizamos también el cell spreading de células individuales de cada genotipo. Para ello, realizamos una proyección con todas las imágenes obtenidas a lo largo del tiempo de cada célula individual, y generamos una imagen final que nos permitió ver la expansión y la migración de la célula en el tiempo estudiado (Figura 27d). Las cuantificaciones demostraron que tanto los MEFs WT y Sos2 KO tenían mayor movilidad y ocupaban un área mayor tras la expansión de los lamelipodios en comparación con los MEFs Sos1 KO y Sos1/2 DKO (Figura 27d y h).

Cuantificamos también el número de lamelipodios por célula en MEFs de los 4 grupos de estudio. Las células carentes de Sos1 (individualmente o en combinación con Sos2) presentaban un menor número de lamelipodios con respecto a las células WT y Sos2 KO (Figura 27i). Curiosamente, las células Sos2 KO generaban un mayor número de lamelipodios en comparación el resto de genotipos (Figura 27i).

Por último, representamos la motilidad celular o posición celular a lo largo del tiempo. Generamos imágenes en las que se representaba en color rojo la posición inicial de cada célula, en verde la posición en la mitad del tiempo estudiado y en azul la posición al final del experimento (Figura 27e), cuando la célula permanece en una misma posición a lo largo del tiempo, los colores se superponen generando un color blanco. Observamos que tanto las células WT como los MEFs Sos2 KO presentaban una migración activa y dirigida a través el eje migratorio, a pesar del menor numero de AF y lamelipodios que mostraban estas últimas (Figura 27e). Las células Sos1 KO presentaban sin embargo una migración mucho menos polar que los MEFs WT y Sos2 KO, pero mantenían una migración mínimamente dirigida, mientras que las células Sos1/2 DKO mostraban una posición celular similar durante todo el experimento, lo que supondría una migración neta menor, ya que las 3 posiciones estudiadas se superponían en mayor parte de la célula, generando un color blanco que representa una posición permanente en el tiempo estudiado (Figura 27e).

En conjunto, estos resultados concluyen que las células Sos2 KO presentan AF poco estables lo que se traduce en un mayor recambio de éstas, que originan un mayor número de lamelipodios con respecto al resto de genotipos. Sin embargo, estos lamelipodios aparecen en múltiples direcciones lo que podría explicar que el cell spreading o que el desplazamiento celular no sea mayor con respecto a 
MEFs WT. En cambio, la ausencia de Sos1, individualmente o en combinación con Sos2, genera un mayor número de AF con una distribución celular diferente. Además, presenta una dinámica de AF menor ya que son más estables, causando de esta manera un menor desplazamiento o migración celular con respecto a MEFs WT y Sos2 KO.

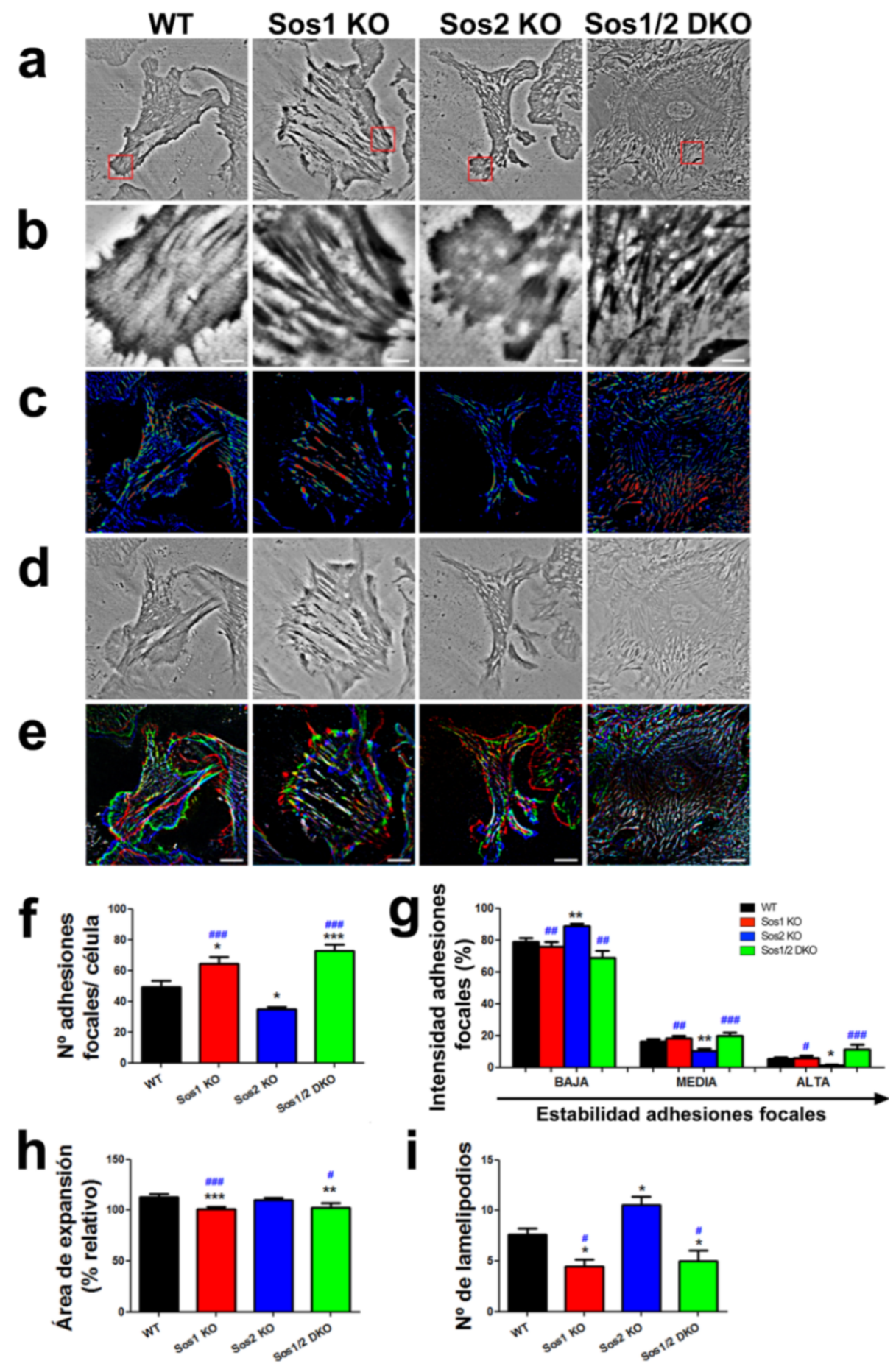


Figura 27. Estudio de la dinámica de adhesiones focales en MEFs de los $\mathbf{4}$ genotipos de estudio. (a) Imágenes de IRM representativas de MEFs individuales de los 4 genotipos. Los recuadros señalan las zonas ampliadas en (b). (b) Aumento de las imágenes del apartado anterior que muestran las AF. Barra de escala: $10 \mu \mathrm{m}$. (c) Imagen de MEFs individuales en tres colores (azul, verde y rojo) que representan la estabilidad de las AF a lo largo del experimento (60 min) en orden de menor a mayor estabilidad, respectivamente. (d) Imágenes representativas del área de expansión celular de MEFs individuales de los 4 grupos de interés. Las imágenes se generaron por superposición de fotografías seriadas de cada célula tomadas en el transcurso del experimento (1 imagen cada 20 segundos durante $60 \mathrm{~min}$ ). (e) Representación del perímetro de células individuales en 3 colores; rojo, verde y azul. Estos colores se corresponden con la posición relativa de estas células en los tiempos 0, 30 y $60 \mathrm{~min}$, respectivamente. Además, las zonas de convergencia de colores (blanco), representan AF estables en el periodo de tiempo estudiado (60 min). Barras de escala: $25 \mu \mathrm{m}$. (f) Número de AF / célula a tiempo 0, en los 4 genotipos de estudio. $n=12 /$ genotipo. (g) Cuantificación de la intensidad de las $A F$, expresado en \%, a partir de imágenes en escala de blancos y grises (apartado d). Dividimos la intensidad en 3 niveles: bajo, medio y alto. La estabilidad de una adhesión focal viene dada por la intensidad representada en una proyección de la posición relativa de una adhesión focal durante los $60 \mathrm{~min}$ del ensayo. Siendo más estables aquellas que presentan mayor intensidad. $\mathrm{n}=9 / \mathrm{genotipo}$. (h) Cuantificación del área de expansión celular de cada uno de los 4 genotipos de interés. El cálculo representa el ratio entre el área total ocupada por cada célula durante el tiempo de estudio (60 min) referido al área que ocupa a tiempo 0. n=10/genotipo. (i) Recuento del número de lamelipodios/célula, en MEFs de los 4 genotipos. $n=12 / g e n o t i p o$. Las barras de error representan el SEM. Las comparaciones se representaron de la siguiente manera: */\# p< 0.05 vs WT y Sos2 KO. Además **/\#\# $\mathrm{p}<0.01 \mathrm{y} * * * / \# \# \# \mathrm{p}<0.001$ vs WT y Sos $2 \mathrm{KO}$, respectivamente.

\subsection{Efecto de la eliminación de Sos1 y Sos2 en las rutas de señalización Ras/MAPK y $\underline{\mathrm{PI} 3 \mathrm{~K} / \mathrm{Akt}}$}

El siguiente paso fue estudiar los niveles de expresión de proteínas que participan en las rutas de señalización mediadas por las proteínas Sos y que son claves en distintos procesos biológicos. En concreto, estudiamos los niveles de activación de las proteínas Ras y Rac. Además, evaluamos los niveles de fosforilación de las proteínas ERK y Akt, tomándolas como proteínas diana de las rutas Ras/MAPK y PI3K/Akt.

\subsubsection{Activación de las rutas Ras/MAPK y PI3K/Akt en células deficientes de las proteínas Sos}

Comenzamos determinando el nivel de activación de Ras (RasGTP) mediante ensayos de pull down. MEFs de los 4 genotipos tratados 9 días con $4 \mathrm{OHT}$ fueron privados de suero durante toda la noche y posteriormente estimulados con PDGF o EGF. Los tiempos de estimulación fueron de 2, 5 y 15 min en el caso del PDGF y de 2, 5 y 10 min para el EGF.

En MEFs WT detectamos que el pico máximo de activación de Ras ocurría a los 2 min tras la estimulación con PDGF, disminuyendo progresivamente en los tiempos posteriores analizados (5 y 15 min; Figura 28a). La cinética de activación de Ras mostrada por las células Sos2 KO era muy similar a la de los MEFs WT (Figura 28a). Sin embargo, la eliminación individual de la proteína Sos1 generaba 


\section{Resultados}

un retraso en la cinética de activación de Ras, detectándose los mayores niveles de RasGTP en tiempos posteriores a los 2 min tras la estimulación (Figura 28a). Finalmente, observamos que la ausencia concomitante de Sos1 y Sos2 resultaba en un bloqueo completo de la activación de Ras (Figura 28a). Es decir, las células Sos1/2 DKO eran incapaces de responder al PDGF.

La cinética de activación de Ras mostrada por las células WT tras estimulación con EGF era muy similar a la observada tras estimulación con PDGF (Figura 28a y b). Aun así, debemos señalar que los niveles de RasGTP cuantificados eran mucho mayores, en todos los tiempos estudiados, en las células tratadas con EGF que en aquellas estimuladas con PDGF (Figura 28a y b). De nuevo, los MEFs deficientes para Sos2 mostraban una cinética de activación comparable a la de los MEFs WT (Figura 28b). En esta ocasión, las células Sos1 KO mostraban una cinética similar a la de las células WT y Sos2 KO, detectándose el máximo nivel de RasGTP tras 2 min de estimulación con EGF (Figura 28b). Sin embargo, a pesar de esta similitud, la ausencia de Sos1 afectaba a la activación de Ras, siendo significativamente menor con respecto a las células WT (Figura 28b). Por último, nuestros resultados mostraron que la eliminación conjunta de Sos1 y Sos2 generaba una incapacidad total de activación de Ras de los MEFs tras estimulación con EGF, al menos en los tiempos analizados (Figura 28b).

De igual manera, estudiamos los niveles de fosforilación de las proteínas diana principales de las rutas Ras/MAPK y PI3K/Akt. Para ello, analizamos la cinética de activación de las proteínas ERK y Akt a corto (2 y $5 \mathrm{~min}$ ), medio $(10,15$ y $30 \mathrm{~min}$ ) y largo plazo (90 y $180 \mathrm{~min}$ ) tras estimulación con los mismos factores de crecimiento anteriormente empleados. Las cuantificaciones se realizaron normalizando el nivel de fosforilación de ambas proteínas con respecto a la cantidad de su proteína total respectiva (ratio proteína fosforilada/proteína total), representándose así los datos en términos relativos, donde el valor de cada tiempo estudiado se ha calculado respecto al tiempo 0.

En MEFs WT estimulados con PDGF, el pico máximo de activación de ERK ocurría a los 5 min, disminuyendo progresivamente en los tiempos posteriores analizados (Figura 28c). Una cinética de fosforilación de ERK muy parecida a la de las células WT fue detectada en los MEFs Sos2 KO (Figura 28c). En cuanto a los MEFs Sos1 KO, éstos presentaban el pico máximo de pERK a los 2 min tras la estimulación, y se reducía progresivamente con el tiempo (Figura 28c). Aunque no existían diferencias significativas, sí que observábamos que la fosforilación de ERK era, por lo general, menor que en los MEFs WT o Sos2 KO. Finalmente, los MEFs Sos1/2 DKO exhibían una cinética de fosforilación de ERK similar al resto de genotipos, cuyo punto máximo de fosforilación ocurría a los 5 min, y a partir de ese 
tiempo, disminuía gradualmente (Figura 28c). Sin embargo, la ausencia combinada de Sos1 y Sos2 en MEFs afectaba a la capacidad fosforilación de ERK, siendo significativamente menor durante todos los tiempos estudiados con respecto a los MEFs WT y Sos2 KO (Figura 28c).

Asimismo, estudiamos el impacto de la eliminación de Sos1 y/o Sos2 en el grado de fosforilación de ERK tras estimulación con EGF en MEFs de los 4 genotipos de estudio. La cinética de fosforilación de ERK era equiparable a la que hemos descrito anteriormente cuando estimulábamos con PDGF (Figura $28 \mathrm{c}$ y d). Las células de los 4 genotipos presentaban niveles máximos de pERK a los 5 min para disminuir progresivamente con el tiempo (Figura 28d). En este caso, se observó que la eliminación individual de Sos 1 o Sos2 tendía a reducir el nivel de fosforilación de ERK a corto (2 y 5 min) y medio plazo (15 $\mathrm{min}$ ) con respecto a las células WT (Figura 28d). Este efecto no era detectado en los tiempos considerados a "largo plazo". La reducción en la fosforilación de ERK a corto y medio plazo (5 y 15 min) era mucho más acusada cuando los MEFs carecían de Sos1 y Sos2 (Figura 28d).

Estudiamos en paralelo el nivel de fosforilación de Akt tras estimulación con PDGF. En este caso, los MEFs WT mostraban el mayor grado de fosforilación de esta proteína 15 min después de la adición del factor de crecimiento, y aunque disminuye en los tiempos posteriores, la activación de esta proteína se mantiene sostenida incluso a largo plazo, a diferencia de lo que ocurría con pERK (Figura 28e). El resto de genotipos analizados (Sos1 KO, Sos2 KO y Sos1/2 DKO) no mostraban un pico de fosforilación claro, sino que el nivel pAkt es muy similar a corto y medio plazo. En los tiempos a largo plazo los niveles de Akt fosforilado disminuyen gradualmente (Figura 28e).

Por último, analizamos la cinética de activación de Akt tras estimulación con EGF. En general, los niveles de pAkt eran menores en las células de los 4 genotipos que los detectados en MEFs de los mismos genotipos estimulados con PDGF (Figura 28e y f). Además, las curvas obtenidas diferían sustancialmente de las descritas en el párrafo anterior. En este caso, las cinéticas de activación en las células WT y Sos2 KO eran prácticamente idénticas, con un pico máximo de fosforilación a los 5 min tras la estimulación, seguido de una fuerte reducción de esta señal en los tiempos posteriores (Figura 28f). Sin embargo, la ausencia de Sos1, ya sea individual o en combinación con Sos2, afectaba sustancialmente a la capacidad de fosforilación de Akt en MEFs tras ser estimulados con EGF (Figura 28f). 
En resumen, nuestros resultados muestran que la ausencia de combinada de Sos1 y Sos 2 conduce a una profunda reducción de los niveles de activación de proteínas clave en el mantenimiento de la homeostasis de la célula.

a
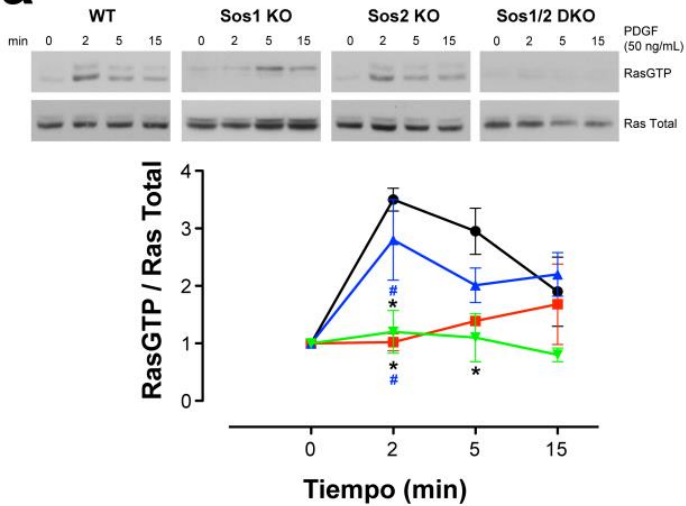

C

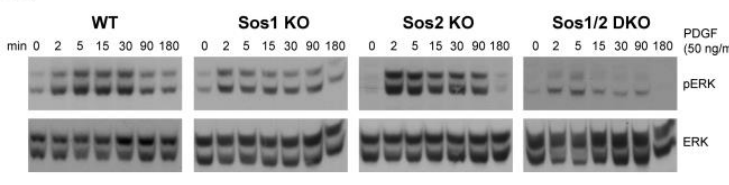

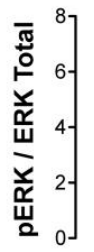

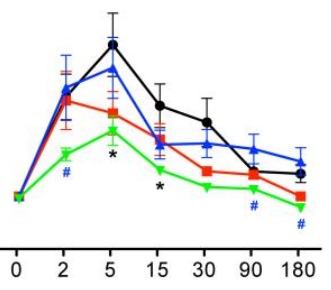

e
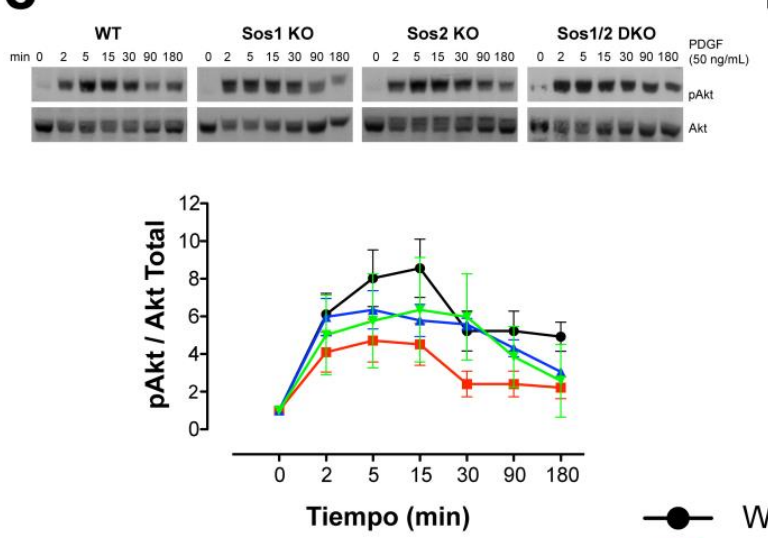

$\rightarrow$ WT

- Sos1KO

$\rightarrow-$ Sos $2 \mathrm{KO}$

$\rightarrow$ Sos $1 / 2$ DKO b
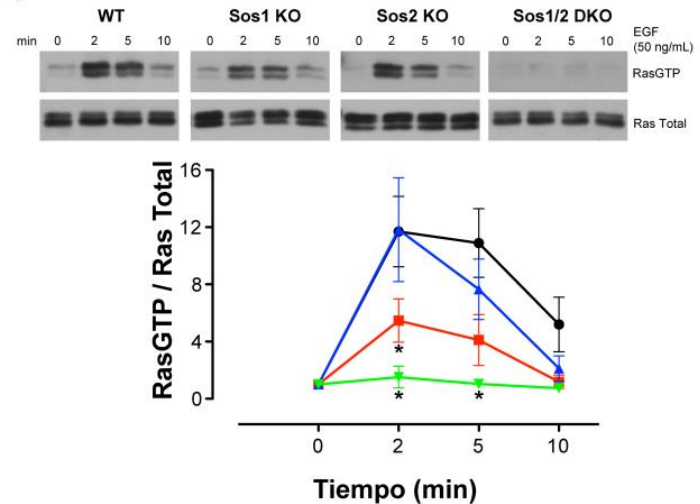

d
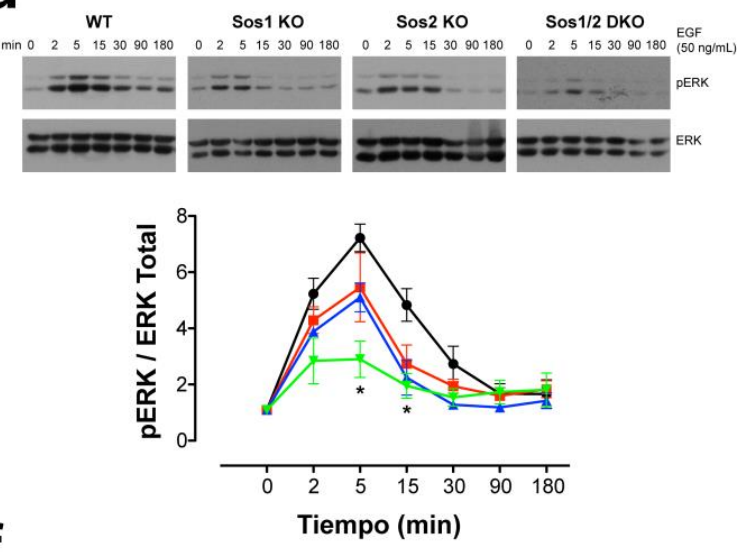

f

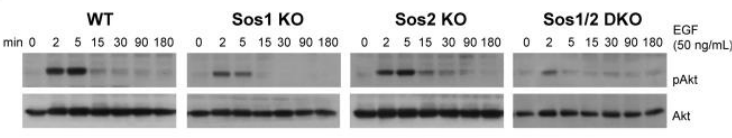

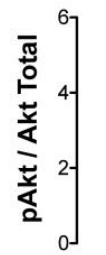

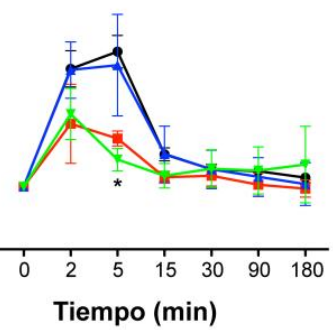


Figura 28. Efecto de la eliminación de Sos1 y/o Sos2 en la activación de Ras y sus principales rutas efectoras. (a y b) Efecto de la eliminación de las proteínas Sos sobre la activación de Ras, tras estimulación con PDGF o EGF, respectivamente. Las imágenes de WB son representativas de cada uno de los genotipos bajo ambas estimulaciones. Las gráficas muestran la cuantificación de los niveles de Ras activo. El nivel de RasGTP fue normalizado respecto al Ras total. Los valores se expresaron tomando como referencia el tiempo 0, al que se le asignó el valor de 1. n=4/genotipo. (c y d) Efecto de la ausencia de las proteínas Sos sobre la fosforilación de ERK tras estimulación con PDGF y EGF respectivamente. Las imágenes de WB son representativas de cada genotipo en las estimulaciones con PDGF y EGF, respectivamente. $n=5 / g e n o t i p o$. (e y f) Las imágenes de WB son representativas de la cinética de fosforilación de Akt en cada uno de los genotipos, tras la estimulación de PDGF y EGF, respectivamente. Las gráficas representan la cinética de fosforilación de Akt tras la eliminación de las proteínas Sos. $n=5 /$ genotipo. Los niveles de fosforilación de ERK y Akt, se calcularon dividiendo los niveles de la proteína fosforilada entre el nivel de proteína total. Los resultados se expresaron en todas las cuantificaciones tomando como referencia el tiempo 0 (Basal), al que se le asignó arbitrariamente el valor 1. Las barras de error de las gráficas corresponden a \pm SEM. Las comparaciones se representaron de la siguiente manera: */\# $p<0.05$ vs WT y Sos2 KO, respectivamente.

\subsubsection{Activación de Rac1 en células deficientes para Sos1 y Sos2}

Realizamos también ensayos de pull down para determinar los niveles de Rac activo (RacGTP). MEFs de los 4 genotipos fueron privados de suero durante toda la noche y posteriormente fueron estimulados con EGF durante 2, 5 y 10 min.

En MEFs WT detectamos valores de RacGTP muy similares en los tiempos 2 y 5 min (Figura 29), que disminuyeron en aproximadamente $1 / 3$ a los 10 min (Figura 29). Los MEFs deficientes para Sos2 mostraban una cinética de activación similar a la de las células WT, con su pico de activación a los 2 minutos y cuya señal disminuye progresivamente (Figura 29). Sin embargo, la cinética de activación en los MEFs Sos1 KO era ligeramente distinta, sostenida en todos los tiempos de estudio tras la estimulación (Figura 29). Finalmente, la deficiencia combinada de Sos1 y Sos2 conducía a una cinética similar a la observada para los MEFs Sos1 KO (Figura 29). Sin embargo, aunque no de forma significativa, los niveles de RacGTP en estas células parecían ser ligeramente menores que los observados en los MEFs WT, Sos1 KO y Sos2 KO (Figura 29). 

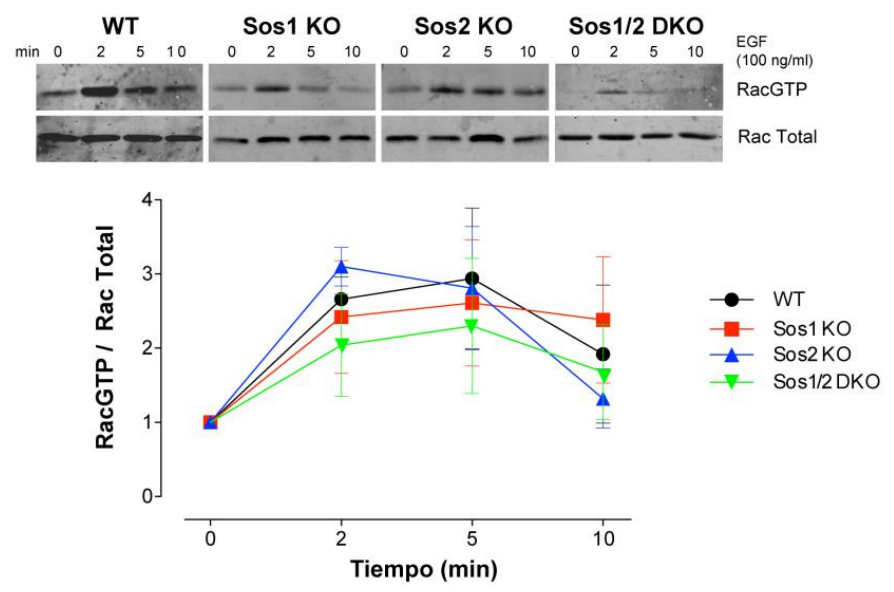

Figura 29. Efecto de la eliminación de Sos1 y/o Sos2 en la activación de Rac1. Imagen de WB representativa de los niveles de RacGTP en células de los 4 grupos experimentales tras 9 días de tratamiento con $40 \mathrm{OH}$ en los tiempos indicados. El nivel de RacGTP se normalizó con respecto al nivel de Rac total en los tiempos estudiados. Los valores se expresaron tomando de referencia el tiempo 0 de cada genotipo, asignándoles el valor de 1. $n=3 /$ genotipo. Las barras de error representan el \pm SEM.

\section{Implicación de Sos1 y Sos2 en autofagia}

\subsection{La eliminación de Sos1 provoca acumulación de lisosomas}

En el apartado 1 describimos la presencia de cuerpos multivesiculares en el citoplasma de los MEFs Sos1 KO y Sos1/2 DKO. Nos propusimos identificar la naturaleza de esos cuerpos y su significado biológico. Para ello, empleamos distintos marcadores que reconocen de forma específica distintos orgánulos celulares.

El marcaje con Lysotracker ${ }^{\circledast}$ es una tinción que se acumula en los lisosomas. La tinción con este marcador se realizó en MEFs de los 4 genotipos sin tratamiento con $40 \mathrm{OHT}$ ( 0 días) y a diferentes tiempos de tratamiento con $4 \mathrm{OHT}$ (3, 6 y 9 días). En los MEFs WT y Sos2 KO, esta tinción reveló un ligero aumento del marcaje punteado en el citoplasma de la célula a lo largo del tratamiento con 4OHT (Figura 30). En cambio, los MEFs Sos1 KO y Sos1/2 DKO presentaban un fuerte incremento del

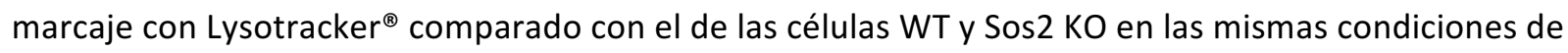
tratamiento (Figura 30), pudiéndose observar incluso agregados citoplasmáticos positivos para esta tinción (Figura 30). 


\section{HT (días)}

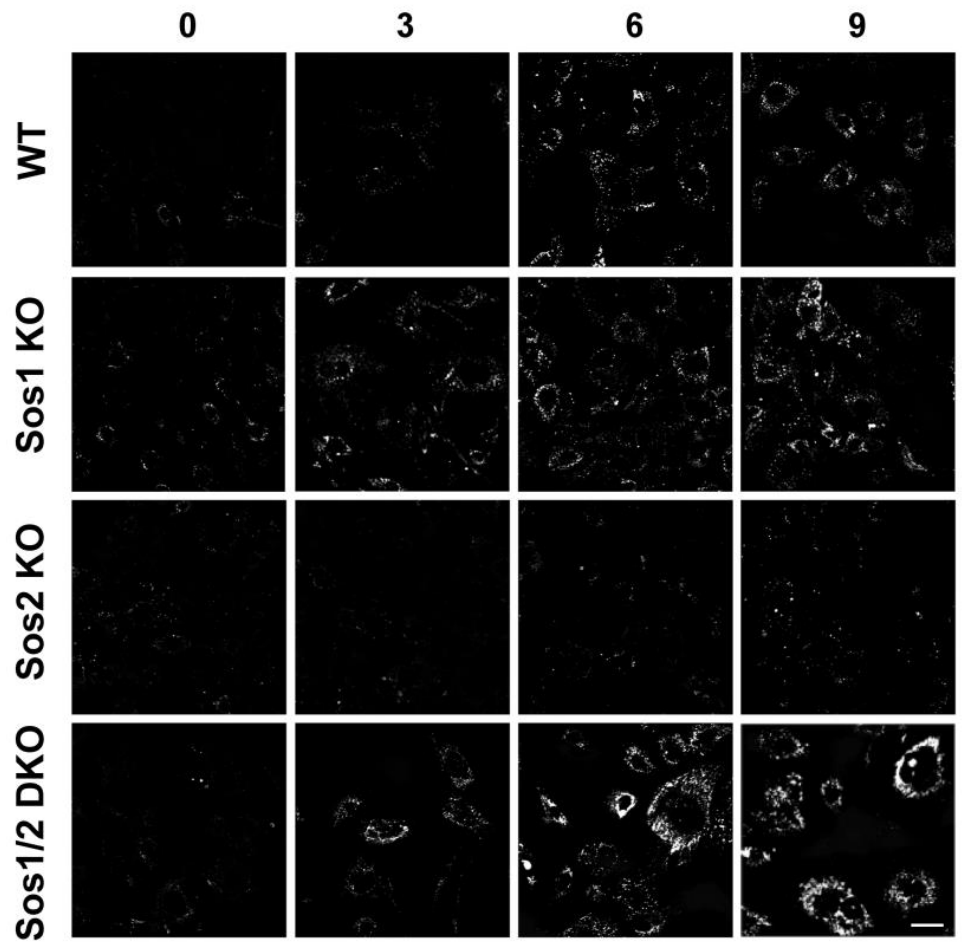

Figura 30. La eliminación de Sos1 induce acumulación de lisosomas. Imágenes de microscopía confocal de MEFs de los 4 genotipos de estudio tratadas con $4 \mathrm{OHT}$ marcados con Lysotracker ${ }^{\circledR}$ durante distintos tiempos: 3,6 y 9 días. El tiempo 0 se corresponde con células sin tratamiento con $40 \mathrm{HT}$. $n=3 /$ genotipo. Barra de escala: $50 \mu \mathrm{m}$.

\subsection{La ausencia de Sos1 activa mecanimos de autofagia}

Durante un proceso de autofagia puede ocurrir una acumulación de lisosomas, similar a la descrita en el apartado anterior. Nos propusimos determinar si existía ese proceso, y en caso de ocurrir, qué orgánulo/s podría/n estar sufriendo dicho proceso en las células carentes de expresión de Sos1. Analizamos mediante doble inmunomarcaje la existencia de coexpresión de LC3B (marcador presente en el autofagosoma) con marcadores específicos para distintos orgánulos celulares (aparato de Golgi, RE liso y mitocondria). Mientras que no encontramos coexpresión de LC3B con los marcadores para Golgi y RE liso (datos no mostrados) sí lo hicimos para un marcador específico de mitocondria.

En concreto, utilizamos MEFs de los 4 genotipos tras 9 días de tratamiento con $40 \mathrm{HT}$ para realizar el doble marcaje para LC3B y Mitotracker ${ }^{\circledR}$ (marcador de mitocondria). Los MEFs WT, al igual que los Sos2 KO, mostraban una tinción para Mitotracker ${ }^{\circledR}$ con numerosas mitocondrias con morfología alargada dispuestas por todo el citoplasma de la célula (Figura 31). Además, no detectamos señal positiva para el anticuerpo LC3B en MEFs de estos genotipos (Figura 31). Sin embargo, los MEFs 
carentes de expresión de Sos1 (Sos1 KO y Sos1/2 DKO) presentaban un patrón de expresión de Mitotracker ${ }^{\circledast}$ alterado, con numerosos acúmulos de esta tinción distribuidos por el citoplasma que además colocalizaban con focos inmunopositivos para LC3B (Figura 31). Este resultado sugería un proceso de autofagia mitocondrial, o mitofagia, ligado a a la eliminación de la proteína Sos1.
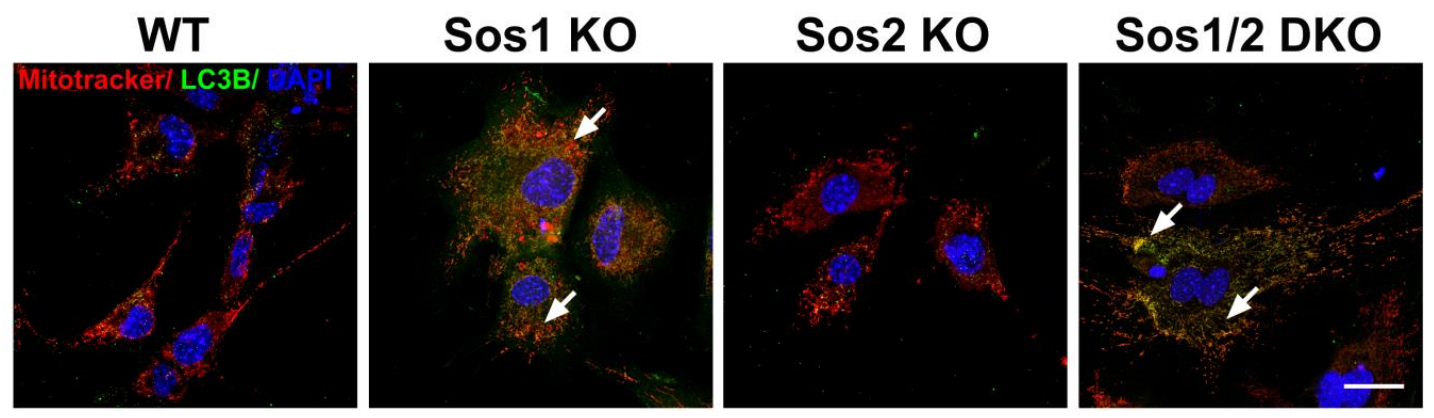

Figura 31. Colocalización de autofagosomas y mitocondrias en ausencia de Sos1. Células de los 4 genotipos tratadas 9 días con $4 \mathrm{OHT}$ y cloroquina, que fueron marcadas con LC3B (verde) y Mitotracker ${ }^{\circledR}$ (rojo) y contrateñidas con DAPI (azul). Colocalización de LC3B (verde) y Mitotracker ${ }^{\circledR}$ (rojo) en células carentes de Sos1 (flechas). Barra de escala: $25 \mu \mathrm{m}$.

\subsection{La ausencia de Sos1 provoca mitofagia}

Los datos anteriores sugerían un proceso de mitofagia en los MEFs mutantes para Sos1. Para confirmar dicho hallazgo, estudiamos la ultraestructura celular mediante microscopía electrónica en MEFs de los 4 genotipos de interés.

Las imágenes de microscopía electrónica de MEFs WT mostraban numerosas mitocondrias con su morfología clásica distribuidas homogéneamente por el citoplasma de la célula (Figura 32). No detectamos en ningún caso mitocondrias u otros orgánulos celulares que se encontraran incluidas en algún tipo de vesícula. Este fenotipo era muy similar al detectado en MEFs Sos2 KO donde podíamos detectar cisternas de retículo endoplásmico rugoso con su morfología alargada y su disposición clásica, así como mitocondrias que no mostraban alteración aparente alguna (Figura 32). En cambio, en el genotipo Sos1 KO, identificamos cisternas de RE rugoso que estaban englobando a una mitocondria (flecha en Figura 32). Además, observábamos estructuras membranosas, compatibles con lisosomas, que englobaban componentes celulares de alta densidad electrónica conocidos como cuerpos mieloides (Figura 32). El análisis de células Sos1/2 DKO mostraba estructuras compatibles con autofagolisosomas que contenían cuerpos de inclusión con diferente densidad electrónica y que en muchos casos pudimos identificar como mitocondrias en degeneración (Figura 32). Estos datos confirman la existencia de mitofagia en células mutantes para Sos1. 

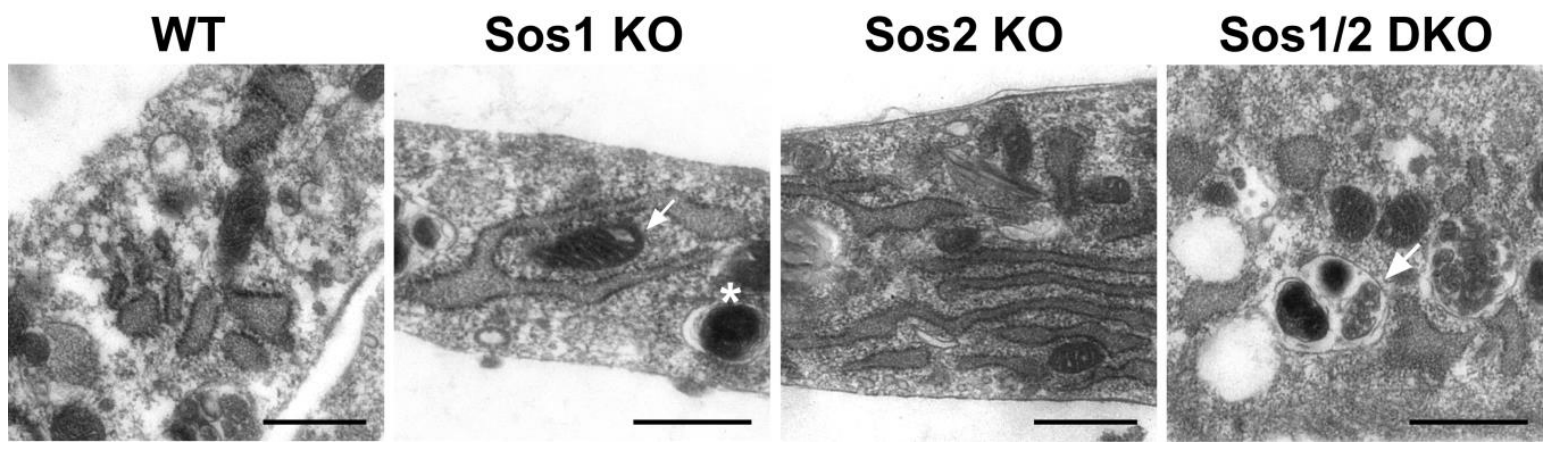

Figura 32. Mitofagia en células mutantes para Sos1. Imágenes de microscopía electrónica de MEFs de los 4 genotipos tras 9 días de tratamiento con $4 \mathrm{OHT}$. Las flechas señalan mitocondrias en diferentes etapas de degradación en MEFs Sos1 KO y Sos1/2 DKO. El asterisco indica la presencia de cuerpos mieloides. Barra de escala: $500 \mathrm{~nm}$ para células WT y Sos2 KO, y 250 nm para Sos1 KO y Sos1/2 DKO, respectivamente.

\section{Importancia de Sos1 y Sos2 en el balance redox de la célula}

\subsection{Acumulación de especies reactivas de oxígeno en células carentes de la proteína} Sos1

El proceso de autofagia en ocasiones es una respuesta de defensa contra un aumento del estrés oxidativo, que puede provocar daño en varios orgánulos, entre ellos la mitocondria (Navarro-Yepes et al., 2014). Además, la mitocondria es la mayor fuente de especies reactivas de oxigeno (ROS, del

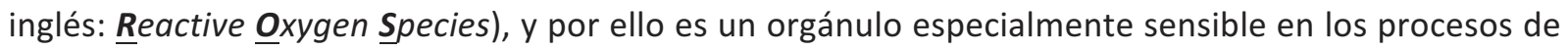
daño oxidativo (Bulteau et al., 2006). Puesto que habíamos detectado un proceso de mitofagia, deseamos analizar si éste alteraba el estado redox (reducción-oxidación) de la célula. Para ello, analizamos diferentes tipos de ROS localizadas en distintos compartimentos celulares.

El compuesto 2-7, dihidrocloro-fluoresceína ( $\mathrm{H}_{2}$ DCFDA) es un indicador general de ROS en la célula. La $\mathrm{H}_{2}$ DCFDA es oxidada por el $\mathrm{H}_{2} \mathrm{O}_{2}$ convirtiéndose en dicloro-fluoresceína (DCFDA) que emite una fluorescencia directamente proporcional a la concentración citoplasmática de $\mathrm{H}_{2} \mathrm{O}_{2}$. Analizamos por citometría de flujo los niveles de DCFDA en MEFs de los 4 genotipos sin tratamiento con $4 \mathrm{OHT}$ y a diferentes tiempos de tratamiento (3, 6 y 9 días). Los resultados indicaban que el nivel de ROS general en MEFs WT y Sos2 KO era muy similar en todos los tiempos estudiados (Figura 33a). Sin embargo, en los MEFs Sos1 KO y Sos1/2 DKO detectamos un aumento significativo de los niveles de ROS citosólicos a partir de los 6 días de tratamiento con $4 \mathrm{OHT}$ (en concordancia con el comienzo de la eliminación de Sos1 mediante el sistema inducible), con respecto a los MEFs WT y Sos2 KO en las mismas 


\section{Resultados}

condiciones (Figura 33a). Este aumento, aunque sin ser estadísticamente significativo, parecía ser incluso mayor en las células Sos1/2 DKO respecto a los MEFs Sos1 KO (Figura 33a).

En segundo lugar utilizamos el dihidroetidio (DHE) para cuantificar los niveles citosólicos del anión superóxido $\left(\mathrm{O}_{2}{ }^{-}\right)$. En presencia de $\mathrm{O}_{2}{ }^{-}$, el DHE se oxida generando productos intermedios como el etidio, que emite una fluorescencia que podemos medir. Los niveles de $\mathrm{O}_{2}{ }^{-}$permanecieron similares en los genotipos WT y Sos2 KO en todos los tiempos de estudio (Figura 33b). Sin embargo, tras 9 días de tratamiento la eliminación de Sos1, individualmente o en combinación con Sos2, generó el aumento de $\mathrm{O}_{2}{ }^{-}$con respecto al resto de tiempos de tratamiento y también con respecto a los genotipos WT y Sos2 KO en esa misma condición (Figura 33b).

Finalmente, analizamos los niveles de anión superóxido mitocondrial $\left(\mathrm{mO}_{2}{ }^{-}\right)$con MitoSOX ${ }^{\mathrm{TM}}$. EI MitoSOX $^{\mathrm{TM}}$ penetra en las mitocondrias de células vivas y se oxida rápidamente por el $\mathrm{mO}_{2}^{-}$ generando un producto altamente fluorescente. El tratamiento con $4 \mathrm{OHT}$ generaba por si mismo un aumento progresivo de los niveles de $\mathrm{mO}_{2}{ }^{-}$a lo largo del tiempo en los 4 grupos de estudio (Figura 33c). No obstante, el tratamiento con $4 \mathrm{OHT}$ durante 6 y 9 días en los MEFs Sos1 KO y Sos1/2 DKO provocaba un incremento significativo de los niveles de $\mathrm{mO}_{2}{ }^{-}$respecto a los MEFs WT y Sos2 $\mathrm{KO}$ a los 6 y 9 días (Figura 33c).

Teniendo en cuenta los resultados anteriores podemos establecer una relación entre el proceso de mitofagia con el aumento del estrés oxidativo citosólico y mitocondrial, todo ello ligado a eliminación de Sos1. Sin embargo, nuestros análisis muestran un posible efecto off-target del $4 \mathrm{OHT}$, provocando un aumento del ROS a medida que el tratamiento con $4 \mathrm{OHT}$ ocurría. Por lo tanto, nos propusimos realizar este mismo estudio en un sistema no dependiente del uso del $40 \mathrm{HT}$.

Para ello, eliminamos Sos1 realizando una infección con adenovirus que expresan la Cre-recombinasa (Adeno-Cre; Ad5-CMV-Cre-eGFP) en MEFs de los 4 genotipos, lo que permitió escindir el gen Sos1 floxeado en MEFs inducibles Sos1 KO y Sos1/2 DKO sin necesidad de adición de 4OHT. Comprobamos mediante WB el nivel de expresión de la proteína Sos1 tras 3, 6 y 9 días post-infección con Adeno-Cre y detectamos una eliminación prácticamente total a partir del día 3 de tratamiento (Figura 34a). Analizamos el nivel del $\mathrm{mO}_{2}{ }^{-}$con MitoSOX ${ }^{\mathrm{TM}}$ en estos MEFs y detectamos de nuevo un aumento significativo del $\mathrm{mO}_{2}{ }^{-}$en MEFs Sos1 KO y Sos1/2 DKO con respecto a MEFs WT y Sos2 KO tras tras 6 y 9 días del tratamiento con Adeno-Cre (Figura 34b). 
Este resultado confirmó que la causa del aumento del estrés oxidativo encontrado en MEFs deficientes para Sos1, se asociaba específicamente a la ausencia de la proteína Sos1, y no a una incapacidad de detoxificación de las ROS acumuladas causada indirectamente por el 4OHT.

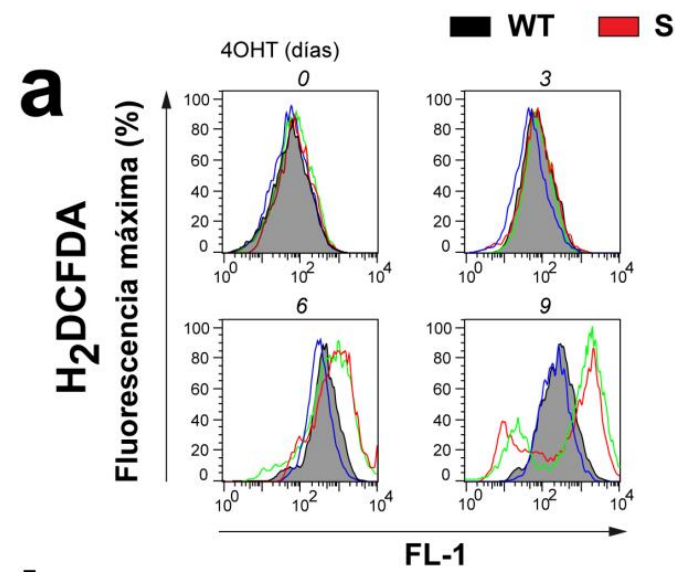

Sos1 KO Sos $2 \mathrm{KO} \square$ Sos1/2 DKO
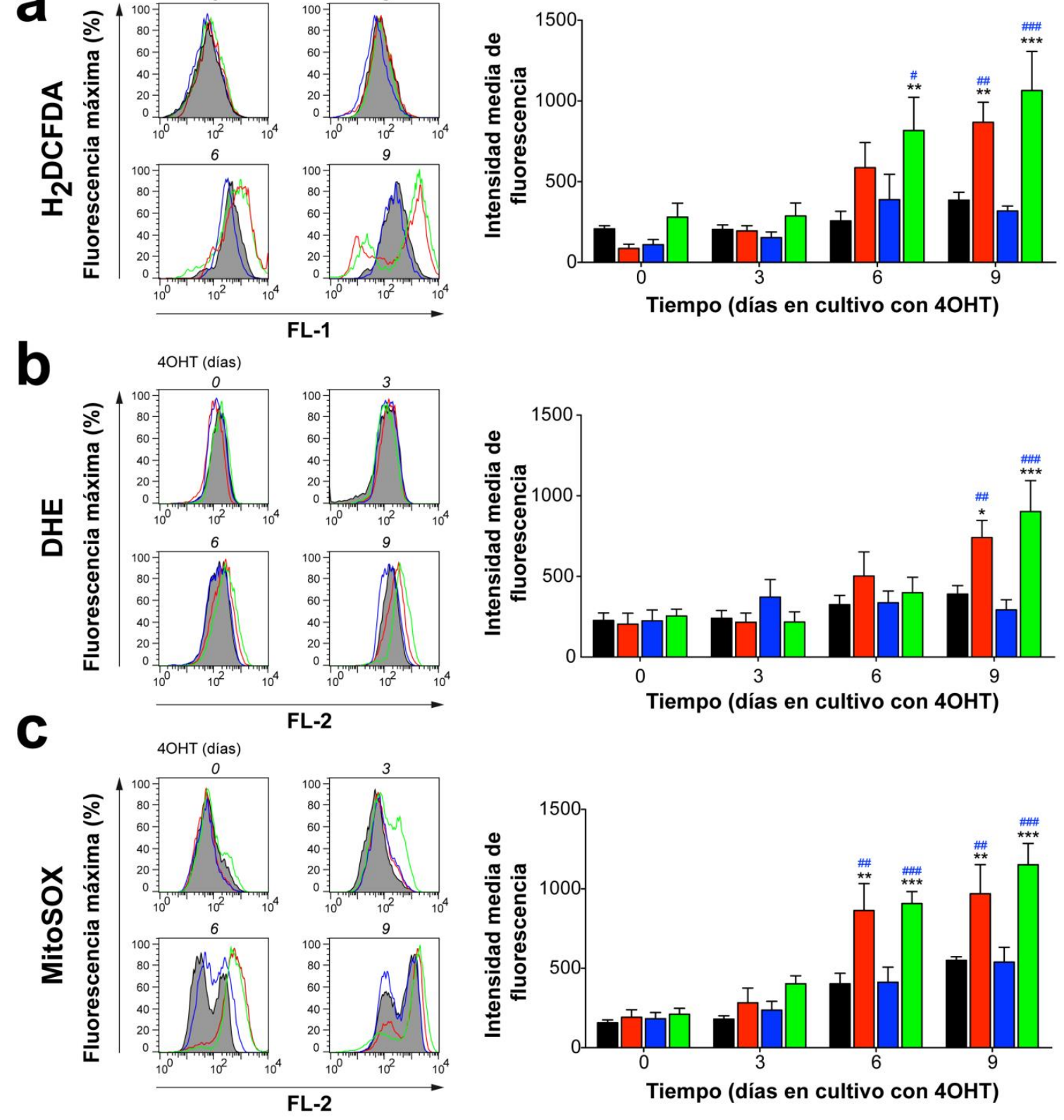

Figura 33. Estado redox en células de los 4 genotipos. El tiempo 0 representa la condición sin tratamiento. Se utilizaron fluoróforos específicos para medir los niveles intracelulares de ROS $\left(\mathrm{H}_{2} \mathrm{DCFDA}\right), \mathrm{O}_{2}^{-}{ }^{-}(\mathrm{DHE})$, y $\mathrm{mO}_{2}^{-}$(MitoSOX ${ }^{\mathrm{TM}}$ ), mediante citometría de flujo. En la parte de la izquierda los histogramas representan cada uno de los análisis de FACS de cada genotipo, para cada fluoróforo empleado. El eje de las $Y$ representa el porcentaje de fluorescencia normalizado con respecto al máximo de fluorescencia detectado. En la parte derecha de la imagen, las gráficas representan valores de intensidad media de fluorescencia. $n=6 /$ genotipo. (a) Determinación intracelular de los niveles de ROS por el compuesto $\mathrm{H}_{2}$ DCFDA. (b) 
Determinación de los niveles de $\mathrm{O}_{2}{ }^{-}$analizado con DHE. (c) Análisis de los niveles de $\mathrm{mO}_{2}{ }^{-}$con MitoSOX ${ }^{\mathrm{TM}}$. Las barras de error representan el SEM. Las comparaciones se representaron de la siguiente manera: */\# $p<0.05$ en la comparación vs WT y Sos2 KO. Además **/\#\# $\mathrm{p}<0.01 \mathrm{y} * * * / \# \# \# \mathrm{p}<0.001$ vs WT y Sos $2 \mathrm{KO}$, respectivamente.

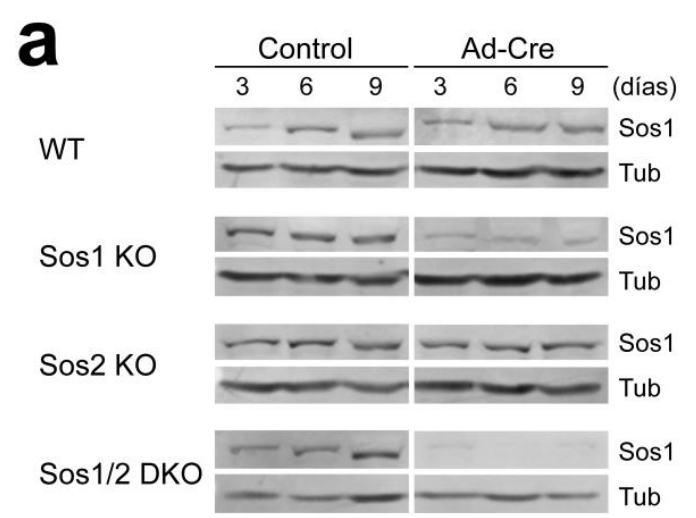

Figura 34. Estado redox mitocondrial en MEFs de los 4 genotipos tras la infección con Adeno-Cre. (a) Imágenes de WB que muestran la eliminación de Sos1 tras la infección con Adeno-Cre en los tiempos 3, 6 y 9 días. Empleamos la tubulina como control de carga. (b) Estudio de los niveles de $\mathrm{mO}_{2}$ medidos con MitoSOXTM representados como intensidad media de fluorescencia. Este parámetro representaba la intensidad media de fluorescencia medida con MitoSOXTM en MEFs tratados con Adeno-Cre con respecto a MEFs sin este tratamiento. $n=3$ /genotipo. Las barras de error representan el SEM. Las comparaciones se representaron de la siguiente manera: */\# $\mathrm{p}<0.05$ en la comparación vs WT y Sos2 KO. Además **/\#\# $\mathrm{p}<$ $0.01 \mathrm{y} * * *$ /\#\#\# $\mathrm{p}<0.001$ vs WT y Sos2 KO, respectivamente.

\subsection{Disminución del potencial de membrana mitocondrial tras la eliminación de Sos1}

La producción y acumulación de ROS de origen mitocondrial puede producir a una pérdida del potencial de membrana mitocondrial $\left(\Delta \Psi_{\mathrm{m}}\right)$ (Vayssier-Taussat et al., 2002) afectando la función normal de este orgánulo.

Nos propusimos analizar si el incremento de ROS en las células carentes de Sos1 tenía un impacto sobre el $\Delta \Psi_{\mathrm{m}}$. Para analizar este parámetro utilizamos el compuesto carbocianida (JC-1). El análisis de este parámetro reveló que el tratamiento con $4 \mathrm{OHT}$ no afectaba de forma significativa al $\Delta \Psi_{\mathrm{m}}$ de MEFs WT y Sos2 KO (Figura 35). Por otro lado, observamos un aumento de JC-1 en forma de monómeros (una disminución del ratio ratio rojo/verde) en las células Sos1 KO (MEFs Sos1 KO y Sos1/2 DKO) con respecto a los MEFs WT y Sos2 KO tras 6 y 9 días de tratamiento con 4OHT (Figura 35). Esta disminución del ratio de fluorescencia rojo/verde reflejaba una disminución del $\Delta \Psi \mathrm{m}$.

Estos resultados demuestran una relación directa entre la acumulación de ROS mitocondriales con la disminución del $\Delta \Psi \mathrm{m}$ ligada a la eliminación de la proteína Sos1. 

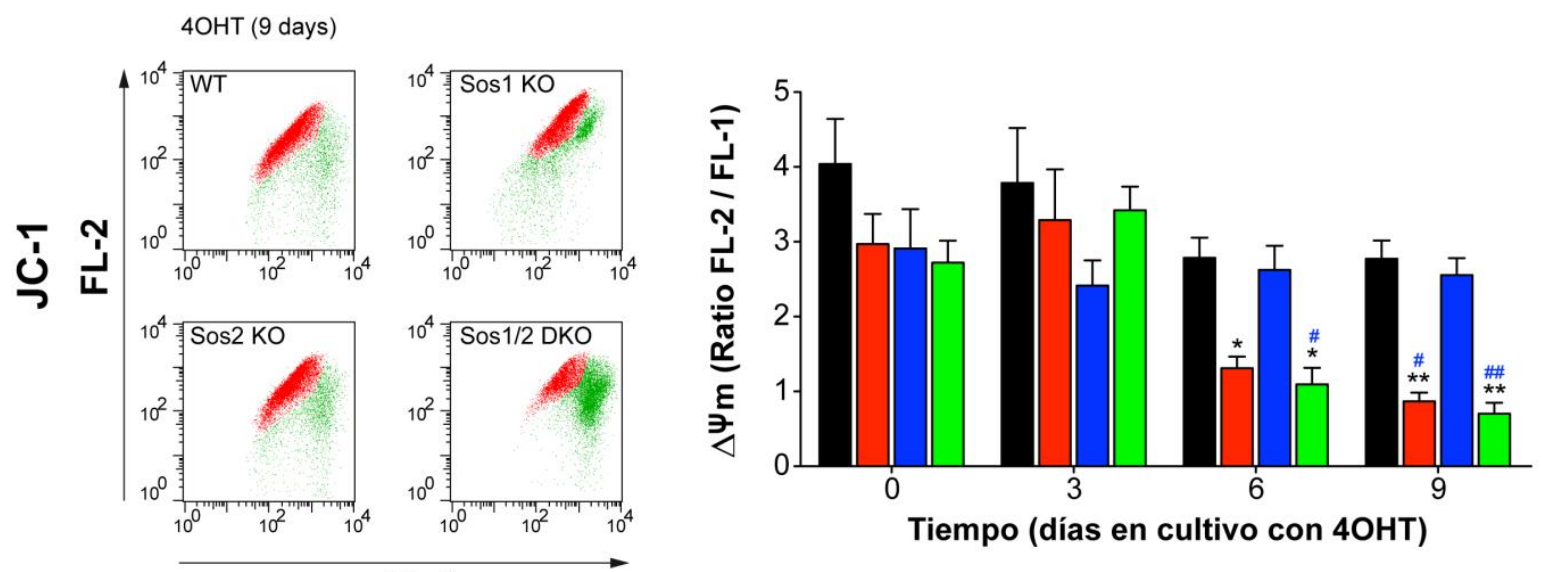

Figura 35. La eliminación de Sos1 altera el $\Delta \boldsymbol{\Psi}_{\mathrm{m}}$ en MEFs. En la parte de la izquierda los histogramas representan la relación rojo/verde del compuesto JC-1 en MEFs de los 4 genotipos tras 9 días de tratamiento con 4OHT. FL1 se corresponde con la fluorescencia verde que emite JC-1 y FL2 con la roja. En la derecha, la gráfica representa el porcentaje de fluorescencia, expresando los porcentajes normalizados con respecto al máximo de fluorescencia detectado a distintos tiempos de tratamiento con $4 \mathrm{OHT}$. $\mathrm{n}=6 /$ genotipo. Las barras de error representan el SEM. Las comparaciones se representaron de la siguiente manera: */\# p< 0.05 vs WT y Sos2 KO. Además **/\#\# $p<0.01$ vs WT y Sos 2 KO, respectivamente

\subsection{Recuperación de la proliferación y organización del citoesqueleto en células}

\section{deficientes para Sos1 tras el tratamiento con antioxidantes}

Nuestros resultados anteriores mostraban una marcada alteración del estado redox en MEFs carentes de expresión de Sos1 (Sos1 KO y Sos1 DKO). El nivel redox de la célula es crucial en la remodelación del citoesqueleto de F-actina (Wilson and González-Billault, 2015) e influye de forma importante en la proliferación celular (Chiu and Dawes, 2012). Nos preguntamos si la recuperación del balance redox en las células Sos1 KO y Sos1/2 DKO podría revertir los defectos observados en la organización del citoesqueleto y en la proliferación. Para comprobar esta hipótesis utilizamos los antioxidantes glutatión (GSH) o N-acetil-cisteína (NAC).

El tratamiento con antioxidantes comenzó el día 8 de tratamiento con $4 \mathrm{OHT}$, por lo que fue posterior a la eliminación de Sos1. A partir de la adición de GSH o NAC analizamos la viabilidad y actividad metabólica in vitro de las células en estudio, usando alamarBlue ${ }^{\circledR}$, durante los 4 días posteriores (Figura 36a). De manera apreciable, ambos antioxidantes producían un aumento sustancial de la viabilidad y la actividad metabólica en las células deficientes para la Sos1 (Sos1 KO y Sos1/2 DKO) a lo largo de todo el experimento, con respecto a la condición sin antioxidantes (Figura 36a). El crecimiento celular de MEFs WT y Sos2 KO no se veía alterado tras la adición de los antioxidantes (Figura 36b). Sorprendentemente, el tratamiento con antioxidantes en las células Sos1 KO no sólo 


\section{Resultados}

provocó una recuperación del crecimiento celular con respecto a la condición sin antioxidantes, sino que alcanzó niveles similares al crecimiento de células WT y Sos2 KO (Figura 36b). Por otro lado, el bloqueo del crecimiento celular que presentaban los MEFs Sos1/2 DKO se revirtió tras la adición de los antioxidantes (Figura 36b), aunque este rescate no igualó los niveles de crecimiento celular de MEFs WT y Sos2 KO (Figura 36b).

En cuanto a la remodelación del citoesqueleto, el tratamiento con NAC no afectaba al perímetro celular de los MEFs WT y Sos2 KO en comparación con las condiciones sin antioxidantes (Figura 36c). De forma interesante, tenía lugar una reducción muy significativa del perímetro celular en MEFs Sos1 KO y Sos1/2 DKO tratados con NAC en comparación con la condición sin NAC (Figura 36c yd). El tratamiento con NAC conducía también a una recuperación de la polaridad celular representada con una organización longitudinal de las fibras de actina en los MEFs Sos1 KO y Sos1/2 DKO, siendo muy similar a la exhibida por los MEFs WT y Sos2 KO (Figura 36c y d). De igual manera, la distribución de las AF en las células deficientes para Sos1 y Sos1/2 en tratamiento con NAC y $40 \mathrm{OHT}$ era mayoritaria en los polos de las células, de manera semejante a MEFs WT y Sos2 KO en ambas condiciones de tratamiento (Figura 36c y d).

Estos resultados sugieren el fuerte impacto que tiene el ROS en las células deficientes para Sos1 sobre las alteraciones que habíamos descrito previamente en la organización del citoesqueleto y la proliferación celular de los MEFs. 


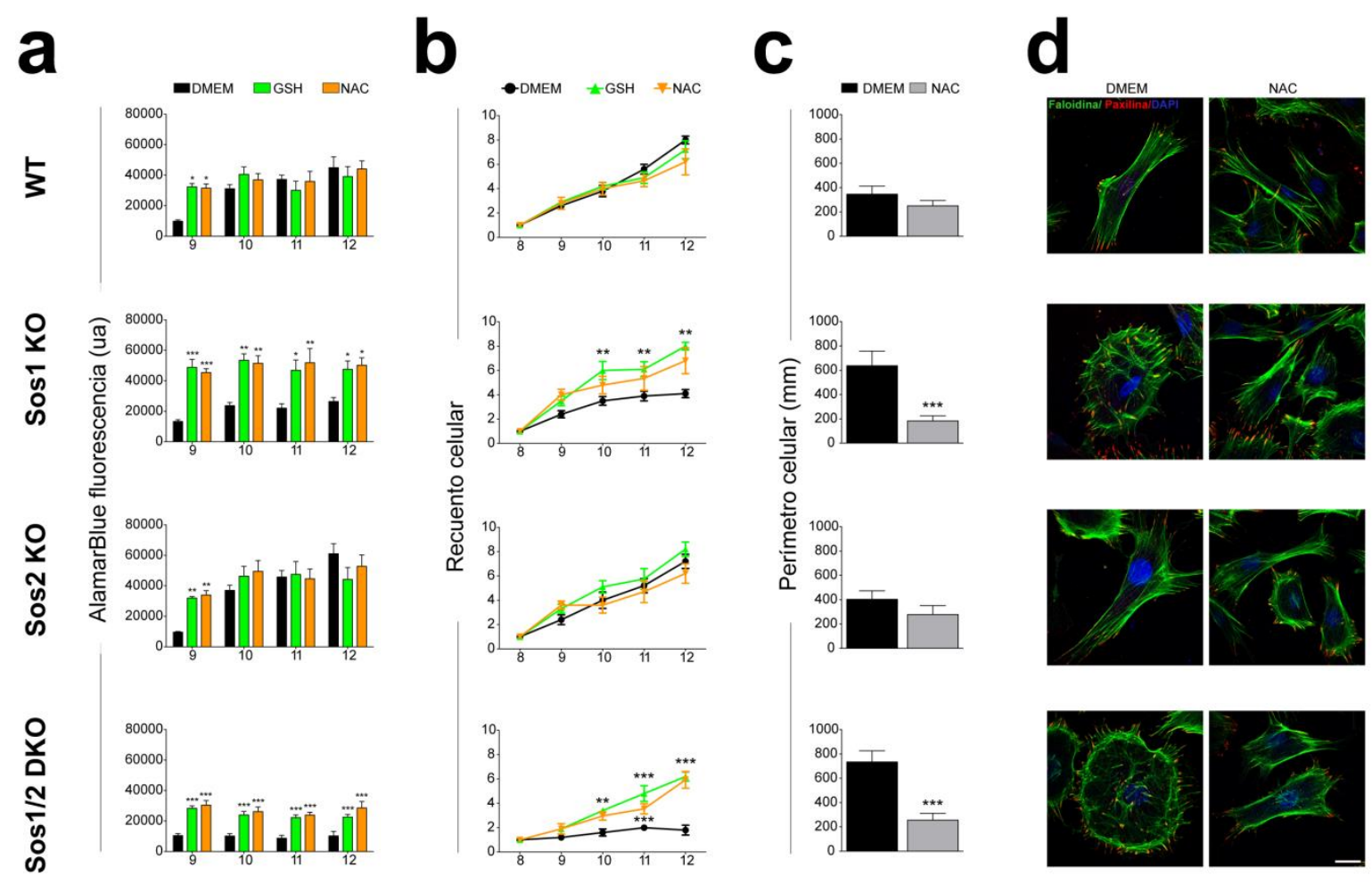

Tiempo (días) en cultivo con $40 \mathrm{OH}$

Figura 36. Efecto del tratamiento con los antioxidantes GSH y NAC en proliferación y morfología celular. (a) Cuantificación de la viabilidad celular y la actividad metabólica mediante el compuesto fluorescente alamarBlue ${ }^{\circledR}$. El histograma representa los cambios de fluorescencia a lo largo del tiempo. $n=6 /$ genotipo. (b) Curva de crecimiento de células de los 4 genotipos con y sin tratamiento con antioxidantes. $n=6 /$ genotipo. (c) Cuantificación del perímetro celular tras el tratamiento concomitante de $4 \mathrm{OHT}$ y NAC durante 9 días. $n=300 / g e n o t i p o$. (d) Imágenes representativas de la organización del citoesqueleto en células sin tratamiento con NAC (parte derecha), y con NAC (parte izquierda). Tinción de las fibras de actina con faloidina

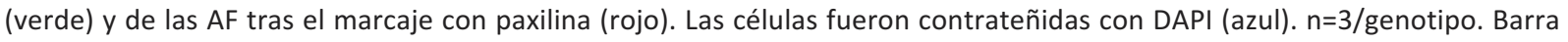
de escala: $25 \mu \mathrm{m}$. Las barras de error representan el SEM. Las comparaciones se representaron de la siguiente manera: $* p<$ 0.05 en la comparación de cada genotipo sin antioxidante vs tratamiento con antioxidantes. Además $* * p<0.01$ y $* * * p<$ 0.001 para cada genotipo correspondiente sin tratamiento con antioxidantes vs tratamiento con antioxidantes.

\subsection{Reversión del efecto en proliferación y del estado redox en células deficientes de}

\section{Sos1 tras el tratamiento con MitoTEMPO}

Los antioxidantes NAC y GSH ejercen su función sobre los niveles de ROS generales de la célula. Determinamos cuál era el efecto en las células si tratábamos de forma específica el estrés oxidativo de origen mitocondrial. Para averiguar si la acumulación del $\mathrm{mO}_{2}{ }^{-}$de las células Sos1 KO y Sos1/2 DKO contribuía en mayor o menor medida en los efectos de la eliminación de Sos1 en otros procesos, como la proliferación y la viabilidad celulares, tratamos las células con MitoTEMPO. MitoTEMPO es un intercambiador de $\mathrm{mO}_{2}^{-}$capaz de eliminar esta ROS de la mitocondria para recuperar el balance redox de la célula. 


\section{Resultados}

El tratamiento con MitoTEMPO comenzó una vez eliminada Sos1, tras 8 de tratamiento con 4OHT. La viabilidad y actividad metabólica de las células WT y Sos2 KO no se veía afectada tras el tratamiento con MitoTEMPO en comparación con las condiciones sin el tratamiento (Figura 37a). Sin embargo, las células Sos1 KO y Sos1/2 DKO tratadas con MitoTEMPO presentaban una recuperación sustancial de la viabilidad y actividad metabólica a partir de los 3 días de tratamiento con este compuesto, con respecto a esas mismas células no tratadas con el antioxidante (Figura 37a). En cuanto a la curva de crecimiento, la administración de MitoTEMPO no generó cambios en el crecimiento celular de MEFs WT y Sos2 KO (Figura 37b). Sin embargo, su uso en MEFs Sos1 KO, mejoró notablemente el recuento celular con respecto a la situación sin antioxidante (Figura 37b). En el caso de los MEFs Sos1/2 DKO detectamos una pequeña recuperación del crecimiento celular, aunque era sustancialmente menor a la detectada en los MEFs Sos1 KO (Figura 37b).

Paralelamente, el análisis de los niveles de ROS generales mediante el uso de $\mathrm{H}_{2}$ DCFDA tras el uso de MitoTEMPO reveló una disminución general de las ROS citosólicas en todos los genotipos, pero esta disminución sólo resultó significativa en MEFs Sos1 KO y Sos1/2 DKO con respecto a las condición sin antioxidante (Figura 37c). Análogamente, se analizó el nivel de $\mathrm{mO}_{2}{ }^{-}$con MitoSOX ${ }^{\mathrm{TM}}$. De forma muy similar, el tratamiento con MitoTEMPO no generó diferencias significativas en los genotipos WT y Sos2 $\mathrm{KO}$ con respecto a la condición sin tratamiento. Sin embargo, los niveles de $\mathrm{mO}_{2}{ }^{-}$de los MEFs Sos1 KO y Sos1/2 DKO se vieron disminuidos significativamente tras el tratamiento de las células con MitoTEMPO (Figura 37c).

Finalmente, analizamos el $\Delta \Psi_{\mathrm{m}}$ en MEFs de los 4 grupos experimentales, y observamos que se producía una tendencia de un aumento generalizado tras el tratamiento con este antioxidante mitocondrial. Sin embargo, las diferencias observadas sólo mostraron significación estadística en células Sos1 KO y Sos1/2 DKO tras el tratamiento con el antioxidante con respecto a la condición sin MitoTEMPO (Figura $37 \mathrm{c}$ ). Es importante destacar que la recuperación del $\Delta \Psi_{\mathrm{m}}$ en células Sos1 $\mathrm{KO}$ alcanzaba niveles similares a los que presentaban los MEFs WT y Sos2 KO en las mismas condiciones de tratamiento, mientras que en MEFs Sos1/2 DKO no alcanzaba los niveles $\Delta \Psi_{\mathrm{m}}$ del resto de genotipos en igualdad de tratamiento con el antioxidante (Figura 37c).

La recuperación de la proliferación celular, del estado redox y del $\Delta \Psi \mathrm{m}$ gracias a la restauración de los niveles de $\mathrm{mO}_{2}^{-}$sugiere una conexión mecanística directa entre el aumento del estrés oxidativo y la disfunción mitocondrial con el resto de alteraciones observadas en las células carentes de Sos1. 

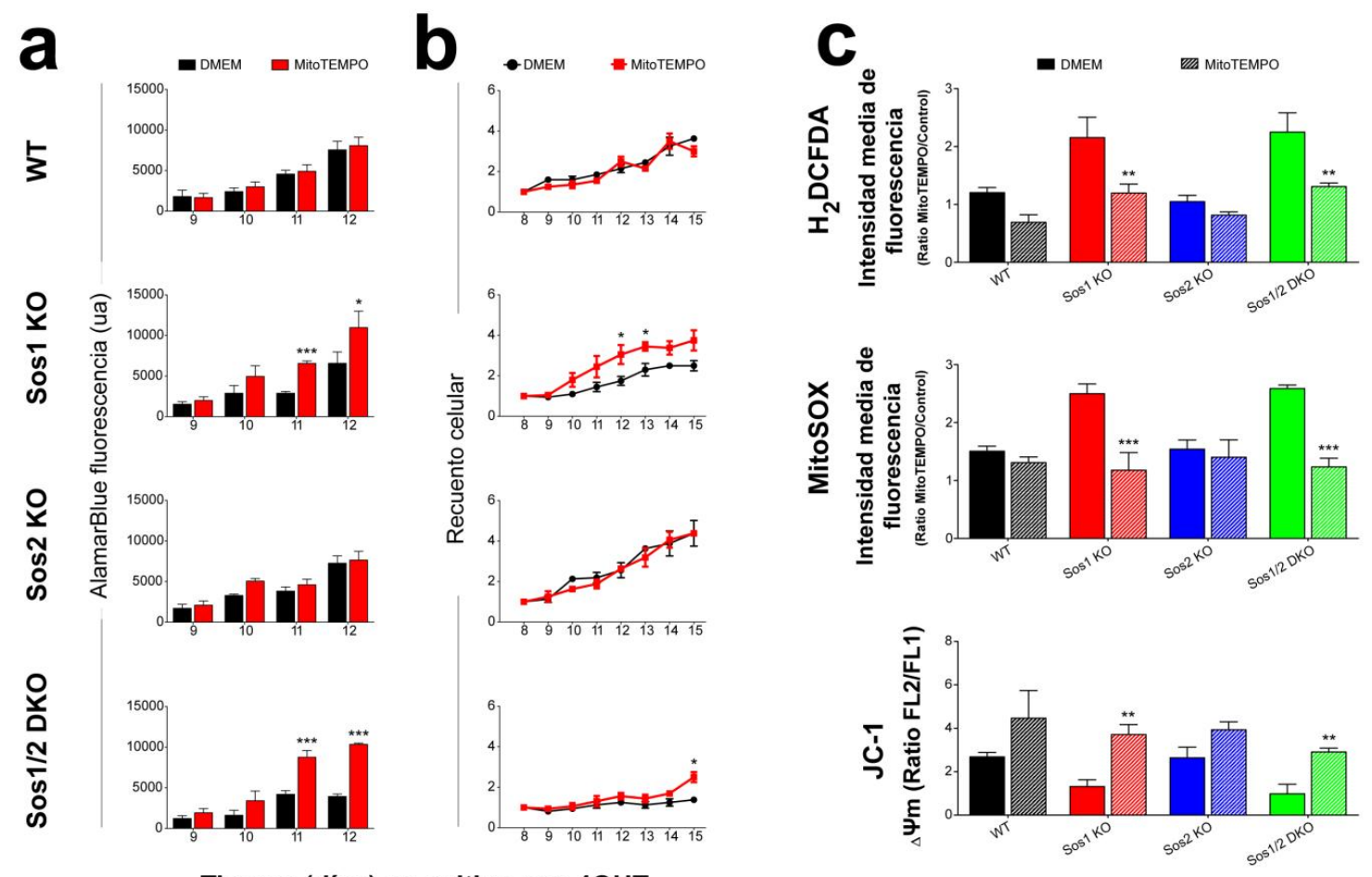

Tiempo (días) en cultivo con $40 \mathrm{OT}$

Figura 37. Efecto del tratamiento con MitoTEMPO en MEFs de los 4 genotipos. Se cultivaron MEFs de los 4 genotipos, tratados durante 8 días con $4 \mathrm{OHT}$ y posteriormente en presencia o ausencia de MitoTEMPO. (a) Cuantificación de la viabilidad y actividad metabólica celular con el compuesto fluorescente alamarBlue ${ }^{\circledR}$. Las gráficas representan la fluorescencia emitida por el compuesto en células tratadas con 4OHT en presencia (barras rojas) o ausencia (barras negras) de MitoTEMPO. (b) Curva de crecimiento durante 7 días consecutivos de células tratadas con MitoTEMPO (rojo) y sin MitoTEMPO (negro). (c) Análisis por citometría de flujo de los compuestos $\mathrm{H}_{2}$ DCFDA, MitoSOX ${ }^{\mathrm{TM}}$ y JC-1, de células tratadas 9 días con $4 \mathrm{OHT}$ (DMEM, barras de colores) y con $4 \mathrm{OHT}$ y MitoTEMPO (barras rayadas). Para las gráficas de análisis por citometría se representó en el eje Y los valores normalizados del ratio entre los valores de las células tratadas con $40 H T$ y MitoTEMPO, con respecto a células tratadas con $4 \mathrm{OHT}$. Las barras de error representan el SEM. Las comparaciones se representaron de la siguiente manera: ${ }^{*} \mathrm{p}<0.05,{ }^{*} \mathrm{p}<0.01$ y ${ }^{* * *} \mathrm{p}<0.001$ para cada genotipo correspondiente sin MitoTEMPO respecto al mismo genotipo tratado con MitoTEMPO. 


\section{Papel funcional de Sos1 y Sos2 en la piel}

Estudios genéticos en ratones han puesto de manifiesto la importancia de la ruta Ras/MAPK para el correcto desarrollo, estratificación y mantenimiento de la fisiología de la piel (Drosten et al., 2014). Se ha descrito que ciertos activadores de GTPasas participan en las rutas de señalización implicadas en la fisiología y la patología de la piel (Menacho-Márquez et al., 2013). Es más, se sabe que la sobreexpresión de la proteína Sos1 en queratinocitos genera una respuesta hiperproliferativa en estas células (Sibilia et al., 2000). En este sentido, nos propusimos estudiar la función concreta de Sos1 y Sos 2 en la piel y la repercusión de su ausencia (individual o combinada) en este órgano, en condiciones fisiológicos y patológicas.

\subsection{Relevancia de Sos1 y Sos2 en la fisiología de la piel.}

\subsubsection{Redundancia funcional parcial de Sos 1 y Sos 2 en la homeostasis de la piel}

En primer lugar analizamos las consecuencias de la eliminación de las proteínas Sos (individual o combinada) en la homeostasis de la piel (Figura 38). El examen de la piel de los ratones WT mostró la estratificación clásica de este órgano en sus distintas capas (epidermis, dermis e hipodermis). En concreto, estos animales mostraban una epidermis con 2 o 3 capas de queratinocitos y un grosor homogéneo en toda su longitud (Figura 38a), de forma muy similar a la epidermis de los animales Sos2 KO (Figura 38a, b y f). Por el contrario, la eliminación individual de Sos1 provocaba una reducción en el grosor de la epidermis comparada con la de los animales WT y Sos2 KO, mostrando ésta una o dos filas de queratinocitos (Figura 38a, b y f). Es más, la ausencia combinada de Sos1 y Sos2 afectaba de forma severa a la estratificación de la epidermis con respecto al resto de genotipos, mostrando frecuentemente una sola capa de queratinocitos e incluso zonas prácticamente desprovistas de este tipo celular (Figura 38a y b). Todo ello conducía a una reducción muy significativa del grosor de esta capa respecto al resto de genotipos (Figura 38f). Estos defectos van acompañados de una deposición de queratina en la superficie epidérmica o estrato corneo, que no tiene lugar de forma tan llamativa en el resto de genotipos (Figura 38b).

La epidermis también comprende una parte de los folículos pilosos, ya que éstos comparten un origen epidérmico y dérmico. No apreciamos diferencias evidentes en la morfología y el número de 
folículos pilosos en los animales Sos1 KO y Sos2 KO con respecto a los animales WT. Sin embargo, resultaba notorio el menor tamaño y número de los folículos en los animales Sos1/2 DKO comparados con el resto de genotipos (Figura 38e). Además, los folículos pilosos de animales mutantes Sos1/2 DKO habían perdido la apariencia normal mostrando un menor espesor de la epidermis interfolicular (epidermis del folículo piloso) y una pérdida de su compactación. Estas alteraciones estaban acompañadas de una reducción importante del número y tamaño de glándulas sebáceas, en comparación con el resto de los genotipos (Figura 38e).

En cuanto a la dermis, no detectamos diferencias en su grosor entre los animales WT y Sos2 KO (Figura 38a y f). Sin embargo, sí que observamos que los animales Sos1 KO y Sos1/2 DKO presentaban una reducción significativa en el grosor de esta capa en comparación con los animales WT y Sos2 KO (Figura 38a y f). Esta reducción posiblemente era debida a una disminución en la densidad celular (Figura 38c), y quizás también en los animales Sos1/2 DKO por la disminución del tamaño y el número de glándulas sebáceas y folículos pilosos.

Por último, el análisis de la hipodermis reveló que la ausencia individual de Sos2 no afectaba al grosor de esta capa respecto a la de los WT (Figura 38a, d y f). Sin embargo, la eliminación simple de Sos1 generaba una importante reducción de la hipodermis en comparación con los animales WT y Sos2 KO (Figura 38a, d y f). De forma muy llamativa, la ausencia conjunta de Sos1 y Sos2 suponía la práctica desaparición de la hipodermis (Figura 38a, d y f).

Estos resultados confirman que la deficiencia de Sos1 juega un papel importante en el mantenimiento de la arquitectura de la piel, en especial en epidermis e hipodermis. Aunque la ausencia individual de Sos2 no afectaba a la histología de la piel, sí parecía tener una cierta función en el mantenimiento de su homeostasis, ya que la ausencia concomitante de Sos1 y Sos2 agravaba aún más el fenotipo respecto a cuando sólo está ausente Sos1. 


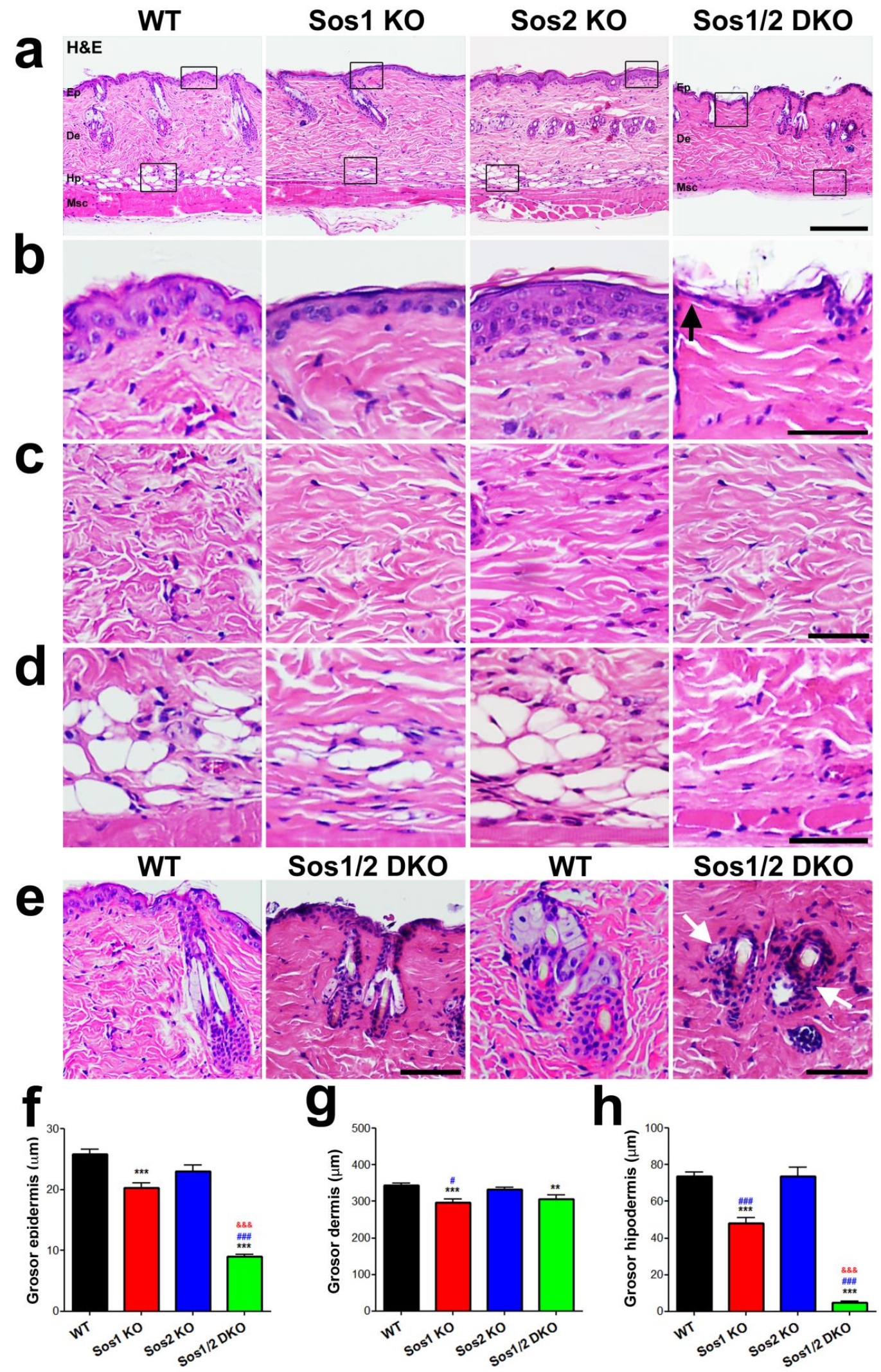


Figura 38. Análisis histológico de la piel en animales de los $\mathbf{4}$ genotipos de estudio. (a) Secciones transversales de piel de la espalda de los 4 genotipos de estudio teñidas con H\&E. Los recuadros indican las zonas ampliadas en los paneles inferiores. Barra de escala: $200 \mu \mathrm{m}$ (b) Imágenes aumentadas del apartado (a) de la epidermis. La flecha señala una pérdida del grosor importante de la epidermis en la zona especificada. (c) Imágenes ampliadas del apartado (a) de la dermis. Nótese la reducción de celularidad en los genotipos Sos1 KO y Sos1/2 DKO. (d) Ampliación de las imágenes del apartado (a) que muestran la hipodermis. (e) Imágenes aumentadas de los folículos pilosos de los genotipos WT y Sos1/2 DKO (izquierda). Barra de escala: $100 \mu \mathrm{m}$. En la parte derecha, ampliación de las glándulas sebáceas en pieles de animales WT y Sos1/2 DKO. Las flechas apuntan una célula sebácea (izquierda) y una pérdida de la organización y compactación de los queratinocitos del folículo piloso (derecha). Barra de escala: $50 \mu \mathrm{m}$. Representaciones gráficas del grosor de la epidermis (f), dermis (g) e hipodermis (h). (b-d) Barras de escala: $25 \mu \mathrm{m}$ (f-g) $\mathrm{n}=3$ /genotipo (100 mediciones para cada individuo). Las barras de error representan el SEM. Las diferencias significativas se establecieron de la siguiente manera: \# $\mathrm{p}<0.05$ vs Sos 2 KO. Además ** p< 0.01 vs WT y ${ }^{* * *} / \& \& \& / \# \# \#$ p 0.001 vs WT, Sos1 KO y Sos2 KO, respectivamente. Ep: Epidermis, De: Dermis, Hp: Hipodermis, Msc: Músculo.

\subsubsection{Importancia de Sos1 y Sos2 en los procesos de proliferación y muerte celular}

Las alteraciones detectadas en las distintas capas de la piel de los animales mutantes para Sos1 (Sos1 KO y Sos1/2 DKO) sugerían una afectación de las células proliferativas de la piel o un incremento de muerte celular, o ambos procesos de forma concomitante. Por ello, analizamos la tasa de proliferación celular y el nivel de muerte celular por apoptosis en la piel de los 4 genotipos de interés mediante inmunomarcaje para BrdU y caspasa-3 activa, respectivamente.

De forma general, la capa de la piel que está en constante proliferación es la epidermis, concretamente la tasa de renovación de la epidermis (queratopoyesis) murina se estima entre 5-9 días (Potten, 1981). En concreto, los queratinocitos proliferativos se localizan en el estrato basal de la epidermis y en la epidermis interfolicular (epidermis de los folículos pilosos).

Cuantificamos el número de células en estado proliferativo en los 4 grupos de estudio y comprobamos que la eliminación de Sos2 no provocaba cambios significativos en este sentido comparado con la capacidad proliferativa de los queratinocitos de la piel de animales WT (Figura 39a y c). Por el contrario, la ausencia individual de Sos1 generaba una disminución significativa del número de queratinocitos proliferativos con respecto al genotipo WT (Figura 39a y c). Por otro lado, la capacidad de proliferación de los queratinocitos en los animales Sos1/2 DKO estaba fuertemente comprometida, viéndose reducída de forma muy significativa respecto al resto de genotipos (Figura 39a y c).

Analizamos también la tasa de muerte celular por apoptosis en la piel de los 4 genotipos de interés. No detectamos células apoptóticas en la piel de animales WT y Sos2 KO en ninguna de las capas de la piel (Figura 39b y d). De forma muy similar, la ausencia individual de Sos1 muy raramente generaba 
apoptosis (Figura 39b y d). Sin embargo, la falta de ambas proteínas Sos incrementaba el número de células apoptóticas, aunque el número seguía siendo muy bajo, con respecto a los animales WT y Sos2 KO, localizándose estas células apoptóticas por lo general en los folículos pilosos o en epidermis (Figura 39b y d).
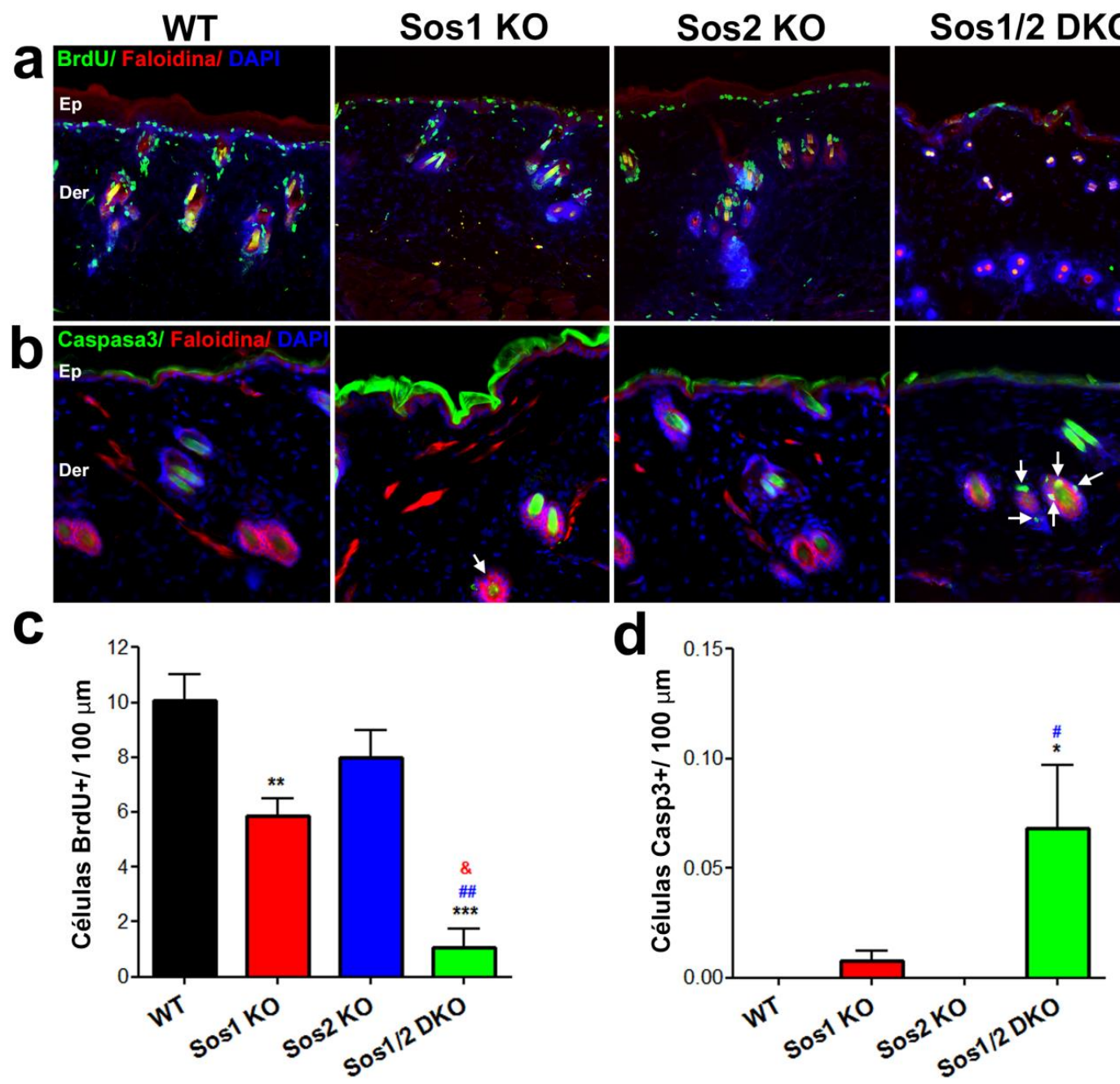

Figura 39. La ausencia de Sos1 afecta a la proliferación pero no a la viabilidad celular en la piel. (a) Imágenes de microscopía confocal de secciones transversales de la piel de los 4 genotipos, marcadas con, BrdU (verde), faloidina (rojo) y contrateñidas con DAPI (azul). Barra de escala: $25 \mu \mathrm{m}$. (b) Secciones de piel de los 4 grupos de estudio marcadas con, caspasa-3 activa (verde), faloidina (rojo) y DAPI (azul). Las flechas señalizan células apoptóticas. Barra de escala: $50 \mu \mathrm{m}$. (c) Gráfica que representa el número de células BrdU positivas por cada $100 \mu \mathrm{m}$. (d) Cuantificación del número de células caspasa3-activa positivas en $100 \mu \mathrm{m}$ de tejido. $\mathrm{n}=3$ /genotipo ( 3 secciones por individuo). Las barras de error representan el SEM. Las comparaciones se representaron de la siguiente manera: */\&/\# $p<0.05$ vs WT, Sos1 KO y Sos2 KO, respectivamente. Además **/\#\# $\mathrm{p}<0.01$ vs WT y Sos2 KO y *** $\mathrm{p}<0.001$ vs WT. Ep: Epidermis, De: Dermis.

\subsubsection{Implicación de Sos1 y Sos2 en la vascularización de la piel}


Tras el estudio de la proliferación y muerte en condiciones fisiológicas, nos preguntamos si la eliminación individual o combinada de Sos1 y Sos2 estaba implicada en la vascularización de la piel. Para estudiar el proceso, realizamos un marcaje con el anticuerpo CD31 (también denominado PECAM) en secciones de piel de los 4 grupos de estudio.

El marcaje resultante, representativo de la vascularización de la piel, mostraba en los animales WT que las células CD31 positivas se repartían de forma mayormente homogénea a lo largo de la dermis (Figura 40). Tomando como referencia del estado vascular el marcaje de CD31 en la piel de animales WT, observamos un marcaje muy similar en la piel de animales Sos2 KO (Figura 40). En cambio, la eliminación de Sos1 parecía provocar una disminución de la densidad vascular en comparación con los animales WT y Sos2 KO (Figura 40). Finalmente, el análisis de la vascularización de la dermis de animales carentes de ambas formas de Sos resultó en un reparto no uniforme del marcaje y en términos generales, una drástica disminución de la densidad vascular con respecto al resto de genotipos (Figura 40).

Las observaciones anteriores nos permiten sugerir que la eliminación de Sos 2 parece prescindible para la vascularización de la piel, mientras que la ausencia de individual de Sos1 parece generar una disminución de la densidad vascular en la piel. Finalmente, la eliminación de ambas proteínas provoca una reducción drástica de los vasos sanguíneos de la piel. 

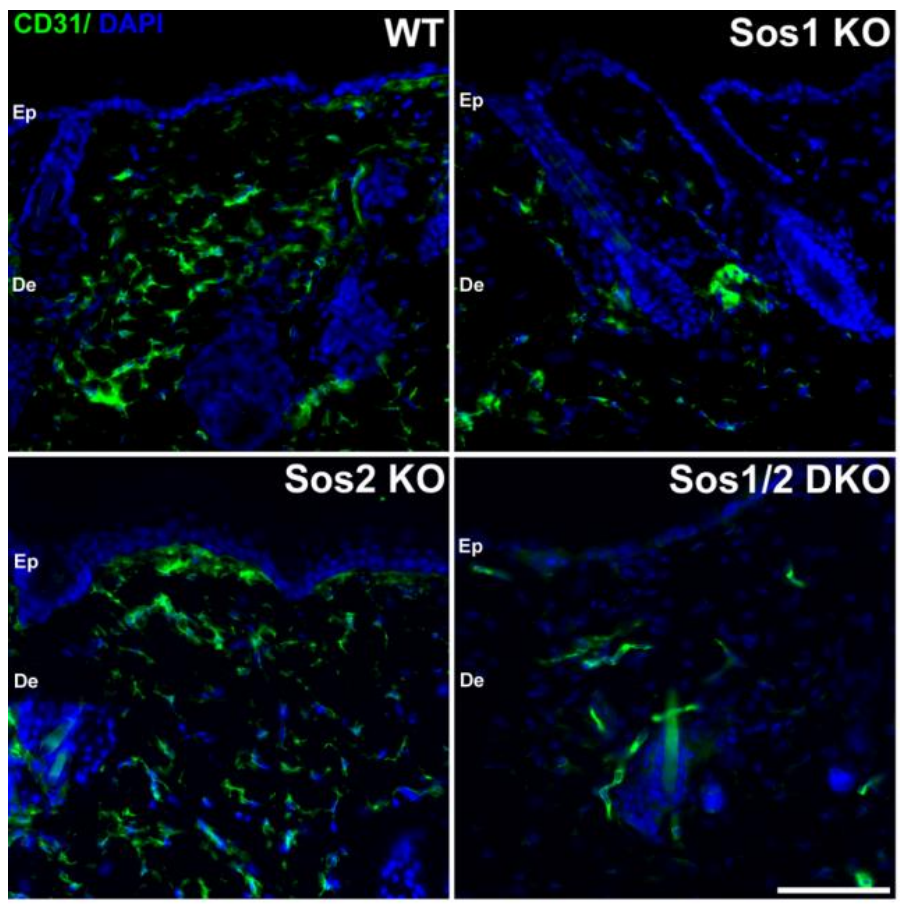

Figura 40. Importancia de las proteínas Sos en la vascularización de la piel. Imágenes de secciones trasversales de la piel de animales de los 4 grupos de estudio, marcadas con CD31 (verde) y con DAPI (azul). Barra de escala: $100 \mu \mathrm{m}$. Ep: Epidermis, De: Dermis.

\subsection{Papel de Sos1 y Sos2 en proliferación, muerte y respuesta inflamatoria en}

\section{respuesta a estímulos.}

Para analizar más en detalle las alteraciones detectadas en proliferación y muerte celular descritas anteriormente, recurrimos a una serie de ensayos a corto plazo, mediante la administración de químicos que permiten generar una respuesta hiperproliferativa, inducir muerte celular e incluso desencadenar una respuesta inflamatoria en la piel murina (Cramer et al., 2003; Florin et al., 2006; Menacho-Márquez et al., 2013).

4.2.1. Estudio de la proliferación dependiente de estímulo en la epidermis de animales deficientes para Sos.

Para inducir una respuesta hiperproliferativa empleamos el TPA, que como se indicó en el "Material y métodos" es un potente promotor tumoral. Administramos de forma tópica una dosis de TPA en la piel de la espalda de animales de los 4 genotipos y cuantificamos el grosor de la epidermis y el número de células BrdU positivas. 
En primer lugar observamos que el grosor de la epidermis dn animales de los 4 genotipos tras la administración de TPA aumentaba con respecto al medido en condiciones fisiológicas (Figura 41a y c). Al igual que ocurría en el estado fisiológico, el grosor de esta capa en los animales Sos2 KO no presentaba cambios con respecto a los animales WT, observándose en ambos de 3 a 4 filas de queratinocitos (Figura 41a-c). El espesor de la epidermis de los animales Sos1 KO era menor (2-3 filas de queratinocitos) con respecto al grosor observado en ratones WT y Sos2 KO (Figura 41b y c). Por último, es importante destacar, que la epidermis de los animales Sos1/2 DKO tratados con TPA presentaban un espesor constante ( 1 o 2 capas de queratinocitos) que no se observaba en el estado fisiológico (Figura 38b y Figura 41b), aunque el grosor de esta capa en estos animales seguía siendo marcadamente menor con respecto al resto de genotipos también tratados con TPA (Figura 41a-c). Para cuantificar el número de células proliferativas empleamos el inmunomarcaje para BrdU. Nuestros resultados demostraron que, del mismo modo que en condiciones fisiológicas, la eliminación de Sos2 no afectaba a la proliferación de los queratinocitos con respecto a los animales WT (Figura 41a, b y d). Asimismo, los animales Sos1 KO mostraban una menor proliferación de queratinocitos en comparación con animales WT y Sos2 KO (Figura 41a, b y d). Al igual que en condiciones fisiológicas, la eliminación simultanea de Sos1 y Sos2 provocaba una reducción notable del número de queratinocitos positivos para BrdU respecto al resto de los genotipos (Figura 41a, b y d).

En concordancia con resultados anteriores, la proteína Sos1 parece desempeñar un papel importante ante esta estímulo hiperproliferativo. Aunque la falta individual de Sos2 parece ser sustituida de manera eficiente por Sos1, nuestros resultados demuestran que Sos2 parece ejercer también una función en este caso, ya que la deficiencia combinada de ambas proteínas reduce marcadamente la proliferación dependiente de estímulo de los queratinocitos. 

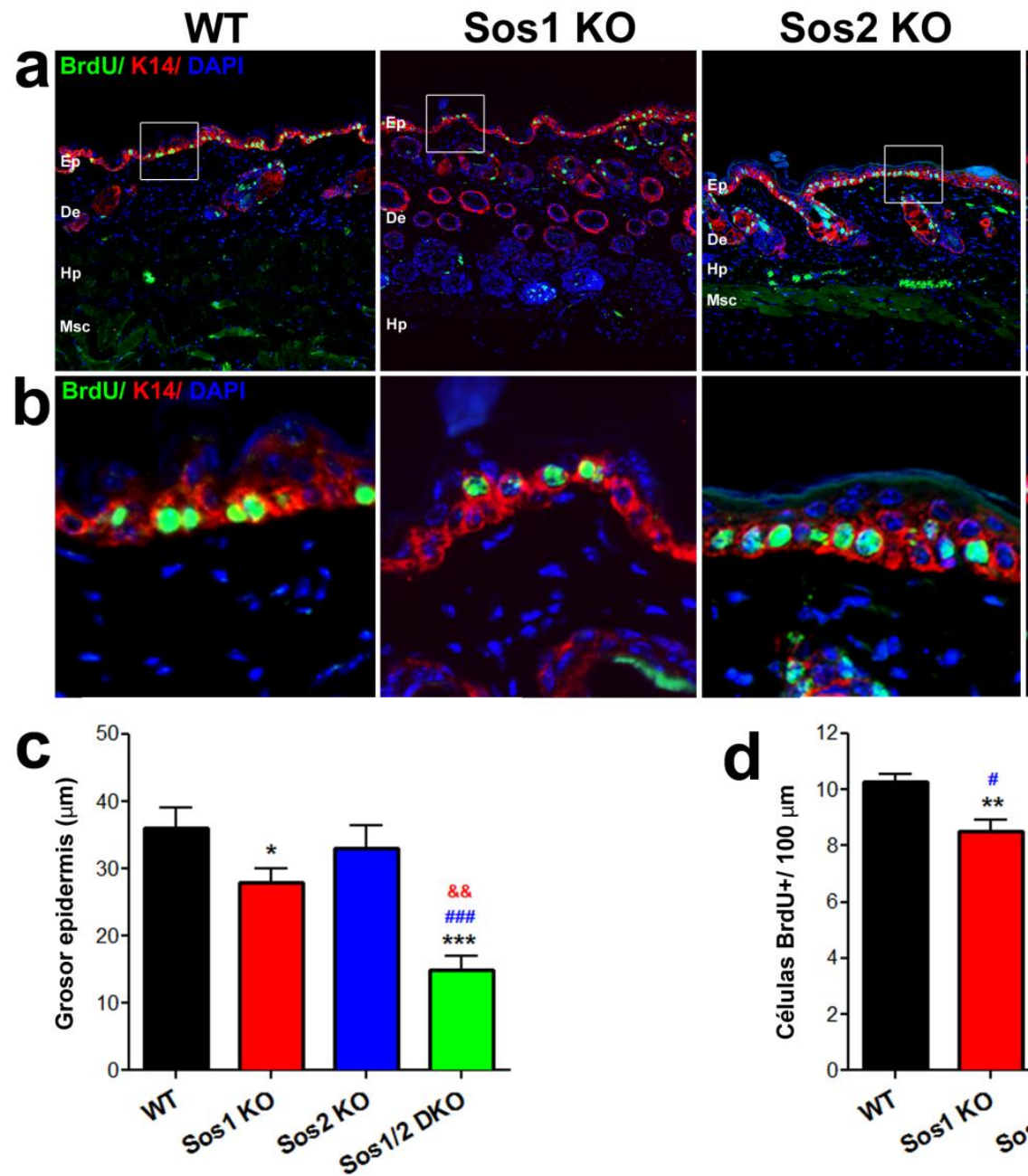

Sos1/2 DKO
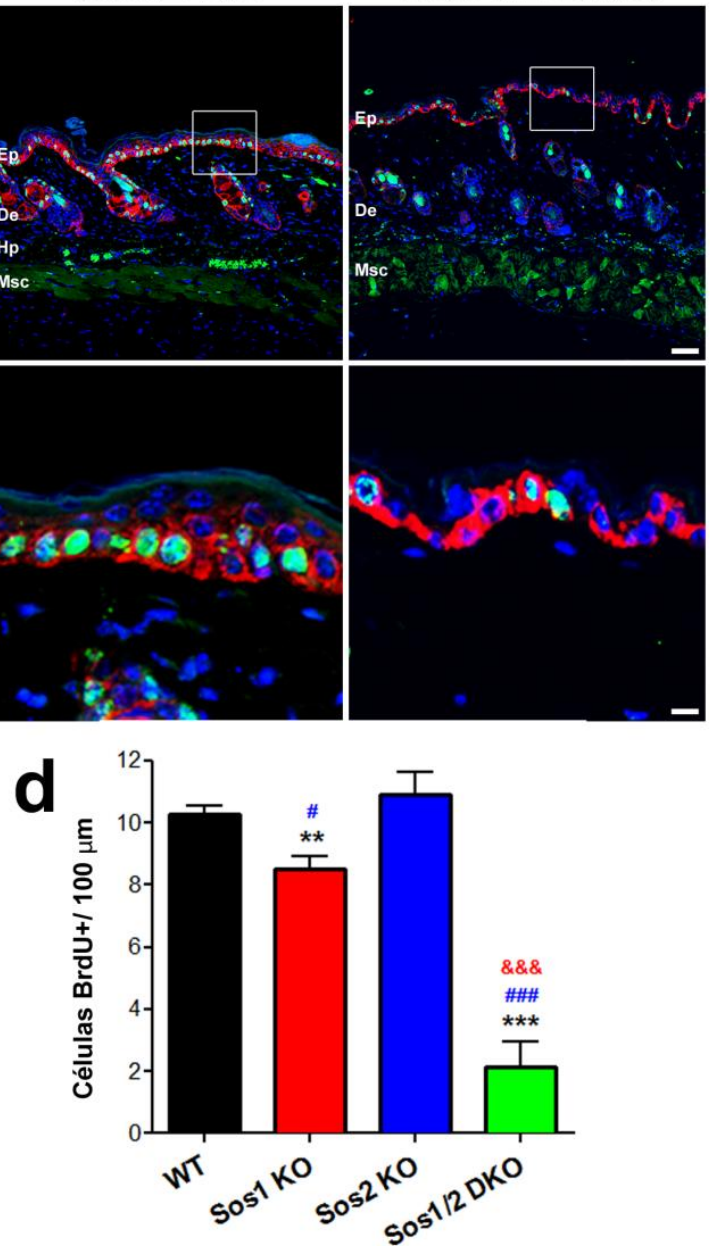

Figura 41. Análisis de la proliferación tras tratamiento con una dosis de TPA. (a) Imágenes de microscopía confocal de secciones transversales de la piel marcadas con BrdU (verde), anticuerpo que reconoce queratinocitos (K-14; rojo) y DAPI (azul). Los recuadros indican las regiones ampliadas en (b). Barra de escala: $25 \mu \mathrm{m}$ (b) Imágenes ampliadas que muestran las células BrdU positivas en la epidermis. Barra de escala: $50 \mu \mathrm{m}$. (c) Gráfica que muestra el grosor epidérmico expresado en $\mu \mathrm{m}$ en los 4 genotipos de interés. $\mathrm{n}=3$ /genotipo (60 mediciones por individuo). (d) Cuantificación del número de células BrdU positivas por cada $100 \mu \mathrm{m}$ de tejido. $\mathrm{n}=3$ /genotipo ( 3 secciones de piel de cada individuo). Las barras de error representan el SEM. Las comparaciones se establecieron del siguiente modo: \&\& $p<0.01$ vs Sos1 KO, además ***/\#\#\# $p<$ 0.001 vs WT y Sos2 KO, respectivamente. Ep: Epidermis, De: Dermis, Hp: Hipodermis, Msc: Músculo.

\subsubsection{Análisis de la muerte celular en ausencia de Sos1 y Sos2 tras un estímulo pro-} apoptótico.

Administramos una sola dosis de DMBA de forma tópica en la piel de la espalda de animales de los 4 genotipos para inducir un proceso de muerte celular por apoptosis. Encontramos células apoptóticas en todas las capas de la piel de los animales de los 4 genotipos, aunque la mayoría eran queratinocitos epidérmicos e interfoliculares (Figura 42a). La cuantificación de las células caspasa-3 
positivas reflejó que los animales WT, Sos1 KO y Sos2 KO mostraban valores muy similares de células apoptóticas (Figura 42a y b). Sin embargo, nuestros resultados reflejaron que la ausencia concomitante de Sos1 y Sos2 conducía a un aumento sustancial, de aproximadamente tres veces más, en el número de células caspasa-3 positivas en la piel de animales Sos1/2 DKO con respecto al resto de genotipos (Figura 42b).

Es decir, no encontramos una relación entre la ausencia individual de las proteínas Sos1 o Sos 2 con el proceso apoptótico dependiente de estímulo. En cambio, asociamos la doble eliminación de las proteínas Sos con una mayor susceptibilidad a la muerte celular en respuesta a un estímulo proapoptótico. Sin embargo, debemos señalar que los valores de células apoptóticas encontrados son extremadamente bajos, por lo que creemos que el impacto fisiológico del incremento en la apoptosis sobre la homeostasis de la piel debe ser prácticamente nulo.

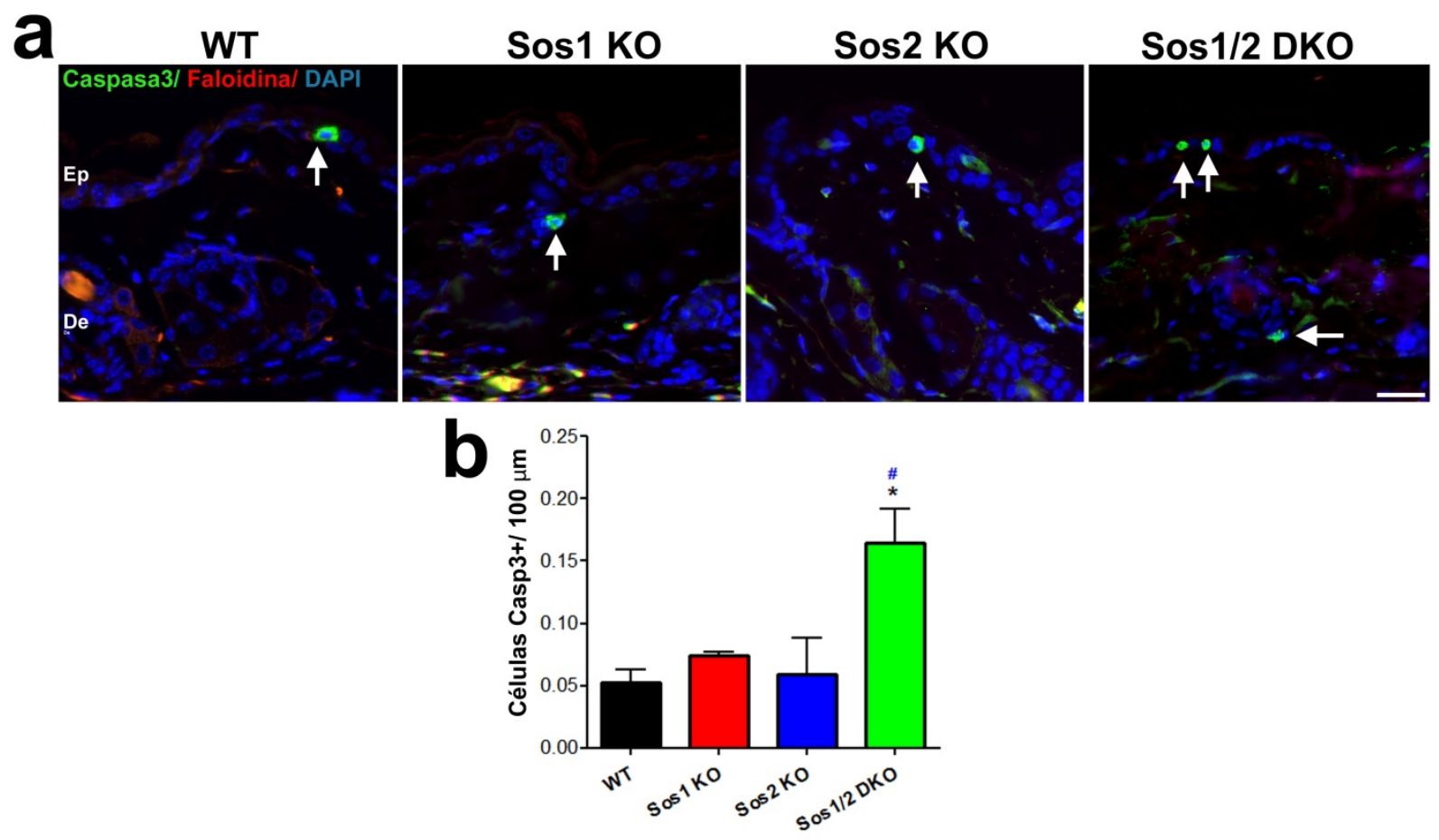

Figura 42. Estudio de la muerte celular tras la aplicación de DMBA. (a) Imágenes de microscopía confocal representativas de la piel de animales WT, Sos1 KO, Sos2 KO y Sos1/2 DKO marcadas para caspasa-3 activa (verde), faloidina (rojo) y DAPI (azul). Las flechas señalan células con marcaje positivo para caspasa-3 activa. Barra de escala: 25 m. (b) Cuantificación del número de células positivas para caspasa-3 activa por cada $100 \mu \mathrm{m}$ de tejido. Las barras de error representan el SEM. Las comparaciones se representaron de la siguiente manera: */\# p< 0.05 vs WT y Sos2 KO, respectivamente. Ep: Epidermis, De: Dermis. 


\subsubsection{Papel de Sos1 y Sos2 en la respuesta inflamatoria}

Se ha descrito el papel crucial de las proteínas Sos en diferentes rutas de señalización implicadas en maduración y activación de células inmunes (Baltanás et al., 2013; Kortum et al., 2011, 2012; Roose et al., 2007). Por ello, decidimos estudiar si la ausencia de una o ambas proteínas Sos podría alterar o modificar la respuesta inflamatoria en la piel.

Debemos recordar (ver "Material y métodos) que la eliminación de Sos1 en los animales Sos1/2 DKO no era completa desde el inicio del experimento, ya que estos experimentos se comenzaron tras 9 días de administración de dieta con TAM y no 12 como en el resto de grupos.

En este caso estudiamos el proceso de respuesta inflamatoria en la piel y de nuevo el efecto en la proliferación, tras la administración tópica de TPA durante 4 días consecutivos (TPA 1-4). La administración de dosis repetidas de TPA genera una hiperplasia en la epidermis, debida a un proceso hiperproliferativo, acompañada de una inflamación aguda mediada principalmente por la infiltración de neutrófilos (Florin et al., 2006).

Puesto que analizamos la respuesta hiperproliferativa tras la administración de una dosis de TPA, también examinamos la tasa de proliferación en este caso. Primeramente cuantificamos el grosor de la epidermis (en relación al proceso hiperplásico) de la piel de animales de los 4 grupos de estudio (Figura 43). Nuestros resultados mostraron que el tratamiento con TPA 1-4 producía un aumento generalizado de entre 2 y 3 veces del grosor epidérmico para cada genotipo, con respecto al estado fisiológico o tras tratamiento TPA 1 (Figura 38b y 38f y Figura 41b y 41c). En las condiciones de tratamiento con TPA 1-4, la ausencia de Sos2 no alteraba el espesor de esta capa con respecto a animales WT (Figura 43a, b y d). Aunque no detectamos diferencias significativas, la ausencia individual de Sos1 parecía atenuar ligeramente este proceso de hiperplasia en relación con los animales WT y Sos2 KO (Figura 43d). Finalmente, a pesar de que el TPA 1-4 causaba un incremento del espesor de la epidermis en los animales Sos1/2 DKO respecto a las condiciones fisiológicas y de TPA1, el grosor de esta capa era notablemente menor que el medido para el resto de genotipos en las mismas condiciones experimentales (Figura 43a, b y d).

A continuación, cuantificamos el número de queratinocitos proliferativos empleando el doble inmunomarcaje para queratinocitos (K-14) y BrdU (Figura 43a y b). Los resultados confirmaron una 
vez más que la eliminación individual de Sos2 no afectaba a la proliferación de estas células con respecto a los animales WT (Figura 43a, b y e). Sin embargo, aunque sin significación estadística, la eliminación de Sos1 disminuía el número de queratinocitos proliferativos con respecto a la epidermis de animales WT y Sos2 KO (Figura 43a, b y e). Por último, la ausencia combinada de Sos1 y Sos2 bloqueaba de una manera muy marcada el efecto hiperproliferativo generado por el tratamiento con TPA 1-4, detectándose un número mucho menor de queratinocitos BrdU-positivos en comparación con el resto de genotipos (Figura $43 a$, b y e).

En tercer lugar, cuantificamos el grosor de la dermis de los animales empleados en este ensayo y observamos que la dermis de animales WT presentaba, al igual que en condiciones fisiológicas (Figura 38 c y 38e), un mayor grosor que la de los animales deficientes para Sos1 (individualmente o en combinación con Sos2). Sin embargo, tras la aplicación de 4 dosis de TPA, la cuantificación del espesor de la dermis en los animales Sos2 KO mostraba una tendencia al aumento con respecto al genotipo WT (Figura 43f). A continuación, evaluamos la respuesta inflamatoria mediada por neutrófilos tras la aplicación de TPA 1-4 mediante la cuantificación del número de células positivas para el inmunomarcaje de la elastasa de neutrófilos, teniendo en cuenta las diferencias del grosor de la dermis encontradas entre los distintos genotipos (Figura 43g). Curiosamente, la eliminación individual de Sos1 no provocaba cambios en el número de neutrófilos con respecto a los animales WT (Figura $43 c$ y f). De forma muy llamativa, el número de neutrófilos en la piel de ratones Sos2 KO tratados con TPA 1-4 era muy superior al del resto de genotipos (Figura 43c y f). Por el contrario, la eliminación de combinada de Sos1 y Sos2 suponía un marcado descenso del número de neutrófilos localizados en la dermis, con respecto al resto de grupos de estudio (Figura $43 \mathrm{c} \mathrm{y} \mathrm{f).}$ 


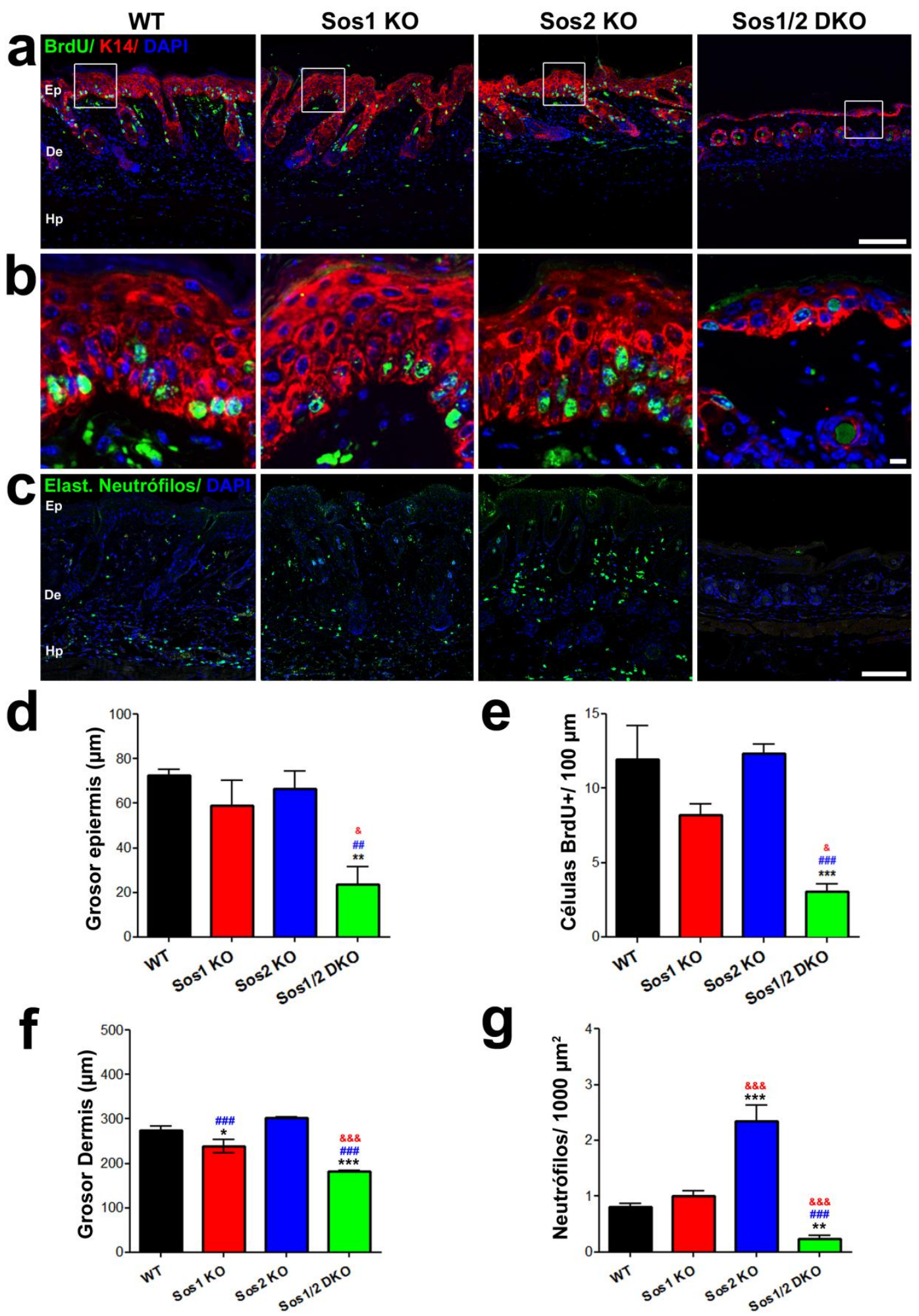

Figura 43. Efectos del TPA 1-4 en proliferación y respuesta inflamatoria aguda. (a) Imágenes de microscopia confocal de la piel de los 4 genotipos marcadas para BrdU (verde), K-14 (rojo) y DAPI (azul). Barra de escala: $100 \mu \mathrm{m}$. Los recuadros indican las regiones aumentadas en (b) (b) Detalle de la epidermis donde se localizan los queratinocitos BrdU-positivos en cada genotipo. Barra de escala: $5 \mu \mathrm{m}$. (c) Imágenes a microscopia confocal de secciones de piel marcadas para la elastasa de 
neutrófilos (verde) y contrateñidas con DAPI (azul). Barra de escala: $100 \mu \mathrm{m}$. (d) Cuantificación del grosor epidérmico de los 4 grupos de estudio. $n=3 /$ genotipo (60 mediciones por individuo). (e) Número de células BrdU positivas en epidermis por cada $100 \mu \mathrm{m}$ de tejido. $\mathrm{n}=3$ /genotipo (3 secciones de piel de cada individuo). (f) Representación del grosor dérmico en los 4 grupos de interés. $\mathrm{n}=3$ /genotipo (30-40 mediciones por individuo). (g) Número de neutrófilos por cada $100 \mu \mathrm{m}$ de tejido en los 4 grupos de estudio. $n=3 / g e n o t i p o ~(3$ secciones de piel de cada individuo). Las barras de error representan el SEM. LaS comparaciones se establecieron: $\& p<0.05$ vs Sos 1 KO, además $* * / \# \# p<0.01$ vs WT y Sos2 KO y ***/\&\&\&/\#\#\# $p<0.001$ vs WT, Sos1 KO y Sos2 KO, respectivamente. Ep: Epidermis, De: Dermis, Hp: Hipodermis.

\subsection{Implicación de Sos1 y Sos2 en el proceso de wound healing}

Del mismo modo que analizamos el WH en MEFs in vitro, nos propusimos analizar este mismo proceso in vivo en la piel de los animales de los 4 genotipos de estudio. El ensayo de WH, o cierre de la herida, in vivo abarca un conjunto de procesos que incluyen proliferación, migración, angiogenesis o respuesta inmune, entre otros (Gillitzer and Goebeler, 2001; Martin, 1997).

Se ha descrito que durante la reparación del daño generado en el WH circular juega un papel importante el proceso de migración de los diferentes tipos celulares implicados (Basu et al., 2001; Evans et al., 2013), mientras que en el ensayo de WH vertical se ha apuntado que el componente proliferativo (células madre de la piel) es crucial para el correcto cierre de la herida (Castilho et al., 2010; Squarize et al., 2010). Por lo tanto, realizamos ambos ensayos para estudiar cada uno de los procesos en detalle.

\subsubsection{Papel de Sos1 y Sos2 en el proceso de remodelación de la piel. WH circular}

Realizamos dos heridas circulares en la piel de la espalda en animales de los 4 genotipos y evaluamos el proceso de cierre de la herida. La cuantificación del cierre de la herida se llevó a cabo midiendo el diámetro de las heridas cada 24 h, durante 10 días consecutivos. En los animales WT, el cierre completo de la herida ocurría transcurridos 10 días desde el comienzo de la herida (Figura 44a y b). Los animales Sos2 KO mostraban una cinética de cierre muy similar al de los WT (Figura 44a y b) e incluso en algunas fases, entre los días 4 y 6 concretamente, coincidiendo con la fase inflamatoria del proceso de $\mathrm{WH}$, detectábamos una tendencia a un cierre de la herida incluso más rápida que la de los WT (Figura 44a). Sin embargo, la evaluación del cierre en animales Sos1 KO reveló una tendencia de retraso en este proceso desde el día 3 tras la herida, que se hizo estadísticamente significativa a partir del día 8, con respecto a los genotipos WT y Sos2 KO (Figura 44a). De hecho, tras 10 días la herida aún no se había cerrado por completo en estos animales (Figura 44a y b). Asimismo, los animales Sos1/2 DKO mostraban los primeros 4-5 días de experimento un comportamiento similar al resto de 
genotipos, probablemente porque la eliminación de Sos1 en estos animales todavía no era completa. A partir del día 7 se produjo un cambio importante en la tendencia de cierre de la herida, retrasándose de forma notoria este proceso respecto al resto de genotipos (Figura 44a y b). Posiblemente, en ese momento la eliminación de Sos1 ya era o estaba cercana a ser completa. Al final del experimento aún restaba por cerrarse un $40 \%$ de la herida en los animales Sos1/2 DKO (Figura).

Para averiguar en qué fase/s concreta/s del cierre de la herida se producían los defectos que impedían la correcta regeneración de la piel en animales Sos1 KO y Sos1/2 DKO, prestamos especial atención al aspecto de las heridas $24 \mathrm{~h}$ después del daño tisular. Observamos que en animales WT (también Sos1 KO y Sos2 KO; datos no mostrados) se formaba una red de fibrina, la cual se encontraba severamente disminuida en animales Sos1/2 DKO (Figura 44c). Este dato sugería que la eliminación combinada de Sos1 y Sos2 afectaba a la primera fase del proceso de WH (hemostasia y coagulación; ver apartado 13 Material y métodos). El seguimiento de las heridas a lo largo del ensayo reveló que los animales de los genotipos WT, así como Sos1 KO y Sos2 KO (datos no mostrados), presentaban una contracción del tejido adyacente a la herida (que se correspondería con la migración de miofibroblastos hacia la herida, así como con la proliferación y migración de queratinocitos) que permitía el cierre de la herida (Figura 44c). Sin embargo, en animales Sos1/2 DKO sólo detectábamos una mínima contracción en la piel adyacente a la herida, que no iba acompañada de una regeneración tisular (Figura 44c).

También analizamos las heridas a los 3 días tras el daño tisular, coincidiendo con la fase inflamatoria e inicio el proceso de proliferación y migración de miofibroblastos. Vimos que los animales WT mostraban una respuesta proliferativa importante en los límites de la herida con un engrosamiento de la epidermis (correspondiente a una proliferación de queratinocitos), un aumento del número de vasos sanguíneos y la formación de una red celular que cubría el área de la herida (Figura 44d). Además, existía un aumento de la celularidad en la dermis, compatible con la proliferación y migración de fibroblastos y células inflamatorias en respuesta al daño (Figura 44d). Por el contrario, los animales Sos1/2 DKO mostraban una epidermis muy delgada, y no se generaba hiperplasia epidérmica en los vértices de la herida (Figura 44d). Tampoco detectamos un número importante de vasos sanguíneos adyacentes ni un incremento de la densidad celular en la dermis (Figura 44d). Además, la red celular que cubría la herida era sustancialmente más delgada que en los animales WT (Figura 44d) lo que apoyaba la idea anterior de una menor proliferación de diferentes tipos de células, 
acompañada de una disminución de la migración celular en ausencia de ambas proteínas Sos (Figura 44a).

Examinamos más en detalle si existía una menor proliferación celular en respuesta a la herida en los animales Sos1/2 DKO. Nuestros resultados mostraron que en ratones WT tenía lugar una fuerte respuesta proliferativa en los vértices de la herida, identificándose células BrdU positivas tanto en dermis como en epidermis (Figura 44d). Sin embargo, esta respuesta proliferativa era prácticamente inexistente en la región equivalente de la piel de los animales Sos1/2 DKO (Figura 44d).

En el caso de los animales Sos2 KO las observaciones realizadas eran equiparables a las de los animales WT (datos no mostrados), mientras que la eliminación individual de Sos1 causaba una respuesta ligeramente menor a la de los animales WT y Sos2 KO, pero no tan marcada como en los animales Sos1/2 DKO (datos no mostrados).

En conjunto, estos resultados sugieren que Sos1 y Sos2 tienen una redundancia funcional en los procesos que suceden en respuesta al WH, aunque debemos señalar que parece que el papel de Sos1 en la participación en estos procesos es más importante que el que ejerce Sos2. 

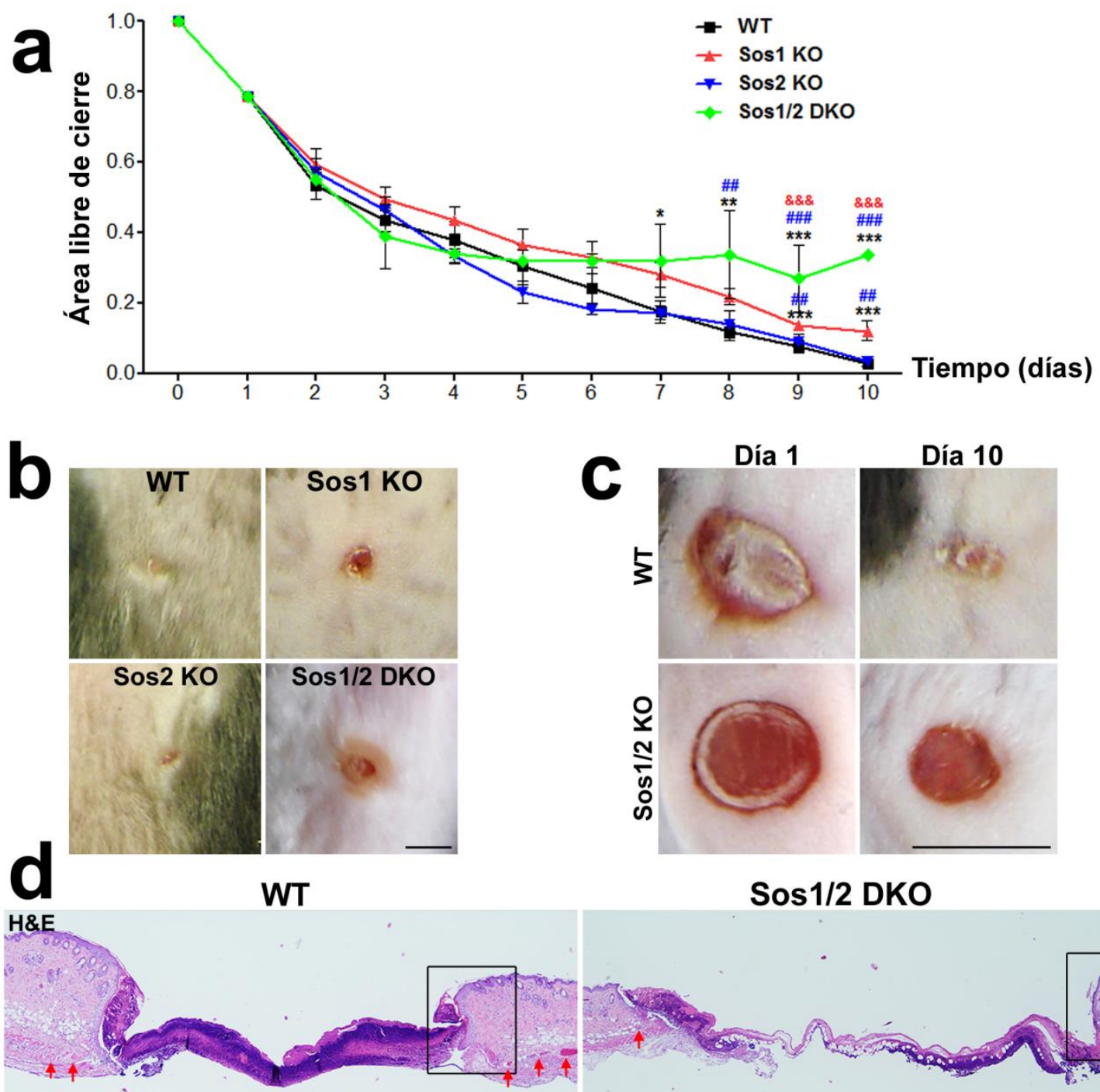

Sos1/2 DKO
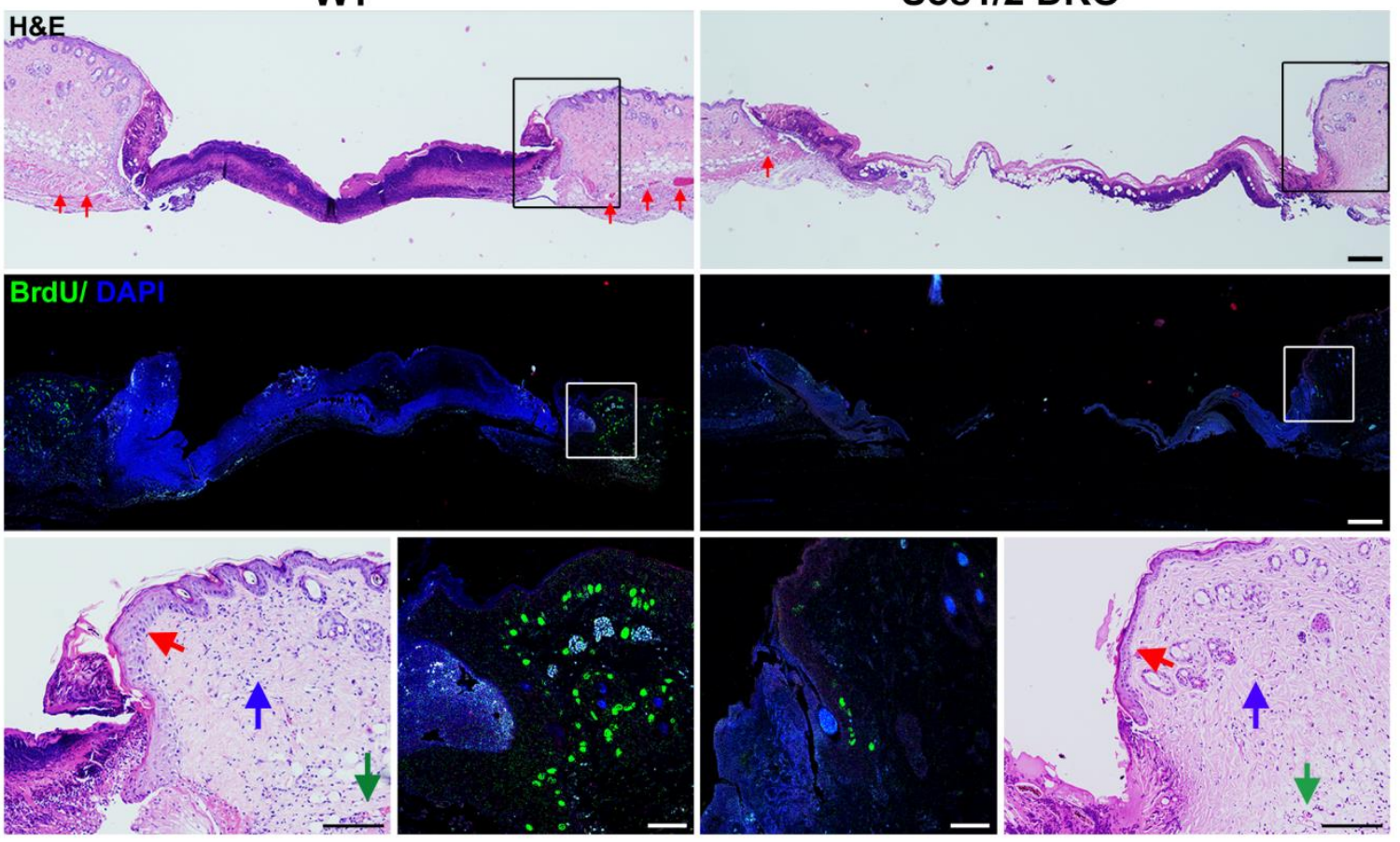
Figura 44. Ensayo de WH circular. (a) Gráfica que representa el área abierta de la herida cada día referido al área inicial

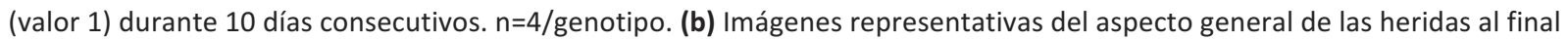
del experimento. Barra de escala: $4 \mathrm{~mm}$. (c) Imágenes de las heridas en animales WT y Sos1/2 DKO tras 1 y 10 días de ensayo de WH. Barra de escala: $4 \mathrm{~mm}$. (d) Imágenes de secciones transversales de piel de animales WT y Sos1/2 DKO 3 días después del WH. La fila superior muestra secciones teñidas para H\&E. Los recuadros delimitan la zona de la piel aumentada más inferior. Nótese que la cantidad de vasos sanguíneos era mucho mayor en el WT que en el Sos1/2 DKO (flechas rojas). Barra de escala: $100 \mu \mathrm{m}$. La fila media muestra imágenes de esas mismas secciones marcadas para BrdU (verde) y DAPI (azul). Barra de escala: $100 \mu \mathrm{m}$. La fila inferior muestra el aumento de las imágenes anteriores donde vemos el engrosamiento epidérmico (flechas rojas), la densidad celular en la dermis (flechas azules) y los vasos sanguíneos adyacentes a la lesión (flechas verdes). También mostramos imágenes con la tinción BrdU/DAPI en la piel de los genotipos WT (izquierda) y Sos1/2 DKO (derecha). Barras de escala: $500 \mu \mathrm{m}$ y $25 \mu \mathrm{m}$, respectivamente. Las barras de error representan el SEM. Las comparaciones se establecieron del siguiente modo: * $\mathrm{p}<0.05$ vs WT, además **/\#\# $p<0.01$ vs WT y Sos2 KO y ***/\&\&\&/\#\#\# $\mathrm{p}<0.001$ vs WT, Sos1 KO y Sos2 KO, respectivamente.

\subsubsection{Importancia de Sos1 y Sos2 en la regeneración cutánea. WH vertical}

En otro set de animales de los 4 genotipos realizamos un corte vertical de $1.5 \mathrm{~cm}$ en la piel de la espalda y analizamos el proceso de este tipo de herida, midiendo diariamente los ejes vertical y horizontal de la herida durante 10 días.

Tomamos como referencia del proceso de regeneración tisular en los animales WT, donde observamos una disminución progresiva del área de la lesión durante el experimento, cerrándose la herida por completo trascurridos 10 días (Figura 45a). Del mismo modo, los animales Sos2 KO mostraban una cinética de cierre de la herida muy similar a los animales WT, e incluso en algún punto del ensayo (días 3, 4 y 5, parte de la fase inflamatoria, ver Material y métodos) detectábamos un proceso de cierre algo más rápido respecto a los animales WT (Figura 45a). De forma similar a lo observado en el WH circular, los animales Sos1 KO mostraban cierto retraso en el cierre de la herida comparada a los genotipos WT y Sos2 (Figura 45a), aunque el cierre se completaba en el mismo espacio temporal que el de los animales WT y Sos2 KO (Figura 45a). Por último, la ausencia combinada de las proteínas Sos, provocaba un retraso significativo en el cierre de la lesión con respecto a animales WT y Sos2 KO en diferentes puntos del ensayo (días 4, 9 y 10). Al final del experimento, a diferencia del resto de genotipos, los animales Sos1/2 DKO no eran capaces de regenerar el tejido dañado (Figura 45a).

Una vez finalizado el experimento, aislamos la piel de la zona de interés y estudiamos la histología de la zona de la herida en los 4 genotipos de interés. En los animales WT observamos que la piel de los bordes de la herida había recuperado la capa muscular y todas las capas de la piel (hipodermis, dermis y epidermis; Figura 45b). En el caso particular de la epidermis detectamos un ligero engrosamiento en el lugar del daño generado (Figura 45b). Además, observamos una nueva 


\section{Resultados}

generación los folículos pilosos en la dermis alrededor de la zona de la herida (Figura 45b). En la parte central de la herida, la epidermis mostraba una disposición diferencial de sus capas, desde el estrato basal hasta el estrato corneo, observándose una importante proliferación del estrato espinoso de la epidermis (acantosis), y un aumento importante de la queratina en el estrato corneo (queratosis; Figura 45b). Ambos procesos son característicos de un proceso hiperproliferativo. El aumento del grosor epidérmico de esta región, suponía aproximadamente el doble del espesor de la epidermis adyacente. En conclusión, el proceso de cierre de la herida en los animales WT se encontraba en la fase de reepitelización (ver Material y métodos), ya que las capas de la piel en los bordes de la herida se habían recuperado hasta la práctica normalidad y en la parte más dañada de la herida (zona central) se detectó una fase de regeneración que probablemente correspondía con la fase de proliferación (Figura 45b).

La regeneración cutánea en los animales Sos2 KO se produjo de forma prácticamente idéntica a los animales WT, tanto en las zonas de los extremos como en la zona central de la herida (Figura 45b). En cuanto a los animales Sos1 KO, éstos mostraban una recuperación del músculo y de las capas de la piel en los extremos de la herida, casi equivalente a la observada en animales WT y Sos2 KO (Figura 45b). Aunque debemos señalar que el restablecimiento de las capas de la piel no incluía una regeneración de folículos pilosos tan clara como la observada en los genotipos WT y Sos2 KO (Figura 45b). Además, la zona central de la herida mostraba un claro proceso de respuesta al daño tisular en el que estaría implicado el proceso migratorio y proliferativo reflejado en un aumento de la celularidad de la dermis, acompañado de un aumento de vasos sanguíneos. También observamos una intensa acantosis así como una importante acumulación de queratina (hiperqueratosis; Figura 45b). Posiblemente, esta respuesta podría pertenecer a una fase de regeneración tisular anterior (fase inflamatoria) a la observada en las zonas centrales de la herida de animales WT y Sos2 KO (Figura 45b).

Finalmente, el cierre de la herida en los animales Sos1/2 DKO resultó sustancialmente diferente a la del resto de genotipos. Por una parte, observamos que en las zonas de los extremos de la herida no existía regeneración de la capa muscular (Figura 45b). Además, la pérdida de la hipodermis descrita ya en condiciones fisiológicas (apartado 5.2.1) hacía imposible la recuperación de esta capa durante este proceso (Figura 45b). Aun así, observamos una cierta proliferación en la epidermis (que mostraba un proceso claro de acantosis e hiperqueratosis), aunque no iba acompañada de una 
recuperación de los folículos pilosos (Figura 45b). Asimismo, el análisis histológico de la zona central de la herida reveló una recuperación tisular muy deficiente, ya que no se habían unido ambos extremos de la herida a través de ninguna capa epitelial, sino que vértices permanecían independientes, únicamente ensamblados por una capa de queratina y componentes del proceso de coagulación (Figura 45b).

Estos resultados en conjunto describen una redundancia funcional de ambas proteínas Sos en este proceso de $\mathrm{WH}$, ya que cada isoforma Sos remplaza (de forma parcial o total) la ausencia de la otra en este proceso. En cambio, la ausencia conjunta de Sos1 y Sos2, provoca un defecto importante en la reparación cutánea, lo que otorga a las proteínas Sos un papel crucial en el proceso de regeneración tisular. 


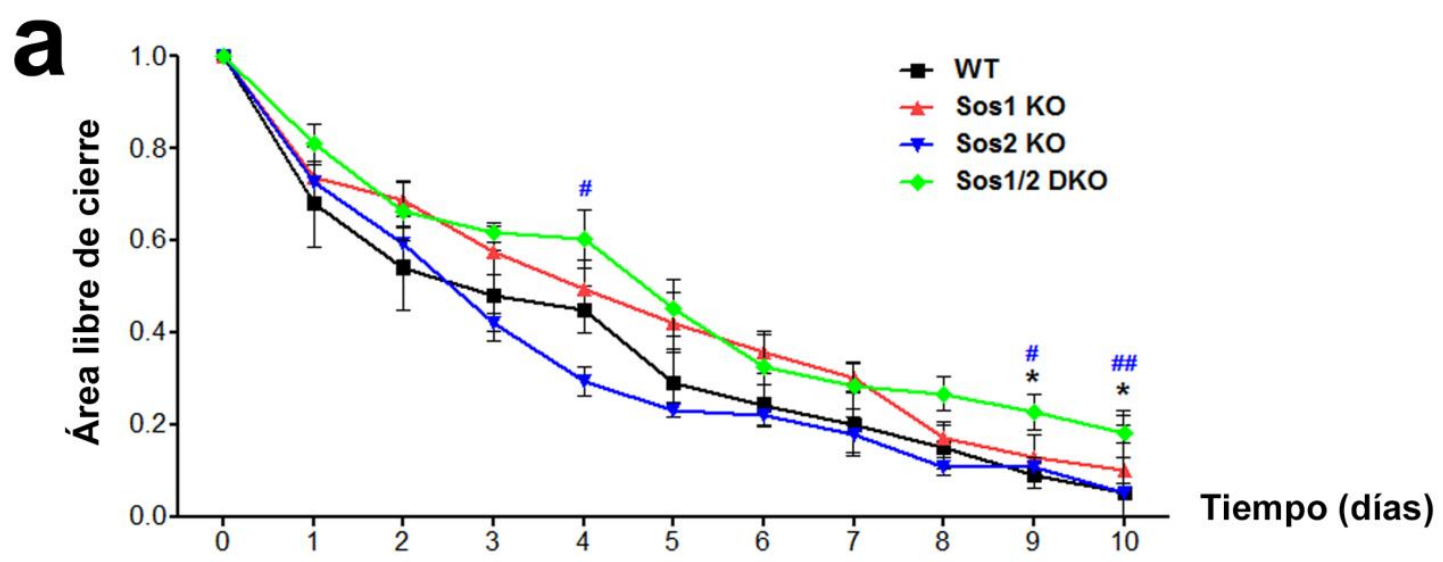

b
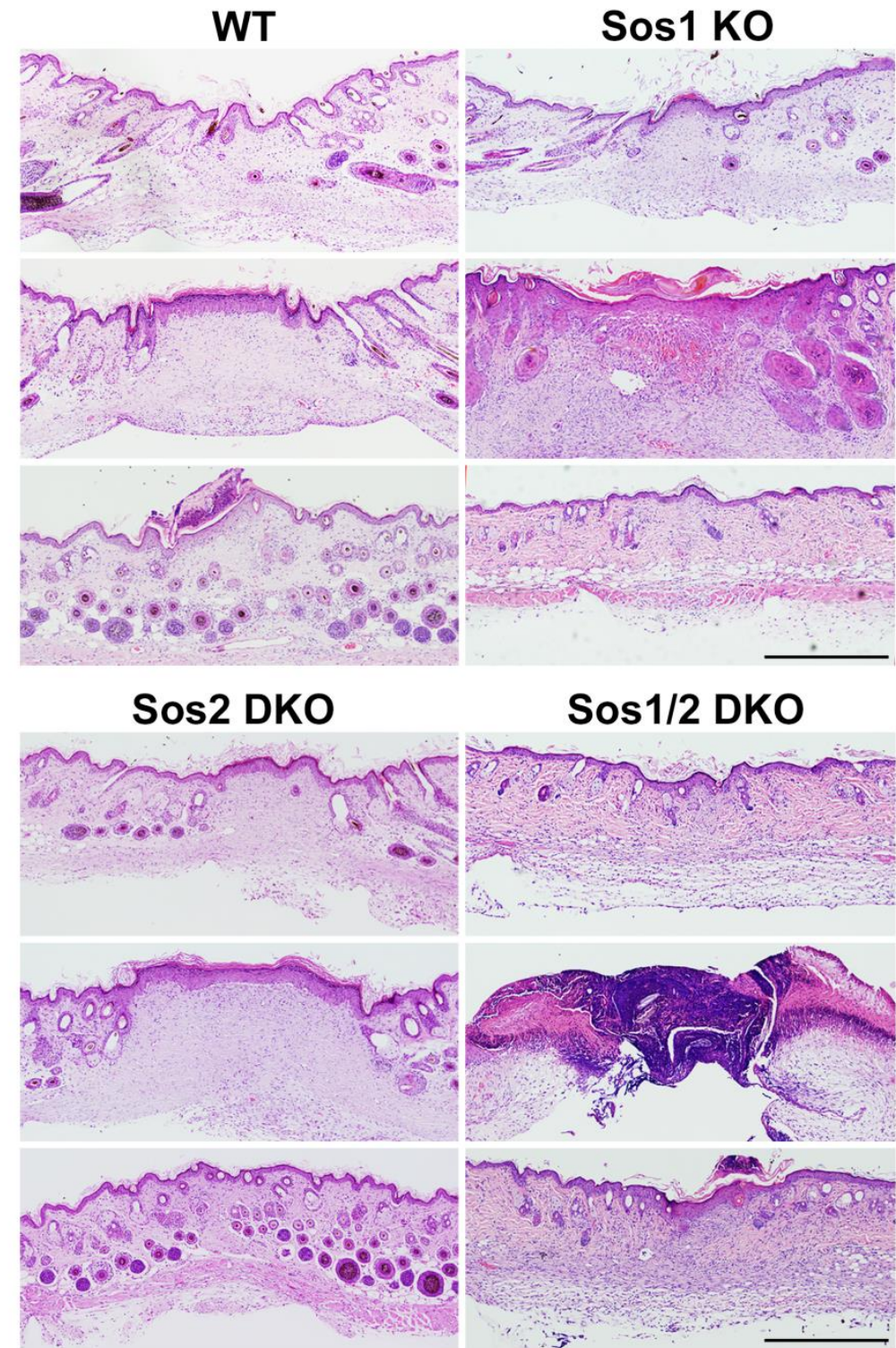
Figura 45. Estudio del proceso de WH vertical. (a) Cuantificación del área abierta de la lesión en cada día del estudio, referida al área inicial de la lesión (valor 1 ) durante 10 días consecutivos. $n=4 /$ genotipo. (b) Imágenes representativas de secciones transversales de la piel de animales de los 4 grupos marcadas con H\&E tras 10 días de proceso de cierre de la herida. La parte superior e inferior de cada genotipo, pertenecen a los extremos de la herida, mientras que la imagen central es original de la región central de la herida. Barras de escala: $500 \mu \mathrm{m}$.

\section{Papel de Sos1 y Sos2 en un modelo de carcinogénesis epitelial inducida}

En los apartado anterior hemos descrito la importancia de las proteínas Sos en la homeostasis de la piel en condiciones fisiológicas y tras un daño tisular. Trabajos previos han relacionado a Sos1 con diferentes tumores humanos (Jongmans et al., 2010; Sini et al., 2004; Watanabe, Nobuo Shinohara, Kimihiko et al., 2000). Además, se sabe que la activación constitutiva de Sos1 en epidermis, provoca la aparición de papilomas con un 100\% de penetrancia (Sibilia et al., 2000), lo que sugiere un papel importante de las proteínas Sos en el proceso tumoral en la piel. Por lo tanto, decidimos estudiar el posible potencial de las proteínas Sos como dianas terapéuticas en tumores de piel.

Para ello, empleamos el modelo de carcinogénesis química DMBA-TPA que genera tumores epiteliales de célula escamosa. Este modelo recapitula fielmente el desarrollo de CCE en humanos (Pérez-Losada and Balmain, 2003).

En concreto, estudiamos mediante el modelo de carcinogénesis inducida por DMBA-TPA el efecto de la ausencia de las proteínas Sos en el inicio y la progresión tumorales (modelo 1) y en tumores ya previamente establecidos (modelo 2, ver Material y métodos).

\subsection{Modelo 1: Importancia de las proteínas Sos en el inicio y progresión tumorales}

Los resultados obtenidos en animales que siguieron el modelo 1 de aplicación del protocolo DMBATPA (ver Material y métodos) permitieron determinar la función de Sos1 y Sos2 en el inicio y progresión de tumores cutáneos inducidos por el sistema DMBA-TPA.

\subsubsection{La ausencia de Sos1 retrasa el inicio y la progresión tumoral}

En primer lugar, empleando el modelo 1 de carcinogénesis analizamos el efecto de la ausencia de expresión de Sos1 o Sos2 en el inicio y la progresión tumoral. Nuestros resultados evidenciaron que la ausencia individual de Sos2 no influía en el inicio tumoral respecto a los animales WT. En ambos genotipos este suceso acontecía alrededor de la semana 12 tras el incio del protocolo DMBA-TPA 


\section{Resultados}

(Figura 46c). Además, el porcentaje de ratones que mostraban tumores era muy similar en ambos genotipos a lo largo del estudio (Figura 46c). Por otra parte, la aparición de los primeros tumores en el animales Sos1 KO se veía retrasada respecto a los genotipos anteriores, ocurriendo 2-3 semanas después que en los grupos WT y Sos2 KO (semana 14-15, Figura 46c). De hecho, durante casi todas las fases del estudio, el porcentaje de ratones Sos1 KO que presentaban tumores era menor en comparación con los animales WT y Sos2 KO (Figura 46c). Debemos señalar que, a diferencia del resto de los genotipos, los animales Sos1/2 DKO recibieron la administración de TAM a partir de la semana 28 de estudio. Por lo tanto, durante las semanas anteriores a la aplicación de TAM estos animales se consideraron "Sos1/2 DKO inducibles" siendo de facto durante todo ese tiempo, deficientes solamente para Sos2. Observamos que el inicio tumoral en estos animales "Sos1/2 DKO inducibles" era incluso anterior al resto de genotipos (Figura 46c). Probablemente, esta diferencia se deba al efecto citostático que tiene el TAM en el resto de los genotipos.

A medida que el tratamiento avanzaba, el número de tumores por ratón se incrementaba en todos los genotipos de estudio (Figura $46 \mathrm{~d}$ y e). En concreto, nuestros resultados indicaban que el número de tumores, a lo largo de todo el estudio, era muy similar entre los genotipos WT y Sos2 KO (Figura 46d). Sin embargo, la ausencia de Sos1 en los animales Sos1 KO provocaba que el número de tumores fuese menor respecto a los animales WT y Sos2 KO (Figura 46d). Cabe resaltar que el número de tumores por ratón en los animales "Sos1/2 DKO inducibles" era ligeramente superior, de forma significativa entre las semanas 10-20 de estudio, al resto de genotipos (Figura 46d-e). Sin embargo, tras la administración de TAM (semana 28) el número de tumores por ratón se reducía, llegando a valores muy similares a los del grupo Sos1 KO (Figura $46 \mathrm{~d}$ y e).

Cuantificamos también el área de los tumores en todos los grupos de estudio a lo largo del tratamiento (Figura $46 \mathrm{f} \mathrm{y} \mathrm{g).} \mathrm{Mientras} \mathrm{que} \mathrm{el} \mathrm{área} \mathrm{tumoral} \mathrm{en} \mathrm{los} \mathrm{grupos} \mathrm{WT} \mathrm{y} \mathrm{Sos2} \mathrm{KO} \mathrm{era} \mathrm{muy} \mathrm{similar}$ en todas las fases del estudio, el crecimiento de los tumores resultó ser significativamente menor en el grupo Sos1 KO con respecto a animales WT y Sos2 KO (Figura $46 \mathrm{f} \mathrm{y} \mathrm{g).} \mathrm{De} \mathrm{forma} \mathrm{similar} \mathrm{a} \mathrm{lo} \mathrm{descrito}$ en los párrafos anteriores, el tamaño tumoral en animales "Sos1/2 DKO inducibles" durante las primeras 28 semanas del tratamiento era similar, e incluso ligeramente superior al de resto de genotipos (Figura $46 \mathrm{f}$ y g). Sin embargo, tras la administración del TAM (ya lo definimos como animal Sos1/2 DKO) el área tumoral se reduce, mostrando al final del estudio valores similares a los del grupo Sos1 KO (Figura $46 f$ y g). 
En conjunto, estos resultados indican que Sos1 juega un papel importante tanto en el inicio como en la progresión tumoral.
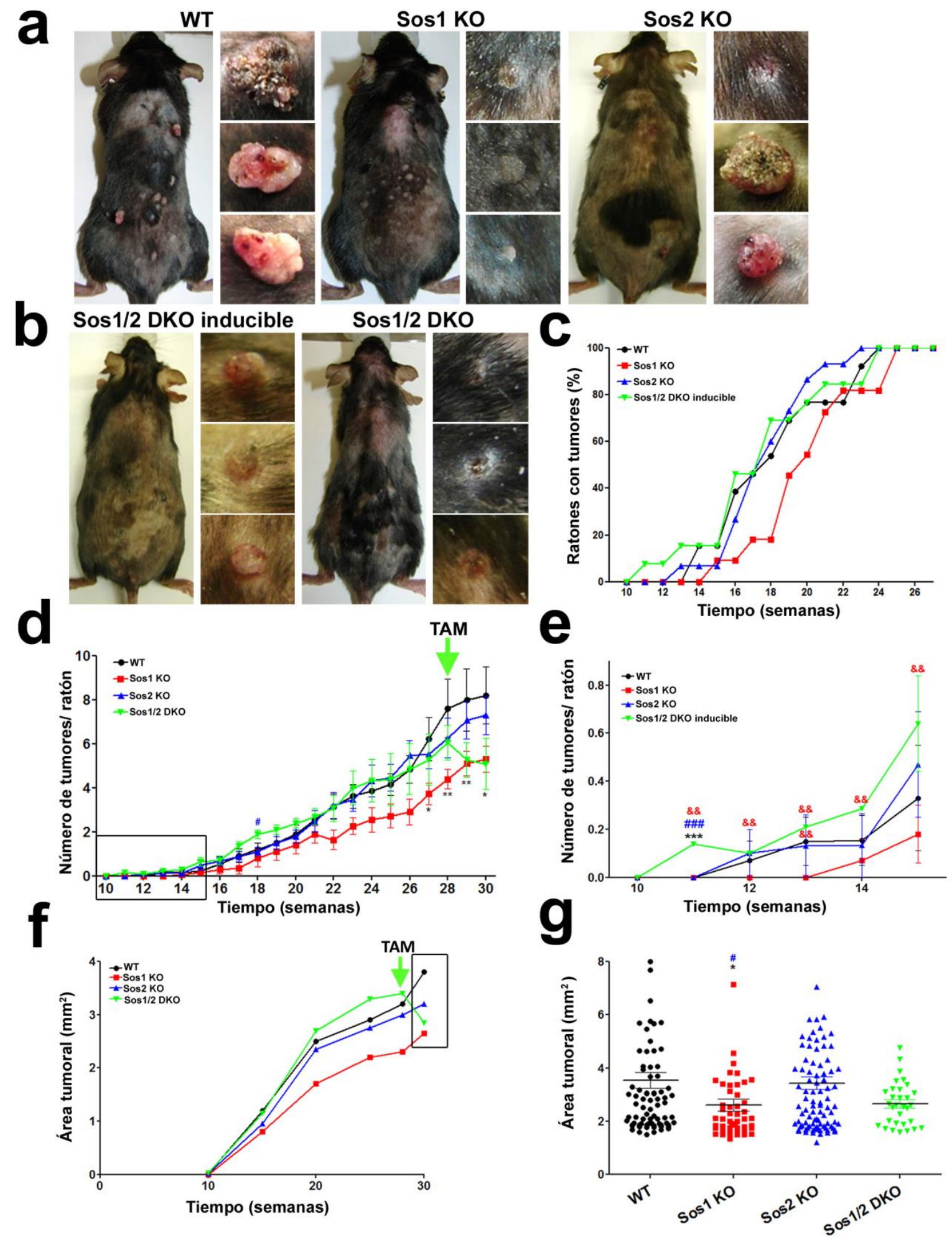
Figura 46. La eliminación de Sos1 retrasa el inicio y la progresión tumoral. (a) Imágenes representativas de animales WT, Sos1 KO y Sos2 KO, y de los tumores generados en estos animales tras 30 semanas de DMBA-TPA. (b) Imágenes representativas de animales "Sos1/2 DKO inducibles" y Sos1/2 DKO y los tumores generados. (c) Porcentaje de ratones de cada genotipo que presentan al menos un tumor, en relación con el número de animales totales empleados para cada genotipo. (d) Gráfico que representa el número de tumores por ratón en cada uno de los genotipos durante 30 semanas. El recuadro indica un aumento de esta gráfica en los tiempos indicados en el apartado (e). La flecha señala el momento en el que se aplica el TAM al grupo Sos1/2 DKO. (f) Evolución del área tumoral en cada uno de los grupos de estudio durante las 30 semanas. El recuadro indica el tamaño tumoral en el tiempo 30 semanas, representado en la gráfica (g). (c-g) n=13 (WT y Sos1/2 DKO), $n=11$ para Sos1 KO y $n=15$ para Sos2 KO. Las barras de error representan el \pm SEM. Las comparaciones se establecieron del siguiente modo: */\# $p<0.05$ vs WT y Sos2 KO, además $* * / \& \& p<0.01$ vs. WT y Sos1 KO y ***/\#\#\#/\&\&\&p< 0.001 vs. WT, Sos1 KO y Sos2 KO, respectivamente.

\subsubsection{Sos1 y Sos2 son necesarias para el desarrollo de carcinomas de célula escamosa}

A continuación, nos propusimos analizar el tipo tumoral específico generado para cada genotipo. Para la identificación y caracterización de los distintos tipos tumorales nos basamos en distintas características anatomo-patológicas que describimos a continuación.

Los tipos de tumor se caracterizaron en base al grado de acantosis, papilomatosis, grado de hiperplasia de glándulas sebáceas, la conservación de la estructura de las capas de la piel y la aparición de atipias celulares. En concreto, los tumores generados en los distintos genotipos fueron clasificados como:

- Papiloma grado 1 (P1): tumor epitelial benigno que presentaba una acantosis de aproximadamente 4 capas de queratinocitos. Se caracteriza por la formación de proyecciones en forma de papila hacia la dermis, que clasificamos histológicamente en función del número de filas de queratinocitos en los estratos basal y espinoso de la epidermis, en este caso 7-8. Estas lesiones preservaban la estructura de todas las capas de la piel y carecían de atipias celulares (Figura 47a).

- Papiloma grado 2 (P2): este grupo de lesiones presentaban un aumento de la acantosis (6 filas de queratinocitos) y de la papilomatosis (10 capas de queratinocitos) con respecto al estadio anterior, aunque conservaban la arquitectura de la piel y no presentaban atipias celulares (Figura 47a).

- Papiloma grado 3 (P3): el grado de acantosis y papilomatosis se muestra similar al P2, pero tiene lugar un aumento importante del tamaño debido a la acumulación de estructuras verrugosas y un importante acúmulo de queratina. Este grado tumoral mantiene la estructura de las capas de la piel, de igual manera que en estadios previos, además carece de atipias celulares características de una lesión maligna (Figura 47a) 
- Queratoacantoma (Q): este tipo de lesión pre-maligna se caracteriza por una acantosis muy severa (10-15 filas de queratinocitos) formando estructuras que englobaban grandes acúmulos de queratina. Se produce una invasión de la dermis por parte de estructuras epidérmicas acompañada de una importante pérdida de la hipodermis. Aunque el grado histológico es mayor que en las lesiones anteriores, no existen atipias celulares en este tipo de tumores. Estas lesiones a menudo pueden sufrir un proceso de necrosis que supone su desaparición, pero en otras ocasiones evolucionan hacia CCE (Figura 47a).

- Carcinoma de célula escamosa (CCE): tumor maligno (presencia de atipias celulares) que presentaba severa acantosis y papilomatosis acompañada de una pérdida de la conservación de las capas de la piel. Tenía lugar una invasión por parte de las células tumorales del tejido subyacente (dermis, hipodermis y músculo; Figura 47a).

- Adenomas sebáceos grado 1 (A1): lesión benigna y por lo tanto, carente de atipias celulares, de origen sebáceo que mostraba un aumento (8 filas) del número y el tamaño de las glándulas sebáceas. El aumento de las glándulas sebáceas en la dermis, hacía que esta disminuyera, sin embargo la estructura de la hipodermis permanecía conservada (Figura 47b).

- Adenomas sebáceos grado 2 y 3 (A2 y A3): lesión tumoral benigna resultante de la evolución de A1 debido al aumento de células sebáceas (10-12 filas), igualmente no presentaba atipias celulares. EI incremento y la elongación de las estructuras sebáceas hiperplásicas generaba una disminución severa de la dermis acompañada de una disminución de la hipodermis (Figura 47b).

La cuantificación de los distintos tipos tumorales catalogados reveló que en los animales WT, alrededor del $60 \%$ de los tumores eran papilomas (Figura 47c). También se detectaron, aunque con muy baja frecuencia, queratoacantomas y CCE (Figura 47c). El resto de tumores generados, aproximadamente un $30 \%$ del total de tumores, se identificaron como benignos de origen sebáceo (Figura 47c).

Por otra parte, los animales Sos1 KO, Sos2 KO y Sos1/2 DKO desarrollaron en su mayor parte papilomas (80-85\%; Figura 47c). Además, alrededor de un 15-20\% de los tumores, resultaron lesiones benignas de glándula sebácea (Figura 47c). A diferencia de lo observado en animales WT, en ninguno de los genotipos Sos1 KO, Sos2 KO y Sos1/2 DKO detectamos CCE (Figura 47c). Debemos señalar que 


\section{Resultados}

mientras que en los grupos Sos2 KO y Sos1/2 DKO se observaron queratoacantomas (estadio tumoral previo a la generación de un tumor maligno) en un pequeño porcentaje (2-3\%), los animales Sos1 KO no presentaban tumores de este grado (Figura 47c).

Asimismo, cuando comparábamos únicamente los distintos tipos de tumores benignos en los 4 grupos de interés, observamos que en los ratones WT, el porcentaje de papilomas se dividía equitativamente entre papilomas de alto y bajo grado (Figura 47d), mientras que la mayoría de tumores sebáceos estaba representada por adenomas de bajo grado (Figura 47d). Los animales Sos1 KO, Sos2 KO y Sos1/2 DKO mostraban un reparto similar de papilomas de bajo (60\%) y alto grado (40\%) (Figura 47d). Además, alrededor de un $12-15 \%$ de las lesiones benignas de los grupos Sos1 KO y Sos2 KO resultaron adenomas de bajo grado, siendo aproximadamente el 2-3\% restante adenomas de alto grado (Figura 47d). Sin embargo, el porcentaje de adenomas de bajo grado era menor en el grupo Sos1/2 DKO (Figura 47d) aumentando el porcentaje de adenomas de alto grado respecto a los grupos Sos1 KO y Sos2 KO (Figura 47d).

En conjunto, estos resultados concluyen que la ausencia de expresión de las proteínas Sos previene el desarrollo de tumores malignos de origen escamoso. Además, el grado patológico de los papilomas generados era menor que en el caso de los grupos WT. 


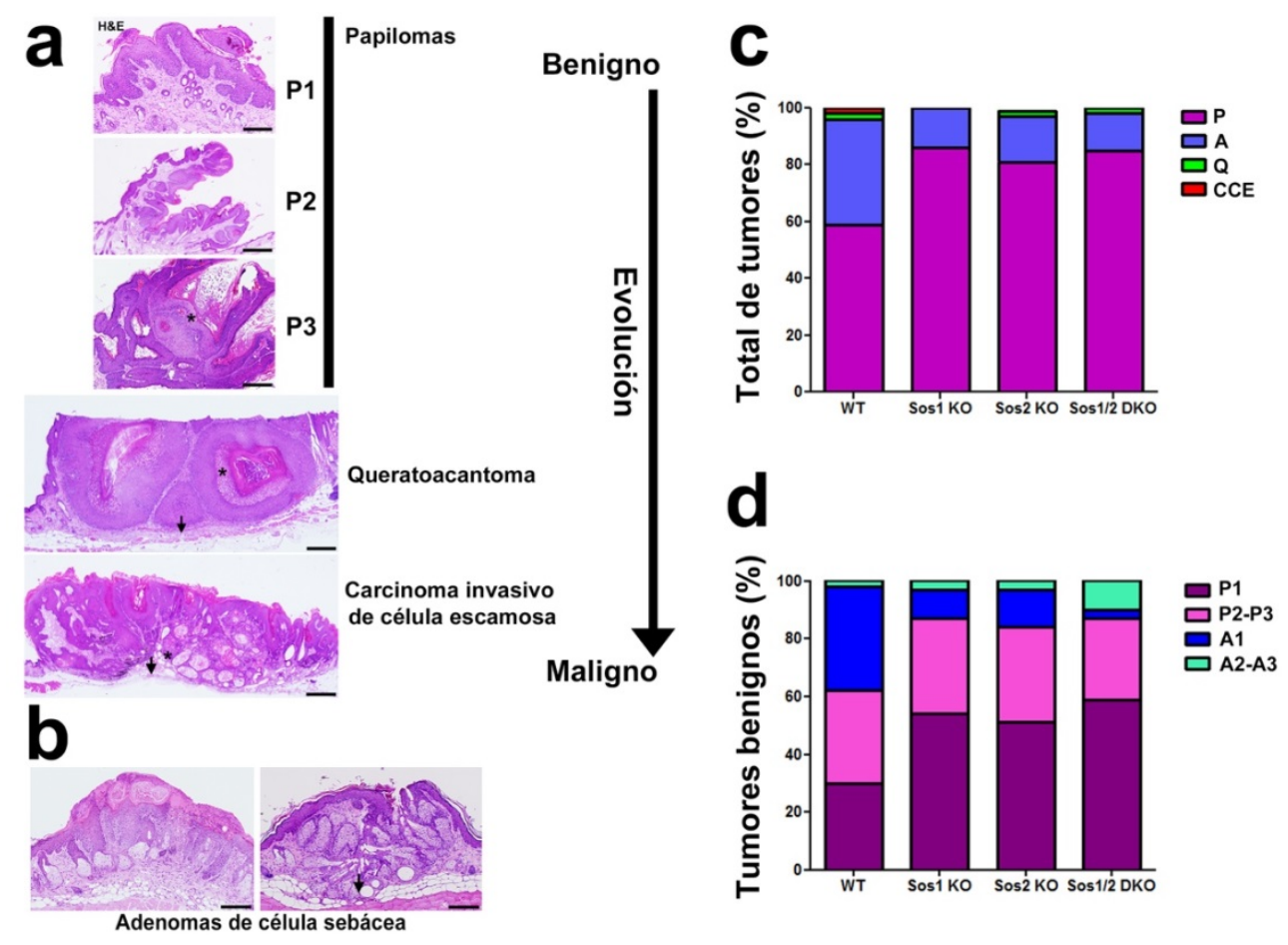

Figura 47. Caracterización y cuantificación de los tumores generados en el modelo 1. (a) Secciones de tumores teñidos con H\&E. Representación del grado tumoral, desde papilomas de bajo grado hasta CCE. En P3 detectamos la formación de estructuras epidérmicas con alta queratinización (asterisco). En el querantoacantoma observamos disminución de la dermis e hipodermis (flecha), y estructuras epidérmicas que encierran acúmulos de queratina (asterisco). En el CCE detectamos invasión de la dermis e hipodermis por parte de la lesión tumoral (flecha), acompañada de una pérdida de la capa muscular y la aparición de estructuras con queratinocitos atípicos (asterisco). Barras de escala: P1=200 $\mu \mathrm{m}, \mathrm{P} 2-\mathrm{P} 3=500 \mu \mathrm{m}$ y Q y $\mathrm{CCE}=2 \mathrm{~mm}$. (b) Secciones de adenomas sebáceos de bajo grado (izquierda) y alto grado (derecha). Detectamos la invasión de la hipodermis por parte del adenoma sebáceo (flecha). Barras de escala: $200 \mu \mathrm{m}$. (c) Gráfica que representa el porcentaje de tipos tumorales respecto al total de tumores para cada genotipo. P: Papilomas, A: Adenomas sebáceos, Q: queratoacantomas y CCE: carcinomas de célula escamosa. (d) Distribución de los tumores benignos expresado en porcentaje para cada genotipo. P1: papilomas de bajo grado, P2-P3: papilomas de alto grado, A1: adenomas de bajo grado y A2-A3: adenomas de alto grado.

\subsubsection{La ausencia de Sos1 reduce la capacidad de proliferación de queratinocitos en}

\section{tumores}

Los resultados anteriores reflejaban una reducción en el número, tamaño y malignidad de los tumores en los animales ausentes de expresión de las proteínas Sos. Nos propusimos analizar que mecanismos eran responsables de estos fenotipos. Para ello, analizamos la capacidad de proliferación y el nivel de apoptosis en distintos tipos celulares en tumores del mismo grado en los 4 grupos experimentales.

En primer lugar analizamos la capacidad de proliferación celular en el tumor. Para ello, cuantificamos el número de células BrdU-positivas en papilomas de un grado tumoral similar de los 4 grupos de 
estudio. En concreto, se cuantificaron los queratinocitos marcados para K-14 positivos para BrdU de la capa basal de la epidermis y de la epidermis interfolicular (Figura 48a).

Nuestros resultados demostraron que la tasa de proliferación de queratinocitos en los papilomas de animales Sos2 KO era similar a la de tumores comparables de animales WT (Figura 48b). Sin embargo, el grado de proliferación en papilomas de animales Sos1 KO y Sos1/2 DKO era significativamente menor en comparación con los tumores WT (Figura 48b).

Estos datos sugieren que la ausencia de Sos1, pero no de Sos2, provoca una reducción de la capacidad proliferativa en el tumor.

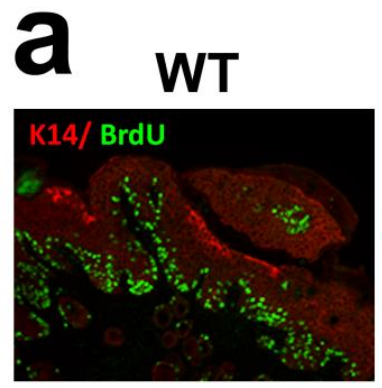

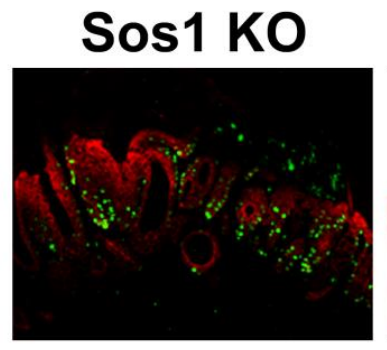

Sos2 KO

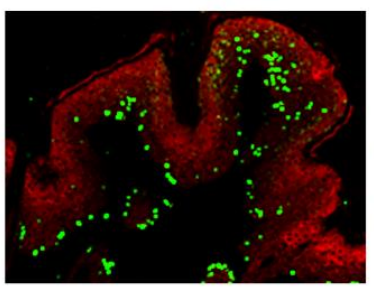

b

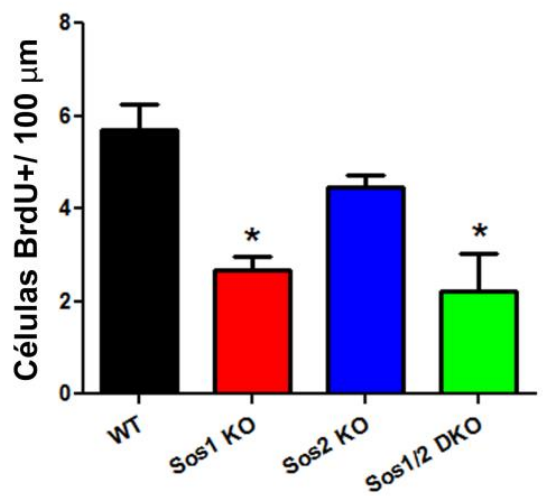

Figura 48. La ausencia de Sos1 reduce la proliferación de las células tumorales. (a) Secciones de tumores de un grado semejante de desarrollo (papilomas grado 1-2), marcados para K14 (rojo) y BrdU (verde). Barra de escala: $50 \mu \mathrm{m}$. (b) Cuantificación del número de células BrdU positivas por cada $100 \mu \mathrm{m}$. $\mathrm{n}=7$ (WT y Sos1 KO) y $\mathrm{n}=5$ (Sos2 KO y Sos1/2 DKO). Las barras de error representan el SEM. Las comparaciones se representaron de la siguiente manera: ${ }^{*} p<0.05$ vs WT.

\subsubsection{Aumento de la apoptosis en tumores deficientes de Sos1 y Sos2.}

A continuación, investigamos si la ausencia de Sos1 y/o Sos2 afectaba a la supervivencia de uno o varios tipos celulares en el tumor. Analizamos y cuantificamos la tasa de muerte celular por apoptosis 
(células positivas para la caspasa-3 activa) en todas las capas de la piel de los tumores (papilomas de similar grado) de los 4 genotipos de estudio (Figura 49a y b).

Nuestros resultados demostraron que los tumores de los animales WT apenas contenían células positivas para la caspasa-3 activa (Figura 49b). De forma muy similar, la ausencia individual de Sos1 o Sos2 causaba, de forma muy esporádica, la muerte celular por apoptosis en células de los papilomas (Figura 49a y b). Sin embargo, aunque en un número bajo, la ausencia simultanea de Sos1 y Sos2 inducía un incremento significativo de la apoptosis en comparación con el resto de genotipos de estudio (Figura 49b).

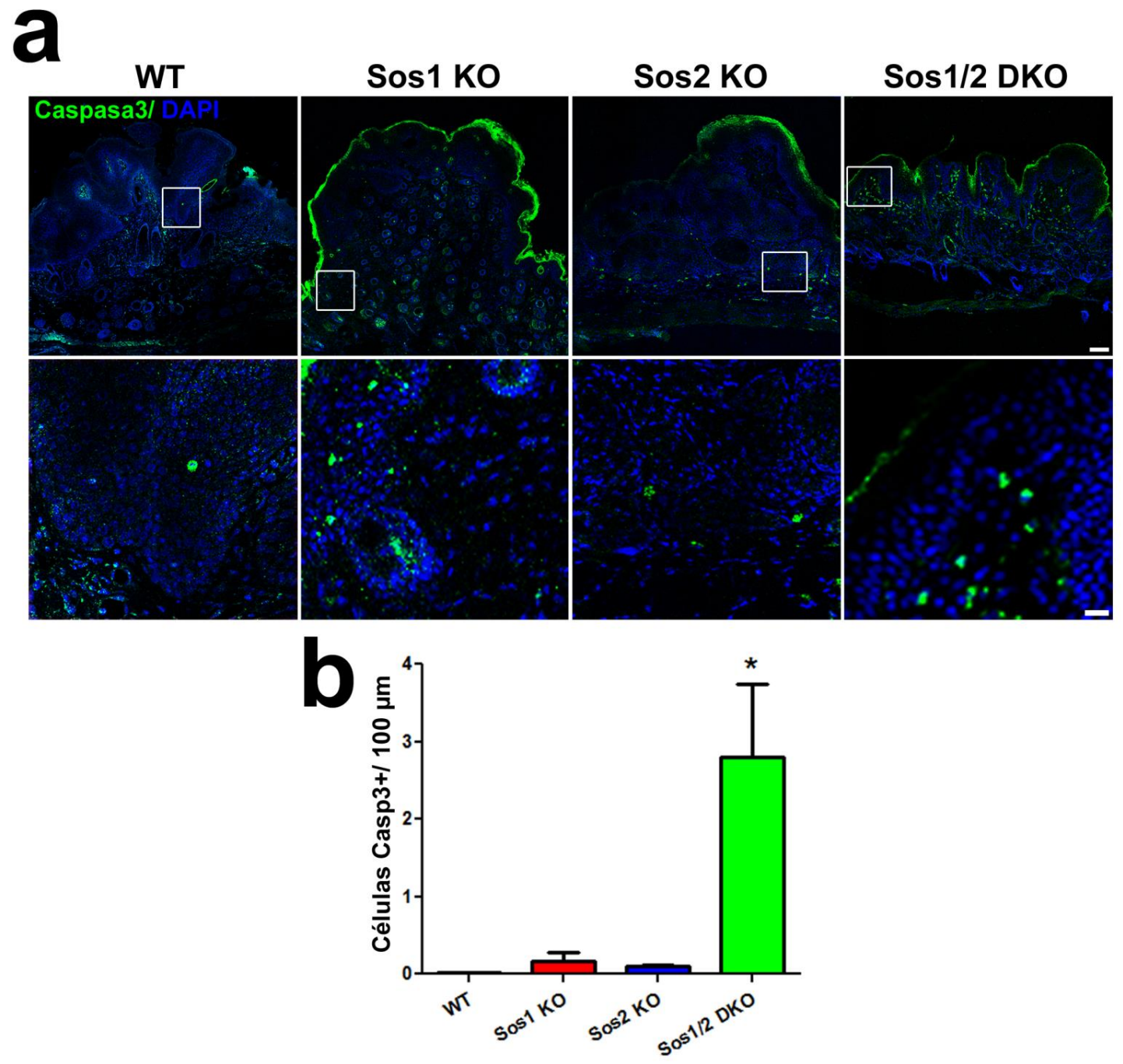

Figura 49. Análisis de muerte celular en tumores de los $\mathbf{4}$ grupos de estudio. (a) Imágenes de microscopia confocal de tumores marcados con caspasa-3 activa (verde) y contrateñidas con DAPI (azul). Barras de escala: $100 \mu \mathrm{m}$ (panel superior) y $25 \mu \mathrm{m}$ (panel inferior). (b) Gráfica que muestra el número de células apoptóticas en los 4 genotipos. n=4 /genotipo. Las barras de error representan el SEM. Las comparaciones se representaron de la siguiente manera: $*^{p<0.05}$ vs WT. 


\section{Resultados}

\subsection{Modelo 2: Implicación de Sos1 en tumores pre-existentes}

En el modelo 2 analizamos el efecto que tenía la eliminación de Sos1 en tumores ya preestablecidos. Puesto que en el modelo 1 no observamos una implicación de la proteína Sos 2 en ninguno de los parámetros estudiados y además el modelo animal es mutante constitutivo para Sos2, restringimos este estudio a los grupos WT y Sos1 KO inducible (no recibió TAM en la etapa inicial del experimento) que fueron sometidos al protocolo de carcinogénesis DMBA-TPA durante 30 semanas como detallamos en la sección "Material y métodos". Transcurridas las 30 semanas, se administró a ambos grupos de estudio dieta con TAM para la eliminación de Sos1 en el grupo "Sos1 KO inducible" y para detectar efectos off-target en el grupo WT. Este protocolo nos permitió estudiar la importancia de Sos1 en tumores previamente establecidos.

\subsubsection{Diminución de la progresión tumoral tras la eliminación de Sos1 en tumores pre-establecidos}

Una vez iniciado el protocolo DMBA-TPA, realizamos una evaluación semanal durante 35 semanas en los animales, analizando distintos parámetros como el momento de inicio del tumor, el número de tumores por ratón y el área de los tumores encontrados para cada genotipo. En primer lugar medimos el porcentaje de ratones que presentaban tumores a lo largo de todo el estudio. Nuestros resultados mostraron que en ambos grupos, WT y "Sos1 KO inducible", la aparición de los tumores ocurría en espacios temporales muy similares, semana 9 tras el inicio de la carcinogénesis en el grupo WT y semana 10 en el grupo "Sos1 KO inducible" (Figura 50b). A la semana 14 el 100\% de los ratones de ambos grupos tenían tumores (Figura 50b).

La cuantificación del número de tumores por ratón y del área de estos tumores reveló que los animales de ambos grupos de estudio mostraban valores prácticamente idénticos hasta la semana 30 (Figura 50c y d). Sin embargo, tras la adición del TAM a ambos grupos transcurridas 30 semanas desde el inicio del tratamiento, se observó una disminución significativa del número de tumores y del tamaño de los mismos en el grupo Sos1 KO (asociado a la desaparición de Sos1) con respecto a los tumores del grupo de animales WT (Figura $50 \mathrm{~d}$ y e). Debemos señalar que tras la adición del TAM al grupo WT, se observó una ligera reducción del número de tumores por animal así como un bloque 
transitorio en el incremento del tamaño del tumor (Figura 50b y c). Estos efectos los asociamos a un efecto off-target del TAM.

Estos datos indican que la eliminacion de Sos1 en tumores de piel generados por carcinogenesis quimica tiene un posible efecto terapeutico, reduciendo tanto el número como el tamaño de los mismos. Estos resultados sugieren que la proteína Sos1 podría ser una potencial diana terapeutica en determinados tumores de piel.
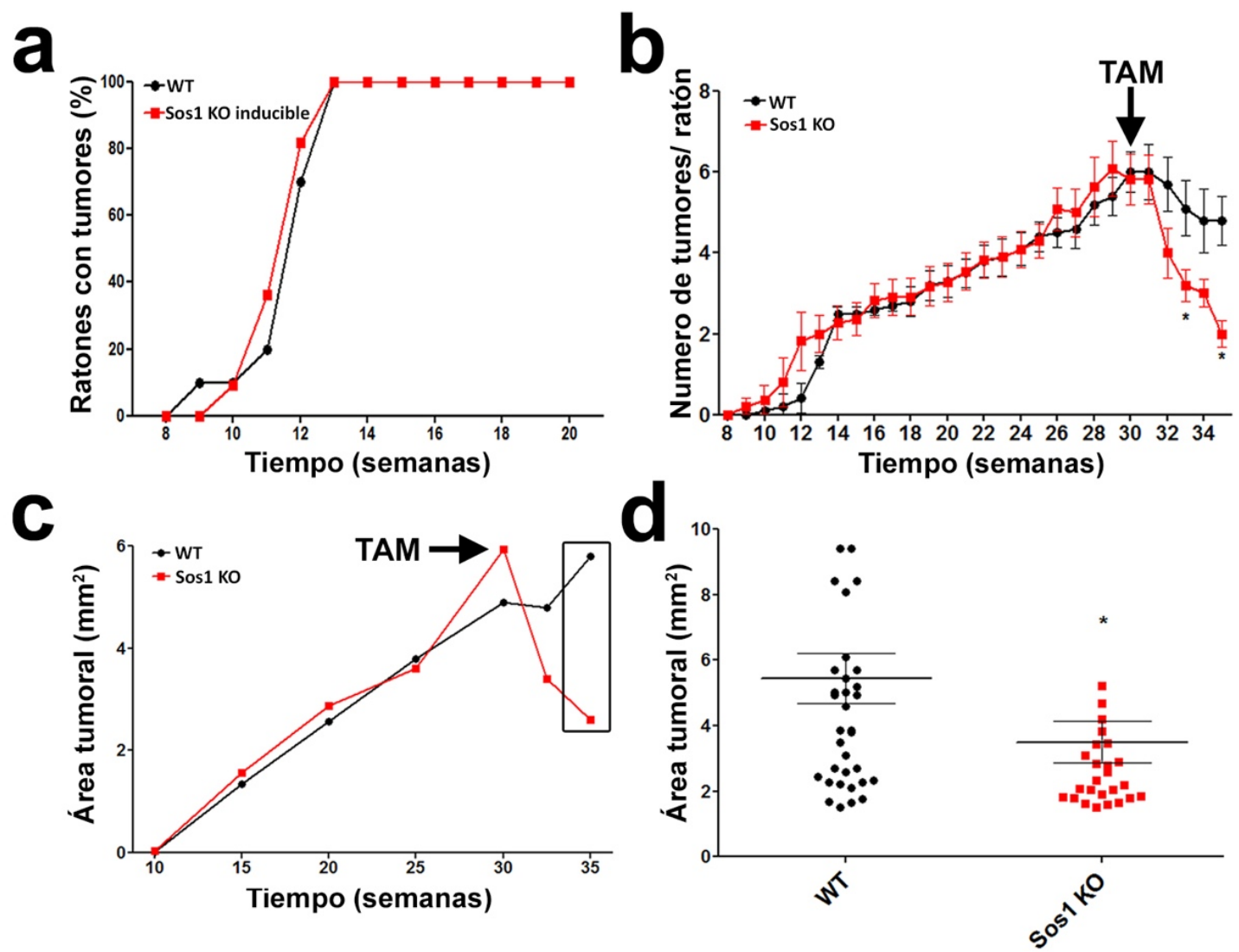

Figura 50. La eliminación de Sos1 reduce el número y tamaño en tumores de piel pre-establecidos. (a) Gráfico que muestra la cinética de aparición y progresión tumorales en ambos grupos durante 35 semanas. (b) Representación del número de tumores por ratón en cada grupo experimental en el inicio tumoral. La flecha señala el momento de aplicación del TAM en ambos grupos (c) Cuantificación del área tumoral en los dos grupos de estudio durante el protocolo DMBA-TPA (35 semanas). La flecha señala el momento de aplicación del TAM en ambos grupos. El recuadro indica el tamaño tumoral a las 35 semanas que se representa en la gráfica del siguiente apartado (d). (d) Gráfica que muestra el área media de los tumores de los dos grupos en estudio al final del estudio. (a-d) $n=11$ (WT) y $n=13$ (Sos1 KO). (b y d) Las barras de error representan el \pm SEM. $* p<0.05$ vs WT.

\subsubsection{Fenotipo tumoral en animales WT y Sos1 KO.}


Al igual que en el "modelo 1" estudiamos y caracterizamos los tipos tumorales que se originaron en cada grupo de estudio. Nuestros resultados indicaban que en el "modelo 2" ambos grupos desarrollaban lesiones del mismo grado tumoral, aunque también se observaron querantoacantomas ( $5 \%$ del total) la mayoría de los tumores eran papilomas y adenomas (Figura 51a). Si representamos el total de las lesiones benignas (origen epitelial y sebáceo) observamos que las lesiones de bajo grado ( $P 1$ y $A 1$ ) se presentan en un porcentaje similar en ambos grupos, y las lesiones de alto grado (P2-P3 y A2) mostraban porcentajes similares entre los grupos estudiados (Figura 51b).

En resumen, los tumores generados en los grupos WT y Sos1 KO presentan un estadio y un fenotipo similares que además se reparte homogéneamente entre tumores de origen epitelial y sebáceo.
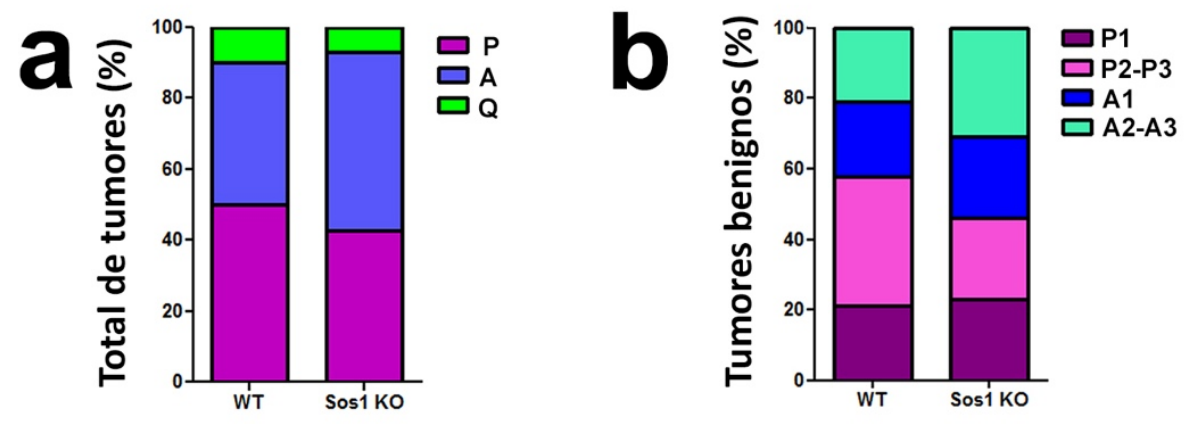

Figura 51. Fenotipo tumoral en animales WT y Sos1 KO generados con el protocolo DMBA-TPA durante 35 semanas. (a) Gráfica que representa el porcentaje de tumores según su origen y evolución; P: papilomas, A: adenomas y Q: queratoacantoma. (b) Representación del tipo de lesión que presenta cada genotipo, expresado en porcentaje con respecto al total de lesiones benignas. P1 y A1: Papilomas y Adenomas de bajo grado, respectivamente. P2-P3 y A2: papilomas y adenomas de alto grado, respectivamente.

\subsubsection{Disminución de la proliferación tumoral tras la eliminación de Sos1}

Para averiguar si la disminución del número y del tamaño tumoral en los tumores ya establecidos tras la eliminación de Sos1 se relacionaba directamente con una disminución de la proliferación, cuantificamos el número de células proliferativas en los tumores generados en los grupos WT y Sos1 KO tras la adición del TAM.

Observamos que la tasa de proliferación de los tumores WT y Sos1 KO a las 30 semanas era muy similar (Figura 52a y b). Transcurridas 2.5 semanas desde la administración de la dieta con TAM, observábamos una tendencia a una disminución de la proliferación tumoral en el grupo Sos1 KO con respecto al grupo WT (Figura 52a). Finalmente, el análisis de la proliferación en tumores de ambos 
grupos (WT y Sos1 KO) tras 5 semanas de administración de TAM mostró que la tasa de proliferación se veía disminuida en los tumores de animales Sos1 KO en comparación con el grupo WT (Figura 52a).

Estos resultados confirman que la proteína Sos1 juega un papel clave en el mantenimiento de la proliferación tumoral.

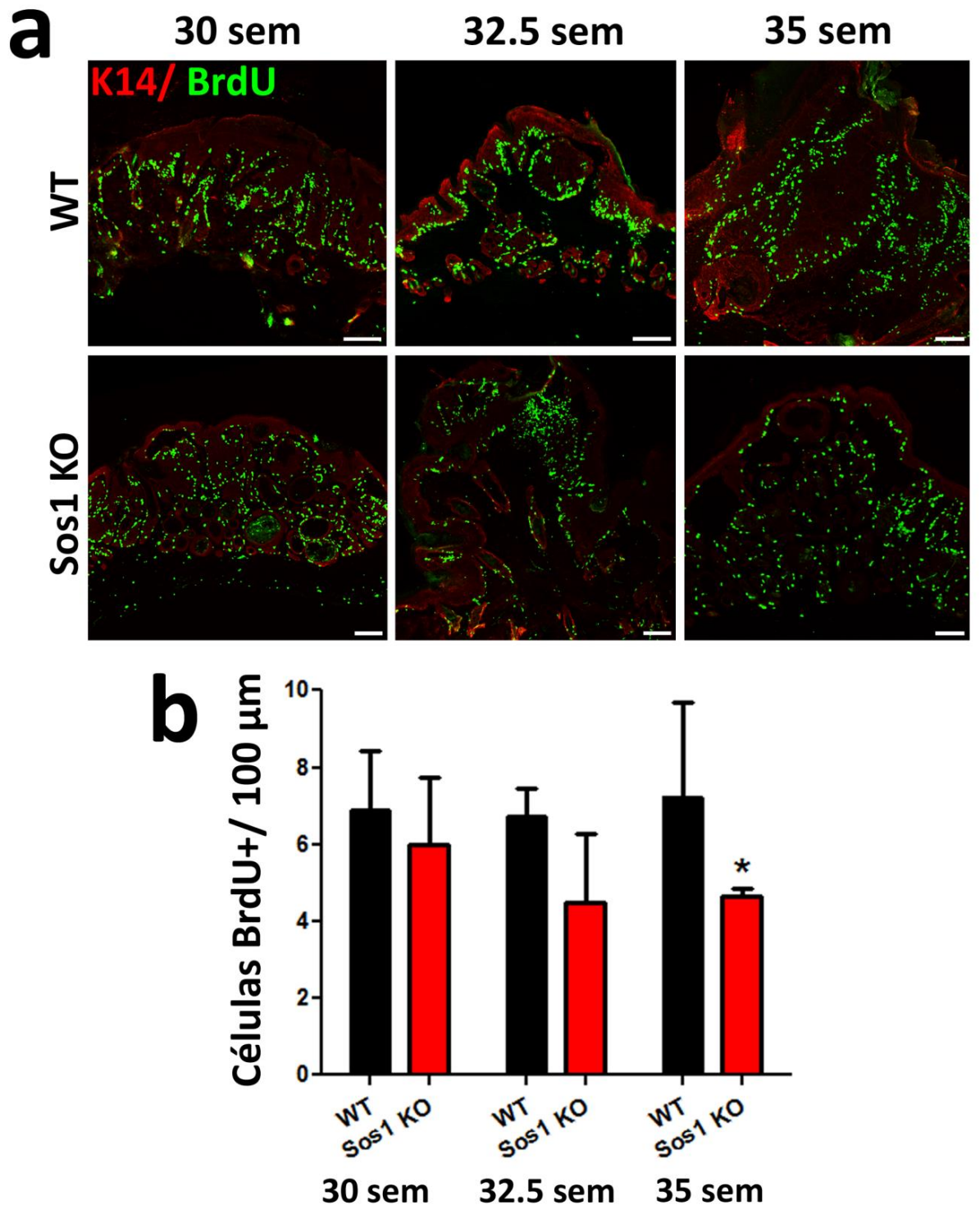

Figura 52. La eliminación de Sos1 reduce la proliferación en tumores pre-establecidos. (a) Secciones histológicas de tumores generados tras 30, 32.5 y 35 semanas de protocolo DMBA-TPA, marcados con K14 (rojo) y BrdU (verde). Barras de escala: $100 \mu \mathrm{m}$. (b) Cuantificación del número de células BrdU positivas por cada $100 \mu \mathrm{m}$. n=3/genotipo y condición. Las barras de error representan el SEM. Las comparaciones se representaron de la siguiente manera: ${ }^{*} p<0.05$ vs WT. 


\section{Implicación de Sos1 y Sos2 en angiogénesis. Ensayo de anillo aórtico.}

Se ha relacionado la letalidad de los animales Sos1 KO durante el estado embrionario a defectos cardiovasculares y en el desarrollo de la placenta (Qian et al., 2000; Wang et al., 1997). Estudios previos describieron un aumento de la vascularización tumoral en ratones donde la expresión de Sos1 (en queratinocitos) era constitutivamente activa (Lichtenberger et al., 2010; Sibilia et al., 2000). Además, nuestros resultados indicaban que la densidad vascular en la piel de animales deficientes Sos1 parecía menor que en los animales WT, además la deficiencia conjunta de Sos1 y Sos2, provocaba un descenso muy sustancial en la vascularización de la piel con respecto al resto de genotipos. En conjunto, estos datos sugerían un rol importante de las proteínas Sos en procesos como la neovascularización o la angiogénesis. Por lo tanto, decidimos profundizar en el estudio del papel de las proteínas Sos en el proceso angiogénico mediante el ensayo ex vivo del anillo aórtico.

Mediante este ensayo, estudiamos la formación de pseudocapilares sanguíneos (sprouts) en explantes de aorta torácica procedente de animales de los 4 genotipos de estudio: WT, Sos1 KO, Sos2 KO y Sos1/2 DKO. Estas estructuras microvasculares, se forman a partir de las células del endotelio del anillo y comienzan a aparecer de manera general transcurridos 2.5 días desde la siembra de los anillos de aorta. Los sprouts necesitan primeramente la aparición de células "punta" o células "tip" que son aquellas células endoteliales que se diferencian y adquieren un fenotipo predominantemente migratorio, que acompañado de la formación de estructuras semejantes a filopodios median el avance de la célula tip. Por el contrario, las células endoteliales adyacentes a esta célula tip adquieren un fenotipo de célula "del tallo" o "stalk" que es altamente proliferativa. La proliferación de estas últimas constituye el nuevo microcapilar (Adams and Alitalo, 2007; Chappell et al., 2011).

En concreto, cuantificamos el número de sprouts por anillo durante 8 días tras el cultivo de explante. Además, medimos la longitud de los sprouts transcurridos 8 días desde el cultivo del anillo aórtico. Nuestros resultados demostraron que existía una reducción en el número de sprouts por anillo desde el día 5 tras el inicio del explante en los genotipos Sos1 KO y Sos2 KO respecto a los anillos provenientes de animales WT (Figura 53a y b). Era especialmente notorio como las aortas de animales Sos1/2 DKO tenían una capacidad muy reducida, casi nula, de generar nuevos pseudocapilares (Figura 53a y b). 
A continuación, estudiamos el crecimiento del sprout. Este proceso sucede en dirección al estímulo angiogénico y requiere tanto proliferación como migración de las células endoteliales. Las células tip son atraídas quimiotácticamente por el gradiente de citoquinas generado en la zona hipóxica (zona fuera de la gota de Matrige ${ }^{\circledR}$ ), que dirige la direccionalidad de la migración y a su vez las células stalk proliferarían activamente generando una mayor longitud del microcapilar.

A diferencia de los resultados anteriores, la ausencia individual de Sos2 no afectaba a la longitud media de los sprouts en comparación con la cuantificada para las aortas WT (Figura 53c). Aunque sin ser significativa, sí observamos una ligera disminución en la elongación de los pseudocapilares en los anillos de animales Sos1 KO con respecto a los genotipos WT y Sos2 KO (Figura 53a y c). Sin embargo, es llamativo como la longitud de los microcapilares generados en los anillos de los animales Sos $1 / 2$ DKO no se acerca mínimamente a la alcanzada en el resto de genotipos de estudio (Figura 53a y c).

En resumen, la función de las células tip parece ser dependiente tanto de Sos 1 como de Sos2. Sin embargo, la proteína Sos1 ejerce una función más importante que Sos2 durante el crecimiento de los sprouts. La ausencia prácticamente total del proceso angiogénico en el caso de los anillos extraídos de animales Sos1/2 DKO indican una redundancia funcional de ambas proteínas en el control de este proceso, pero como indicamos anteriormente, la función de Sos1 se antoja más importante que la de Sos2. 

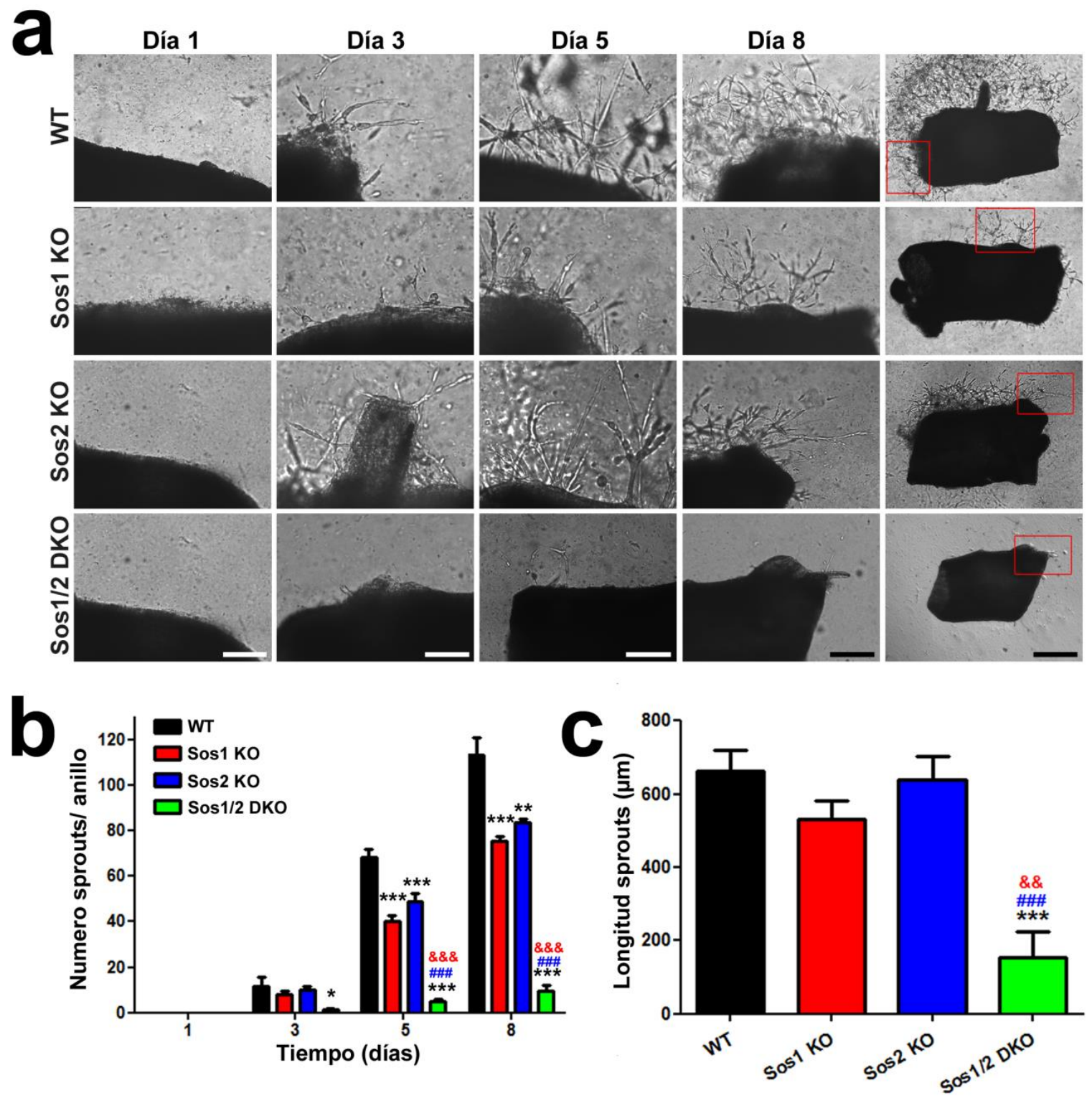

Figura 53. Capacidad de formación de microcapilares en ausencia de las proteínas Sos. (a) Imagen de anillos aórticos de los 4 genotipos de estudio, en los tiempos $1,3,5$ y 8 días de cultivo. Los recuadros representan las imágenes aumentadas mostradas. (b) Cuantificación del número de pseudocapilares o sprouts en los tiempos 1, 3, 5 y 8 días explantes aórticos originales de animales de los 4 genotipos de estudio. (c) Gráfica que representa la longitud de los sprouts tras 8 días en cultivo). Barras de escala: $200 \mu \mathrm{m}$ y $500 \mu \mathrm{m}$ en los aumentos en el explante completo, respectivamente. Las barras de error representan el SEM. Las comparaciones se establecieron del siguiente modo: ${ }^{*} p<0.05$ vs WT, además $* * / \& \& p<0.01$ vs WT y Sos1 KO $\mathrm{y}^{* * *} / \& \& \& / \# \# \# \mathrm{p}<0.001 \mathrm{vs} \mathrm{WT}$, Sos1 KO y Sos2 KO, respectivamente. 

Discusión 

En el presente trabajo hemos analizado la especificidad o redundancia funcional de los miembros de la familia Sos tanto in vitro en condiciones fisiológicas, como in vivo en condiciones fisiológicas y/o patológicas en distintos procesos biológicos. Para ello, hemos empleado los modelos animales murinos generados previamente en nuestro laboratorio donde podemos eliminar la proteína Sos1 de forma individual o en combinación con Sos2 durante la etapa adulta.

Los estudios in vitro realizados en MEFs primarios muestra que existen ciertos parámetros en los que Sos1 ha mostrado una especificidad funcional, como el mantenimiento de la morfología celular o el nivel de compactación de la cromatina. Por otro lado, hemos encontrado otros procesos biológicos donde ambas proteínas actúan de forma redundante, como la migración, y también, aunque en menor medida, el control de la proliferación celular o el control del balance del estado redox de la célula, detectando una función dominante de Sos1 sobre Sos2 en todos estos procesos. Asimismo, hemos descrito por primera vez una función específica de la proteína Sos2 en relación con la regulación de procesos de adhesión celular y dinámica de AF. Además, acorde a los resultados obtenidos, parece que las proteínas Sos no tienen un papel primordial en la regulacion de la supervivencia celular.

Por otro lado, los estudios in vivo han mostrado de nuevo una prevalencia funcional de la proteína Sos1 sobre Sos2 en el mantenimiento de la homeostasis de la piel, así como en los contextos experimentales que necesitan de un balance altamente coordinado y regulado de distintos procesos biológicos como la proliferación, migración, angiogénesis o respuesta inflamatoria, entre otros, como son el cierre de una herida o el proceso de carcinogénesis epitelial.

El conjunto de estos resultados manifiesta la clara prevalencia de la proteína Sos1 respecto a Sos2 en la mayoría de los procesos estudiados. Sin embargo, aunque Sos2 de manera individual resulta prescindible en estos procesos, su ausencia resulta importante cuando Sos1 está ausente. No obstante, hemos identificado funciones biológicas asociadas a la proteína Sos2 que no habían sido descritas previamente. 


\section{Especificidad funcional de Sos1 en el mantenimiento de la morfología celular}

Nuestros resultados han demostrado una especificidad funcional de Sos1 en el mantenimiento de la morfología celular, ya que su ausencia, individual o combinada con Sos2, generaba una notable alteración del citoesqueleto caracterizada por una pérdida de la polaridad, y una morfología aplanada acompañada de un aumento del perímetro celular. La morfología de estas células deficientes para Sos1 es muy similar a la que muestran los fibroblastos Rasless carentes de la expresión de las tres formas canónicas de Ras (H-, N-y K-Ras) (Drosten et al., 2010). Este aumento del tamaño celular y apariencia quiescente se ha observado también en otros tipos celulares primarios como los queratinocitos Rasless (Drosten et al., 2014). Estos datos sugieren la importancia en la señalización de Sos1 a través de Ras en la regulación de la morfología celular.

\section{Prevalencia funcional de Sos1 en el control de proliferación celular, la progresión del ciclo celular, el nivel de compactación de la cromatina y la integridad del DNA}

Los resultados aquí presentados han puesto de manifiesto la importancia de Sos1 en la regulación positiva de la proliferación celular. Anteriormente no se había descrito una función relevante para Sos2 en la regulación de este proceso. Gracias a la disposición de un sistema en el que podemos eliminar de forma combinada Sos1 y Sos2 hemos podido determinar que la presencia de Sos2 es importante cuando Sos1 está ausente, ya que atenúa de cierta manera los defectos en la proliferación derivados de la eliminación de Sos1. La atribución de la función crítica de Sos1 en proliferación es consistente con trabajos previos. En consonancia con nuestros resultados, la inhibición de la expresión de Sos1 mediante el uso de dominantes negativos en células CHO-IR resulta en una reducción de la proliferación de estas células tras estimulación con insulina (Sakaue et al., 1995). Asimismo, trabajos realizados en MEFs derivados de ratones deficientes para Sos1 también muestran defectos en la proliferación (Ginel-Picardo, 2012; Qian et al., 2000). En este contexto, mutaciones que originan ganancia de función de Sos1 tienen como resultado una respuesta hiperproliferativa (Chen et al., 2010b; Lee et al., 2006; Minella et al., 2011; Timofeeva et al., 2009). 
Un análisis detallado del ciclo celular mostraba que la ausencia de Sos1 causaba un aumento del porcentaje de células en las fases G2/M que se relacionaba con una disminución de MEFs en el resto de fases. Aunque nuestros estudios no han permitido aclarar qué fase del ciclo celular está específicamente afectada, los resultados obtenidos sugerían que la ausencia de Sos1 provocaba fallos en la mitosis y/o en la citocinesis. Sorprendentemente, experimentos de inhibición de expresión de Sos1 mediante el uso de lentivirus en fibroblastos inmortalizados resultan en un retraso en la progresión de la fase G1 del ciclo celular (Ginel-Picardo, 2012). De hecho, se ha descrito con anterioridad la importancia de las proteínas Ras en la progresión de la fase G1 del ciclo celular (Lovec et al., 1994; Malumbres and Pellicer, 1998; Mulcahy et al., 1985; Sherr and Roberts, 1995). Es más, defectos en la señalización a través de Ras suponen un bloqueo del ciclo celular en fase G1 (Drosten et al., 2010; Malumbres and Pellicer, 1998). En este momento desconocemos el porqué de estas divergencias entre los estudios anteriores y el nuestro. Una de las posibilidades que planteamos es que los estudios donde se han visto los defectos en la progresión en la fase G1 del ciclo celular se han realizado en células inmortalizadas (Drosten et al., 2010; Ginel-Picardo, 2012) mientras que todos nuestros estudios se han hecho en MEFs primarios. Planteamos que el proceso de inmortalización puede haber alterado la expresión de determinadas proteínas implicadas en el ciclo celular que podrían explicar esta disparidad en los resultados.

Alteraciones en otras proteínas altamente implicadas en la regulación del ciclo celular podrían explicar el fenómeno anteriormente descrito. Por ejemplo, se sabe que la estimulación de la ruta Ras/ERK por factores de crecimiento induce la expresión de $\mathrm{p} 21^{\mathrm{CIP} 1}$, cuyos niveles son mínimos en células quiescentes (Liu et al., 1996). p21 ${ }^{\mathrm{CIP} 1}$ funciona como un sensor de la intensidad de la señal estimuladora, pues un fuerte aumento de su expresión conduce a una parada del ciclo en G1 (Pumiglia and Decker, 1997; Sewing et al., 1997; Woods et al., 1997). Por otro lado, p27 ${ }^{\text {KIP1 }}$ está altamente expresado en células quiescentes, pues su transcripción se estimula por medio de rutas inhibidoras de la progresión del ciclo (Burgering et al., 2000; Kuiperij et al., 2005). Tras la entrada en fase G1 por estimulación mitogénica, las rutas efectoras de Ras reducen los niveles de p2 $27^{\text {KIP1 }}$ progresivamente, mediante su degradación proteica, la inhibición de su transcripción (Aktas et al., 1997; Kawada et al., 1997; Pruitt and Der, 2001; Takuwa and Takuwa, 1997), o siendo translocada al citoplasma (Fujita et al., 2003). Además, se sabe que existe un aumento de los niveles de p27 $7^{\mathrm{KIP} 1}$ en respuesta al daño en el DNA, así p27 $7^{\text {KIP1 }}$ participaría en el bloqueo en G2/M de estas células (Cuadrado et al., 2009; Payne et al., 2008; See et al., 2010). 
Nuestros resultados mostraban un estado quiescente de las células acompañado de una acumulación de las células en la fase $\mathrm{G} 2 / \mathrm{M}$ y además la presencia de focos de lesión en el DNA, en los MEFs deficientes para Sos1. Por ello, creemos que sería interesante estudiar el estado de activación de p2 $7^{\text {KIP1 }}$, así como su localización celular, en los MEFs de los cuatro grupos de estudio. Sería importante determinar si en células Sos1 KO y/o Sos1/2 DKO existe un incremento de expresión de p2 $7^{\mathrm{KIP} 1}$ en el núcleo, y si por el contrario en las células proliferativas WT y Sos2 KO, p2 $7^{\mathrm{KIP} 1}$ se encuentra mayoritariamente en el citoplasma, donde realizaría otras funciones ya descritas mediante la interacción con diversas proteínas como Grb2 (Moeller et al., 2003; Sugiyama et al., 2001), RhoA (Besson et al., 2004) o Citron K (Serres et al., 2012). Estas proteínas estarían implicadas en procesos como la propia degradación de $\mathrm{p} 27^{\mathrm{KIP1}}$ (Sugiyama et al., 2001) y la regulación de la ruta Ras/MAPK (Moeller et al., 2003), la regulación de la señalización a través de RhoA (Besson et al., 2004) y la mitosis/citocinesis (Serres et al., 2012), respectivamente. En este sentido, estudios anteriores mostraron que el silenciamiento de Sos1 en MEFs inmortalizados reducía ligeramente el nivel de expresión de p2 $7^{\mathrm{KIP} 1}$, aunque en ese caso no se estudió la localización de la proteína en la célula (Ginel-Picardo, 2012).

Un estudio más detallado del nivel de expresión y localización subcelular de esta proteína así como otras incluyendo $\mathrm{p} 21^{\mathrm{CIP} 1}$, ciclinas o CDKs así como experimentos de sincronización de estas células en las distintas fases del ciclo celular aportarán información muy útil que ayudará a clarificar esta cuestión.

En consonancia con la reducción en la capacidad proliferativa mostrada por los MEFs carentes de expresión de Sos1, estas células también presentaban un claro proceso de heterocromatinización, que estaba asociado además con daño en el DNA. Es decir, el nivel transcripcional global de las células Sos1 KO y Sos1/2 DKO era mucho menor que el de los MEFs WT y Sos2 KO. En este sentido, un trabajo previo de nuestro laboratorio (Ginel-Picardo, 2012) reveló que la eliminación de Sos1 tiene un efecto muy superior sobre la expresión génica que la eliminación de Sos2, demostrando que la eliminación de Sos1 tiene un fuerte impacto en el transcriptoma, induciendo preferentemente la represión transcripcional. Estos resultados ponen de manifiesto la influencia de Sos1 en la regulación de la transcripción génica y la incapacidad de Sos2 para compensar su ausencia en este contexto. En esta línea, otro trabajo previo de nuestro grupo de investigacion demostró que los MEFs Rasless presentan un perfil transcriptómico preferentemente reprimido (Azrak et al., 2013). 
En conjunto, estos resultados muestran una función predominante de Sos1 sobre Sos2 en la

proliferación, la progresión del ciclo celular y el mantenimiento del nivel transcripcional global de la célula, aunque debemos señalar la relativa importancia que puede tener Sos2 en un contexto celular en el que Sos1 está ausente.

\section{Implicación de las proteínas Sos en la organización del citoesqueleto}

Un análisis detallado de las alteraciones morfológicas de las células deficientes en Sos 1 y Sos $1 / 2$ reveló que éstas tenían una disposición atípica de las fibras de actina y de las AF. La desorganización de las fibras de F-actina reflejaba una pérdida notable de la polaridad celular. Las AF por su parte eran más numerosas y estaban repartidas ampliamente por el citoplasma, y no solamente en los polos de la célula. Aunque la proteína Sos 2 de forma individual resultaba prescindible en la organización del citoesqueleto parecía tener un papel contributivo, ya que las alteraciones en células Sos1/2 DKO en la distribución de las AF era aun mayor que en MEFs carentes únicamente de Sos1.

Debido a la actividad dual de Sos1 como RasGEF y RacGEF, podemos sugerir que defectos en la señalización mediada por Ras o por Rac, o ambas, como consecuencia de la ausencia de las proteínas Sos, son los responsables de estas modificaciones en la disposición del citoesqueleto. Por un lado, las alteraciones aquí presentadas en las células deficientes para Sos1 eran comparables a las observadas en MEFs Rasless (Drosten et al., 2010) donde la distribución de la F-actina es muy similar a la observada en células Sos1 KO y Sos1/2 DKO. Además, la localización y el aumento del número de las AF asociadas a la pérdida de las proteínas Ras resulta equiparable a la de las proteínas Sos1 y Sos1/2, sugiriendo que los cambios en la organización del citoesqueleto descritos podrían deberse a la ausencia de la señalización mediada por Ras. Por otro lado, la ausencia de Sos1 podría alterar también la activación de Rac1 y de este modo generar cambios en el citoesqueleto. Sin embargo, la organización del citoesqueleto de MEFs Sos1 KO y Sos1/2 DKO no se parece a la que presentan fibroblastos deficientes en Rac1 (Guo et al., 2006; Steffen et al., 2013; Vidali et al., 2006). Estos resultados sugieren que las alteraciones en el citoesqueleto en los MEFs Sos1 KO y Sos1/2 DKO son principalmente reflejo de una alteración de la señalización mediada por Ras. En este sentido, debemos señalar que en fibroblastos, los principales RasGEFs son las proteínas Sos, mientras que existen otros miembros de la familia de RacGEFs claves en la activación de Rac que podrían compensar la ausencia de Sos. Por lo tanto, cabe esperar que la ausencia de Sos1 y Sos2 en 
fibroblastos afecte principalmente a las rutas mediadas por Ras, aunque no debemos descartar posibles defectos en las rutas mediadas por Rac.

Como describimos en los resultados, la distribución y localización de la paxilina estaba alterada en los MEFs deficientes en Sos1. La paxilina es una proteína localizada en las AF que desempeña una función clave de la señalización efectora mediada por las RhoGTPasas Rac y Rho, en particular, está implicada en la migración y adhesión celulares. Por lo tanto, a continuación discutiremos en profundidad el efecto de la eliminación, individual o combinada, de las proteínas Sos en la migración.

\section{Papel de las proteínas Sos en la migración celular}

La implicación de las proteínas Sos en la migración celular fue analizada mediante el ensayo de WH en MEFs de los 4 grupos de estudio. Con este ensayo determinamos que este proceso celular es, de los estudiados en este trabajo, donde las proteínas Sos presentan una mayor redundancia funcional, aunque de nuevo, Sos1 presenta una prevalencia funcional sobre Sos2 ya que la eliminación individual de Sos1, pero no de Sos2, generaba un cierto retraso en el cierre de la herida. El análisis de perfil transcriptómico en MEFs inmortalizados carentes de Sos1 o Sos2 ha revelado la alteración de la expresión génica en grupos de genes relacionados con la migración en las células carentes de Sos1 pero no de Sos2 (Ginel-Picardo, 2012). Otros trabajos han relacionado también la eliminación combinada de las proteínas Sos con una menor migración en células T de ratón (Guittard et al., 2015). Nuestras observaciones se asemejan mucho a lo observado en MEFs Rasless, donde la falta de señalización mediada por Ras afecta al proceso de migración (Drosten et al., 2010).

Los fibroblastos migran de manera dirigida a través de lamelipodios hacia un estímulo quimiotáctico (Lo et al., 2000). Para ello tiene que establecerse una polaridad celular, y posteriormente un recambio dinámico de formación/desaparición de estructuras de acto-miosina (Ridley et al., 2003). La disminución de la migración asociada a la ausencia de las proteínas Sos es compatible una menor polaridad. Esta pérdida de la polaridad también se observa en las células Rasless lo que podría ser una de las causas en los defectos en migración que muestran estos fibroblastos (Drosten et al., 2010). La alteración de la señal mediada por Ras, ya sea por ausencia de las proteínas Sos o de las proteínas Ras, podría inducir cambios en la regulación/función de proteínas clave en el proceso de polarización previo al comienzo de la migración celular, tales como Cdc42, PI3K o la miosina II (Cramer, 2010; Mseka et al., 2007; Nobes and Hall, 1999; Vicente-Manzanares et al., 2007, 2008, 2009; Yam et al., 
2007). De hecho, MEFs primarios carentes de Cdc42 presentan defectos en la capacidad de migración (Yang et al., 2006). También se ha demostrado que MEFs con alteraciones en la miosina II muestran una polarización defectuosa que resulta en una migración alterada (Vicente-Manzanares et al., 2008).

Tras una correcta polarización, la célula debe formar y mantener lamelipodios a través del establecimiento de AF. En este proceso interviene el complejo WAVE, que a través de la activación de Rac1 y en colaboración con integrinas y otros componentes, son necesarios para generar y estabilizar los complejos focales (Hu et al., 2015; Ladwein and Rottner, 2008; Takenawa and Suetsugu, 2007). Por otro lado, la reposición y mantenimiento de las AF los regula fundamentalmente la GTPasa RhoA. Además, se ha sugerido que RhoA, a través de FAK, actúa sobre la paxilina en este proceso (EtienneManneville, 2013), lo que podría corresponderse con las alteraciones observadas en el nivel de expresión y localización de esta proteína en células deficientes de Sos1.

Mediante IRM hemos detectado que la ausencia de Sos1 causaba un incremento del número de AF que estaban repartidas por una mayor superficie de la membrana. Además, observamos la ausencia de un eje de retracción definido en MEFs deficientes de Sos1 que podría ser compatible con alteraciones en la miosina II (Vicente-Manzanares et al., 2008). Este aumento de AF refleja un menor recambio de las mismas en MEFs Sos1 KO y Sos1/2 DKO, que se debe a un aumento en la estabilidad de las AF. De este modo, la disminución en la reposición de las AF en estas células podría explicar el defecto en su velocidad de migración, puesto que las AF del eje de retracción parecen permanecer unidas al sustrato más tiempo. Por el contrario, la eliminación de Sos2 genera un menor número de AF debido a un recambio más activo con respecto al resto de genotipos. De hecho, las AF solapadas que se observan se deben a la creación de AF de novo en la misma región, y no al mantenimiento de una $\mathrm{AF}$ en un mismo lugar. Este importante incremento de la renovación de las AF en los MEFs Sos2 KO no se ve reflejado en una mayor capacidad de migración, lo que puede deberse a la constante renovación de AF en diferentes lugares del eje de migración y retracción. Todos estos datos sugieren que Sos2 jugaría un papel importante en el mantenimiento de las AF.

Aunque desconocemos cual es el mecanismo por el que Sos1 y/o Sos2 regulan la dinámica de las AF, planteamos que una posibilidad pueda ser a través de las isoformas de la miosina II, IIA y IIB. La miosina IIA se localiza en el frente de avance y resulta esencial para la retracción y la maduración de las $\mathrm{AF}$, mientras que la miosina IIB, se localiza en regiones centrales y la parte posterior de la célula donde es esencial para la formación del eje de retracción (Even-Ram et al., 2007; Vicente-Manzanares 
et al., 2007). Fallos en la funcionalidad de ambas isoformas serían compatibles con la migración defectuosa observada tras la eliminación de Sos1 y la dinámica de AF alterada en los MEFs carentes de Sos. Planteamos estudiar en detalle la activación de la miosina II, así como la importancia de cada de cada isoforma (miosina IIA y IIB) en los MEFs de los 4 genotipos, dada su importancia en la dinámica de AF (Chrzanowska-Wodnicka and Burridge, 1996; Crowley and Horwitz, 1995; VicenteManzanares et al., 2007, 2008, 2009). Este estudio podría explicar defectos en la polaridad celular, en la localización de las AF, así como alteraciones en la contractilidad celular.

Asimismo, los defectos en el ensamblaje/desensamblaje de las AF pueden ser la causa de las alteraciones en la formación de lamelipodios. Está ampliamente descrita la función esencial de Rac1 en la formación de los lamelipodios en MEFs (Guo et al., 2006; Steffen et al., 2013; Vidali et al., 2006), por lo que defectos en este proceso podrían implicar una alteración de la actividad y/o la función de Rac1. De este modo, la disminución del número de lamelipodios en las células deficientes de Sos1, individualmente o en combinación con Sos2, podría corresponderse con una disminución de la activación de Rac1. Sos1 es capaz de activar Rac1 mediante la formación del complejo Sos1/Eps8/E3b1 (Scita et al., 1999; Sini et al., 2004) y además, fibroblastos deficientes de Rac1 muestran una disminución de la migración asociada a la incapacidad de formar lamelipodios (Vidali et al., 2006) y presentan una pérdida de la polaridad (Steffen et al., 2013). Sin embargo, características como la disposición alterada de las AF, el aumento de tamaño y la distribución de las fibras de actina en MEFs carentes de Sos1 no resulta coincidente con lo descrito en MEFs Rac1 KO (Steffen et al., 2013; Vidali et al., 2006). Por lo que los efectos observados no se deben, al menos únicamente, a una posible menor activación de Rac1. Por el contrario, los MEFs Sos2 KO presentan una multiplicidad de lamelipodios en el frente migratorio que hace que el lamelipodio principal que dirige la migración cambie constantemente, y de este modo, podría explicarase que no suponga una migración o desplazamiento mayor que los MEFs WT. Este patrón de creación/desaparición de un mayor número de lamelipodios en los MEFs Sos2 KO concuerda con la mayor dinámica de AF observada en relación al resto de genotipos.

Estos resultados indican que las proteínas Sos juegan un papel importante en la migración celular modulando la dinámica de AF. En concreto, los datos sugieren que cada proteína Sos tiene un papel específico en este procesi. Por un lado, Sos1 resulta importante para la polarización, la formación del lamelipodio y una correcta reposición de las AF. Por otro lado, Sos2 es clave en el mantenimiento 
tanto del lamelipodio como de las AF. La activación controlada en el espacio y en el tiempo de las GTPasas Cdc42, Rac1 y RhoA en también necesaria para un control coordinado del proceso de migración celular. En este sentido es posible que las proteínas Sos regulen de alguna manera la expresión de alguna o varias de estas RhoGTPasas.

\section{Papel de las proteínas Sos en la adhesión celular}

La diferente capacidad de generar protrusiones citoplasmáticas observada en las células Sos1 KO y Sos1/2 DKO puede afectar no solo al proceso migratorio, sino también al propio proceso de adhesión de las células al sustrato. Los resultados obtenidos en cuanto al papel de las proteínas Sos en la adhesión fueron sorprendentes. Por un lado, no detectamos alteración en la capacidad de adhesión celular ante la ausencia individual de Sos1, aunque estas células sí mostraban cambios en la dinámica de las protrusiones. Éstas se generaban con un retraso relativo en el tiempo y además eran extensas y se repartían por la práctica totalidad del citoplasma. En otro tipo celular como el linfocito T, se ha descrito la importancia de Sos1 en el proceso adhesión celular mediada por integrinas (Toffali et al., 2017). La disminución de la expresión de Sos1 es estas células resultaba en un descenso de la activación de Rac1 y de RhoA (Toffali et al., 2017).

Por otro lado, la eliminación individual de Sos2 generaba un sorprendente aumento de la capacidad de adhesión celular en los MEFs Sos2 KO. Estas células se caracterizaban por una mayor formación de protrusiones muy dinámicas de pequeño tamaño, que no se asemejaban a ninguna del resto de genotipos. En este sentido, debemos señalar que el análisis de expresión génica por hibridación de microarrays de MEFs inmortalizados deficientes en Sos2 muestran modificaciones en genes asociados a procesos de adhesión que no se detectaron en las células deficientes en Sos1 o WT (Ginel-Picardo, 2012). Una situación similar a la encontrada en nuestras células se ha observado con las proteínas homólogas RhoA y RhoC en células PC3, donde la deficiencia de una u otra proteína genera una dinámica de protrusiones diferente (Vega et al., 2011). En este caso, se planteó que los efectores de la señalización de una y otra GTPasa fueran diferentes (Vega et al., 2011). Parece que la regulación de la dinámica de protrusiones mediada por RhoA y RhoC es diferente cuando falta una u otra con respecto a la regulación de ambas en condiciones fisiológicas, donde ambas participan en el proceso. En nuestro caso, planteamos que en condiciones normales la proteína Sos2 podría regular 
negativamente el proceso de adhesión o bien que su ausencia genere mecanismos compensatorios que supongan un aumento exacerbado de la capacidad de adhesión.

Finalmente, el drástico defecto en la adhesión de las células Sos1/2 DKO podría deberse a una pérdida de la regulación de la adhesión que ejercen en colaboración Sos1 y Sos2, que podría ir acompañada de una menor viabilidad celular y menor plasticidad de la membrana plasmática en estas células.

\section{Activación de las rutas Ras/MAPK y PI3K/Akt en células carentes de las proteínas Sos}

Puesto que las proteínas Sos son los principales RasGEFs que median la activación de Ras en fibroblastos y por lo tanto influyen en las principales rutas de señalización mediadas por Ras, analizamos en detalle los niveles de activación de Ras y de las principales proteínas efectoras de Ras.

Nuestros resultados han demostrado que la eliminación individual de Sos1, pero no de Sos2, disminuye el nivel de activación de Ras tras la estimulación con distintos factores de crecimientos en tiempo cortos. Resultados muy similares han sido descritos con anterioridad en líneas de fibroblastos inmortalizados carentes de expresión de Sos1 (Ginel-Picardo, 2012). A diferencia de los estudios previos, el hecho de disponer de un sistema que nos permite eliminar de forma concomitante las proteínas Sos nos ha permitido describir que la ausencia de ambas proteínas produce un bloqueo prácticamente completo de la activación de Ras tras la estimulación con distintos factores de crecimiento. Así, hemos podido determinar que a pesar de que la ausencia de Sos2 parece prescindible en el proceso de activación de Ras, su presencia se antoja importante cuando Sos1 está ausente. Estos resultados están en consonancia con la mayoría de datos que hemos descrito en los procesos estudiados en el presente trabajo, como la proliferación, la progresión del ciclo celular, o la migración, donde Sos1 tiene un papel dominante sobre Sos2, mientras que Sos2 parece ser prescindible de manera individual, aunque es importante cuando Sos1 está ausente.

A continuación analizamos los niveles de fosforilación de las proteínas ERK y Akt como principales proteínas efectores de las rutas Ras/MAPK y PI3K/Akt, respectivamente. Los resultados aquí presentados demostraron que la ausencia de Sos1 afectaba al nivel de fosforilación de ERK tras estimulación con distintos factores de crecimiento. Estos datos coinciden con trabajos previos que 
muestran una disminución en el nivel de activación de ERK en MEFs carentes de Sos1, tras estimulación con EGF o FBS (Ginel-Picardo, 2012; Qian et al., 2000; Wang et al., 1997). Además, trabajos realizados en otros tipos celulares muestran un papel clave de Sos1 en la fosforilación de ERK ante distintos estímulos, como por ejemplo en células Jurkat (Roose JP et al., 2007), en timocitos (Jun et al., 2013; Kortum et al., 2011, 2012), en linfocitos B (Alles et al., 2017) o en células CHO-IR (Sakaue et al., 1995). En la misma línea que los resultados anteriores respecto a la función inicialmente prescindible de Sos 2 en la mayoría de procesos estudiados, su ausencia individual tampoco generaba cambios en el perfil de fosforilación de ERK con respecto a las condiciones control tras estimulación con PDGF. En concordancia con el bloqueo de la activación de Ras en MEFs carentes de ambas isoformas de Sos, observamos un descenso importante de la fosforilación de ERK a corto, medio y largo plazo con respecto a MEFs WT y Sos2 KO. Esta disminución se correspondería con los defectos graves observados en proliferación, progresión del ciclo celular, etc.

Resultados algo más sorprendentes encontramos tras estimulación con EGF. En este caso, la eliminación simple de Sos1, pero también de Sos2, mostraba una tendencia a la disminución en la fosforilación de ERK en la señalización a través de EGFR a corto plazo. Este resultado es sorprendente porque el nivel ERK fosforilado en ausencia de Sos1 o Sos2 resultaba prácticamente equivalente, lo que contrasta con las claras diferencias entre los MEFs Sos1 KO y Sos2 KO en la mayoría de los procesos analizados en el presente trabajo y particularmente los referentes al nivel de activación de Ras.

En cuanto a los niveles de activación de la quinasa Akt tras la estimulación de PDGF o EGF, nuestros resultados demostraron que tras estimulación con PDGF no existían diferencias entre los 4 genotipos de estudio. En cambio, tras estimulación con EGF detectamos dos patrones muy claros en la cinética de activación de Akt en función de la presencia/ausencia de la proteína Sos1. Los MEFs carentes de la Sos1 mostraban una reducción en el nivel de fosforilación de Akt. Las diferencias detectadas dependiendo de estímulo pueden deberse a que la estimulación de PDGFR, pero no EGFR, puede activar directamente a PI3K (Otsu et al., 1991) de forma independiente a Ras. Sin embargo, la activación de la ruta PI3K/Akt a través del EGFR depende mayoritariamente de su activación a través de Ras (Kodaki et al., 1994; Otsu et al., 1991; Rodríguez-Viciana et al., 1994, 1997). En este caso además, la fosforilación de Akt sería independiente de Sos2, de manera individual o combinada con Sos1, puesto que el perfil de activación de Akt es prácticamente idéntico en MEFs Sos1 KO y MEFs 
Sos1/2 DKO. Estos resultados se asemejan a los observados en MEFs Rasless donde la ausencia de las proteínas Ras provoca una disminución de los niveles de fosforilación de Akt tras la estimulación con EGF (Song et al., 2013), demostrando una clara relación entre la activación de Ras y de Akt a través del EGFR y mucho menor a través de PDGFR.

En resumen, la eliminación de ambas proteínas Sos provoca una ausencia de activación de Ras ante un estímulo mitogénico, mostrando los miembros de esta familia de RasGEFs una redundancia funcional parcial en este sentido. Por lo tanto, la deficiencia en la señalización mediada por Ras debida a la eliminación conjunta de Sos1 y Sos2 explicaría los graves defectos observados en procesos como proliferación, progresión del ciclo celular, estado de la transcripción y organización del citoesqueleto o migración, entre otros. La imposibilidad de activar Ras en las células Sos1/2 DKO es equiparable a la observada en los MEFs Rasless (Drosten et al., 2010; Song et al., 2013). Además, el efecto de la eliminación de las proteínas Sos sobre la activación de las rutas Ras/MAPK y PI3K/Akt depende del RTK estimulado.

\section{Activación de Rac1 en células deficientes de las proteínas Sos}

Debido a la función dual de Sos1 como RasGEF y RacGEF, decidimos además analizar si la ausencia individual o combinada de las proteínas Sos afectaba al nivel de activación de Rac1 ante un estímulo.

Nuestros resultados han demostrado que no existían diferencias significativas en la activación de Rac1 entre los MEFs de los 4 genotipos. Sin embargo, debemos señalar que sí observábamos una tendencia a una menor activación de Rac1 en MEFs Sos1 KO y Sos1/2 DKO. Por el momento debemos tomar este resultado con cautela, dada la variabilidad de los resultados obtenidos entre las distintas réplicas de este ensayo de pull down. Una de las razones más plausibles para no encontrar diferencias en los niveles de activación de Rac1 es que, a diferencia de lo que ocurre con Ras, existen otros RacGEFs importantes en MEFs que pueden compensar la deficiencia de las proteínas Sos. Además, existen otras cuestiones metodológicas a tener en cuenta. La variabilidad observada puede deberse en primer lugar a la mayor capacidad de hidrólisis que tiene RacGTP con respecto a RasGTP, que puede haber generado mayores diferencias entre las distintas replicas realizadas (Boriack-Sjodin et al., 1998). En segundo lugar, la concentración utilizada del factor de crecimiento EGF (100 ng/ml) puede no haber sido la óptima. De hecho, la estimulación con altas dosis de EGF ha demostrado saturar la capacidad de activación de la ruta de señalización a través del EGFR, promoviendo la 
internalización de los complejos Grb2/Sos (Di Guglielmo et al., 1994), lo que podría disminuir la disociación de los complejos Grb2/Sos y con ello reducir la abundancia de Sos1 libre para unirse con las proteínas Eps8/E3b1 para activar a Rac1. Por estas razones, es necesario optimizar el protocolo de este ensayo para llegar a un resultado concluyente, y no descartar posibles alteraciones de la activación de Rac1 en ausencia de las proteínas Sos como se ha descrito en trabajos anteriores (Sini et al., 2004; Toffali et al., 2017).

\section{Prevalencia de Sos1 sobre Sos2 en la regulación del estado redox y el mantenimiento de la homeostasis mitocondrial}

Uno de los hallazgos más significativos en este trabajo en relación con los experimentos in vitro es la relación entre la eliminación de Sos1 y el incremento de ROS en la célula.

Nuestros resultados demostraron que la ausencia Sos1 y en mayor medida de Sos1/2 inducía un aumento del estrés oxidativo que afectaba de manera notoria a la funcionalidad de la mitocondria, que conducia a un proceso de mitofagia, que a su vez generaba una fuerte alteración del estado redox de la célula. Análisis adicionales confirmaron que el aumento del estrés oxidativo en las células carentes de Sos1 no era debido a un efecto off target del 4OHT. Sin embargo, los resultados sí sugerían que aunque la ausencia de Sos1 inducía un estrés oxidativo, también sensibilizaba a la célula a la respuesta tras el tratamiento con un agente oxidante. La implicación del estrés oxidativo en la alteración de la homeostasis celular se puso de manifiesto tras la atenuación de varios de los defectos encontrados en las células Sos1 KO y Sos1/2 DKO tales como la proliferación y la organización del citoesqueleto de actina tras el tratamiento con distintos tipos de antioxidantes.

De este modo, podemos establecer una relación directa entre la deficiencia de Sos1 y la desregulación del balance redox de la célula, teniendo como consecuencia el aumento del estrés oxidativo, la disminución del $\Delta \Psi$ y la aparición de mitofagia. Además, estos resultados indican que la eliminación de Sos1 por sí misma es capaz de provocar el aumento de ROS y que hipersensibiliza a estas células a la adición del $4 \mathrm{OHT}$. Esta observación podría establecer una relación entre la falta de Sos1 y una deficiencia en la maquinaria detoxificadora de las ROS intracelulares. En este sentido, trabajos anteriores de nuestro laboratorio describieron la incapacidad de detoxificación de las ROS intracelulares en MEFs inmortales deficientes en Sos1. Por otra parte, y en consonancia con nuestro 
trabajo, el silenciamiento de Sos2 no inducía un aumento del estrés oxidativo (Ginel-Picardo, 2012). Sin embargo, y a diferencia de nuestros resultados, el tratamiento con el agente oxidante tBHP (del inglés: tert-Butyl $\underline{H}$ ydroperoxide) causaba la acumulación de ROS tanto en MEFs deficientes en Sos1 como en Sos2. Además, se analizó la fosforilación de JNK, tras la estimulación con FBS, dada su importancia en la respuesta a estímulos de estrés oxidativo (Kamata et al., 2005; Martindale and Holbrook, 2002). De acuerdo con el aumento de ROS intracelular observado en células carentes de Sos1 en condiciones basales, se ha encontrado una mayor fosforilación de JNK en estos MEFs respecto a su control (Ginel-Picardo, 2012). Es más, la eliminación de Sos1 en estas células induce la sobreexpresión de genes esenciales en la homeostasis mitocondrial y la biogénesis de la mitocondria como Dnaja3 y Mfn2 (Ginel-Picardo, 2012). Estos datos apoyan que Sos1 puede estar involucrado en la homeostasis mitocondrial.

De acuerdo con las posibles explicaciones que podrían relacionar la ausencia de las proteínas Sos con el estrés oxidativo, consideramos interesante que aunque de forma mayoritaria las proteínas Ras se localizan en la membrana plasmática, se han identificado también en diferentes compartimentos subcelulares, como RE (Omerovic et al., 2007), aparato de Golgi (Hancock et al., 1990), endosomas (Goodwin et al., 2005) y mitocondrias (Bivona et al., 2006; Plowman et al., 2008; Rebollo et al., 1999). Mediante fraccionamiento subcelular, las tres formas canónicas de Ras han sido detectadas en la fracción mitocondrial de células T de ratón, y estas tres proteínas co-inmunoprecipitaron con el factor pro-apoptótico Bcl-2 (Rebollo et al., 1999). Posteriormente, otros grupos solo detectaron a las proteínas K-Ras y N-Ras constitutivamente asociadas a mitocondrias purificadas (Bivona et al., 2006; Plowman et al., 2008). La proteína K-Ras interacciona con la membrana externa de la mitocondria, mientras que $\mathrm{N}$-Ras se asocia tanto a la membrana externa como a la membrana interna mitocondrial (Bivona et al., 2006; Plowman et al., 2008). Además, observaron que la morfología mitocondrial se ve afectada en células que no expresaban alguna de estas dos proteínas Ras, siendo la principal función de Ras en este compartimento contribuir a la supervivencia celular (Plowman et al., 2008). Otros autores han descrito que la PKC es capaz de fosforilar a K-Ras en la Ser181 y así antagonizar el dominio de interacción de K-Ras con la membrana plasmática, lo que promovería la translocación al citosol y su acumulación en la mitocondria (Rasola et al., 2010), aunque de manera general se ha asociado que la fosforilación de K-Ras estimula la apoptosis en células transformadas por K-Ras (Bivona et al., 2006). Aunque existen pocos datos sobre la funcionalidad de Ras en la mitocondria, cabría la posibilidad de que la ausencia de las proteínas Sos disminuyera la activación de Ras en las 
mitocondrias y esto condujese a una afectación de la homeostasis mitocondrial similar a la que hemos descrito en este trabajo. En relación a la posibilidad de que un RasGEF esté involucrado en el control del estés oxidativo en un compartimento subcelular, se ha descrito recientemente que los GEFs RasGRF1 y RasGRF2 son esenciales en la regulación del estrés oxidativo del RE (Wu et al., 2017).

\section{Función prevalente de Sos1 en el mantenimiento de la homeostasis de la} piel

Inicialmente examinamos la implicación de las proteínas Sos1 y Sos2 en el mantenimiento de la homeostasis de la piel. Para ello, analizamos en detalle la histología de esta estructura en los distintos genotipos de estudio. Nuestros resultados demostraron que la ausencia individual de Sos1, pero no de Sos2, afectaba a la integridad de las distintas poblaciones celulares y estructuras en las distintas capas de la piel. La ausencia combinada de Sos1 y Sos2 incrementaba mucho más las alteraciones observadas en los animales Sos1 KO. Los resultados aquí mostrados confirman por lo tanto la importancia de las proteínas Sos en el mantenimiento de la homeostasis de la piel, con un papel prevalente de Sos1 sobre Sos2. Trabajos anteriores han documentado la importancia de la señalización mediada por Ras en el mantenimiento de la integridad de la piel (Doma et al., 2013; Drosten et al., 2014; Kern et al., 2011). A diferencia de lo que ocurre con las proteínas Sos, parece que existe una especificidad funcional de K-Ras en este proceso ya que la ausencia individual o combinada de las otras dos formas canónicas de Ras no afecta a la homeostasis de la piel, pero cuando se elimina K-Ras la integridad epitelial está severamente afectada (Drosten et al., 2014). Para confirmar esta hipótesis sería necesario analizar la histología de la piel en animales deficientes sólo para K-Ras, y si se observasen alteraciones equivalentes con las encontradas en ausencia de Sos1 y Sos2, los resultados sugerirían que las proteínas Sos, principalmente Sos1, señalizarían a través de K-Ras en este órgano. También se ha estudiado el papel de otros efectores de Ras en el mantenimiento de la integridad de la piel. Por ejemplo, la ausencia individual de las proteínas B-Raf y C-Raf no tienen impacto en la histología de la piel, sugiriendo una redundancia funcional de estas proteínas (Ehrenreiter et al., 2005; Galabova-Kovacs et al., 2006a). Las proteínas Mek1 y Mek2 y las proteínas ERK1 y ERK2 muestran también redundancia funcional en el mantenimiento de la homeostasis epitelial puesto que la ausencia individual de cada una de estas proteínas no afecta a la integridad de la piel (Dumesic et al., 2009; Scholl et al., 2007). Sin embargo, la ausencia combinada de Mek1/2 o de ERK1/2 sí afecta de forma clara a la homeostasis de la piel (Dumesic et al., 2009; Scholl et al., 2007). 
Posteriormente, analizamos en detalle cada una de la alteraciones específicas que llevaban a tal pérdida de la integridad de la piel en los animales carentes de expresión de ambas proteínas Sos y en menor medida los simples mutantes para Sos1.

Debido a la notable implicación de Sos1 y en menor medida Sos2 en el control de la proliferación celular analizamos en primer lugar la tasa de proliferación de los queratinocitos de la epidermis en los 4 grupos de análisis. Nuestros resultados demostraron que la eliminación individual de Sos1 reducía la capacidad de proliferación de los queratinocitos siendo esta reducción mucho más acusada cuando Sos1 y Sos2 estaban ausentes de manera simultánea, provocando la disminución del grosor de la epidermis en estos animales. Estos resultados concuerdan con la función primordial que tienen las proteínas Sos en el control de la proliferación celular en distintos linajes celulares y/o tejidos como hemos demostrado en nuestros experimentos in vitro y que hemos discutido con anterioridad en apartados anteriores. Se ha descrito que la ruta de señalización EGFR-Ras-Raf es esencial y el control de la proliferación de los queratinocitos (Doma et al., 2013). De hecho, los ratones Rasless también muestran una disminución de la proliferación de los queratinocitos (Drosten et al., 2014). De forma similar, la eliminación simultánea de las proteínas ERK1/2 en queratinocitos humanos inhibe la proliferación (Dumesic et al., 2009).

Debemos señalar que la disminución en el grosor de la epidermis o del resto de capas de la piel observada en los ratones Sos1 KO y Sos1/2 DKO podía ser debido a un proceso de muerte celular. Sin embargo, nuestros estudios no han encontrado que la eliminación de Sos1 y/o Sos2 causara un proceso de apoptosis que pudiera explicar los fenotipos encontrados. Estos resultados coinciden con nuestros experimentos in vitro y experimentos anteriores realizados en nuestro laboratorio (GinelPicardo, 2012) en los que no se ha relacionado la eliminación de Sos1 y/o Sos2 con la muerte celular en fibroblastos.

Una de las alteraciones encontradas en la dermis de los ratones Sos1/2 DKO es la fuerte afectación de los folículos pilosos y las glándulas sebáceas. En los folículos pilosos se localizan las células madre de la epidermis que están en constante división celular. Nuestros resultados mostraban una reducción de la proliferación celular en la región del folículo piloso, pudiendo así afectar a su integridad. Además se sabe que la desregulación de la señalización medida por EGFR a través de Ras afecta a la integridad del folículo piloso (Doma et al., 2013). Asimismo, la eliminación combinada de Mek1 y Mek2 provoca una notable reducción del número de folículos pilosos (Scholl et al., 2007). Además, 
aunque Rac1 no parece esencial en la homeostasis de la piel sí desempeña una función crítica en el mantenimiento de la integridad del folículo piloso y de las glándulas sebáceas (Benitah et al., 2005; Castilho et al., 2010; Chrostek et al., 2006). Nuestros resultados in vitro mostraban que no existía una reducción significativa del nivel de activación de Rac, sin embargo no podemos descartar que la ausencia de Sos1/2 tenga un efecto sobre Rac en la piel y pueda afectar al mantenimiento de los folículos pilosos y las glándulas sebáceas.

Fue llamativa la fuerte reducción de la vascularización cutánea que detectamos en los animales Sos1 KO y de forma aún más importante en los ratones Sos1/2 DKO. Estos datos sugerían una implicación de las proteínas Sos en el proceso vasculogénico y de angiogénesis que no se ha descrito previamente por otros autores. Estos resultados se complementan con los análisis ex vivo del anillo aórtico realizados en este trabajo donde hemos descrito la implicación de las proteínas Sos en el proceso de angiogénesis. Además, análisis de expresión génica realizados MEFs inmorales ko para Sos1 (GinelPicardo, 2012) mostraron alteraciones en genes como Notch1, que tiene una función es crucial en el proceso angiogénico (Kume T, 2009). Por otro lado, la letalidad de los embriones deficientes de Sos1 era provocada por defectos en la placenta. Estos fallos estaban relacionados con una disminución importante de los niveles del VEGFR1, y podían ser un reflejo de alteraciones en el proceso de angiogénesis (Fong et al., 1995, Qian et al., 2000). Por otro lado se sabe que proteínas efectoras como las GTPasas Ras Rab1 y R-Ras están implicadas en el proceso angiogénico y la migración endotelial vascular (Chrzanowska-Wodnicka et al., 2008; Murillo et al., 2014; Sawada et al., 2012). Además, la señalización mediada por B-Raf parece ser clave en el proceso angiogénico (Galabova-Kovacs et al., 2006b). En resumen, en este trabajo describimos una nueva función potencial de las proteínas Sos en el control de la angiogénesis. Las proteínas Sos tendrían una redundancia funcional en este proceso aunque con un rol dominante de Sos1 sobre Sos2.

La capa de la piel más afectada por la eliminación concomitante de Sos1 y Sos2 era la hipodermis. Mientras que la ausencia individual inducía una reducción considerable del grosor de este estrato, en el caso de los animales Sos1/2 DKO esta capa llegaba incluso a desaparecer. Esta capa esta principalmente formada por tejido adiposo. Observaciones previas realizadas en nuestro laboratorio demostraron que la eliminación conjunta de las proteínas Sos afectaba drásticamente a la integridad del tejido adiposo en ratones (Baltanás et al., 2013). En conjunto, estos datos sugieren que las proteínas Sos son importantes y tienen una redundancia funcional en el mantenimiento de la 
homeostasis de los adipocitos. Trabajos futuros deberán estudiar en detalle esta posible función de las proteínas Sos.

\section{Importancia de las proteínas Sos en la reparación del daño tisular en la piel}

El ensayo de WH o reparación de la herida permite analizar una secuencia de diferentes procesos biológicos que incluyen la proliferación, la migración, la respuesta inflamatoria o la neovascularización entre otros (Reinke and Sorg, 2012), y que necesitan estar altamente coordinados para dar una respuesta satisfactoria ante el daño generado. Por lo tanto, consideramos que este ensayo aporta información muy valiosa en cuanto a la función de las proteínas Sos 1 y Sos 2 en cada uno de estos procesos en respuesta a un daño.

Nuestros resultados han demostrado que la eliminación individual de Sos1, pero no de Sos2, retrasa levemente el proceso del cierre de la herida mientras que la eliminación concomitante de ambas proteínas resulta en un defecto notable en el proceso de cierre. Este resultado está en consonancia con los resultados obtenidos en este trabajo para el ensayo de WH in vitro realizado en fibroblastos de los mismos genotipos. Por lo tanto, existe una redundancia funcional de las proteínas Sos aunque con un mayor peso específico de Sos1 en el conjunto de estos procesos. A continuación analizaremos

y discutiremos paso por paso los distintos procesos que tienen lugar durante el cierre de la herida y el papel específico de cada una de las proteínas Sos pudiera tener para cada caso.

Durante los primeros pasos de la reparación del tejido epitelial se forma una red de fibrina en la zona de la herida (Reinke and Sorg, 2012). Nuestros resultados han demostrado que los animales Sos1/2 DKO carecen o apenas sintetizan esta red de fibrina. Desconocemos exactamente la causa subyacente que origina esta alteración. Se sabe que la fibrina es sintetizada a partir de fibrinógeno, que se produce en el hígado (Guadiz et al., 1997; Weisel, 2005). Trabajos anteriores de nuestro laboratorio han documentado que la homeostasis del hígado está severamente afectada en los animales Sos1/2 DKO (Baltanás et al., 2013). Planteamos que el daño hepático que muestran los ratones Sos1/2 DKO pudiera afectar a la síntesis de fibrinógeno y consecuentemente de fibrina.

Los siguientes procesos que tienen lugar durante la reparación del tejido epitelial son la proliferación de los queratinocitos y la migración de distintos tipos celulares, principalmente fibroblastos, hacia el 
lugar de la herida, y que se encargan de la contracción del tejido adyacente a la herida y la generación de una tensión mecánica. En consonancia con los resultados obtenidos en condiciones fisiológicas en la piel, la eliminación combinada de las proteínas Sos1 y Sos2 reduce notablemente la capacidad proliferativa de los queratinocitos, incluso ante un estímulo hiperproliferativo como es el WH. Por otro lado, los animales Sos1/2 DKO exhibían una menor contracción del tejido adyacente a la lesión con respecto al resto de genotipos, lo que podría reflejar una menor migración de fibroblastos a la zona de la herida. De hecho, los resultados in vitro presentados en este trabajo han demostrado que la ausencia concomitante de Sos1 y Sos2 bloquea el proceso de migración en MEFs primarios en un ensayo de WH.

Otro de los procesos que ocurre durante el cierre de la herida es el de la respuesta inflamatoria donde células del sistema inmune como los neutrófilos, macrófagos o linfocitos $\mathrm{T}$ proliferan y/o migran a la región de la herida para dar una respuesta inmunitaria acorde con el daño infligido. Aunque no hemos estudiado de forma específica la respuesta inmune tras la lesión cutánea en los animales de los distintos genotipos planteamos que este proceso posiblemente este alterado en los animales carentes de expresión de Sos1, sobretodo en los animales Sos1/2 DKO. Esta hipótesis se basa en los defectos encontrados durante este trabajo en la proliferación y la migración en otros linajes celulares. Además, se sabe que los linfocitos T son un tipo celular especialmente sensible a la ausencia de las proteínas Sos (Baltanás et al., 2013; Guittard et al., 2015; Kortum et al., 2011). Por otra parte, aunque los neutrófilos son células que no son capaces de proliferar sí que migran para ejercer su acción, siendo la señalización a través de la ruta de PI3K esencial para su activación (Hawkins et al., 2010). Por último, aunque la participación de Sos1 no es crucial, sí se ha demostrado que participa en el proceso de diferenciación de estas células (Gobert Gosse et al., 2005; Saleem et al., 1995).

Uno de los últimos procesos que suceden durante la reparación epitelial es un proceso de angiogénesis. Nuestros resultados demostraban la presencia de un número mucho menor de vasos sanguíneos en los animales Sos1/2 DKO en las regiones adyacentes a la herida que en el resto de genotipos. Estos resultados concuerdan con la reducción de la vascularización en la dermis de animales deficientes para Sos1 en condiciones fisiológicas y en la menor capacidad angiogénica de los anillos aórticos extraídos de animales Sos1/2 DKO. 
En resumen, nuestros resultados muestran un bloqueo del proceso de reparación tisular en los animales Sos1/2 DKO causado por diferentes alteraciones en los distintos procesos que participan en la reparación del epitelio como la proliferación, la migración o la angiogénesis. Además sugerimos que la respuesta inflamatoria sea defectuosa en estos animales. Estos resultados son consistentes con trabajos previos que demuestran la importancia de la ruta EGFR/Ras/Raf en este proceso de cierre de la herida (Doma et al., 2013). En concreto, este eje de señalización participa en el control de la proliferación, la migración y la adhesión de los queratinocitos (Ehrenreiter et al., 2005; Marikovsky et al., 1993; Shirakata et al., 2005; Yoshioka et al., 2010). Trabajos previos han mostrado la importancia de proteínas efectoras de Ras tales como C-Raf en la reparación epitelial tras un daño tisular, ya que su eliminación en la piel disminuye la capacidad de regeneración cutánea que se ve reflejado en una menor migración de queratinocitos y fibroblastos (Ehrenreiter et al., 2005). Por último, aunque no hemos estudiado los niveles de activación de Rac en estos experimentos debemos tener en cuenta que una deficiencia de Sos1 podría afectar a la señalización mediada por Rac, ya que es importante en la reparación del tejido epitelial (Castilho et al., 2010).

\section{La eliminación de Sos1 afecta al inicio y a la progresión tumoral en tumores epiteliales inducidos químicamente}

Una vez descrita por primera vez una función importante de las proteínas Sos en el mantenimiento de la homeostasis de la piel en condiciones fisiológicas y en respuesta a un daño agudo del tejido epitelial, el siguiente paso fue analizar el papel de estas proteínas en un proceso patológico. En concreto, evaluamos su función en el inicio y desarrollo de tumores epiteliales generados químicamente, en concreto empleando el protocolo DMBA-TPA (Pérez-Losada and Balmain, 2003; Quintanilla et al., 1986).

Nuestros datos demostraron que la eliminación de Sos1 retrasaba el inicio y la progresión de los tumores inducidos químicamente. Por el contrario, la eliminación individual de la proteína Sos2 no mostraba efecto alguno en el inicio y la progresión de los tumores. Sin embargo, la ausencia de Sos1 previene la aparición de tumores malignos y además, el grado de evolución de los tumores benignos catalogados era menor que en el resto de genotipos. El efecto de la eliminación combinada de Sos1 y Sos2 no pudo realizarse debido a la temprana letalidad de los animales Sos1/2 DKO (Baltanás et al., 2013). Nuestros resultados relacionaban directamente la reducción en el número y tamaño de los 
tumores en los animales Sos1 KO con una clara reducción de la proliferación en los tumores, aunque no con un proceso de apoptosis en las células del tumor. Estos resultados concuerdan con lo observado en condiciones fisiológicas y tras la inducción de un daño tisular, donde la ausencia de las proteínas Sos, en especial de Sos1, afecta de forma muy marcada al proceso de proliferación sin influir en la supervivencia celular.

Se ha demostrado ampliamente la función clave de las proteínas Ras en el inicio tumoral, concretamente las mutaciones de K-Ras en tumores humanos se detectan en etapas tempranas del proceso neoplásico en un elevado número de tumores (Forbes et al., 2011). Trabajos adicionales indican que mutaciones de las proteínas Ras son esenciales en el inicio tumoral (Baer et al., 2014; Mo et al., 2007; Nussinov et al., 2015). En particular, en el modelo de carcinogénesis DMBA-TPA se ha descrito que la mutación mayoritaria se produce en H-Ras (Balmain, Ramsden, Bowden, \& Smith, n.d.; Ise et al., 2000) y en su ausencia, la mutación mayoritaria en este protocolo se produce en K-Ras (Ise et al., 2000). De este modo, las proteínas Sos, y en particular Sos1, que ha demostrado una mayor capacidad RasGEF, podría mediar la activación de las formas wt de Ras por parte de Ras oncogénico (Jeng et al., 2012). Además, trabajos previos han descrito que la eliminación de otros RasGEFs conducen a efectos muy similares a los mostrados en nuestro trabajo. Concretamente, la eliminación de RasGRP1 en ratones reduce el inicio y la progresión tumoral en el mismo modelo de carcinogénesis epitelial utilizado por nosotros (Sharma et al., 2010, 2014), mientras que la sobreexpresión de RasGRP1 incrementa la tumorigénesis epitelial generada mediante la aplicación de DMBA-TPA (Luke et al., 2007). Además, otros trabajos han asociado la sobreexpresión de RasGRP1 con la aparición espontánea de tumores epiteliales (Oki-Idouchi and Lorenzo, 2007). Asimismo, la eliminación de RacGEFs como Vav2/3 o Tiam1 disminuye la incidencia tumoral epitelial en el protocolo de carcinogénesis DMBA-TPA (Lambert et al., 2002; Menacho-Márquez et al., 2013).

Para estudiar en detalle los procesos que ocurrían durante las primeras etapas del inicio y el desarrollo tumoral empleamos diversos experimentos "a corto plazo". Por ejemplo, la administración de TPA en la piel nos permitió mimetizar de cierta manera la respuesta hiperproliferativa que ocurre en esas primeras fases del inicio y desarrollo del tumor. De nuevo, la implicación de Sos1 en la regulación positiva de la proliferación se vio fielmente reflejada ya que los animales Sos1 KO, y más aún los Sos1/2 DKO, mostraban mucha menor proliferación tras el estímulo que el resto de genotipos. Sin embargo, debemos señalar que incluso la eliminación concomitante de Sos1 y Sos2 no bloqueaba 
por completo la capacidad de proliferar de los queratinocitos, ya que estos son capaces de responder al estímulo hiperproliferativo y aumentar notablemente su tasa de proliferación respecto a lo que ocurre en condiciones fisiológicas. Además, indujimos una respuesta pro-apoptótica tras la administración de una dosis de DMBA. En consonancia con todos los resultados tanto in vitro como in vivo expuestos en el presente trabajo, las proteínas Sos1 y/o Sos 2 no parecen ser esenciales en la muerte por apoptosis medada por caspasa 3. En conjunto, estos resultados indican que el retraso del inicio y la progresión tumoral se corresponden principalmente con una menor proliferación de los queratinocitos.

Estos datos coinciden con el papel clave de las proteínas Ras y de sus proteínas activadoras y efectoras en el inicio y la progresión tumoral en la piel (Doma et al., 2013; Kern et al., 2011; May et al., 2015). En concreto, se sabe que la sobreexpresión de Sos1 en queratinocitos del estrato basal provoca el desarrollo espontáneo de papilomas (Sibilia et al., 2000) lo que concuerda con nuestros resultados ya que la eliminación de Sos1 disminuye el desarrollo de papilomas. Por otro lado, también se ha relacionado la ganancia de función de Sos1 con el desarrollo de tumores granulares en la piel de pacientes con SN. En cuanto a la influencia de Sos1 en el desarrollo de tumores malignos, se ha descrito que la sobreexpresión de Sos1 promueve la resistencia al cisplatino en CCE a través de la activación de la ruta Ras/MAPK (Kong et al., 2015) y además el fármaco Belinostat disminuye los niveles de expresión de las proteínas Sos mejorando en este caso la prognosis en los casos de CCE (Kong et al., 2017).

Los experimentos a corto plazo con TPA también nos permitieron estudiar el papel de las proteínas Sos durante la respuesta inflamatoria. En concreto analizamos el patrón de expresión de los neutrófilos. En este caso obtuvimos unos resultados llamativos que difererían del perfil de resultados obtenidos en otros procesos estudiados. Mientras que la ausencia individual de Sos1 no afectaba a la respuesta de los neutrófilos inducida por TPA, la falta de expresión de Sos2 aumentaba la capacidad de respuesta de los neutrófilos al estímulo. Por el contrario, la eliminación concomitante de las proteínas Sos bloqueaba prácticamente la llegada de neutrófilos a la región de la piel tratada con TPA. Teniendo en cuenta que los neutrófilos son células que no proliferan y que además no se habían observado diferencias en el recuento de neutrófilos total en sangre periférica entre los animales de los 4 genotipos de estudio (Baltanás et al., 2013) proponemos que estas respuestas divergentes sean probablemente debidas a alteraciones en los mecanismos de migración y/o quimiotaxis. Si fuera 
debido a una afectación en la migración, este patrón no coincidiría con las alteraciones que hemos observado en la migración de los MEFs, donde la ausencia individual de Sos1 reduce la capacidad de migración, mientras que la eliminación de Sos2 no generaba diferencias respecto a las condiciones control. Debemos recordar que la dinámica de adhesiones focales observada en MEFs Sos2 KO les confería, en principio, una ventaja en la capacidad de migración respecto a los fibroblastos del resto de genotipos. Pudiera ser que en el caso de los neutrófilos esta supuesta ventaja se reflejara en una mayor velocidad de migración a la región bajo estimulo inflamatorio.

A diferencia de los MEFs, los neutrófilos necesitan de la acción coordinada de otros RasGEFs como C3G o RasGRP4 para dar una respuesta inflamatoria eficiente (Futosi et al., 2013; Suire et al., 2012). Nuestros resultados indican que la presencia de Sos1 es prescindible durante la respuesta inflamatoria al TPA en la piel y que la deficiencia de Sos 2 no solo no bloquea si no que acelera este proceso. Pudiera ser que un exista un desbalance entre las señales de los distintos RasGEFs por la ausencia de Sos1 o Sos2. Por otro lado, la ausencia combinada de ambas proteínas Sos bloqueaba casi por completo esta respuesta, no pudiendo ser compensada por otros RasGEFs presentes en los neutrófilos.

Los neutrófilos son reclutados al lugar de inflamación en respuesta a distintas sustancias quimioatrayentes, siendo muy importante la señalización mediada por las RhoGTPasas y la familia de proteínas PI3K en este proceso (Hawkins et al., 2010; van Helden et al., 2012). Aunque no hemos estudiado los niveles de activación de estas proteínas, y en concreto Rac, en la piel ante estos estímulos planteamos que la ausencia de las proteínas Sos pudiera alterar de manera alguna esta señalización provocando el fenotipo observado.

Otra opción que planteamos es que la reducción de los vasos sanguíneos observada en los animales Sos1/2 DKO pueda afectar a la migración transendotelial necesaria para que los neutrófilos lleguen a la región afectada. Esta hipótesis podría servir en el caso de los animales Sos1/2 DKO pero no explicar los resultados obtenidos para los animales Sos2 KO.

No creemos que las diferencias observadas entre genotipos en cuanto a la respuesta inmune mediada por neutrófilos sean importantes en el retraso del inicio o progresión de los tumores inducidos químicamente en los animales Sos1 KO, aunque si que se corresponde con una limitación de la 
respuesta inmune ante un estimulo, lo que coincidiría con la hipótesis antes expuesta referente a la posible afectación de la respuesta inmune en el proceso de cierre de la herida.

\section{La eliminación de Sos1 en tumores epiteliales pre-existentes reduce el crecimiento tumoral}

La siguiente cuestión que nos plantemos fue estudiar el papel de Sos1 en tumores previamente establecidos. Nuestros resultados revelaron que la eliminación de Sos1 reducía de manera significativa el número y el tamaño de tumores ya existentes, que se relacionaba directamente con una disminución significativa de la proliferación de los queratinocitos. Está ampliamente descrito que la activación constitutiva de las proteínas Ras y de proteínas efectoras de Ras no solo participan en el inicio tumoral, sino que son claves en la progresión tumoral (Castellano et al., 2013; Wang et al., 2013; Zou et al., 2014). Por ello, la eliminación de Sos1 podría disminuir la activación de Ras y en consecuencia de las rutas de señalización efectoras y de este modo podría explicarse una menor tasa de proliferación. Además, se ha descrito que en procesos como la transformación tumoral es necesario una activación mantenida del oncogén, lo que se correlaciona con la capacidad de Sos1 para señalizar a largo plazo en células inmortales (Qian et al., 2000). Además, la disminución de la respuesta proliferativa tras el tratamiento con TPA en condiciones de ausencia de Sos1 también contemplaría las siguientes posibilidades:

1) Se ha descrito que el uso del protocolo carcinogénico DMBA-TPA el gen diana mutado con mayor frecuencia es H-Ras (Balmain et al., 1984; Ise et al., 2000), de este modo, basándonos en que Ras oncogénico promueve la activación de las formas Ras wt a través de Sos1 (Jeng et al., 2012), la eliminación de Sos1 en células que presentasen Ras oncogénico podría suponer una menor activación de las formas Ras $w t$, y así una disminución significativa de la señalización a través de Ras/MAPK y con ellos una menor tasa proliferativa que promovería la regresión tumoral, como se ha descrito en otros tipos de tumores (Jeng et al., 2012).

2) Por otro lado, se ha descrito que Sos interacciona con la proteína Ezrina (Geissler et al., 2013; Sperka et al., 2011), esta proteína regula la activación de Ras a través de Sos actuando como una proteína de unión del complejo Sos/Ras (Geissler et al., 2013). En concreto, la Ezrina es una de las tres proteínas ERM (Ezrina-Radixina-Moesina) que se unen a la actina y modulan procesos como la 
morfogénesis epitelial, adhesión y migración (Arpin et al., 2011; Bretscher et al., 2002; Fehon et al., 2010) claves en la progresión tumoral. De este modo, la eliminación de Sos1, podría suponer una disminución de RasGTP en las células hiperproliferativas tumorales y así promover una menor formación de los complejos Sos/Ras/Ezrina (Geissler et al., 2013) con la consecuente menor progresión tumoral promovida por las proteínas ERM. Por otro lado, varios trabajos han relacionado a Sos1 con la progresión tumoral, aunque en otros modelos y en estadios más tardíos a los descritos en este modelo de carcinogénesis, en particular, se ha descrito que Sos1 mediante la formación del complejo Sos1/Eps8/E3b1 podría estar implicado en la capacidad metastásica (Chen et al., 2010a; Fang et al., 2017) en células de cáncer de ovario. De este modo, la unión de Sos1 con diversas proteínas podría modificar la progresión tumoral. 



\section{Conclusiones \\ Conclusions}





\section{Conclusiones}

De acuerdo con los objetivos planteados y tras el análisis y discusión de los resultados de este trabajo de investigación, las conclusiones se resumen a continuación:

1. La eliminación de Sos1 altera la morfología celular, la progresión del ciclo celular, el nivel de compactación de la cromatina y la integridad del DNA en MEFs primarios. Además, existe una reducción de la proliferación en ausencia de Sos1, que es más acusada tras la eliminación conjunta de Sos1 y Sos2. Por otro lado, la ausencia de Sos1 y/o Sos2 no afecta a la supervivencia ligada a un proceso apoptótico. Estos resultados sugieren una especificidad funcional de Sos1 en la mayoría de los parámetros analizados, aunque existe una redundancia funcional parcial de ambas proteínas en la regulación de la proliferación.

2. La ausencia individual de Sos1, pero no de Sos2, retrasa pero no impide la migración celular. Sin embargo, la eliminación combinada de Sos1 y Sos2 resulta en un defecto notable de la capacidad de migración de MEFs primarios. Estos resultados indican una redundancia funcional de ambas proteínas en el control de este proceso, con un papel prevalente de Sos1. Por otra parte, la eliminación de Sos1 no altera el proceso de adhesión, mientras que la falta de Sos2 incrementa la adhesión celular. En cambio, la eliminación simultánea de Sos1 y Sos2 limita notablemente la capacidad de adhesión de los MEFs. Estos resultados sugieren un rol no descrito anteriormente para Sos1 y Sos2 en la regulación de la adhesión celular.

3. La eliminación individual o combinada de Sos1 induce un aumento de estrés oxidativo de la célula y una pérdida de la homeostasis mitocondrial en MEFs primarios, mientras que la eliminación de Sos2 no genera alteraciones en estos procesos. Estos datos muestran una conexión mecanística entre Sos1 y el balance redox celular.

4. La eliminación de Sos1 produce una disminución de la activación de Ras y de las proteínas efectoras de las rutas Ras/MAPK y PI3K/Akt. Este efecto no se observa en ausencia de Sos2. Sin embargo, la deficiencia combinada de Sos1 y Sos2 bloquea casi totalmente la activación de Ras y reduce en mayor grado la activación de las proteínas efectoras, con respecto a los defectos observados en ausencia sólo de Sos1. Estos datos demuestran una dominancia funcional de Sos1 sobre Sos2 en la transmisión de la señal a las proteínas 
efectoras, pero también ponen de manifiesto la importancia de Sos2 en la regulación de estas rutas de senalización. Por otro lado, ni Sos1 ni Sos2 parecen esenciales en la activación de Rac en MEFs primarios.

5. La deficiencia individual de Sos1, pero no de Sos2, afecta a la arquitectura de la piel en todas sus capas. La integridad de la piel se encuentra aún más afectada cuando Sos1 y Sos2 están ausentes. Por lo tanto, las proteínas Sos son necesarias para el mantenimiento de la homeostasis de la piel y muestran una redundancia funcional, con un papel prevalente de Sos1 sobre Sos2.

6. La ausencia individual de Sos1, pero no de Sos2, reduce pero no impide la capacidad de reparación cutánea. No obstante, la eliminación conjunta de Sos1 y Sos2 provoca un defecto grave en el proceso de regeneración de la piel. Estos datos indican una redundancia funcional parcial de las proteínas Sos.

7. La eliminación de Sos1 retrasa el inicio y la progresión de los tumores epiteliales inducidos químicamente, previene la malignidad tumoral y reduce de manera significativa el número y el tamaño de tumores pre-existentes. Estos cambios se asocian a una reducción de la proliferación celular. Por otro lado, la falta de Sos 2 previene la malignidad tumoral, pero no influye en el inicio y crecimiento tumorales. En conjunto, las proteínas Sos aparecen como dianas terapéuticas potenciales en tumores de origen epitelial. 
The main conclusions of this work are summarized below:

1. Sos1 depletion impairs cell morphology, cell cycle progression, chromatin remodeling and DNA integrity in primary MEFs. In addition, cell proliferation is markedly reduced after single Sos1 removal and almost totally gone after Sos1 and Sos2 simultaneous deletion. Sos1 and/or Sos2 removal do not show any significant involvement in apoptosis. This data indicates functional specificity for Sos1 in most of the analyzed processes, although both Sos proteins show a partial functional redundancy in cell proliferation.

2. Single Sos1 deletion, but not Sos2, shows a partial time delay in cell migration. In contrast, combined Sos 1 and Sos2 depletion results in noticeably delayed cell migration in primary MEFs. This data reveals functional redundancy between Sos1 and Sos2 for this process, with a dominant role for Sos1 over Sos2. Interestingly, Sos1 deficiency does not affect to cell adhesion capability, but Sos2 individual absence results in enhanced cell adhesion. However, concomitant depletion of Sos1 and Sos2 leads to a significant reduction in cell adhesion ability. These results represent a new previously undefined role for Sos proteins in the regulation of cell adhesion.

3. Sos1-absence leads to an increase of oxidative stress and mitochondrial dysfunction in primary MEFs, whereas Sos2 is dispensable in this regard. Our data uncover a direct mechanistic link between Sos1 and control of intracellular oxidative stress.

4. The evaluation of the level of activation of Ras and downstream effectors in the Rasmitogen-activated protein kinase and PI3K pathways show that the individual absence of Sos1, but not Sos2, reduces the capacity of these proteins to be activated upon stimulus. However, RasGTP formation is practically absent and both ERK and Akt phosphorylation show significant reduction under simultaneous deletion of Sos1 and Sos2. These observations suggest partial functional overlapping of both proteins, although with a dominance of Sos1 over Sos2 regarding Ras- and Ras mediated activation

5. Sos1 single depletion causes overall alteration of skin architecture, reduced keratinocyte proliferation, affected hair follicle and blood vessels integrity in the dermis and altered the adipose tissue of hypodermis. These modifications in the skin homeostasis become worse 
when both Sos isoforms are absent. Our results unveil new, previously undefined, roles for Sos proteins with a dominance of Sos1 over Sos2, in the maintenance of skin homeostasis.

6. Sos1 lack results in a slight delay in wound repair, whereas single absence of Sos2 does not affect to this process. Simultaneous Sos $1 / 2$ disruption results in a practically blockade of wound repair, consistent with a reduction of cell proliferation and migration. Overall, our results demonstrate a partial functional overlapping of Sos1 and Sos2 in the highly coordinated events controlling tissue remodeling.

7. Sos1 disruption delays tumor initiation and decreases tumor promotion in chemicallyinduced skin carcinogenesis. Moreover, Sos1 absence prevented malignant tumor formation. In addition, deletion of Sos1 isoform in preexisting chemically-induced papillomas resulted in a decrease in tumor growth by reducing keratinocyte proliferation. Additionally, Sos2 absence prevents tumor malignancy, although is dispensable for tumor initiation and maintenance. Overall, our data unveil a previously unknown antitumurogenic effect of Sos proteins at different phases of skin tumor development thus making it possible to postulate Sos isoforms as potential therapeutic targets in prevention and/or treatment of epidermal-origin cancer. 


\section{Bibliografía}



- Adams, R.H., and Alitalo, K. (2007). Molecular regulation of angiogenesis and lymphangiogenesis. Nat. Rev. Mol. Cell Biol. 8, 464-478.

- Van Aelst, L., and D'Souza-Schorey, C. (1997). Rho GTPases and signaling networks. Genes Dev. 11, $2295-2322$.

- $\quad$ Aktas, H., Cai, H., and Cooper, G.M. (1997). Ras links growth factor signaling to the cell cycle machinery via regulation of cyclin D1 and the Cdk inhibitor p27KIP1. Mol. Cell. Biol. 17, 3850-3857.

- $\quad$ Alan, J.K., and Lundquist, E.A. (2013). Mutationally activated Rho GTPases in cancer. Small GTPases 4, $159-163$.

- $\quad$ Albanese, C., Johnson, J., Watanabe, G., Eklund, N., Vu, D., Arnold, A., and Pestell, R.G. (1995). Transforming p21ras mutants and c-Ets-2 activate the cyclin D1 promoter through distinguishable regions. J. Biol. Chem. 270, 23589-23597.

- $\quad$ Alessi, D.R., Caudwell, F.B., Andjelkovic, M., Hemmings, B.A., and Cohen, P. (1996). Molecular basis for the substrate specificity of protein kinase B; comparison with MAPKAP kinase-1 and p70 S6 kinase. FEBS Lett. 399, 333-338.

- $\quad$ Alessi, D.R., Deak, M., Casamayor, A., Caudwell, F.B., Morrice, N., Norman, D.G., Gaffney, P., Reese, C.B., MacDougall, C.N., Harbison, D., et al. (1997). 3-Phosphoinositide-dependent protein kinase-1 (PDK1): structural and functional homology with the Drosophila DSTPK61 kinase. Curr. Biol. 7, 776-789.

- $\quad$ Alles, J., Ludwig, N., Rheinheimer, S., Leidinger, P., Grässer, F.A., Keller, A., and Meese, E. (2017). MiR-148a impairs Ras/ERK signaling in B lymphocytes by targeting SOS proteins. Oncotarget.

- Almoguera, C., Shibata, D., Forrester, K., Martin, J., Arnheim, N., and Perucho, M. (1988). Most human carcinomas of the exocrine pancreas contain mutant c-K-ras genes. Cell 53, 549-554.

- $\quad$ Alvarez-Moya, B. (2010). Regulacion de la funcionalidad de K-Ras por union a CaM y fosforilacion de la ser181. Universidad de Barcelona.

- $\quad$ Amano, M., Tsumura, Y., Taki, K., Harada, H., Mori, K., Nishioka, T., Kato, K., Suzuki, T., Nishioka, Y., Iwamatsu, A., et al. (2010). A Proteomic Approach for Comprehensively Screening Substrates of Protein Kinases Such as Rho-Kinase. PLoS One 5, e8704.

- Amsen, E.M., Pham, N., Pak, Y., and Rotin, D. (2006). The guanine nucleotide exchange factor CNrasGEF regulates melanogenesis and cell survival in melanoma cells. J. Biol. Chem. 281, 121-128.

- $\quad$ Andjelković, M., Alessi, D.R., Meier, R., Fernandez, A., Lamb, N.J., Frech, M., Cron, P., Cohen, P., Lucocq, J.M., and Hemmings, B.A. (1997). Role of translocation in the activation and function of protein kinase B. J. Biol. Chem. 272, 31515-31524.

- $\quad$ Anjum, R., and Blenis, J. (2008). The RSK family of kinases: emerging roles in cellular signalling. Nat. Rev. Mol. Cell Biol. 9, 747-758.

- $\quad$ Anjum, R., Roux, P.P., Ballif, B.A., Gygi, S.P., and Blenis, J. (2005). The tumor suppressor DAP kinase is a target of RSK-mediated survival signaling. Curr. Biol. 15, 1762-1767.

- $\quad$ Aoki, Y., Niihori, T., Kawame, H., Kurosawa, K., Ohashi, H., Tanaka, Y., Filocamo, M., Kato, K., Suzuki, Y., Kure, S., et al. (2005). Germline mutations in HRAS proto-oncogene cause Costello syndrome. Nat. Genet. 37, 10381040.

- $\quad$ Appels, N.M.G.M., Beijnen, J.H., and Schellens, J.H.M. (2005). Development of farnesyl transferase inhibitors: a review. Oncologist 10, 565-578.

- $\quad$ Aronheim, A., Engelberg, D., Li, N., al-Alawi, N., Schlessinger, J., and Karin, M. (1994). Membrane targeting of the nucleotide exchange factor Sos is sufficient for activating the Ras signaling pathway. Cell 78, 949-961.

- Arozarena, I., Calvo, F., and Crespo, P. (2011). Ras, an actor on many stages: posttranslational modifications, localization, and site-specified events. Genes Cancer 2, 182-194.

- Arpin, M., Chirivino, D., Naba, A., and Zwaenepoel, I. (2011). Emerging role for ERM proteins in cell adhesion and migration. Cell Adh. Migr. 5, 199-206.

- $\quad$ Asano, E., Maeda, M., Hasegawa, H., Ito, S., Hyodo, T., Yuan, H., Takahashi, M., Hamaguchi, M., and Senga, T. (2011). Role of Palladin Phosphorylation by Extracellular Signal-Regulated Kinase in Cell Migration. PLoS One 6, e29338.

- Ascierto, P.A. (2012). MEK inhibition in BRAF-mutated melanoma. N. Engl. J. Med. 367, 1364; author reply 1365.

- $\quad$ Aspenström, P., Fransson, A., and Saras, J. (2004). Rho GTPases have diverse effects on the organization of the actin filament system. Biochem. J. 377, 327-337.

- Avraham, H., Park, S.Y., Schinkmann, K., and Avraham, S. (2000). RAFTK/Pyk2-mediated cellular signalling. Cell. Signal. 12, 123-133.

- $\quad$ Azrak, S.S., Ginel-Picardo, A., Drosten, M., Barbacid, M., and Santos, E. (2013). Reversible, interrelated mRNA and miRNA expression patterns in the transcriptome of Rasless fibroblasts: functional and mechanistic implications. BMC Genomics 14, 731. 
- $\quad$ Baer, R., Cintas, C., Dufresne, M., Cassant-Sourdy, S., Schönhuber, N., Planque, L., Lulka, H., Couderc, B., Bousquet, C., Garmy-Susini, B., et al. (2014). Pancreatic cell plasticity and cancer initiation induced by oncogenic Kras is completely dependent on wild-type PI 3-kinase p110 $\alpha$. Genes Dev. 28, 2621-2635.

- Bagrodia, S., Dérijard, B., Davis, R.J., and Cerione, R.A. (1995). Cdc42 and PAK-mediated signaling leads to Jun kinase and p38 mitogen-activated protein kinase activation. J. Biol. Chem. 270, 27995-27998.

- Baines, A.T., Xu, D., and Der, C.J. (2011). Inhibition of Ras for cancer treatment: the search continues. Future Med. Chem. 3, 1787-1808.

- Balmain, A., Ramsden, M., Bowden, G.T., and Smith, J. (1984). Activation of the mouse cellular Harvey-ras gene in chemically induced benign skin papillomas. Nature 307, 658-660.

- Balmanno, K., and Cook, S.J. (1999). Sustained MAP kinase activation is required for the expression of cyclin D1, p21Cip1 and a subset of AP-1 proteins in CCL39 cells. Oncogene 18, 3085-3097.

- Baltanás, F.C., Pérez-Andrés, M., Ginel-Picardo, A., Diaz, D., Jimeno, D., Liceras-Boillos, P., Kortum, R.L., Samelson, L.E., Orfao, A., and Santos, E. (2013). Functional Redundancy of Sos1 and Sos2 for Lymphopoiesis and Organismal Homeostasis and Survival. Mol. Cell. Biol. 33, 4562-4578.

- $\quad$ Bar-Sagi, D. (2001). A Ras by any other name. Mol. Cell. Biol. 21, 1441-1443.

- $\quad$ Barbacid, M. (1987). ras Genes. Annu. Rev. Biochem. 56, 779-827.

- $\quad$ Barbacid, M. (1990). ras oncogenes: their role in neoplasia. Eur. J. Clin. Invest. 20, 225-235.

- $\quad$ Barberis, L., Wary, K.K., Fiucci, G., Liu, F., Hirsch, E., Brancaccio, M., Altruda, F., Tarone, G., and Giancotti, F.G. (2000). Distinct roles of the adaptor protein Shc and focal adhesion kinase in integrin signaling to ERK. J. Biol. Chem. 275, 36532-36540.

- $\quad$ Barouki, R., Coumoul, X., and Fernández-Salguero, P.M. (2007). The aryl hydrocarbon receptor, more than a xenobiotic-interacting protein. FEBS Lett. 581, 3608-3615.

- $\quad$ Barroso, I., Luan, J., Middelberg, R.P.S., Harding, A.-H., Franks, P.W., Jakes, R.W., Clayton, D., Schafer, A.J., O'Rahilly, S., and Wareham, N.J. (2003). Candidate gene association study in type 2 diabetes indicates a role for genes involved in beta-cell function as well as insulin action. PLoS Biol. 1, E20.

- $\quad$ Barry, S.T., and Critchley, D.R. (1994). The RhoA-dependent assembly of focal adhesions in Swiss 3T3 cells is associated with increased tyrosine phosphorylation and the recruitment of both pp125FAK and protein kinase C-delta to focal adhesions. J. Cell Sci. 107 ( Pt 7), 2033-2045.

- $\quad$ Barski, A., Cuddapah, S., Cui, K., Roh, T.Y., Schones, D.E., Wang, Z., Wei, G., Chepelev, I., and Zhao, K. (2007). High-Resolution Profiling of Histone Methylations in the Human Genome. Cell 129, 823-837.

- Basu, A., Kligman, L.H., Samulewicz, S.J., and Howe, C.C. (2001). Impaired wound healing in mice deficient in a matricellular protein SPARC (osteonectin, BM-40). BMC Cell Biol. 2, 15.

- Baxevanis, A.D., Arents, G., Moudrianakis, E.N., and Landsman, D. (1995). A variety of DNA-binding and multimeric proteins contain the histone fold motif. Nucleic Acids Res. 23, 2685-2691.

- $\quad$ Benitah, S.A., Frye, M., Glogauer, M., and Watt, F.M. (2005a). Stem Cell Depletion Through Epidermal Deletion of Rac1. Science (80-. ). 309, 933-935.

- $\quad$ Besson, A., Gurian-West, M., Schmidt, A., Hall, A., and Roberts, J.M. (2004). p27Kip1 modulates cell migration through the regulation of RhoA activation. Genes Dev. 18, 862-876.

- $\quad$ Bivona, T.G., Pérez de Castro, I., Ahearn, I.M., Grana, T.M., Chiu, V.K., Lockyer, P.J., Cullen, P.J., Pellicer, A., Cox, A.D., and Philips, M.R. (2003). Phospholipase Cgamma activates Ras on the Golgi apparatus by means of RasGRP1. Nature 424, 694-698.

- $\quad$ Bivona, T.G., Quatela, S.E., Bodemann, B.O., Ahearn, I.M., Soskis, M.J., Mor, A., Miura, J., Wiener, H.H., Wright, L., Saba, S.G., et al. (2006). PKC Regulates a Farnesyl-Electrostatic Switch on K-Ras that Promotes its Association with Bcl-XI on Mitochondria and Induces Apoptosis. Mol. Cell 21, 481-493.

- Blanpain, C., and Fuchs, E. (2009). Epidermal homeostasis: a balancing act of stem cells in the skin. Nat. Rev. Mol. Cell Biol. 10, 207-217.

- $\quad$ Boguski, M.S., and McCormick, F. (1993). Proteins regulating Ras and its relatives. Nature 366, 643-654.

- Bollag, G., and McCormick, F. (1991). Regulators and Effectors of ras Proteins. Annu. Rev. Cell Biol. 7, 601-632.

- Bonfini, L., Karlovich, C.A., Dasgupta, C., and Banerjee, U. (1992). The Son of sevenless gene product: a putative activator of Ras. Science 255, 603-606.

- $\quad$ Bonni, A., Brunet, A., West, A.E., Datta, S.R., Takasu, M.A., and Greenberg, M.E. (1999). Cell survival promoted by the Ras-MAPK signaling pathway by transcription-dependent and -independent mechanisms. Science 286, 1358-1362.

- $\quad$ Boriack-Sjodin, P.A., Margarit, S.M., Bar-Sagi, D., and Kuriyan, J. (1998). The structural basis of the activation of Ras by Sos. Nature 394, 337-343.

- Bos, J.L., Fearon, E.R., Hamilton, S.R., Vries, M.V., van Boom, J.H., van der Eb, A.J., and Vogelstein, B. (1987). Prevalence of ras gene mutations in human colorectal cancers. Nature 327, 293-297. 
- Bos, J.L., Rehmann, H., and Wittinghofer, A. (2007). GEFs and GAPs: critical elements in the control of small G proteins. Cell 129, 865-877.

- Boulalas, I., Zaravinos, A., Karyotis, I., Delakas, D., and Spandidos, D.A. (2009). Activation of RAS Family Genes in Urothelial Carcinoma. J. Urol. 181, 2312-2319.

- $\quad$ Bowtell, D., Fu, P., Simon, M., and Senior, P. (1992). Identification of murine homologues of the Drosophila son of sevenless gene: potential activators of ras. Proc. Natl. Acad. Sci. U. S. A. 89, 6511-6515.

- $\quad$ Boykevisch, S., Zhao, C., Sondermann, H., Philippidou, P., Halegoua, S., Kuriyan, J., and Bar-Sagi, D. (2006). Regulation of ras signaling dynamics by Sos-mediated positive feedback. Curr. Biol. 16, 2173-2179.

- Bozulic, L., Surucu, B., Hynx, D., and Hemmings, B.A. (2008). PKBalpha/Akt1 Acts Downstream of DNA-PK in the DNA Double-Strand Break Response and Promotes Survival. Mol. Cell 30, 203-213.

- Brambilla, R., Gnesutta, N., Minichiello, L., White, G., Roylance, A.J., Herron, C.E., Ramsey, M., Wolfer, D.P., Cestari, V., Rossi-Arnaud, C., et al. (1997). A role for the Ras signalling pathway in synaptic transmission and long-term memory. Nature 390, 281-286.

- Braun, B.S., Archard, J.A., Van Ziffle, J.A.G., Tuveson, D.A., Jacks, T.E., and Shannon, K. (2006). Somatic activation of a conditional KrasG12D allele causes ineffective erythropoiesis in vivo. Blood 108, 2041-2044.

- $\quad$ Bretscher, A., Edwards, K., and Fehon, R.G. (2002). ERM proteins and merlin: integrators at the cell cortex. Nat. Rev. Mol. Cell Biol. 3, 586-599.

- $\quad$ Broek, D., Toda, T., Michaeli, T., Levin, L., Birchmeier, C., Zoller, M., Powers, S., and Wigler, M. (1987). The S. cerevisiae CDC25 gene product regulates the RAS/adenylate cyclase pathway. Cell 48, 789-799.

- Brognard, J., Sierecki, E., Gao, T., and Newton, A.C. (2007). PHLPP and a Second Isoform, PHLPP2, Differentially Attenuate the Amplitude of Akt Signaling by Regulating Distinct Akt Isoforms. Mol. Cell 25, 917-931.

- Brondello, J.M., Pouysségur, J., and McKenzie, F.R. (1999). Reduced MAP kinase phosphatase-1 degradation after p42/p44MAPK-dependent phosphorylation. Science 286, 2514-2517.

- $\quad$ Brunet, A., Bonni, A., Zigmond, M.J., Lin, M.Z., Juo, P., Hu, L.S., Anderson, M.J., Arden, K.C., Blenis, J., and Greenberg, M.E. (1999). Akt promotes cell survival by phosphorylating and inhibiting a Forkhead transcription factor. Cell 96, 857-868.

- $\quad$ Buday, L., and Downward, J. (2008). Many faces of Ras activation. Biochim. Biophys. Acta 1786, 178-187.

- Bulteau, A.-L., Szweda, L.I., and Friguet, B. (2006). Mitochondrial protein oxidation and degradation in response to oxidative stress and aging. Exp. Gerontol. 41, 653-657.

- $\quad$ Burgering, B.M.T., Medema, R.H., Kops, G.J.P.L., and Bos, J.L. (2000). AFX-like Forkhead transcription factors mediate cell-cycle regulation by Ras and PKB through p27kip1. Nature 404, 782-787.

- $\quad$ Byrne, J.L., Paterson, H.F., and Marshall, C.J. (1996). p21Ras activation by the guanine nucleotide exchange factor Sos, requires the Sos/Grb2 interaction and a second ligand-dependent signal involving the Sos $\mathrm{N}$ terminus. Oncogene 13, 2055-2065.

- Caloca, M.J., Zugaza, J.L., and Bustelo, X.R. (2003). Exchange Factors of the RasGRP Family Mediate Ras Activation in the Golgi. J. Biol. Chem. 278, 33465-33473.

- $\quad$ Cardone, M.H., Roy, N., Stennicke, H.R., Salvesen, G.S., Franke, T.F., Stanbridge, E., Frisch, S., and Reed, J.C. (1998). Regulation of cell death protease caspase-9 by phosphorylation. Science 282, 1318-1321.

- Cargnello, M., and Roux, P.P. (2011). Activation and function of the MAPKs and their substrates, the MAPKactivated protein kinases. Microbiol. Mol. Biol. Rev. 75, 50-83.

- $\quad$ Carvalho, C., Pereira, H.M., Ferreira, J., Pina, C., Mendonça, D., Rosa, a C., and Carmo-Fonseca, M. (2001). Chromosomal G-dark bands determine the spatial organization of centromeric heterochromatin in the nucleus. Mol. Biol. Cell 12, 3563-3572.

- Castellano, E., and Santos, E. (2011). Functional Specificity of Ras Isoforms: So Similar but So Different. Genes Cancer 2, 216-231.

- Castellano, E., De Las Rivas, J., Guerrero, C., and Santos, E. (2007). Transcriptional networks of knockout cell lines identify functional specificities of $\mathrm{H}$-Ras and $\mathrm{N}$-Ras: significant involvement of $\mathrm{N}$-Ras in biotic and defense responses. Oncogene 26, 917-933.

- $\quad$ Castellano, E., Guerrero, C., Núñez, A., De Las Rivas, J., and Santos, E. (2009). Serum-dependent transcriptional networks identify distinct functional roles for $\mathrm{H}$-Ras and N-Ras during initial stages of the cell cycle. Genome Biol. 10, R123.

- Castellano, E., Sheridan, C., Thin, M., Nye, E., Spencer-Dene, B., Diefenbacher, M., Moore, C., Kumar, M., Murillo, M., Gr?nroos, E., et al. (2013). Requirement for Interaction of PI3-Kinase p110 $\alpha$ with RAS in Lung Tumor Maintenance. Cancer Cell 24, 617-630.

- $\quad$ Castilho, R.M., Squarize, C.H., Leelahavanichkul, K., Zheng, Y., Bugge, T., and Gutkind, J.S. (2010a). Rac1 Is Required for Epithelial Stem Cell Function during Dermal and Oral Mucosal Wound Healing but Not for Tissue Homeostasis in Mice. PLoS One 5, e10503. 
- $\quad$ Castilho, R.M., Squarize, C.H., Leelahavanichkul, K., Zheng, Y., Bugge, T., and Gutkind, J.S. (2010b). Rac1 is required for epithelial stem cell function during dermal and oral mucosal wound healing but not for tissue homeostasis in mice. PLoS One 5.

- Castillo-Martin, M., Domingo-Domenech, J., Karni-Schmidt, O., Matos, T., and Cordon-Cardo, C. (2010). Molecular pathways of urothelial development and bladder tumorigenesis. Urol. Oncol. Semin. Orig. Investig. 28, 401-408.

- $\quad$ Cawthon, R.M., Weiss, R., Xu, G.F., Viskochil, D., Culver, M., Stevens, J., Robertson, M., Dunn, D., Gesteland, R., and O'Connell, P. (1990). A major segment of the neurofibromatosis type 1 gene: cDNA sequence, genomic structure, and point mutations. Cell 62, 193-201.

- Chahal, S.S., Matthews, H.R., and Bradbury, E.M. (1980). Acetylation of histone H4 and its role in chromatin structure and function. Nature 287, 76-79.

- Chambard, J.-C., Lefloch, R., Pouysségur, J., and Lenormand, P. (2007). ERK implication in cell cycle regulation. Biochim. Biophys. Acta 1773, 1299-1310.

- $\quad$ Chang, L., and Karin, M. (2001). Mammalian MAP kinase signalling cascades. Nature 410, 37-40.

- Chang, C., Hopper, N.A., and Sternberg, P.W. (2000). Caenorhabditis elegans SOS-1 is necessary for multiple RAS-mediated developmental signals. EMBO J. 19, 3283-3294.

- Chappell, J.C., Wiley, D.M., and Bautch, V.L. (2011). Regulation of blood vessel sprouting. Semin. Cell Dev. Biol. 22, 1005-1011.

- Chardin, P., Camonis, J.H., Gale, N.W., van Aelst, L., Schlessinger, J., Wigler, M.H., and Bar-Sagi, D. (1993). Human Sos1: a guanine nucleotide exchange factor for Ras that binds to GRB2. Science 260, 1338-1343.

- Chen, H., Wu, X., Pan, Z.K., and Huang, S. (2010a). Integrity of SOS1/EPS8/ABI1 tri-complex determines ovarian cancer metastasis. Cancer Res. 70, 9979-9990.

- $\quad$ Chen, P.-C., Wakimoto, H., Conner, D., Araki, T., Yuan, T., Roberts, A., Seidman, C.E., Bronson, R., Neel, B.G., Seidman, J.G., et al. (2010). Activation of multiple signaling pathways causes developmental defects in mice with a Noonan syndrome-associated Sos1 mutation. J. Clin. Invest. 120, 4353-4365.

- Chen, R.-H., Corbalán-Garcia, S., and Bar-Sagi, D. (1997). The role of the PH domain in the signal-dependent membrane targeting of Sos. EMBO J. 16, 1351-1359.

- Cherfils, J., and Zeghouf, M. (2013). Regulation of Small GTPases by GEFs, GAPs, and GDIs. Physiol. Rev. 93, 269-309.

- $\quad$ Cherniack, A.D., Klarlund, J.K., and Czech, M.P. (1994). Phosphorylation of the Ras nucleotide exchange factor son of sevenless by mitogen-activated protein kinase. J. Biol. Chem. 269, 4717-4720.

- Chiariello, M., Vaqué, J.P., Crespo, P., and Gutkind, J.S. (2010). Activation of Ras and Rho GTPases and MAP Kinases by G-Protein-Coupled Receptors. In Methods in Molecular Biology (Clifton, N.J.), pp. 137-150.

- $\quad$ Chiu, J., and Dawes, I.W. (2012). Redox control of cell proliferation. Trends Cell Biol. 22, 592-601.

- Chiu, V.K., Bivona, T., Hach, A., Sajous, J.B., Silletti, J., Wiener, H., Johnson, R.L., Cox, A.D., and Philips, M.R. (2002). Ras signalling on the endoplasmic reticulum and the Golgi. Nat. Cell Biol. 4, 343-350.

- $\quad$ Christensen, S.M., Tu, H.-L., Jun, J.E., Alvarez, S., Triplet, M.G., Iwig, J.S., Yadav, K.K., Bar-Sagi, D., Roose, J.P., and Groves, J.T. (2016). One-way membrane trafficking of SOS in receptor-triggered Ras activation. Nat. Struct. Mol. Biol. 23, 838-846.

- Chrostek, A., Wu, X., Quondamatteo, F., Hu, R., Sanecka, A., Niemann, C., Langbein, L., Haase, I., and Brakebusch, C. (2006). Rac1 Is Crucial for Hair Follicle Integrity but Is Not Essential for Maintenance of the Epidermis. Mol. Cell. Biol. 26, 6957-6970.

- Chrzanowska-Wodnicka, M., and Burridge, K. (1996). Rho-stimulated contractility drives the formation of stress fibers and focal adhesions. J. Cell Biol. 133, 1403-1415.

- Chrzanowska-Wodnicka, M., Kraus, A.E., Gale, D., White, G.C., and Vansluys, J. (2008). Defective angiogenesis, endothelial migration, proliferation, and MAPK signaling in Rap1b-deficient mice. Blood 111, 2647-2656.

- Clyde-Smith, J., Silins, G., Gartside, M., Grimmond, S., Etheridge, M., Apolloni, A., Hayward, N., and Hancock, J.F. (2000). Characterization of RasGRP2, a plasma membrane-targeted, dual specificity Ras/Rap exchange factor. J. Biol. Chem. 275, 32260-32267.

- Corbalán-García, S., Yang, S.S., Degenhardt, K.R., and Bar-Sagi, D. (1996). Identification of the mitogenactivated protein kinase phosphorylation sites on human Sos1 that regulate interaction with Grb2. Mol. Cell. Biol. 16, 5674-5682.

- $\quad$ Corbalán-García, S., Margarit, S.M., Galron, D., Yang, S.S., and Bar-Sagi, D. (1998). Regulation of Sos activity by intramolecular interactions. Mol. Cell. Biol. 18, 880-886.

- Cordeddu, V., Yin, J.C., Gunnarsson, C., Virtanen, C., Drunat, S., Lepri, F., De Luca, A., Rossi, C., Ciolfi, A., Pugh, T.J., et al. (2015). Activating Mutations Affecting the Dbl Homology Domain of SOS2 Cause Noonan Syndrome. Hum. Mutat. 36, 1080-1087.

- Cox, A.D., Fesik, S.W., Kimmelman, A.C., Luo, J., and Der, C.J. (2014). Drugging the undruggable RAS: Mission 
Possible? Nat. Rev. Drug Discov. 13, 828-851.

- $\quad$ Cramer, L.P. (2010). Forming the cell rear first: breaking cell symmetry to trigger directed cell migration. Nat. Cell Biol. 12, 628-632.

- Cramer, T., Yamanishi, Y., Clausen, B.E., Förster, I., Pawlinski, R., Mackman, N., Haase, V.H., Jaenisch, R., Corr, M., Nizet, V., et al. (2003). HIF-1alpha is essential for myeloid cell-mediated inflammation. Cell 112, 645-657.

- Crittenden, J.R., Bergmeier, W., Zhang, Y., Piffath, C.L., Liang, Y., Wagner, D.D., Housman, D.E., and Graybiel, A.M. (2004). CaIDAG-GEFI integrates signaling for platelet aggregation and thrombus formation. Nat. Med. 10, 982-986.

- Cross, D.A., Alessi, D.R., Cohen, P., Andjelkovich, M., and Hemmings, B.A. (1995). Inhibition of glycogen synthase kinase-3 by insulin mediated by protein kinase B. Nature $378,785-789$.

- Crowley, E., and Horwitz, A.F. (1995). Tyrosine phosphorylation and cytoskeletal tension regulate the release of fibroblast adhesions. J. Cell Biol. 131, 525-537.

- Cuadrado, A., and Nebreda, A.R. (2010). Mechanisms and functions of p38 MAPK signalling. Biochem. J. 429, 403-417.

- Cuadrado, M., Gutiérrez-Martínez, P., Swat, A., Nebreda, A.R., and Fernández-Capetillo, O. (2009). p27Kip1 stabilization is essential for the maintenance of cell cycle arrest in response to DNA damage. Cancer Res. 69, 8726-8732.

- $\quad$ Dajee, M., Tarutani, M., Deng, H., Cai, T., and Khavari, P.A. (2002). Epidermal Ras blockade demonstrates spatially localized Ras promotion of proliferation and inhibition of differentiation. Oncogene 21, 1527-1538.

- Daksis, J.I., Lu, R.Y., Facchini, L.M., Marhin, W.W., and Penn, L.J. (1994). Myc induces cyclin D1 expression in the absence of de novo protein synthesis and links mitogen-stimulated signal transduction to the cell cycle. Oncogene 9, 3635-3645.

- $\quad$ Das, B., Shu, X., Day, G.-J., Han, J., Krishna, U.M., Falck, J.R., and Broek, D. (2000). Control of Intramolecular Interactions between the Pleckstrin Homology and Dbl Homology Domains of Vav and Sos1 Regulates Rac Binding. J. Biol. Chem. 275, 15074-15081.

- $\quad$ Datta, S.R., Dudek, H., Tao, X., Masters, S., Fu, H., Gotoh, Y., and Greenberg, M.E. (1997). Akt phosphorylation of BAD couples survival signals to the cell-intrinsic death machinery. Cell 91, 231-241.

- Davis, M.J., Ha, B.H., Holman, E.C., Halaban, R., Schlessinger, J., and Boggon, T.J. (2013). RAC1P29S is a spontaneously activating cancer-associated GTPase. Proc. Natl. Acad. Sci. 110, 912-917.

- $\quad$ Denayer, E., Devriendt, K., de Ravel, T., Van Buggenhout, G., Smeets, E., Francois, I., Sznajer, Y., Craen, M., Leventopoulos, G., Mutesa, L., et al. (2010). Tumor spectrum in children with Noonan syndrome and SOS1 or RAF1 mutations. Genes. Chromosomes Cancer 49, 242-252.

- $\quad$ Depeille, P., Henricks, L.M., van de Ven, R.A., Lemmens, E., Wang, C.Y., Matli, M., Werb, Z., Haigis, K.M., Donner, D., Warren, R., et al. (2015). RasGRP1 opposes proliferative EGFR-SOS1-Ras signals and restricts intestinal epithelial cell growth. Nat Cell Biol 17, 804-815.

- Devreotes, P., and Janetopoulos, C. (2003). Eukaryotic Chemotaxis: Distinctions between Directional Sensing and Polarization. J. Biol. Chem. 278, 20445-20448.

- $\quad$ Dhanasekaran, D.N., Kashef, K., Lee, C.M., Xu, H., and Reddy, E.P. (2007). Scaffold proteins of MAP-kinase modules. Oncogene 26, 3185-3202.

- Dhillon, A.S., and Kolch, W. (2002). Untying the regulation of the Raf-1 kinase. Arch. Biochem. Biophys. 404, 39.

- $\quad$ Dikic, I., Tokiwa, G., Lev, S., Courtneidge, S.A., and Schlessinger, J. (1996). A role for Pyk2 and Src in linking Gprotein-coupled receptors with MAP kinase activation. Nature 383, 547-550.

- Doma, E., Rupp, C., and Baccarini, M. (2013). EGFR-Ras-Raf Signaling in Epidermal Stem Cells: Roles in Hair Follicle Development, Regeneration, Tissue Remodeling and Epidermal Cancers. Int. J. Mol. Sci. 14, 1936119384.

- $\quad$ Dominguez, R., and Holmes, K.C. (2011). Actin Structure and Function. Annu. Rev. Biophys. 40, 169-186.

- Dong Chen, Waters, S.B., Holt, K.H., and Pessin, J.E. (1996). SOS phosphorylation and disassociation of the Grb2-SOS complex by the ERK and JNK signaling pathways. J. Biol. Chem. 271, 6328-6332.

- Douville, E., and Downward, J. (1997). EGF induced SOS phosphorylation in PC12 cells involves P90 RSK-2. Oncogene 15, 373-383.

- $\quad$ Dower, N.A., Stang, S.L., Bottorff, D.A., Ebinu, J.O., Dickie, P., Ostergaard, H.L., and Stone, J.C. (2000). RasGRP is essential for mouse thymocyte differentiation and TCR signaling. Nat. Immunol. 1, 317-321.

- Dowler, S., Montalvo, L., Cantrell, D., Morrice, N., and Alessi, D.R. (2000). Phosphoinositide 3-kinasedependent phosphorylation of the dual adaptor for phosphotyrosine and 3-phosphoinositides by the Src family of tyrosine kinase. Biochem. J. 349, 605-610.

- Drosten, M., Dhawahir, A., Sum, E.Y.M., Urosevic, J., Lechuga, C.G., Esteban, L.M., Castellano, E., Guerra, C., 
Santos, E., and Barbacid, M. (2010). Genetic analysis of Ras signalling pathways in cell proliferation, migration and survival. EMBO J. 29, 1091-1104.

- Drosten, M., Lechuga, C.G., and Barbacid, M. (2014). Ras signaling is essential for skin development. Oncogene 33, 2857-2865.

- Dumesic, P.A., Scholl, F.A., Barragan, D.I., and Khavari, P.A. (2009). Erk1/2 MAP kinases are required for epidermal G2/M progression. J. Cell Biol. 185, 409-422.

- $\quad$ Dusaban, S.S., Kunkel, M.T., Smrcka, A. V., and Brown, J.H. (2015). Thrombin Promotes Sustained Signaling and Inflammatory Gene Expression through the CDC25 and Ras-associating Domains of Phospholipase C $\epsilon$. J. Biol. Chem. 290, 26776-26783.

- Ebinu, J.O., Bottorff, D.A., Chan, E.Y., Stang, S.L., Dunn, R.J., and Stone, J.C. (1998). RasGRP, a Ras guanyl nucleotide- releasing protein with calcium- and diacylglycerol-binding motifs. Science 280, 1082-1086.

- Edwards, E., Geng, L., Tan, J., Onishko, H., Donnelly, E., and Hallahan, D.E. (2002). Phosphatidylinositol 3kinase/Akt signaling in the response of vascular endothelium to ionizing radiation. Cancer Res. 62, 4671-4677.

- $\quad$ Egan, S.E., Giddings, B.W., Brooks, M.W., Buday, L., Sizeland, A.M., and Weinberg, R.A. (1993). Association of Sos Ras exchange protein with Grb2 is implicated in tyrosine kinase signal transduction and transformation. Nature 363, 45-51.

- Ehrenreiter, K., Piazzolla, D., Velamoor, V., Sobczak, I., Small, J.V., Takeda, J., Leung, T., and Baccarini, M. (2005). Raf-1 regulates Rho signaling and cell migration. J. Cell Biol. 168, 955-964.

- $\quad$ Escobedo, J.A., Navankasattusas, S., Kavanaugh, W.M., Milfay, D., Fried, V.A., and Williams, L.T. (1991). cDNA cloning of a novel $85 \mathrm{kd}$ protein that has SH2 domains and regulates binding of PI3-kinase to the PDGF betareceptor. Cell 65, 75-82.

- $\quad$ Esteban, L.M., Fernández-Medarde, A., López, E., Yienger, K., Guerrero, C., Ward, J.M., Tessarollo, L., and Santos, E. (2000). Ras-guanine nucleotide exchange factor sos2 is dispensable for mouse growth and development. Mol. Cell. Biol. 20, 6410-6413.

- $\quad$ Esteban, L.M., Vicario-Abejón, C., Fernández-Salguero, P., Fernández-Medarde, A., Swaminathan, N., Yienger, K., Lopez, E., Malumbres, M., McKay, R., Ward, J.M., et al. (2001). Targeted genomic disruption of H-ras and Nras, individually or in combination, reveals the dispensability of both loci for mouse growth and development. Mol. Cell. Biol. 21, 1444-1452.

- $\quad$ Etienne-Manneville, S. (2013). Microtubules in Cell Migration. Annu. Rev. Cell Dev. Biol. 29, 471-499.

- Etienne-Manneville, S., and Hall, A. (2002). Rho GTPases in cell biology. Nature 420, 629-635.

- $\quad$ Evans, N.D., Oreffo, R.O.C., Healy, E., Thurner, P.J., and Man, Y.H. (2013). Epithelial mechanobiology, skin wound healing, and the stem cell niche. J. Mech. Behav. Biomed. Mater. 28, 397-409.

- $\quad$ Even-Ram, S., Doyle, A.D., Conti, M.A., Matsumoto, K., Adelstein, R.S., and Yamada, K.M. (2007). Myosin IIA regulates cell motility and actomyosin-microtubule crosstalk. Nat. Cell Biol. 9, 299-309.

- $\quad$ Fam, N.P., Fan, W.T., Wang, Z., Zhang, L.J., Chen, H., and Moran, M.F. (1997). Cloning and characterization of Ras-GRF2, a novel guanine nucleotide exchange factor for Ras. Mol. Cell. Biol. 17, 1396-1406.

- $\quad$ Fang, D., Chen, H., Zhu, J.Y., Wang, W., Teng, Y., Ding, H.-F., Jing, Q., Su, S.-B., and Huang, S. (2017). Epithelialmesenchymal transition of ovarian cancer cells is sustained by Rac1 through simultaneous activation of MEK1/2 and Src signaling pathways. Oncogene 36, 1546-1558.

- $\quad$ Farnsworth, C.L., Freshney, N.W., Rosen, L.B., Ghosh, A., Greenberg, M.E., and Feig, L.A. (1995). Calcium activation of Ras mediated by neuronal exchange factor Ras-GRF. Nature 376, 524-527.

- Fehon, R.G., McClatchey, A.I., and Bretscher, A. (2010). Organizing the cell cortex: the role of ERM proteins. Nat. Rev. Mol. Cell Biol. 11, 276-287.

- $\quad$ Feramisco, J.R., Gross, M., Kamata, T., Rosenberg, M., and Sweet, R.W. (1984). Microinjection of the oncogene form of the human $\mathrm{H}$-ras (T-24) protein results in rapid proliferation of quiescent cells. Cell 38, 109-117.

- Fernandez-Medarde, A., and Santos, E. (2011a). Ras in Cancer and Developmental Diseases. Genes Cancer 2, 344-358.

- Fernández-Medarde, A., and Santos, E. (2011b). The RasGrf family of mammalian guanine nucleotide exchange factors. Biochim. Biophys. Acta - Rev. Cancer 1815, 170-188.

- $\quad$ Fernández-Medarde, A., Barhoum, R., Riquelme, R., Porteros, A., Núñez, A., de Luis, A., de Las Rivas, J., de la Villa, P., Varela-Nieto, I., and Santos, E. (2009). RasGRF1 disruption causes retinal photoreception defects and associated transcriptomic alterations. J. Neurochem. 110, 641-652.

- Field, L.A., Love, B., Deyarmin, B., Hooke, J.A., Shriver, C.D., and Ellsworth, R.E. (2012). Identification of differentially expressed genes in breast tumors from African American compared with Caucasian women. Cancer 118, 1334-1344.

- $\quad$ Fisher, T.L., and Blenis, J. (1996). Evidence for two catalytically active kinase domains in pp90rsk. Mol. Cell. Biol. 16, 1212-1219.

- $\quad$ Florin, L., Knebel, J., Zigrino, P., Vonderstrass, B., Mauch, C., Schorpp-Kistner, M., Szabowski, A, and Angel, P. 
(2006). Delayed wound healing and epidermal hyperproliferation in mice lacking JunB in the skin. J Invest Dermatol 126, 902-911.

- $\quad$ Font de Mora, J., Esteban, L.M., Burks, D.J., Núñez, A., Garcés, C., García-Barrado, M.J., Iglesias-Osma, M.C., Moratinos, J., Ward, J.M., and Santos, E. (2003). Ras-GRF1 signaling is required for normal cell development and glucose homeostasis. EMBO J. 22, 3039-3049.

- $\quad$ Forbes, S.A., Bindal, N., Bamford, S., Cole, C., Kok, C.Y., Beare, D., Jia, M., Shepherd, R., Leung, K., Menzies, A., et al. (2011). COSMIC: mining complete cancer genomes in the Catalogue of Somatic Mutations in Cancer. Nucleic Acids Res. 39, D945-D950.

- $\quad$ Franke, T.F. (2008). PI3K/Akt: getting it right matters. Oncogene 27, 6473-6488.

- $\quad$ Franke, T.F., Yang, S.I., Chan, T.O., Datta, K., Kazlauskas, A., Morrison, D.K., Kaplan, D.R., and Tsichlis, P.N. (1995). The protein kinase encoded by the Akt proto-oncogene is a target of the PDGF-activated phosphatidylinositol 3-kinase. Cell 81, 727-736.

- $\quad$ Franke, T.F., Kaplan, D.R., and Cantley, L.C. (1997). PI3K: downstream AKTion blocks apoptosis. Cell 88, 435437.

- $\quad$ Freedman, T.S., Sondermann, H., Friedland, G.D., Kortemme, T., Bar-Sagi, D., Marqusee, S., and Kuriyan, J. (2006). A Ras-induced conformational switch in the Ras activator Son of sevenless. Proc. Natl. Acad. Sci. U. S. A. 103, 16692-16697.

- $\quad$ Fujita, N., Sato, S., and Tsuruo, T. (2003). Phosphorylation of p27Kip1 at Threonine 198 by p90 Ribosomal Protein S6 Kinases Promotes Its Binding to 14-3-3 and Cytoplasmic Localization. J. Biol. Chem. 278, 4925449260.

- $\quad$ Di Fulvio, M., Lehman, N., Lin, X., López, I., and Gómez-Cambronero, J. (2006). The elucidation of novel SH2 binding sites on PLD2. Oncogene 25, 3032-3040.

- Futosi, K., Fodor, S., and M?csai, A. (2013). Neutrophil cell surface receptors and their intracellular signal transduction pathways. Int. Immunopharmacol. 17, 638-650.

- Galabova-Kovacs, G., Kolbus, A., Matzen, D., Meiss, K., Piazzolla, D., Rubiolo, C., Steinitz, K., and Baccarini, M. (2006a). ERK and Beyond: Insights from B-Raf and Raf-1 Conditional Knockouts. Cell Cycle 5, 1514-1518.

- Galabova-Kovacs, G., Matzen, D., Piazzolla, D., Meissl, K., Plyushch, T., Chen, A.P., Silva, A., and Baccarini, M. (2006b). Essential role of B-Raf in ERK activation during extraembryonic development. Proc. Natl. Acad. Sci. $103,1325-1330$.

- Gale, N.W., Kaplan, S., Lowenstein, E.J., Schlessinger, J., and Bar-Sagi, D. (1993). Grb2 mediates the EGFdependent activation of guanine nucleotide exchange on Ras. Nature 363, 88-92.

- Ganguly, A.K., Pramanik, B.N., Huang, E.C., Liberles, S., Heimark, L., Liu, Y.H., Tsarbopoulos, A., Doll, R.J., Taveras, A.G., Remiszewski, S., et al. (1997). Detection and structural characterization of ras oncoproteininhibitors complexes by electrospray mass spectrometry. Bioorg. Med. Chem. 5, 817-820.

- Gao, T., Furnari, F., and Newton, A.C. (2005). PHLPP: A Phosphatase that Directly Dephosphorylates Akt, Promotes Apoptosis, and Suppresses Tumor Growth. Mol. Cell 18, 13-24.

- $\quad$ Gardai, S.J., Hildeman, D.A., Frankel, S.K., Whitlock, B.B., Frasch, S.C., Borregaard, N., Marrack, P., Bratton, D.L., and Henson, P.M. (2004). Phosphorylation of Bax Ser184 by Akt regulates its activity and apoptosis in neutrophils. J. Biol. Chem. 279, 21085-21095.

- $\quad$ Geissler, K.J., Jung, M.J., Riecken, L.B., Sperka, T., Cui, Y., Schacke, S., Merkel, U., Markwart, R., Rubio, I., Than, M.E., et al. (2013). Regulation of Son of sevenless by the membrane-actin linker protein ezrin. Proc. Natl. Acad. Sci. U. S. A. 110, 20587-20592.

- $\quad$ Ghandour, H., Cullere, X., Alvarez, A., Luscinskas, F.W., and Mayadas, T.N. (2007). Essential role for Rap1 GTPase and its guanine exchange factor CalDAG-GEFI in LFA-1 but not VLA-4 integrin mediated human T-cell adhesion. Blood 110, 3682-3690.

- $\quad$ Giese, K.P., Friedman, E., Telliez, J.B., Fedorov, N.B., Wines, M., Feig, L.A., and Silva, A.J. (2001). Hippocampusdependent learning and memory is impaired in mice lacking the Ras-guanine-nucleotide releasing factor 1 (Ras-GRF1). Neuropharmacology 41, 791-800.

- $\quad$ Gillitzer, R., and Goebeler, M. (2001). Chemokines in cutaneous wound healing. J. Leukoc. Biol. 69, 513-521.

- Ginel-Picardo, A. (2012). Caracterizacion genomica y funcional de fibroblastos embrionarios derivados de ratones knockout para Sos1 y Sos2. Universidad de Salamanca.

- Gobert Gosse, S., Bourgin, C., Liu, W.Q., Garbay, C., and Mouchiroud, G. (2005). M-CSF stimulated differentiation requires persistent MEK activity and MAPK phosphorylation independent of Grb2-Sos association and phosphatidylinositol 3-kinase activity. Cell. Signal. 17, 1352-1362.

- $\quad$ Goodwin, J.S., Drake, K.R., Rogers, C., Wright, L., Lippincott-Schwartz, J., Philips, M.R., and Kenworthy, A.K. (2005). Depalmitoylated Ras traffics to and from the Golgi complex via a nonvesicular pathway. J. Cell Biol. $170,261-272$. 
- $\quad$ Gorisch, S.M. (2005). Histone acetylation increases chromatin accessibility. J. Cell Sci. 118, 5825-5834.

- $\quad$ Gotoh, T., Niino, Y., Tokuda, M., Hatase, O., Nakamura, S., Matsuda, M., and Hattori, S. (1997). Activation of RRas by Ras-guanine nucleotide-releasing factor. J. Biol. Chem. 272, 18602-18607.

- Gotoh, T., Tian, X., and Feig, L.A. (2001). Prenylation of target GTPases contributes to signaling specificity of Ras-guanine nucleotide exchange factors. J. Biol. Chem. 276, 38029-38035.

- $\quad$ Graham, S.M., Vojtek, A.B., Huff, S.Y., Cox, A.D., Clark, G.J., Cooper, J.A., and Der, C.J. (1996). TC21 causes transformation by Raf-independent signaling pathways. Mol. Cell. Biol. 16, 6132-6140.

- Guadiz, G., Sporn, L.A., and Simpson-Haidaris, P.J. (1997). Thrombin cleavage-independent deposition of fibrinogen in extracellular matrices. Blood 90, 2644-2653.

- Guerrero, C., Rojas, J.M., Chedid, M., Esteban, L.M., Zimonjic, D.B., Popescu, N.C., Font de Mora, J., and Santos, E. (1996). Expression of alternative forms of Ras exchange factors GRF and SOS1 in different human tissues and cell lines. Oncogene 12, 1097-1107.

- Di Guglielmo, G.M., Baass, P.C., Ou, W.J., Posner, B.I., and Bergeron, J.J. (1994). Compartmentalization of SHC, GRB2 and mSOS, and hyperphosphorylation of Raf-1 by EGF but not insulin in liver parenchyma. EMBO J. 13, 4269-4277.

- $\quad$ Guittard, G., Kortum, R.L., Balagopalan, L., Cuburu, N., Nguyen, P., Sommers, C.L., and Samelson, L.E. (2015). Absence of both Sos- 1 and Sos- 2 in peripheral $\mathrm{CD} 4{ }^{+} \mathrm{T}$ cells leads to PI3K pathway activation and defects in migration. Eur. J. Immunol. 45, 2389-2395.

- $\quad$ Guittard, G., Gallardo, D.L., Li, W., Melis, N., Lui, J.C., Kortum, R.L., Shakarishvili, N.G., Huh, S., Baron, J., Weigert, R., et al. (2017). Unexpected Cartilage Phenotype in CD4-Cre-Conditional SOS-Deficient Mice. Front. Immunol. 8, 343.

- $\quad$ Guo, F., Debidda, M., Yang, L., Williams, D.A., and Zheng, Y. (2006). Genetic deletion of Rac1 GTPase reveals its critical role in actin stress fiber formation and focal adhesion complex assembly. J. Biol. Chem. 281, 1865218659.

- $\quad$ Gureasko, J., Galush, W.J., Boykevisch, S., Sondermann, H., Bar-Sagi, D., Groves, J.T., and Kuriyan, J. (2008). Membrane-dependent signal integration by the Ras activator Son of sevenless. Nat. Struct. Mol. Biol. 15, 452461.

- Gureasko, J., Kuchment, O., Makino, D.L., Sondermann, H., Bar-Sagi, D., and Kuriyan, J. (2010). Role of the histone domain in the autoinhibition and activation of the Ras activator Son of Sevenless. Proc. Natl. Acad. Sci. U. S. A. $107,3430-3435$.

- Haigis, K.M., Kendall, K.R., Wang, Y., Cheung, A., Haigis, M.C., Glickman, J.N., Niwa-Kawakita, M., SweetCordero, A., Sebolt-Leopold, J., Shannon, K.M., et al. (2008). Differential effects of oncogenic K-Ras and N-Ras on proliferation, differentiation and tumor progression in the colon. Nat. Genet. 40, 600-608.

- Hakkinen, L., and Csiszar, A. (2007). Hereditary Gingival Fibromatosis: Characteristics and Novel Putative Pathogenic Mechanisms. J. Dent. Res. 86, 25-34.

- Halaban, R. (2015). RAC1 and Melanoma. Clin. Ther. 37, 682-685.

- Hall, A. (1998). G proteins and small GTPases: distant relatives keep in touch. Science 280, 2074-2075.

- Hamilton, G., Proitsi, P., Jehu, L., Morgan, A., Williams, J., O’Donovan, M.C., Owen, M.J., Powell, J.F., and Lovestone, S. (2007). Candidate gene association study of insulin signaling genes and Alzheimer's disease: evidence for SOS2, PCK1, and PPARgamma as susceptibility loci. Am. J. Med. Genet. B. Neuropsychiatr. Genet. $144 B, 508-516$.

- Hancock, J.F. (2003). Ras proteins: different signals from different locations. Nat. Rev. Mol. Cell Biol. 4, 373384.

- Hancock, J.F., Paterson, H., and Marshall, C.J. (1990). A polybasic domain or palmitoylation is required in addition to the CAAX motif to localize p21ras to the plasma membrane. Cell 63, 133-139.

- Hart, T.C., Zhang, Y., Gorry, M.C., Hart, P.S., Cooper, M., Marazita, M.L., Marks, J.M., Cortelli, J.R., and Pallos, D. (2002). A mutation in the SOS1 gene causes hereditary gingival fibromatosis type 1. Am. J. Hum. Genet. 70, 943-954.

- $\quad$ Hawkins, P.T., Eguinoa, A., Qiu, R.G., Stokoe, D., Cooke, F.T., Walters, R., Wennström, S., Claesson-Welsh, L., Evans, T., and Symons, M. (1995). PDGF stimulates an increase in GTP-Rac via activation of phosphoinositide 3kinase. Curr. Biol. 5, 393-403.

- Hawkins, P.T., Stephens, L.R., Suire, S., and Wilson, M. (2010). PI3K Signaling in Neutrophils. In Current Topics in Microbiology and Immunology, pp. 183-202.

- $\quad$ van Helden, S.F.G., Anthony, E.C., Dee, R., and Hordijk, P.L. (2012). Rho GTPase Expression in Human Myeloid Cells. PLoS One 7, e42563.

- Hennig, A., Markwart, R., Esparza-Franco, M.A., Ladds, G., and Rubio, I. (2015). Ras activation revisited: role of GEF and GAP systems. Biol. Chem. 396, 831-848.

- Hezel, A.F., Kimmelman, A.C., Stanger, B.Z., Bardeesy, N., and Depinho, R.A. (2006). Genetics and biology of 
pancreatic ductal adenocarcinoma. Genes Dev. 20, 1218-1249.

- Hill, M.M., Feng, J., and Hemmings, B.A. (2002). Identification of a plasma membrane Raft-associated PKB Ser473 kinase activity that is distinct from ILK and PDK1. Curr. Biol. 12, 1251-1255.

- Hocker, H.J., Cho, K.-J., Chen, C.-Y.K., Rambahal, N., Sagineedu, S.R., Shaari, K., Stanslas, J., Hancock, J.F., and Gorfe, A.A. (2013). Andrographolide derivatives inhibit guanine nucleotide exchange and abrogate oncogenic Ras function. Proc. Natl. Acad. Sci. U. S. A. 110, 10201-10206.

- Hodis, E., Watson, I.R., Kryukov, G. V., Arold, S.T., Imielinski, M., Theurillat, J.-P., Nickerson, E., Auclair, D., Li, L., Place, C., et al. (2012). A Landscape of Driver Mutations in Melanoma. Cell 150, 251-263.

- Hoffman, G.R., and Cerione, R.A. (2002). Signaling to the Rho GTPases: networking with the DH domain. FEBS Lett. 513, 85-91.

- Holgado-Madruga, M., Emlet, D.R., Moscatello, D.K., Godwin, A.K., and Wong, A.J. (1996). A Grb2-associated docking protein in EGF- and insulin-receptor signalling. Nature 379, 560-564.

- Holt, K.H., Kasson, B.G., and Pessin, J.E. (1996). Insulin stimulation of a MEK-dependent but ERK-independent SOS protein kinase. Mol. Cell. Biol. 16, 577-583.

- Hu, Y.-L., Lu, S., Szeto, K.W., Sun, J., Wang, Y., Lasheras, J.C., and Chien, S. (2015). FAK and paxillin dynamics at focal adhesions in the protrusions of migrating cells. Sci. Rep. 4, 6024.

- Huang, Y.E., lijima, M., Parent, C.A., Funamoto, S., Firtel, R.A., and Devreotes, P. (2003). Receptor-mediated Regulation of PI3Ks Confines PI(3,4,5)P3 to the Leading Edge of Chemotaxing Cells. Mol. Biol. Cell 14, 19131922.

- Hughes, D.A., Fukui, Y., and Yamamoto, M. (1990). Homologous activators of ras in fission and budding yeast. Nature 344, 355-357.

- $\quad$ lavarone, C., Catania, A., Marinissen, M.J., Visconti, R., Acunzo, M., Tarantino, C., Carlomagno, M.S., Bruni, C.B., Gutkind, J.S., and Chiariello, M. (2003). The Platelet-derived Growth Factor Controls c-myc Expression through a JNK- and AP-1-dependent Signaling Pathway. J. Biol. Chem. 278, 50024-50030.

- Innocenti, M., Tenca, P., Frittoli, E., Faretta, M., Tocchetti, A., Di Fiore, P.P., and Scita, G. (2002). Mechanisms through which Sos-1 coordinates the activation of Ras and Rac. J. Cell Biol. 156, 125-136.

- Innocenti, M., Frittoli, E., Ponzanelli, I., Falck, J.R., Brachmann, S.M., Di Fiore, P.P., and Scita, G. (2003). Phosphoinositide 3-kinase activates Rac by entering in a complex with Eps8, Abi1, and Sos-1. J. Cell Biol. 160, 17-23.

- Iritani, B.M., Alberola-Ila, J., Forbush, K.A., and Perimutter, R.M. (1999). Distinct signals mediate maturation and allelic exclusion in lymphocyte progenitors. Immunity 10, 713-722.

- Isakoff, S.J., Cardozo, T., Andreev, J., Li, Z., Ferguson, K.M., Abagyan, R., Lemmon, M.A., Aronheim, A., and Skolnik, E.Y. (1998). Identification and analysis of PH domain-containing targets of phosphatidylinositol 3kinase using a novel in vivo assay in yeast. EMBO J. 17, 5374-5387.

- $\quad$ Ise, K., Nakamura, K., Nakao, K., Shimizu, S., Harada, H., Ichise, T., Miyoshi, J., Gondo, Y., Ishikawa, T., Aiba, A., et al. (2000). Targeted deletion of the H-ras gene decreases tumor formation in mouse skin carcinogenesis. Oncogene 19, 2951-2956.

- $\quad$ Iversen, L., Tu, H.-L., Lin, W.-C., Christensen, S.M., Abel, S.M., Iwig, J., Wu, H.-J., Gureasko, J., Rhodes, C., Petit, R.S., et al. (2014). Molecular kinetics. Ras activation by SOS: allosteric regulation by altered fluctuation dynamics. Science 345, 50-54.

- Izeradjene, K., Combs, C., Best, M., Gopinathan, A., Wagner, A., Grady, W.M., Deng, C.-X., Hruban, R.H., Adsay, N.V., Tuveson, D.A., et al. (2007). Kras(G12D) and Smad4/Dpc4 haploinsufficiency cooperate to induce mucinous cystic neoplasms and invasive adenocarcinoma of the pancreas. Cancer Cell 11, 229-243.

- Jackson, E.L., Willis, N., Mercer, K., Bronson, R.T., Crowley, D., Montoya, R., Jacks, T., and Tuveson, D.A. (2001). Analysis of lung tumor initiation and progression using conditional expression of oncogenic K-ras. Genes Dev. $15,3243-3248$.

- Jaffe, A.B., and Hall, A. (2005). RHO GTPASES: Biochemistry and Biology. Annu. Rev. Cell Dev. Biol. 21, $247-269$.

- Janes, S.M., and Watt, F.M. (2006). New roles for integrins in squamous-cell carcinoma. Nat. Rev. Cancer 6, 175-183.

- Jang, S.-I., Lee, E.-J., Hart, P.S., Ramaswami, M., Pallos, D., and Hart, T.C. (2007). Germ line gain of function with SOS1 mutation in hereditary gingival fibromatosis. J. Biol. Chem. 282, 20245-20255.

- Jaumot, M., Yan, J., Clyde-Smith, J., Sluimer, J., and Hancock, J.F. (2002). The linker domain of the Ha-Ras hypervariable region regulates interactions with exchange factors, Raf-1 and phosphoinositide 3-kinase. J. Biol. Chem. 277, 272-278.

- Jeng, H.-H., Taylor, L.J., and Bar-Sagi, D. (2012). Sos-mediated cross-activation of wild-type Ras by oncogenic Ras is essential for tumorigenesis. Nat. Commun. 3, 1168.

- Jiang, Y., Chen, C., Li, Z., Guo, W., Gegner, J.A., Lin, S., and Han, J. (1996). Characterization of the structure and 
function of a new mitogen-activated protein kinase (p38beta). J. Biol. Chem. 271, 17920-17926.

- Jimeno, D., Gómez, C., Calzada, N., de la Villa, P., Lillo, C., and Santos, E. (2016). RASGRF2 controls nuclear migration in postnatal retinal cone photoreceptors. J. Cell Sci. 129, 729-742.

- Johnson, G.L., and Lapadat, R. (2002). Mitogen-activated protein kinase pathways mediated by ERK, JNK, and p38 protein kinases. Science 298, 1911-1912.

- Johnson, L., Greenbaum, D., Cichowski, K., Mercer, K., Murphy, E., Schmitt, E., Bronson, R.T., Umanoff, H., Edelmann, W., Kucherlapati, R., et al. (1997). K-ras is an essential gene in the mouse with partial functional overlap with N-ras. Genes Dev. 11, 2468-2481.

- Jones, M.K., and Jackson, J.H. (1998). Ras-GRF activates Ha-Ras, but not N-Ras or K-Ras 4B, protein in vivo. J. Biol. Chem. 273, 1782-1787.

- Jongmans, M.C.J., Hoogerbrugge, P.M., Hilkens, L., Flucke, U., van der Burgt, I., Noordam, K., RuiterkampVersteeg, M., Yntema, H.G., Nillesen, W.M., Ligtenberg, M.J.L., et al. (2010). Noonan syndrome, the SOS1 gene and embryonal rhabdomyosarcoma. Genes, Chromosom. Cancer 49, 635-641.

- Jorge, R., Zarich, N., Oliva, J.L., Azañedo, M., Martínez, N., de la Cruz, X., and Rojas, J.M. (2002). hSos1 Contains a New Amino-terminal Regulatory Motif with Specific Binding Affinity for Its Pleckstrin Homology Domain. J. Biol. Chem. 277, 44171-44179.

- Jun, J.E., Yang, M., Chen, H., Chakraborty, A.K., and Roose, J.P. (2013). Activation of extracellular signalregulated kinase but not of p38 mitogen-activated protein kinase pathways in lymphocytes requires allosteric activation of SOS. Mol. Cell. Biol. 33, 2470-2484.

- $\quad$ Kamata, H., Honda, S., Maeda, S., Chang, L., Hirata, H., and Karin, M. (2005). Reactive Oxygen Species Promote TNFalpha-Induced Death and Sustained JNK Activation by Inhibiting MAP Kinase Phosphatases. Cell 120, 649661.

- $\quad$ Karlovich, C.A., Bonfini, L., McCollam, L., Rogge, R.D., Daga, A., Czech, M.P., and Banerjee, U. (1995). In vivo functional analysis of the Ras exchange factor son of sevenless. Science 268, 576-579.

- Karlsson, R., Pedersen, E.D., Wang, Z., and Brakebusch, C. (2009). Rho GTPase function in tumorigenesis. Biochim. Biophys. Acta - Rev. Cancer 1796, 91-98.

- $\quad$ Karnoub, A.E., and Weinberg, R.A. (2008). Ras oncogenes: split personalities. Nat. Rev. Mol. Cell Biol. 9, 517531.

- $\quad$ Katsoulotos, G.P., Qi, M., Qi, J.C., Tanaka, K., Hughes, W.E., Molloy, T.J., Adachi, R., Stevens, R.L., and Krilis, S.A. (2008). The Diacylglycerol-dependent translocation of ras guanine nucleotide-releasing protein 4 inside a human mast cell line results in substantial phenotypic changes, including expression of interleukin 13 receptor alpha2. J. Biol. Chem. 283, 1610-1621.

- $\quad$ Kawada, M., Yamagoe, S., Murakami, Y., Suzuki, K., Mizuno, S., and Uehara, Y. (1997). Induction of p27Kip1 degradation and anchorage independence by Ras through the MAP kinase signaling pathway. Oncogene 15, 629-637.

- $\quad$ Kazlauskas, A., and Cooper, J.A. (1990). Phosphorylation of the PDGF receptor beta subunit creates a tight binding site for phosphatidylinositol 3 kinase. EMBO J. 9, 3279-3286.

- Kern, F., Niault, T., and Baccarini, M. (2011). Ras and Raf pathways in epidermis development and carcinogenesis. Br. J. Cancer 104, 229-234.

- Khavari, T.A., and Rinn, J. (2007). Ras/Erk MAPK signaling in epidermal homeostasis and neoplasia. Cell Cycle 6, 2928-2931.

- Kim, J.-H., Shirouzu, M., Kataoka, T., Bowtell, D., and Yokoyama, S. (1998). Activation of Ras and its downstream extracellular signal-regulated protein kinases by the CDC25 homology domain of mouse Son-ofsevenless 1 (mSos1). Oncogene 16, 2597-2607.

- $\quad$ Kipp, B.R., Barr Fritcher, E.G., Clayton, A.C., Gores, G.J., Roberts, L.R., Zhang, J., Levy, M.J., and Halling, K.C. (2010). Comparison of KRAS Mutation Analysis and FISH for Detecting Pancreatobiliary Tract Cancer in Cytology Specimens Collected During Endoscopic Retrograde Cholangiopancreatography. J. Mol. Diagnostics 12, 780-786.

- Kiyono, M., Kato, J., Kataoka, T., Kaziro, Y., and Satoh, T. (2000). Stimulation of Ras guanine nucleotide exchange activity of Ras-GRF1/CDC25(Mm) upon tyrosine phosphorylation by the Cdc42-regulated kinase ACK1. J. Biol. Chem. 275, 29788-29793.

- $\quad$ Klarlund, J.K., Cherniack, A.D., and Czech, M.P. (1995). Divergent mechanisms for homologous desensitization of p21ras by insulin and growth factors. J. Biol. Chem. 270, 23421-23428.

- Klemke, R.L., Cai, S., Giannini, A.L., Gallagher, P.J., de Lanerolle, P., and Cheresh, D.A. (1997). Regulation of cell motility by mitogen-activated protein kinase. J. Cell Biol. 137, 481-492.

- Kodaki, T., Woscholski, R., Hallberg, B., Rodriguez-Viciana, P., Downward, J., and Parker, P.J. (1994). The activation of phosphatidylinositol 3-kinase by Ras. Curr. Biol. 4, 798-806.

- $\quad$ Koera, K., Nakamura, K., Nakao, K., Miyoshi, J., Toyoshima, K., Hatta, T., Otani, H., Aiba, A., and Katsuki, M. 
(1997). K-ras is essential for the development of the mouse embryo. Oncogene 15, 1151-1159.

- Kolch, W. (2005). Coordinating ERK/MAPK signalling through scaffolds and inhibitors. Nat. Rev. Mol. Cell Biol. 6, 827-837.

- $\quad$ Kolch, W., Heidecker, G., Kochs, G., Hummel, R., Vahidi, H., Mischak, H., Finkenzeller, G., Marmé, D., and Rapp, U.R. (1993). Protein kinase C $\alpha$ activates RAF-1 by direct phosphorylation. Nature 364, 249-252.

- Komatsu, T., Kukelyansky, I., McCaffery, J.M., Ueno, T., Varela, L.C., and Inoue, T. (2010). Organelle-specific, rapid induction of molecular activities and membrane tethering. Nat. Methods 7, 206-208.

- $\quad$ Kong, L.R., Chua, K.N., Sim, W.J., Ng, H.C., Bi, C., Ho, J., Nga, M.E., Pang, Y.H., Ong, W.R., Soo, R.A., et al. (2015). MEK Inhibition Overcomes Cisplatin Resistance Conferred by SOS/MAPK Pathway Activation in Squamous Cell Carcinoma. Mol. Cancer Ther. 14, 1750-1760.

- $\quad$ Kong, L.R., Tan, T.Z., Ong, W.R., Bi, C., Huynh, H., Lee, S.C., Chng, W.J., Eichhorn, P.J.A., and Goh, B.C. (2017). Belinostat exerts antitumor cytotoxicity through the ubiquitin-proteasome pathway in lung squamous cell carcinoma. Mol. Oncol.

- $\quad$ Kontaridis, M.I., Swanson, K.D., David, F.S., Barford, D., and Neel, B.G. (2006). PTPN11 (Shp2) Mutations in LEOPARD Syndrome Have Dominant Negative, Not Activating, Effects. J. Biol. Chem. 281, 6785-6792.

- Kops, G.J., and Burgering, B.M. (1999). Forkhead transcription factors: new insights into protein kinase B (cakt) signaling. J. Mol. Med. (Berl). 77, 656-665.

- $\quad$ Kornberg, L., Earp, H.S., Parsons, J.T., Schaller, M., and Juliano, R.L. (1992). Cell adhesion or integrin clustering increases phosphorylation of a focal adhesion-associated tyrosine kinase. J. Biol. Chem. 267, 23439-23442.

- $\quad$ Kortum, R.L., Sommers, C.L., Alexander, C.P., Pinski, J.M., Li, W., Grinberg, A., Lee, J., Love, P.E., and Samelson, L.E. (2011). Targeted Sos1 deletion reveals its critical role in early T-cell development. Proc. Natl. Acad. Sci. U. S. A. $108,12407-12412$.

- $\quad$ Kortum, R.L., Sommers, C.L., Pinski, J.M., Alexander, C.P., Merrill, R.K., Li, W., Love, P.E., and Samelson, L.E. (2012). Deconstructing Ras Signaling in the Thymus. Mol. Cell. Biol. 32, 2748-2759.

- $\quad$ Kortum, R.L., Balagopalan, L., Alexander, C.P., Garcia, J., Pinski, J.M., Merrill, R.K., Nguyen, P.H., Li, W., Agarwal, I., Akpan, I.O., et al. (2013). The ability of Sos1 to oligomerize the adaptor protein LAT is separable from its guanine nucleotide exchange activity in vivo. Sci. Signal. 6, ra99.

- $\quad$ Koster, M.I., Dai, D., Marinari, B., Sano, Y., Costanzo, A., Karin, M., and Roop, D.R. (2007). p63 induces key target genes required for epidermal morphogenesis. Proc. Natl. Acad. Sci. 104, 3255-3260.

- Kouhara, H., Hadari, Y.R., Spivak-Kroizman, T., Schilling, J., Bar-Sagi, D., Lax, I., and Schlessinger, J. (1997). A lipid-anchored Grb2-binding protein that links FGF-receptor activation to the Ras/MAPK signaling pathway. Cell 89, 693-702.

- $\quad$ Krauthammer, M., Kong, Y., Ha, B.H., Evans, P., Bacchiocchi, A., McCusker, J.P., Cheng, E., Davis, M.J., Goh, G., Choi, M., et al. (2012). Exome sequencing identifies recurrent somatic RAC1 mutations in melanoma. Nat. Genet. 44, 1006-1014.

- $\quad$ Krugmann, S., Anderson, K.E., Ridley, S.H., Risso, N., McGregor, A., Coadwell, J., Davidson, K., Eguinoa, A., Ellson, C.D., Lipp, P., et al. (2002). Identification of ARAP3, a novel PI3K effector regulating both Arf and Rho GTPases, by selective capture on phosphoinositide affinity matrices. Mol. Cell 9, 95-108.

- Ksionda, O., Limnander, A., and Roose, J.P. (2013). RasGRP Ras guanine nucleotide exchange factors in cancer. Front. Biol. (Beijing). 8, 508-532.

- $\quad$ Kubiseski, T.J., Chook, Y.M., Parris, W.E., Rozakis-Adcock, M., and Pawson, T. (1997). High affinity binding of the pleckstrin homology domain of mSos1 to phosphatidylinositol (4,5)-bisphosphate. J. Biol. Chem. 272, 1799-1804.

- $\quad$ Kuiperij, H.B., van der Horst, A., Raaijmakers, J., Weijzen, S., Medema, R.H., Bos, J.L., Burgering, B.M.T., and Zwartkruis, F.J.T. (2005). Activation of FoxO transcription factors contributes to the antiproliferative effect of cAMP. Oncogene 24, 2087-2095.

- $\quad$ Kumar, S., Maxwell, I.Z., Heisterkamp, A., Polte, T.R., Lele, T.P., Salanga, M., Mazur, E., and Ingber, D.E. (2006). Viscoelastic Retraction of Single Living Stress Fibers and Its Impact on Cell Shape, Cytoskeletal Organization, and Extracellular Matrix Mechanics. Biophys. J. 90, 3762-3773.

- Kuo, Y.-C., Huang, K.-Y., Yang, C.-H., Yang, Y.-S., Lee, W.-Y., and Chiang, C.-W. (2008). Regulation of Phosphorylation of Thr-308 of Akt, Cell Proliferation, and Survival by the B55? Regulatory Subunit Targeting of the Protein Phosphatase 2A Holoenzyme to Akt. J. Biol. Chem. 283, 1882-1892.

- $\quad$ Kyriakis, J.M., App, H., Zhang, X., Banerjee, P., Brautigan, D.L., Rapp, U.R., and Avruch, J. (1992). Raf-1 activates MAP kinase-kinase. Nature 358, 417-421.

- Ladwein, M., and Rottner, K. (2008). On the Rho'd: The regulation of membrane protrusions by Rho-GTPases. FEBS Lett. 582, 2066-2074.

- $\quad$ Lambert, J.M., Lambert, Q.T., Reuther, G.W., Malliri, A., Siderovski, D.P., Sondek, J., Collard, J.G., and Der, C.J. 
(2002). Tiam1 mediates Ras activation of Rac by a PI(3)K-independent mechanism. Nat. Cell Biol. 4, 621-625.

- $\quad$ Lanfrancone, L., Pelicci, G., Brizzi, M.F., Aronica, M.G., Casciari, C., Giuli, S., Pegoraro, L., Pawson, T., Pelicci, P.G., and Arouica, M.G. (1995). Overexpression of Shc proteins potentiates the proliferative response to the granulocyte-macrophage colony-stimulating factor and recruitment of Grb2/SoS and Grb2/p140 complexes to the beta receptor subunit. Oncogene 10, 907-917.

- Langlois, W.J., Sasaoka, T., Saltiel, A.R., and Olefsky, J.M. (1995). Negative feedback regulation and desensitization of insulin- and epidermal growth factor-stimulated p21ras activation. J. Biol. Chem. 270, 25320-25323.

- $\quad$ Laurens, N., Koolwijk, P., and de Maat, M.P. (2006). Fibrin structure and wound healing. J. Thromb. Haemost. 4, 932-939.

- Lavoie, J.N., Rivard, N., L'Allemain, G., and Pouysségur, J. (1996). A temporal and biochemical link between growth factor-activated MAP kinases, cyclin D1 induction and cell cycle entry. Prog. Cell Cycle Res. 2, 49-58.

- $\quad$ Ledford, H. (2015). Cancer studies clash over mechanisms of malignancy. Nature 528, 317-317.

- Lee, E.J., Jang, S.I., Pallos, D., Kather, J., and Hart, T.C. (2006). Characterization of fibroblasts with Son of Sevenless-1 mutation. J. Dent. Res. 85, 1050-1055.

- Lee, J.S.H., Chang, M.I., Tseng, Y., and Wirtz, D. (2005). Cdc42 mediates nucleus movement and MTOC polarization in Swiss 3T3 fibroblasts under mechanical shear stress. Mol. Biol. Cell 16, 871-880.

- $\quad$ Lee, Y.K., Low-Nam, S.T., Chung, J.K., Hansen, S.D., Lam, H.Y.M., Alvarez, S., and Groves, J.T. (2017). Mechanism of SOS PR-domain autoinhibition revealed by single-molecule assays on native protein from lysate. Nat. Commun. 8, 15061.

- $\quad$ Leinweber, B.D., Leavis, P.C., Grabarek, Z., Wang, C.L., and Morgan, K.G. (1999). Extracellular regulated kinase (ERK) interaction with actin and the calponin homology $(\mathrm{CH})$ domain of actin-binding proteins. Biochem. J. 344 Pt 1, 117-123.

- Lemmon, M.A., and Ferguson, K.M. (2000). Signal-dependent membrane targeting by pleckstrin homology (PH) domains. Biochem. J. 350 Pt 1, 1-18.

- Lemmon, M.A., Ferguson, K.M., and Schlessinger, J. (1996). PH domains: diverse sequences with a common fold recruit signaling molecules to the cell surface. Cell 85, 621-624.

- Leon, J., Guerrero, I., and Pellicer, A. (1987). Differential expression of the ras gene family in mice. Mol. Cell. Biol. 7, 1535-1540.

- $\quad$ Leshchiner, E.S., Parkhitko, A., Bird, G.H., Luccarelli, J., Bellairs, J.A., Escudero, S., Opoku-Nsiah, K., Godes, M., Perrimon, N., and Walensky, L.D. (2015). Direct inhibition of oncogenic KRAS by hydrocarbon-stapled SOS1 helices. Proc. Natl. Acad. Sci. 112, 1761-1766.

- Ley, R., Balmanno, K., Hadfield, K., Weston, C., and Cook, S.J. (2003). Activation of the ERK1/2 Signaling Pathway Promotes Phosphorylation and Proteasome-dependent Degradation of the BH3-only Protein, Bim. J. Biol. Chem. 278, 18811-18816.

- $\quad$ Li, A., Qin, L., Wang, W., Zhu, R., Yu, Y., Liu, H., and Wang, S. (2011). The use of layered double hydroxides as DNA vaccine delivery vector for enhancement of anti-melanoma immune response. Biomaterials 32, 469-477.

- $\quad$ Li, A., Ma, Y., Jin, M., Mason, S., Mort, R.L., Blyth, K., Larue, L., Sansom, O.J., and Machesky, L.M. (2012). Activated Mutant NRasQ61K Drives Aberrant Melanocyte Signaling, Survival, and Invasiveness via a Rac1Dependent Mechanism. J. Invest. Dermatol. 132, 2610-2621.

- $\quad$ Li, M., Li, Y., Weeks, O., Mijatovic, V., Teumer, A., Huffman, J.E., Tromp, G., Fuchsberger, C., Gorski, M., Lyytikäinen, L.-P., et al. (2017). SOS2 and ACP1 Loci Identified through Large-Scale Exome Chip Analysis Regulate Kidney Development and Function. J. Am. Soc. Nephrol. 28, 981-994.

- $\quad$ Li, W., Nishimura, R., Kashishian, A., Batzer, A.G., Kim, W.J., Cooper, J.A., and Schlessinger, J. (1994). A new function for a phosphotyrosine phosphatase: linking GRB2-Sos to a receptor tyrosine kinase. Mol. Cell. Biol. 14, 509-517.

- Liao, J., Wolfman, J.C., and Wolfman, A. (2003). K-Ras Regulates the Steady-state Expression of Matrix Metalloproteinase 2 in Fibroblasts. J. Biol. Chem. 278, 31871-31878.

- Liceras-Boillos, P., García-Navas, R., Ginel-Picardo, A., Anta, B., Pérez-Andrés, M., Lillo, C., Gómez, C., Jimeno, D., Fernández-Medarde, A., Baltanás, F.C., et al. (2016). Sos1 disruption impairs cellular proliferation and viability through an increase in mitochondrial oxidative stress in primary MEFs. Oncogene 1-14.

- $\quad$ Lichtenberger, B.M., Tan, P.K., Niederleithner, H., Ferrara, N., Petzelbauer, P., and Sibilia, M. (2010). Autocrine VEGF signaling synergizes with EGFR in tumor cells to promote epithelial cancer development. Cell 140, 268279.

- $\quad$ Lindsay, C.R., Lawn, S., Campbell, A.D., Faller, W.J., Rambow, F., Mort, R.L., Timpson, P., Li, A., Cammareri, P., Ridgway, R.A., et al. (2011). P-Rex1 is required for efficient melanoblast migration and melanoma metastasis. Nat. Commun. 2, 555.

- Liu, B.X., Wei, W., and Broek, D. (1993). The catalytic domain of the mouse sos1 gene product activates Ras 
proteins in vivo and in vitro. Oncogene $8,3081-3084$.

- Liu, Y., Martindale, J.L., Gorospe, M., and Holbrook, N.J. (1996). Regulation of p21WAF1/CIP1 expression through mitogen-activated protein kinase signaling pathway. Cancer Res. 56, 31-35.

- Lo, C.M., Wang, H.B., Dembo, M., and Wang, Y.L. (2000). Cell movement is guided by the rigidity of the substrate. Biophys. J. 79, 144-152.

- $\quad$ Lomberk, G., Wallrath, L., and Urrutia, R. (2006). The Heterochromatin Protein 1 family. Genome Biol. 7, 228.

- $\quad$ López-llasaca, M., Crespo, P., Pellici, P.G., Gutkind, J.S., and Wetzker, R. (1997). Linkage of G protein-coupled receptors to the MAPK signaling pathway through PI 3-kinase gamma. Science 275, 394-397.

- Lovec, H., Sewing, A., Lucibello, F.C., Müller, R., and Möröy, T. (1994). Oncogenic activity of cyclin D1 revealed through cooperation with Ha-ras: link between cell cycle control and malignant transformation. Oncogene 9 , 323-326.

- $\quad$ Lowenstein, E.J., Daly, R.J., Batzer, A.G., Li, W., Margolis, B., Lammers, R., Ullrich, A., Skolnik, E.Y., Bar-Sagi, D., and Schlessinger, J. (1992). The SH2 and SH3 domain-containing protein GRB2 links receptor tyrosine kinases to ras signaling. Cell 70, 431-442.

- Lozano, M.L., Cook, A., Bastida, J.M., Paul, D.S., Iruin, G., Cid, A.R., Adan-Pedroso, R., Ramon Gonzalez-Porras, J., Hernandez-Rivas, J.M., Fletcher, S.J., et al. (2016). Novel mutations in RASGRP2, which encodes CalDAGGEFI, abrogate Rap1 activation, causing platelet dysfunction. Blood 128, 1282-1289.

- Luke, C.T., Oki-Idouchi, C.E., Cline, J.M., and Lorenzo, P.S. (2007). RasGRP1 overexpression in the epidermis of transgenic mice contributes to tumor progression during multistage skin carcinogenesis. Cancer Res. 67, 10190-10197.

- Malumbres, M., and Barbacid, M. (2003). Timeline: RAS oncogenes: the first 30 years. Nat. Rev. Cancer 3, 459465.

- Malumbres, M., and Pellicer, A. (1998). RAS pathways to cell cycle control and cell transformation. Front. Biosci. 3, d887-912.

- Manning, B.D., and Cantley, L.C. (2007). AKT/PKB signaling: navigating downstream. Cell 129, 1261-1274.

- Manyes, L., Arribas, M., Gomez, C., Calzada, N., Fernandez-Medarde, A., and Santos, E. (2014). Transcriptional profiling reveals functional links between RasGrf1 and Pttg1 in pancreatic beta cells. BMC Genomics 15, 1019.

- Marais, R., Light, Y., Paterson, H.F., and Marshall, C.J. (1995). Ras recruits Raf-1 to the plasma membrane for activation by tyrosine phosphorylation. EMBO J. 14, 3136-3145.

- Margarit, S.M., Sondermann, H., Hall, B.E., Nagar, B., Hoelz, A., Pirruccello, M., Bar-Sagi, D., and Kuriyan, J. (2003). Structural evidence for feedback activation by Ras.GTP of the Ras-specific nucleotide exchange factor SOS. Cell 112, 685-695.

- $\quad$ Marikovsky, M., Breuing, K., Liu, P.Y., Eriksson, E., Higashiyama, S., Farber, P., Abraham, J., and Klagsbrun, M. (1993). Appearance of heparin-binding EGF-like growth factor in wound fluid as a response to injury. Proc. Natl. Acad. Sci. U. S. A. 90, 3889-3893.

- Martin, P. (1997). Wound healing--aiming for perfect skin regeneration. Science 276, 75-81.

- Martindale, J.L., and Holbrook, N.J. (2002). Cellular response to oxidative stress: Signaling for suicide and survival. J. Cell. Physiol. 192, 1-15.

- Matallanas, D., Arozarena, I., Berciano, M.T., Aaronson, D.S., Pellicer, A., Lafarga, M., and Crespo, P. (2003). Differences on the Inhibitory Specificities of H-Ras, K-Ras, and N-Ras (N17) Dominant Negative Mutants Are Related to Their Membrane Microlocalization. J. Biol. Chem. 278, 4572-4581.

- Mattingly, R.R., Saini, V., and Macara, I.G. (1999). Activation of the Ras-GRF/CDC25Mm exchange factor by lysophosphatidic acid. Cell. Signal. 11, 603-610.

- Maurer, T., Garrenton, L.S., Oh, A., Pitts, K., Anderson, D.J., Skelton, N.J., Fauber, B.P., Pan, B., Malek, S., Stokoe, D., et al. (2012). Small-molecule ligands bind to a distinct pocket in Ras and inhibit SOS-mediated nucleotide exchange activity. Proc. Natl. Acad. Sci. U. S. A. 109, 5299-5304.

- May, U., Prince, S., Vähätupa, M., Laitinen, A.M., Nieminen, K., Uusitalo-Järvinen, H., and Järvinen, T.A.H. (2015). Resistance of R-Ras knockout mice to skin tumour induction. Sci. Rep. 5, 11663.

- Mayer, B.J., Ren, R., Clark, K.L., and Baltimore, D. (1993). A putative modular domain present in diverse signaling proteins. Cell 73, 629-630.

- Mazieres, J., Pradines, A., and Favre, G. (2004). Perspectives on farnesyl transferase inhibitors in cancer therapy. Cancer Lett. 206, 159-167.

- McCollam, L., Bonfini, L., Karlovich, C.A., Conway, B.R., Kozma, L.M., Banerjee, U., and Czech, M.P. (1995). Functional roles for the pleckstrin and $\mathrm{Dbl}$ homology regions in the Ras exchange factor Son-of-sevenless. J. Biol. Chem. 270, 15954-15957.

- McGrath, J.P., Capon, D.J., Goeddel, D. V, and Levinson, A.D. (1984). Comparative biochemical properties of normal and activated human ras p21 protein. Nature 310, 644-649. 
- McKay, M.M., and Morrison, D.K. (2007). Integrating signals from RTKs to ERK/MAPK. Oncogene 26, 31133121.

- Meloche, S., and Pouysségur, J. (2007). The ERK1/2 mitogen-activated protein kinase pathway as a master regulator of the G1- to S-phase transition. Oncogene 26, 3227-3239.

- Menacho-Márquez, M., García-Escudero, R., Ojeda, V., Abad, A., Delgado, P., Costa, C., Ruiz, S., Alarcón, B., Paramio, J.M., and Bustelo, X.R. (2013). The Rho Exchange Factors Vav2 and Vav3 Favor Skin Tumor Initiation and Promotion by Engaging Extracellular Signaling Loops. PLoS Biol. 11, e1001615.

- Mendoza, M.C., Er, E.E., and Blenis, J. (2011). The Ras-ERK and PI3K-mTOR pathways: cross-talk and compensation. Trends Biochem. Sci. 36, 320-328.

- Mettouchi, A., Klein, S., Guo, W., Lopez-Lago, M., Lemichez, E., Westwick, J.K., and Giancotti, F.G. (2001). Integrin-specific activation of Rac controls progression through the $\mathrm{G}(1)$ phase of the cell cycle. Mol. Cell 8 , 115-127.

- Miao, H., Li, S., Hu, Y.-L., Yuan, S., Zhao, Y., Chen, B.P.C., Puzon-McLaughlin, W., Tarui, T., Shyy, J.Y.-J., Takada, Y., et al. (2002). Differential regulation of Rho GTPases by beta1 and beta3 integrins: the role of an extracellular domain of integrin in intracellular signaling. J. Cell Sci. 115, 2199-2206.

- Michiels, F., Habets, G.G.M., Stam, J.C., van der Kammen, R.A., and Collard, J.G. (1995). A role for Rac in Tiamlinduced membrane ruffling and invasion. Nature $375,338-340$.

- $\quad$ Minella, D., Wannenes, F., Biancolella, M., Amati, F., Testa, B., Nardone, A., Bueno, S., Fabbri, A., Lauro, D., Novelli, G., et al. (2011). SOS1 over-expression in genital skin fibroblasts from hirsute women: A putative role of the SOS1/RAS pathway in the pathogenesis of hirsutism. J. Biol. Regul. Homeost. Agents 25, 615-626.

- Misaki, R., Morimatsu, M., Uemura, T., Waguri, S., Miyoshi, E., Taniguchi, N., Matsuda, M., and Taguchi, T. (2010). Palmitoylated Ras proteins traffic through recycling endosomes to the plasma membrane during exocytosis. J. Cell Biol. 191, 23-29.

- Mitin, N., Rossman, K.L., and Der, C.J. (2005). Signaling interplay in Ras superfamily function. Curr. Biol. 15, R563-74.

- Mo, L., Zheng, X., Huang, H.-Y., Shapiro, E., Lepor, H., Cordon-Cardo, C., Sun, T.-T., and Wu, X.-R. (2007). Hyperactivation of Ha-ras oncogene, but not Ink4a/Arf deficiency, triggers bladder tumorigenesis. J. Clin. Invest. 117, 314-325.

- Modzelewska, K., Elgort, M.G., Huang, J., Jongeward, G., Lauritzen, A., Yoon, C.H., Sternberg, P.W., and Moghal, N. (2007). An activating mutation in sos-1 identifies its Dbl domain as a critical inhibitor of the epidermal growth factor receptor pathway during Caenorhabditis elegans vulval development. Mol. Cell. Biol. 27, 3695-3707.

- Moeller, S.J., Head, E.D., and Sheaff, R.J. (2003). p27Kip1 inhibition of GRB2-SOS formation can regulate Ras activation. Mol. Cell. Biol. 23, 3735-3752.

- Mori, S., Cortes, J., Kantarjian, H., Zhang, W., Andreef, M., and Ravandi, F. (2008). Potential role of sorafenib in the treatment of acute myeloid leukemia. Leuk. Lymphoma 49, 2246-2255.

- Mseka, T., and Cramer, L.P. (2011). Actin depolymerization-based force retracts the cell rear in polarizing and migrating cells. Curr. Biol. 21, 2085-2091.

- Mseka, T., Bamburg, J.R., and Cramer, L.P. (2007). ADF/cofilin family proteins control formation of oriented actin-filament bundles in the cell body to trigger fibroblast polarization. J. Cell Sci. 120, 4332-4344.

- Mulcahy, L.S., Smith, M.R., and Stacey, D.W. (1985). Requirement for ras proto-oncogene function during serum-stimulated growth of NIH 3T3 cells. Nature 313, 241-243.

- Murillo, M.M., Zelenay, S., Nye, E., Castellano, E., Lassailly, F., Stamp, G., and Downward, J. (2014). RAS interaction with PI3K p110 $\alpha$ is required for tumor-induced angiogenesis. J. Clin. Invest. 124, 3601-3611.

- Murphy, L.O., and Blenis, J. (2006). MAPK signal specificity: the right place at the right time. Trends Biochem. Sci. 31, 268-275.

- $\quad$ Murphy, L.O., Smith, S., Chen, R.-H., Fingar, D.C., and Blenis, J. (2002). Molecular interpretation of ERK signal duration by immediate early gene products. Nat. Cell Biol. 4, 556-564.

- Murphy, L.O., MacKeigan, J.P., and Blenis, J. (2004). A network of immediate early gene products propagates subtle differences in mitogen-activated protein kinase signal amplitude and duration. Mol. Cell. Biol. 24, 144153.

- $\quad$ Nava, C., Hanna, N., Michot, C., Pereira, S., Pouvreau, N., Niihori, T., Aoki, Y., Matsubara, Y., Arveiler, B., Lacombe, D., et al. (2007). Cardio-facio-cutaneous and Noonan syndromes due to mutations in the RAS/MAPK signalling pathway: genotype phenotype relationships and overlap with Costello syndrome. J. Med. Genet. 44, 763-771.

- $\quad$ Navarro-Yepes, J., Burns, M., Anandhan, A., Khalimonchuk, O., del Razo, L.M., Quintanilla-Vega, B., Pappa, A., Panayiotidis, M.I., and Franco, R. (2014). Oxidative stress, redox signaling, and autophagy: cell death versus survival. Antioxid. Redox Signal. 21, 66-85. 
- $\quad$ Nickerson, S., Joy, S.T., Arora, P.S., and Bar-Sagi, D. (2013). An Orthosteric Inhibitor of the RAS-SOS Interaction. In The Enzymes, pp. 25-39.

- $\quad$ Nielsen, K.H., Papageorge, A.G., Vass, W.C., Willumsen, B.M., and Lowy, D.R. (1997). The Ras-specific exchange factors mouse Sos 1 (mSos 1 ) and mSos2 are regulated differently: mSos 2 contains ubiquitination signals absent in mSos1. Mol. Cell. Biol. 17, 7132-7138.

- $\quad$ Nimnual, A., and Bar-Sagi, D. (2002). The Two Hats of SOS. Sci. Signal. 2002, pe36-pe36.

- Nimnual, A.S., Yatsula, B.A., and Bar-Sagi, D. (1998). Coupling of Ras and Rac guanosine triphosphatases through the Ras exchanger Sos. Science 279, 560-563.

- Nobes, C.D., and Hall, A. (1999). Rho GTPases control polarity, protrusion, and adhesion during cell movement. J. Cell Biol. 144, 1235-1244.

- Noonan, J.A. (2007). Noonan syndrome and related disorders: Alterations in growth and puberty. Rev. Endocr. Metab. Disord. 7, 251-255.

- $\quad$ Nussinov, R., Muratcioglu, S., Tsai, C.-J., Jang, H., Gursoy, A., and Keskin, O. (2015). The Key Role of Calmodulin in KRAS-Driven Adenocarcinomas. Mol. Cancer Res. 13, 1265-1273.

- Oh-hora, M., Johmura, S., Hashimoto, A., Hikida, M., and Kurosaki, T. (2003). Requirement for Ras Guanine Nucleotide Releasing Protein 3 in Coupling Phospholipase C-gamma2 to Ras in B Cell Receptor Signaling. J. Exp. Med. 198, 1841-1851.

- $\quad$ Ohba, Y., Mochizuki, N., Yamashita, S., Chan, A.M., Schrader, J.W., Hattori, S., Nagashima, K., and Matsuda, M. (2000). Regulatory Proteins of R-Ras, TC21/R-Ras2, and M-Ras/R-Ras3. J. Biol. Chem. 275, 20020-20026.

- $\quad$ Ohtsuka, T., Hata, Y., Ide, N., Yasuda, T., Inoue, E., Inoue, T., Mizoguchi, A., and Takai, Y. (1999). nRap GEP: A Novel Neural GDP/GTP Exchange Protein for Rap1 Small G Protein That Interacts with Synaptic Scaffolding Molecule (S-SCAM). Biochem. Biophys. Res. Commun. 265, 38-44.

- $\quad$ Okada, S., and Pessin, J.E. (1996). Interactions between Src homology (SH) 2/SH3 adapter proteins and the guanylnucleotide exchange factor SOS are differentially regulated by insulin and epidermal growth factor. J. Biol. Chem. 271, 25533-25538.

- $\quad$ Oki, T., Kitaura, J., Watanabe-Okochi, N., Nishimura, K., Maehara, A., Uchida, T., Komeno, Y., Nakahara, F., Harada, Y., Sonoki, T., et al. (2012). Aberrant expression of RasGRP1 cooperates with gain-of-function NOTCH1 mutations in T-cell leukemogenesis. Leukemia 26, 1038-1045.

- $\quad$ Oki-Idouchi, C.E., and Lorenzo, P.S. (2007). Transgenic Overexpression of RasGRP1 in Mouse Epidermis Results in Spontaneous Tumors of the Skin. Cancer Res. 67, 276-280.

- $\quad$ Olivier, J.P., Raabe, T., Henkemeyer, M., Dickson, B., Mbamalu, G., Margolis, B., Schlessinger, J., Hafen, E., and Pawson, T. (1993). A Drosophila SH2-SH3 adaptor protein implicated in coupling the sevenless tyrosine kinase to an activator of Ras guanine nucleotide exchange, Sos. Cell 73, 179-191.

- Omerovic, J., Laude, A.J., and Prior, I.A. (2007). Ras proteins: paradigms for compartmentalised and isoformspecific signalling. Cell. Mol. Life Sci. 64, 2575-2589.

- $\quad$ Osterop, A.P., Medema, R.H., vd Zon, G.C., Bos, J.L., Möller, W., and Maassen, J.A. (1993). Epidermal-growthfactor receptors generate Ras.GTP more efficiently than insulin receptors. Eur. J. Biochem. 212, 477-482.

- $\quad$ Otsu, M., Hiles, I., Gout, I., Fry, M.J., Ruiz-Larrea, F., Panayotou, G., Thompson, A., Dhand, R., Hsuan, J., and Totty, N. (1991). Characterization of two $85 \mathrm{kd}$ proteins that associate with receptor tyrosine kinases, middleT/pp60c-src complexes, and PI3-kinase. Cell 65, 91-104.

- Pandit, B., Sarkozy, A., Pennacchio, L.A., Carta, C., Oishi, K., Martinelli, S., Pogna, E.A., Schackwitz, W., Ustaszewska, A., Landstrom, A., et al. (2007). Gain-of-function RAF1 mutations cause Noonan and LEOPARD syndromes with hypertrophic cardiomyopathy. Nat. Genet. 39, 1007-1012.

- Parada, L.F., Tabin, C.J., Shih, C., and Weinberg, R.A. (1982). Human EJ bladder carcinoma oncogene is homologue of Harvey sarcoma virus ras gene. Nature 297, 474-478.

- Park, J.E., and Barbul, A. (2004). Understanding the role of immune regulation in wound healing. Am. J. Surg. 187.

- Parri, M., and Chiarugi, P. (2010). Rac and Rho GTPases in cancer cell motility control. Cell Commun. Signal. 8, 23.

- Parsons, J.T., Horwitz, A.R., and Schwartz, M.A. (2010). Cell adhesion: integrating cytoskeletal dynamics and cellular tension. Nat. Rev. Mol. Cell Biol. 11, 633-643.

- $\quad$ Patgiri, A., Yadav, K.K., Arora, P.S., and Bar-Sagi, D. (2011). An orthosteric inhibitor of the Ras-Sos interaction. Nat. Chem. Biol. 7, 585-587.

- $\quad$ Payne, S.R., Zhang, S., Tsuchiya, K., Moser, R., Gurley, K.E., Longton, G., deBoer, J., and Kemp, C.J. (2008). p27kip1 deficiency impairs $G 2 / M$ arrest in response to DNA damage, leading to an increase in genetic instability. Mol. Cell. Biol. 28, 258-268.

- $\quad$ Pearson, L.L., Castle, B.E., and Kehry, M.R. (2001). CD40-mediated signaling in monocytic cells: up-regulation of 
tumor necrosis factor receptor-associated factor mRNAs and activation of mitogen-activated protein kinase signaling pathways. Int. Immunol. 13, 273-283.

- Perez-Losada, J., and Balmain, A. (2003). Stem-cell hierarchy in skin cancer. Nat. Rev. Cancer 3, 434-443.

- $\quad$ Peri, F., Airoldi, C., Colombo, S., Martegani, E., van Neuren, A.S., Stein, M., Marinzi, C., and Nicotra, F. (2005). Design, Synthesis and Biological Evaluation of Sugar-Derived Ras Inhibitors. ChemBioChem 6, 1839-1848.

- Perlson, E., Hanz, S., Ben-Yaakov, K., Segal-Ruder, Y., Seger, R., and Fainzilber, M. (2005). Vimentin-dependent spatial translocation of an activated MAP kinase in injured nerve. Neuron 45, 715-726.

- $\quad$ Perucho, M., Goldfarb, M., Shimizu, K., Lama, C., Fogh, J., and Wigler, M. (1981). Human-tumor-derived cell lines contain common and different transforming genes. Cell 27, 467-476.

- $\quad$ Pham, N., Cheglakov, I., Koch, C.A., de Hoog, C.L., Moran, M.F., and Rotin, D. (2000). The guanine nucleotide exchange factor CNrasGEF activates ras in response to CAMP and CGMP. Curr. Biol. 10, 555-558.

- $\quad$ Pierre, S., Bats, A.-S., Chevallier, A., Bui, L.-C., Ambolet-Camoit, A., Garlatti, M., Aggerbeck, M., Barouki, R., and Coumoul, X. (2011). Induction of the Ras activator Son of Sevenless 1 by environmental pollutants mediates their effects on cellular proliferation. Biochem. Pharmacol. 81, 304-313.

- Plotnikov, A., Zehorai, E., Procaccia, S., and Seger, R. (2011). The MAPK cascades: Signaling components, nuclear roles and mechanisms of nuclear translocation. Biochim. Biophys. Acta - Mol. Cell Res. 1813, 16191633.

- $\quad$ Plowman, S.J., Williamson, D.J., O'Sullivan, M.J., Doig, J., Ritchie, A.-M., Harrison, D.J., Melton, D.W., Arends, M.J., Hooper, M.L., and Patek, C.E. (2003). While K-ras is essential for mouse development, expression of the K-ras 4A splice variant is dispensable. Mol. Cell. Biol. 23, 9245-9250.

- $\quad$ Plowman, S.J., Muncke, C., Parton, R.G., and Hancock, J.F. (2005). H-ras, K-ras, and inner plasma membrane raft proteins operate in nanoclusters with differential dependence on the actin cytoskeleton. Proc. Natl. Acad. Sci. 102, 15500-15505.

- Plowman, S.J., Ariotti, N., Goodall, A., Parton, R.G., and Hancock, J.F. (2008). Electrostatic Interactions Positively Regulate K-Ras Nanocluster Formation and Function. Mol. Cell. Biol. 28, 4377-4385.

- Porfiri, E., and McCormick, F. (1996). Regulation of epidermal growth factor receptor signaling by phosphorylation of the ras exchange factor hSOS1. J. Biol. Chem. 271, 5871-5877.

- Porfiri, E., Evans, T., Chardin, P., and Hancock, J.F. (1994). Prenylation of Ras proteins is required for efficient hSOS1-promoted guanine nucleotide exchange. J. Biol. Chem. 269, 22672-22677.

- Potten, C.S. (1981). Cell replacement in epidermis (keratopoiesis) via discrete units of proliferation. Int. Rev. Cytol. 69, 271-318.

- $\quad$ Pratilas, C.A., Taylor, B.S., Ye, Q., Viale, A., Sander, C., Solit, D.B., and Rosen, N. (2009). (V600E)BRAF is associated with disabled feedback inhibition of RAF-MEK signaling and elevated transcriptional output of the pathway. Proc. Natl. Acad. Sci. U. S. A. 106, 4519-4524.

- Prior, I.A., and Hancock, J.F. (2012). Ras trafficking, localization and compartmentalized signalling. Semin. Cell Dev. Biol. 23, 145-153.

- $\quad$ Pruitt, K., and Der, C.J. (2001). Ras and Rho regulation of the cell cycle and oncogenesis. Cancer Lett. 171, 110.

- $\quad$ Pulciani, S., Santos, E., Lauver, A. V, Long, L.K., Aaronson, S.A., and Barbacid, M. (1982). Oncogenes in solid human tumours. Nature 300, 539-542.

- $\quad$ Pumiglia, K.M., and Decker, S.J. (1997). Cell cycle arrest mediated by the MEK/mitogen-activated protein kinase pathway. Proc. Natl. Acad. Sci. U. S. A. 94, 448-452.

- $\quad$ Qian, X., Vass, W.C., Papageorge, A.G., Anborgh, P.H., and Lowy, D.R. (1998). N terminus of Sos1 Ras exchange factor: critical roles for the Dbl and pleckstrin homology domains. Mol Cell Biol 18, 771-778.

- $\quad$ Qian, X., Esteban, L., Vass, W.C., Upadhyaya, C., Papageorge, A.G., Yienger, K., Ward, J.M., Lowy, D.R., and Santos, E. (2000). The Sos1 and Sos2 Ras-specific exchange factors: differences in placental expression and signaling properties. Embo J 19, 642-654.

- $\quad$ Quilliam, L.A., Hisaka, M.M., Zhong, S., Lowry, A., Mosteller, R.D., Han, J., Drugan, J.K., Broek, D., Campbell, S.L., and Der, C.J. (1996). Involvement of the switch 2 domain of Ras in its interaction with guanine nucleotide exchange factors. J. Biol. Chem. 271, 11076-11082.

- $\quad$ Quilliam, L.A., Castro, A.F., Rogers-Graham, K.S., Martin, C.B., Der, C.J., and Bi, C. (1999). M-Ras/R-Ras3, a transforming ras protein regulated by Sos1, GRF1, and p120 Ras GTPase-activating protein, interacts with the putative Ras effector AF6. J. Biol. Chem. 274, 23850-23857.

- Quintanilla, M., Brown, K., Ramsden, M., and Balmain, A. (1986). Carcinogen-specific mutation and amplification of Ha-ras during mouse skin carcinogenesis. Nature 322, 78-80.

- Raman, M., Chen, W., and Cobb, M.H. (2007). Differential regulation and properties of MAPKs. Oncogene 26, 3100-3112.

- $\quad$ Rameh, L.E., Arvidsson, A. k, Carraway, K.L., Couvillon, A.D., Rathbun, G., Crompton, A., VanRenterghem, B., 
Czech, M.P., Ravichandran, K.S., Burakoff, S.J., et al. (1997). A comparative analysis of the phosphoinositide binding specificity of pleckstrin homology domains. J. Biol. Chem. 272, 22059-22066.

- $\quad$ Ranganathan, A.C., Adam, A.P., Zhang, L., and Aguirre-Ghiso, J.A. (2006). Tumor cell dormancy induced by p38SAPK and ER-stress signaling: an adaptive advantage for metastatic cells? Cancer Biol. Ther. 5, 729-735.

- Rasola, A., Sciacovelli, M., Chiara, F., Pantic, B., Brusilow, W.S., and Bernardi, P. (2010). Activation of mitochondrial ERK protects cancer cells from death through inhibition of the permeability transition. Proc. Natl. Acad. Sci. 107, 726-731.

- Rebollo, A., Pérez-Sala, D., and Martínez-A, C. (1999). Bcl-2 differentially targets K-, N-, and H-Ras to mitochondria in IL-2 supplemented or deprived cells: Implications in prevention of apoptosis. Oncogene 18, 4930-4939.

- $\quad$ Regan, C.P., Li, W., Boucher, D.M., Spatz, S., Su, M.S., and Kuida, K. (2002). Erk5 null mice display multiple extraembryonic vascular and embryonic cardiovascular defects. Proc. Natl. Acad. Sci. U. S. A. 99, 9248-9253.

- $\quad$ Reid, T.S., Long, S.B., and Beese, L.S. (2004). Crystallographic Analysis Reveals that Anticancer Clinical Candidate L-778,123 Inhibits Protein Farnesyltransferase and Geranylgeranyltransferase-I by Different Binding Modes. Biochemistry 43, 9000-9008.

- $\quad$ Reinke, J.M., and Sorg, H. (2012). Wound repair and regeneration. Eur. Surg. Res. 49, 35-43.

- Repasky, G.A., Chenette, E.J., and Der, C.J. (2004). Renewing the conspiracy theory debate: does Raf function alone to mediate Ras oncogenesis? Trends Cell Biol. 14, 639-647.

- $\quad$ Repertinger, S.K., Campagnaro, E., Fuhrman, J., El-Abaseri, T., Yuspa, S.H., and Hansen, L.A. (2004). EGFR enhances early healing after cutaneous incisional wounding. J. Invest. Dermatol. 123, 982-989.

- $\quad$ Ridley, A.J. (2001). Rho family proteins: coordinating cell responses. Trends Cell Biol. 11, 471-477.

- Ridley, A.J., and Hall, A. (1992). Distinct patterns of actin organization regulated by the small GTP-binding proteins Rac and Rho. Cold Spring Harb. Symp. Quant. Biol. 57, 661-671.

- $\quad$ Ridley, A.J., Schwartz, M.A., Burridge, K., Firtel, R.A., Ginsberg, M.H., Borisy, G., Parsons, J.T., and Horwitz, A.R. (2003). Cell Migration: Integrating Signals from Front to Back. Science (80-. ). 302, 1704-1709.

- $\quad$ Ritt, D.A., Abreu-Blanco, M.T., Bindu, L., Durrant, D.E., Zhou, M., Specht, S.I., Stephen, A.G., Holderfield, M., and Morrison, D.K. (2016). Inhibition of Ras/Raf/MEK/ERK Pathway Signaling by a Stress-Induced PhosphoRegulatory Circuit. Mol. Cell 64, 875-887.

- $\quad$ Roberts, P.J., and Der, C.J. (2007). Targeting the Raf-MEK-ERK mitogen-activated protein kinase cascade for the treatment of cancer. Oncogene 26, 3291-3310.

- $\quad$ Robinson, L.C., Gibbs, J.B., Marshall, M.S., Sigal, I.S., and Tatchell, K. (1987). CDC25: a component of the RASadenylate cyclase pathway in Saccharomyces cerevisiae. Science 235, 1218-1221.

- $\quad$ Rodríguez-Viciana, P., Warne, P.H., Dhand, R., Vanhaesebroeck, B., Gout, I., Fry, M.J., Waterfield, M.D., and Downward, J. (1994). Phosphatidylinositol-3-OH kinase direct target of Ras. Nature 370, 527-532.

- $\quad$ Rodríguez-Viciana, P., Warne, P.H., Vanhaesebroeck, B., Waterfield, M.D., and Downward, J. (1996). Activation of phosphoinositide 3-kinase by interaction with Ras and by point mutation. EMBO J. 15, 2442-2451.

- $\quad$ Rodríguez-Viciana, P., Warne, P.H., Khwaja, A., Marte, B.M., Pappin, D., Das, P., Waterfield, M.D., Ridley, A., and Downward, J. (1997). Role of phosphoinositide 3-OH kinase in cell transformation and control of the actin cytoskeleton by Ras. Cell 89, 457-467.

- $\quad$ Rogge, R.D., Karlovich, C.A., and Banerjee, U. (1991). Genetic dissection of a neurodevelopmental pathway: Son of sevenless functions downstream of the sevenless and EGF receptor tyrosine kinases. Cell 64, 39-48.

- $\quad$ Rojas, J.M., Subleski, M., Coque, J.J., Guerrero, C., Saez, R., Li, B.Q., Lopez, E., Zarich, N., Aroca, P., Kamata, T., et al. (1999). Isoform-specific insertion near the Grb2-binding domain modulates the intrinsic guanine nucleotide exchange activity of hSos1. Oncogene 18, 1651-1661.

- Rojas, J.M., Oliva, J.L., and Santos, E. (2011). Mammalian Son of Sevenless Guanine Nucleotide Exchange Factors: Old Concepts and New Perspectives. Genes Cancer 2, 298-305.

- $\quad$ Roose, J.P., Mollenauer, M., Gupta, V.A., Stone, J., and Weiss, A. (2005). A Diacylglycerol-Protein Kinase CRasGRP1 Pathway Directs Ras Activation upon Antigen Receptor Stimulation of T Cells. Mol. Cell. Biol. 25, 4426-4441.

- $\quad$ Roose, J.P., Mollenauer, M., Ho, M., Kurosaki, T., and Weiss, A. (2007). Unusual interplay of two types of Ras activators, RasGRP and SOS, establishes sensitive and robust Ras activation in lymphocytes. Mol. Cell. Biol. 27, 2732-2745.

- $\quad$ Roskoski, R. (2012). ERK1/2 MAP kinases: Structure, function, and regulation. Pharmacol. Res. 66, $105-143$.

- $\quad$ Roy, S., Plowman, S., Rotblat, B., Prior, I.A., Muncke, C., Grainger, S., Parton, R.G., Henis, Y.I., Kloog, Y., and Hancock, J.F. (2005). Individual palmitoyl residues serve distinct roles in H-ras trafficking, microlocalization, and signaling. Mol. Cell. Biol. 25, 6722-6733.

- $\quad$ Rozakis-Adcock, M., Fernley, R., Wade, J., Pawson, T., and Bowtell, D. (1993). The SH2 and SH3 domains of 
mammalian Grb2 couple the EGF receptor to the Ras activator mSos1. Nature 363, 83-85.

- $\quad$ Rozakis-Adcock, M., van der Geer, P., Mbamalu, G., and Pawson, T. (1995). MAP kinase phosphorylation of mSos1 promotes dissociation of mSos1-Shc and mSos1-EGF receptor complexes. Oncogene 11, 1417-1426.

- $\quad$ Rubio, I., Rennert, K., Wittig, U., Beer, K., Dürst, M., Stang, S.L., Stone, J., and Wetzker, R. (2006). Ras activation in response to phorbol ester proceeds independently of the EGFR via an unconventional nucleotide-exchange factor system in COS-7 cells. Biochem. J. 398, 243-256.

- $\quad$ Ruderman, N.B., Kapeller, R., White, M.F., and Cantley, L.C. (1990). Activation of phosphatidylinositol 3-kinase by insulin. Proc. Natl. Acad. Sci. U. S. A. 87, 1411-1415.

- Ruiz, S., Santos, E., and Bustelo, X.R. (2007). RasGRF2, a Guanosine Nucleotide Exchange Factor for Ras GTPases, Participates in T-Cell Signaling Responses. Mol. Cell. Biol. 27, 8127-8142.

- $\quad$ Ruiz, S., Santos, E., and Bustelo, X.R. (2009). The Use of Knockout Mice Reveals a Synergistic Role of the Vav1 and Rasgrf2 Gene Deficiencies in Lymphomagenesis and Metastasis. PLoS One 4, e8229.

- $\quad$ Ruusala, A., and Aspenstrom, P. (2008). The Atypical Rho GTPase Wrch1 Collaborates with the Nonreceptor Tyrosine Kinases Pyk2 and Src in Regulating Cytoskeletal Dynamics. Mol. Cell. Biol. 28, 1802-1814.

- $\quad$ Sabapathy, K., Hochedlinger, K., Nam, S.Y., Bauer, A., Karin, M., and Wagner, E.F. (2004). Distinct Roles for JNK1 and JNK2 in Regulating JNK Activity and c-Jun-Dependent Cell Proliferation. Mol. Cell 15, 713-725.

- $\quad$ Sakaue, M., Bowtell, D., and Kasuga, M. (1995). A dominant-negative mutant of mSOS1 inhibits insulin-induced Ras activation and reveals Ras-dependent and -independent insulin signaling pathways. Mol. Cell. Biol. 15, 379-388.

- $\quad$ Saleem, A., Kharbanda, S., Yuan, Z.M., and Kufe, D. (1995). Monocyte colony-stimulating factor stimulates binding of phosphatidylinositol 3-kinase to Grb2.Sos complexes in human monocytes. J. Biol. Chem. 270, 10380-10383.

- $\quad$ Sánchez-Torres, J.M., Viteri, S., Molina, M.A., and Rosell, R. (2013). BRAF mutant non-small cell lung cancer and treatment with BRAF inhibitors. Transl. Lung Cancer Res. 2, 244-250.

- Santoro, C., Giugliano, T., Melone, M.A.B., Cirillo, M., Schettino, C., Bernardo, P., Cirillo, G., Perrotta, S., and Piluso, G. (2017). Multiple spinal nerve enlargement and SOS1 mutation: further evidence of overlap between Neurofibromatosis type 1 and Noonan phenotype. Clin. Genet.

- $\quad$ Santos, E., and Nebreda, A.R. (1989). Structural and functional properties of ras proteins. FASEB J. 3, 21512163.

- $\quad$ Santos, E., Tronick, S.R., Aaronson, S.A., Pulciani, S., and Barbacid, M. (1982). T24 human bladder carcinoma oncogene is an activated form of the normal human homologue of BALB- and Harvey-MSV transforming genes. Nature 298, 343-347.

- Santos, E., Martin-Zanca, D., Reddy, E.P., Pierotti, M.A., Della Porta, G., and Barbacid, M. (1984). Malignant activation of a K-ras oncogene in lung carcinoma but not in normal tissue of the same patient. Science 223, 661-664.

- $\quad$ Sarbassov, D.D., Guertin, D.A., Ali, S.M., and Sabatini, D.M. (2005). Phosphorylation and Regulation of Akt/PKB by the Rictor-mTOR Complex. Science (80-. ). 307, 1098-1101.

- Sarkozy, A., Carta, C., Moretti, S., Zampino, G., Digilio, M.C., Pantaleoni, F., Scioletti, A.P., Esposito, G., Cordeddu, V., Lepri, F., et al. (2009). Germline BRAF mutations in Noonan, LEOPARD, and cardiofaciocutaneous syndromes: molecular diversity and associated phenotypic spectrum. Hum. Mutat. 30, 695-702.

- Satoh, T., Endo, M., Nakafuku, M., Akiyama, T., Yamamoto, T., and Kaziro, Y. (1990). Accumulation of p21ras.GTP in response to stimulation with epidermal growth factor and oncogene products with tyrosine kinase activity. Proc. Natl. Acad. Sci. U. S. A. 87, 7926-7929.

- $\quad$ Sawada, J., Urakami, T., Li, F., Urakami, A., Zhu, W., Fukuda, M., Li, D.Y., Ruoslahti, E., and Komatsu, M. (2012). Small GTPase R-Ras Regulates Integrity and Functionality of Tumor Blood Vessels. Cancer Cell 22, 235-249.

- Schiller, M.R. (2006). Coupling receptor tyrosine kinases to Rho GTPases-GEFs what's the link. Cell. Signal. 18, 1834-1843.

- $\quad$ Schlessinger, J. (2000). Cell signaling by receptor tyrosine kinases. Cell 103, 211-225.

- $\quad$ Scholl, F.A., Dumesic, P.A., Barragan, D.I., Harada, K., Bissonauth, V., Charron, J., and Khavari, P.A. (2007). Mek1/2 MAPK kinases are essential for Mammalian development, homeostasis, and Raf-induced hyperplasia. Dev. Cell 12, 615-629.

- $\quad$ Schöpel, M., Jockers, K.F.G., Düppe, P.M., Autzen, J., Potheraveedu, V.N., Ince, S., Yip, K.T., Heumann, R., Herrmann, C., Scherkenbeck, J., et al. (2013). Bisphenol A binds to Ras proteins and competes with guanine nucleotide exchange: implications for GTPase-selective antagonists. J. Med. Chem. 56, 9664-9672.

- $\quad$ Schubbert, S., Zenker, M., Rowe, S.L., Boll, S., Klein, C., Bollag, G., van der Burgt, I., Musante, L., Kalscheuer, V., Wehner, L.-E., et al. (2006). Germline KRAS mutations cause Noonan syndrome. Nat. Genet. 38, 331-336.

- $\quad$ Scita, G., Nordstrom, J., Carbone, R., Tenca, P., Giardina, G., Gutkind, S., Bjarnegård, M., Betsholtz, C., and Di Fiore, P.P. (1999). EPS8 and E3B1 transduce signals from Ras to Rac. Nature 401, 290-293. 
- $\quad$ Scita, G., Tenca, P., Areces, L.B., Tocchetti, A., Frittoli, E., Giardina, G., Ponzanelli, I., Sini, P., Innocenti, M., and Di Fiore, P.P. (2001). An effector region in Eps8 is responsible for the activation of the Rac-specific GEF activity of Sos-1 and for the proper localization of the Rac-based actin-polymerizing machine. J. Cell Biol. 154, 10311044.

- $\quad$ See, W.L., Miller, J.P., Squatrito, M., Holland, E., Resh, M.D., and Koff, A. (2010). Defective DNA double-strand break repair underlies enhanced tumorigenesis and chromosomal instability in p27-deficient mice with growth factor-induced oligodendrogliomas. Oncogene 29, 1720-1731.

- $\quad$ Seger, R., Ahn, N.G., Posada, J., Munar, E.S., Jensen, A.M., Cooper, J.A., Cobb, M.H., and Krebs, E.G. (1992). Purification and characterization of mitogen-activated protein kinase activator(s) from epidermal growth factor-stimulated A431 cells. J. Biol. Chem. 267, 14373-14381.

- Serres, M.P., Kossatz, U., Chi, Y., Roberts, J.M., Malek, N.P., and Besson, A. (2012). p27(Kip1) controls cytokinesis via the regulation of citron kinase activation. J. Clin. Invest. 122, 844-858.

- Servant, G., Weiner, O.D., Herzmark, P., Balla, T., Sedat, J.W., and Bourne, H.R. (2000). Polarization of chemoattractant receptor signaling during neutrophil chemotaxis. Science 287, 1037-1040.

- Sewing, A., Wiseman, B., Lloyd, A.C., and Land, H. (1997). High-intensity Raf signal causes cell cycle arrest mediated by p21Cip1. Mol. Cell. Biol. 17, 5588-5597.

- Shahbazian, D., Roux, P.P., Mieulet, V., Cohen, M.S., Raught, B., Taunton, J., Hershey, J.W.B., Blenis, J., Pende, M., and Sonenberg, N. (2006). The mTOR/PI3K and MAPK pathways converge on elF4B to control its phosphorylation and activity. EMBO J. 25, 2781-2791.

- $\quad$ Shannon, K., and Bollag, G. (2007). Sending out an SOS. Nat. Genet. 39, 8-9.

- Shapiro, P. (2002). Ras-MAP kinase signaling pathways and control of cell proliferation: relevance to cancer therapy. Crit Rev Clin Lab Sci 39, 285-330.

- $\quad$ Sharma, A., Luke, C.T., Dower, N.A., Stone, J.C., and Lorenzo, P.S. (2010). RasGRP1 is essential for ras activation by the tumor promoter 12-O-tetradecanoylphorbol-13-acetate in epidermal keratinocytes. J. Biol. Chem. 285, 15724-15730.

- Sharma, A., Fonseca, L.L., Rajani, C., Yanagida, J.K., Endo, Y., Cline, J.M., Stone, J.C., Ji, J., Ramos, J.W., and Lorenzo, P.S. (2014). Targeted deletion of RasGRP1 impairs skin tumorigenesis. Carcinogenesis 35, 1084-1091.

- Shaw, R.J., and Cantley, L.C. (2006). Ras, PI(3)K and mTOR signalling controls tumour cell growth. Nature 441, 424-430.

- Sherr, C.J., and Roberts, J.M. (1995). Inhibitors of mammalian G1 cyclin-dependent kinases. Genes Dev. 9, 1149-1163.

- $\quad$ Shields, J.M., Pruitt, K., McFall, A., Shaub, A., and Der, C.J. (2000). Understanding Ras: "it ain"t over "til it"s over'. Trends Cell Biol. 10, 147-154.

- $\quad$ Shimizu, K., Goldfarb, M., Suard, Y., Perucho, M., Li, Y., Kamata, T., Feramisco, J., Stavnezer, E., Fogh, J., and Wigler, M.H. (1983). Three human transforming genes are related to the viral ras oncogenes. Proc. Natl. Acad. Sci. U. S. A. 80, 2112-2116.

- $\quad$ Shinohara, N., Ogiso, Y., Tanaka, M., Sazawa, A., Harabayashi, T., and Koyanagi, T. (1997). The significance of Ras guanine nucleotide exchange factor, son of sevenless protein, in renal cell carcinoma cell lines. J. Urol. 158, 908-911.

- $\quad$ Shirakata, Y., Kimura, R., Nanba, D., Iwamoto, R., Tokumaru, S., Morimoto, C., Yokota, K., Nakamura, M., Sayama, K., Mekada, E., et al. (2005). Heparin-binding EGF-like growth factor accelerates keratinocyte migration and skin wound healing. J. Cell Sci. 118, 2363-2370.

- Shou, C., Farnsworth, C.L., Neel, B.G., and Feig, L.A. (1992). Molecular cloning of cDNAs encoding a guaninenucleotide-releasing factor for Ras p21. Nature 358, 351-354.

- $\quad$ Sibilia, M., and Wagner, E.F. (1995). Strain-dependent epithelial defects in mice lacking the EGF receptor. Science 269, 234-238.

- $\quad$ Sibilia, M., Fleischmann, A., Behrens, A., Stingl, L., Carroll, J., Watt, F.M., Schlessinger, J., and Wagner, E.F. (2000). The EGF receptor provides an essential survival signal for SOS-dependent skin tumor development. Cell $102,211-220$.

- Simon, M.A., Bowtell, D.D., Dodson, G.S., Laverty, T.R., and Rubin, G.M. (1991). Ras1 and a putative guanine nucleotide exchange factor perform crucial steps in signaling by the sevenless protein tyrosine kinase. Cell 67, 701-716.

- Simon, M.A., Dodson, G.S., and Rubin, G.M. (1993). An SH3-SH2-SH3 protein is required for p21Ras1 activation and binds to sevenless and Sos proteins in vitro. Cell 73, 169-177.

- $\quad$ Sini, P., Cannas, A., Koleske, A.J., Di Fiore, P.P., and Scita, G. (2004). Abl-dependent tyrosine phosphorylation of Sos-1 mediates growth-factor-induced Rac activation. Nat. Cell Biol. 6, 268-274.

- $\quad$ Skolnik, E.Y., Lee, C.H., Batzer, A., Vicentini, L.M., Zhou, M., Daly, R., Myers, M.J., Backer, J.M., Ullrich, A., and 
White, M.F. (1993). The SH2/SH3 domain-containing protein GRB2 interacts with tyrosine-phosphorylated IRS1 and Shc: implications for insulin control of ras signalling. EMBO J. 12, 1929-1936.

- Smith, R.A., Dumas, J., Adnane, L., and Wilhelm, S.M. (2006). Recent advances in the research and development of RAF kinase inhibitors. Curr. Top. Med. Chem. 6, 1071-1089.

- Sohn, S.J., Sarvis, B.K., Cado, D., and Winoto, A. (2002). ERK5 MAPK Regulates Embryonic Angiogenesis and Acts as a Hypoxia-sensitive Repressor of Vascular Endothelial Growth Factor Expression. J. Biol. Chem. 277, 43344-43351.

- $\quad$ Soisson, S.M., Nimnual, A.S., Uy, M., Bar-Sagi, D., and Kuriyan, J. (1998). Crystal structure of the Dbl and pleckstrin homology domains from the human Son of sevenless protein. Cell 95, 259-268.

- Sondermann, H., Soisson, S.M., Bar-Sagi, D., and Kuriyan, J. (2003). Tandem histone folds in the structure of the N-terminal segment of the ras activator Son of Sevenless. Structure 11, 1583-1593.

- Sondermann, H., Soisson, S.M., Boykevisch, S., Yang, S.-S., Bar-Sagi, D., and Kuriyan, J. (2004). Structural analysis of autoinhibition in the Ras activator Son of sevenless. Cell 119, 393-405.

- Sondermann, H., Nagar, B., Bar-Sagi, D., and Kuriyan, J. (2005). Computational docking and solution x-ray scattering predict a membrane-interacting role for the histone domain of the Ras activator son of sevenless. Proc. Natl. Acad. Sci. 102, 16632-16637.

- Song, C., Hu, C.-D., Masago, M., Kariya, K. -i., Yamawaki-Kataoka, Y., Shibatohge, M., Wu, D., Satoh, T., and Kataoka, T. (2001). Regulation of a Novel Human Phospholipase C, PLC, through Membrane Targeting by Ras. J. Biol. Chem. 276, 2752-2757.

- $\quad$ Song, S.-P., Hennig, A., Schubert, K., Markwart, R., Schmidt, P., Prior, I.A., Böhmer, F.-D., and Rubio, I. (2013). Ras palmitoylation is necessary for $\mathrm{N}$-Ras activation and signal propagation in growth factor signalling. Biochem. J. 454, 323-332.

- $\quad$ Sperka, T., Geissler, K.J., Merkel, U., Scholl, I., Rubio, I., Herrlich, P., and Morrison, H.L. (2011). Activation of Ras requires the ERM-dependent link of actin to the plasma membrane. PLoS One 6, e27511.

- $\quad$ Squarize, C.H., Castilho, R.M., Bugge, T.H., and Gutkind, J.S. (2010). Accelerated Wound Healing by mTOR Activation in Genetically Defined Mouse Models. PLoS One 5, e10643.

- Stacey, D.W., and Kung, H.F. (1984). Transformation of NIH 3T3 cells by microinjection of Ha-ras p21 protein. Nature 310, 508-511.

- Stacey, D., Bilbao, A., Maroteaux, M., Jia, T., Easton, A.C., Longueville, S., Nymberg, C., Banaschewski, T., Barker, G.J., Büchel, C., et al. (2012). RASGRF2 regulates alcohol-induced reinforcement by influencing mesolimbic dopamine neuron activity and dopamine release. Proc. Natl. Acad. Sci. U. S. A. 109, 21128-21133.

- $\quad$ Steffen, A., Ladwein, M., Dimchev, G.A., Hein, A., Schwenkmezger, L., Arens, S., Ladwein, K.I., Holleboom, J.M., Schur, F., Small, J. V., et al. (2013). Rac function is crucial for cell migration but is not required for spreading and focal adhesion formation. J. Cell Sci. 126, 4572-4588.

- Stokoe, D., Macdonald, S.G., Cadwallader, K., Symons, M., and Hancock, J.F. (1994). Activation of Raf as a result of recruitment to the plasma membrane. Science 264, 1463-1467.

- $\quad$ Stokoe, D., Stephens, L.R., Copeland, T., Gaffney, P.R., Reese, C.B., Painter, G.F., Holmes, A.B., McCormick, F., and Hawkins, P.T. (1997). Dual role of phosphatidylinositol-3,4,5-trisphosphate in the activation of protein kinase B. Science 277, 567-570.

- Sugiyama, Y., Tomoda, K., Tanaka, T., Arata, Y., Yoneda-Kato, N., and Kato, J. (2001). Direct binding of the signal-transducing adaptor Grb2 facilitates down-regulation of the cyclin-dependent kinase inhibitor p27Kip1. J. Biol. Chem. 276, 12084-12090.

- $\quad$ Suire, S., Lecureuil, C., Anderson, K.E., Damoulakis, G., Niewczas, I., Davidson, K., Guillou, H., Pan, D., Clark, J., Hawkins, P.T., et al. (2012). GPCR activation of Ras and PI3Kc in neutrophils depends on PLCb2/b3 and the RasGEF RasGRP4. EMBO J. 31, 3118-3129.

- $\quad$ Sun, Q., Burke, J.P., Phan, J., Burns, M.C., Olejniczak, E.T., Waterson, A.G., Lee, T., Rossanese, O.W., and Fesik, S.W. (2012). Discovery of Small Molecules that Bind to K-Ras and Inhibit Sos-Mediated Activation. Angew. Chemie Int. Ed. 51, 6140-6143.

- Takai, Y., Sasaki, T., and Matozaki, T. (2001). Small GTP-binding proteins. Physiol. Rev. 81, 153-208.

- Takenawa, T., and Suetsugu, S. (2007). The WASP/WAVE protein network: connecting the membrane to the cytoskeleton. Nat. Rev. Mol. Cell Biol. 8, 37-48.

- $\quad$ Takuwa, N., and Takuwa, Y. (1997). Ras activity late in G1 phase required for p27kip1 downregulation, passage through the restriction point, and entry into $S$ phase in growth factor-stimulated NIH 3 T3 fibroblasts. Mol. Cell. Biol. 17, 5348-5358.

- $\quad$ Tartaglia, M., Mehler, E.L., Goldberg, R., Zampino, G., Brunner, H.G., Kremer, H., van der Burgt, I., Crosby, A.H., Ion, A., Jeffery, S., et al. (2001). Mutations in PTPN11, encoding the protein tyrosine phosphatase SHP-2, cause Noonan syndrome. Nat. Genet. 29, 465-468.

- Tartaglia, M., Pennacchio, L.A., Zhao, C., Yadav, K.K., Fodale, V., Sarkozy, A., Pandit, B., Oishi, K., Martinelli, S., 
Schackwitz, W., et al. (2007). Gain-of-function SOS1 mutations cause a distinctive form of Noonan syndrome. Nat. Genet. 39, 75-79.

- Tartaglia, M., Zampino, G., and Gelb, B.D. (2010). Noonan syndrome: clinical aspects and molecular pathogenesis. Mol. Syndromol. 1, 2-26.

- $\quad$ Teixeira, C., Stang, S.L., Zheng, Y., Beswick, N.S., and Stone, J.C. (2003). Integration of DAG signaling systems mediated by PKC-dependent phosphorylation of RasGRP3. Blood 102, 1414-1420.

- Thomas, E.K., Cancelas, J.A., Chae, H.-D., Cox, A.D., Keller, P.J., Perrotti, D., Neviani, P., Druker, B.J., Setchell, K.D.R., Zheng, Y., et al. (2007). Rac Guanosine Triphosphatases Represent Integrating Molecular Therapeutic Targets for BCR-ABL-Induced Myeloproliferative Disease. Cancer Cell 12, 467-478.

- Thornton, T.M., and Rincon, M. (2009). Non-classical p38 map kinase functions: cell cycle checkpoints and survival. Int. J. Biol. Sci. 5, 44-51.

- $\quad$ Thurmond, L.M., Lauer, L.D., House, R. V., Cook, J.C., and Dean, J.H. (1987). Immunosuppression following exposure to 7,12-dimethylbenz[a]anthracene (DMBA) in Ah-responsive and Ah-nonresponsive mice. Toxicol. Appl. Pharmacol. 91, 450-460.

- Tian, X., and Feig, L.A. (2006). Age-dependent participation of Ras-GRF proteins in coupling calcium-permeable AMPA glutamate receptors to Ras/Erk signaling in cortical neurons. J. Biol. Chem. 281, 7578-7582.

- Tidyman, W.E., and Rauen, K.A. (2016). Pathogenetics of the RASopathies. Hum. Mol. Genet. 25, R123-R132.

- Timofeeva, O.A., Zhang, X., Ressom, H.W., Varghese, R.S., Kallakury, B.V.S., Wang, K., Ji, Y., Cheema, A., Jung, M., Brown, M.L., et al. (2009). Enhanced expression of SOS1 is detected in prostate cancer epithelial cells from African-American men. Int. J. Oncol. 35, 751-760.

- Toffali, L., Montresor, A., Mirenda, M., Scita, G., and Laudanna, C. (2017). SOS1, ARHGEF1, and DOCK2 rhoGEFs Mediate JAK-Dependent LFA-1 Activation by Chemokines. J. Immunol. 198, 708-717.

- Tognon, C.E., Kirk, H.E., Passmore, L.A., Whitehead, I.P., Der, C.J., and Kay, R.J. (1998). Regulation of RasGRP via a phorbol ester-responsive C1 domain. Mol. Cell. Biol. 18, 6995-7008.

- Toker, A., and Newton, A.C. (2000). Akt/protein kinase B is regulated by autophosphorylation at the hypothetical PDK-2 site. J. Biol. Chem. 275, 8271-8274.

- Tumbar, T., Guasch, G., Greco, V., Blanpain, C., Lowry, W.E., Rendl, M., and Fuchs, E. (2004). Defining the Epithelial Stem Cell Niche in Skin. Science (80-. ). 303, 359-363.

- Turjanski, A.G., Vaque, J.P., and Gutkind, J.S. (2007). MAP kinases and the control of nuclear events. Oncogene 26, 3240-3253.

- $\quad$ Turner, C.E. (2000). Paxillin and focal adhesion signalling. Nat. Cell Biol. 2, E231-E236.

- Umanoff, H., Edelmann, W., Pellicer, A., and Kucherlapati, R. (1995). The murine N-ras gene is not essential for growth and development. Proc. Natl. Acad. Sci. U. S. A. 92, 1709-1713.

- Vanoers, N., and Weiss, A. (1995). The Syk/ZAP-70 protein tyrosine kinase connection to antigen receptor signalling processes. Semin. Immunol. 7, 227-236.

- Vaughn, C.P., ZoBell, S.D., Furtado, L. V., Baker, C.L., and Samowitz, W.S. (2011). Frequency of KRAS, BRAF, and NRAS mutations in colorectal cancer. Genes, Chromosom. Cancer 50, 307-312.

- Vayssier-Taussat, M., Kreps, S.E., Adrie, C., Dall'Ava, J., Christiani, D., and Polla, B.S. (2002). Mitochondrial membrane potential: A novel biomarker of oxidative environmental stress. Environ. Health Perspect. 110, 301-305.

- Vega, F.M., Fruhwirth, G., Ng, T., and Ridley, A.J. (2011). RhoA and RhoC have distinct roles in migration and invasion by acting through different targets. J. Cell Biol. 193, 655-665.

- Vicente-Manzanares, M., Zareno, J., Whitmore, L., Choi, C.K., and Horwitz, A.F. (2007). Regulation of protrusion, adhesion dynamics, and polarity by myosins IIA and IIB in migrating cells. J. Cell Biol. 176, 573-580.

- Vicente-Manzanares, M., Koach, M.A., Whitmore, L., Lamers, M.L., and Horwitz, A.F. (2008). Segregation and activation of myosin IIB creates a rear in migrating cells. J. Cell Biol. 183, 543-554.

- Vicente-Manzanares, M., Ma, X., Adelstein, R.S., and Horwitz, A.R. (2009). Non-muscle myosin II takes centre stage in cell adhesion and migration. Nat. Rev. Mol. Cell Biol. 10, 778-790.

- Vidali, L., Chen, F., Cicchetti, G., Ohta, Y., and Kwiatkowski, D.J. (2006). Rac1-null Mouse Embryonic Fibroblasts Are Motile and Respond to Platelet-derived Growth Factor. Mol. Biol. Cell 17, 2377-2390.

- Villalonga, P., López-Alcala, C., Bosch, M., Chiloeches, A., Rocamora, N., Gil, J., Marais, R., Marshall, C.J., Bachs, O., and Agell, N. (2001). Calmodulin Binds to K-Ras, but Not to H- or N-Ras, and Modulates Its Downstream Signaling. Mol. Cell. Biol. 21, 7345-7354.

- Vivanco, I., and Sawyers, C.L. (2002). The phosphatidylinositol 3-Kinase AKT pathway in human cancer. Nat. Rev. Cancer 2, 489-501.

- Vojtek, A.B., and Der, C.J. (1998). Increasing complexity of the Ras signaling pathway. J. Biol. Chem. 273, 19925-19928. 
- Vuori, K., Hirai, H., Aizawa, S., and Ruoslahti, E. (1996). Introduction of p130cas signaling complex formation upon integrin-mediated cell adhesion: a role for Src family kinases. Mol. Cell. Biol. 16, 2606-2613.

- Walsh, A.B., and Bar-Sagi, D. (2001). Differential activation of the Rac pathway by Ha-Ras and K-Ras. J. Biol. Chem. 276, 15609-15615.

- Wang, D.S., Shaw, R., Winkelmann, J.C., and Shaw, G. (1994). Binding of PH Domains of beta-AdrenergicReceptor Kinase and beta-Spectrin to WD40/beta-Transducin Repeat Containing Regions of the beta-Subunit of Trimeric G-Proteins. Biochem. Biophys. Res. Commun. 203, 29-35.

- Wang, D.Z., Hammond, V.E., Abud, H.E., Bertoncello, I., McAvoy, J.W., and Bowtell, D.D. (1997). Mutation in Sos1 dominantly enhances a weak allele of the EGFR, demonstrating a requirement for Sos1 in EGFR signaling and development. Genes Dev. 11, 309-320.

- Wang, W., Fisher, E.M.C., Jia, Q., Dunn, J.M., Porfiri, E., Downward, J., and Egan, S.E. (1995). The Grb2 binding domain of mSos1 is not required for downstream signal transduction. Nat. Genet. 10, 294-300.

- Wang, X., Finegan, K.G., Robinson, A.C., Knowles, L., Khosravi-Far, R., Hinchliffe, K.A., Boot-Handford, R.P., and Tournier, C. (2006). Activation of extracellular signal-regulated protein kinase 5 downregulates FasL upon osmotic stress. Cell Death Differ. 13, 2099-2108.

- Wang, Y., Velho, S., Vakiani, E., Peng, S., Bass, A.J., Chu, G.C., Gierut, J., Bugni, J.M., Der, C.J., Philips, M., et al. (2013). Mutant N-RAS Protects Colorectal Cancer Cells from Stress-Induced Apoptosis and Contributes to Cancer Development and Progression. Cancer Discov. 3, 294-307.

- Wang, Z., Pedersen, E., Basse, A., Lefever, T., Peyrollier, K., Kapoor, S., Mei, Q., Karlsson, R., Chrostek-Grashoff, A., and Brakebusch, C. (2010). Rac1 is crucial for Ras-dependent skin tumor formation by controlling Pak1Mek-Erk hyperactivation and hyperproliferation in vivo. Oncogene 29, 3362-3373.

- Ward, C.W., Gough, K.H., Rashke, M., Wan, S.S., Tribbick, G., and Wang, J. (1996). Systematic mapping of potential binding sites for Shc and Grb2 SH2 domains on insulin receptor substrate-1 and the receptors for insulin, epidermal growth factor, platelet-derived growth factor, and fibroblast growth factor. J. Biol. Chem. 271, 5603-5609.

- Warnecke, N., Poltorak, M., Kowtharapu, B.S., Arndt, B., Stone, J.C., Schraven, B., and Simeoni, L. (2012). TCRmediated Erk activation does not depend on Sos and Grb2 in peripheral human T cells. EMBO Rep. 13, 386391.

- Watanabe, Nobuo Shinohara, Kimihiko, T., Shinohara, N., Moriya, K., Sazawa, A., Kobayashi, Y., Ogiso, Y., Takiguchi, M., Yasuda, J., Koyanagi, T., Kuzumaki, N., et al. (2000). Significance of the Grb2 and Son of Sevenless (Sos) Proteins in Human Bladder Cancer Cell Lines. IUBMB Life (International Union Biochem. Mol. Biol. Life) 49, 317-320.

- Waters, S.B., Holt, K.H., Ross, S.E., Syu, L.J., Guan, K.L., Saltiel, A.R., Koretzky, G.A., and Pessin, J.E. (1995). Desensitization of Ras activation by a feedback disassociation of the SOS-Grb2 complex. J. Biol. Chem. 270, 20883-20886.

- Weber, J.D., Raben, D.M., Phillips, P.J., and Baldassare, J.J. (1997). Sustained activation of extracellular-signalregulated kinase 1 (ERK1) is required for the continued expression of cyclin D1 in G1 phase. Biochem. J. 326 ( Pt 1), 61-68.

- Webster, M., Witkin, K.L., and Cohen-Fix, O. (2009). Sizing up the nucleus: nuclear shape, size and nuclearenvelope assembly. J. Cell Sci. 122, 1477-1486.

- Wei, W., Das, B., Park, W., and Broek, D. (1994). Cloning and analysis of human cDNAs encoding a 140-kDa brain guanine nucleotide-exchange factor, Cdc25GEF, which regulates the function of Ras. Gene 151, 279-284.

- Weisel, J.W. (2005). Fibrinogen and Fibrin. In Advances in Protein Chemistry, pp. 247-299.

- Welch, H.C.E., Coadwell, W.J., Ellson, C.D., Ferguson, G.J., Andrews, S.R., Erdjument-Bromage, H., Tempst, P., Hawkins, P.T., and Stephens, L.R. (2002). P-Rex1, a PtdIns(3,4,5)P3- and Gbetagamma-regulated guaninenucleotide exchange factor for Rac. Cell 108, 809-821.

- Welsh, G.I., Foulstone, E.J., Young, S.W., Tavaré, J.M., and Proud, C.G. (1994). Wortmannin inhibits the effects of insulin and serum on the activities of glycogen synthase kinase-3 and mitogen-activated protein kinase. Biochem. J. 303 (Pt 1), 15-20.

- Wennerberg, K., Rossman, K.L., and Der, C.J. (2005). The Ras superfamily at a glance. J. Cell Sci. 118, 843-846.

- Wennström, S., Siegbahn, A., Yokote, K., Arvidsson, A.K., Heldin, C.H., Mori, S., and Claesson-Welsh, L. (1994a). Membrane ruffling and chemotaxis transduced by the PDGF beta-receptor require the binding site for phosphatidylinositol 3' kinase. Oncogene 9, 651-660.

- Wennström, S., Hawkins, P., Cooke, F., Hara, K., Yonezawa, K., Kasuga, M., Jackson, T., Claesson-Welsh, L., and Stephens, L. (1994b). Activation of phosphoinositide 3-kinase is required for PDGF-stimulated membrane ruffling. Curr. Biol. 4, 385-393.

- Weston, C.R., and Davis, R.J. (2002). The JNK signal transduction pathway. Curr. Opin. Genet. Dev. 12, 14-21.

- Widmann, C., Gibson, S., Jarpe, M.B., and Johnson, G.L. (1999). Mitogen-activated protein kinase: conservation 
of a three-kinase module from yeast to human. Physiol. Rev. 79, 143-180.

- Wilson, C., and González-Billault, C. (2015). Regulation of cytoskeletal dynamics by redox signaling and oxidative stress: implications for neuronal development and trafficking. Front. Cell. Neurosci. 9.

- Winston, L.A., and Hunter, T. (1996). Intracellular signalling: putting JAKs on the kinase MAP. Curr. Biol. 6, 668671.

- Winter, J.J.G., Anderson, M., Blades, K., Brassington, C., Breeze, A.L., Chresta, C., Embrey, K., Fairley, G., Faulder, P., Finlay, M.R. V., et al. (2015). Small Molecule Binding Sites on the Ras:SOS Complex Can Be Exploited for Inhibition of Ras Activation. J. Med. Chem. 58, 2265-2274.

- Wong, K.-K., Engelman, J.A., and Cantley, L.C. (2010). Targeting the PI3K signaling pathway in cancer. Curr. Opin. Genet. Dev. 20, 87-90.

- Woods, D., Parry, D., Cherwinski, H., Bosch, E., Lees, E., and McMahon, M. (1997). Raf-induced proliferation or cell cycle arrest is determined by the level of Raf activity with arrest mediated by p21Cip1. Mol. Cell. Biol. 17, 5598-5611.

- Wu, R.-F., Ma, Z., Liu, Z., and Terada, L.S. (2010). Nox4-Derived H2O2 Mediates Endoplasmic Reticulum Signaling through Local Ras Activation. Mol. Cell. Biol. 30, 3553-3568.

- Wu, R.F., Liao, C., Hatoum, H., Fu, G., Ochoa, C.D., and Terada, L.S. (2017). RasGRF Couples Nox4-Dependent Endoplasmic Reticulum Signaling to RasHighlights. Arterioscler. Thromb. Vasc. Biol. 37, 98-107.

- Wullschleger, S., Loewith, R., and Hall, M.N. (2006). TOR Signaling in Growth and Metabolism. Cell 124, 471484.

- Yadav, K.K., and Bar-Sagi, D. (2010). Allosteric gating of Son of sevenless activity by the histone domain. Proc. Natl. Acad. Sci. U. S. A. 107, 3436-3440.

- Yam, P.T., Wilson, C.A., Ji, L., Hebert, B., Barnhart, E.L., Dye, N.A., Wiseman, P.W., Danuser, G., and Theriot, J.A. (2007). Actin-myosin network reorganization breaks symmetry at the cell rear to spontaneously initiate polarized cell motility. J. Cell Biol. 178, 1207-1221.

- Yan, J., Roy, S., Apolloni, A., Lane, A., and Hancock, J.F. (1998). Ras isoforms vary in their ability to activate Raf1 and phosphoinositide 3-kinase. J. Biol. Chem. 273, 24052-24056.

- Yang, H., and Mattingly, R.R. (2006). The Ras-GRF1 exchange factor coordinates activation of H-Ras and Rac1 to control neuronal morphology. Mol. Biol. Cell 17, 2177-2189.

- Yang, L., Wang, L., and Zheng, Y. (2006). Gene Targeting of Cdc42 and Cdc42GAP Affirms the Critical Involvement of $\mathrm{Cdc} 42$ in Filopodia Induction, Directed Migration, and Proliferation in Primary Mouse Embryonic Fibroblasts. Mol. Biol. Cell 17, 4675-4685.

- $\quad$ Yang, S.S., Van Aelst, L., and Bar-Sagi, D. (1995). Differential interactions of human Sos1 and Sos2 with Grb2. J. Biol. Chem. 270, 18212-18215.

- $\quad$ Yang, Y., Li, L., Wong, G.W., Krilis, S.A., Madhusudhan, M.S., Sali, A., and Stevens, R.L. (2002). RasGRP4, a New Mast Cell-restricted Ras Guanine Nucleotide-releasing Protein with Calcium- and Diacylglycerol-binding Motifs. Identification of defective variants of this signaling protein in asthma, mastocytosis, and mast cell leukemia patients and demonstration of the importance of rasgrp4 in mast cell development and function. J. Biol. Chem. $277,25756-25774$.

- Yao, L., Kawakami, Y., and Kawakami, T. (1994). The pleckstrin homology domain of Bruton tyrosine kinase interacts with protein kinase C. Proc. Natl. Acad. Sci. U. S. A. 91, 9175-9179.

- Yoon, S., and Seger, R. (2006). The extracellular signal-regulated kinase: Multiple substrates regulate diverse cellular functions. Growth Factors 24, 21-44.

- Yoshioka, R., Shiraishi, A., Kobayashi, T., Morita, S.-I., Hayashi, Y., Higashiyama, S., and Ohashi, Y. (2010). Corneal epithelial wound healing impaired in keratinocyte-specific HB-EGF-deficient mice in vivo and in vitro. Invest. Ophthalmol. Vis. Sci. 51, 5630-5639.

- Zarich, N., Oliva, J.L., Jorge, R., Santos, E., and Rojas, J.M. (2000). The isoform-specific stretch of hSos1 defines a new Grb2-binding domain. Oncogene 19, 5872-5883.

- $\quad$ Zhang, C.-Z., Spektor, A., Cornils, H., Francis, J.M., Jackson, E.K., Liu, S., Meyerson, M., and Pellman, D. (2015). Chromothripsis from DNA damage in micronuclei. Nature 522, 179-184.

- Zhao, C., Du, G., Skowronek, K., Frohman, M.A., and Bar-Sagi, D. (2007). Phospholipase D2-generated phosphatidic acid couples EGFR stimulation to Ras activation by Sos. Nat. Cell Biol. 9, 707-712.

- Zhao, H., Li, Y.Y., Fucini, R. V, Ross, S.E., Pessin, J.E., and Koretzky, G.A. (1997). T cell receptor-induced phosphorylation of Sos requires activity of CD45, Lck, and protein kinase C, but not ERK. J. Biol. Chem. 272, 21625-21634.

- Zheng, Y., and Quilliam, L.A. (2003). Activation of the Ras superfamily of small GTPases. Workshop on exchange factors. EMBO Rep. 4, 463-468.

- Zhu, M., Fuller, D.M., and Zhang, W. (2012). The Role of Ras Guanine Nucleotide Releasing Protein 4 in Fc RI- 
mediated Signaling, Mast Cell Function, and T Cell Development. J. Biol. Chem. 287, 8135-8143.

- Zou, M., Baitei, E.Y., Alzahrani, A.S., BinHumaid, F.S., Alkhafaji, D., Al-Rijjal, R.A., Meyer, B.F., and Shi, Y. (2014).

Concomitant RAS, RET/PTC, or BRAF mutations in advanced stage of papillary thyroid carcinoma. Thyroid 24, 1256-1266. 


\section{English summary}


In vivo analysis 
In vitro analysis

\title{
SOS1 DISRUPTION IMPAIRS CELLULAR PROLIFERATION AND VIABILITY THROUGH AN INCREASE IN MITOCHONDRIAL OXIDATIVE STRESS IN PRIMARY MEFS
}

\author{
Please note that this work has been already published: \\ "Sos1 disruption impairs celular proliferation and viability through an increase in mitocondrial \\ oxidative stress in primary MEFs" \\ Liceras-Boillos P, García-Navas R, Ginel-Picardo A, Anta B, Pérez-Andrés M, Lillo C, Gómez C, Jimeno \\ D, Fernández-Medarde A, Baltanás FC, Santos E.
}

Oncogene. 2016. 35(50):6389-6402. doi: 10.1038/onc.2016.169. PMID: 2715761

We have here included an additional figure (Figure SD1) that was not displayed in the publication. This figure adds new valuable information about the role of Sos proteins in cell migration and/or adhesion. In particular, we show the involvement of Sos1 and Sos2 in the regulation of the focal adhesion dynamics.

\section{ABSTRACT}

Using a 4-hydroxytamoxifen (4OHT)-inducible, conditional Sos1-null mutation, we analyzed wild-type (WT), single Sos1 KO, Sos2 KO and double Sos1/2 KO primary mouse embryonic fibroblasts (MEF) with an aim at evaluating the functional specificity or redundancy of the Sos1 and Sos2 alleles at the cellular level. The 4OHT-induced Sos1 KO and Sos1/2 DKO MEFs exhibited distinct flat morphology, enlarged cell perimeter and altered cytoskeletal organization that were not observed in the WT and Sos2 KO counterparts. The Sos1 KO and Sos1/2 DKO MEFs also displayed significant accumulation, in comparison with WT and Sos2 KO MEFs, of cytoplasmic vesicular bodies identified as autophagosomes containing degraded mitochondria by means of electron microscopy and specific markers. Cellular proliferation and migration were impaired in Sos1 KO and Sos1/2 DKO MEFs in comparison with WT and Sos2 KO MEFs, whereas cell adhesion was only impaired upon depletion of both Sos isoforms. RasGTP formation was practically absent in Sos1/2 DKO MEFs as compared with the other genotypes and extracellular signal-regulated kinase phosphorylation showed only significant reduction after combined Sos1/2 depletion. Consistent with a mitophagic phenotype, in vivo labeling with specific fluorophores uncovered increased levels of oxidative stress (elevated intracellular reactive oxygen species and mitochondrial superoxide and loss of mitochondrial membrane potential) in the Sos1 KO and the Sos1/2 DKO cells as compared with Sos2 KO and WT 
MEFs. Interestingly, treatment of the MEF cultures with antioxidants corrected the altered phenotypes of Sos1 KO and Sos1/2 DKO MEFs by restoring their altered perimeter size and proliferative rate to levels similar to those of WT and Sos2 KO MEFs. Our data uncover a direct mechanistic link between Sos1 and control of intracellular oxidative stress, and demonstrate functional prevalence of Sos1 over Sos2 with regards to cellular proliferation and viability.

\section{INTRODUCTION}

Among the main families of activators of small GTPases by guanine nucleotide exchange (RasGEF) in mammals (Sos, GRF and GRP), the Sos proteins are the most widely expressed and functionally relevant with regards to Ras activation by upstream signals ${ }^{1-6}$. The Sos family encompasses two highly homologous, ubiquitously expressed members (Sos1 and Sos2) functioning in multiple signaling pathways promoting Ras and Rac activation downstream of a wide variety of receptors ${ }^{4-8}$. The Sos proteins contribute to signal internalization and Ras activation through a process involving their recruitment from the cytosol to the plasma membrane via complex formation with proteins such as Grb2 $^{1,9,10}$ and have also been reported to bind E3b1 and Eps8 in a tri-complex showing GEF activity toward $\operatorname{Rac}^{11,12}$.

Because of their structural homology and similar expression patterns, the specific functional properties of Sos1 and Sos 2 are not clearly defined yet. We showed previously that Sos 1 constitutive null animals die during mid-embryonic gestation ${ }^{13}$ whereas adult Sos2-null mice are viable and fertile $^{14}$. Indeed, as the Sos2 isoform appeared to be mostly dispensable, a majority of functional studies has so far focused on assigning functional roles to Sos $1^{14-22}$ whereas the lethality of Sos1-null embryos $^{13}$, has strongly restricted the possibility of analyzing various cell types with regards to Sos $1 / 2$ functions.

Recently, we successfully bypassed the lethality of homozygous Sos1-null mutations by placing a floxed Sos1-null allele ${ }^{17,23}$ under the control of a tamoxifen-inducible Cre allowing full-body deletion of the targeted Sos1 gene and subsequent analysis of resulting phenotypes in adult mice ${ }^{24}$. We showed that Sos1/2 DKO animals died precipitously whereas single Sos1- or Sos2-deficient mice were viable, suggesting functional redundancy between Sos1 and Sos2 for organismal homeostasis and survival. The availability of viable Sos1- and Sos1/2-null mutants made possible by our conditional Sos1 KO experimental system allows us now to address previously unanswered questions regarding functional specificity and/or redundancy of Sos1 and Sos2 in specific cell lineages or tissues. 
Here, we isolated and cultured primary MEFs of four relevant genotypes (WT, Sos1 KO, Sos2 KO and Sos1/2 DKO) raised on the same genetic background with an aim at evaluating the functional specificity or redundancy of the Sos1 and Sos2 alleles in different cellular processes. Our data revealed partial redundancy of these isoforms in some cellular processes but uncovered a clear functional prevalence of Sos1 over Sos2 with regards to cellular proliferation and viability as well as a direct mechanistic link between Sos1 and proper maintenance of the intracellular redox homeostasis in MEFs.

\section{MATERIAL AND METHODS}

\section{Cell culture}

WT, Sos1 KO, Sos2 KO, and Sos1/2 DKO MEFs were isolated from E13.5 embryos of the corresponding genotypes $^{24}$ and analyzed as primary, low passage $(\leq 8)$ cultured cells. All experimental groups were treated with $4 \mathrm{OHT}(0.3 \mu \mathrm{M}$, Sigma) under identical conditions to induce Sos1 removal and also exclude any possible off-target effects.-For Sos1 and Sos2 silencing in the absence of 4OHT, immortalized MEFs were infected with lentiviral shRNA constructs (MISSION shRNA, Sigma) targeting Sos1 (NM_009231) or Sos2 (XM_127051) transcripts independently, and a non-specific transcript (SHC002V) as control. Adeno-Cre-mediated deletion of floxed Sos1 was achieved using viral vector Ad5CMVCre-eGFP (VVC-U lowa-1174).

\section{Cellular proliferation, viability and migration assays}

For growth curve evaluation, 4OHT-treated primary MEFs from all experimental groups were seeded ( $8 \times 104$ cells/well) onto 6-well microplates and total numbers of viable cells per well were measured at $24 \mathrm{~h}$ intervals as indicated. For cell cycle studies, BrdU-labeled MEFs were analyzed by flow cytometry ( 1 x 104 cells per run; FACSCanto II; BD Biosciences, CA, USA) using Infinicyt software (Cytognos SL, Spain). Number of mitotic cells and timing of mitosis was monitored using Nikon Eclipse TE2000 living cell microscopy and Metamorf software to process the images.

Cellular senescence and apoptosis were evaluated, respectively, using a $\beta$-Galactosidase staining kit (Cell Signaling, 9860) or antibodies to cleaved-caspase 3 and PARP. In vitro scratch wound assays were performed as described62 using Image-J software (FIJI) to trace movement of individual cells.

\section{Electron microscopy}

MEFs fixed with glutaraldehyde and paraformaldehyde were embedded in Embed-812 (Electron Microscopy Sciences, Hatfield, PA, USA), stained with uranyl acetate and lead citrate and 
photomicrographed in a ZEISS EM900 TEM (Oberkochen, Germany) with a coupled digital camera using ImageSP software (Minsk, Belarus).

\section{Interference Reflection Microscopy assay}

8 days $4 \mathrm{OHT}$-treated MEFs from the four relevant genotypes (WT, Sos1 KO, Sos2 KO and Sos1/2 DKO) were seeded in glass-bottomed dishes (P35G-0-10-C, MatTek) pre-treated with fibronectin (10 $\mu \mathrm{g} / \mathrm{ml}$ ), and recorded $24 \mathrm{~h}$ after seeding for $1 \mathrm{~h}$ in confocal microscope (Zeiss LSM510) by using IRM settings of ZEN software (ZEISS Microscopy).

\section{Immunocytochemistry, immunoblotting and biochemical assays}

MEFs fixed with paraformaldehyde were incubated with primary antibodies (overnight) and with specific secondary antibodies conjugated to fluorochomes (FITC or Texas Red (Jackson ImmunoResearch, PA, USA) (45 $\mathrm{min}$ ) before counterstaining with DAPI and/or Alexa Fluor 488conjugated Phalloidin (Invitrogen) and examination with a laser confocal microscope (Leica SP5). Cellpermeant probes MitoTracker ${ }^{\mathrm{TM}}$ (Invitrogen, M-7512) and LysoTracker ${ }^{\mathrm{TM}}$ (Invitrogen, L7526) were applied in vivo to MEFs grown on borosilicate slides coated with $0.1 \%$ Poly-L-Lysine.

Western immunoblotting of MEF protein lysates was performed as previously described63.

Pull-down in vivo activation assays were essentially as described for quantitation of RasGTP64 or RacGTP65. RasGTP/total-Ras and RacGTP/total-Rac ratios were quantified using Image-J software.

The kinetics of ERK and AKT activation was estimated as pERK/total-ERK and pAKT/total-AKT ratios calculated from WB signals produced by antibodies recognizing the basal and activated forms of these kinases and quantitated using Image-J software.

Antibodies used: anti-pERK (SC7383), anti-ERK (SC94), anti-PARP (SC25780), anti-Sos1 (SC256), antiSos2 (SC258) were from Santa Cruz Biotechnology (CA, USA); anti-pAKT was a gift of Dr. Pandiella; anti-AKT (2920), anti-cleaved Caspase 3 (9661) and anti-LC3 (2775S) were from Cell Signaling (CA, USA); FITC-conjugated Anti-BrdU (556028) and anti-Rac (610651) were from BD (CA, USA); anti-rH2AX (05-636), anti-H3K9me3 (07-442), anti-HP1Y (MAB3450), anti-Paxilin (05-417) and anti-Ras (05-516) were from Millipore (CA, USA); anti-H4 acetylated and anti-Tubulin (T5293) were from Chemicon and Sigma, respectively.

\section{Analysis of the redox parameters}

Commercial fluorescent redox probes were used according to the manufacturer's instructions. Overall intracellular ROS was measured using $\mathrm{H}_{2}$ DCFDA (Invitrogen, D-399). Overall intracellular levels of superoxide anion $\left(\mathrm{O}_{2}^{-}\right)$were determined using dihydroethidium (Invitrogen, D-1168). ROS production 
triggered by tert-butyl hydroperoxide addition (50-300 $\mu \mathrm{M}, 2 \mathrm{~h}$, Sigma) was also monitored with dihydroethidium. Mitochondrial superoxide $\left(\mathrm{mO}_{2}{ }^{-}\right)$levels were quantitated using MitoSOX (Invitrogen, M36008). Probe fluorescence was evaluated using a FACStar flow cytometer (Becton Dickinson, Sparks, MD, USA) and FlowJo 8.7 software (FLOWJO, Ashland, OR, USA). Mitochondrial membrane potential $\left(\Delta \Psi_{\mathrm{m}}\right)$ was assessed as the ratio between JC-1 green fluorescence (depolarized mitochondrial membrane) and JC-1 red fluorescence (polarized mitochondrial membrane) using the JC-1 dye (Invitrogen, T-3168). Controls were run in the presence of $50 \mu \mathrm{M}$ carbonyl cyanide 3chlorophenyl hydrazone, an uncoupling agent abolishing $\Delta \Psi_{\mathrm{m}}$. The effect of cellular antioxidants NAC (Sigma A7250,10 mM) and GSH (Sigma G4251,10 mM) or the mitochondrial superoxide scavenger MitoTEMPO (SC-221945, $100 \mu \mathrm{M}$ ) was monitored by incubation with AlamarBlue (Invitrogen, DAL1100) to measure resulting rates of proliferation and metabolic activity.

\section{Statistics}

Statistical analyses were performed with the SPSS v21 software package (SPSS Inc., Chicago, IL, USA) using one-way analysis of variance and Bonferroni's tests.

\section{RESULTS}

Sos1 depletion is accompanied by morphological alterations, chromatin reorganization, DNA damage and mitophagy in primary MEFs

Morphological examination of primary MEFs of the four relevant Sos genotypes (WT, single Sos1 KO, single Sos2 KO and Sos1/2 DKO) cultured in the presence of 4OHT for up to 9-15 days, a period of time ensuring practically total disappearance of the Sos1 protein in all lines containing the Sos1-null conditional allele (Figure 1a), documented that WT and Sos2-devoid MEFs showed regular fibroblastic morphology with thin, fusiform cytoplasm and round nuclear shape (Figure 1b). In contrast, Sos1 KO and DKO MEFs displayed flattened cellular shapes and enlarged cellular body in comparison to the WT and Sos2 KO MEFs (Figure 1b). Cell body perimeter was significantly higher in the Sos1/2 DKO and Sos1 KO MEFs as compared to the WT and Sos2 KO MEFs, with no differences in body size detected between Sos1- and Sos1/2-devoid cells (Figure 1c). Phalloidin and paxillin immunostaining further evidenced the occurrence of marked cytoskeletal reorganization in connection with Sos1, but not Sos2, removal (Figure 1d). In contrast to the WT and Sos2 KO cells, an increase of focal adhesions was observed in the end-feet of numerous lamellipodia emerging from the Sos1- and Sos1/2-lacking cells (Figure 1d). 
Sos1-depletion also entailed significantly altered expression of various nuclear, chromatin-associated histone markers in Sos1 KO and Sos1/2 DKO MEFs as compared to their WT and Sos2-devoid counterparts. Immunolabeling for H3K9me3 and HP1 $\gamma$ (Figure 1e) as markers of silent heterochromatin and for acetylated $\mathrm{H} 4$ histone (Figure 1f) as marker of chromatin remodeling in transcriptionally active domains ${ }^{25-27}$ revealed that Sos1-lacking MEFs displayed opposite staining patterns to those of WT and Sos2-null MEFs. Immunostaining of the phosphorylated form of the histone variant $\gamma \mathrm{H} 2 \mathrm{AX}$ (DNA damage sensor ${ }^{28}$ ) showed complete absence of labeling in the nuclei of both the WT and Sos2-deficient MEFs, but most Sos1 KO and Sos1/2 DKO MEFs exhibited varying numbers of $\mathrm{H}_{2} \mathrm{AX}$-immunoreactive nuclear foci (Figure 1g) indicating the occurrence of DNA damage following Sos1 elimination.

Light microscopy observations revealed a striking accumulation in Sos1 KO and Sos1/2 DKO MEFs of cytoplasmic, vesicular bodies that were mostly absent in WT and Sos2 KO counterparts (Figure 1b). A time-course analysis involving LysoTracker staining of $4 \mathrm{OHT}$-treated MEFs of all genotypes (Figure 2a) documented an earlier (visible 3 days after $4 \mathrm{OHT}$-induction) and much more intense accumulation of lysosomal bodies in the cytoplasm of Sos1 KO and Sos1/2 DKO MEFs as compared to WT and Sos2deficient cells. The nature of these intracellular degradation bodies was ascertained as mitophagy by electron microscopy studies showing the presence of mitochondria at various stages of degradation, inside membrane-bound lysosomal structures that were abundant in the cytoplasm of Sos1- and Sos1/2-null MEFs but not of WT and Sos2 KO cells (Figure 2b). These observations suggested a mechanistic link between the 4OHT-induced disappearance of Sos1 and the occurrence of autophagic/mitophagic processes that was further confirmed by immunostaining studies showing colocalization of MitoTracker and an antibody against the specific autophagosome marker $\mathrm{LC}-3 \mathrm{~B}^{29}$ in Sos1 KO and DKO MEFs as opposed to WT and Sos2-devoid MEFs (Figure 2c).

\section{Differential roles of Sos1 and Sos 2 in cell migration and adhesion}

The migratory ability of cells devoid of Sos isoforms was tested using in vitro scratch assays (Figures 4a and b). Although WT and Sos2 KO MEF cultures exhibited similar wound-closure kinetics, the Sos1 KO MEF cultures showed a partial time delay in the kinetics of that process in comparison with WT and Sos2 KO MEFs (Figures $4 a$ and b). In contrast, the combined Sos $1 / 2$ deletion resulted in noticeably delayed cell migration as compared with the rest of genotypes from $8 \mathrm{~h}$ onward, and the scratched area of DKO cultures was not completely closed even after $24 \mathrm{~h}$ post-wound (Figures $4 \mathrm{a}$ and b). Analysis of the migratory tracks of individual MEFs during scratch wound closure (Figures $4 \mathrm{c}$ 
and d) documented that WT MEFs migrated actively and widely and that single Sos1-devoid cells also migrated randomly but the amplitude of their movement was reduced in comparison with WT or Sos2 KO MEFs. Additionally, focal adhesion dynamic was analyzed investigate in detail the migratory kinetics of those four genotypes by IRM. This analysis revealed a lower number of focal adhesions in Sos1 devoid cells (Figure SD1a, b and f) and reduced spreading area as well as a lower number of lamellipodia with respect to WT MEFs (Figure SD1d, e, h and i). In addition, focal adhesions turnover was less dynamic in Sos1 KO and Sos1/2 DKO MEFs as compared to WT MEFs (Figure SD1c and g). Surprisingly, Sos2 KO MEFs showed a distinctive cytoskeleton dynamic. They exhibited a higher number of focal adhesions and higher focal adhesion turnover with respect to the rest of genotypes (Figure SD1a, b, c and g). However, this dynamic turnover exhibited was related with a higher number of lamellipodia (Figure SD1e and i) but showed a lower spreading area (Figure SD1d and h). The increase in the number of lamellipodia but with the same spreading area as WT MEFs could be explained by the lamellipodial multiplicity which could explain the same migration rate and migratory distance of Sos2 KO cells as compared to WT (Figure 4a, b, c y d). In contrast, the migratory ability of the DKO MEFs was much more limited than that shown by the single Sos1- or Sos2-null MEFs (Figure 4c). Accordingly, quantitation of the speed and distances covered by the individual cells of each phenotype showed lower values for Sos1/2 DKO and Sos1 KO cells in comparison with WT and Sos2 KO MEFs (Figure 4d). The ability of MEFs to adhere to the surface of plastic culture dishes showed also significant reduction in Sos1/2 DKO MEFs as compared with all other genotypes (Figure 4e). Interestingly, although the Sos1-null MEFs exhibited similar adhesion rates than WT MEFs, the Sos2null MEFs displayed enhanced cell adhesion ability in comparison with WT and Sos1 KO MEFs (Figure 4e).

\section{Ras signaling pathway components in Sos-deficient MEFs}

Our analyses of in vivo Ras activation by means of pull down assays using GST-Raf RBD fusion proteins showed similar levels of Ras activation after 5-10 min of platelet-derived growth factor (PDGF) stimulation in WT and single Sos-null MEFs. In contrast, the kinetics of Ras activation appeared to be slower in the Sos1 KO MEFs at $2 \mathrm{~min}$, and a practically complete blockade was observed in the DKO MEFs as compared with the other genotypes (Figure 5a). Similar impairment of Ras activation was detected in Sos1-depleted MEFs after stimulation with epidermal growth factor (EGF) (Figure 5b). On the other hand, no significant differences were detected among the four different genotypes in assays of Rac activation upon EGF stimulation (Figure 5c). 
The evaluation of the level of activation of downstream effectors in the Ras-mitogen-activated protein kinase pathway showed that the individual absence of either Sos 1 or Sos 2 isoforms did not significantly alter the levels of extracellular signal regulated kinases 1 and 2 (ERK1/2) phosphorylation in comparison with WT MEFs, and only the combined depletion of both isoforms resulted in a significant reduction of the phospho-ERK/ERK ratio as compared with WT and Sos2-deficient MEFs (Figure 5d). Moreover, the same time course upon PDGF stimulation did not uncover any obvious differences among MEFs of the four genotypes with regards to phosphatidylinositol 3 kinase (PI3K)/AKT signaling, as no significant differences in levels of AKT phosphorylation at Ser473 were detected for any of the time points analyzed (Figure 5e).

\section{Sos1 depletion is linked to increased intracellular oxidative stress in MEFs}

To test the hypothesis of a mechanistic connection between Sos1 removal and the cellular mechanisms eliciting autophagy/ mitophagy in Sos1-deficient cells, we quantitated different types of redox molecular species in various subcellular compartments. Our analyses of live MEF cultures loaded with $2^{\prime}, 7^{\prime}$-dichlorodihydrofluorescein- diacetate (H2DCFDA), a general indicator of reactive oxygen species (ROS) in cells30 revealed that, concomitant to the progression of the 4OHT-driven Sos1 depletion, a significant accumulation of ROS occurred specifically in the Sos1- and Sos1/2- null MEFs as compared with the Sos2 KO and WT counterparts (Figure 6a). Furthermore, the use of dihydroethidium31 to quantitate the cytosolic levels of superoxide anion (O2 - ) accumulated in MEFs demonstrated that the depletion of Sos1 (individually or in combination with Sos2 depletion) was also accompanied by significant enhancement of the cytoplasmic levels of superoxide with respect to WT and Sos2-devoid cells (Figure 6b). Finally, using MitoSOX as specific probe of mitochondrial superoxide ( $\mathrm{mO2}$ - ) 32,33 confirmed the increase of this anion in mitochondria of Sos1- and Sos1/2devoid MEFs after 6-9 days of $4 \mathrm{OHT}$ treatment as compared with WT and Sos1/2 DKO MEFs, with no significant differences being observed between WT and Sos2-devoid MEFs or between Sos1 KO and DKO MEFs (Figure 6c).

As the above data suggested mitochondrial stress in Sos1- devoid MEFs, we measured their mitochondrial membrane potential $\left(\Delta \Psi_{\mathrm{m}}\right)$ using the specific JC-1 carbocyanine dye.34 Consistent with the increased $\mathrm{mO}_{2}^{-}$levels detected with MitoSox, we observed a progressive reduction of $\Delta \Psi_{\mathrm{m}}$ in the same MEFs that was particularly evident in correlation with the progressive depletion of Sos1 occurring in Sos1 KO and Sos1/2 DKO MEFs after 6-9 days of 4OHT treatment (Figure 6d). In contrast, the Sos2- null MEFs did not show any significant reduction of $\Delta \Psi \mathrm{m}$ when compared with WT MEFs 
(Figure $6 \mathrm{~d}$ ). It should be mentioned that to identify phenotypes exclusively linked to Sos1 or Sos2 while avoiding nonspecific, off-target phenotypes caused by $4 \mathrm{OHT}$ induction, all different MEF genotypes were cultured in the presence of this compound. Regarding this, we noticed that although the described redox alterations were preferentially observed in Sos1-lacking MEFs, some limited degree of alteration was also observed in WT and Sos2-null MEFs after long-term 4OHT treatments (6-9 days) as compared with their corresponding, untreated time-point controls (0 days) with regards to accumulation of lysosomes (Figure 2a) or intracellular ROS and mO2 - (Figures 6a-c). This raised the question of whether the increased oxidative stress detected in Sos1-devoid MEFs could be directly caused by Sos1 depletion or rather an indirect consequence of potential inability of Sos1lacking MEFs to effectively detoxify ROS accumulated as a possible off-target effect ${ }^{35,36}$ of $4 \mathrm{OHT}$ treatment. To clarify this point, we analyzed MEFs where Sos1 removal was independent of $4 \mathrm{OHT}$ treatment. Using immortalized MEFs infected with lentiviral short hairpin RNA (shRNA) constructs specifically targeting the Sos1 or Sos2 transcripts to drive partial removal of these proteins (Figure 7a), we observed a significant elevation of intracellular ROS in shSos1- silenced MEFs as compared with their control counterparts growing under basal conditions (Figure 7b). In contrast, Sos2 silencing did not result in any obvious alteration of redox state with respect to their specific shControl fibroblasts (Figure 7b). Furthermore, after treatment with tert-butyl hydroperoxide to induce oxidative stress37 in the Sos1- and Sos2-silenced clones, we observed much higher accumulation of intracellular ROS in shSos1-silenced fibroblasts than in shSos2-silenced cells in comparison with their respective shControl clones (Figure 7b). Finally, using viral adeno-Cre to induce Sos1 deletion in our MEFs (Figure 7c), we also detected a specific increase of mitochondrial superoxide in Sos1 KO and Sos1/2 DKO MEFs (Figure 7d) as compared with similarly treated WT and Sos2 KO MEFs, thus confirming that the altered redox phenotypes of Sos1-devoid MEFs are specifically linked to the absence of Sos1 and not mere off-target effects of $4 \mathrm{OHT}$ treatment.

\section{Reversion of altered phenotypes of Sos1-deficient MEFs by antioxidants}

To identify mechanistic clues accounting for the cellular phenotypes exhibited by Sos-devoid MEFs, we analyzed the effect of inhibitors of different signaling processes on active MEFs of the four genotypes using alamarBlue, a non-toxic fluorescent indicator allowing accurate in vivo quantitation of their metabolic activity and cell viability. ${ }^{38}$ We observed that, among all different inhibitors tried, only the antioxidants $\mathrm{N}$-acetyl-cysteine (NAC) and reduced glutathione (GSH) produced significant changes of fluorescence in relation to untreated controls that distinguished the Sos1- and Sos1/2-null 
MEFs from the similarly treated WT and Sos2 MEFs (Figure 8a). In contrast, other inhibitors having different molecular targets than NAC or GSH (including rapamycin, resveratrol or the PI3K inhibitor LY29002) did not cause any significant alterations of the patterns of alamarBlue fluorescence (data not shown), suggesting that the signaling processes targeted by them are not exclusively dependent upon Sos1 or Sos2 function and confirming that ROS accumulation in Sos1 KO and DKO MEFs is a direct consequence of Sos1 removal. The existence of a direct mechanistic link between Sos1 and the altered cellular phenotypes identified above in Sos1-devoid MEFs was further confirmed by direct measurements of cellular growth in MEFs treated with the same antioxidants. Although NAC and GSH did not affect the proliferation rates of WT or Sos2 KO MEFs, treatment with those antioxidants fully restored the significantly impaired proliferative ability initially observed (Figure 3 ) in untreated Sos1 KO or Sos1/2 DKO MEFs to levels similar to those of WT and Sos2 KO MEFs (Figure 8b). The same antioxidant treatment resulted also in reversion of the flattened, extended spread morphological phenotypes initially observed in those MEFs (Figure 1). Treatment with NAC resulted in reversion of the perimeter size and cytoskeletal architecture of Sos1 KO and DKO MEFs to parameter values similar to those of untreated WT and Sos2 KO MEFs (Figures $8 \mathrm{c}$ and d). Furthermore, using MitoTempo, a superoxide scavenger acting specifically at the mitochondrial level ${ }^{39}$ (Figures $8 \mathrm{e}-\mathrm{g}$ ), we also documented the specific reversion of the altered levels of metabolic activity and viability (Figure 8e), proliferative ability (Figure $8 \mathrm{f}$ ) and oxidative stress (Figure 8g) of Sos1 KO and Sos1/2 DKO MEFs, whereas the treatment with this scavenger did not cause any significant change of those parameters in WT or Sos2 KO MEFs.

\section{DISCUSSION}

Our side-by-side analyses of comparable sets of biological samples arising from mice of four genotypes (WT, Sos1 KO, Sos2 KO and Sos1/2 DKO) sharing the same genetic background, have established a direct correlation between 4OHT-induced Sos1 depletion and the appearance of distinctive cellular phenotypes in MEFs. These included profound changes of cell size and morphology as well as expression of nuclear markers indicating lower transcriptional activity and DNA damage, and accumulation of cytoplasmic autophagosomal bodies containing mitochondria at various stages of degradation. Cellular proliferation was also markedly reduced in Sos1-null MEFs and almost totally gone in the Sos1/2 DKO MEFs. The distinctive prevalence of these cellular alterations in Sos1 KO and DKO MEFs supported a specific mechanistic link between the disappearance of Sos1 and the 
development of those defective phenotypes. On the other hand, the fact that these phenotypes were always much more marked in DKO than in single Sos1-null MEFs suggests that Sos2 absence may still play a partial contributing role to their generation when Sos1 is already absent in MEFs ${ }^{24,40-46}$. It is also relevant that the absence of specific markers of senescence or apoptosis excluded those particular cellular processes as possible mechanisms responsible for development of the defective phenotypic features of Sos1-devoid MEFs, which are reminiscent of those of Rasless fibroblasts devoid of $\mathrm{H}-, \mathrm{N}$ and K-Ras, the known canonical targets of Sos1 proteins ${ }^{47,48}$. The critical role of Sos1 in control of cell proliferation uncovered by our current study is also consistent with previous reports documenting the relevance of gain-of-function Sos1 mutations in this process ${ }^{43-46}$.

In contrast to the dominant role uncovered here for Sos1 in proliferation, our studies only showed statistically significant blockade of cellular migration or adhesion in DKO MEFs, suggesting partial redundancy of Sos 1 and Sos 2 regarding these processes and indicating that the mechanisms linking Sos1 to control of proliferation are different from those involved in its participation in control of migration or adhesion. Whereas these data are consistent with reports of the impaired migratory ability of Rasless fibroblasts ${ }^{47}$ or of T-cells devoid of both Sos $1 / 2$ isoforms ${ }^{40}$, more detailed studies will be needed in future to precisely define the specific contributions of Sos isoforms to migration or adhesion processes in MEFs.

Searching for mechanistic clues relevant to the Sos-dependent cellular phenotypes described in these studies, we observed that the Ras- and ERK-activation assays only showed inhibition in the case of the DKO MEFs although it was apparent that the kinetics of Ras activation was slower for the Sos1-null MEF at short times of stimulation, whereas the Rac- and AKT-activation assays showed similar, unchanged patterns of activation for all four different genotypes. This observation, together with the observed phenotypic similarities to Rasless cells $s^{47,48}$ would be consistent with a preferential mechanistic contribution of Ras proteins to the phenotypic alterations observed in Sos1-depleted MEFs. However, Rac contribution cannot be formally excluded in light of the simultaneous expression in our Sos-depleted MEFs of other known Rac-GEFs, such as Tiam-1, Vav2 or Vav3 ${ }^{49,50}$. These observations indicate that Sos1 or Sos2 alone can support normal levels of Ras and ERK activation in the absence of each other and suggest partial functional overlapping of both isoforms, although with a slight dominance of Sos1 over Sos2 regarding Ras activation. These data on Ras-ERK activation are consistent with our observations in immortalized, lentivirally-Sos1-silenced fibroblasts (not shown) and our previous report showing unchanged rates of short-term activation of Ras and ERK in 
immortalized fibroblasts from constitutive Sos1 KO mice ${ }^{13}$. They are also consistent with data from other cell types documenting the critical role of Sos1 for ERK activation in Jurkat T cells ${ }^{51}$ or for intrathymic ERK activation in normal T cell development ${ }^{17,23}$, although TCR-mediated ERK activation in peripheral $\mathrm{CD}^{+} \mathrm{T}$ cells does not depend on Sos1 and Sos $2^{17,40,52}$.

Regarding PI3K/AKT signaling we observed, somewhat unexpectedly, that the levels of AKT phosphorylation upon PDGF stimulation were not significantly altered after individual, or even combined, depletion of both Sos isoforms. These data on primary MEFs are in contrast to previous reports showing significant activation of the PI3K pathway in fibroblasts expressing dominant negative mSos1 constructs $^{53}$ or in Sos1/2 DKO CD4 ${ }^{+}$T-cells upon TCR and IL-2 stimulation ${ }^{40}$. Interestingly, our immortalized, shRNA-silenced or constitutive Sos1 KO fibroblasts showed also increased levels of AKT phosphorylation in comparison to WT controls (not shown). Although we do not understand the mechanistic basis for the differences between our MEF data and those reported for other fibroblastic and non-fibroblastic cellular systems, we speculate that the immortalization process, rather than the absence of Sos proteins, may have triggered compensatory changes involving activation of the PI3K pathway.

From the mechanistic point of view, one of the most significant findings reported here is the demonstration of a specific link between Sos1 depletion and development of intracellular and mitochondrial oxidative stress in MEFs. Using specific fluorophores we detected significant accumulation of intracellular ROS and $\mathrm{mO}_{2}{ }^{-}$in close temporal synchronicity with the progressive disappearance of Sos1 occurring in Sos1 KO and DKO MEFs upon 4OHT-induction. Consistent with the occurrence of mitochondrial dysfunction ${ }^{54-56}$ caused by the increased oxidative stress, we also detected a parallel loss of $\Delta \Psi \mathrm{m}$ in the same Sos1-devoid MEFs. As $40 H T$ is also a known cytotoxic antitumor agent that has been reported to induce apoptotic or autophagic degradation processes in a variety of tumor cell types ${ }^{35,36}$, we also discarded the possibility that off-target effects of $4 \mathrm{OHT}$ could be acting as the primary, initiating cause of the altered redox phenotypes manifested in Sos1-devoid MEFs by demonstrating the occurrence of similar increases of oxidative stress and alterations of redox status in Sos1-knocked-down MEFs in the absence of 4OHT. Furthermore, the existence of a direct mechanistic connection of the increased oxidative stress and mitochondrial dysfunction with the rest of phenotypic alterations observed in Sos1-deficient MEFs was experimentally proven by the experiments where general cellular antioxidants as $\mathrm{GSH}$ or $\mathrm{NAC}^{57,58}$ or the specific mitochondrial superoxide scavenger MitoTEMPO ${ }^{39}$, but not other inhibitors such as rapamycin or LY29002, rescued 
the proliferative and morphological parameters of Sos1-devoid MEFs to values similar to those of WT MEFs.

Altogether, our data uncover a critical role of Sos1 in control of intracellular oxidative stress and proper maintenance of redox homeostasis in MEFs. Our results indicate that Sos1 depletion is by itself able to enhance levels of oxidative stress in MEFs in the absence of external oxidant stimuli and, in addition, it also hypersensitizes these cells to externally added sources of oxidative stress such as $4 \mathrm{OHT}$ or t-BHP, probably reflecting impaired ability of the Sos1-devoid cells to detoxify the excess accumulation of intracellular ROS. Our data also indicates that the increased oxidative stress occurring in the absence of Sos1 (individually or in combination with Sos2) leads to subsequent changes of cellular morphology and cytoskeletal organization as well as intracellular autophagosomal degradation and defective viability and proliferation that are fully reversible by treatment with antioxidants.

Future studies will be needed to identify the exact molecular switches linking Sos1 disappearance to increased oxidative stress and subsequent development of associated, defective cellular phenotypes. Having excluded apoptosis and senescence, it will also be important to identify the nature of the cellular mechanisms responsible for the cell cycle arrest and reduced viability and proliferation observed in Sos1 KO, and more markedly, in the Sos1/2-null MEFs. The phenotypic similarities exhibited by Sos-deficient MEFs and Rasless cells ${ }^{47}$ suggest that detailed metabolic and transcriptomic studies of Sos1/2-deficient MEFs rescued of their defective phenotypes by antioxidants, similar to those performed in proliferation-rescued Rasless cells ${ }^{48}$, may be instrumental for that purpose. As the main biochemical role of Sos 1 is facilitating the activation of Ras proteins to the RasGTP status ${ }^{59}$ and it is also established that oncogenic Ras proteins activate ROS production and intracellular apoptotic and autophagic degradation processes in a variety of tumor systems ${ }^{56,60,61}$, an interesting possibility is that some/part of the same molecular machinery participating in Ras oncogene-dependent processes may also account for generation of the phenotypes of Sos1-devoid MEFs.

\section{ACKNOWLEDGEMENTS}

Work supported by grants FIS PI16/02137 from ISCIII (MINECO), SA043U16 (UIC 076) from JCyL, Spain and AECC. FC and CG are supported by a postdoctoral grant from the CiberONC and AECC, respectively. Research co-financed by FEDER funds. PL is supported by predoctoral contract from JCyL and FEDER funds. 


\section{REFERENCES}

1. Buday L \& Downward J. Many faces of Ras activation. Biochim Biophys Acta 2008; 1786: 178-187

2. Karnoub AE \& Weinberg RA. Ras oncogenes: split personalities. Nat Rev Mol Cell Biol 2008; 9: 517-531

3. Castellano E \& Santos E. Functional specificity of ras isoforms: so similar but so different. Genes Cancer 2011; 2: 216-231

4. Rojas JM, Oliva JL \& Santos E. Mammalian son of sevenless Guanine nucleotide exchange factors: old concepts and new perspectives. Genes Cancer 2011; 2: 298-305

5. Cherfils J \& Zeghouf M. Regulation of Small GTPases by GEFs, GAPs, and GDIs. Physiol Rev 2013; 93: $269-309$

6. Hennig A, Markwart R, Esparza-Franco MA, Ladds G \& Rubio I. Ras activation revisited: role of GEF and GAP systems. Biological chemistry 2015; 396: 831-848

7. Groves JT \& Kuriyan J. Molecular mechanisms in signal transduction at the membrane. Nat Struct Mol Biol 2010; 17: $659-665$

8. Schlessinger J. Cell signaling by receptor tyrosine kinases. Cell 2000; 103: 211-225

9. Chardin P, Camonis JH, Gale NW, van Aelst L, Schlessinger J, Wigler MH et al. Human Sos1: a guanine nucleotide exchange factor for Ras that binds to GRB2. Science 1993; 260: 1338-1343

10. Gale NW, Kaplan S, Lowenstein EJ, Schlessinger J \& Bar-Sagi D. Grb2 mediates the EGF-dependent activation of guanine nucleotide exchange on Ras. Nature 1993; 363: 88-92

11. Scita G, Tenca P, Areces LB, Tocchetti A, Frittoli E, Giardina G et al. An effector region in Eps8 is responsible for the activation of the Rac-specific GEF activity of Sos-1 and for the proper localization of the Rac-based actin-polymerizing machine. J Cell Biol 2001; 154: 1031-1044

12. Nimnual A \& Bar-Sagi D. The two hats of SOS. SCi STKE 2002; 2002: pe36

13. Qian X, Esteban L, Vass WC, Upadhyaya C, Papageorge AG, Yienger $\mathrm{K}$ et al. The Sos1 and Sos2 Ras-specific exchange factors: differences in placental expression and signaling properties. EMBO J 2000; 19: 642-654

14. Esteban LM, Fernandez-Medarde A, Lopez E, Yienger K, Guerrero C, Ward JM et al. Ras-guanine nucleotide exchange factor sos2 is dispensable for mouse growth and development. Molecular and cellular biology 2000; 20: 6410-6413 15. Arai JA, Li S \& Feig LA. Sos2 is dispensable for NMDA-induced Erk activation and LTP induction. Neurosci Lett 2009; 455: $22-25$

16. Poltorak M, Meinert I, Stone JC, Schraven B \& Simeoni L. Sos1 regulates sustained TCR-mediated Erk activation. Eur J Immunol 2014; 44: 1535-1540

17. Kortum RL, Sommers CL, Alexander CP, Pinski JM, Li W, Grinberg A et al. Targeted Sos1 deletion reveals its critical role in early T-cell development. Proc Natl Acad Sci U S A 2011; 108: 12407-12412

18. Sakaue M, Bowtell D \& Kasuga M. A dominant-negative mutant of mSOS1 inhibits insulin-induced Ras activation and reveals Ras-dependent and -independent insulin signaling pathways. Molecular and cellular biology 1995; 15: 379-388

19. Wang DZ, Hammond VE, Abud HE, Bertoncello I, McAvoy JW \& Bowtell DD. Mutation in Sos1 dominantly enhances a weak allele of the EGFR, demonstrating a requirement for Sos1 in EGFR signaling and development. Genes Dev 1997; 11: $309-320$

20. Boykevisch S, Zhao C, Sondermann H, Philippidou P, Halegoua S, Kuriyan J et al. Regulation of ras signaling dynamics by Sos-mediated positive feedback. Curr Biol 2006; 16: 2173-2179

21. Oh-hora M, Johmura S, Hashimoto A, Hikida M \& Kurosaki T. Requirement for Ras guanine nucleotide releasing protein 3 in coupling phospholipase C-gamma2 to Ras in B cell receptor signaling. J Exp Med 2003; 198: 1841-1851

22. Kumkhaek C, Aerbajinai W, Liu W, Zhu J, Uchida N, Kurlander R et al. MASL1 induces erythroid differentiation in human erythropoietin-dependent CD34+ cells through the Raf/MEK/ERK pathway. Blood 2013

23. Kortum RL, Sommers CL, Pinski JM, Alexander CP, Merrill RK, Li W et al. Deconstructing Ras signaling in the thymus. Molecular and cellular biology 2012; 32: 2748-2759

24. Baltanas FC, Perez-Andres M, Ginel-Picardo A, Diaz D, Jimeno D, Liceras-Boillos P et al. Functional redundancy of Sos1 and Sos2 for lymphopoiesis and organismal homeostasis and survival. Molecular and cellular biology 2013; 33: 45624578

25. Schotta G, Lachner M, Sarma K, Ebert A, Sengupta R, Reuter G et al. A silencing pathway to induce H3-K9 and H4K20 trimethylation at constitutive heterochromatin. Genes \& development 2004; 18: 1251-1262

26. Jaskelioff $\mathrm{M} \&$ Peterson CL. Chromatin and transcription: histones continue to make their marks. Nature cell biology 2003; 5: 395-399

27. Hendzel MJ, Kruhlak MJ \& Bazett-Jones DP. Organization of highly acetylated chromatin around sites of heterogeneous nuclear RNA accumulation. Mol Biol Cell 1998; 9: 2491-2507

28. Fernandez-Capetillo O, Lee A, Nussenzweig M \& Nussenzweig A. H2AX: the histone guardian of the genome. DNA Repair (Amst) 2004; 3: 959-967

29. Klionsky DJ \& Emr SD. Autophagy as a regulated pathway of cellular degradation. Science 2000; 290: 1717-1721 
30. Wang H \& Joseph JA. Quantifying cellular oxidative stress by dichlorofluorescein assay using microplate reader. Free radical biology \& medicine 1999; 27: 612-616

31. Bindokas VP, Jordan J, Lee CC \& Miller RJ. Superoxide production in rat hippocampal neurons: selective imaging with hydroethidine. The Journal of neuroscience : the official journal of the Society for Neuroscience 1996; 16: 1324-1336

32. Mukhopadhyay P, Rajesh M, Yoshihiro K, Hasko G \& Pacher P. Simple quantitative detection of mitochondrial superoxide production in live cells. Biochemical and biophysical research communications 2007; 358: 203-208

33. Yokosuka T, Goto H, Fujii H, Naruto T, Takeuchi M, Tanoshima R et al. Flow cytometric chemosensitivity assay using JC1, a sensor of mitochondrial transmembrane potential, in acute leukemia. Cancer chemotherapy and pharmacology 2013; 72: 1335-1342

34. Smiley ST, Reers M, Mottola-Hartshorn C, Lin M, Chen A, Smith TW et al. Intracellular heterogeneity in mitochondrial membrane potentials revealed by a J-aggregate-forming lipophilic cation JC-1. Proceedings of the National Academy of Sciences of the United States of America 1991; 88: 3671-3675

35. Cardoso CM, Moreno AJ, Almeida LM \& Custodio JB. Comparison of the changes in adenine nucleotides of rat liver mitochondria induced by tamoxifen and 4-hydroxytamoxifen. Toxicology in vitro : an international journal published in association with BIBRA 2003; 17: 663-670

36. Kohli L, Kaza N, Coric T, Byer SJ, Brossier NM, Klocke BJ et al. 4-Hydroxytamoxifen induces autophagic death through K-Ras degradation. Cancer research 2013; 73: 4395-4405

37. Castilho RF, Kowaltowski AJ, Meinicke AR \& Vercesi AE. Oxidative damage of mitochondria induced by Fe(II)citrate or t-butyl hydroperoxide in the presence of Ca2+: effect of coenzyme Q redox state. Free radical biology \& medicine 1995; 18: $55-59$

38. Nakayama GR, Caton MC, Nova MP \& Parandoosh Z. Assessment of the Alamar Blue assay for cellular growth and viability in vitro. Journal of immunological methods 1997; 204: 205-208

39. Liang HL, Sedlic F, Bosnjak Z \& Nilakantan V. SOD1 and MitoTEMPO partially prevent mitochondrial permeability transition pore opening, necrosis, and mitochondrial apoptosis after ATP depletion recovery. Free radical biology \& medicine 2010; 49: 1550-1560

40. Guittard G, Kortum RL, Balagopalan L, Cuburu N, Nguyen P, Sommers CL et al. Absence of both Sos-1 and Sos-2 in peripheral CD4 T cells leads to PI3K pathway activation and defects in migration. Eur J Immunol 2015

41. Huang AC, Hsu SC, Kuo CL, Liao CL, Lai KC, Lin TP et al. Involvement of matrix metalloproteinases in the inhibition of cell invasion and migration through the inhibition of NF-[kappa]B by the new synthesized ethyl 2-[N-p-chlorobenzyl-(2'methyl)]anilino-4-oxo-4,5-dihydrofuran-3-carboxylate (JOTO1007) in human cervical cancer Ca ski cells. In Vivo 2009; 23: 613-619

42. Lv Z \& Yang L. MiR-124 inhibits the growth of glioblastoma through the downregulation of SOS1. Mol Med Rep 2013; 8: 345-349

43. Lee EJ, Jang SI, Pallos D, Kather J \& Hart TC. Characterization of fibroblasts with Son of Sevenless-1 mutation. J Dent Res 2006; 85: 1050-1055

44. Chen PC, Wakimoto H, Conner D, Araki T, Yuan T, Roberts A et al. Activation of multiple signaling pathways causes developmental defects in mice with a Noonan syndrome-associated Sos1 mutation. J Clin Invest 2010; 120: 4353-4365

45. Timofeeva OA, Zhang X, Ressom HW, Varghese RS, Kallakury BV, Wang K et al. Enhanced expression of SOS1 is detected in prostate cancer epithelial cells from African-American men. Int J Oncol 2009; 35: 751-760

46. Pierre S, Bats AS, Chevallier A, Bui LC, Ambolet-Camoit A, Garlatti M et al. Induction of the Ras activator Son of Sevenless 1 by environmental pollutants mediates their effects on cellular proliferation. Biochem Pharmacol 2011; 81: 304313

47. Drosten M, Dhawahir A, Sum EY, Urosevic J, Lechuga CG, Esteban LM et al. Genetic analysis of Ras signalling pathways in cell proliferation, migration and survival. EMBO J 2010; 29: 1091-1104

48. Azrak SS, Ginel-Picardo A, Drosten M, Barbacid M \& Santos E. Reversible, interrelated mRNA and miRNA expression patterns in the transcriptome of Rasless fibroblasts: functional and mechanistic implications. BMC Genomics 2013; 14: 731

49. Hunter SG, Zhuang G, Brantley-Sieders D, Swat W, Cowan CW \& Chen J. Essential role of Vav family guanine nucleotide exchange factors in EphA receptor-mediated angiogenesis. Molecular and cellular biology 2006; 26: 4830-4842

50. Yoo S, Kim Y, Lee H, Park S \& Park S. A gene trap knockout of the Tiam-1 protein results in malformation of the early embryonic brain. Molecules and cells 2012; 34: 103-108

51. Roose JP, Mollenauer M, Ho M, Kurosaki T \& Weiss A. Unusual interplay of two types of Ras activators, RasGRP and SOS, establishes sensitive and robust Ras activation in lymphocytes. Molecular and cellular biology 2007; 27: 2732-2745

52. Warnecke N, Poltorak M, Kowtharapu BS, Arndt B, Stone JC, Schraven B et al. TCR-mediated Erk activation does not depend on Sos and Grb2 in peripheral human T cells. EMBO Rep 2012; 13: 386-391

53. Park D, Pandey SK, Maksimova E, Kole S \& Bernier M. Akt-dependent antiapoptotic action of insulin is sensitive to farnesyltransferase inhibitor. Biochemistry 2000; 39: 12513-12521 
54. Moiseeva O, Bourdeau V, Roux A, Deschenes-Simard X \& Ferbeyre G. Mitochondrial dysfunction contributes to oncogene-induced senescence. Molecular and cellular biology 2009; 29: 4495-4507

55. Hu Y, Lu W, Chen G, Wang P, Chen Z, Zhou Y et al. K-ras(G12V) transformation leads to mitochondrial dysfunction and a metabolic switch from oxidative phosphorylation to glycolysis. Cell research 2012; 22: 399-412

56. Neuzil J, Rohlena J \& Dong LF. K-Ras and mitochondria: dangerous liaisons. Cell research 2012; 22: 285-287

57. Mari M, Morales A, Colell A, Garcia-Ruiz C \& Fernandez-Checa JC. Mitochondrial glutathione, a key survival antioxidant. Antioxidants \& redox signaling 2009; 11: 2685-2700

58. Dodd S, Dean O, Copolov DL, Malhi GS \& Berk M. N-acetylcysteine for antioxidant therapy: pharmacology and clinical utility. Expert opinion on biological therapy 2008; 8: 1955-1962

59. Jeng HH, Taylor LJ \& Bar-Sagi D. Sos-mediated cross-activation of wild-type Ras by oncogenic Ras is essential for tumorigenesis. Nature communications 2012; 3: 1168

60. Bellot GL, Liu D \& Pervaiz S. ROS, autophagy, mitochondria and cancer: Ras, the hidden master? Mitochondrion 2013; 13: 155-162

61. Marino G, Martins I \& Kroemer G. Autophagy in Ras-induced malignant transformation: fatal or vital? Molecular cell 2011; 42: 1-3

62. Liang CC, Park AY \& Guan JL. In vitro scratch assay: a convenient and inexpensive method for analysis of cell migration in vitro. Nat Protoc 2007; 2: 329-333

63. Castellano E, Guerrero C, Nunez A, De Las Rivas J \& Santos E. Serum-dependent transcriptional networks identify distinct functional roles for H-Ras and N-Ras during initial stages of the cell cycle. Genome Biol 2009; 10: R123

64. Martin-Encabo S, Santos E \& Guerrero C. C3G mediated suppression of malignant transformation involves activation of PP2A phosphatases at the subcortical actin cytoskeleton. Experimental cell research 2007; 313: $3881-3891$

65. Castro-Castro A, Ojeda V, Barreira M, Sauzeau V, Navarro-Lerida I, Muriel O et al. Coronin 1A promotes a cytoskeletal-based feedback loop that facilitates Rac1 translocation and activation. The EMBO journal 2011; 30: 3913-3927 
FIGURES AND FIGURE LEGENDS

a

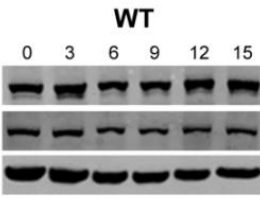

Sos1 KO

Sos2 KO

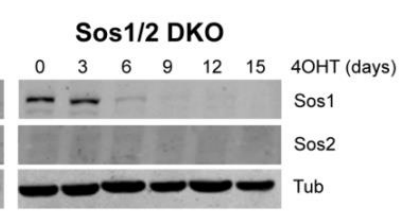

b
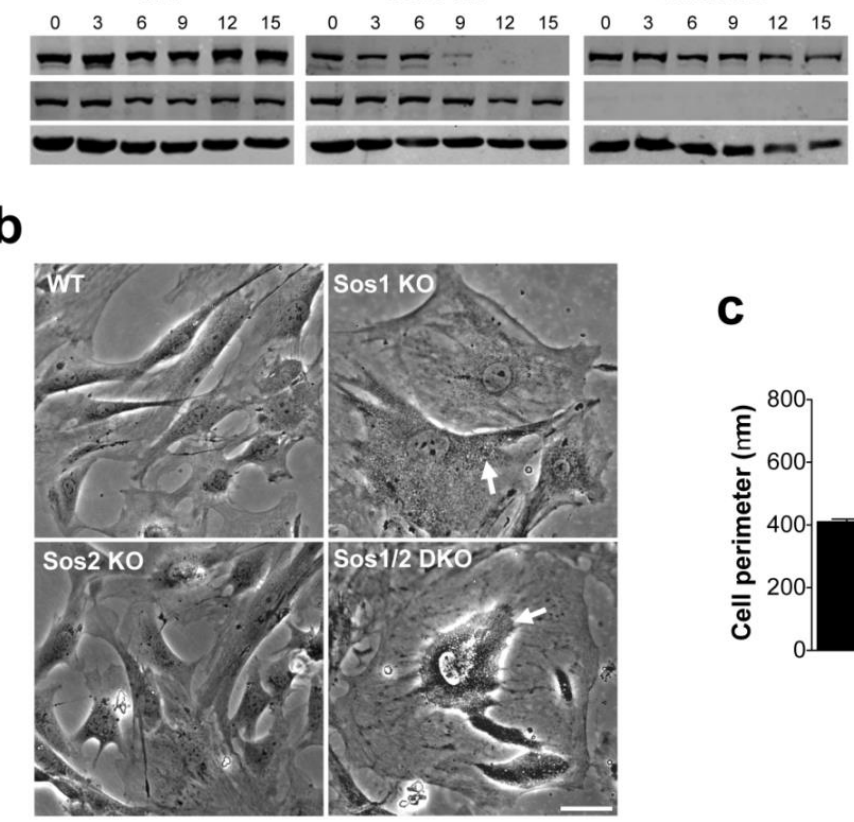

C
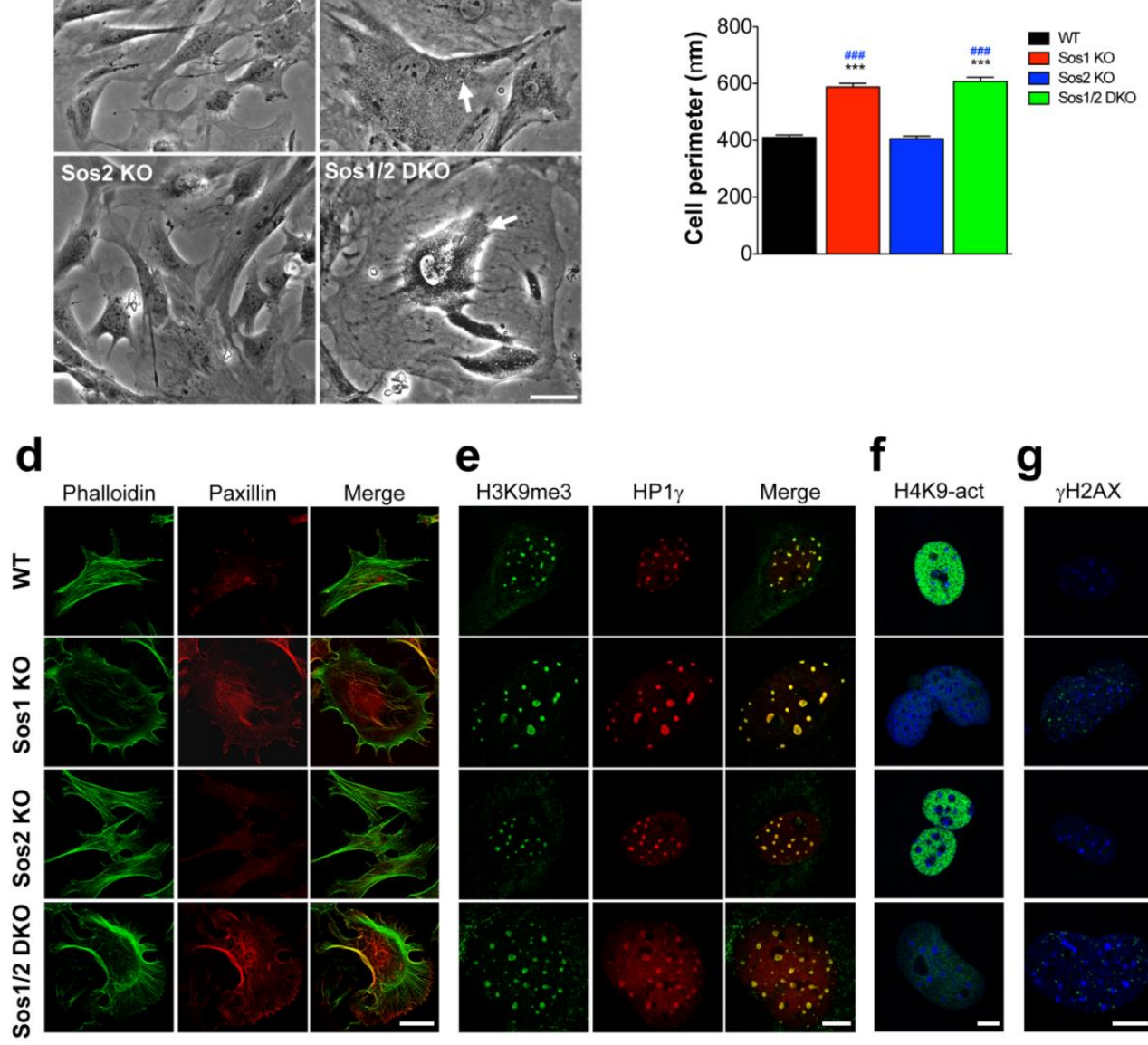

f

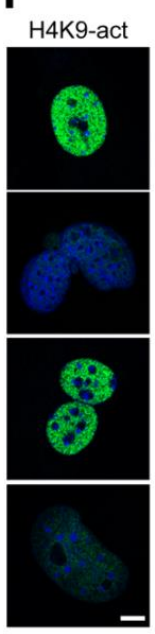

g
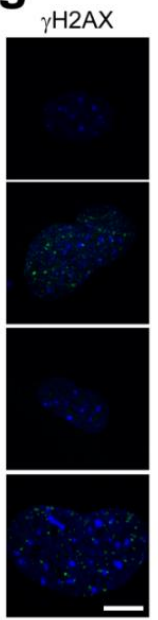

Figure 1. Cellular phenotype alterations linked to genomic disruption of Sos1 and/or Sos2 in primary MEFs. (a) Representative western immunoblots showing the time course of Sos 1 and Sos2 depletion in cultures of primary, early passage $(\leq 8)$ MEFs of the indicated genotypes incubated in the presence of $4 \mathrm{OHT}$ for the times indicated. (b) Representative light microscopic images $(\times 20$ magnification, Nikon Eclipse TE2000 microscope) of live MEF cultures of the four relevant Sos genotypes after growing on culture dishes in the presence of $4 \mathrm{OHT}$ for 9 days. Arrows point to vesicular bodies accumulated in Sos1-depleted cells. Scale bar for all pictures in the panel: $100 \mu \mathrm{m}$. (c) Measurement of the perimeter of individual MEFs of the four indicated Sos genotypes. Images of 300 individual cells of each genotype (originated from three to five separate individual mice in each case) were edited and processed using Metamorf and Image-J software (NIH) to quantify their perimeter length. Data expressed as the mean \pm sem. Statistical values calculated using analysis of variance and Bonferroni post hoc analysis. ${ }^{* * *}$, \#\#\# $\mathrm{P}<0.001$ versus WT and versus Sos2 KO, respectively. (d-g) Representative confocal microscopy images of MEFs of the four relevant genotypes after co-staining for Phalloidin (green) and Paxilin (red) (d); H3K9me3 (green) and HP1Y (red) (e); acetylated histone $\mathrm{H} 4$ and 4,6-diamidino-2-phenylindole (DAPI) (f); and $\mathrm{\gamma H} 2 \mathrm{AX}$ and DAPI (g). Scale bars: $\mathrm{d}: 50 \mu \mathrm{m}$; e-g: $10 \mu \mathrm{m}$. 
0
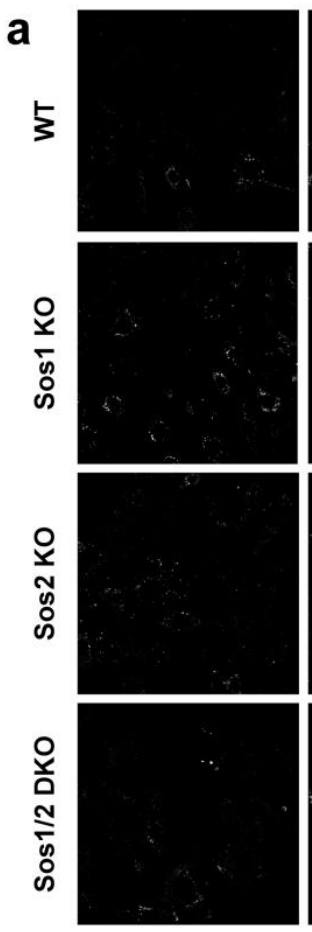

3
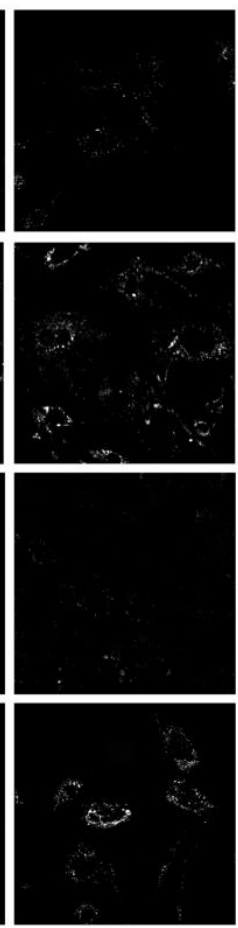

$4 \mathrm{OHT}$ (days)

6
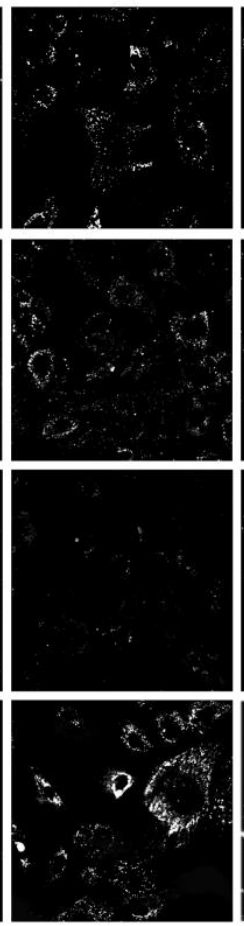

9
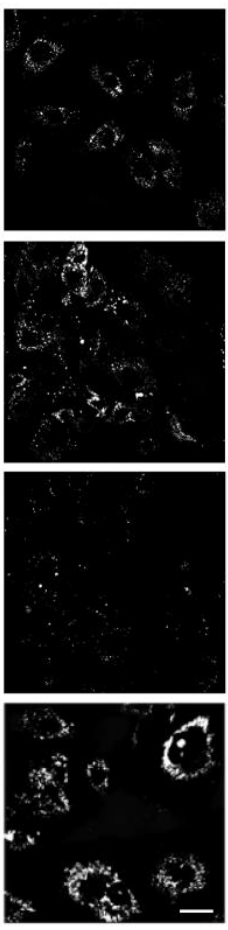

b WT

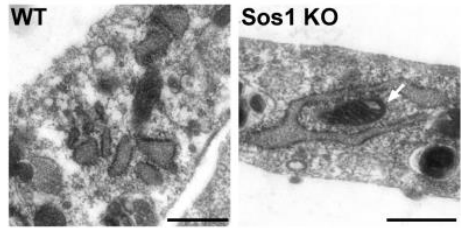

Sos2 KO

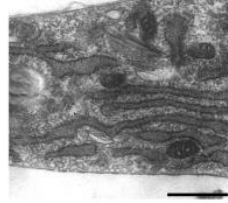

C

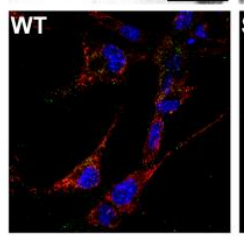

Sos2 KO

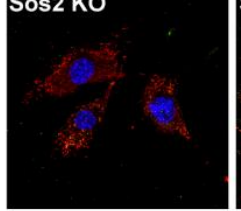

Sos1 KO
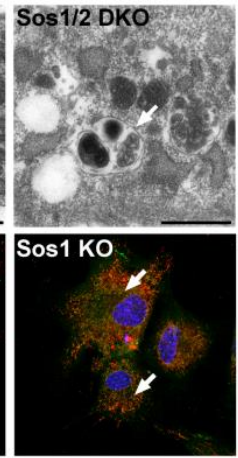

Sos $1 / 2$ DKO

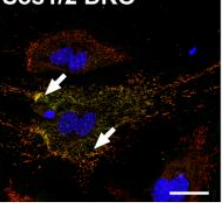

Figure 2. (a) Time-course of lysosome accumulation in MEFs devoid of Sos1. MEF monolayers of the four relevant Sos genotypes were grown in parallel in the presence of $4 \mathrm{OHT}$ for the times indicated and stained in vivo with LysoTracker ${ }^{\mathrm{TM}}$ dye as described in Methods. Scale bar: $50 \mu \mathrm{m}$. (b) Representative electron micrographs of MEFs of the four genotypes. Uranyl acetate and lead citrate staining revealed a significant accumulation of phagosomes containing degraded mitochondria in the cytoplasm of Sos1 KO and Sos1/2 DKO MEFs in comparison to MEFs of the other two genotypes that had been equally treated with $4 \mathrm{OHT}$ for 9 days. Arrows point to mitochondria. Scale bars: $500 \mathrm{~nm}$ for WT and Sos2 KO; $250 \mathrm{nM}$ for Sos1 KO and DKO. (c) Co-localization of autophagic and mitochondrial markers in Sos1-devoid MEFs. MEFs of the four relevant genotypes that had been cultured in the presence of $4 \mathrm{OHT}$ to induce Sos1 deletion and chloroquine to stop autophagic flow were then fixed and doubly immunostained using commercial Mitotracker ${ }^{\mathrm{TM}}$ dye (red) and antibodies against LC3B (green) and photographed under a confocal microscope. Arrows point to areas of colocalization in Sos1-depleted cells. Scale bar for all pictures in the panel: $25 \mu \mathrm{m}$. 
a

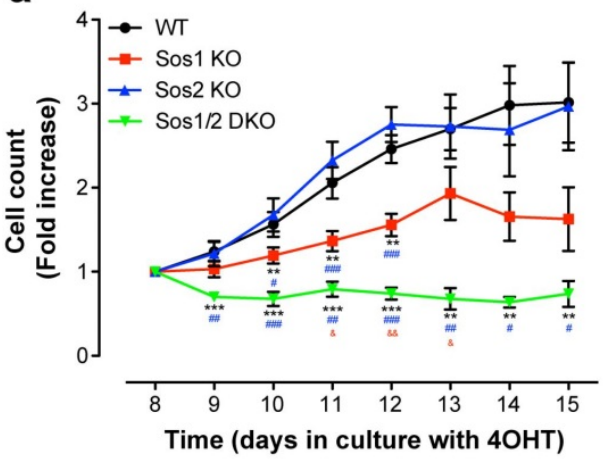

C

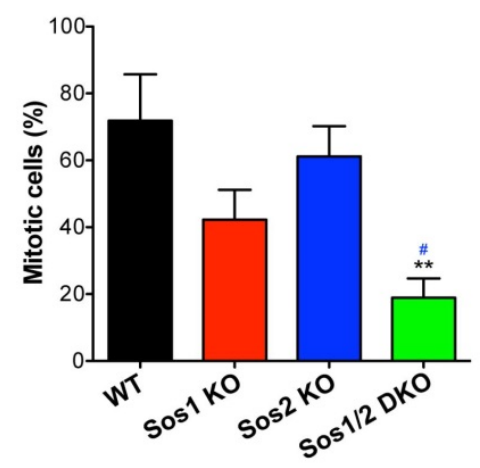

b

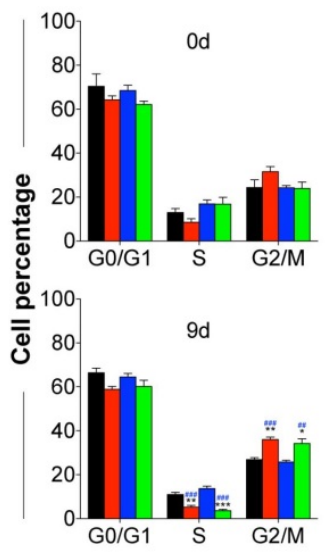

d

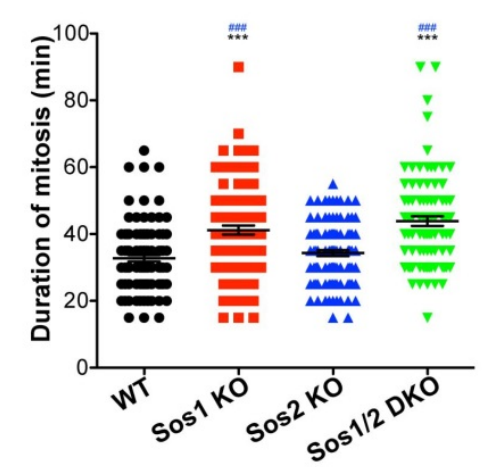

Figure 3. (a) Growth curve of MEFs in culture. Equal numbers of cells (80000/well) of the 4 relevant genotypes that had been previously expanded in 4OHT-supplemented medium for 8 days were seeded in the same medium on plastic multi-well dishes and subsequently the growth curve for each genotype was determined by performing daily cell counts of trypan blue-stained, resuspended cells in each individual well using a Thoma chamber. All determinations were always done in duplicate. Statistical significance: * versus WT; ${ }^{*}$ versus Sos2 KO; ${ }^{*}$ versus Sos1 KO; $n=6 ;{ }^{\#, \&} P<0.05 ;{ }^{* *}, \#, \& \& P<0.01 ;{ }^{* * *}, \# \#+0.001$. (b) Cell cycle phase distribution in MEF cultures. BrdU- and PI-stained cells from subconfluent MEF cultures of the indicated genotypes that were grown in the presence of $4 \mathrm{OHT}$ for the number of days indicated were analyzed using gated flow cytometry as indicated in Methods. Bars represent percentage of the total number of cultured cells that were identified in the indicated phases of the cell cycle. ${ }^{*}$ versus WT; ${ }^{*}$ versus Sos2 KO; $n=6$ for each genotype. ${ }^{*, \#} P<0.05 ;{ }^{* *, \# \#} P<0.01 ;{ }^{* * * *}$

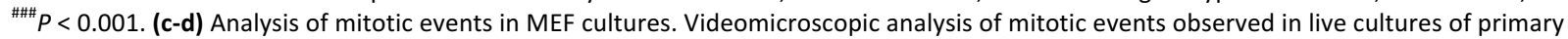
MEFs of the indicated genotypes that were previously starved in culture medium with $0.1 \%$ FBS for $48-52 \mathrm{~h}$ and subsequently re-stimulated for $40 \mathrm{~h}$ in the presence of $20 \%$ FBS. Number of total mitotic events observed and average duration of mitosis were determined in sets of 90-100 individual cells per genotype. * versus WT; ${ }^{\#}$ versus Sos2 KO; $n=6$ for each genotype. ${ }^{\#} P<0.05 ;{ }^{* *} P<0.01 ;{ }^{* * *}, \# \# \#<0.001$. 

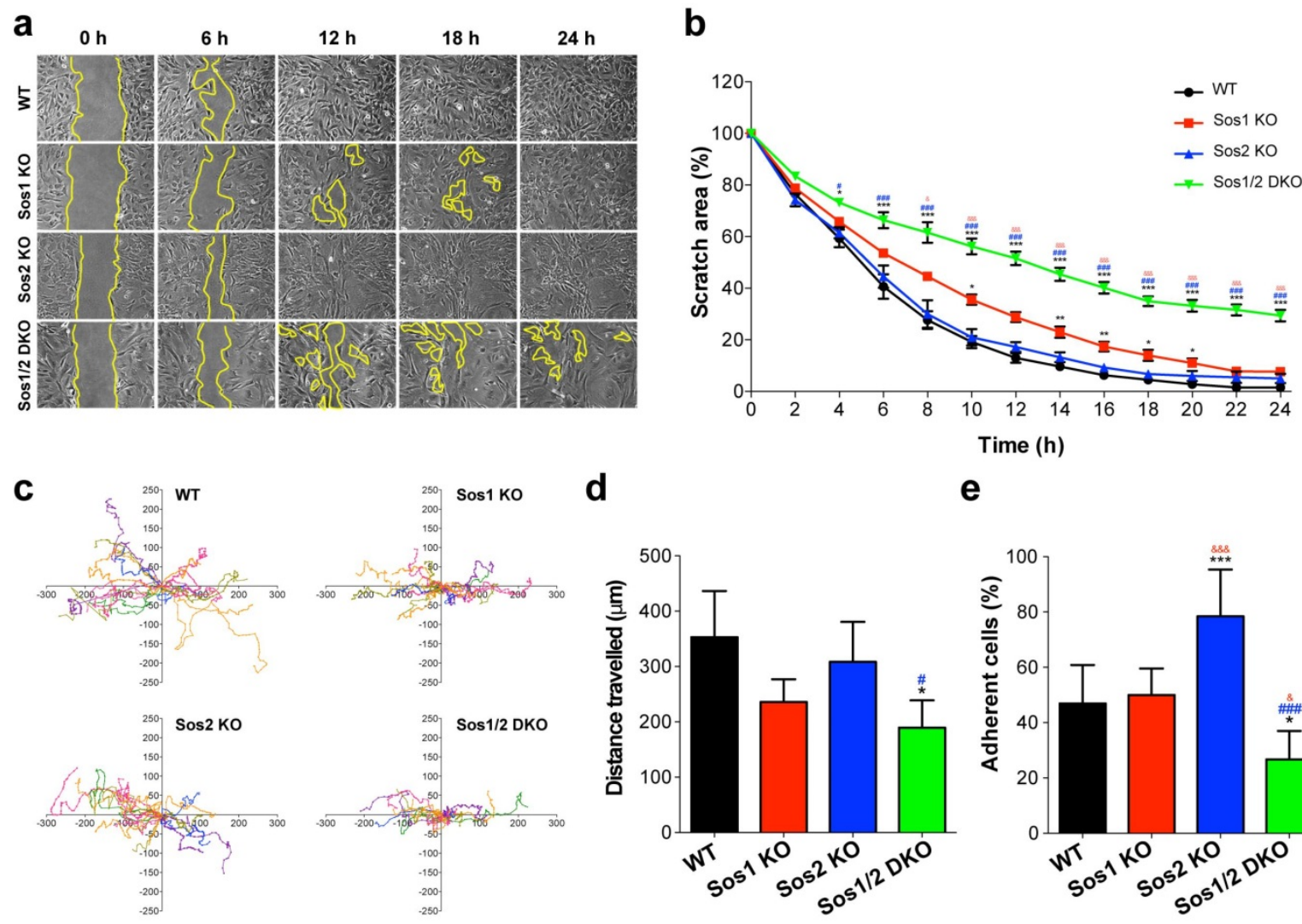

d e
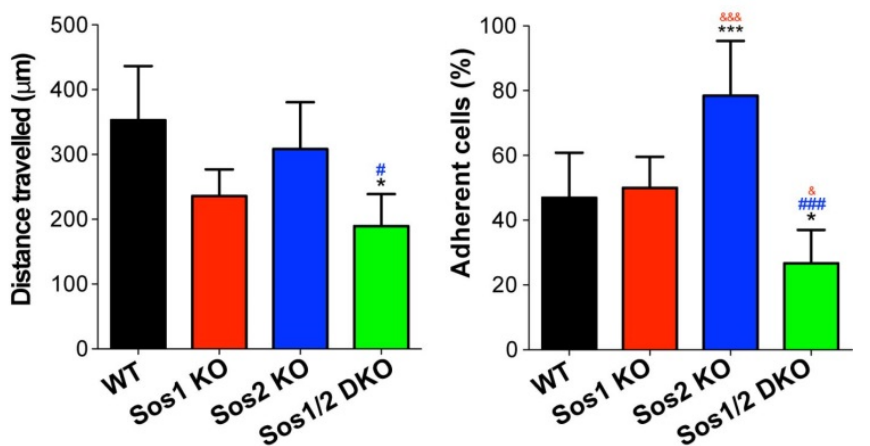

Figure 4. (a-b) In vitro scratch-wound assays. Confluent MEF monolayers of the indicated genotypes were scratched with a micropipette tip and closure of the wounded area was then recorded for $24 \mathrm{~h}$ by phase-contrast photomicroscopy (10X magnification for all pictures) (a). Graph quantitating percentages of the wounded, scratched area still remaining for each genotype at the times indicated (b). Data expressed as the mean \pm sem. ${ }^{*}$ versus WT; ${ }^{\#}$ versus Sos2 KO; ${ }^{\text {v }}$ versus Sos1 KO; $n=6$ for each genotype. ${ }^{*, \#, ~ \& ~} P<0.05 ;{ }^{* *} P<0.01 ;{ }^{* * *}, \# \#$, \&\&\& $P<0.001$. (c-d) Migration tracks of individual MEFs. Time-lapse videomicroscopic $x-y$ tracings of the movement of selected, individual cells recorded during a $12 \mathrm{~h}$ period in the scratch area of live cultures of the four indicated genotypes (c). The recorded videos also allowed quantitation of the average speed and total distance traveled by the individual cells of each genotype (d). 20 independent, non-mitotic cells from 3-5 different lines were recorded for each genotype. $X$ and $Y$ axis values in $\mu \mathrm{m}$. Data expressed as the mean \pm sem. * versus WT; ${ }^{\#}$ versus Sos $2 \mathrm{KO}$; , \# $P<$ 0.05. (e) Cell adhesion assays. Equal numbers of cells previously expanded in the presence of $4 \mathrm{OHT}\left(8 \times 10^{4}\right.$ cells/well) were added onto 12 well microplates containing regular DMEM culture medium. After parallel incubation for $2 \mathrm{~h}$ and washing of the surface of the plates, the adherent cells were resuspended by tripsinization and counted using a Thoma chamber. Data expressed as the mean \pm sem. * versus WT; ${ }^{*}$ versus Sos2 KO; ${ }^{\&}$ versus Sos1 KO; $n=8$ for each genotype; ${ }^{*} \&<<0.05 ;{ }^{* * *}, \# \#, \& \& \&<<0.001$. 

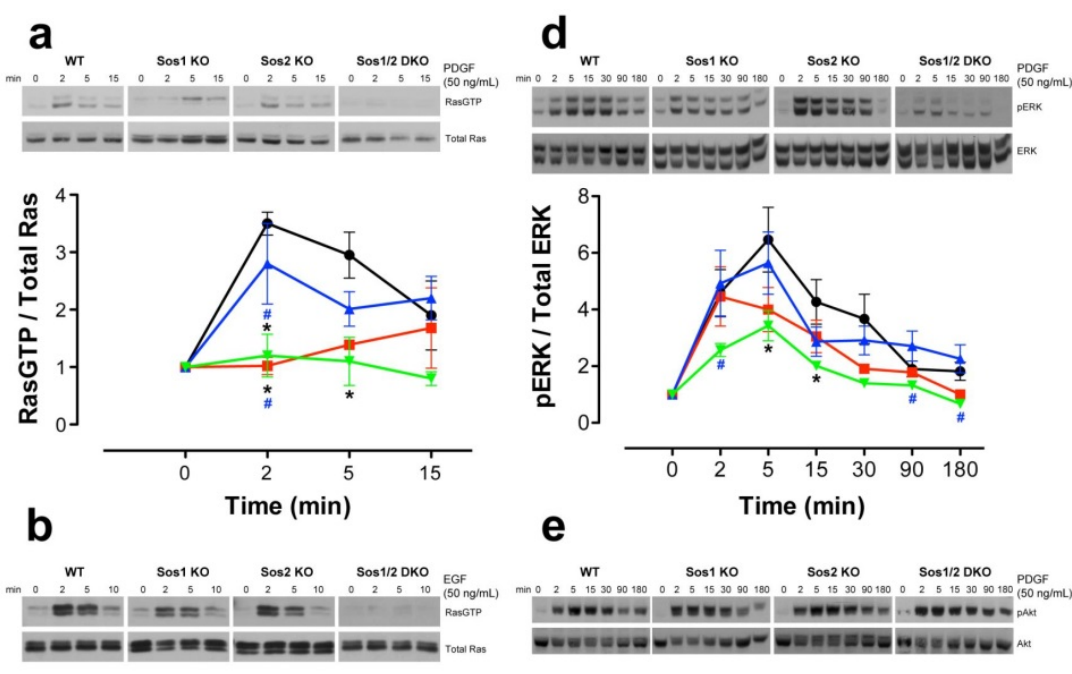

e
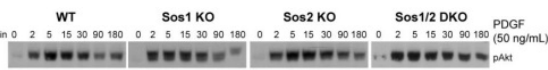

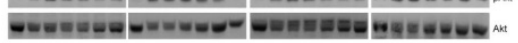
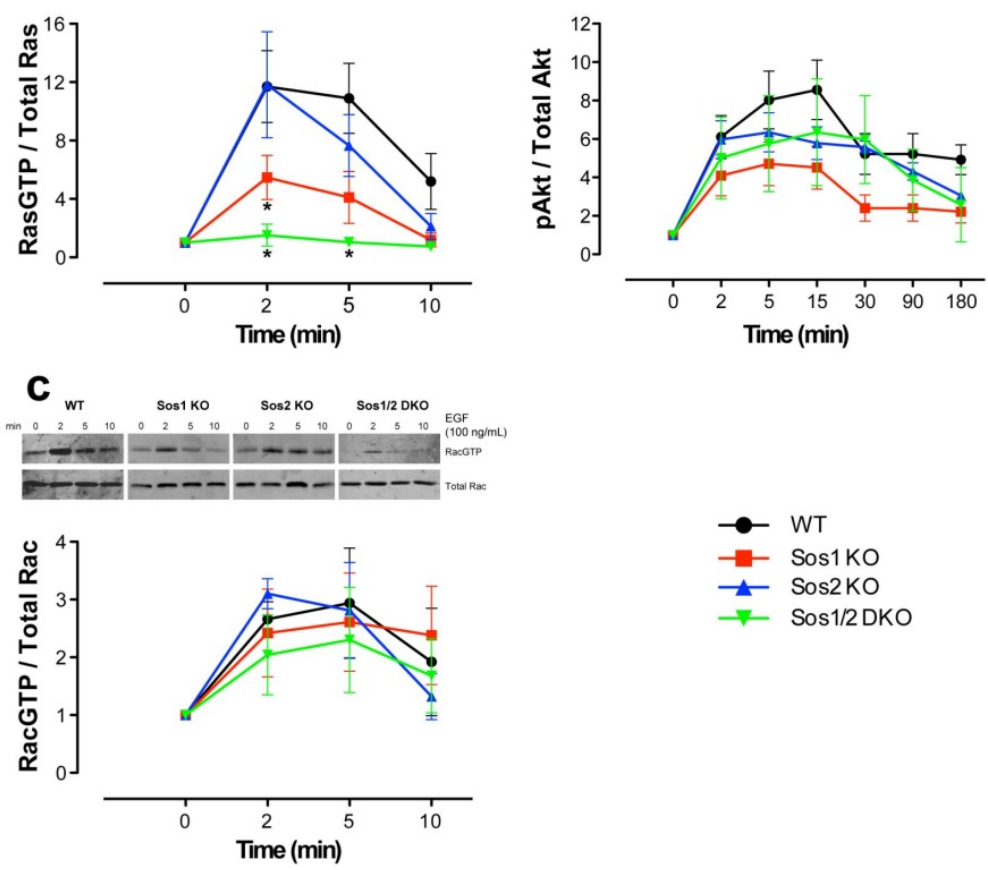

Figure 5. Activation of components of the Ras signaling pathway. Subconfluent cultures of WT (black), Sos1 KO (red), Sos2 KO (blue) and Sos1/2 DKO (green) MEFs grown in the presence of $4 \mathrm{OHT}$ were serum-starved before stimulation with PDGF (50 ng/ml) or EGF (100 ng/ml) and subsequent analysis of the activation of the indicated GTPases and downstream effector kinases. (a) Ras activation. RasGTP pull-down in vivo activation assays performed as described in Methods after PDGF stimulation for the times indicated. Data expressed as normalized ratios between amount of RasGTP and total Ras detected in Western immunoblots using a specific pan-Ras antibody. Data expressed as the mean \pm s.e.m. * versus WT; ${ }^{*}$ versus Sos $2 \mathrm{KO} ; n=6$ for WT; $n=4$ for rest of genotypes ${ }^{*}$ " $P<0.05$. (b) Rac activation. RacGTP pull-down in vivo activation assays were performed as described in Methods after EGF stimulation for the times indicated. Data expressed as normalized ratios between amount of RacGTP and total Rac detected in Western immunoblots using a specific Rac antibody. Error bars $=s$.e.m. $n=6$ for WT; $n=5$ for rest of genotypes. (c) MAPK signaling. Time course of ERK activation after PDGF stimulation. Activation levels expressed as normalized ratios between the amount of phosphoERK and total ERK quantitated by immunoblot assays of MEF extracts with specific antibodies for the phosphorylated and unphosphorylated forms of this kinase. * versus WT; " versus Sos2 KO; $n=9$ for WT; $n=5$ for rest of genotypes. ${ }^{*}, \# P<0.05$. (d) PI3K/AKT signaling. Time course of AKT activation after PDGF stimulation. Activation levels expressed as normalized ratios between the amount of phosphoAkt and total Akt quantitated by immunoblot assays of MEF extracts with specific antibodies for the phosphorylated and unphosphorylated forms of this kinase. Error bars $=$ sem. $n=8$ for WT; $n=5$ for rest of genotypes 


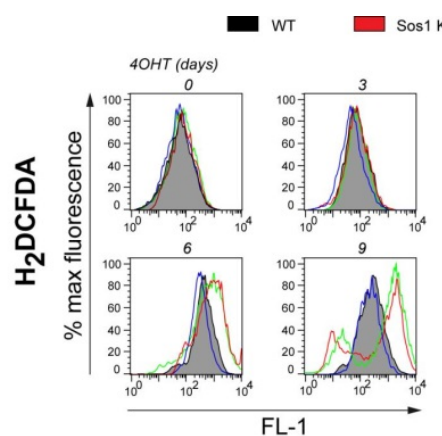

Sos 2 KO $\square$ Sos $1 / 2$ DKO

\section{a}
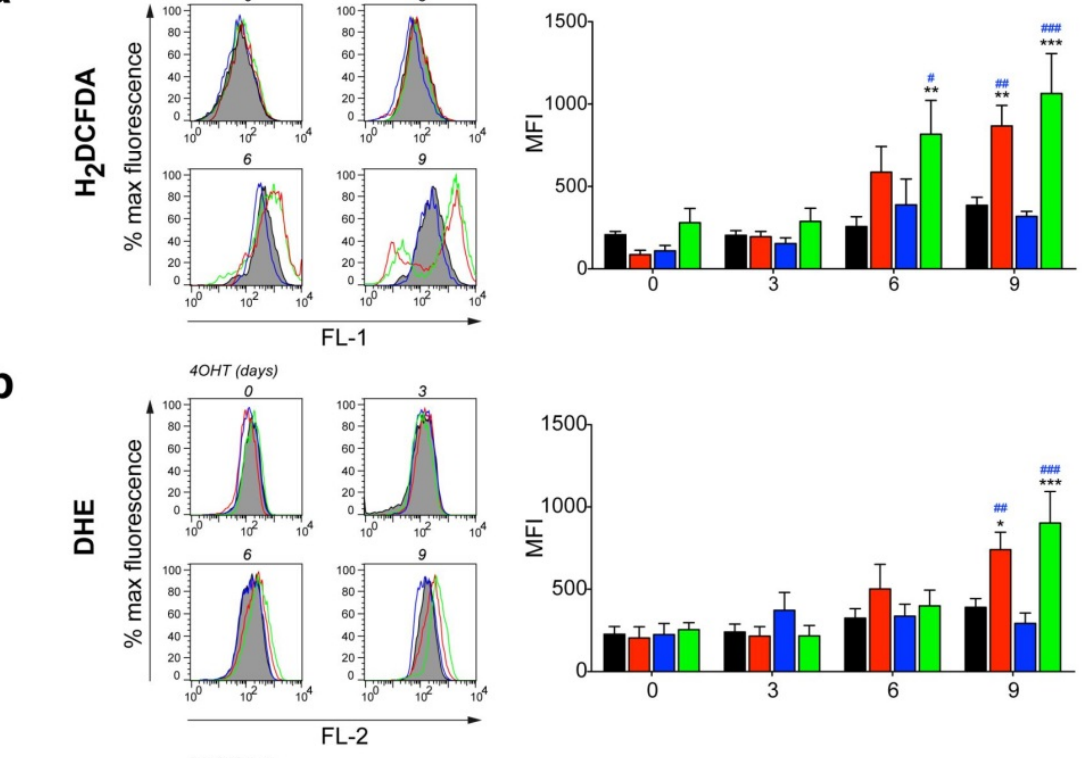

C
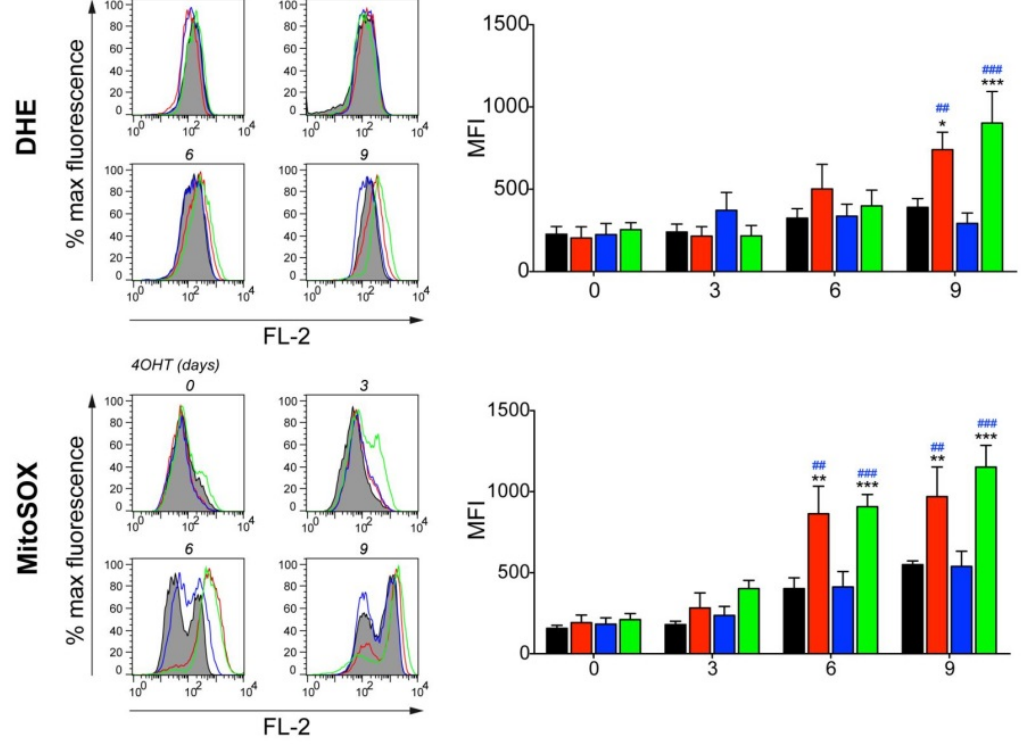

d
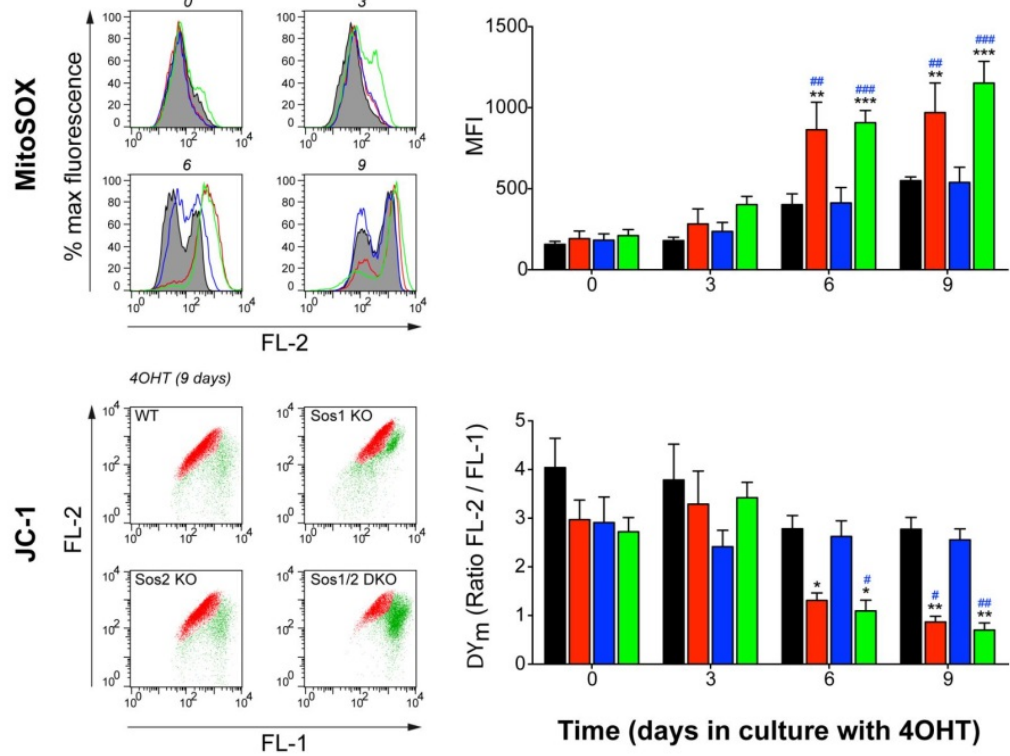

Time (days in culture with $40 \mathrm{OH}$ )

Figure 6. Sos1 depletion and increase of intracellular oxidative stress in MEFs. In vivo measurements of various redox parameters in living, WT (black), Sos1 KO (red), Sos2 KO (blue) and Sos1/2 DKO (green) MEFs cultured on solid dishes under similar conditions in the presence of 4OHT. At the times indicated (0,3, 6 and 9 days) the MEFs $\left(1.5 \times 10^{5}\right.$ cells per assay) were stained with various specific fluorophore probes for the quantification of intracellular ROS $\left(\mathrm{H}_{2} \mathrm{DCFDA}, 5 \mu \mathrm{M}\right)$; intracellular $\mathrm{O}_{2}^{-}$(DHE, $\left.5 \mu \mathrm{M}\right)$; mitochondrial $\mathrm{O}_{2}^{-}$(MitoSOX, $\left.5 \mu \mathrm{M}\right)$ and mitochondrial membrane potential (JC-1, $3 \mu \mathrm{M}$ ) by means of subsequent FACS analysis (10000 events in each case) as described in Methods. Left side: histograms and dot plots showing a single, representative flow cytometric run of MEFs of the four genotypes per each individual fluorophore assayed. FL1: green channel. FL2: red channel. Y-axis scale units in the histograms (\% of Max fluorescence) represent normalized percentages of the maximum fluorescence count detected in each run. Right side: Bar plots showing average FACS fluorescence values calculated for the indicated fluorophores and time points from the data generated in six separate experiments performed per fluorophore. Y-axis units of the bar plots (MFI) represent mean fluorescence intensity units. Quantitative data expressed as mean \pm sem resulting from 6 independent experiments performed for all fluorophores and genotypes, with all determinations run in duplicate. ${ }^{*}$ versus WT; ${ }^{\#}$ versus Sos2 KO; ${ }^{\&}$ vs Sos1 KO; $n=6$ for each genotype ${ }^{*}, \#, \&<0.05 ;{ }^{* *}, \# \#$, \&\& $P<0.01 ;{ }^{* * *}, \# \#+0.001$. (a) Determination of intracellular levels of reactive oxigen species (ROS) in MEFs by means of $\mathrm{H}_{2}$ DCFDA. (b) Determination of intracellular levels of cytosolic superoxide anion $\mathrm{O}_{2}{ }^{-}$in MEFs by means of DHE. (c) Determination of mitochondrial levels of superoxide $\mathrm{O}_{2}{ }^{-}$in MEFs by means of MitoSOX. (d) Determination of mitochondrial membrane potential $(\Delta \Psi \mathrm{m})$ in MEFs by means of JC-1 
a

WT

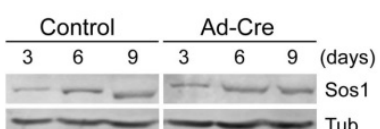

Sos1 KO

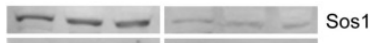

Sos1 KO

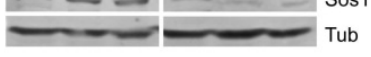

Sos2 KO

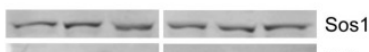

Sos2 KO

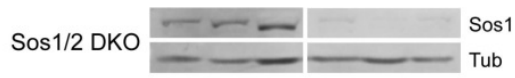

b

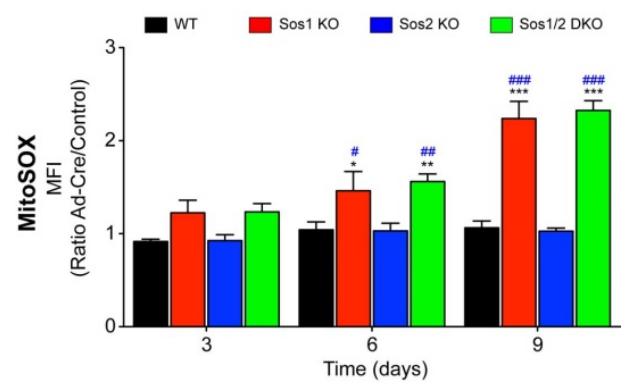

Figure 7. Measurement of cellular oxidative stress in MEFs after infection with viral adeno-Cre. (c) Representative western immunoblots showing time course of Sos1 depletion in cultures of early passage MEFs of the indicated genotypes that were kept untreated (Control, left panel) or infected with $300 \mathrm{MOI}$ of Ad5CMVCre-eGFP (Ad-Cre, right panel) for the times indicated (days). (d) MitoSOX quantitation of in vivo levels of mitochondrial superoxide $\left(\mathrm{O}_{2}{ }^{\circ}\right)$ in cultured MEFs of the four relevant genotypes after infection with viral adeno-Cre for the indicated times (days). $\mathrm{Y}$ axis units in the bar plot represent ratios between the fluorescence intensities (MFI) of adeno-Cre-treated and untreated, control MEF samples. Data expressed as mean \pm sem resulting from three independent experiments. ${ }^{*} \mathrm{P}<0.05$ versus WT; \# versus Sos2 KO; $\mathrm{n}=3$ for each genotype. ${ }^{* *},{ }^{\# \#} \mathrm{P}<0.01 ;{ }^{* * *},{ }^{\# \# \#} \mathrm{P}<0.001$. 

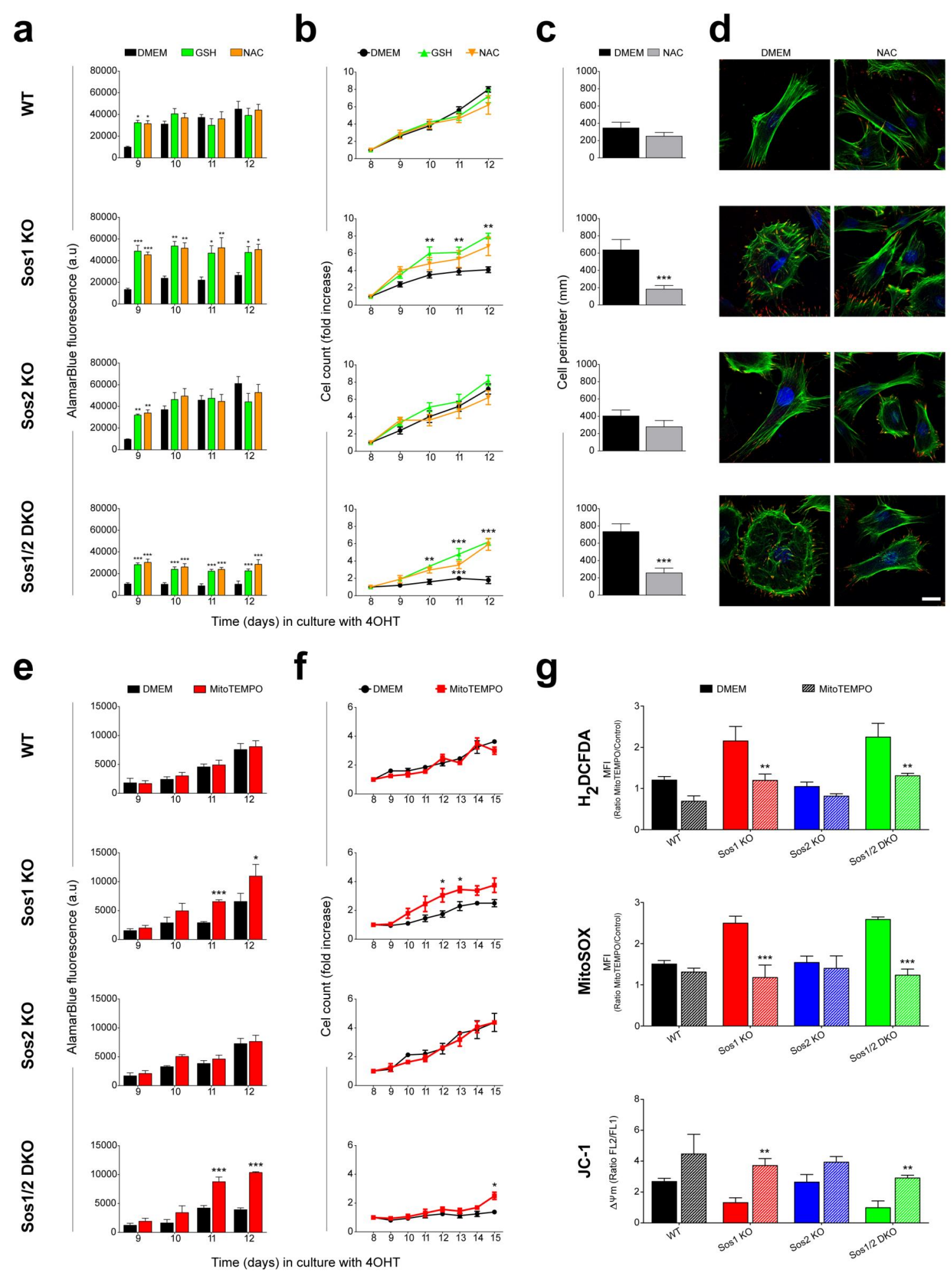


\section{In vitro analysis}

Figure 8. Rescue of defective phenotypes of Sos1-devoid MEFs by antioxidants. (a-d) Treatment with cellular antioxidants Glutathione (GSH) and N-acetyl-cysteine (NAC). Primary MEFs of the four relevant Sos $1 / 2$ genotypes that had been previously expanded for 8 days in the presence of $4 \mathrm{OHT}$ to insure depletion of Sos 1 in the pertinent strains were seeded onto 96 -well $\left(1.5 \times 10^{3}\right.$ cells per well, panel a) or 24 -well $\left(2 \times 10^{4}\right.$ cells per well, panel b) plastic dishes in complete DMEM medium containing $40 \mathrm{HT}$. $24 \mathrm{~h}$ after seeding, the indicated antioxidants Glutathione (GSH 10mM), N-acetyl-cysteine (NAC $10 \mathrm{mM}$ ) were added to the cultures and the metabolic activity and cellular viability of the untreated (DMEM) and treated (GSH, NAC) MEF cultures was quantitated for 4 additional days by means of AlamarBlue fluorescence assays (panel a) or by direct cell count (panel b) as described in Methods. (a) AlamarBlue assays of metabolic activity and cellular viability. Histogram representation of changes of AlamarBlue fluorescence over time. Data expressed as the mean \pm sem from six different experiments, where each individual data point was the mean of measurements made in six individual wells in each case. * versus untreated control MEFs. $n=6,{ }^{*} P<0.05 ;{ }^{* *} P<0.01 ;{ }^{* * *} P<0.001$. (b) Cell count proliferation growth curves. MEFs were resuspended by trypsinization and counted using a Thoma chamber. Data expressed as the mean \pm s.e.m from six different experiments, where each individual data point was the mean of measurements made in six individual wells in each case. ${ }^{*}$ versus untreated control MEFs. $n=6,{ }^{* *} P<0.01 ;{ }^{* * *} P<0.001$. (c) Changes of cell perimeter caused by antioxidants. Perimeter measurements of WT, Sos1 KO, Sos2 KO and Sos1/2 DKO MEFs after growing on dishes for 9 days in 4OHT-supplemented DMEM medium in the presence (NAC) or the absence (DMEM) of 10 mM NAC. 300 individual cells per genotype were measured in each of 6 separate experiments. ${ }^{*}$ versus untreated, same genotype. $n=6 .{ }^{* * *} P<0.001$. (d) Morphological reversal of Sos1-depleted MEFs by NAC treatment. Representative confocal microscopy images of MEFs of the four relevant genotypes after co-staining for Phalloidin (green) and Paxilin (red). Scale bar: $25 \mu \mathrm{m}$ for all photographs in the panel. (e-g) Treatment with the mitochondrial superoxide scavenger MitoTEMPO. Primary MEF cultures of the four relevant Sos genotypes that had been previously expanded for 7 days, in the presence or absence of $4 \mathrm{OHT}$, were supplemented with $100 \mu \mathrm{M}$ of a specific mitochondrial superoxide scavenger (MitoTEMPO) or kept untreated (DMEM) under the same culture conditions. After 24 hours (day 8), the MEFs were plated onto plastic, 96 well dishes $\left(1.5 \times 10^{3}\right.$ cells per well, for analyses of metabolic activity and cellular viability by AlamarBlue assays, panel e), 24 -well dishes ( $2 \times$ $10^{4}$ cells per well, for analysis of the growth curve, panel f), or 6 -well dishes $\left(1.5 \times 10^{5}\right.$ cells per well, for FACS measurements of intracellular ROS levels using specific fluorescent probes, panel g). (e) Histogram representation of AlamarBlue fluorescence levels measured in 4OHTtreated MEFs grown in the presence (red bars) or the absence (black bars) of MitoTEMPO for the indicated number of days in culture. (f) Cellular proliferation curves of MitoTEMPO-treated (red) and -untreated (black) MEF cultures during the indicated time period (days). MEFs were resuspended by trypsinization and cell counts determined by using a Thoma chamber. Data expressed as the mean \pm sem from 4 different experiments, where each individual data point was the mean of measurements made in six individual wells in each case. ${ }^{*}$ versus untreated control MEFs. $n=4,{ }^{*} P<0.05$. (g) In vivo quantification of several redox parameters in MitoTEMPO-treated (colored bars crossed by diagonal lines) and -untreated (solid colored bars) MEFs of the 4 relevant genotypes (each identified by the indicated color). FACS fluorescence measurements performed (10000 events in each case) on 9 days-old MEF cultures using specific fluorophores for intracellular ROS (H2DCFDA, $5 \mu \mathrm{M}$ ), mitochondrial $2^{-}$(MitoSOX, $5 \mu \mathrm{M}$ ) and mitochondrial membrane potential (JC-1, $\left.3 \mu \mathrm{M}\right)$ as described in Methods. For all conditions and genotypes analyzed, the $\mathrm{Y}$-axis units in the bar plots always represent normalized values calculated as the ratio between the MFI signals measured in MEFs cultured in the presence of 4OHT (Sos1 depleted) and the same MEFs cultured in the absence of 4OHT

(Sos1 expressed). Data expressed as mean \pm sem of four different experiments $(n=4)$. Statistical ${ }^{*} p$-values comparing MitoTEMPO-treated versus untreated cultures in each genotype, with all determinations run in duplicate. ${ }^{* *} P<0.01 ;{ }^{* * *} P<0.001$. 


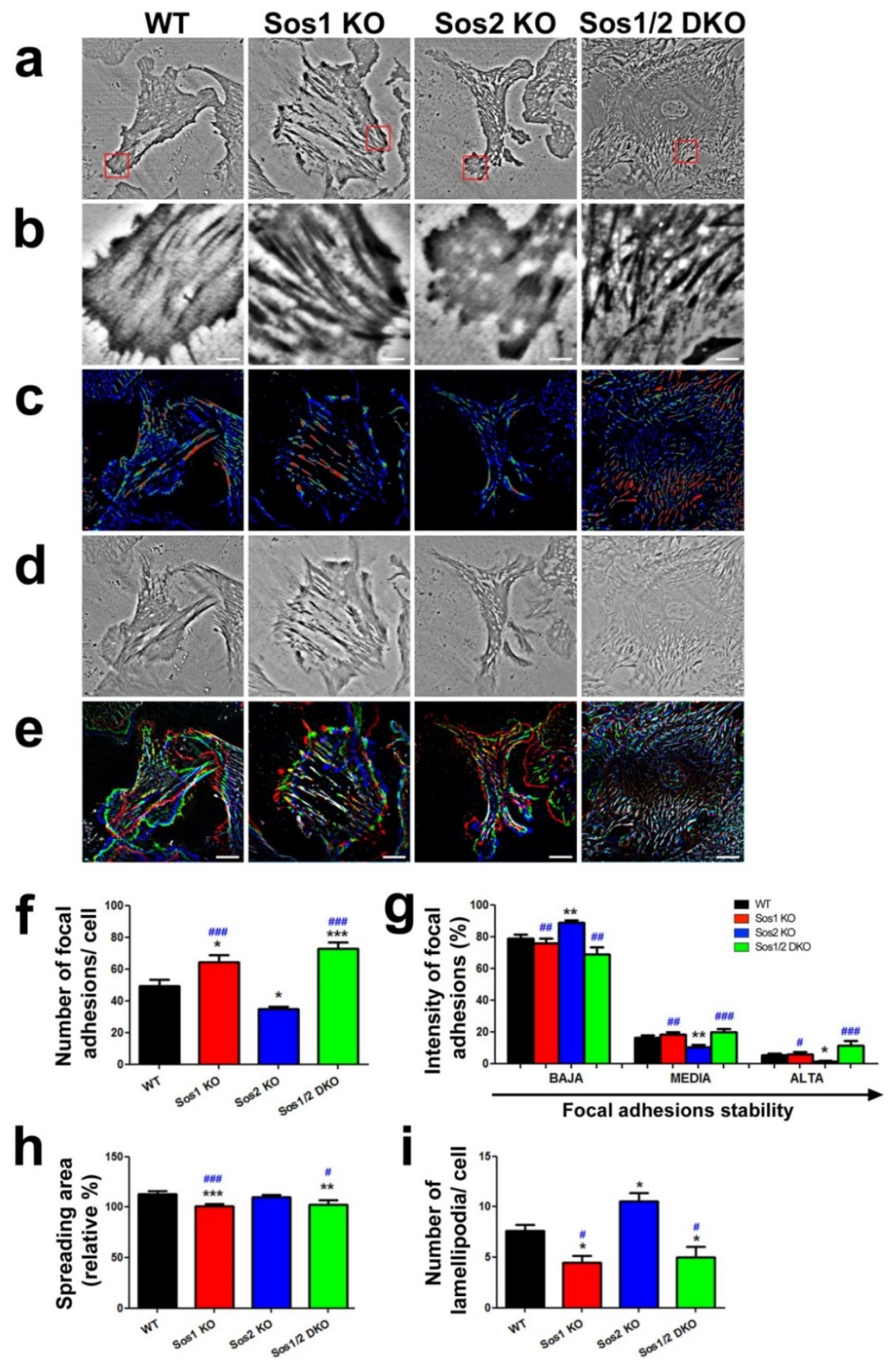

Figure SD1: (a) IRM representative images from MEFs WT, Sos1 KO, Sos2 KO and Sos1/2 DKO MEFs after 9 days of 4OHT treatment. Squared boxes showed magnification in (b). (b) Magnification of focal adhesions of the leading edge in individual cells. Scale bar: $10 \mu \mathrm{m}$. (c) Individual MEFs represented in three colors (blue, green and red) that represent focal adhesion stability throughout the experiment (60 $\mathrm{min}$ ) from low to high stability, respectively. (d) Representative images of cell spreading area in individual MEFs from all experimental groups. Overlapping image from time-lapse images (1 image every $20 \mathrm{sec}$ for $60 \mathrm{~min}$ ). (e) Cell perimeter represented with three individual colors: red, green and blue. These colors correspond with relative position of those individual cells at 0,30 and 60 min, respectively. Indeed, colored converged sites (white) represent stable focal adhesions during $60 \mathrm{~min}$. Scale bar: $25 \mu \mathrm{m}$. (f) Number of focal adhesions/cell. n=12/genotype. (g) Quantification of intensity of focal adhesions expressed in percentage that represents the stability of focal adhesions=9/genotype. (h) Quantification of spreading area in the four experimental groups expressed as total area/initial area. $\mathrm{n}=10 /$ genotype. (i) Number of lamellipodia/cell in individual cells from all experimental groups. $n=12 /$ genotype. Data expressed as the mean \pm sem. ${ }^{*}, \quad \mathrm{P}<0.05, * * /^{\# \#} \mathrm{p}<0.01$ and $* * * /^{\# \#} \mathrm{p}<0.001$ vs WT and Sos2 KO, respectively. 
In vivo analysis

\section{FUNCTIONAL ROLE OF THE SOS1 AND SOS2 RAS-GEFS IN MOUSE SKIN HOMEOSTASIS AND CARCINOGENESIS}

\section{ABSTRACT}

Ras proteins cycle continuously between active (RasGTP) and inactive (RasGDP) states and this process is controlled by negative and positive regulators. The Sos-family of Ras activators comprises two highly homologous but functionally different isoforms, Sos1 and Sos2. Previous studies documented that Ras signaling is essential for skin homeostasis and carcinogenesis. In addition, Sos upregulation results in development of skin papillomas in mice.

Using TAM-inducible Sos1- and Sos1/2 DKOs mice, we have assessed whether Sos proteins play a role in skin homeostasis under physiological and pathological conditions. Our data showed that Sos1 depletion caused a general alteration of skin homeostasis, reduced keratinocyte proliferation, affected hair follicle and blood vessels integrity in the dermis and altered the adipose tissue of hypodermis. These modifications in the skin homeostasis became worse when both Sos isoforms were absent. Involvement of Sos isoforms upon skin wound healing was also evaluated. Simultaneous Sos $1 / 2$ disruption resulted in a practically blockade of wound repair, consistent with a reduction of cell proliferation and migration as well an almost ablated neutrophil-mediated inflammatory response to the injury site. Finally, Sos1 disruption delayed tumor initiation and decreased Ras-driven tumor promotion in DMBA/TPA-induced skin carcinogenesis. Moreover, Sos1 absence prevented malignant tumor formation. In addition, deletion of Sos1 isoform in preexisting chemically-induced papillomas resulted in a decrease in tumor growth by reducing keratinocyte proliferation.

Our results unveil new, previously undefined, roles for Sos proteins in the maintenance of skin homeostasis but also regulating different biological processes upon skin injury. These observations support the consideration of Sos proteins as potential therapeutic targets in prevention and/or treatment of Ras-driven epidermal cancer tumors.

\section{INTRODUCTION}

Ras proteins are critical signal transduction regulators controlling signaling pathways that regulate different biological processes such us cell proliferation, differentiation, migration and survival in different tissues cell types or at different developmental stages. These small GTPases are continuously cycling between inactive (Ras-GDP) and active (Ras-GTP) conformations in a process 
modulated by cellular negative (GTPase activating proteins, Ras-GAPs) and positive (Guanine nucleotide Exchange Factors, Ras-GEFs) regulators (Buday and Downward, 2008)' (Hennig et al., 2015)' (Castellano and Santos, 2011)' (Cherfils and Zeghouf, 2013). Among the main mammalian RasGEF families (Sos, GRF and GRP), the Sos proteins are the most widely expressed and functionally relevant with regards to Ras and Rac activation by upstream cellular signals (Pierre et al., 2011b)'(Rojas et al., 2011).

Ras activation by point mutation leads to a variety of pathological alterations including multiple tumor types (sporadic mutations) and various developmental syndromes (inherited mutations; (Castellano and Santos, 2011)' (Fernandez-Medarde and Santos, 2011b)). However, it is unknown whether potential, alternative activation mechanisms, including hyperactivation of Ras-GEFs or dysregulation of other components of Ras mediated signaling, may also result in physiological or pathological alterations.

The Sos family of GEFs encompasses two highly homologous members, Sos1 and Sos2, which are ubiquitously expressed and function in multiple signaling pathways promoting Ras activation downstream of a wide variety of receptor tyrosine kinases as well as some cytokine and G proteincoupled receptors (Rojas et al., 2011). Because of their structural homology and expression patterns, the specific functional properties of Sos1 and Sos2 have not yet been clearly defined. Our prior analyses of constitutive knockout strains showed that Sos1 constitutive null animals die during midembryonic gestation (Qian et al., 2000), whereas adult Sos2 knockout mice are perfectly viable and fertile (Esteban et al., 2000). Characterization of isolated Sos1 and Sos2 KO MEFs also revealed a critical requirement of Sos1, but not Sos2, for transformation by upstream tyrosine kinases and for maintenance of long-term Ras-MAPK activation (Qian et al., 2000). The generation of conditional Sos1 null mutants (Kortum et al., 2011) made possible to address previously unanswered questions regarding the viability of adult mice systemically expressing Sos1 null mutations, or the functional specificity and/or redundancy of Sos1 and Sos 2 in specific cell lineages and tissues under physiological and pathological conditions. In this regard, it was successfully bypassed the lethality of homozygous Sos1-null mutations by placing a floxed Sos1-null allele under the control of a tamoxifen-inducible Cre allowing full-body deletion of the targeted Sos1 gene and subsequent analysis of resulting phenotypes in adult mice (Baltanás et al., 2013). Sos1/2 DKO animals died precipitously, whereas single Sos1- or Sos2-deficient mice were viable, suggesting functional redundancy between Sos1 and Sos2 for lymphopoiesis, organismal homeostasis and survival (Baltanás et al., 2013). The availability of 
viable Sos1- and Sos1/2-null mutants allowed to address previously unanswered questions regarding functional specificity and/or redundancy of Sos1 and Sos2 in specific cell lineages or tissues. In this regard, our recent study performed in primary mouse embryonic fibroblasts documented that single Sos1- but no single Sos2-deletion decreased cell proliferation rate, altered cell morphology and reduced cell migration, through and increase in mitochondrial oxidative stress (Liceras-Boillos et al., 2016). However, the specific role of Sos proteins in a large number of cell lineages and tissues under physiological and/or pathological conditions has not been still examined.

Ras activation and subsequent signaling pathways have been demonstrated to be critical during skin development and homeostasis (Doma et al., 2013; Drosten et al., 2014b; Kern et al., 2011b). In addition, Ras-mediated signaling pathway also participates during tissue remodeling upon skin injury and even during of skin tumor development (Kern et al., 2011)'(Doma et al., 2013). In this regard, an upregulation of members of the Sos family of RasGEFs results in development of skin papillomas with $100 \%$ penetrance (Sibilia et al., 2000b) (Lichtenberger et al., 2010). Although these studies indicate that Sos proteins must be involved in the skin homeostasis and/or in response to skin-related pathological conditions, little is known about the specific role of these proteins in these biological contexts.

Using our viable Sos1- and Sos1/2-null mutants, we aim at evaluating the specific role of Sos proteins in maintenance of skin homeostasis and the healing processes of the skin upon injury. Additionally, potential effects of Sos1/2 disruption, individually or combined, on initiation and/or progression of mouse tumor models of epithelial origin will be investigated by using the widely known two-stage system of DMBA (7,12-dimethylbenz[ $\alpha$ ]anthracene) and TPA(12-0-tetradecanoylphorbol-13-acetate)induced skin tumorigenesis (Perez-Losada and Balmain, 2003). This carcinogenesis model is a twostage carcinogenesis method which recapitulates the nature multistage of human epithelial skin cancer development.

Unraveling the functional peculiarities of Sos proteins using our specifically designed experimental model system is likely to yield significant benefits at the level of physiological knowledge by improving the basic understanding of Sos-dependent cellular signaling mechanisms and pathways. Ascertaining the exact functional contributions of these proteins may also provide a basis for use of these RasGEFs as diagnostic markers or therapy targets in this pathological context.

\section{MATERIAL AND METHODS}




\section{Generation of tamoxifen-inducible, Sos1 null mice}

To bypass embryonic lethality of Sos1 null mice we generated a tamoxifen-inducible, Sos1 null mice as previously described (Kortum et al 2011). Briefly, a mouse strain harboring a floxed version of Sos1 with exon 10 flanked by Lck-CRe-sensitive LoxP sites (Sos1 ${ }^{\mathrm{fl} / \mathrm{fl}}$ (Kortum et al., 2011) was crossed with mice expressing a tamoxifen (TAM)-inducible Cre-recombinase downstream of the RNA polymerase II promoter to generate homozygous (Sos $1^{\mathrm{fl}-\mathrm{Cre}} / \operatorname{Sos} 1^{\mathrm{fl}-\mathrm{Cre}}$ ). To obtain the mice of the four genotypes of interest in this work, these mice were then mated with constitutive Sos 2 null mutant mice (Sos $2^{-1}$ ) as described (Baltanás et al., 2013). Resulting heterozygous Sos $1^{\mathrm{fl-Cre} /+} / \mathrm{Sos}_{2}^{+/-}$mice were interbred to generate four distinct genotypes on a common genetic background used for this work: WT (Sos $1^{+-C r e /+-}$ Cre $/$ Sos $2^{+/+}$), single Sos1 KO (Sos1 $1^{\text {fl-Cre }} /$ Sos $\left.1^{\text {fl-Cre }}\right)$, single Sos2 KO (Sos $1^{+- \text {Cre/+-Cre }} /$ Sos $2^{-/-}$), and Sos1/2 DKO $\left(\operatorname{Sos} 1^{\mathrm{fl}-\mathrm{Cr} / \mathrm{fl}-\mathrm{Cre}} / \mathrm{Sos}^{-1-}\right.$ ). The genotype of animals was determined by PCR as described (Baltanás et al., 2013).

The Cre-ER ${ }^{\mathrm{T} 2}$ recombinase was activated as follows. As TAM is an antagonist of the estrogen receptor, a 10-day washout period habituation with a soy-free diet (Teklad $16 \%$ global protein rodent diet, \#2916; Harlan) was given to the animals prior to the actual TAM treatments. Afterwards, a TAMcontaining chow diet (Harlan; Teklad CRD TAM400/CreER) was administered, and experimental determinations were performed on each specific set of WT and KO animals at various time points. All experimental groups were treated with TAM (after weaning the litters) under identical conditions to exclude any possible off-target effects. The animals were kept, handled, and sacrificed in accordance with current European and Spanish legislation, and all experiments were approved by the Bioethics Committee of our Cancer Research Center.

\section{Role of Sos proteins in physiological conditions}

To examine the functional role of Sos proteins in skin homeostasis, 6-8 weeks-old mice of the four relevant genotypes ( $n=4$ per genotype) receive a 10 -day washout period habituation with a soy-free diet and then, a TAM-containing diet was applied for 12 days. The back skin was shaved $48 \mathrm{~h}$ previous to the end of TAM-treatment. At the end of the experiment, mice were i.p injected with BrdU (100 g/g weight, Sigma, B5002) $1.5 \mathrm{~h}$ before the sacrifice. After euthanasia, the dorsal skin was collected fixed in $4 \%$ of PFA overnight $(\mathrm{o} / \mathrm{n})$ at $4^{\circ} \mathrm{C}$ and embedded in paraffin.

\section{Wound healing assay}

Using sterile biopsy punches (Stiefel ${ }^{\circ}$ ), two round full-thickness excisional wounds of $4 \mathrm{~mm}$ of diameter were performed in the previously shaved dorsal skin of anaesthetized 12 days TAM-treated 
6-8 weeks old mice of WT, Sos1 KO and Sos2 KO ( $n=6$ per genotype). Due to lethality of Sos1/2 DKO mice (Baltanás et al., 2013), this experiment was carried out in 4 days TAM-treated mice of this genotype $(n=6)$. The area of the wound was then measured daily during 10 days after the injury using an electronic caliper (Caliper ${ }^{\circ}$ ). After the last measurement, the mice were euthanized, the skin was isolated and fixed in $4 \%$ of PFA overnight at $4^{\circ} \mathrm{C}$, and paraffin embedded according to standard procedures. A set of animals of the four relevant genotypes were killed 3 days after the injury and the skink was collected and handled as indicated.

\section{TPA-induced hyperproliferation and inflammation}

6-8 weeks old mice of the four relevant genotypes ( $n=3$ per genotype) were TAM-treated for 12 days. Then, dorsal skin was shaved and, after 24 hours, TPA (6.8 nmol/200 $\mu$ lacetone, Sigma, P-8139) was then applied for either one or four consecutive doses (1 dose/day). Twenty-four hours after the last treatment, mice were i.p injected with BrdU (100 $\mu \mathrm{g} / \mathrm{g}$ weight) $1.5 \mathrm{~h}$ before the sacrifice. After euthanasia, the skin was isolated and fixed in $4 \%$ of PFA o/n at $4^{\circ} \mathrm{C}$ and and paraffin embedded.

\section{DMBA-induced apoptosis}

For short-term studies of apoptosis, 6-8 weeks old, 12 days TAM-treated, mice from the four experimental groups were employed. After shaving, a single dose of DMBA (25 nmol in $200 \mu$ of acetone, Sigma, D3254) was applied in the dorsal skin. Twenty-four hours after the treatment the mice were euthanized and the tissue was processed as described above.

\section{DMBA-TPA induced skin carcinogenesis}

Two different models were employed. To analyze the role of Sos proteins in tumor initiation and progression we use "Model 1" of skin carcinogenesis. 6-8 weeks-old, 12 days TAM-treated WT, Sos1 $K O$, Sos2 KO ( $n=13,11,15$, respectively) mice were treated with DMBA and TPA to induce skin tumors (Perez-Losada and Balmain, 2003). Briefly, the dorsal skin was shaved and $48 \mathrm{~h}$ later, the two-stage carcinogenic DMBA/TPA protocol was initiated using a single topic dose of DMBA ( $25 \mu \mathrm{g}$ in $200 \mu \mathrm{l}$ of acetone). After 3 days, the promotion phase was initiated using topic application of TPA ( $1 \times 10^{-4} \mathrm{M}$ in $200 \mu \mathrm{l}$ of acetone, Sigma, P-8139) twice a week for 30 weeks. In the case of Sos1/2 DKO mice ( $n=13)$, this group was TAM-treated 28 weeks after the initiation of DMBA/TPA protocol.

We also investigated the role of Sos1 protein in tumors already established by using "Model 2" of carcinogenesis. Non TAM-treated, 6-8 weeks-old WT $(n=11)$ and Sos1 KO $(n=13)$ mice were subjected to the DMBA/TPA protocol as above described, for 28.5 weeks. Then, they received soy-free diet for 10 days and TAM-containing chow diet was administered for 2.5 or 5 weeks. In both models, the 
number, size and incidence of papilloma was measured weakly. At the end of experiment, mice of all groups of interest were i.p injected with $\mathrm{BrdU}(100 \mu \mathrm{g} / \mathrm{g}$ weight) $1.5 \mathrm{~h}$ before the sacrifice. Tumors were collected, and one set of them were fixed in $4 \%$ of paraformaldehyde $\mathrm{o} / \mathrm{n}$ at $4^{\circ} \mathrm{C}$ and embedded in paraffin.

\section{Histological analysis and immunostaining}

Paraffin-embedded skin samples were cut in $3 \mu \mathrm{m}$ thick sections, and stained with hematoxylin/eosin (H\&E) following standard procedures. The thickness of the different skin layers in the different experimental contexts was measured in vertical cross sections. Tumor sections were analyzed by pathologists to classify them according to their malignancy grade and levels of differentiation, from benign lesions including: papilloma grade 1, 2 and 3, keratoacanthoma (last benign stage) to squamous cell carcinoma (malignant) stage depending on their acanthosis or epidermal thickness, papillomatosis or invaginated buds depth and grade of keratosis (keratinocytes cell death). Sebaceous adenomas were also detected.

For immunohistochemical analysis, paraffin sections were dewaxed, microwaved in citrate buffer $(\mathrm{pH}$ 6), blocked with $0.1 \%$ Triton-X100, $2 \%$ goat serum (Gibco) and 5\% BSA in PBS, and incubated overnight with the specific marker to detect macrophage, mouse anti-F4/80 (1:400, Life Technologies, MF48000) at $4^{\circ} \mathrm{C}$. After exhaustive washing with PBS, sections were incubated with appropriate biotin-conjugated secondary antibodies (all used at a 1:1.000 dilution in PBST) followed 1:200 Vectastain Elite $A B C$ reagent (Vector). The reaction product was visualized by incubating the sections in $0.025 \% 3,3$-diaminobenzidine and $0.003 \%$ hydrogen peroxide in PBS until the desired staining intensity was reached.

For immunofluorescent staining, sections were dewaxed and microwaved in citrate buffer, later washed 3 times in PBS and then blocked with 0.1\% Triton-X100, 2\% Goat serum and 5\% BSA solution in PBS, prior to incubation with primary antibodies overnight at $4^{\circ} \mathrm{C}$. After incubation of primary antibodies, samples were washed 3 times with PBS and the corresponding fluorochrome-conjugated secondary antibodies were applied for $1 \mathrm{~h}$ at room temperature. To specifically detect BrdU expression in proliferating cells, dewaxed sections were denaturalized in $2 \mathrm{~N} \mathrm{HCl}$ at $37^{\circ} \mathrm{C}$ for $1 \mathrm{~h}$, washed extensively in $0.1 \mathrm{M}$ borate buffer, blocked with 5\% BSA in $0.1 \%$ Triton-PBS, and incubated overnight with anti-BrdU antibody. Primary antibodies used in these experiments included rabbit polyclonal anti-keratin 14 (1:5000, Covance, PRB-155P), rat monoclonal anti-BrdU (1:5000, Accurate chemical, OBT00030CX) mouse anti-CD31 (1:2500, BD, \#557355), rabbit polyclonal anti-cleaved 
caspase-3 (1:500, Cell Signaling, \#9661), mouse anti-neutrophil elastase (1:400, Abcam, ab68671). Images from immunofluorescence experiments were captured using a Leica CTR600 microscope. Quantification of both standard and immunofluorescence signals was done manually with ImageJ software.

\section{Aortic ring assay}

8-weeks-old mice from the four relevant genotypes ( $n=5$ per genotype) were TAM-treated for 12 days. Animals were killed and thoracic aortae were gently collected and transferred to Petri dish containing Hanks-PB buffer (Gibco, 14170-088) supplemented with antibiotics ( $50 \mathrm{U} / \mathrm{ml}$ of penicillin, $50 \mu \mathrm{g} / \mathrm{ml}$ of streptomycin and $25 \mu \mathrm{g} / \mathrm{ml}$ of amphotericin B). Aortae were then cut in $1 \mathrm{~mm}$-thick rings with a scalpel, and aortic ring were embedded in Matrigel (BD, 356237) in $3.5 \mathrm{~cm}$ diameter dishes. The plates were then incubated at $37{ }^{\circ} \mathrm{C}$ and $5 \% \mathrm{CO}_{2}$ for $30 \mathrm{~min}$. Then, $1 \mathrm{ml}$ of culture medium containing: DMEM F-12 (Gibco) 20\% of FBS, $50 \mathrm{mg}$ of heparin (Hospira), $15 \mathrm{mg}$ of ECGS (Sigma, E2759), $0.3 \mu \mathrm{M} 4 \mathrm{OHT}, 1 \mathrm{mM}$ of glutamine, $50 \mathrm{U} / \mathrm{ml}$ de penicillin, $50 \mu \mathrm{g} / \mathrm{ml}$ of streptomycin and 25 $\mu \mathrm{g} / \mathrm{ml}$ of amphotericin $\mathrm{B}$, was added to each dish. The plates were maintained at $37^{\circ} \mathrm{C}$ and $5 \% \mathrm{CO}_{2}$ for 8 days. During that time the samples were photographed and vascular sprouts were scored at 1, 3, 5 and 8 days using Zeiss Axiovert 135 microscope. The number of sprouts per ring and the length of the sprouts were measured by using imageJ software ( $V$ 1.6.0).

\section{Statistical analysis}

Statistical analyses were performed with the SPSS v21 software package (SPSS Inc., Chicago, IL, USA) using one-way analysis of variance and Bonferroni's tests and T-test.

\section{RESULTS}

\section{Sos1 is the prevalent RasGEF for maintenance of skin architecture}

We initially examined whether Sos $1 / 2$ protein depletion (individually or in combination) altered skin homeostasis. Histological examination of dorsal skin revealed no differences in the overall skin architecture of Sos2 KO mutants as compared with WT counterparts (Figure 1a). In particular, the thickness of the three epithelial layers were almost identical in both genotypes, with similar keratinocyte organization and hair follicles morphology and distribution in the epidermal layer, a comparable cellularity in the connective tissue of dermis (Figures $1 a, b, f$ ). No significant alterations were observed either in the hypodermal layer of Sos2 KO mutants (Figures 1a,d). In contrast, single Sos1 deletion induced following TAM-treatment resulted in significant reduction of all epithelial 
layers respect to WT and Sos2 KO counterparts (Figure 1). Moreover, combined absence of both Sos proteins caused a severe overall disruption of skin architecture (Figure 1). Epidermal thickness was particularly affected in Sos1/2 DKO mice, exhibiting a noticeable reduction as compared with the rest of groups (Figure 1a,b,f). In these mice, regions in the epidermis were devoid of keratinocytes and exhibited an abnormal keratin deposition in the corneal layer that was not observed in the WT, Sos1 $\mathrm{KO}$ or Sos2 KO dorsal skins (Figure 1b). We also observed distorted hair follicles whose number and size, as also happened in sebaceous glands, appeared diminished as compared with WT counterparts (Figure 1e). Dermal thickness was also reduced in relation to WT and Sos2 KO mice, although exhibited similar values than the Sos1 KO group (Figures 1a,c,g). Similarly to Sos1 KO mice, cellularity in the dermal connective tissue of Sos1/2 DKO mice was significantly decreased in comparison with WT and Sos2 KO mice (Figure 1c). Of note, combined deletion of the Sos $1 / 2$ proteins resulted in a dramatic reduction of hypodermal thickness relative to the rest of genotypes (Figures 1a,d,h). We even detected the complete disappearance of this epithelial layer in several samples from Sos $1 / 2$ DKO mice (Figure 1a). These data suggest that Sos2 single depletion is not required to maintain skin homeostasis or, at least, its absence can be functionally compensated by Sos1. However, Sos1 seems to play a significant role in the maintenance of overall skin architecture. Interestingly, concomitant absence of both Sos proteins profoundly affect skin homeostasis, indicating a functional redundancy of both isoforms for cutaneous organization, although with a prevalent role of Sos1 over Sos2.

\section{Sos1 KO and Sos1/2 DKO mice show decreased keratinocyte proliferation and increased cell apoptosis}

We next examined in detail whether the loss of epidermal thickness observed in Sos1 and Sos1/2 DKO mice skin was a direct consequence of an alteration in the proliferative capacity of keratinocytes and/or if Sos depletion caused apoptosis in some cell type located in that layer. As expected, most BrdU-positive keratinocytes were located in the basal keratinocyte layer and interfollicular epidermis (Figure 2a). Overall, assessment of absolute BrdU-positive keratinocytes counts showed that Sos2 depletion did not affect to proliferative ability of keratinocytes as compared to WT (Figures 2a,c). However, TAM-induced Sos1 deletion in Sos1 KO mice resulted in a significant reduction, by $40 \%$, of proliferative keratinocytes as compared with WT counterpart (Figures 2a,c). Such decrease became even more pronounced in the Sos1/2 DKO mice (Figures 2a,c), an observation which is consistent with the marked reduction of epidermal thickness among Sos1/2 DKO mice described above (Figure 1). 
Immunostaining detecting the expression of cleaved caspase-3 was used to identify apoptotic cells. None or very few cells were found to be cleaved caspase-3 positive in the skin of WT, Sos1 KO, Sos2 $\mathrm{KO}$ mice (Figure $2 \mathrm{~b}$ ). Although the number of apoptotic cells detected was significantly higher in the skin of Sos1/2 DKO mice in comparison with WT and Sos2 KO mice (Figure 2d), it should be noted that the overall number of these cells was too low in the skin of Sos1/2 DKO mice, and probably this slight increase is not involved in the severe alteration of skin homeostasis documented in this group.

\section{Sos1 KO disruption is associated with decreased vascularization and angiogenesis in the skin}

The vasculature in the dorsal skin of TAM-treated mice of the four relevant genotypes was characterized by using CD31 immunostaining. Interestingly, our results documented that TAMinduced Sos1 depletion, in both Sos1 KO and Sos1/2 DKO mice, caused a marked reduction in vascularization of the skin, being particularly noticeable in the dermis, as compared with WT and Sos2 KO counterparts (Figure 3). These observations are consistent with the reduction in the dermal thickness in Sos1-deleted mice reported in Figure 1. The potential role of Sos proteins in angiogenesis was additionally analyzed by using the ex vivo assays of aortic ring (Figure SD1). Our results documented that single absence of Sos1 or Sos2 resulted in a significant reduction of the number of sprouts (Figure SD1b). Interestingly, the formation of the sprouts from the aortic ring was almost fully blocked (Figure SD1b). However, the length of the sprouts was only diminished under simultaneous deletion of Sos1 and Sos2 (Figure SD1c).

\section{Sos1/2 proteins depletion delays tissue remodeling in wounded skin}

It is known that after cutaneous wounding a well-coordinated sequential events occurs that comprises provisional changes in the balance between cell proliferation and differentiation as well as an activation of the immune system. Here we evaluated the effect of Sos $1 / 2$ protein deletion (individually or combined) during cutaneous response to damage.

Two round full-thickness excisions were performed in the dorsal skin of 12 days TAM-treated WT, Sos1 KO, Sos2 KO mice and 4 days TAM-treated Sos1/2 DKO mice, and the healing process was daily measured for 10 days (Figure 4). Our present results showed that the healing time in WT control group took 10 days (Figures $4 a, b)$. The single absence of Sos2 did not alter this process, its kinetic of wound repair was almost exactly the same than that of WT counterpart (Figures 4a,b). By contrast, TAM-induced Sos1 depletion in Sos1 KO mice led to a slight delay in wound closure in relation to WT 
and Sos 2 KO groups, remaining about 15\% of the wound still open at the end of the assay (Figures 4a, b). Interestingly, simultaneous absence of Sos proteins strongly affected to tissue remodeling process. Our results indicated that during the initial phases of healing (days 1-3 after injury), the closure of the wound is very similar in Sos1/2 DKO mice than in the rest of groups (Figure 4a). It should be noted that at this time point, TAM-induced Sos1 depletion in these mice was not complete at this stage. However, from 4 days post-injury onwards, the closed area of the wound remained unchanged, remaining about $40 \%$ of the wound still open (Figures $4 a, b$ ).

The first step in the process of wound healing involves fibrin matrix secretion that not only reduces blood loss, but also participates in tissue repair, immune cell adhesion, endothelial cell adhesion, among others. We did not find differences in fibrin deposition between single Sos mutants (Sos1 KO and Sos2 KO) respect to WT counterparts (data not shown), however, wounds in Sos1/2 DKO mice showed a substantial reduction of fibrin matrix as compared with WT counterpart (Figure 4c).

During initial phases of repair, fibroblasts migrate to the site of injury and synthetize a wide battery of chemical substances to replace lost tissue (Laurens et al., 2006). The mechanical forces that fibroblasts create as they move through the wounded tissue generate mechanical tension, which promotes wound closure. Whereas the contraction of the tissue at the proximity to the wound in WT, Sos1 KO and Sos2 KO mice was similar (data not shown), we did not visualize this phenomenon in Sos1/2 DKO counterparts (Figure 4c).

We next analyzed in detail the events happening during inflammatory and proliferative phases of healing. In WT mice, histological examination showed epidermal hyperplasia in the edge of the wounds, consistent with a clear proliferative and migratory responses of keratinocytes (Figure 4d). In this regard, immunolabeling for BrdU confirmed a profound reduction of proliferative keratinocytes in the edge of the injury as compared with that in WT controls (Figure 4d). Additionally, an increment of the cellularity and blood vessels was documented in the dermis of these mice (Figure 4d). By contrast, Sos1/2 DKO mice did not exhibit hyperplasia in the epidermis of the wound edge. Moreover, no significant increment of either cellularity or blood vessel as response to the injury were observed in the dermis of this experimental group (Figure $4 \mathrm{~d}$ ).

\section{Sos1, but not Sos2-depletion, impairs initiation and promotion of DMBA/TPA-induced skin tumors}

Our previous data suggested an important role of the Sos proteins to maintain skin homeostasis under physiological conditions and after injury. We next aimed to evaluate the role of Sos proteins 
during the initiation and promotion phases of DMBA/TPA-induced skin carcinogenesis. Mice from WT, Sos1 KO and Sos2 KO groups were TAM-treated for 12 days prior to initiation with model 1 DMBA/TPA protocol (see Material and Methods). As indicated, the application of this protocol in Sos1/2 DKO group was limited due to vulnerability of these mice (Baltanas et al, 2013). Although they were DMBA/TPA-treated in the same way that the rest of groups, mice from this genotype did not receive TAM-administration previous to the initiation of the chemically-induced carcinogenesis, but from 30 weeks after initiation of carcinogenesis, so this group was referred as "Sos $1 / 2$ DKO inducible".

Our results documented that TAM-induced Sos1 deletion caused a delay of tumor development compared with WT control group (Figure 5c). By contrast, single Sos2 protein absence had not impact in DMBA/TPA-induced skin carcinogenesis, in comparison with WT counterparts (Figure 5c). Of note, tumor initiation in Sos1/2 DKO inducible was faster than in the rest of mice groups (Figure 5c). This could be explained because this group lacked TAM-treatment at this stage of analysis, which could indicate an off-target effect of TAM by retarding tumor initiation. Additionally, both the average number of tumors per mouse and tumor size were significantly reduced in Sos1 KO mice as compared with WT group (Figures $5 \mathrm{~d}-\mathrm{g}$ ). In contrast, Sos2 lacking mice showed similar number and size of tumors than WT mice (Figures $5 \mathrm{~d}$-g). Additionally, our present results showed a noticeable reduction in both number and size of tumors in Sos1/2 DKO inducible group upon TAM-administration (Figure $5 d)$. These results were consistent with the marked reduction of proliferative keratinocytes detected in Sos1-depleted tumors (Sos1 KO and Sos1/2 DKO) as compared with tumors collected from WT and Sos2 KO mice (Figures 6a,b). However, assessment to analyze cell death showed that single Sos protein (Sos1 or Sos2) absence did not sensitize skin tumor cells to apoptosis (Figures 6a,c). Although combined Sos depletion statistically increased the percentage of apoptotic cells into the tumor respect those in WT, Sos1 KO and Sos2 KO mice, it should be noted the total number of apoptotic cells in Sos1/2 DKO mice was to low, probably without any significant biological involvement in tumor number and size decreased detected in these mice.

\section{Both Sos1- and Sos1/2-depletion reduces TPA-mediated hyperproliferation but do not sensitizes skin cells to DMBA-induced apoptosis}

To further analyze the sequence of events taking place during the initiation and early promotion phases of the carcinogenesis, we performed specific short-term experiments by inducing an 
hyperproliferative, inflammatory and apoptotic responses in the dorsal skin of mice from all experimental groups. This battery of assays additionally allows to evaluate the effect of concomitant lack of both Sos isoforms during the early phases of DMBA/TPA-induced skin cancer.

To determine the role of Sos proteins under hyperproliferative conditions, either one or four consecutive doses of TPA were topically applied in the dorsal skin of TAM-treated mice of the four relevant genotypes. TPA-induced hyperproliferation resulted in a gain in epidermal thickness in all experimental groups (being more pronounced after TPA 1-4 treatment) with respect to physiological conditions (Figures 7a,b,e). Measurement of epidermal thickness documented that the individual absence Sos2 did not affect this epithelial layer upon TPA-treatment with respect WT counterpart (Figures 7a,b,e). By contrast, TAM-induced Sos1 individual depletion caused a slight, although not statistically significant, reduction of epidermal layer respect WT animals (Figures 7a,b,e). Interestingly, this decrease became much more marked under simultaneous disruption of both Sos1/2 proteins (Figures $7 a, b, e)$.

Consistent with the increase of epidermal thickness upon TPA administration, the number of BrdUpositive cells upon TPA application, most of them located in basal and suprabasal epidermal layers, was further increased in the four relevant mice groups in comparison with untreated animals of the respective genotypes (Figures 2 and 7). In concordance with the epidermal disruption detected in TPA-treated Sos1-depleted mice (Sos1 KO and Sos1 DKO), the number of BrdU-positive keratinocytes were equivalently diminished in Sos1 KO and Sos1/2 DKO mice as compared with respective WT control and Sos2 KO counterparts (Figure 7f).

TPA1-4 short-term approach also allowed investigating the role of Sos proteins on neutrophilmediated inflammatory response upon TPA-treatment. Our results evidenced that the thickness of the dermis was reduced in Sos1 KO mice as compared to WT and Sos2 KO groups (Figure 7c). This reduction was even more evident in Sos1/2 DKO mice (Figure 7a). Unexpectedly, the density of neutrophils infiltrated in the dermis of TPA-treated Sos1 KO mice was very similar as compared with WT counterpart (Figure 7g). Moreover, Sos2 absence in Sos2 KO mice resulted in a huge increment of neutrophil infiltration as compared with the rest of experimental groups (Figure $7 \mathrm{~g}$ ). By contrast, combined Sos proteins depletion resulted in an almost total ablation of neutrophil response to inflammatory stimulus (Figure $7 \mathrm{~g}$ ).

Finally, we examined the effect of Sos $1 / 2$ proteins depletion (individually or combined) on DMBAinduced apoptosis, individuals from all experimental groups (WT, Sos1 KO, Sos2 KO and Sos1/2 DKO) 
were topically treated in the back skin with one dose of DMBA. An increased apoptosis was observed in the skin of all experimental groups as compared with untreated mice (Figures 2 and 7). Only dual absence of Sos proteins seemed to slightly sensitize keratinocytes to DMBA-induced apoptosis (Figure $7 d, h)$. By contrast, individual loss of Sos1 or Sos 2 did not alter the apoptosis rate in the skin cells with respect WT control mice (Figure $7 d, h$ )

\section{Sos 1 deletion prevents formation of malignant tumors}

We also investigated the role of Sos proteins in the pathological grade the chemically-induced tumors. Based on histopathologycal analysis, DMBA/TPA-generated tumors that ranged from benign lesions to premalignant lesions and aggressive tumors were characterized and classified for each specific experimental group. Our results showed that about $60 \%$ of the DMBA/TPA-induced tumors in WT mice were papillomas (Figure 8). Although with low frequency, tumors with a higher grade of malignancy including keratoacanthomas and, squamous cell carcinomas were also detected (Figure). The rest of tumors ( $30 \%$ ) were cataloged as sebaceous adenomas (Figure 8). In Sos1 KO, Sos2 KO and Sos1/2 DKO mice, induced tumors were mainly identified as papilloma ( 85\%, Figure 8 ) and benign sebaceous adenoma (15-20\%). Interestingly, differing from the observations in WT mice, no malignant squamous cell carcinomas were detected in the Sos mutant groups (Sos1 KO, Sos2 KO and Sos1/2 DKO). The level of pathology of the papilloma was additionally analyzed in the four relevant genotypes (Figure 8). Similarly, the pathological grade of the papilloma found in WT control mice was higher than that observed in Sos-depleted null mutants (Figure 8).

\section{Sos1 disruption reduces tumor growth in pre-existing papilloma}

To determine whether Sos1 protein depletion could effectively reduce or at least block growth in preexisting tumors, non TAM-treated WT and Sos1 KO mice were subjected to the model 2 of DMBA/TPA carcinogenesis (see Material and Methods). Our results documented a significant reduction of both the number and size of pre-existing tumors in Sos1 KO mice upon TAM application (Figure 9). In addition, it should be noted that the WT group showed a slight reduction in the number of tumors after TAM-treatment, probably reflecting an off-target cytostatic effect of TAM (Figure 9). Such reduction was directly related with a progressive decrease of keratinocyte proliferation in tumors of Sos1 KO mice upon TAM-administration in comparison with WT counterparts (Figure 10). 


\section{DISCUSION}

Here, we have documented the important role of Sos proteins in skin homeostasis under physiological conditions, after skin tissue damage and during an epithelial tumorigenic process. Whereas Ras-mediated signaling is known to play a key function in the skin development (Kern et al., 2011b)'(Drosten et al., 2014), the specific involvement of the RasGEFs family of proteins, Sos, during this processes remains poorly understood.

Our results using comparable sets of mice of four genotypes (WT, Sos1 KO, Sos2 KO and Sos1/2 DKO) sharing the same genetic background, have established a direct correlation between Sos1 protein depletion and the alteration of the skin homeostasis under physiological conditions. These alterations included a profound reduction of skin thickness that was correlated with a decrease in keratinocyte proliferation and epidermal abnormalities, affectation of hair follicle and sebaceous gland integrity and diminution of cellularity and blood vessels in the dermis and disappearance of adipose cells in hypodermis. In addition, the fact that these phenotypes were always much more marked in Sos $1 / 2$ DKO mice indicates that Sos2 absence exhibits a partial contributing function in the maintenance of skin cytoarchitecture when Sos1 expression is already absent. Despite the profound alteration in the skin homeostasis caused by Sos1- or Sos1/2-disruption, it is relevant that we did not detect any sign of apoptosis induction in the skin of both Sos1 KO and Sos1/2 DKO mice. These results are consistent with previous data demonstrating that deletion of the three known canonical targets of Sos proteins (H-Ras, N-Ras and K-Ras) block proliferation in keratynocytes or mouse embryonic fibroblasts, but does not affect cell survival (Drosten et al., 2014)'(Drosten et al., 2010). Conversely, transgenic mice expressing a dominant form of Sos in the skin showed an hyperproliferative skin affectation leading to tissue hyperplasia (Sibilia et al, 2000). The key role of Sos1 in control of cell proliferation has been largely documented in other cell lineages, tissues and organs (Depeille et al., 2015)'(Baltanás et al., 2013)'(Liceras-Boillos et al., 2016)'(Chen et al., 2010c)'(Pierre et al., 2011b). Our data also documented that concomitant absence of Sos1 and Sos2 severely disrupted hair follicle and sebaceous gland organization. Previous works reported that EGFR-mediated Ras signaling pathway deregulation affects to hair follicle integrity (Doma et al., 2013). As previously described, Sos-1 protein coordinates the activation of both Ras and Rac (Scita et al., 2001)'(Innocenti et al., 2002). In this regard, Rac1 is known to play a critical role in sustaining the integrity of the hair follicle and sebaceous gland although seems to be not essential for maintenance of the epidermis (Benitah et al., 2005b)'(Chrostek et al., 2006)'(Castilho et al., 2010a). Interestingly, histological analysis and CD31 immunostaining 
showed a reduction of blood vessels in the dermis of both Sos1 KO and Sos1/2 DKO mice. Moreover, aortic ring ex vivo assays to study angiogenesis revealed significant defects in microvessels formation when Sos proteins are absent. These data suggest an important involvement of Sos 1 and Sos 2 in the regulation of the angiogenesis and the integrity of blood vessels. Although this potential role for Sos proteins has not been previously reported, it is known that small GTPases are involved in angiogenic process, endothelial migration and regulates integrity and functionality of blood vessels (Chrzanowska-Wodnicka et al., 2008)'(Sawada et al., 2012)'(Murillo et al., 2014). We may suggest that Sos proteins could participate in activation of small GTPases that importantly contribute to angiogenic process. The integrity of the hypodermis was also affected in Sos1 KO mice being even more affected, almost disappeared, in Sos1/2 DKO mice. This layer consists mainly of adipose tissue. In this regard, our previous work demonstrated that adipose tissue was dramatically affected after simultaneous Sos proteins disruption (Baltanás et al., 2013). These observations indicate that both Sos isoforms importantly contribute to the homeostasis of adipose cells. More detailed studies will be needed in future to precisely understand the specific role of Sos isoforms in this cell type.

Cutaneous response to damage involves a number of well-coordinated events including epidermal proliferation and migration, activation of the immune system and angiogenesis, among others (Reinke and Sorg, 2012). Here we evaluated the role of Sos1 and Sos2 proteins (individually or combined) in these processes in response to wounding. In contrast to the dominant role showed by Sos1 in proliferation, it seems that there is a functional redundancy of both Sos isoforms in the sequence of events controlling the closure of the wound. The first phase of re-epithelialization upon injury involves fibrin matrix secretion in the wound (Park and Barbul, 2004), (Laurens et al., 2006), that was substantially reduced of fibrin matrix when both Sos isoforms were absent. Fibrin is synthetized from fibrinogen which is mainly produced in the liver (Guadiz et al., 1997)'(Weisel, 2005). Our previous report documented the severe affectation of liver functionality in Sos1/2 DKO mice (Baltanás et al., 2013). In addition, during the first steps in the process of healing, different cell types including keratinocytes and fibroblasts migrate to the injury site and proliferate. Our previous data discussed above pointed out the importance of Sos1, predominantly, but also of Sos2 in cell proliferation. Consistently, our data here presented demonstrated a marked reduction of cell proliferation in the wound of mice lacking the expression of both isoforms. In addition, previous works demonstrated a significant blockade of migration in both Ras- and Sos-depleted mouse fibroblasts after wounding (Drosten et al., 2010)'(Liceras-Boillos et al., 2016). The next step during 
wound closure process involves inflammatory response, where immune cells such as macrophages are recruited to the injury site. Interestingly, no signs of alteration in the viability of macrophages were detected in the skin of Sos lacking mice under physiological conditions. Consistently, no differences in the number of circulating macrophages in the blood of Sos lacking mice as compared with control WT counterpart (Baltanás et al., 2013). However, absence of Sos1 protein, individually or combined with Sos2, strongly affects recruitment of this immune cell upon injury. These data suggest a defect in the proliferative and/or migratory capacity of macrophages upon inflammatory stimulus when Sos1 protein is absent. In this regard, it is known that Sos proteins are involved in macrophage proliferation (Lanfrancone et al., 1995). We surmise that Sos absence should therefore affect the capability of these cells to proliferate, although an additional Ras-mediated or Rac-mediated alteration in the migratory capacity of these cells should not be discarded. Later stages of wounding involve an angiogenic process (Park and Barbul, 2004). We have already uncovered a potential role of both Sos proteins during angiogenesis. Therefore, defects on angiogenesis during wound repair in Sos-depleted mice should be expected.

Overall, our results showed a blockade of skin re-epithelialization in Sos1/2 DKO mice that is caused by alterations during the highly coordinated events controlling tissue remodeling including decrease in keratinocyte proliferation, defects in the capacity of migration of different cell types as well as deficiency in both inflammatory and angiogenic processes. Consistently, previous studies documented the importance of EGFR-Ras-Raf pathway in the wound healing process, in particular for keratinocyte proliferation migration and adhesion (Marikovsky et al., 1993)'(Shirakata et al., 2005)'(Yoshioka et al., 2010). Nevertheless, it should be noted that EGFR activation is important, but not absolutely necessary, to complete wound closure (Repertinger et al., 2004). In addition, Rac 1 that is also activated by Sos1, appear to be required to orchestrate the response during tissue remodeling (Castilho et al., 2010a).

Finally, we aimed to evaluate to potential role of Sos proteins as potential therapeutic targets in chemically-induced skin carcinogenesis. The results here presented revealed that Sos1-, but not Sos2absence, delayed tumor initiation and disrupted tumor promotion, mainly by reducing keratinocyte proliferation, rather than increasing cell death, in agreement with the predominant role of Sos1 over Sos2 on cell proliferation as above discussed. Several evidences described a pivotal role of Ras proteins and its upstream regulators and downstream effectors during promotion in epidermal tumurogenesis (Kern et al., 2011b)'(May et al., 2015)'(Doma et al., 2013)'(Menacho-Márquez et al., 
2013b). In particular, transgenic mice expressing dominant form of Sos1 in basal keratinocytes developed skin papillomas (Sibilia et al., 2000a). Importantly, our results pointed out that Sos1 depletion prevented the development of SCC after DMBA/TPA-induced carcinogenesis. It has been described that Sos upregulation leads to cisplatin resistance in SCC cells through MAPK/ERK activation (Kong et al., 2015). A recent report has documented that belinostat blocks Sos-mediated MAPK activation, exerting anti-tumor toxicity in SCC (Kong et al., 2017).

Strikingly, skin neutrophil-mediated inflammatory response to DMBA/TPA treatment during promotion phase was not affected when Sos1 was individually ablated. Moreover, single Sos 2 protein absence resulted in an increment of neutrophil infiltration during the promotion phase. However, concomitant Sos deletion almost abrogates recruitment of immune cells. Additionally, our previous study documented an enhanced cell adhesion ability of mouse fibroblasts (Liceras-Boillos et al., 2016). Previous studies concerning Sos 2 isoform reveled the dispensability of this protein due to its single depletion had not impact on organismal survival (Esteban et al., 2000), thymocyte and B-cell maturation (Kortum et al., 2011)'(Baltanás et al., 2013) or in proliferative and/or migratory capacity in mouse fibroblasts (Liceras-Boillos et al., 2016). However, its presence is critical in all these processes when Sos1 is already absent (Kortum et al., 2011)'(Baltanás et al., 2013)'(Liceras-Boillos et al., 2016). Further detailed analysis will be needed to determine a potential functional specificity in certain biological processes.

The data presented here also documented that deletion of Sos1 not only prevented skin tumor initiation and promotion, but also decreased tumor growth in preexisting papillomas by reducing cell proliferation into the tumor. Overall, these results unveil a previously unknown anti-tumurogenic effect of Sos proteins at different phases of skin tumor development thus making it possible to postulate Sos isoforms as potential therapeutic targets in prevention and/or treatment of epidermalorigin cancer.

\section{ACKNOWLEDGEMENTS}

Work supported by grants FIS PI16/02137 from ISCIII (MINECO), SA043U16 (UIC 076) from JCyL, Spain and AECC. FC and CG are supported by a postdoctoral grant from the CiberONC and AECC, respectively. Research co-financed by FEDER funds. PL is supported by predoctoral contract from JCyL and FEDER funds. 


\section{REFERENCES}

1 Buday L, Downward J. Many faces of Ras activation. Biochim Biophys Acta 2008; 1786: 178-87.

2 Hennig A, Markwart R, Esparza-Franco MA, Ladds G, Rubio I. Ras activation revisited: role of GEF and GAP systems. Biol Chem 2015; 396: 831-48.

3 Castellano E, Santos E. Functional Specificity of Ras Isoforms: So Similar but So Different. Genes Cancer 2011; 2: 216-231.

4 Cherfils J, Zeghouf M. Regulation of Small GTPases by GEFs, GAPs, and GDIs. Physiol Rev 2013; 93: 269-309.

5 Pierre S, Bats A-S, Chevallier A, Bui L-C, Ambolet-Camoit A, Garlatti M et al. Induction of the Ras activator Son of Sevenless 1 by environmental pollutants mediates their effects on cellular proliferation. Biochem Pharmacol 2011; 81: 304-313.

6 Rojas JM, Oliva JL, Santos E. Mammalian Son of Sevenless Guanine Nucleotide Exchange Factors: Old Concepts and New Perspectives. Genes Cancer 2011; 2: 298-305.

$7 \quad$ Fernandez-Medarde A, Santos E. Ras in Cancer and Developmental Diseases. Genes Cancer 2011; 2: 344-358.

8 Qian X, Esteban L, Vass WC, Upadhyaya C, Papageorge AG, Yienger K et al. The Sos1 and Sos2 Ras-specific exchange factors: differences in placental expression and signaling properties. Embo J 2000; 19: 642-654.

9 Esteban LM, Fernández-Medarde A, López E, Yienger K, Guerrero C, Ward JM et al. Ras-guanine nucleotide exchange factor sos2 is dispensable for mouse growth and development. Mol Cell Biol 2000; 20: 6410-6413. Kortum RL, Sommers CL, Alexander CP, Pinski JM, Li W, Grinberg A et al. Targeted Sos1 deletion reveals its critical role in early T-cell development. Proc Natl Acad Sci U S A 2011; 108: 12407-12.

Baltanás FC, Pérez-Andrés M, Ginel-Picardo A, Diaz D, Jimeno D, Liceras-Boillos $P$ et al. Functional Redundancy of Sos1 and Sos2 for Lymphopoiesis and Organismal Homeostasis and Survival. Mol Cell Biol 2013; 33: 4562-78. Liceras-Boillos P, García-Navas R, Ginel-Picardo A, Anta B, Pérez-Andrés M, Lillo C et al. Sos1 disruption impairs cellular proliferation and viability through an increase in mitochondrial oxidative stress in primary MEFs. Oncogene 2016; : 1-14.

Drosten M, Lechuga CG, Barbacid M. Ras signaling is essential for skin development. Oncogene 2014; 33: 28572865.

Kern F, Niault T, Baccarini M. Ras and Raf pathways in epidermis development and carcinogenesis. Br J Cancer 2011; 104: 229-234.

Doma E, Rupp C, Baccarini M. EGFR-Ras-Raf Signaling in Epidermal Stem Cells: Roles in Hair Follicle Development, Regeneration, Tissue Remodeling and Epidermal Cancers. Int J Mol Sci 2013; 14: 19361-19384.

Sibilia M, Fleischmann A, Behrens A, Stingl L, Carroll J, Watt FM et al. The EGF Receptor Provides an Essential Survival Signal for SOS-Dependent Skin Tumor Development. Cell 2000; 102: 211-220.

Lichtenberger BM, Tan PK, Niederleithner H, Ferrara N, Petzelbauer P, Sibilia M. Autocrine VEGF signaling synergizes with EGFR in tumor cells to promote epithelial cancer development. Cell 2010; 140: 268-79. Perez-Losada J, Balmain A. Stem-cell hierarchy in skin cancer. Nat Rev Cancer 2003; 3: 434-443.

Laurens N, Koolwijk P, de Maat MP. Fibrin structure and wound healing. J. Thromb. Haemost. 2006; 4: $932-939$. Drosten M, Dhawahir A, Sum EYM, Urosevic J, Lechuga CG, Esteban LM et al. Genetic analysis of Ras signalling pathways in cell proliferation, migration and survival. EMBO J 2010; 29: 1091-1104. Depeille P, Henricks LM, van de Ven RA, Lemmens E, Wang CY, Matli M et al. RasGRP1 opposes proliferative EGFRSOS1-Ras signals and restricts intestinal epithelial cell growth. Nat Cell Biol 2015; 17: 804-815.

Chen P-C, Wakimoto H, Conner D, Araki T, Yuan T, Roberts A et al. Activation of multiple signaling pathways causes developmental defects in mice with a Noonan syndrome-associated Sos1 mutation. J Clin Invest 2010; 120: 435365.

Scita G, Tenca P, Areces LB, Tocchetti A, Frittoli E, Giardina G et al. An effector region in Eps8 is responsible for the activation of the Rac-specific GEF activity of Sos-1 and for the proper localization of the Rac-based actinpolymerizing machine. J Cell Biol 2001; 154: 1031-1044. Innocenti M, Tenca P, Frittoli E, Faretta M, Tocchetti A, Di Fiore PP et al. Mechanisms through which Sos-1 coordinates the activation of Ras and Rac. J Cell Biol 2002; 156: 125-136. Benitah SA, Frye M, Glogauer M, Watt FM. Stem cell depletion through epidermal deletion of Rac1. Science 2005; 309: 933-5.

Chrostek A, Wu X, Quondamatteo F, Hu R, Sanecka A, Niemann C et al. Rac1 Is Crucial for Hair Follicle Integrity but Is Not Essential for Maintenance of the Epidermis. Mol Cell Biol 2006; 26: 6957-6970. 2010; 5: e10503. proliferation, and MAPK signaling in Rap1b-deficient mice. Blood 2008; 111: 2647-56. 
Sawada J, Urakami T, Li F, Urakami A, Zhu W, Fukuda M et al. Small GTPase R-Ras Regulates Integrity and Functionality of Tumor Blood Vessels. Cancer Cell 2012; 22: 235-249.

Murillo MM, Zelenay S, Nye E, Castellano E, Lassailly F, Stamp G et al. RAS interaction with PI3K p110 $\alpha$ is required for tumor-induced angiogenesis. J Clin Invest 2014; 124: 3601-11.

Reinke JM, Sorg H. Wound repair and regeneration. Eur Surg Res 2012; 49: 35-43.

Park JE, Barbul A. Understanding the role of immune regulation in wound healing. Am. J. Surg. $2004 ; 187$. doi:10.1016/S0002-9610(03)00296-4.

Guadiz G, Sporn LA, Simpson-Haidaris PJ. Thrombin cleavage-independent deposition of fibrinogen in extracellular matrices. Blood 1997; 90: 2644-53.

Weisel JW. Fibrinogen and Fibrin. In: Advances in protein chemistry. 2005, pp 247-299.

Lanfrancone L, Pelicci G, Brizzi MF, Aronica MG, Casciari C, Giuli S et al. Overexpression of Shc proteins potentiates the proliferative response to the granulocyte-macrophage colony-stimulating factor and recruitment of Grb2/SoS and Grb2/p140 complexes to the beta receptor subunit. Oncogene 1995; 10: 907-917.

Marikovsky M, Breuing K, Liu PY, Eriksson E, Higashiyama S, Farber P et al. Appearance of heparin-binding EGF-like growth factor in wound fluid as a response to injury. Proc Natl Acad Sci U S A 1993; 90: 3889-93.

Shirakata Y, Kimura R, Nanba D, Iwamoto R, Tokumaru S, Morimoto C et al. Heparin-binding EGF-like growth factor accelerates keratinocyte migration and skin wound healing. J Cell Sci 2005; 118: 2363-2370.

Yoshioka R, Shiraishi A, Kobayashi T, Morita S-I, Hayashi Y, Higashiyama S et al. Corneal epithelial wound healing impaired in keratinocyte-specific HB-EGF-deficient mice in vivo and in vitro. Invest Ophthalmol Vis Sci 2010; 51: 5630-9.

Repertinger SK, Campagnaro E, Fuhrman J, El-Abaseri T, Yuspa SH, Hansen LA. EGFR enhances early healing after cutaneous incisional wounding. J Invest Dermatol 2004; 123: 982-9.

May U, Prince S, Vähätupa M, Laitinen AM, Nieminen K, Uusitalo-Järvinen H et al. Resistance of R-Ras knockout mice to skin tumour induction. Sci Rep 2015; 5: 11663.

1 Menacho-Márquez M, García-Escudero R, Ojeda V, Abad A, Delgado P, Costa C et al. The Rho Exchange Factors Vav2 and Vav3 Favor Skin Tumor Initiation and Promotion by Engaging Extracellular Signaling Loops. PLoS Biol 2013; 11. doi:10.1371/journal.pbio.1001615.

2 Sibilia M, Fleischmann A, Behrens A, Stingl L, Carroll J, Watt FM et al. The EGF receptor provides an essential survival signal for SOS-dependent skin tumor development. Cell 2000; 102: 211-20.

Kong LR, Chua KN, Sim WJ, Ng HC, Bi C, Ho J et al. MEK Inhibition Overcomes Cisplatin Resistance Conferred by SOS/MAPK Pathway Activation in Squamous Cell Carcinoma. Mol Cancer Ther 2015; 14: 1750-1760.

Kong LR, Tan TZ, Ong WR, Bi C, Huynh H, Lee SC et al. Belinostat exerts antitumor cytotoxicity through the ubiquitinproteasome pathway in lung squamous cell carcinoma. Mol Oncol 2017. doi:10.1002/1878-0261.12064. 
FIGURES AND FIGURE LEGENDS

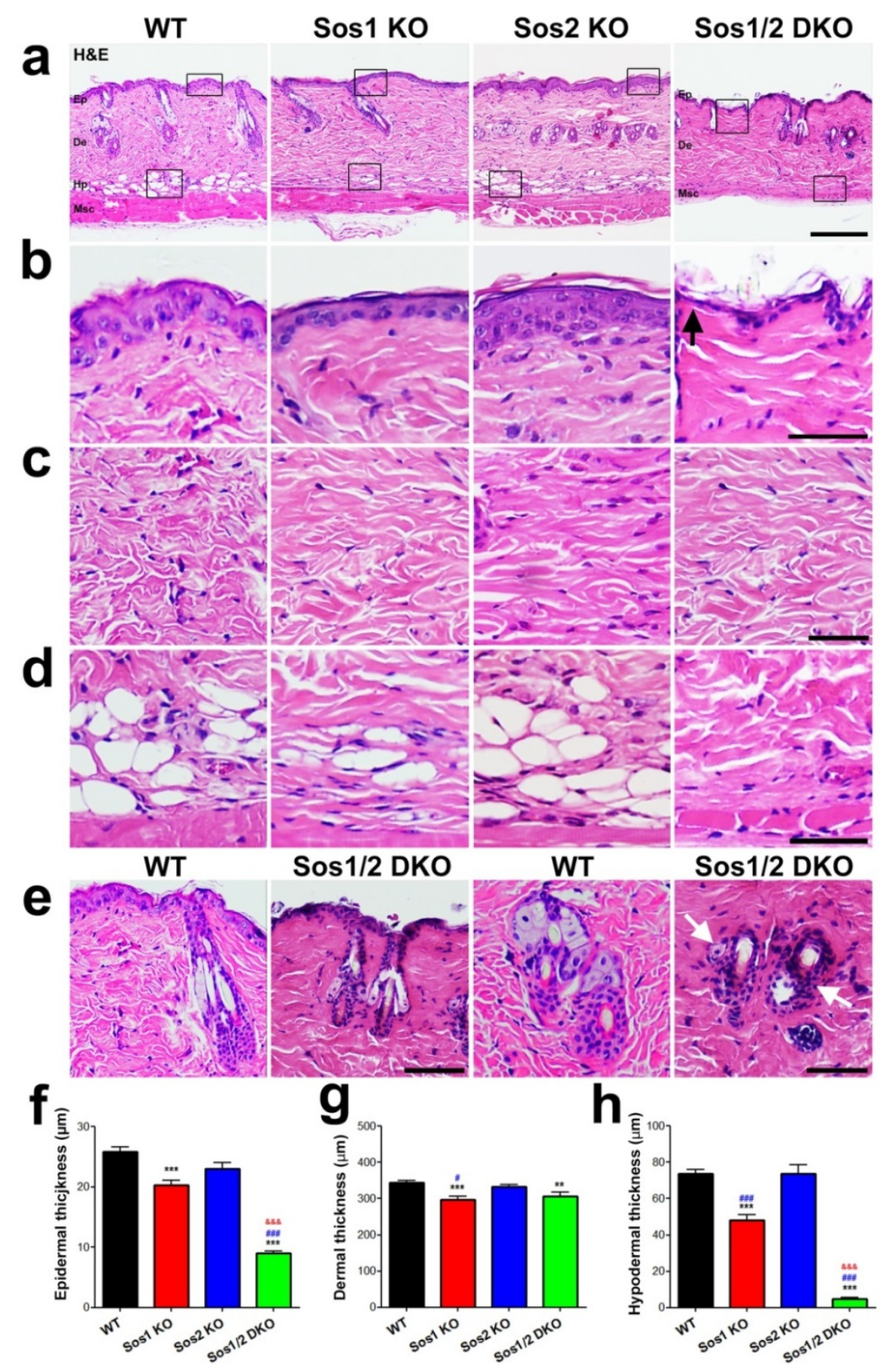

Figure 1. Role for Sos proteins in skin homeostasis. (a) Paraffin sections from the skin of WT, Sos 1 KO, Sos 2 KO and Sos $1 / 2$ DKO mice at day 12 after TAM feeding, stained with hematoxylin and eosin (H\&E). Scale bar: $200 \mu \mathrm{m}$ (b-d) Higher magnifications of boxed areas shown in (a) reflecting the epidermis (b), dermis (c) and hypodermis (d) for each experimental group. (b) Note the reduction of keratinocytes in epidermis of Sos1 depleted mice (Sos1 KO and Sos1/2 DKO) respect WT and Sos2 KO counterparts. (c) The cellularity in the dermis of both Sos1 KO and Sos1/DKO mice appears to be reduced as compared with WT and Sos2 KO groups. (d) Sos1 KO mice showed a loss of adipose tissue in the hypodermis, that is almost complete in Sos1/2 DKO. (b-d) Scale bars: $25 \mu \mathrm{m}$. (e) Higher magnifications of hair follicles (left panels) and sebaceous cells (right panels) from WT and Sos1/2 DKO. Scale bar: $100 \mu \mathrm{m}$. Left arrow points to a sebaceous gland and right arrow shows a loss of integrity of hair follicle keratinocytes. Scale bar: $50 \mu \mathrm{m}$. Quantitation of thickness in epidermis (f), dermis ( $g$ ) and hypodermis (h). (f-g) n=3/genotype (100 measurements per mouse). Data expressed as the mean \pm sem. \# $p<0.05$ vs Sos2 KO; ${ }^{* *} p<0.01$ vs WT; ***/\&\&\&/\#\#\# p< 0.001 vs WT, Sos1 KO y Sos2 KO, respectively. Ep: Epidermis, De: Dermis, Hp: Hypodermis, Msc: Muscle. 


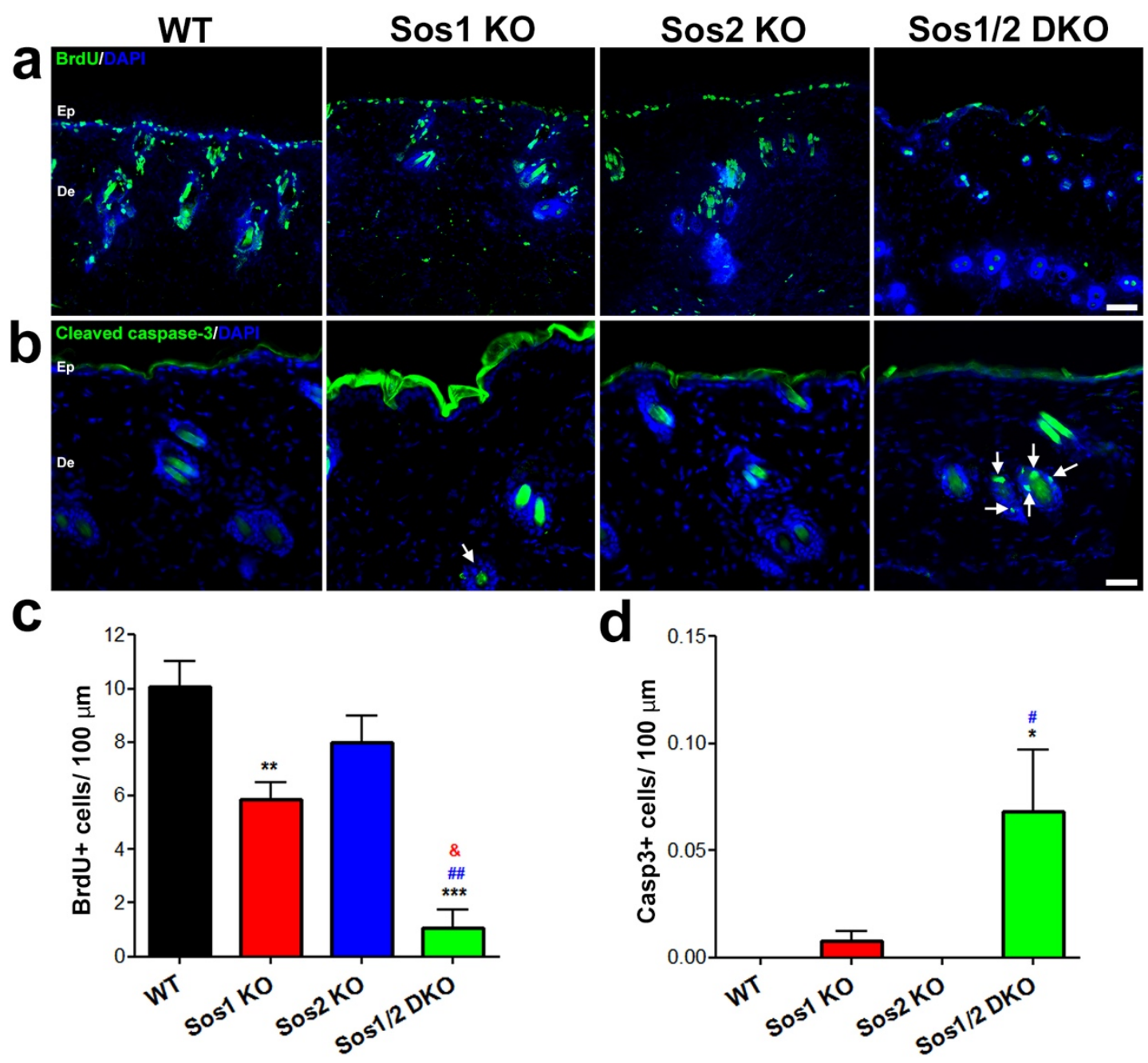

Figure 2. Prevalent role of Sos1 over Sos2 in control of keratinocyte proliferation. (a) Representative confocal microscopy images of skin sections of the four relevant genotypes after co-staining for BrdU (green) and DAPI (blue). Scale bar: $25 \mu \mathrm{m}$. (b) cleaved caspase-3 (green) and DAPI (blue) co-labeling performed in paraffin sections from skin of four experimental groups. Scale bar: $50 \mu \mathrm{m}$. (c) Quantitation of BrdU positive cells. (d) Quantitation of number of apoptotic cells. $n=3 /$ genotype ( 3 sections per animal). Data expressed as the mean \pm sem. $* / \& / \# p<0.05$ vs WT, Sos1 KO y Sos2 KO, respectively, ${ }^{* *} / \# \# p<0.01$ vs WT and Sos2 KO, ${ }^{* * *} p<0.001$ vs WT. Ep: Epidermis, De: Dermis. 


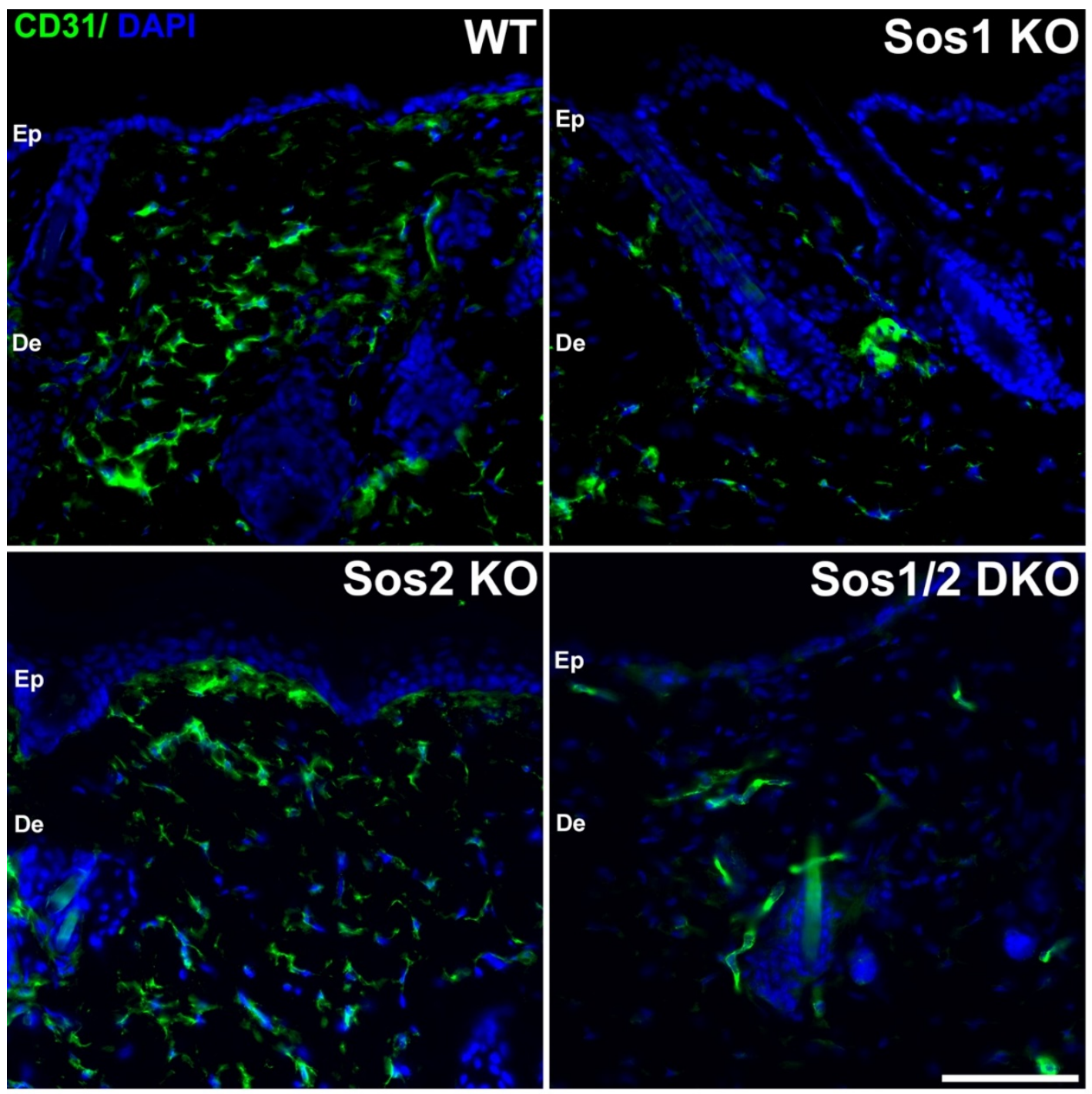

Figure 3. Sos1 depletion affects blood vessels. Representative confocal microscopy images of skin sections of the four relevant genotypes: WT, Sos1 KO, Sos2 KO and Sos1/2 DKO, co-stained for CD31 (green) and DAPI (blue). Scale bar: 100 m. Ep: Epidermis, De: Dermis. 

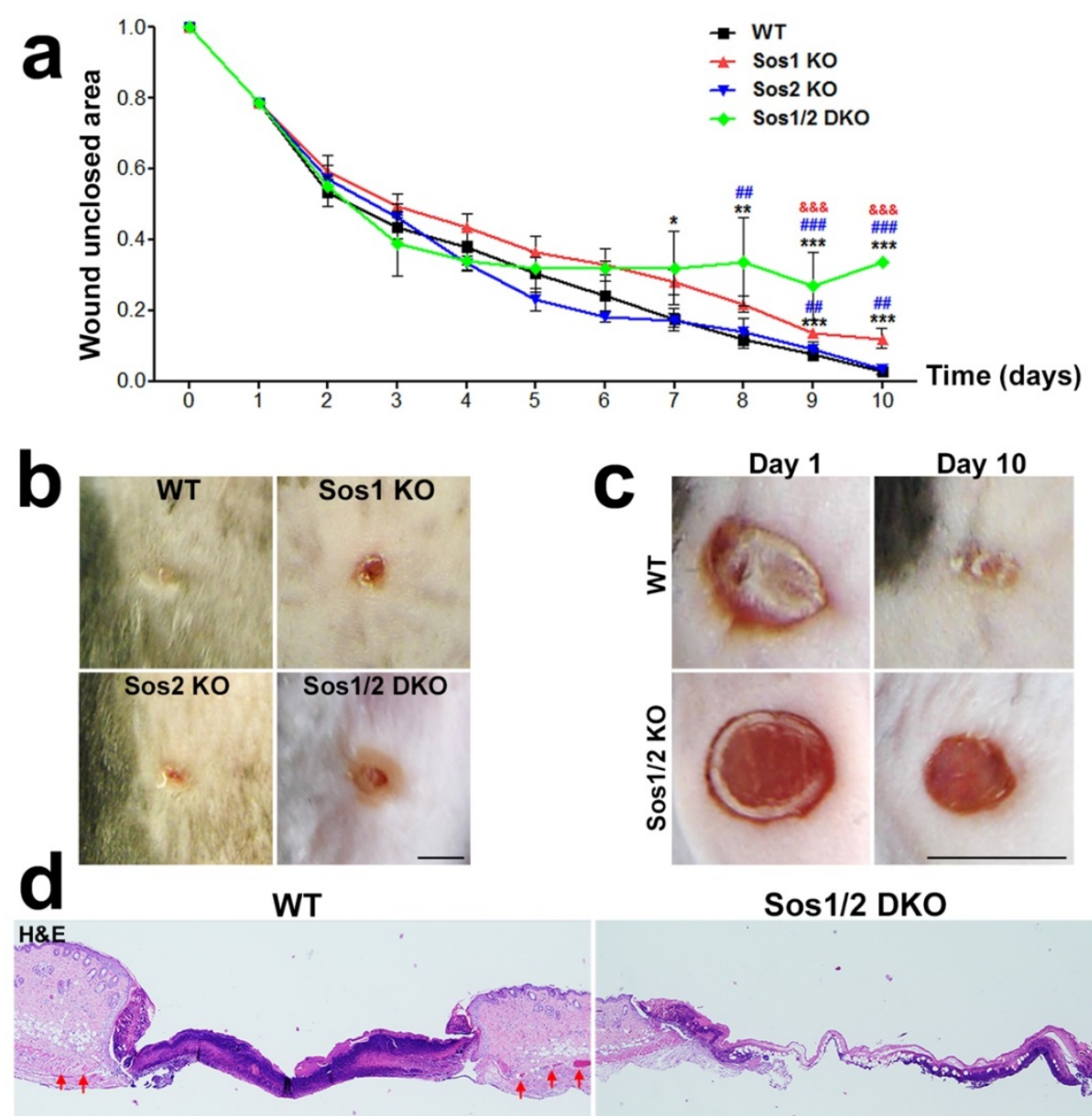

Sos $1 / 2$ DKO
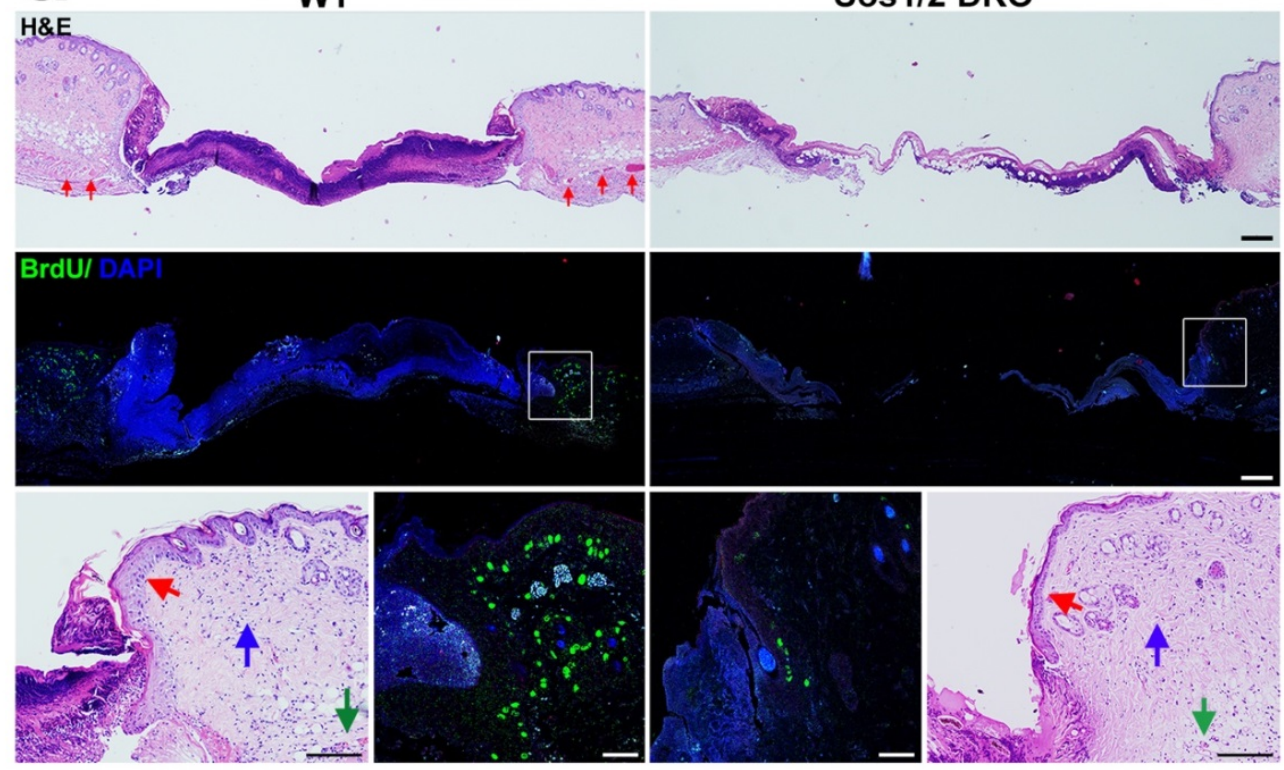

Figure 4. Sos proteins depletion affects wound closure process. (a) Graph quantizing the ratio of wound unclosed area in the four relevant genotypes. $n=4 /$ genotype. Data expressed as the mean \pm sem (b) Representative pictures of the wound at the end of experiment or each experimental group. Scale bar: $4 \mathrm{~mm}$. (c) Images showing the wound at day 1 and day 10 in both WT and Sos1/2 DKO. Scale bar: $4 \mathrm{~mm}$. (d) Paraffin sections from WT and Sos1/2 DKO mice stained for H\&E or co-stained (upper panels) for BrdU (green) and DAPI (blue) in middle panels. Higher magnifications of boxed areas shown. Note that the presence of blood vessels is more frequent in the skin of WT than in Sos1/2 DKO mice (red arrows). Scale bars: $100 \mu \mathrm{m}$. Lower panels show higher magnifications of boxed areas showing epidermal hyperplasia (red arrows), cellularity in dermis (blue arrows) and blood vessels adjacent to the injury (green arrows). Scale bars: $500 \mu \mathrm{m}$ y $25 \mu \mathrm{m}$, respectively. ${ }^{*} \mathrm{p}<0.05$ vs WT, ${ }^{* *} / \# \# \mathrm{p}<0.01$ vs WT and Sos $2 \mathrm{KO},{ }^{* * *} / \& \& \& / \# \# \# \mathrm{p}<0.001$ vs WT, Sos1 KO y Sos 2 KO, respectively. 


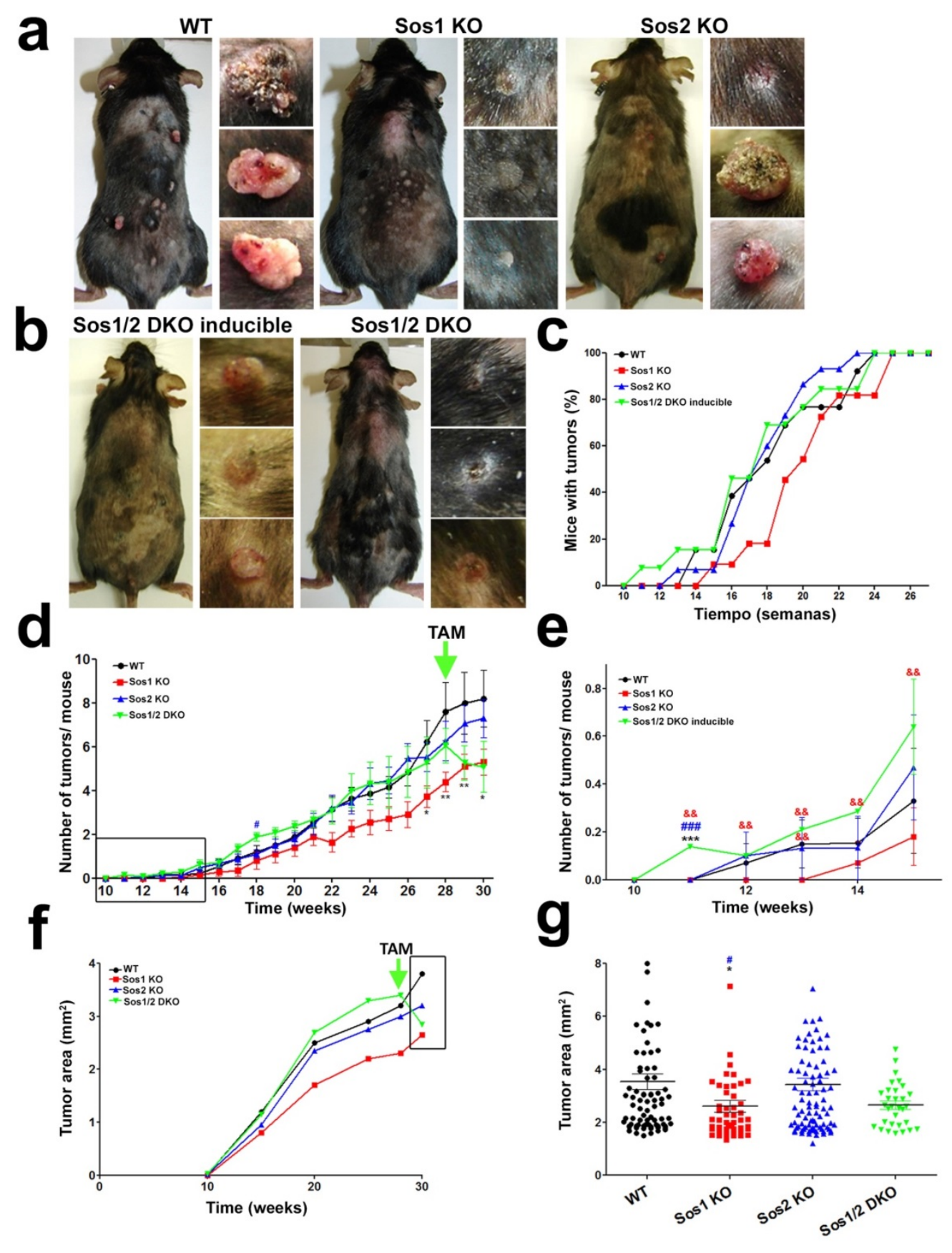

Figure 5. Sos1 depletion delays tumor initiation and progression. (a) Representative images of WT, Sos1 KO y Sos2 KO, and the generated tumors after 30 weeks of DMBA/TPA-induced carcinogenesis. (b) Representative images of non TAM-treated Sos1/2 DKO mice (Sos1/2 DKO inducible) and Sos1/2 DKO mice and the generated tumors after 30 weeks of DMBA/TPA-induced carcinogenesis. (c) Quantitation of percentage o mice with tumors during the experiment in all experimental groups. (d) Graph representing the number of tumors per mouse for each experimental group during 30 weeks. Green arrow points out when TAM was added to Sos1/2 DKO mice. Box indicates the region amplified in (e). (f) Evolution of mean tumor area for each experimental group. Arrow points out the period of time in which TAM is added to Sos1/2 DKO mice. Box indicates the region amplified in (g). (c-g) n=13 (WT and Sos1/2 DKO), n=11 for Sos1 KO and n=15 for Sos2 KO. Data

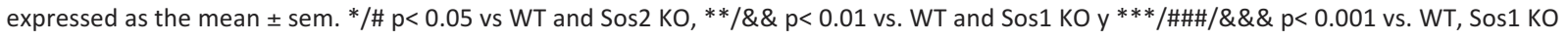
and Sos2 KO, respectively. 

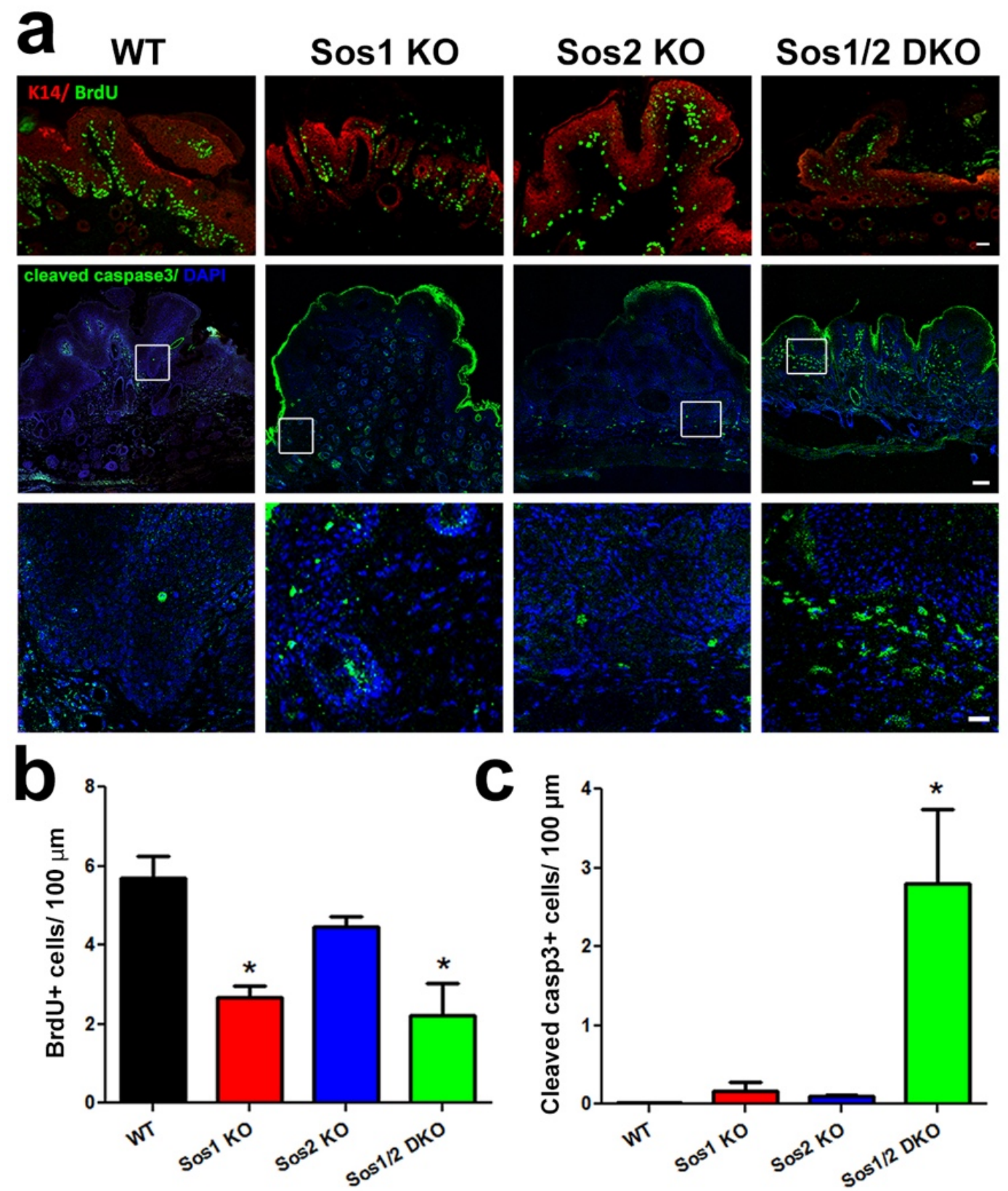

Figure 6. Analysis of cell proliferation and cell survival in Sos-lacking tumors. (a) In the upper panels, confocal images of skin sections immunostained for K14 (red) and BrdU (green). Scale bar: $50 \mu \mathrm{m}$. Representative confocal images of sections stained for cleaved caspasa-3 (green) and DAPI (blue). Scale bars: $100 \mu \mathrm{m}$ (medium panel) and $25 \mu \mathrm{m}$ (inferior panel). (b) Quantitation of BrdU-positive cells every 100 $\mu \mathrm{m} . \mathrm{n}=7$ (WT y Sos1 KO) and n=5 (Sos2 KO y Sos1/2 DKO). (c) Graph shows the number of apoptotic cells every $100 \mu \mathrm{m}$. $\mathrm{n}=4$ /genotype. Data expressed as the mean \pm sem. ${ }^{*} p<0.05$ vs WT. 


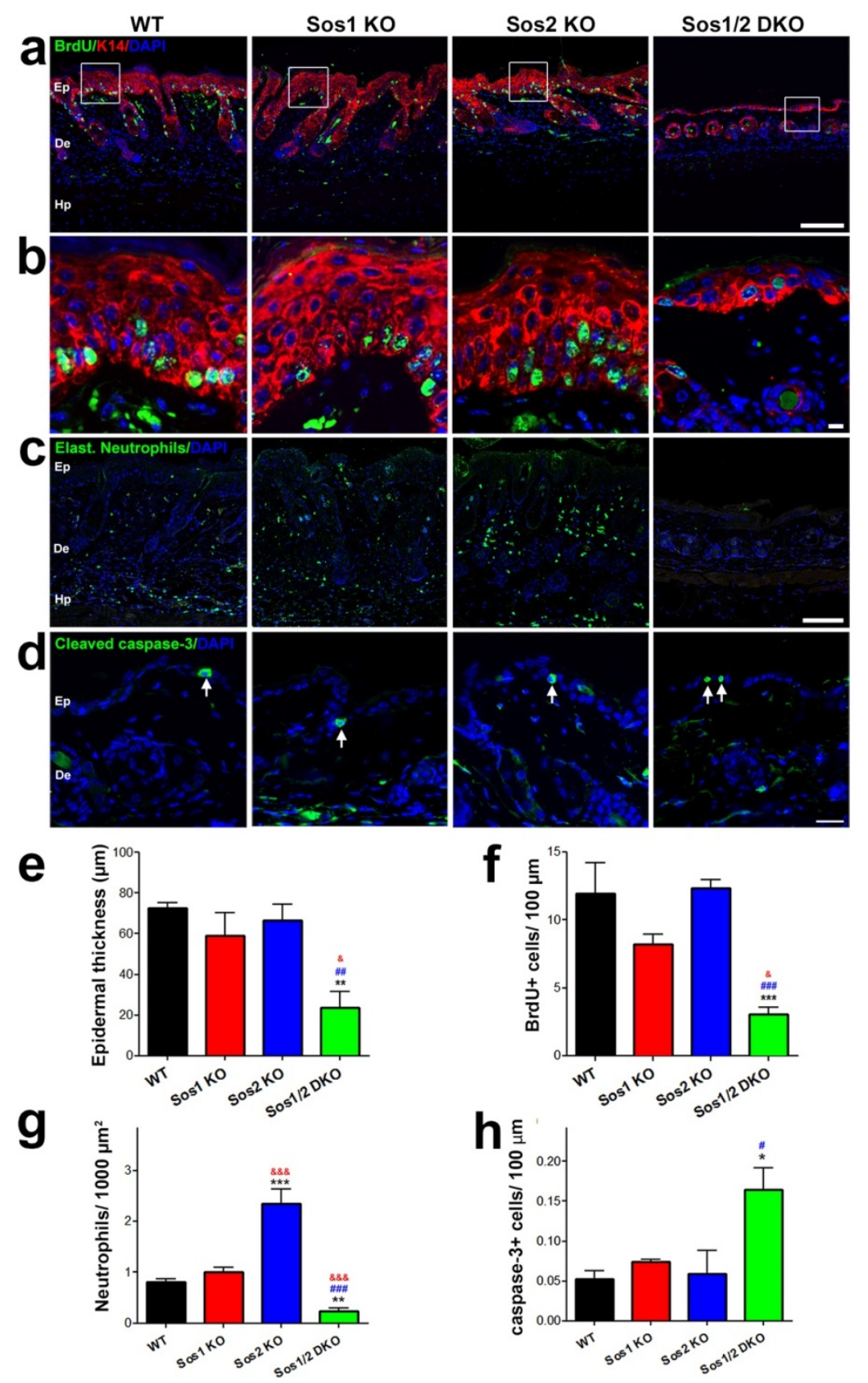

Figure 7. Sos proteins play an important role during the skin tumor promotion phase. (a) Confocal images of immunofluorescence detection of BrdU (green), K-14 (red) and DAPI (blue) in TPA-treated skin sections from the four experimental groups. Scale bar: $100 \mu \mathrm{m}$. (b). High magnifications of boxed areas in (a). Scale bar: $5 \mu \mathrm{m}$. (c) TPA-treated skin sections were stained with antibody to detect neutrophils (green) and counterstained with DAPI (blue). Scale bar: $100 \mu \mathrm{m}$. (d) Representative confocal images from the DMBA-treated WT, Sos1 KO, Sos2 KO y Sos1/2 DKO mice immunolabeled for cleaved caspase-3 (green) and counterstained with DAPI (blue). Arrows point out apoptotic keratinocytes. Scale bar: $25 \mu \mathrm{m}$. (e) Measurement of epidermal thickness in TPA-treated skin. $n=3 / g e n o t y p e ~(60$ measurements per mouse). (f) Quantitation of number of BrdU-positive cells in the epidermis per $100 \mu \mathrm{m}$. $\mathrm{n}=3$ /genotype ( 3 sections per mouse). (g) Number of neutrophils per $1000 \mu \mathrm{m}^{2}$ of tissue in the four experimental groups. $\mathrm{n}=3$ /genotype (3 sections per mouse). (h) Quantitation of cleaved caspase-3 positive cells every $100 \mu \mathrm{m}$. Data expressed as the mean \pm sem. \& $\mathrm{p}<0.05$ vs Sos $1 \mathrm{KO}, * * / \# \# \mathrm{p}<0.01$ vs WT and Sos2 KO, $* * * / \& \& \& / \# \# \#$ p 0.001 vs WT, Sos1 KO y Sos2 KO, respectively. Ep: Epidermis, De: Dermis, Hp: Hypodermis. 


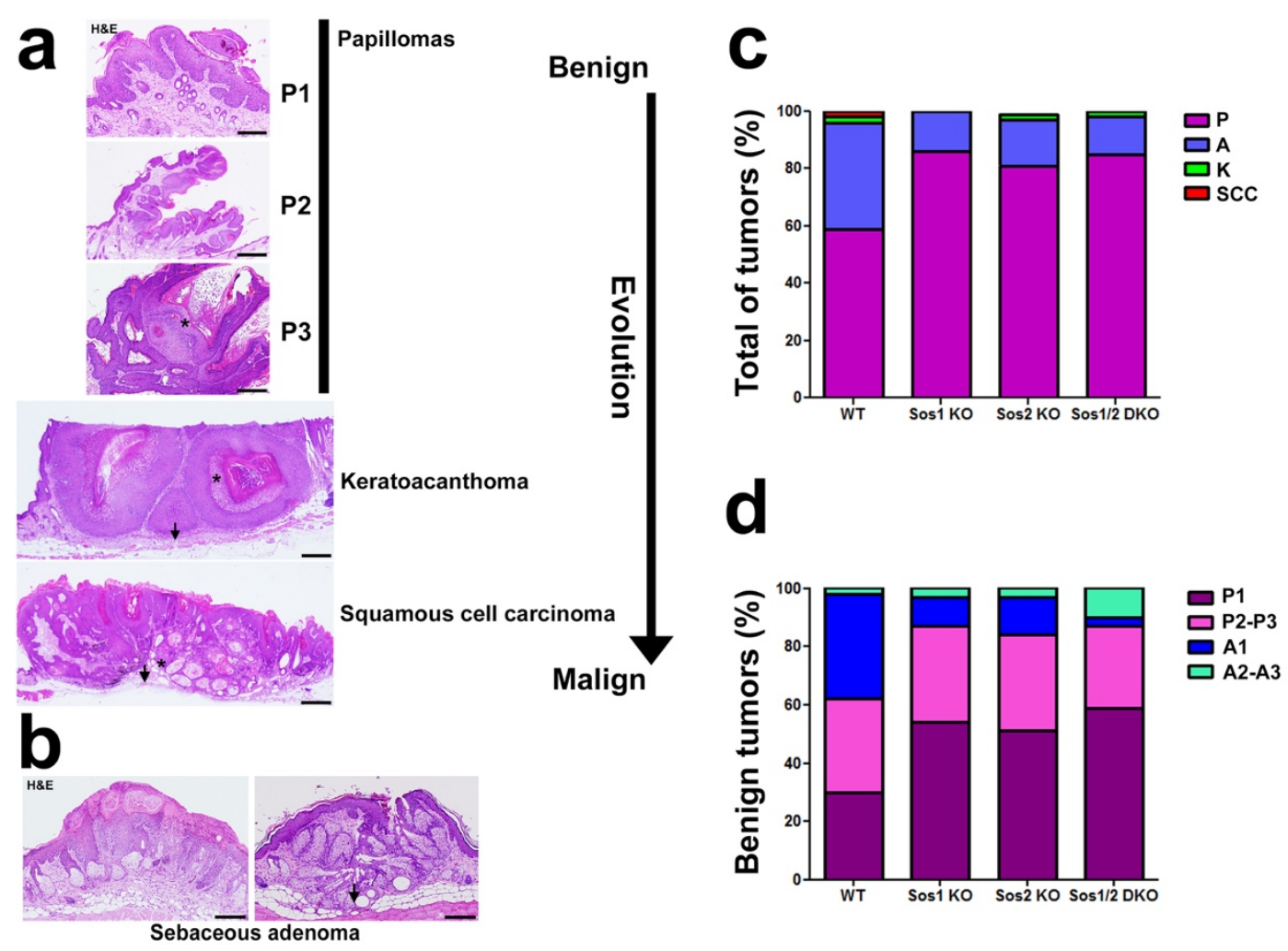

Figure 8. Sos1 absence prevents malign tumor formation. (a) Paraffin sections of skin tumors collected from mice of the four experimental groups stained with H\&E. Base on anatomo-pathological analyses, tumors were classified from benign papilloma of different grades (P1-P3) to malign squamous cell carcinoma. Note in P3 the formation of highly keratinized epidermal structures (asterisk), as well as a marked diminution of dermis and hypodermis (arrow), and epidermal-like structures engulfing keratin (asterisk) in the keratoacanthoma. Note in SCC how the dermis and the hypodermis invaded by the tumor (arrow), with a loss of muscle tissue and the presence of structures with atypical keratinocytes (asterisk). Scale bars: $P 1=200 \mu \mathrm{m}, \mathrm{P} 2-\mathrm{P} 3=500 \mu \mathrm{m}$ y $\mathrm{Q}$ and $\mathrm{SCC}=2 \mathrm{~mm}$. (b) Representative images of paraffin sections of low-grade sebaceous adenoma (left panel) and high-grade sebaceous adenoma (right). Note the invasion of the hypodermis by the sebaceous adenoma (arrow). Scale bars: $200 \mu \mathrm{m}$. (c) Bar chart represents the percentage of each tumor type found in each genotype. P: Papilloma, A: sebaceous adenoma, K: Keratoacanthoma and SSC: squamous cell carcinoma. (d) Graphs representing the distribution of benign tumors in the four experimental groups. P1: Low grade papilloma, P2-P3: medium/high-grade papilloma, A1: Low-grade sebaceous adenoma and A2-A3: medium/high-grade sebaceous adenoma. 

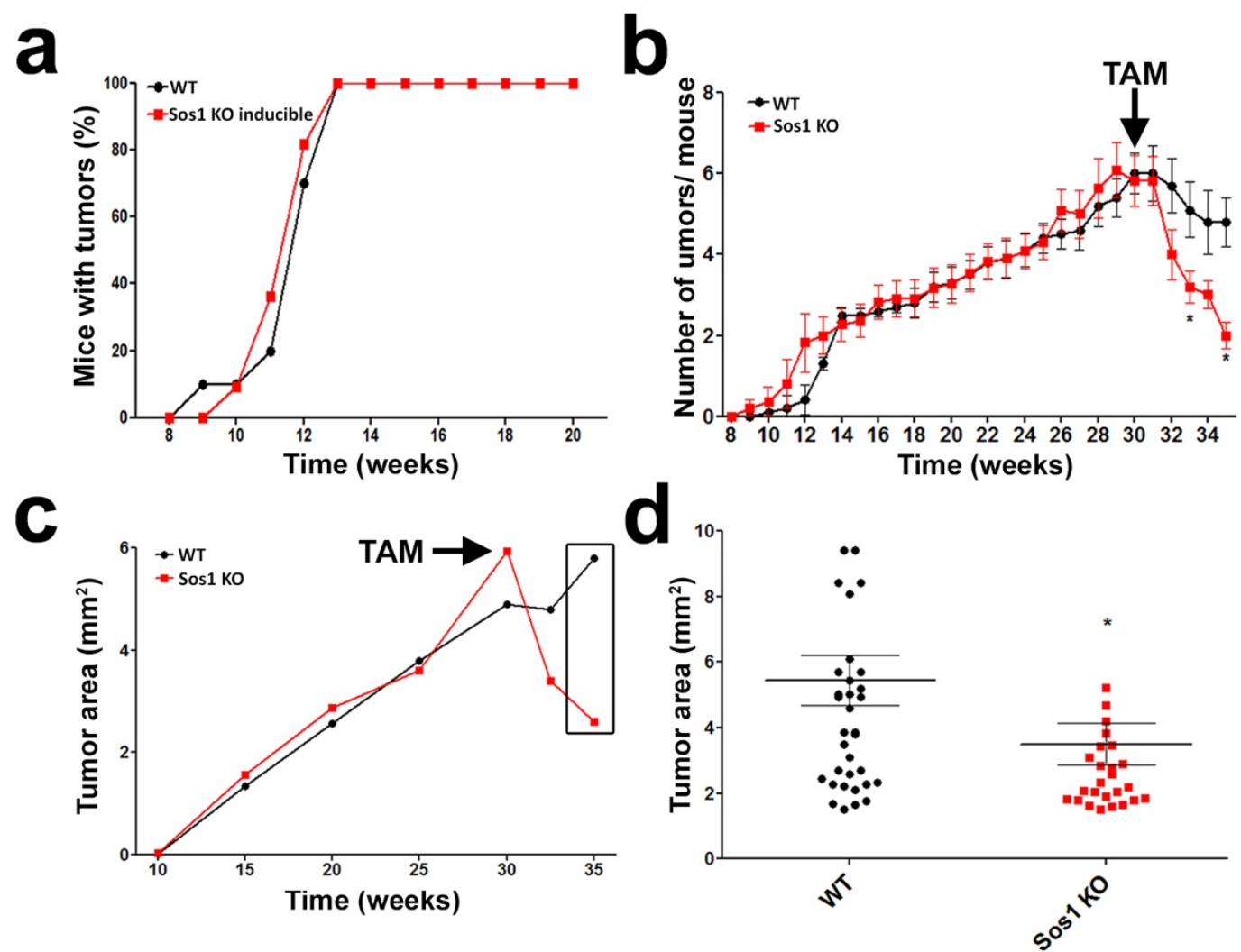

Figure 9. Sos1 depletion reduces the number and size of pre-established tumors. (a) Tumor initiation and development is practically identical in both WT and non TAM-treated Sos1 KO mice (Sos1 KO inducible) (b) Graph represents the number of tumors per mouse. Arrow indicates time point of TAM administration in both experimental groups. (c) Measurement of tumor area in both experimental groups along the whole experiment. Arrow points out the time point of TAM administration in both experimental groups. Boxed area indicates measurement showed in (d). (a-d) $n=11$ (WT) and $n=13$ (Sos1 KO). (b y d) Data expressed as the mean \pm sem. ${ }^{*} p<0.05$ vs WT. TAM:Tamoxifen. 

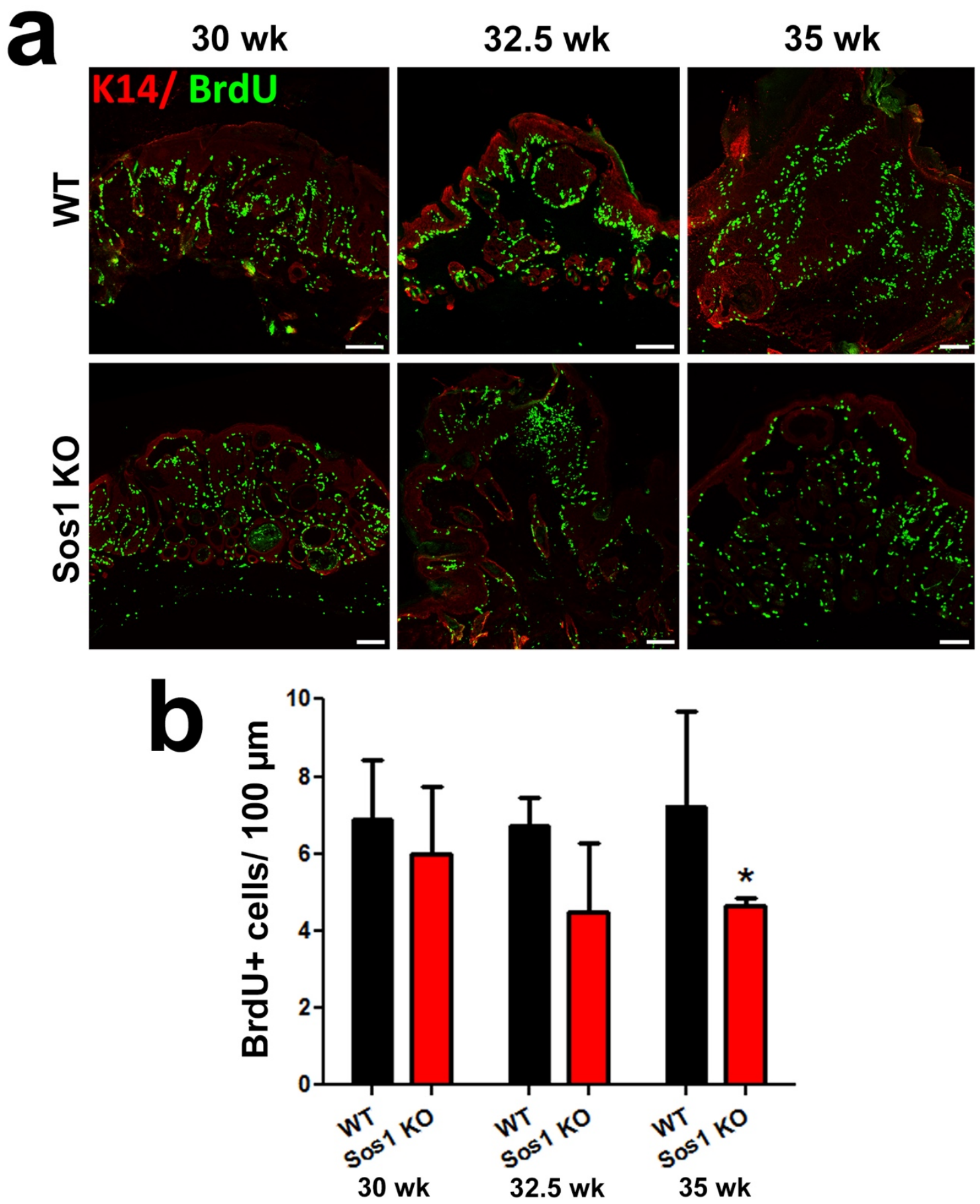

Figure 10. Sos1 deletion reduces cell proliferation in pre-established tumors. (a) Paraffin sections of tumors collected from WT and Sos 1 $\mathrm{KO}$ at the beginning of TAM treatment ( $30 \mathrm{wk}$ ), $2.5 \mathrm{wk}$ after TAM administration ( $32.5 \mathrm{wk}$ ) and at the end of the treatment ( $35 \mathrm{wk}$ ), immunostained for $\mathrm{K} 14$ (red) and BrdU (green). Scale bar: $100 \mu \mathrm{m}$. (b) Bar chart represents quantitation of proliferative cells in comparable tumors at the different time points. $n=3 /$ genotype and condition. Data expressed as the mean \pm sem. ${ }^{*} p<0.05$ vs WT. 

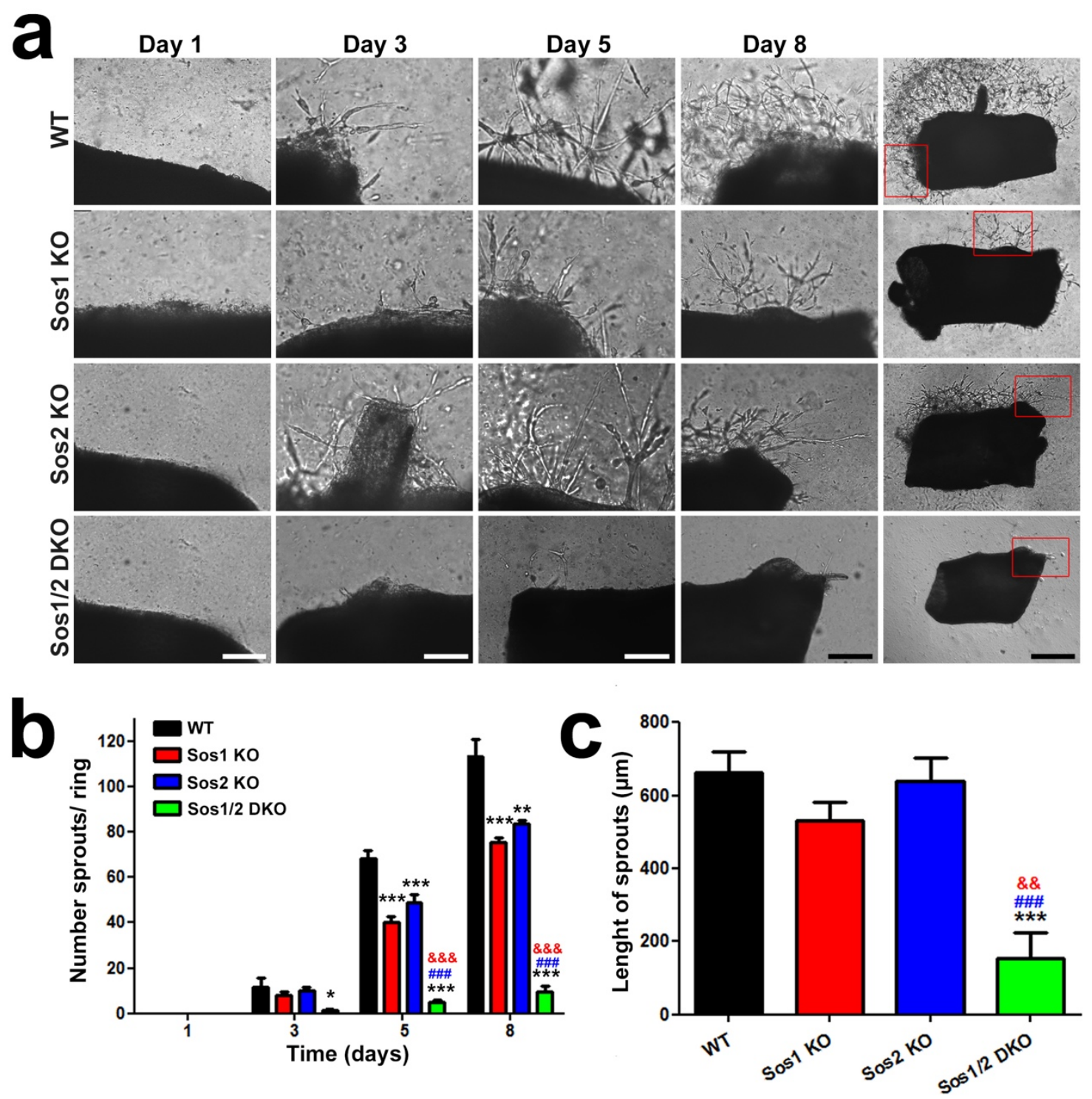

Figure SD1. Sos proteins absence induces defects during angiogenesis. a) Representative images of aortic rings explant at 1, 3, 5 and 8 days post-culture. Squared boxes represent magnified areas at day 8. b) Quantitation of number of sprouts at 1, 3, 5 y 8 days in the aortic rings of the four genotypes. c) Bar chart represents the lenght of the sprouts at the end of the study. Scale bar: $200 \mu \mathrm{m}$ and $500 \mu \mathrm{m}$ in the magnifications. Data expressed as the mean \pm sem. ${ }^{*} p<0.05$ vs WT, $* * / \& \& p<0.01$ vs WT and Sos 1 KO, $* * * / \& \& \& / \# \#$ p $<0.001$ vs WT, Sos 1 $\mathrm{KO}$ and Sos2 KO, respectively. 